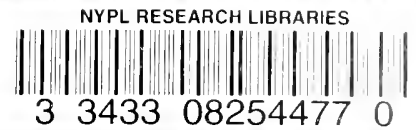

tition.

(2)

1 15

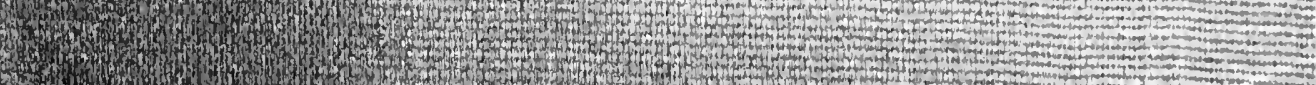
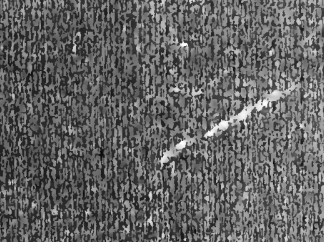

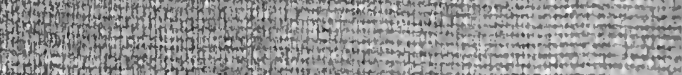

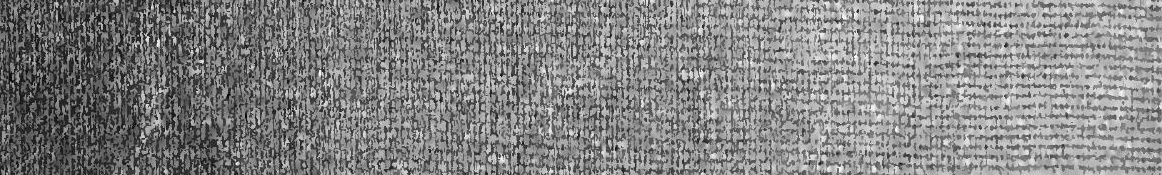

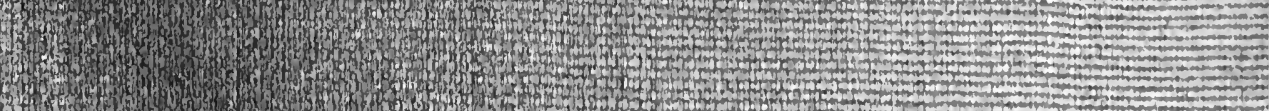
xis H. H. 


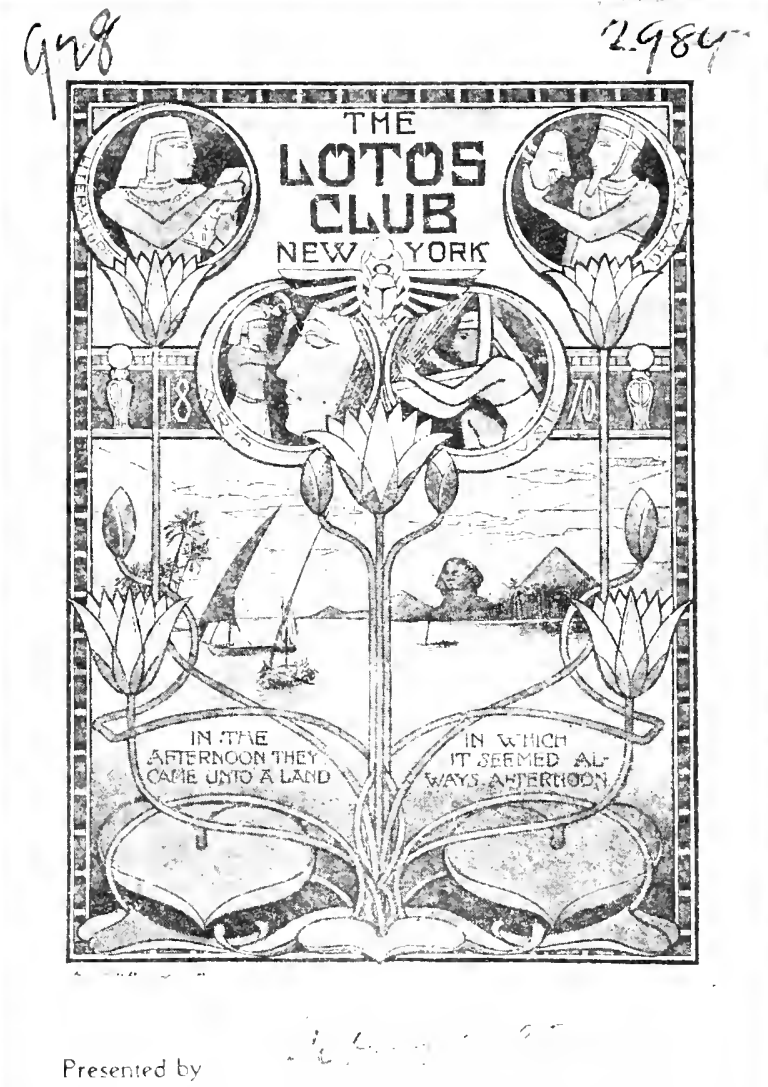



Digitized by the Internet Archive in 2007 with funding from

Microsoft Corporation

http://www.archive.org/details/lifestoryofrasmu00ande 

$T_{0}$

Tolm Elderkin. Isq.

with it k kind permal vequas

y Oprnachubung 




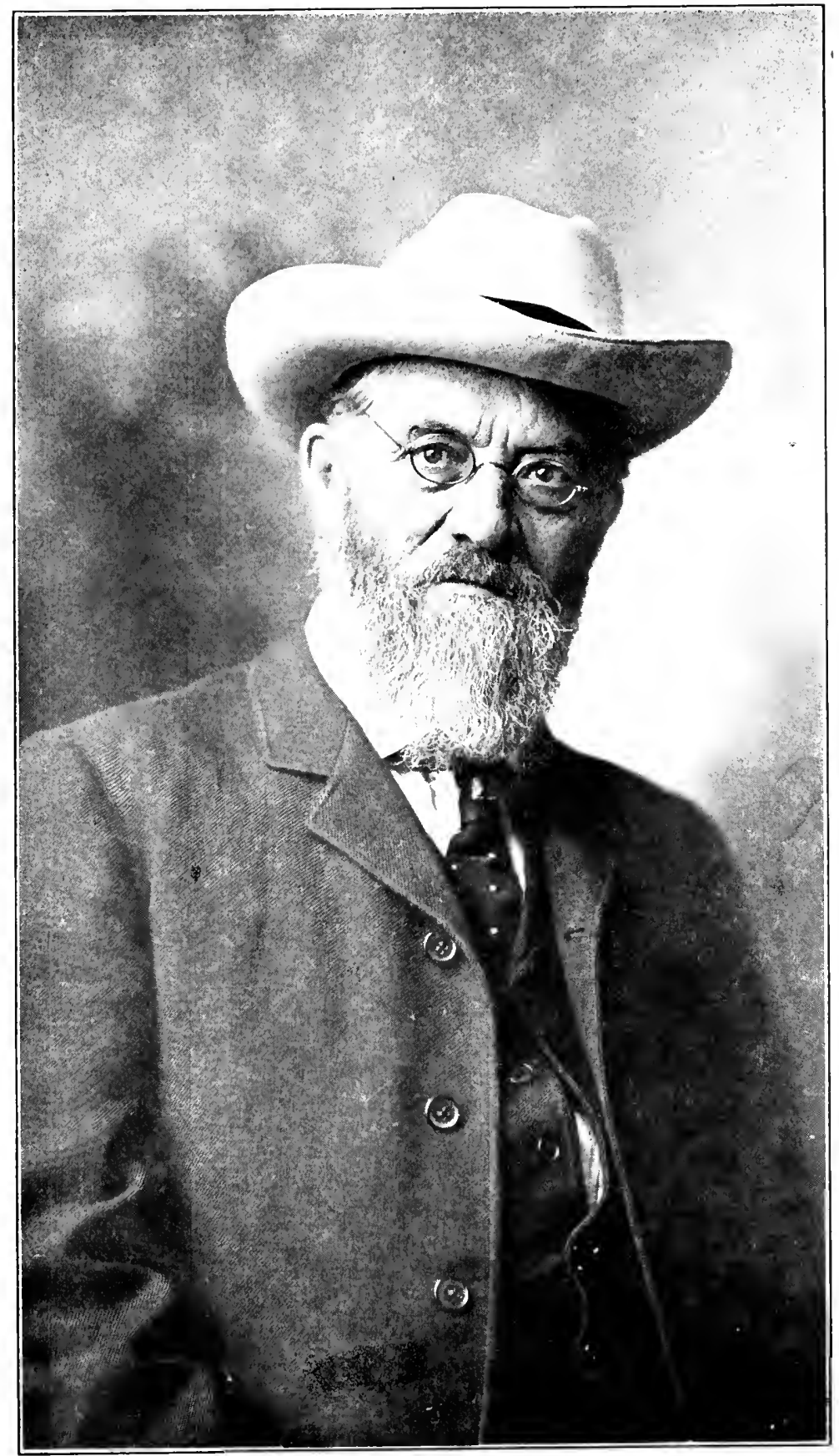

Rasmus B. Anderson 


\section{LIFE STORY}

OF

\section{RASMUS B. ANDERSON}

\section{WRITTEN BY HIMSELF}

With the assistance of

ALBERT O. BARTON

MADISON, WIS. 


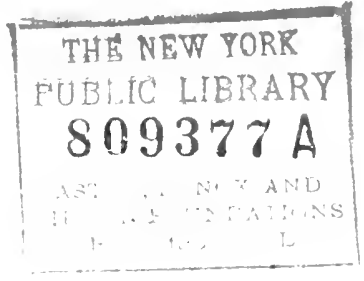

Copyright, 1915

BY RASMUS B. ANDERSON

All rights reserved

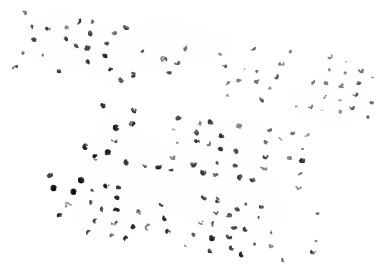


TO THOSE

OF

NORWEGIAN BIRTH OR DESCENT

WHO HAVE HELPED TO MAKE AMERICA.

ON THE FARMS, IN THE INDUSTRIES, IN COMMERCE, IN LITERATURE, SCIENCE. AND ART, WHO, BY THEIR RELIGIOUS AND SECULAR TEACHING AND

EXAMPLE HAVE HELPED TO BUILD THE NATION SPIRITUALLY.

MORALLY :AND INTELLECTUALLY, AND WHO HAVE

BEEN LOYAL TO THE STARS AND STRIPES

IN PEACE AND IN WAR,

THIS VOLUME IS DEDICATED 



\section{TABLE OF CONTENTS.}

CHAPTER I

Family History

CHAPTER II

First Split in the Church

CHAPTER III

Beginning of the Norwegian-American Press

CHAPTER IV

More Family History

CHAPTER V

I Leave Home

CHAPTER VI

Leave Milwaukee

CHAPTER VII

Half Way Creek

CHAPTER VIII

Back Home

CHAPTER IX

Go to Decorah

CHAPTER $X$

Discipline of the School

CHAPTER XI

The Students Rebel. 
The Next Day

CHAPTER XIII

CHAPTER XIV

The Missouri Synod

CHAPTER XV

Ambitious Plans

CHAPTER XVI

Albion Academy

CHAPTER XVII

Reply to a Protest....................
CHAPTER XVIII

More About Albion Academy

CHAPTER XIX

My Third Year at Albion

CHAPTER XX

Swedes Settle on the North Shore of Koshkonong Lake..... 90

CHAPTER XXI

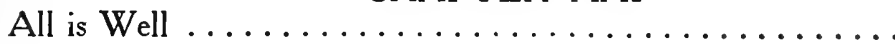

CHAPTER XXII

Dip Into the Political Sea.................... 96

\section{CHAPTER XXIII}

Am Elected Representative to the Annual Synod Meeting.....

\section{CHAPTER XXIV}

I Meet Ole Bull. .

CHAPTER XXV

Letter from a Schoolmate.

CHAPTER XXVI

Pride Goeth Before a Fall .

CHAPTER XXVII

More About Albion. 
Table of Contents.

CHAPTER XXVIII

Albion Students

CHAPTER XXIX

I Leave Albion

CHAPTER XXX

More Trouble

CHAPTER XXXI

At the University

CHAPTER XXXII

Chadbourne Leaves the University.

CHAPTER XXXIII

My First Visit to Norway

CHAPTER XXXIV

An Ole Bull Episode

CHAPTER XXXV

Land in the Old World

\section{CHAPTER XXXVI}

Prof. Sven Oftedal

CHAPTER XXXVII

Back to Norway

CHAPTER XXXVIII

The Millennial Celebration

CHAPTER XXXIX

Stavanger and Vicinity

CHAPTER XL

The Petit Done and the Undone Vast.....
The John A. Johnson Fund........... 188

CHAPTER XLII

The Leif Erikson Monument. 
Meet Thomas A. Edison.

CHAPTER XLIV

In Norway Again......................... 194

CHAPTER XLV

Björnson as a Fellow Traveler............... 196

CHAPTER XLVI

Ole Bull, Edward Grieg and Björnson ........... 198

CHAPTER XLVII

Prof. Sven Loven . . . . . . . . . . . . . . . . . . . . . 201

CHAPTER XLVIII

Return to America ....................... 203

CHAPTER XLIX

More About the Leif Erikson Monument............ 206

CHAPTER L

Strenuous Days ..................... 210

CHAPTER LI

First Chair of Scandinavian Languages........... 213

CHAPTER LII

"Norse Mythology" ................... 214

CHAPTER LIII

More About Ole Bull................... 222

CHAPTER LIV

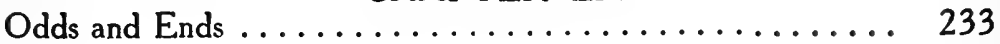

CHAPTER LV

J. C. Dundas ...................... 235

CHAPTER LVI

Survey of Field in the Seventies.............. 241 
Table of Contents.

CHAPTER LVIII

Landsmaal in Norway

More About the Seventies

CHAPTER LIX

CHAPTER LX

St. John's Day ......................... 254

CHAPTER LXI

More Odds and Ends..................... 257

CHAPTER LXII

How Butterfield Saw Me in $1879 \ldots \ldots \ldots \ldots \ldots \ldots .261$

CHAPTER LXIII

The Icelanders $\ldots \ldots \ldots \ldots \ldots \ldots \ldots \ldots \ldots \ldots, 274$

CHAPTER LXIV

More About the Icelanders................. 282

CHAPTER LXV

Controversies $\ldots \ldots \ldots \ldots \ldots \ldots \ldots \ldots \ldots \ldots \ldots . \ldots 288$

CHAPTER LXVI

The Fleisher Episode . . . . . . . . . . . . . . . . . . 293

CHAPTER LXVII

Kristofer Janson ........................ 298

CHAPTER LXVIII

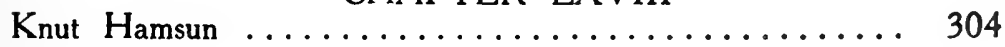

CHAPTER LXIX

More About Knut Hamsun .................. 314

Carl Lumholtz ....................... 320

CHAPTER LXXI

The Busy Seventies $\ldots \ldots \ldots \ldots \ldots \ldots \ldots \ldots \ldots, 322$

CHAPTER LXXII

Hungarian Literature 
Remenyi and Petön

\section{CHAPTER LXXIV}

More About Remenyi and Petöf.

CHAPTER LXXV

Birth of the Missouri Synod ................. 334

CHAPTER LXXVI

CHAPTER LXXVII

Arne Kulterstad

CHAPTER LXXVIII

More About Björnson

CHAPTER LXXIX

Life Insurance

CHAPTER LXXX

Paul du Chaillu

CHAPTER LXXXI

Leave the University

\section{CHAPTER LXXXII}

Life Insurance Continued

CHAPTER LXXXIII

I Insure Prof. Sven Oftedal................... 364

CHAPTER LXXXIV

The Madison Literary Club.

CHAPTER LXXXV

Ygdrasil

CHAPTER LXXXVI

A Term as Diplomat 


\section{CHAPTER LXXXIX}

\section{CHAPTER XCI}

Arrive in Copenhagen and Call on Worsaae. . . . . . . . . . 399

CHAPTER XCII

CHAPTER XCIII

Court Etiquette 406

CHAPTER XCIV

The Czar

CHAPTER XCV

Official Calls

CHAPTER XCVI

Estrup

CHAPTER XCVII

Carlos Butterfield \& Co.

\section{CHAPTER XCIX}

The Kearsarge and the Pensacola.

CHAPTER C

Postal Money Orders

CHAPTER CI

A Case of Extradition

CHAPTER CII 
Heineman Sends Pork to New York.

CHAPTER CIV

Olaf Poulsen

CHAPTER CV

The Jacobsens

CHAPTER CVI

Sarah Bernhardt

CHAPTER CVII

Bismarck

CHAPTER CVIII

Johan Sverdrup

CHAPTER CIX

The Czar is Humbled 468

CHAPTER CX

Claude McDonald

CHAPTER CXI

CHAPTER CXII

Munich

CHAPTER CXIII

Henrik Ibsen

CHAPTER CXIV

Georg Brandes

CHAPTER CXV

August Strindberg

CHAPTER CXVI

Goldschmidt

CHAPTER CXVII 
Random Notes

CHAPTER CXVIII

Standard Oil

CHAPTER CXIX

CHAPTER CXX

The King of Portugal and His Minister ......... 518

CHAPTER CXXI

Odds and Ends

CHAPTER CXXII

Lectures

CHAPTER CXXIII

Rosenborg Wine

CHAPTER CXXIV

Callers

CHAPTER CXXV

A Danish-American Paper Attacks Royal Family of Denmark 529

CHAPTER CXXVI

Literary Work

\section{CHAPTER CXXVII}

Diplomats Must Not Talk

CHAPTER CXXVIII

Emperor Wilhelm II

CHAPTER CXXIX

Lincoln

CHAPTER CXXX

The Prince of Wales

\section{CHAPTER CXXXI}

My Diplomatic Career Ends.

CHAPTER CXXXII

What Became of Enander 


\section{CHAPTER CXXXIV}

Mr. Barton and I Take a Rest. . . . . . . . . . . 564

CHAPTER CXXXV

Mr. Barton and I Resume Work ............. 565

\section{CHAPTER CXXXVI}

I Go to Work Again in America............. 567

CHAPTER CXXXVII

Life Insurance ..................... 572

CHAPTER CXXXVIII

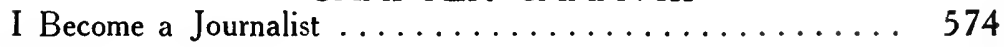

CHAPTER CXXXIX

Rubber ..................... 576

CHAPTER CXL

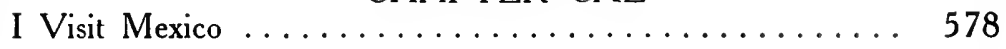

CHAPTER CXLI

I Am Wrecked

CHAPTER CXLII

The Bennett Law ...................... 594

CHAPTER CXLIII

More Politics

CHAPTER CXLIV

Prominent Wisconsin People................... 604

CHAPTER CXLV
I Become Postmaster $\ldots \ldots \ldots \ldots \ldots \ldots \ldots \ldots \ldots \ldots \ldots$

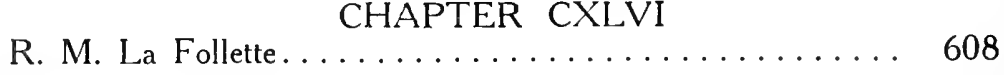

CHAPTER CXLVII

Det Norske Selskab.................... 627 


$$
\text { Table of Contents. }
$$

\section{CHAPTER CXLVIII}

Rupture With Our Saviour's Congregation........... 652

\section{CHAPTER CXLIX}

My Portrait in Snorre................. 656

\section{CHAPTER CL}

Time to Close .......................... 662

Bibliography ..................... 673 


\section{LIST OF ILLUSTRATIONS.}

Page

Rasmus B. Anderson. .................... Frontispiece

R. B. Anderson in the Winter of 1873-74, as Seen by the Artist, J. R. Stuart. . . . . . . . . . . . . . . . . . 209

Mrs. Bertha Karina Anderson, in Gown Worn at Queen's Reception ................................. 525

Fac-simile Letter from H. Mansfeld-Büllner......... 561

Albert O. Barton .......................... 564 


\section{PREFACE}

After long and repeated urging on the part of many friends, Prof. Rasmus B. Anderson has undertaken the writing of his autobiography which he has also consented to give to the readers of this paper in installments, beginning with the opening of the new year.

Prof. Anderson's career has been interesting from many points of view. His parents were among the earliest Norwegian settlers in this country, so that his story reaches back and practically covers the whole period of Norwegian settlement. He was a member of the first class to graduate from Luther College at Decorah, Iowa, was the first man to hold a chair in Scandinavian languages and literature in an American university, and was the first of Scandinavian parentage to represent our country abroad, serving as United States minister to Denmark from 1885 to 1889 . He has also written and translated numerous books dealing with Scandinavian history and literature. In the American supplement to the Encyclopædia Britannica he is called the father of Norwegian literature in America. Prof. Anderson has enjoyed the acquaintance of many eminent men, such as the poet Longfellow, Prof. John Fiske, Ole Bull, Henrik Ibsen, Björnstjerne Björnson, Paul du Chaillu, Bismarck, Admiral George Dewey, Fridtjof Nansen, Sophus Bugge, Ivar Aasen, all of the Sindings, Georg Brandes, Holger Drachmann, the Czar of Russia, the late king Edward of England, the various royal heads of Denmark, Norway and Sweden, Greece and Portugal and the members 
of their families, Mark Twain, Bayard Taylor, W. D. Howells, Grover Cleveland, Theodore Roosevelt, Johan Sverdrup, and others. Of all of these he will have some interesting incidents for his readers.

His autobiography will be particularly interesting from two points of view, his accounts of the beginnings of Norwegian settlements in this country and his recollections and estimates of the notables he met not only during his nearly five years' residence near the court of Denmark, but also before and since. Because of his own interesting career and his relations with the notables of his day, Prof. Anderson had been frequently urged to tell his life story. He finally agreed to do so on the condition that someone would take down the facts from his dictation. This the writer of this article has undertaken to do and has also suggested their publication in installments in "Amerika."

Prof. Anderson is a good story-teller, with a rare memory for details and a high appreciation of dramatic values and his story will no doubt be read with great interest, particularly by the younger generation of Norwegian-Americans in this country.

\section{Albert O. Barton.}

Madison, Wis., Nov., 1913.

With great persistence several of my friends have urged me to write the story of my life. Again and again I have refused largely for the reason that the constant use of "I" is distasteful to me. I have, however, finally yielded to the importunities of my friends and Mr. Barton has already transcribed enough to make many installments in "Amerika". In autobiography the narrator becomes the center around which the story is gathered and told. He appears to be the chief actor in episodes, where he was in fact a mere supernumerary. It is difficult to draw the line, but an effort will be made to keep the author in abey- 
ance and rivet the attention of the readers not only to incidents with which he has been more or less personally identified, but more particularly to events of which he has been the observer.

While I shall at all times do my best to tell the truth and hew close to the line, letting the chips fall where they may, it is my purpose to bestow praise without flattery and find fault without malice.

My friends know that I am approaching the three score and ten and probably feel that if this work is not done now it will never be done at all.

I consider myself exceptionally fortunate in getting so competent a transcriber as Mr. Albert O. Barton. Mr. Barton is himself of Norwegian parentage, a graduate of the university of Wisconsin and a journalist of many years experience. He was for some time Senator LaFollette's private secretary and assisted the latter in the preparation of his autobiography.

Rasmus B. Anderson. 



\title{
LIFE STORY OF RASMUS B. ANDERSON
}

\section{CHAPTER I.}

\section{FAMILY HISTORY.}

\author{
Bellum Vita-Vita Bcllum. \\ War is Life and Life is War. \\ Der, hvorom intet er at stride, er \\ heller ingen seir at vinde.
}

Adopting the conventional form of autobiography, I will begin by saying that I was born in the town of Albion, Dane county, Wisconsin, January 12, 1846. My father was Bjorn Anderson Kvelve, born in Vikedal, Norway, June 3, 1801 ; died in the town of Albion, Dane county, Wisconsin, August 10, 1850. My mother's maiden name was von Krogh, her full name before her marriage being Abel Catherine von Krogh. She was born in Sandeid, near Vikedal, Norway, October 8, 1809. She died October 31, 1885, at the home of her daughter, Mrs. T. A. Torgerson, near Bristol, Worth county, Iowa, where she had made her home for the eighteen years previous to her death. My father was of the peasant class, a man of great energy and ambition, and before coming to this country owned a small farm in Vikedal, a short distance north of Stavanger. The farm name was Kvelve. 
My mother was of a prominent military family which by various intermarriages had been connected with many other of the more prominent families of the country, including royalty. The von Kroghs had come into Denmark from Germany about 1640 and the military annals of Denmark and Norway from that time on show many officers bearing that name. My mother's grand uncle, General George Frederick von Krogh (born 1732, died 1816), was commander in chief of the Norwegian army. He lived in Trondhjem where he owned the magnificent house at which King Haakon stopped when he came to Trondhjem to be crowned. This house was built by his son's mother-in-law, Mrs. Scholler. The son went to Denmark and gave the house to his father. I have now in my possession General von Krogh's cane which bears part of the coatof-arms of the family. Later a cousin of my mother commanded the Danish army at Isted, the chief battle in the first war with Prussia in the ' 40 s.' Her father, who had been an officer in the war with Sweden in 1808-9, had been wounded. On being retired and pensioned he had bought a farm at Westbo, in Sandeid, and it is probable that my father and mother first met at church there. My mother's decision to marry a peasant was an offense in the eyes of her more aristocratic family, so their marriage was somewhat in the nature of a misalliance. They were married in July, 1831.

But she had further offended by marrying a dissenter from the established church. My father belonged to the Society of the Friends. During the Napoleonic wars a Norwegian ship was captured and taken to England, the Danes and Norwegians at this period being friendly to Napoleon. In England the captives fell in with the sect of Quakers, who treated them with the greatest kindness. Eventually the prisoners accepted the faith of the Friends.

After the battle of Waterloo they were returned to Norway. Most of these captives were from Stavanger and on their re- 
tem they organized a Quaker congregation in that city. Religious freedom had not yet been established in Norway, so the little society had much trouble with the government. It was not until in the ' 40 s that the harsh laws then prevailing were abrogated, thus giving full religious freedom. A large book was written in English on the persecutions to which these Norwegian Quakers were subjected.

My father had become acquainted with these Quakers. $\mathrm{H}_{\mathrm{c}}$ owned a small coasting vessel and in addition to attending to his farm he carried on a coasting trade, carrying fish, produce, etc., to Stavanger and bringing back goods. At Stavanger he met the Quakers and eventually identified himself with them, thus becoming a dissenter. This was in the middle of the '20s.

My father was a born agitator and frequently stirred up trouble by urging his views, and this fact combined with the displeasure my mother had created in her family by her marriage, made their life less agreeable than they had hoped it would be. My father sought to cheer his wife by telling her of the land beyond the seas where they might freely hold whatcver views they chose and where class distinctions were not so pronounced and offensive. If necessary to their peace, he said, they could go there.

Finding the persecutions and ostracisms to which they were subjected unendurable, the Norwegian Quakers in 1821 determined to raise a fund and send two men to America to find them land and homes in the new world. The men sent out were Kleng Peerson and Knut Eide. Eide died while in America on this journey, but after three years Kleng Peerson returned (1824) and gave a glowing account of what he had seen and heard in America. He had met a party of Friends in New York and these had proposed to find homes for the Norwegian Quakers in Orleans county, New York, on the shores of Lake Ontario, north of Rochester. Accordingly these Quakers in 1825 combined and purchased a small sloop 
which they ballasted with iron and on July 4, 1825, the first little Norwegian emigrant party sailed out of the harbor of Stavanger, bound for New York, where they landed Octoler 9, having been a little over three months at sea. Their vessel was "Restaurationen", which may thus appropriately be called the Norwegian Mayflower. There were 52 members in the party which set sail, but 53 in the party that landed, a girl baby having been born at sea. This sloop baby is Mrs. Margaret Atwater of Western Springs, Ill., still living at a hale old age, the only other survivor of the sloop pariy at the last reports being Mirs. Hulda Olson of Sheridan, La.Salle county, IIl., who came as a child on that eventful voyage.*

After adjusing some trouble they had with the American authorities because of the overloading of their boat, the immigrants landed and were received by the Quakers of New York, who helped them to their destination in Orleans county. They settled at Kendall and there descendants of members of this sloop party may yet be found.

In 1833 Kleng Pcerson left the Kendall settlement and went west. About 80 miles west of Chicago he located what has since become known as the Fox River settlement. He found a desirable tract of land in LaSalle county and on his recommendation many of the settlers at Kendall moved with their families in 1834 to the new home and founded the first Norwcgian settlement west of the lakes and the second in this country. It is still a flourishing Norwegian community.

My father had kept in touch with the sloopers which developed in him the resolution to emigrate, and on the basis of the reports received from America he began to agitate emigration in the community. He found a number of neighbors willing to go and then went to Stavanger and persuaded a ship company to equip a vessel to take a load of emigrants to New

\footnotetext{
*Since this was pulished in "Amerika" Mrs. Hulda Olson has passed away.
} 
York. However, before they were ready to embark so many others wanted to go that it was necessary to fit out a second ship. Accordingly, two Kohler brigs, "Norden" and "Den Norske Klippe", left Stavanger in the spring of 1836 loaded with emigrants bound for New York. My faiher was generally regarded as the leader of the party.

Miy father and mother and their two sons, Andrew and Bruun, were passengers on the "Norden". There were about 150 passengers on the iwo vessels. These were all bound for the Fox River settlement in LaSalle county, Illinois, but my father and his family left the party at Rochester, N. Y., where they spent the summer and the following winter, my father obtaining employment in the city as a cooper.

The next year, 1837, my father and his family moved to the Fox River setulement, where they remained for the next three years. However, not liking the conditions there, my father, in 1840, went northwards with three companions and crossed the Rock river into what is now the town of Albion, Dane county, Wisconsin. There he found such conditions as he liked and June 22, 1840, bought 80 acres of government land, being thus among the very first of Norwegians to enter land in Dane county. His entry was the west half of the southeast quarter of Section 1. The township had then no name, but with the arrival of a colony of English Primitive Methodists in 1844 it was given the name of Albion.

My father built a log cabin and the next year, 1841 , brought his family to its new home. My mother was the first white woman to live in the town, and my sister Martha was the first white clild born there. At that time the Indians had a camp on my father's land and the nearest white woman that my mother could visit was at Milion, iwelve miles away.

My father was greatly interested in education. Besides spending much time in teaching his children himself he twice employed private teachers for that purpose. One of these by 
name Corneliuson later became register of deeds of Dane county. I Ie spent one winter at my father's house and taught the children for his board. The other tutor employed was Gabriel Bjornson, who also later became a county official. Neither of them was then married. Also while the settlers were discussing the building of a school house my father cut logs and hauled them to the roadside and built the frrst school house largely at his own expense. It was donated to the district. Here was the only district school that I ever attended. The school house was used for many years, after which my mother bought it and had it moved on the old home farm where it is still standing.

My parents had the usual experiences of pioneer life, my father raising wheat and hauling it to Milwaukee and my mother making all the clothes for her children, besides meetirig her many other household duties. They had begun to prosper and my father had purchased more land and all looked very encouraging for the future when he was suddenly cut of by cholera. This dreadful scourge swept through the settlement in the summer of 1850 and for a time it was feared it would wipe out the community. Practically every home was tumed into a bouse of mourning. In one nearby family all the members died except two little girls. One of these girls later becarne Mrs. Ole Melaas of Stoughton, Wis. All of us in our family also came down with the disease, but my father and my second eldest brother Bruun, then sixteen years old, were the only ones to die. My brother died August 6 and four days later my father passed away. As I was only four years old at the time of my father's deaih, I have only a faint recollection of him, but I remember sitting by his sickbed and fanning him to drive away the flies. A neighbor, Ole Teigen, father of Dr. K. M. Teigen, the well known Norwegian-American writer, made coffins for my father and my brother and buried them. My father had set aside a corner of his farm for a private 
cemetery and here he and my brother were buried. There also is buried my mother, my stepfather and my own first child and there $I$ expect to be laid to rest. A monument and an iron fence mark the little burial ground.

My mother was left a widow with eight children, but bravely remained on the farm and held her family together until the older members were able to go out and make their own way in the world. In 1854 she was again married, her second husband being Ingebright Amundson from near Stavanger, Norway. He died in 1860, leaving one son, now Dr. A. C. Amundson of Cambridge. Of the children in our family a few words may here be said:

My oldest brother, Andrew, was born in Norway in 1832, so he was eighteen years old when our father died. Being ambitious, he left home and became a sailor on the great lakes, becoming in time chief steward on a propellor running between Milwaukee and Buffalo. After some years he became tired of sailing and when the railroad was built to Edgerton, Wis., near our home, he opened a general store at that place. Not prospering here, he went to Milwaukee and became a clerk in the large drygoods house of Candee, Dibble \& Co. After clerking some years he married a Swedish lady of that city and in 1861 opened a store of his own in Milwaukee. He was nearly ruined by the war which then broke out and tried to enlist, but as he had once frozen his feet while out hunting and had thus lost a toe he was rejected. Soon afterwards he removed to Goodhue couniy, Minnesota, where he is still living and where he has become a prosperous farmer and raised a large family.

Elizabeth, my oldest sister, was born in LaSalle county, Ill., in 1837. She married a pioneer farmer of Goodhue county, Minn., named Hans Danielson. He served in the Indian war in Minnesota in 1862 and lost a leg. He died three years ago leaving a large family. My sister is still living.

Cecilia, who was also born in LaSalle county, Ill., was mar- 
ried to Rev. S. S. Reque, who died some years ago while pastor at Spring Grove, Minn. My sister died about a dozen years ago. They also had a large family.

Martha, while on a visit to our sister Elizabeth in Minnesota, was married to a Dane named Lewis Johnson, who is a leading farmer there.

Dina was married to Rev. T. A. Torgerson, who died a half dozen years ago in Worth county, Iowa, having been for many years president of the so-called Iowa district of the Norwegian Synod. She is now living with her son, August, who succeeded his father as pastor.

I was the next in the family and then came Abel, who is now a Lutheran minister at Montevideo, Minn. He was educated at Albion academy, the University of Wisconsin, Decorah and St. Louis.

Bruun, now known as Brown, is a prosperous merchant at Spring Grove, Minn.

Dr. A. C. Amundson, the youngest of the family, is a physician and bank president at Cambridge, Wis.

All of us except Andrew attended Norwegian parochial school and were prepared for confirmation. If my father had lived we would probably all have been brought up as Quakers. The children who had been born in Norway had been baptised there according to law. When my father died the other six children had not been baptised.

It is interesting to note here that the first Scandinavian Methodist was a Dane named Christian Willerup. He had been ordained as a Methodist minister and became active in promoting the faith. He came to Cambridge, Wis., in the early ' 40 s and went among the Norwegians in and around Cambridge making proselytes and there he organized the first Scandinavian Methodist society in the world. Here he and his congregation built a stone church, which in remodeled form is still standing. 
Jenny Lind, the famous Swedish songstress, contributed $\$ 200$ to this church.

Willerup came to our home and succeeded in persuading my mother that the children ought to be baptised, so the whole flock received baptism on the same day.

After founding the church at Cambridge, Willerup returned to the old world to promote the cause of Methodism in Denmark and Norway. He was very successful in his efforts and was made superintendent of the Methodist church in the countries of Denmark, Norway and Sweden. After he had baptised us I did not see him again until I went to Copenhagen as United States minister in 1885, when one of the first things I did was to look him up. He was then old and crippled and had largely lost his memory. His wife was younger and more vigorous and tried to have him recall the occasion when he baptised a whole family of children in America, but we received only a smile in return. Soon afterwards he died.

The church founded by Willerup at Cambridge became the nucleus of Methodist work among the Scandinavians which has grown to large proportions among the Danes, Norwegians and Swedes on both sides of the Atlantic. Norwegian Methodist congregations now exist at Cambridge, Stoughton, Milwaukee, Chicago and various other points in the northwest. The Norwegian-Danish Methodist church has a professorship at the Northwestern university at Evanston, Ill., and also publishes a church paper in Norwegian. The name of the paper is "Den Christelige Talsmand".

Having been baptised by Willerup it would have been natural to expect that we should join the Methodist church and this might have happened had not my mother been connected by marriage with the wife of Rev. A. C. Preus.

As has been indicated, the sloopers of 1825 were nearly all Quakers. A few of the immigrants who came in 1836 were also Quakers. Those who remained in Kendall had regular 
Quaker worship, but those who came westward were too scattered and not numerous enough to organize a Quaker church. Many of the Norwegians of the LaSalle county settlement were also influenced by Mormon missionaries and one of the sloopers named Haukaas became a high priest of Melchisedec in the Mormon church. Lay preachers of various kinds traveled through the settlements, each holding services in his own way.

Most of the Norwegian settlers of this period, however, were known as Haugianere or followers of Hans Nilsen Hauge. Early in 1839 Elling Eielsen came to America from Voss and exercised a great influence. He had been a lay preacher before leaving Norway and after coining to America he gave all his time and energy to preaching the gospel among his countrymen. In 1842 he built a meeting house in the town of Norway, LaSalle county, Ill., and this was the first building put up for church purposes among the Norwegians in this country. Eielsen had himself ordained by a Rev. F. A. Hoffman, at Duncan's Grove, twenty miles north of Chicago, October 3, 1843, and in that way he became the first ordained Norwegian Lutheran minister in this country.

Eielsen founded a church of his own which grew into a large organization, but in the ' 70 s a rupture occurred in this body and the majority then assumed the name of the Hauge Synod, with headquarters at Red Wing, Minn., where it has a large school. A small minority remained loyal to Eielsen, claiming to be the original Eielsen organization. This body still exists, having about a dozen ministers, but more than twice as many congregations. The president of the body, Rev. S. M. Stenby, lives in Clear Lake, Iowa.

The firsi work toward establishing what is now known as the Synod of the Norwegian Evangelical Lutheran church of America was done by C. L. Clausen.

Claus Lauritz Clausen was a Dane. He was born Novem- 
ber 3, 1820, on the island of Erö, Fyen Stift, in Denmark, and he died in Paulsbo, Washington, in 1892.

In 1841 he came to Norway to seek work in the missionary field in South Africa, but he found that there did not seem to be an opening for him in that direction. Tollef $\mathrm{O}$. Bache, a merchant in Drammen, whose son Soren, with Johannes Johannesen, had settled in Muskego, Wis., and was anxious to send a teacher to America in order that his own grandchildren and other children growing up there might be properly instructed in the religion and language of their fathers. Tollef Bache's attention had been called to this young man, Clausen. A proposition was made and Clausen accepted. He first went to Denmark, and married Martha F. Rasmussen, and then prcceeded to his new field of work in Muskego, where he arrived with his young wife in August, 1843.

After arriving in Muskego it seemed to him and to the people of Miuskego that his services were more needed as a preacher than as a teacher, and accordingly he was called as preacher, duly exarnined by a German Lutheran minister by name L. F. E. Krause and ordained by him on the 18th of October, 1843, just fifteen days after Elling Eielsen had been ordained. Clausen at once Legan to preach in Even Heg's barn, in the houses of the settlers and in school houses. On the second Sunday after Easter, 1844, he confrmed the first class of children in Even Heg's barn. This was the first Norwegian Lutheran confrrmation in America. In the fall of 1843 the congregation (sit venia verbo) decided to build a church. Heg gave the ground on the so-called Indian Mound, and here the church was built. Tollef Bache in Drammen contributed $\$ 400$ to the church, and the building of it was begun early in 1844 . The dedication took place March 13, 1845. It was the first Norwegian church built in America.

Clausen was a strong and interesting character. He was a 
leading figure in the Norwegian Synod for years and president of that body, but in the ' 60 s he became involved in a bitter controversy with his brethren over the slavery question. The Norwegian pastors, influenced by the German Missouri Synod with headquarters at St. Louis, had taken up the defense of slavery which led Clausen to sever his connection with the Synod in 1868. From that time on he was connected with the Norwegian-Danish conference, another Lutheran body. He was also instrumental in founding the second newspaper among the Norwegians of this country at Inmansville, Rock county, Wis., where he was pastor for a time. The paper was known as "Emigranten".

In the early ' 50 s he moved to Mitchell county, Iowa, where he founded a new Norwegian settlement and the town of St. Ansgar. Here also he built churches. He served as a member of the Iowa legislature and during the civil war was chaplain for a time of the Fifteenth Wisconsin regiment, known as the Norwegian regiment. After the war he was particularly active in the controversy over the doctrine of slavery which had not yet been repudiated by the Norwegian Synod and for that matter has not yet been definitely disavowed. Its practical defense of slavery did the Synod much harm. When the question came up for the last time at the Synod meeting in Chicago in 1868 and where it was again practically endorsed Mr. Clausen and I and a couple of other delegates walked out of the meeting and Clausen was never afterward connected with the Synod.

It was known in Norway that a considerable number of Norwegians had located in the southeastern part of Dane county in what is still called in church parlance East Koshkonong, West Koshkonong and Liberty Prairie, so a number of persons in Norway raised a fund and induced Rev. J. W. C. Dietrichson, a minister known to them, to go to America to organize the Lutheran church there. He left Norway in the brig Washington 
May 16, 1844, and landed in New York July 9. After preaching iwice to the Norwegians, Swedes and Danes of New York he came westward to the Muskego settlement where he stopped a short time with Rev. Mr. Clausen, whose ordination he recognized as regular in every respect. Late in August he proceeded to Koshkonong where he at once began preaching and organizing congregations. $\mathrm{O}_{\mathrm{n}}$ October 10 he organized the socalled East Church in the town of Christiana and on October 13, the so-called West Church, in the present town of Pleasant Springs. The following year he returned to Norway where he remained for a year and during his absence his congregations at Koshkonong were served by Mr. Clausen. In 1846 he came back to Wisconsin and remained until 1850 when he relurned to Norway to remain.

During his last four years in this country, besides serving his lwo congregations at Koshkonong, he visited the various localities where Norwegian settlements had been established, such as Bluc Mounds, Primrose, Wiota, Rock county, Fox River (IIl.) and Chicago, preaching to the settlers and making efforts to gather them into organized congregations.

In 1850 he was succeeded by Rev. A. C. Preus, who was also a regular graduate in theology of the University of Norway and had been ordained by a Norwegian bishop. Other ministers also soon came from Norway to serve the congregations partially organized by Mr. Dietrichson in the newer settlements. By 1853 these ministers and congregations felt strong enough to get together and organize what is known as the Norwegian Synod, at present divided into five districts. A meeting for that purpose had been held in 1852 at the parsonage on Koshkonong and the next year (1853) another meeting was held at Immansville, on Rock Prairie, where organization was effected.

Now it so happened that Rev. A. C. Preus was married to a granddaughter of the distinguished Norwegian bishop and 
poet in Bergen, Johan Nordahl Brun, one of the most eminent preachers and poets of his day. My mother's aunt was married to a son of Bishop Brun, a minister at Fjeldberg, near Bergen, a parsonage where my mother was an occasional visitor before her marriage. It will be seen, therefore, that my mother and Mrs. Preus were quite closely connected by marriage, and the further fact that they were many thousands of miles from Norway brought them together as if they were sisters. As our home was only three miles from the Preus parsonage they were able to see each other frequently. While my father had not only refused to take part in organizing the Norwegian congregation, but, being a born agitator, had done all in his power to throw obstacles in Mr. Dietrichson's way, it was nevertheless perfectly natural that my mother, who had never become devoted to the religion of the Friends and who had now had her children baptised by a Methodist, should find it easy to become a member of Mr. Preus' congregation.

Mr. Dietrichson was highly educated and scholarly and was considered a very able minister. At the same time he was strict and overbearing. He was also thought to be avaricious. In regard to this charge made against this distinguished pioneer preacher, the late John A. Johnson, founder of the Gisholt Machine company, frequently told the following story:

As a boy preparing for confirmation he lived at the Dietrichson parsonage doing chores for his board. One day an American stopped at the parsonage to call on the pastor and recquested young Jens (Jens Shipnes, later changed to John A. Johnson) to hold his horse for him. When the American left he handed the boy a dime. This was observed by the pastor, who promptly took it from the boy and kept it.

The following story illustrates his severity and strictness as a pastor:

In building the East Koshkonong church it was agreed among the members that each one should furnish his share of 
logs hewn ready to put into the walls, and each one should contribute a number of days work. In this way the church was built and roofed. It had no seats, however, so it was further agreed that each father of a household should bring two benches, one for the men's side of the church and one for the women's side. Among the settlers then living on the banks of Koshkonong creek was one Peter Funkeli. His conduct was not above reproach in the eyes of his pastor, who had now and then found it necessary to discipline him. When persuasion no longer served the purpose Mr. Dietrichson determined to exercise his authority in accordance with the rules of the church of Norway. He decreed that for a number of services Mr. Funkeli should occupy a seat on a bench next to the entrance door. This was to be his punishment. The next Sunday Mr. Funkeli came late to church and disregarding the order of the pastor took his seat on the bench which he himself had furnished and which was the first one in front of the pulpit, suspended on the south wall. Mr. Dietrichson stopped preaching, spoke to Funkeli and requested him to go back and take his seat near the door. Funkeli paid no attention to the order. The pastor insisted on obedience. Funkeli replied that the seat on which he was sitting belonged to him and he refused to leave it. Dietrichson then left the pulpit and called the wardens to come to his assistance in putting the rebellious member out of the church by force. Dietrichson, who was a powerful man, assisted the wardens and Funkeli was finally ejected although he resisted vigorously. Funkeli then went to my father and laid the matter before him. My father told Funkeli that he could prosecute Dietrichson for assault and battery. This suited Funkeli. An attorney in Cambridge named Isaac Brown was engaged and my father having by that time acquired considerable proficiency in the English language served as interpreter for the witnesses. The case was tried before Justice Stillman at Albion Center. Funkeli won his case and Dietrichson was 
fined $\$ 10$ and costs, a large sum in those days, and in accordance with what has been stated above an amount that must have looked quite large to the pastor. This happened on Dietrichson's first visit to America, in 1845, just before his first return to Norway. While in Norway in 1845-46 Dietrichson wrote a book of considerable size giving an account of his experiences and his work among his countrymen in America. This book was published in Stavanger in 1846. In the '90s I reedited and reprinted it. The last pages of this book are devoted entirely to this Funkeli episode and Dietrichson tells that he had appealed the case to the circuit court at Madison, but that his attorney had neglected to attend to the case on time. The attorney, he said, arrived one day too late. Of course we know that the law abounds in technicalities.

Without going into the niceties of theology we might say that Dietrichson represented the church of Norway, the Norwegian Lutheran; but he was known to be somewhat influenced by Grundtvigianism. As poet, historian, theologian, Grundtvig was probably the greatest mind Denmark ever produced. $\mathrm{He}$ held the view that the only parts of the Scriptures that were inspired were the words instituting the sacraments, the Lord's prayer and the Decalogue, the remainder he considered as merely so much church history. With the Passages of the Bible which he held to be inspired he also included the apostolic creed or three articles of faith, which are not found in the Bible. Dietrichson was inclined toward somewhat the same views. 


\section{CHAPTER II.}

\section{FIRST SPLIT IN THE CHURCH.}

While discussing church matters it might be interesting to here note the first split in the Norwegian Lutheran church in this country. I have the story as it was told me by Hon. Gunnuf Tollefson of Primrose. If we go back to 1843 there were only two ordained ministers among the Norwegians in America -Elling Eielsen and the Dane, C. L. Clatisen. In the beginning these two were in harmony and worked together to build up that Norwegian-American Lutheran church which has since been split into half a dozen different organizations. The first split or division came about in this manner: On Jefferson Prairie, near Beloit, a little girl had been left an orphan by the death of her parents. Rev. Elling Eielsen took this little girl with him to Muskego and had her placed with a Roman Catholic family. For this he was severely criticised. Norwegian Lutherans could not understand how he could turn the child over to Catholic foster parents and the matter created a great deal of discussion and aroused considerable criticism and ill will. The affair finally came up before Mr. Clausen and his congregation in Muskego. In the meantime Eielsen doubtless coming to the conclusion that he had made a mistake went to the farm where the girl had been placed and in the dusk of the cvening kidnapped her while she was outside playing. But 
this only served to aggravate the case. Eilsen did not appear before the meeting and was declared guilty of two offenses, first of giving the child over to Catholics, and, second, of kidnapping. The result was that Eielsen and Clausen parted company and Eielsen founded his own church. I understand that the girl who was the innocent cause of this rupture grew up, was married and moved to northern Michigan.

NoTE.-Since the above was published in "Amerika" I received a communication from Rev. Erik O. Mörstad of Forest county, Wis. His article is published in full in "Amerika" for Feb. 27, 1914. The gist of Mörstad's communication is that Clausen and Eiclsen had never worked together and consequently there could be no split. I believe Rev. Mörstad is correct in his contention, and gladly accept his statements, well supported by evidence, as entirely satisfactory. We may, however, safely assume that the kidnapping incident would naturally have a tendency to make the separation more pronounced. 


\section{CHAPTER III.}

\section{BEGINNING OF THE NORWEGIAN-AMERICAN PRESS.}

From 1836 immigration from Norway increased quite rapidly, each year bringing one or two ships with immigrants, and by 1847 there were Norwegian settlements in LaSalle county, Ill., in different parts of Dane county, Wisconsin, and in the counties of Rock, Racine, Waukesha, Iowa, LaFayette and Columbia. But as yet there was no Norwegian newspapers among them.

The founder of the Norwegian-American press and of the first paper in any Scandinavian tongue on this side of the Atlantic was James De Noon Reymert. Mr. Reymert was born near Farsund, in Norway. His ancestors on his father's side came several generations back from Germany. Five of Reymert's forebears were Lutheran ministers. His mother was a Scotch woman, her maiden name being De Noon. James received a good education and at the age of twenty he went to Scotland to visit his mother's relatives. After a year in Scotland he went to New York. From New York Reymert soon went to look up his countrymen who had settled in the West and he at once located at Norway, Racine County, Wis. There he married a Miss Hansen, daughter of a teacher in dancing, who had lately arrived from Norway. In company with Even Heg, Reymert undertook in 1847 to publish a newspaper 
in the Norwegian language and founded at Norway, Racine county, "Nordlyset" (Northern Lights), a four-page, six-column paper, edited by Reymert. Even Heg was the father of the later Colonel Hans $\mathrm{Heg}$, who, as state prison commissioner of Wisconsin (1860-62), was the first Norwegian to hold a state office in the United States and who while prison commissioner organized the Fifteenth Wisconsin regiment (the Norwegian regiment) which he led in the bloody battle of Chickamauga in 1863 where he fell with a brigadier general's commisssion in his pocket. Reymert and Heg published their paper for a year and of this issue $I$ secured in the ' 90 s a complete bound volume from an old pioneer named Christopher Hanson then living at St. Ansgar, lowa. This volume, with a lot of other bound volumes of Norwegian-American newspapers, including a complete set of "Emigranten", I afterward turned over to the library of the United Norwegian Lutheran church connected with the theological seminary of this church at St. Anthony Park, Minneapolis.

I also reprinted in my paper "America" all the editorials found in this volume of "Nordlyset", the copy that I had being, so far as I know, the only one in existence. In this way I wished to make sure that its contents and the pioneer history it contained would be rescued from oblivion. Ait the end of the first year Heg and Reymert finding Norwegian journalism in this country to be unprofitable sold their printing plant to Knut Langeland and $O$. J. Hatlestad. Langeland in the ' 60 s became the first edicor of the widely known Chicago Norwegian newspaper "Slandinaven". He served one term as a member of the Wisconsin assembly in 1860 and also as a republican presidential clector in 1880 . Langeland had come from Norway in 1837, was a self-made man and became the ablest and most noted Scandinavian-American journalist of his time. O. J. Hatlestad became a preacher and later the president of the so-called Norwegian Lutheran Augustana Synod, which afterward be- 
came merged in what is now the United church and partly in what is known as the Free church.

Langeland and Hatlestad moved the "Nordlyset" printing plant to Racine, Wis., where they changed the name of the paper to "Demokraten" and continued its publication for a year (1848). Then they dissolved partnership, Langeland taking the plant and moving with it to Janesville, Wis., and in 1851 turned it over to the "Emigranten" which was that year launched at Immansville, near the present Orfordville, in Rock county. From 1851 until late in the '60s "Emigranten" was the leading Norwegian paper among the Norwegians of America. After having been published a few years at Immansville it was moved to Madison, Wis., and finally united with a paper at La Crosse known as "Fædrelandet". The founders of "Emigranten" were Rev. C. L. Clausen and K. J. Fleischer. After its removal to Madison C. F. Solberg, who is still living in Milwaukee, became its sole owner and editor.

To return to Reymert. He was an all-round business man and possessed great ambition. He built a plank road from Muskego to Milwaukee, started a saw mill and handled real estate. He read law by himself and was the first Norwegian admitted to the bar in Wisconsin. He was elected a member of the Wisconsin constitutional convention and helped frame the constitution of Wisconsin in 1847-8 and was a member of the first state legislature, which met in 1849. In 1854-55 he served as state senator and in 1857 was again a member of the assembly. Later we find Reymert in charge of the United States land office at Hudson, Wis., under appointment by President Buchanan and while there he was nominated for congress but failed of election. From Hudson he went to $\mathrm{New}$ York where he established himself as a lawyer and became one of the founders of the Hercules Fire Insurance company which proved a gigantic failure. On account of this failure he went 
to the Pacific coast where he entered into mining enterprises and acquired considerable wealth. He lived to a ripe old age and died at Los Angeles, Cal., about 1900: A nephew of Reymert's is at present a successful lawyer in New York City. 


\section{CHAPTER IV.}

\section{MORE FAMILY HISTORY.}

Resuming the thread of family narrative, I will say that our farm consisted of 210 acres and we all remained upon it until the children one by one were able to shift for themselves. The ambition of all seemed to be to go out in the world and become the architects of their own fortunes. My eldest brother, Andrew, had left home before my father died and gone with a couple of neighbors' sons of the same age to cut timber near Port Washington, a short distance north of Milwaukee. After that he became a sailor on the great lakes as heretofore stated. All the girls went out as housemaids, working for American families in Albion, Milton, Janesville, and other places, until they married.

When I was about thirteen years old Rev. A. C. Preus of Koshkonong and Rev. C. L. Clausen of St. Ansgar, Iowa, united in engaging a family tutor. They secured a university student from Norway by name Carl Johan Rasch, who gave the children instruction at the Koshkonong parsonage. Clausen sent his son Martin to be taught with the Preus children. Then as I had the reputation of being a bright scholar at the common school and also at the parochial school, where I was taught Norwegian and religion, Mr. Preus requested my mother and stepfather to let me attend this private school at the parsonage which was three miles from our home. I was eager 
to attend this school and for a whole school year I walked the three miles to school and back again six days a week. At this school I was taught the rudiments of Latin and German and received some lessons in general history. At the age of $14 \mathrm{I}$ was confirmed. Meanwhile the private school at the parsonage was discontinued. I was very anxious to attend Albion academy, which was only a short distance from our home, and had recently been founded, but my parents did not feel able to fumish me with the necessary funds. 


\section{CHAPTER $V$.}

\section{LEAVE HOME.}

That same year, 1860, my oldest brother had opened a store of his own on Spring street in Milwaukee. He offered me an opportunity to clerk for him for my board. He had recently married and established a home. Afterward he moved his store from Spring street to Reed street, Milwaukee, continuing the business for a little more than a year, when he sold out. Milwaukee was then a city of about 60,000 people. During the year or a little more that I spent in Milwaukee, I saw the great bank riot, the Germans and others attacking the banks to get out their deposits. The governor had to send militia to quell the riot. I also saw the first Wisconsin regiment in camp at the west end of Spring street, now Grand avenue, under Col. Starkweather. I saw this regiment leave for the front and heard Gov. Randall make a speech to the soldiers at the railroad station from the top of a freight car. During the presidential campaign of 1860 I saw the great wide-awake processions in oilcloth capes marching through the streets of Milwaukee carrying kerosene lamps. I also saw the candidate Stephen A. Douglas ride in a carriage drawn by four or six white horses from the railroad station to the front of the city hall. I stood quite near the platform while Mr. Douglas was speaking. In the midst of his speech the platform broke down. Fortunately nobody was hurt, but a cry went up from the republicans in the 
audience that the "Little Giant" was running for president on a poor platform.

Besides helping my broher Andrew in the store I engaged in the business of an apple peddler. Every day I filled my basket with apples and looked for my customers, partly on the Spring street bridge, but mainly in the offices of business men. I had Alexander Mitchell, the president of the Milwaukee Marine and Fire Insurance bank, as a frequent customer and thereby hangs a tale.

In the latter part of the '70s it was still customary for all people of any prominence-in office or out of office-to have railroad passes. In the city of Madison all the state officers, all the judges, all the county officers and city officers, including the aldermen and their families, had annual passes on the railroads entering Madison. With these passes they could go to Chicago or Milwaukee to do shopping or attend theaters and concerts. I had no pass. When Mrs. Anderson was asked to join some of the ladies with whom she was acquainted to attend some event in Chicago or Milwaukee she had no pass and consequently was unable to go. She finally took me to task by saying that if I was as smart as I pretended to be I'd have a pass too. Nettled by this I went to my library, determined to find a way of getting a railroad pass if such a thing were possible. I canvassed several schemes in my.mind, but finally settled on the following: Alexander Mitchell was then president of the Chicago, Milwaukee \& St. Paul railroad. As a boy 14 years old I had sold apples to him. Why not make use of this fact to secure a pass from him? I sent him a letter reading substantially as follows:

"Honorable Alexander Mitchell, ex-Member of Congress, President Chicago, Milwaukee \& St. Paul Railroad, etc., Milwaukee, Wis. Sir :

"Nearly twenty years ago a small white-headed Norwegian apple-boy was in the habit of calling on you at your 
office in your bank. If he happened to find you in good humor you would select with the greatest care, three beautiful red Spitzenbergs and pay the boy 5 cents and many a time you made that boy happy. That little white-headed apple-boy was I, sir, and I am now a professor in the University of Wisconsin and am drawing a great salary. I have, also, as you may have observed perpetrated on the public sundry books which are returning me immense dividends in the way of royalties. The facts are, Mr. Mitchell, that my income has of late become so alarmingly large that I have been seriously puzzled as to how to get my surplus funds properly invested. But I have finally decided to invest these surplus funds in a private railroad from Chicago to Madison via Milwaukee. Now please do not become alarmed, Mr. Mitchell, as my private road is not to enter into serious competition with the great Chicago, Milwaukee \& St. Paul road, but mine is to be a splendid railroad in all its appointments. I shall have a perfectly level and well ballasted roadbed. I shall have the most modern locomotives and most skilful engineers. Mine shall be all palace cars and dining cars with the most careful, courteous and accommodating conductors and attendants.

"And now, sir, when this projected road of mine is completed it is my intention to give to yourself and lady an annual pass as a token of recognition of your kindness to me as an apple-boy and I shall never forget to renew it every new year's day. But now it has occurred to me that, inasmuch as it will take some little time before this projected road of mine will be completed, you might be willing to let me and my wife ride on your lines in anticipation of all the magnificent rides you and your lady are to have on mine."

Well, the letter brought from Mr. Mitchell a pass for Mrs. Anderson and me and this pass was renewed every January as long as Mr. Mitchell lived. He had a folder map in which he preserved this letter of mine as a curiosity, having it tied up with 
silk ribbons. Then he invited Mrs. Anderson and me to make his house our home whenever we came to Milwaukee. He assigned to us what he called the "red room" in his mansion and placed his coach and driver at our disposal. I do not think Mr. Mitchell remembered buying any Spitzenbergs from me, but he made up his mind that he remembered it and took great pains to introduce me to his various acquaintances as one whom he had befriended as a boy. When he lacked one for a game of euchre he would telegraph to Madison for me to come to Milwaukee and help out.

I lived with my brother in Milwaukee until he sold out, or about a year. Among the other interesting circumstances connected with my life there I may mention that I narrowly escaped being a passenger on the Lady Elgin when she went down off the shore of Waukegan, causing the greatest marine disaster in the history of the great lakes. I had arranged to go on that excursion which proved fatal to so many, but an Irish girl whom I was to escort to the boat was so long in dressing that when we arrived at the pier the boat had just pulled out. I afterwards went to the depot and saw a whole car-load of dead bodies unloaded.

In Milwaukee I was present at a meeting in Stamm's hall on the south side called by Hans C. Heg for the purpose of getting volunteers for the Fifteenth Wisconsin regiment. Hans C. Heg had twice been elected state prison commissioner at Waupun, an office which at that time was elective. He was the first Norwegian-American to be elected to a state office in this country. He resigned the office for the purpose of organizing a regiment to help put down the rebellion. He succeeded in raising the regiment, became colonel and fell at the battle of Chickamauga. Mr. Heg impressed me as a fine-looking, eloquent man and very earnest and enthusiastic.

My brother Andrew sold out his business on Reed street in 
Milwaukee to Hatlestad, Hjelm \& Ole Heg. Hatlestad was a brother of Rev. O. J. Hatlestad and Ole Heg was a brother of Col. Heg. Ole Heg afterwards became a sutler in the 15 th regiment. I was engaged as clerk in the new firm and continued in their employ for a few weeks. Then, I presume in October, 1861, I one day met a stranger on the Walker's point bridge (the whole south side was called Walker's point then). He spoke to me and asked me whether I knew of any boy that could speak Norwegian. I informed him that my parents were Norwegian and that I was able to speak the language. He then told me that he had a general store in La Crescent, Minn., across the Mississippi from La Crosse, and that he needed a clerk that could speak the Norwegian language. This man was W. H. Merrick. His father was a prominent attorney in Milwaukee, having an office on the northwest corner of East Water and Wisconsin streets. I indicated a willingness to go to La Crescent and so he took me to his father's office where a contract was made and I received a railroad ticliet from Milwaukee to La Crosse, agreeing to leave Milwaukee that night. I returned to my employers, informed them what I had done, obtained their consent and took the train the same evering for La Crosse. This ended my career as a clerk and apple-peddler in the metropolis of Wisconsin. I had scen more or less of Milwaukee life and the city having at that tine already a large German population, I had availed mysclf of cvery opportunity to acquire a spcaking knowledge of the German tonguc. In fact, I may say without boasting that the day I leit Milwauke I could speak with about equal fluency English, Norwegion and German. 


\section{CHAPTER VI.}

\section{LEAVE MILWAUKEE.}

Early the next morning I landed in La Crosse where I took a ferry boat for La Crescent which became my home until New Year's. During my whole stay there I had the annoyance of not being able to get the points of the compass correct. Every day the sun rose in the west and set in the east. Wisconsin was on the west and Minnesota on the east side of the Mississippi. I knew this was wrong, but it was utterly impossible for me to get the matter righted.

A large part of the little town La Crescent consisted of a colony of southerners from Cape Girardeau, on the Mississippi, below St. Louis. They had moved away from their southern home on account of the war of the rebellion and had taken with them their personal property including some of their slaves. They seemed to be living in easy circumstances and had negroes, both as male and female servants. These southerners were Baptists and in La Crescent they had built a church and also what may be called an academy, or more properly a select school. The pastor of the congregation and also the principal of this select school was a young man by name Sheldon Jackson.

Right here I want to make a digression. In course of time Sheldon Jackson had become the head of the educational department for the aborigines of Alaska, at Washington. As such 
official he made annual visits to the different parts of Alaska and made investigations as to what the government could do to improve the conditions of the Eskimos, physically, intellectually, morally, and, I may perhaps add, spiritually. On my return from Denmark in 1889 I read a report written by Sheldon Jackson, giving an account of the vast amount of reindeer moss growing, especially in the northwestern part of Alaska. This moss covered the country ankle deep and there were then no reindeer in the country to make use of it. It was claimed there was sufficient moss to support millions of reindeer. Jackson had decided to import a few reindeer from Siberia, on the other side of Bering strait, and some natives of that country as herders, in order to start a reindeer industry among the Eskimos. He tells this story, that in bringing a small herd of deer from Siberia in a government ship the officers of the boat were delighted to get reindeer milk for their coffee, but when they afterwards found that the Siberian herders to milk the decr threw the animal on the ground, sucked the milk from the teats with their mouihs and then spit it into a cup, they preferred thereafter to drink their coffee black. The fact is that the $\mathrm{Si}$ berian reindeer are only half domesticated and their herders are less than half civilized. One winter while minister to Denmark I made a journey with my friend Dr. Frantz Moeller of cod-liver oil fame to the land of the mid-day moon, that is to say: to the Lofoten islands and Lapland. I went principally to make an investigation of the cod-fishing and the cod-liver oil industry in the Lofoten islands, but I also had an opportunity of visiting a number of camps or villages of Lapps. I found that the Lapland reindeer was thoroughly domesticated and that the Lapps themselves were highly civilized. They had for generations been converted to the Lutheran religion, were organized politically and ecclesiastically and had churches and schools; their children were all confrrmed and could read and write. But while the reindeer moss was growing ankle decp in Alaska it 
was continually growing more and more scarce in Lapland and the Lapps were compelled to flit from one place to another to find a scant subsistence for their valuable herds of reindeer.

Having read this report on Alaska it occurred to me that if our government wished to introduce the reindeer industry in Alaska it would be better to get both the animals and the herders from Lapland than from Siberia. I therefore went to Washington and laid this matter before the chief of the United States educational department.

In that office I found Dr. Sheldon Jackson and in the course of our acquaintance we discovered that we had perhaps known cach other in La Crescent, Minn., in the autumn of 1861 . I remembered that I had attended his church and he remembered that there was a white-headed Norwegian boy clerking in Merrick's store. Dr. Jackson, who was the chief of the educational department, accepted my suggestions with the greatest enthusiasm and decided to carry them out as speedily as possible.

Sheldon Jackson authorized me to find a suitable person to go to Lapland for a colony of Lapps. I selected Mr. William Kjellman, a man then living in Madison, Wis. He was born and raised in Hammerfest, Norway, and had had extensive dealings with the Lapps, being also able to speak their language. He proceeded at once to Washington where he received his government appointment and instructions and went thence directly to Karashok and Kautekeino, in Lapland. He secured a permit from the government authorities of Norway and engaged several families, with their children and their dogs, to spend three years in Alaska to teach the Eskimos how to take carc of reindeer. At the end of three years our government agreed to return them to their homes. On their way to Alaska they camped for a few days in Madison, Wis., and then proceeded to the coast to continue by steamer to their destination. These Lapps being members of the Lutheran church, the government agreed to send with them a Luth- 
eran pastor and teacher. Dr. Sheldon Jackson left it to me to select the pastor. I turned this matter over to Rev. H. A. Preus, Columbia county, Wis., the president of the Norwegian Synod and he recommended Rev. T. L. Brevig, then of Hudson, Wis., to take this position. Mr. Brevig went with the Lapps and served for some years as their pastor, the instructor of their children and so far as he was able as their physician.

Before leaving Madison one couple of these Lapps werc united in wedlock by Rev. Mr. Brevig. Mr. Kjellman and the Lapps soon found that the Siberian reindeer were not serviceable and that their domestication would probably take several generations and so the government sent Mr. Kjellman back to Lapland the following year to purchase a shipload of rcindeer and bring them to Alaska. This he did, but there were unexpected delays on the journey and at Sitka, in Alaska, more than half of his herd perished from want of suitable fodder. The remainder were brought to their destination and became the nucleus of the now exceedingly prosperous reindeer industry in Northwestern Alaska, where a number of reindecr are also used in the mail service as mail carriers. Mr. Kjellman and a couple of these Lapps were among the first to discover gold at what is now Nome City. They returned to the United States with their coffers well filled with this precious metal. One of the Lapps sent $\$ 80,000$ to a bank in Tromsö, Norway. The Lapps finally returned to their native land.

The Norwegian Synod is still maintaining its mission among the natives at Teller station, Alaska. Sheldon Jackson died several years ago. 


\section{CHAPTER VII.}

\section{HALF WAY CREEK.}

While I lived at $\mathrm{La}$ Crescent there came to attend this Baptist select school or seminary a young boy from Houston, Minn., by name Even Homme, who was destined to acquire considerable prominence among the Norwegian-Americans. He became the founder of that group of charitable institutions in Wittenberg, Wis., including an orphan home, a home for the aged, factories for supporting them, manufacturing pulpits, etc., a printing establishment, a church and various other things. This boy Homme and I usually spent our Sundays together, taking long walks over the high bluffs along the Mississippi rear La Crescent.

My stepfather had died in the year 1860 , at the old home, in Albion, before I left Milwaukee. In the fall of 1861 the Norwegian Synod had opened a sort of academy at Half Way Creek, in La Crosse county, Wis., about a dozen miles north of La Crosse, and a few miles north of Onalaska, at the parsonage of the Half Way Creek congregation. This was the first institution of higher learning established by the Norwegians on this side of the Atlantic. It was domiciled at this parsonage for one year and then moved to Decorah, Iowa, and was thus the beginning of the now widely known Luther college of which I am listed as the first graduate. The teachers at Half Way Creek were Prof. Laur. Larsen and Prof. F. A. Schmidt, the latter a German. 
Prof. Larsen was the president of Luther college for more than forty years and is still living at Decorah, being at this writing past 80 years old.* Prof. Schmidt later became professor of theology and has for many years been one of the faculty of the theological seminary of the United Lutheran church at Minneapolis. He still lives at Minneapolis as a professor emeritus, giving occasional lectures at the seminary.

At the Half Way Creek school there were in all sixteen students during the year though not that number at any one time. A part of them went home for the Christmas holidays and did not return and others took their places during the winter and spring term. Of these sixteen eight are dead, the eighth death being that of John Ollis in Madison, November 16, 1913. Eight are still living and so far as I know all prosperous and in reasonably good health. These eight are: Rev. Olaus Norman of Ashby, Minn., Ole Vik of Brooton, Minn., Mr. Evans (Folkestad) of Alexandria, Minn., Eilif Olson of Canton, S. D., P. P. Iverslie of Minneapolis, Minn., B. Hovde of Manitowoc, Wis., Lasse Bothun of South Dakota and R. B. Anderson.

After my stepfather's death our Koshkonong pastor, Rev. J. A. Ottesen, urged my mother very strongly to send me to Half Way Creek. He knew that I had been taught the rudiments of Latin, German and some other branches at the home of his predecessor, Rev. A. C. Preus. Immigration from Norway was increasing rapidly. A great number of new congregations were being organized and there was consequently a greater need of ministers than could be supplied by the University of Norway. The purpose of the school at Half Way Creek and Decorah was chiefly to educate young men for the ministry, and I presume Rev. Otteson thought that there was timber in me out of which to make a Lutheran clergyman. I

* Since the above was written, Prof. L. Larsen has died. 
am sorry to add that in this he was greatly mistaken. My mother was easily persuaded by $\mathrm{Mr}$. Otteson and so about Christmas, in 1861 , I received a letter from home informing me that there was place for me at the school at Half Way Creek and urging me to proceed thither at once. I did not need to be asked twice, because to go to school and get an education was the chief ambition of my life. I obtained my employer's consent and before leaving him he handed me a splendid testimonial of character and as it were to give emphasis to this testimonial he helped me pick out in the store a complete suit of clollics, including a coat, trousers and vest, underwear, socks, a winier cap and toots, of which he made me a present.

I lost track of W. H. Merrick. I had no idea what had become of him, but the day after I had been appointed United States minister to Denmark I received a congratulatory telegram from him from Portland, Oregon. In the telegram he stated that he had never forgotten the nice boy that clerked for him, but that he had lost track of me until he had read a newspaper dispatch about my appointment.

On leaving LaCrescent and bidding goodbye to Mr. Homme wo made an agreement that if I liked the school he would come and join me later. I urged him to come and the next autumn he too became a student at Luther college in Decorah. He was too old to take a full college course, so after spending a ycar at Decorah he was sent to the theological seminary at St. Louis after which he became a minister in the Norwegian Synod. He afterwards joined the anti-Missourian or F. A. Schmidt faction and then became the founder and promoter of the Wittenberg institutions already mentioned. He died several years ago.

The school year at Half W Way Creek ended early in June and the students engaged a farmer to take their trunks to LaCrosse, but the boys themselves used the same means of conveyance as the Apostles are said to have employed. We all 
walked and trotted in a bunch from Half Way Creek to La Crosse. The parsonage which served as the cradle of the first Norwegian-American higher institution of learning was, I think, in the ' 80 s, burned to the ground and a more pretentious building was erected in its stead. To tell the truth I was not pleased with the school. It did not meet my expectations. I realized that my two professors were men of considerable learning and high personal character, but I could not help comparing the general equipment of this school with what I had heard or read about American academies and colleges. While I was eager to get an education I thought I had better go to work and earn enough to pay my way at some American college of standing. I therefore decided not to return home to the farm in Albion, but to go back to Milwaukee where I felt sure I could find employment at fair wages. It must be remembered that this was in the midst of the war of the rebellion when thousands of able-bodied young men had gone to the front as soldiers and that there consequently was a scarcity of labor of all kinds. Well, I went to Milwaukee where I was immediately engaged to clerk by the same mein that bought out my brother's store and for whom I had worked a short time before going to La Crescent.

Before taking my position I obtained a week off to visit my home. My mother and brothers and sisters were wondering what had become of me. Two other boys from Half Way Creek had returned to Koshkonong but were unable to give any account of me. They said they had lost track of me in La Crosse. A few days later, however, the lost boy put in an appearance and the anxiety ended. It so happened that the wife of Rev. Mr. Ottesen, the wife of Rev. O. J. Hjort and another lady, Miss Norman, a member of the Ottesen household, were visiting at our house when I arrived home. When I said that I did not like the school and that I had secured a position in Milwaukee Mrs. Ottesen and the other ladies were 
greatly displeased. They took both me and my mother in hand and insisted that I must go to Decorah, lowa, in the fall. They asked my mother to exercise her authority and make me obey her. The scene produced a flood of tears and the result was that I had to yield to their wishes and cancel my engagement in Milwaukee. 


\section{CHAPTER VIII.}

\section{BACK HOME.}

I spent the summer at home doing the ordinary work on the farm. Labor was so scarce that my sisters had to work in the harvest field. In the books I had from Half Way Creek I studied at least an hour every day and the most of the Sundays and while I was working in the fields I reviewed in my mind as much as possible of what I had read in my books. I think this practice more than anything else I can mention helped to give me the memory for which I have sometimes been praised.

We were approaching the 4th of July and the people in the neighborhood had decided to celebrate the day. Some of the neighbors had gotten together and planned a celebration in a grove on Jens Naset's farm. There was to be music, by the Albion Prairie band, singing, speaking and refreshments. But where to get the orator of the day was the great problem. I was the only person in the whole neighborhood who had attended a higher institution of learning. Besides I had been absent from home a couple of years, had lived in Milwaukee and in Minnesota, all of which tended to give more or less prestige. A committee of three were appointed to wait on me and extend to me a formal invitation to be the orator of the day at the fourth of July celebration only a week later. I replied to the committee in the most formal manner possible, thanked them for the honor conferred on me and informed them that it 
would give me great pleasure to accede to their wishes. I forgot that I had never spoken in public in my life, that I had never heard a fourth of July oration, that I had not the faintest idea of what a person was to say on such an occasion. But I now cither had to keep my promise or go to Led and play sick. My stepfather had been a constant reader of the New York Tribune. And here I may add that my first recollection of newspaper reading was during the trial of John Brown at Harper's Ferry. The New York Tribune contained a very full account of the court proceedings in this famous trial, and when we received the Tribune all work was suspended and one of my sisters had to read every word aloud to the family. I may say that that reading made a deep impression on my mind though I was at the time only a dozen years old. The copies of the New York Tribune had not been destroyed, but were kept in a large imported Norwegian chest upstairs. It occurred to me that by going through all these copies of the Tribune I doubtless would find something that I could crib and make use of as a fourth of July oration. But all my search was in vain, and in the meantime the fourth was drawing nearer and nearer. It was the fourth of July, 1862, in the midst of our great civil war and so I took the bull by the horns, so to speak, and wrote out a few pages about our relatives and friends engaged in putting down the rebellion, I tried to describe the life and dangers of the soldier. I had at my elbow an abridged Webster's dictionary in which I hunted industriously for big words, thinking that an oration ought to be "hifalutin" as possible. I used a lot of words of which I scarcely knew the meaning myself. I would look at the word oppose, for instance, and take "repugn" instead and so on.

I copied this speech in my finest Italian hand and every day that remained before the fourth I went into the woods nearby and rehearsed it to the birds and squirrels. I fnally knew it well by heart. It had been thoroughly advertised that I was 
to speak and on that beautiful fourth of July people came by the wagonload--buggies were scarce in those days-from far and near to take part in the celebration and to hear the famous orator. A high platform had been built under an immense oak tree with loose boards for a floor. There were no steps leading up to the platform. I took hold of the end of one of these boards to lift myself onto the platform. I lifted the board instead, falling on my back on the ground with the board on top of me. In this manner I made my first bow to an admiring public. I was helped up again and after music by the band, etc., I was introduced. I recited my speech in a loud voice and with much feeling. Many of the women in the audience who probably had no comprehension of my big words shed tears profusely and used their handkerchiefs energetically when they heard me refer to their husbands, sons and brothers who were facing rebels in the south. On account of this reference to husbands, sons and brothers on southern battlefields my oration was vociferously applauded and pronounced a great success. My sister Dina got my manuscript and laid it away. She kept it until three or four years ago when I visited her in Worth county, lowa. Then she brought it out to show it to me and made me a present of it. 


\section{CHAPTER IX.}

\section{GO TO DECORAH.}

In September all the boys from the eastern part of Dane county that were going to Luther college at Decorah were coralled at Madison to take the same train for Prairie du Chien which was at that time the terminus of the so-called Milwaukee \& Prairie du Chien railroad. At Prairie du Chien we crossed the river on the ferry to McGregor which was then the metropolis of northern Iowa. At McGregor we were joined by other young men bound for Decorah; we hired a couple of teams with farm wagons to take our trunks and belongings to Decorah, some forty miles distant, and the whole group of boys took tickets by the "Foot and Walker's" line. We made the journey by foot in two short days. I shall never forget the delicious wild grapes and wild plums that we gathered and ate on the way.

I have no doubt that our simple primitive way of going to college was fully as interesting and enjoyable as the more stylish modern way.

Luther college at Decorah had been planned, but had not yet been built. All there was of it was a considerable tract of land on the west side of the river at Decorah which had been secured, but for the college itself not even the necessary funds had been raised. The Norwegian Synod had purchased an old hotel built of brick and called the St. Cloud. This building stood near the business center of the east side. It was re- 
modeled internally so as to serve the purposes of a school for a couple of years. The basement was converted into a dining room, and a part of the first floor was occupied by Prof. Larsen as the head of the institution. In fact, the students had only one small room on this floor and this was occupied by the uppermost class to which I belonged, for study and recitations. The second floor was occupied in the same manner by the rest of the body of students and the third floor consisted of a single attic room in which all the forty to sixty students slept in single beds. Such were our accommodations the first two years except that the second year, 1863, a small one-story building was erected on the west side of the old hotel as a recitation room. The new building, also called "hutitu," was two stories. The first floor was for sludy and recitations and the second floor was filled with beds for students.

It would be interesting to have moving pictures of this old school with its body of students. The students were not such as are now found as beginners in college. Only a few of them were young boys in their teens. The majority of them were men away up in the twenties and even in the thirties. There were men who sported heavy beards and had more years to their credit than either one of their professors.

During the recess hours this whole body of students could be seen in the middle of the street in front of the college playing marbles. A large number of them were dressed in homespun. My mother had sheared the sheep, spun the wool, dyed the yarn, woven the cloth and cut and sewed the coat, vest and trousers that I wore. I remember how lovely my sisters Cecilia and Dina looked in dresses which they had themselves made from cloth woven by our mother. 


\section{CHAPTER X.}

\section{DISCIPLINE OF THE SCHOOL.}

The discipline at this school during its early years was most severe and rigid, particularly when we consider the mature years of the gieat majority of its students. I cannot conceive of such strict rules governing a body of students unless it should be at West Point or Annapolis. The whole day, from 6 o'clock in the morning until 10 at night, was cut up into fragments. The rules plainly written were pasted inside of the door of each recitation room. These rules prescribed what a student was to do every hour and partly every half hour of the whole day. In the forenoon, after breakfast, there was a half hour recess during which the students were strictly forbidden to clo any writing or to look inside of a book. At noon and in the evening there was an hour when the same rule was enforced. The only hour when the students could either study or read, or write letters, or do nothing, or go to bed, was from 9 to 10 in the evening.

Students under 18 were not allowed the use of tobacco. All recitations except English grammar and mathematics were conducted in the Norwegian language. The school included five and a half days a week, that is, from Monday morning until Saturday noon. Instead of a daily there was a weekly timetable, some branches occurring only once a week, others twice, some three times, while as I remember Latin occurred every 
day. The theory was that all the branches to be studied during the whole six years' course should be started at the beginning of the first year and carried on pari grassu until graduation. One unfortunate result of this was that if a student on account of ill health or financial embarrassment was obliged to leave school he would take home with him only a smattering or a very elementary knowledge of a dozen different subjects. The argument in favor of such a course was that the student would rcceive a more harmonious development of his mental faculties. As I understand it, this system has long since bcen abandoned at Luther college.

Naturally the students chafed more or less under this rigid system of discipline and made many complaints in regard to the crowded guarters in which they had to live. The fare in the dining room was severely criticised by the students and the students had to take turns after each meal to wash and wipe the dishes. Students also had to take turns to saw and carry in wood. The students had to take turns in sweeping the floors. In fact they had to do all the housekeeping of the institution except the cooking. On several occasions the students met and discussed affairs and appointed committees to lay their complaints before Prof. Larsen. He would express his sympathy and point to the hill on the west side of the river and ask us to be patient until we could move into the new building. Then things would be different. We decided to be patient, that is, the most of us did. During the spring vacation of 1864 , being unwilling to submit to these hardships any longer, I went home and made it known to my family that I would not return to Decorah. But Rev. Mr. Ottesen, his wife and Miss Norman again appeared on the scene and told my mother that she must drive me back if I did not go willingly. I replied that if she insisted I would not disobey her and so I went back. The two last summers I spent in Decorah, that is, 1864 and '65, I was hired by the Norwegian congregation of Decorah to teach their 
parochial school. The school was held in the annex above mentioned and I got my board in the families of the congregation, boarding a few days with each. The last year, from September, 1864, to June, 1865, Mr. J. D. Jacobson, afterwards Prof. Jacobson, and I secured a room at Mr. Wheelock's on Broadway street and boarded ourselves. Twice a week we got a tin pail of soup at the college and the balance of my food during the whole year consisted of bread and molasses, excepting that I occasionally was invited out for a Sunday dinner when one need not be surprised to hear I took in a good supply. I had the advantage of an extensive acquaintance, having the summer before served as parochial teacher.

In the fall of 1865 the new college building was finished. It had cost the Norwegian pioneers about $\$ 75,000$ and this money was raised while the country was in the throes of the civil war. The dedication was to take place October 14. The week before all the students emigrated from the old $S$ t. Cloud hotel where they had been housed for three years to enter this magnificent building on the hill. The dedication of Luther college was the greatest event among the Norwegians in America up to that date. People came from far and near, from Wisconsin, from Illinois, from various parts of Iowa and from Minnesota. Husbands came with their wives. All the ministers then connected with the Norwegian Synod were there as a matter of course and many of them too had their wives with them. The people were anxious to see dedicated the school which they had built with stch great sacrifice of their hardearned money. The little town of Decorah was thronged with visitors. The great German Missouri Synod was represented by the distinguished Dr. Walther, the greatest Lutheran theologian of modern times, and by other prominent scholars of that organization. The 14th of October was a beautiful day and the dedication ceremonies were most impressive. They mark a most memorable event in Norwegian-American history. 


\section{CHAPTER XI.}

\section{THE STUDENTS REBEL.}

But the students were not satisfied. After getting into the new building we found that the conditions were to be very much the same as before. There were the same rules about washing and wiping dishes, sweeping floors and sawing and carrying wood. The students were bunched together in the same old way in their different recitation rooms which they were to use during hours of study. The hours from 6 in the morning until 10 at night were parcelled out in the same manner as before. No student was permitted to go down town without asking leave. The college was a four-story building, the fourth story being a mansard divided into four corner rooms by two halls crossing each other. These corner rooms received no other light or ventilation than what could be gotten through bull's-eyes of each. In these four rooms in the attic all the students were to sleep, so that if one student was afflicted with any trouble it easily spread among the whole student body.

The discatisfaction among the students culminated in a unanimous strike or insurrection. I was a member of the highest class and it may not be considered improper for me to add that I had to some extent inherited my father's qualities as an agitator. I talked over our grievances with the members of my own class and with various members of the lower classes and found a unanimous opinion that something ought to be done. The conditions being favorable I called a meeting of all the 
students except the new arrivals. These were excluded. The meeting was held in one of the large recitation rooms. I was unanimously elected chairman of the meeting and chief leader of the campaign about to be inaugurated. A program was outlined and resolutions were adopted. After the dedication excrcises it was announced that the students were at the service of the visitors. Our professors had requested the students to take all the strangers through the building and show them all its splendid appointments. I gave orders to obey these instructions, but to take that opportunity of explaining to the visitors how badly everything had been planned and arranged and that the students must not fail to take the guests into the dormitories. After the dedication ceremonies the ministers were to remain a few days for a conference in which our professors would take part as members. I and a couple of other members of my class had been appointed to give instruction in various lower classes during the conference. My instructions were that we should hear the lessons in the classes of the new arrivals, but that no member of the other classes must touch a book pending the strike, that is, until we had secured complete victory or until our demands had been granted. I also insisted on the maintainance of perfect good order and decorum in every respect. My fellow students had made me their unanimous choice as the leader or generalissimo of this great revolution. I promised to be faithful to the cause and assured them that they had chosen a leader on whom they could rely and with all the youthful energy and ardor there was in me I called upon all not to leave me in the lurch. I had an apprehension that the students might be taken to task by the ministers from whose congregations they had come. With the greatest enthusiasm the whole body of students present assured me of their absolute loyalty. But I still had doubts and in order to get all the students committed to our program I prepared with considerable care a document in which I stated in the briefest possible form 
the changes and reforms which we demanded. This document I submitted to every student for his signature, agreeing on my part to put it in my pocket and not to produce it or make any use of it except as a last resort. If any one in my little army should prove a traitor or deserter I could produce the goods and show his signature under this declaration.

Much of this program was carried out in a magnificent manner. The hundreds of visitors were taken in squads by the students and shown every part of the college building from the basement to the dormitories in the mansard. Men and women from the various Norwegian settlements escorted by students went with heavy hearts from one story to the other and many of them shed tears most copiously on the representations made to them by the students. All these people who had come filled with enthusiasm for the great work that had been accomplished returned home the day after the dedication with sad hearts and serious misgivings. As students we had gained one point. We had drawn attention to the conditions of which we complained and made them a subject of serious discussion in every Norwegian settlement in America.

While I was getting signatures to this declaration or bill of rights Isak Preus, one of the new arrivals among the students, and son of the Rev. A. C. Preus, whom I have already mentioned as being married to a relative of my mother's, a kid of some fifteen summers, wanted to be one of the signers. When I refused to permit him to sign he became angry and declared that he would "tell his papa". He did tell his father, and in this way information about our document was soon brought to the attention of our professors and spread among all the ministers who remained in Decorah for the three-day conference. I had planned to have a committee appear before our professors and, if necessary, before the whole conference, but the action of young Isak Preus resulted in a complete change in the development of the revolution. Instead of our sending a committee 
to the professors, the conference in session sent for me to appear before this venerable body as the leader of the insurrection.

Ministers and professors were in session. The students were in their respective classrooms maintaining the utmost quiet and order. All books were on their shelves. It was a part of the program not to engage in any study or reading. I was in the room of the small upper class, where we were engaged in a heart-to-heart discussion of what might happen. Without any warning a minister walked in, took a look at the situation and walked out again. By and by another minister walked in in the same manner, looked at us and walked out again without saying a word. A third minister visited us in exactly the same manner. It appeared that these three ministers made their rounds to all the other classrooms and made their reports to the conference. A little later Rev. A. C. Preus, who had confirmed me, and at whose parsonage I had received my elementary instruction in German and in Latin, took me into a room by ourselves where he exhausted his eloquence, both in scolding and in entreating, to get me to surrender and put a stop to the rebellion. His efforts were of no avail whatever. I returned to my classmates and had scarcely told of the inquisition to which I had been subjected before Rev. J. A. Ottesen came in and invited me to go with him to the same room where I had just had a conference with Rev. Á. C. Preus. Rev. Ottesen was my own and my mother's pastor and as such claimed to have some authority over me. He too was unable, either by threats or kindness, to get me to abandon the position to which I had been called by my fellow students. While I was making the report of my interview with $\mathrm{Mr}$. Ottesen to my classmates Rev. O. J. Hjort of Paint Creek, Alamakee county, Iowa, invited me to the same sort of conference. His wife was a sister of Rev. J. A. Ottesen and I had spent all my Christmas vacations and at least one of my Easter vacations at his very hospitable parsonage. Rev. Hjort's efforts were as fruitless 
as those of Preus and Ottesen. It was like pouring water on a duck's back. I did not want to disappoint my fellow students, who had faith in me and had chosen me for their leader. I had told them in open meeting that they might rely on my faithfulness to the cause which we had espoused. I returned to my classroom stronger in my convictions and purposes than ever.

Later the president of the college, Prof. L. Larsen, entered our classroom, evidently sent there by the conference. He tried to be diplomatic in his tactics. He said: "I have been informed that a petition has been circulated and signed by the students. This petition I would like to see." Of course he well knew that it was in my possession, but what I allude to as his diplomatic tactics is the fact that instead of asking me for it he turned to my classmates and asked them, one by one, saying, "Have you it, Norman?" "No", would be the reply. "Have you it, Juve?". "No." "Have you it, Bergh?" "No." "Have you it, Stub?" "No." And thus he proceeded, leaving me for the last one, when he asked, "Have you it, Rasmus?" He was in the habit of addressing me by my first name. I said, "Yes sir, I have." "I would like to see it."

"You can't have it, sir."

"Rasmus Anderson, do you not know that when I ask you for something you have you owe me obedience, and must give it to me."

I answered, "In this case I cannot comply with your request."

Prof. Larsen grew more and more excited. The veins in his forehead were swollen and he burst out, saying:

"I demand of you, Rasmus Anderson, that you give me that petition."

Again I firmly refused.

He then said, "Aye, aye, Rasmus, we'll see about this," and started to leave the room. When he had reached the door I 
called him back and assuming all the dignity of which I was capable I said to him:

"The petition you ask for does not belong to me alone. It is merely in my custody. I do not, however, care to act arbitrarily in the matter, and am willing to leave it to my classmates who are here present as to whether I ought to give it you or not. You may ask them one at a time."

He then looked about him as if he wanted to select the weakest one to begin with and said, "Have you any objections, Juve?"

Not having the courage of his convictions Juve, after a little hesitation, blurted out, "No."

"Have you any objections, Norman?" "No."

The rest followed suit and said "no" and then I took the document out of my inside pocket and with as much ceremony as I could muster I said scmething like this:

"My fellow classmates having no objections I have the honor herewith to hand you this petition, Prof. Larsen."

After this scene Prof. Larsen hurried back to the conference, the happy possessor of our bill of rights. My classmates and I sat looking at each other with most serious faces, each one doubtless considering what was next on the program. I told them that I would be the first to be arrested and examined, but assured them that they could depend absolutely on my loyalty. In a few moments President Larsen again entered our room and said, "Rasmus Anderson, you are to go with me".

I went with him and he escorted me into a large room where the whole body of professors and ministers were in session. The number of professors had by this time been increased to four, Mr. L. Siewers and Rev. N. Brandt having been added to the original faculty. The ministers and professors formed a semi-circle. In front of them was a table at which sat the chairman and the secretary. I was asked to sit down in a chair in front of this table facing the conference. Before I sat 
down I took a look at them all, tried to smile and asked whether the intention was that I was to be president of this meeting. President Larsen informed me that they did not want any insults from me and asked me to sit down. When I had taken my seat President Larsen stood up and read aloud the document signed by the students and which I had written in English. Then he translated it into Norwegian. Turning to me he said, "This looks like your handwriting, Rasmus Anderson. Have you written this?"

I said, "Yes, sir."

"Are you also the author of this document?"

I said, "I am, sir."

"Do you actually mean what you have written here?"

I told him, "Most assuredly."

Though it may seem somewhat egotistic I will here make a slight digression to explain that I was at that time considered to be the best student that up to that time had attended Luther college. I was completing a six-year course in about three and a half years; had obtained the highest standing at every semiannual examination and had also taken up independently a number of studies not found in the Luther college curriculum. Among such studies were French, botany and higher mathematics.

In the college curriculum we had only a small book not much more then 100 pages as a text book in Norwegian history. It was a little skeleton work written for the elementary schools in Norway by Sigwart Petersen. But once in passing through Madison on my way to Decorah I called on the pioneer Norwegian bookseller in this country, Mr. Monsen, and purchased from him a copy of Jacob Aal's translation of Snorre Sturlason's "Norges Kongesagaer," the so-called "Heimskringla." For this copy I paid $\$ 11$, a great deal of money for me at that time, but I have ever since looked upon it as the best investment I ever made. This book became the foundation of my whole 
after career. Thus it will be seen that I read and studied extensively outside of the regular Luther college curriculum of that day. What I wish to emphasize in this digression is that on account of my standing as a student the professors and ministers at this conference were anxious to save me if possible from suspension or dismissal. If there was to be a scapegoat on account of the insurrection I have no doubt that they would have been glad to find another victim for this purpose.

After getting my admission that I was the writer and author of the document signed by me and the other students and which had now been read and translated by Prof. Larsen I was subjected to a rigid examination, perhaps it might be styled a third degree process. Questions came in rapid succession from all parts of the auditorium. I replied to all as well as I was able and was utterly deaf to all suggestions of surrender. I have often heard it said that "the defiance and fearlessness of that lad in the face of so august an assembly was most astonishing." What became of the document I do not know, but I hope it is preserved somewhere in the archives of Luther college. I was repeatedly requested to retract and to apologize, but I stubbornly refused to do so. It was then unanimously voted by the whole conference that I was at once to be expelled from the college. As a final act in this proceeding I was addressed in long speeches by Prof. Larsen and by Prof. Schmidt and in brief remarks by Prof. Siewers and Prof. Brandt and then I was told that I might take my leave.

While the investigation and trial was proceeding I observed that two members of the conference left the room by a back door. For what reason they did this did not at the time occur to me. After I had paid my respects and said goodbye to the conference I hastened out into the halls of the college, entered various classrooms looking for my fellow students, but none were to be found. I wanted to inform them of what had happened to me and to urge them not to flinch, but stand by their 
colors even though they had lost their leader. The fact was that the two men who had left the conference room had gone out and gathered all the students into the college chapel and kept them well guarded there. While I was going from classroom to classroom I met two students who had not yet been coralled and shouting to them that I had been expelled and urging them not desert the cause, I heard a voice behind me, "I think the most sensible thing you can do, Rasmus, is to get your things packed and get away from here. Come with me!" The person speaking to me was Prof. L. Siewers. He had been appointed to take charge of me and get me away from the college at the earliest possible moment. It was his duty to see to it that I did not come in touch with any of my fellow students. He stood guard while I packed my trunk which I was to send for the next day. It was nearly midnight before I was through. Prof. Siewers escorted me to the door of the college. There stood two ministers who escorted me as far as to the bridge between East and West Decorah. I wish to repeat that it was nearly midnight and I was absolutely penniless.

In a brushwood on the way to the bridge one of my fellow students, T. O. Juve, was hiding and apparently waiting for me to go by. Hearing footsteps he spoke saying, "Is it you, Rasmus?" but my escorts answered for me by asking him, "Who are you?" Nothing more was heard from Juve. After my escorts had left me at the bridge I went to the east end of the town to the house of Mr. Tobiason. I had taught his children in the parochial school, had taken meals at his house and was well acquainted with the family. I knocked at his front door, the people in the house wondering who could be making all this disturbance at this time of night. Mr. Tobiason got out of bed, opened the door. I told my tale of woe and he gave the refugee a bed to sleep in and breakfast in the morning. The balance of the insurrection can be told in very few words. 
After I had been expelled T. O. Juve was called before the conference and seated in the same chair that I had occupied. He was the second signer of the document, and after a few preliminaries he was requested to retract. He was made to understand, that if he did retract, he would receive full pardon, but if he did not, he would at once be expelled. Mr. Juve had a suspicion, as he afterwards told me, that I had retracted and that the conference would be pleased to make an example of him. He tried to meet diplomacy with diplomacy. Before retracting he said he would like to know what Rasmus Anderson had done. Prof. Larsen promptly replied: "That does not concern you, Mr. Juve. The question is what you are going to do about it." This prompt answer from Prof. Larsen convinced Juve that they had saved me and now simply were after his scalp. And so without much hesitation he wilted and retracted.

The same course was adopted with O. A. Norman, who was the third to appear before the conference. He also retracted and apologized.

Although it was late in the evening the whole conference before which we three had been tried adjourned to the chapel, where all the students. who had signed the petition and bill of rights had been coralled. Juve and Norman were brought in there as shining lights and examples. The document was again read and translated. This was done in the chapel, while I was occupied with my packing.

After it had been shown how Juve and Norman had retracted and apologized Prof. Larsen addressed himself to the whole body of students, pointed to Juve and Norman as shining examples and said that if there were any others who did not wish to retract he wanted to hear from them. The students looked at each other; there being no one who cared to break the ice and be first, the silence was not broken. Prof. Larsen 


\section{The Students Rebel.}

expressed himself as highly gratified at this and stated that the whole conference looked upon this silence as an acquiescence and full retraction. All received full pardon and were dismissed. Thus ended the first Punic or rather punitive war. 


\section{CHAPTER XII.}

\section{WHAT BECAME OF ME?}

What did I get out of it? A considerable amount of cheap advertising; the name of the naughty boy at Luther college became a household word in every Norwegian settlement in the United States. An enterprising photographer in Decorah, by name Richardson, took my picture and sold it to people in Decorah and vicinity. The next annual meeting of the Synod was held in Manitowoc, Wisconsin. At that meeting a report was made of the insurrection at Luther college and therein it was stated that with God's help "we got rid of the weed". This report was unanimously approved. At the same time this event that I have now described became a most important turning point in my life. Had these things not occurred there is no doubt that I would have gone to St. Louis the following year, there taken my three-years course in theology at the Concordia seminary of the German Missouri Synod, then been ordained as a minister, received a call and, if my life had been spared, I would at this time still be preaching from some NorwegianAmerican pulpit.

While it was expected of me that I would return home to Koshkonong I decided to remain in Decorah. Although I was penniless I was not without resources. Early the next morning after my expulsion I went to the store of Cleghorn \& Monte, clothing merchants, and at once secured a position as a 
clerk. I had had some experience in selling goods, both in Milwaukee and at La Crescent, and Messrs. Cleghorn and Monte thought there might be profit in the notoriety that I had just achieved. I was engaged at $\$ 40$ a month.

At this time there was no railroad entering Decorah, but during the past year the Milwaukee \& Prairie du Chien road had been continued from McGregor into Iowa, and at this time had reached a terminus called Conover, about seven miles south of Decorah. The conference of ministers had adjourned the same night as I was expelled and were returning to their homes the next day. Many of them had to be taken to Conover where they were to take the train for Wisconsin. Among the ministers was Rev. S. S. Reque, married to my sister Cecilia, and Rev. T. A. Torgerson, engaged to be married to my sister Dina. I decided that I would take Reque and Torgerson to Conover, and to do it in the following ostentatious manner: Having secured a position with Cleghorn \& Monte, I arranged to begin work there the following day.

I selected from the store a new suit of clothes, the best to be then found in the store, including shoes, and a fine hat. At the livery stable I engaged the best rig and the finest pair of horses to be had and with these I drove in great style up to the front of Luther college. In front of the college stood a number of rigs, chiefly lumber wagons, to take the members of the conference to the station at Conover. Inside of the college the people were busy packing and bidding goodbye. I got my stylish rig well up toward the front entrance and sat there waiting. The front windows of the college were filled with spectators. I presume they were wondering who the distinguished guest might be. I presume it was also determined that it was obligatory on the president of the college to receive the guest in person. He came; he bowed to me, but I had been so transformed by my new clothes that he did not recognize me. Besides he was very nearsighted; he came nearer and nearer, took my proffered hand 
and finally looked close into my face. Suddenly it flashed upon him that it was none other than Rasmus Anderson. His expression of disgust was indescribable. He turned away from me with an "ish," and hastened back into the college. This served only to increase the curiosity of those inside and every window was crowded with spectators. A little later the janitor of the college, the amiable Ole Dalemo, came out to see me. I told him my errand; I said I wished to take Reque and Torgerson to Conover in my rig and requested him to notify them of this fact. He soon returned and informed me that Reque had accepted my invitation, but that Torgerson had refused to ride with me. In saying goodbye to me this big hearted man, Ole Dalemo, slipped a silver dollar into my hand.

On the way to Conover I listened patiently to all the upbraidings of my brother-in-law Reque, but all he had to say fell on me like water on a duck's back; it left no impression. I was utterly deaf both to his scolding and his pleading. At Conover we had to wait a couple of hours for the train. I mingled with the crowd at the station, looking them boldly and defiantly in the face, the most of them returning my looks with scorn.

But something was about to happen. The reader will remember that before I was confirmed I had received instructions from a private tutor at the Koshkonong parsonage. The tutor was Carl Johan Rasch, scion of a distinguished family in Christiania, Norway, and he was engaged jointly by Rev. A. C. Preus and Rev. C. L. Clausen of St. Ansgar, Iowa. At the parsonage on Koshkonong, Clausen's oldest son, Martin, was also a pupil. At the time now under discussion he had entered Luther college as a student. In this way we were brought together again. Rev. C. L. Clausen knew me through his son and had become considerably interested in me.

Around the Conover station the virgin forest was growing. Rev. Clausen spoke to me kindly and took me aside into the brushwood for a conference. He told me how painful it had 
been to him as a member of the conference to witness my stubbornness and defiance on the evening before. He told me I was committing a grave sin and ruining my future. He pleaded with me with all the ardor of his large heart and with tears rolling down his cheeks urged me by all means to retrieve my steps and to make a suitable apology for my conduct. This was more than I could stand and I made a complete surrender. I had wilted. All broken down I promised Mr. Clausen I would lose no time in seeing President Larsen and the other members of the faculty, make a full retraction and ask their pardon. I was not in a mood to return to the depot platform and exhibit more of my defiance to the ministers there. I at once untied my horses and started back to Decorah. My heart was heavy. Midway between Conover and Decorah lived a young lady by name Ingrid Egge. She was a schoolma'am. She afterwards married Rev. L. J. Markhus. After his death she was for a time matron of the Lutheran ladies' seminary in Red Wing, Minn., and she is known as translator of the Norwegian story "Laila," by the Norwegian author Fries. She still lives, I think, at Willmar, Minn. Her brother, Dr. Albert Egge, is a professor at the state agricultural college of Washington, a scholar and writer of note. I invited Ingrid for a short drive. She had heard about the affair at the college, disapproved of my conduct and pleaded with me during our short drive to "be a good boy." Otherwise she would have to cut my acquaintance. She was older than I and I had great respect for her opinion. I also promised her that I would do my best to make things right.

Having returned my team to the livery stable I proceeded in the dusk of the evening toward the college. On the way I met Prof. F. A. Schmidt, but he avoided me and refused to talk with me. I reached the college and rapped at Prof. Larsen's door.

He was in his office upstairs. His wife stroked my cheeks and caressed me, telling me how sorry she was that I had been 
so naughty. I tore myself away from her to make my way upstairs, but in the middle of the stairway I was met and seized by Miss Neuberg, a sister of Mrs. Larsen. She too smothered me with caresses and told me how sorry she was for me and for my family. Having torn myself away from her too I knocked at Prof. Larsen's door. Imagine his surprise when he saw the naughty boy standing before him! It was no longer the naughty boy but the penitent boy. Prof. Larsen could scarcely believe his own eyes and ears. He looked at me with bewilderment and listened to my story of repentance with astonishment. I never saw that splendid man look more beautiful; tears of joy streamed down his cheeks. We had a session together never to be forgotten. At its close he fell on his knees beside one chair and I on my knees beside another and a fervent prayer ascended from the lips of Prof. Larsen. I felt relieved and humbly took my leave. Before returning to my boarding place I called on Prof. Schmidt, Prof. Brandt and Prof. Siewers and informed them of what had happened and asked for their pardon. Prof. Schmidt and Prof. Brandt were entirely willing to forgive me, but Prof. Siewers received me coldly and stated that he could not forget the manner in which I had treated him. This remark might refer to my rudeness toward him the night before, while he stood guard over me; but, as a matter of fact, it had a deeper source. He had met my sister Dina and had been smitten. She refused to listen to his protestations of love and he was unable to win her. He suspected me of taking sides against him in this courtship or at least of not having been ardent in advocating his cause and this was what he alluded to as something he could never forget. But time heals all ills, and years afterwards Sicwers and I became the best of friends. 


\section{CHAPTER XIII.}

\section{THE NEXT DAY.}

The next day I took my position behind the counter in Cleghorn \& Monte's clothing store. There the most of my former fellow students called on me when they came down town. They were anxious to have me come back to college. Farmers from the surrounding country would enter the store in groups and someone would point me out as the fellow they wanted to look at. I may say without boasting that in this way I was the means of drawing not a little trade to the store. Engaging me as a clerk proved to be a good investment for Cleghorn \& Monte. Cleghorn, by the way, had been captain in a Wisconsin regiment during the war of the rebellion and Mrs. Cleghorn was a niece of Judge H. S. Orton of the supreme court of Wisconsin.

In the midst of all this my desire to complete my course of education kept steadily growing. I discussed the matter with my former fellow students and classmates and corresponded with my mother. After a few weeks I went to call on Prof. Larsen. He received me with his usual kindness. I knew I could not get any assistance from home to continue my studies without the recommendation of Prof. Larsen and our Koshkonong pastor, Rev. J. A. Ottesen. I stated my errand; I said I was anxious to continue my studies and graduate. In one way and another I had formed a great idea of Yale college, I presume from studying on my own hook Dana's textbook on 
geology, and so I indicated to Prof. Larsen that I preferred to go to Yale, but that I would be satisfied to re-enter Luther college or go to the German Missouri Synod's college at Fort Wayne, Ind. After reflecting for some time, Prof Larsen told me that he was sorry that it was not possible for him to recommend to me to continue as a student. On account of my temperament and fondness for agitation, to a considerable extent, he claimed, inherited from my father, he did not think it would be best for me to choose an academic career. $\mathrm{He}$ feared that an equipment of knowledge might prove my undoing and with the utmost kindness in his words he advised and urged me to return home to my mother and make a good farmer of myself adding that the education I had received would be of great help to me on the farm. I am unable to describe what a profound shock this advice was to me; if accepted it would smash to bits all my ambitious dreams of a career as a scholar among my fellow men. I braced up and told Prof. Larsen that I was surprised; that I had not looked for such advice; that I could not accept it, and that "here and now our ways part." I left him and this interview became the turning point in my carecr. 


\section{CHAPTER XIV.}

\section{THE MISSOURI SYNOD.}

At this time there had developed among the Norwegians in this country a considerable opposition to the Norwegian Synod. As may be easily realized, the Preuses, the Ottesens, the Korens, the Stubs, the Dietrichsons, etc., came from the so called "conditioned" classes in Norway. They and their wives were sons and daughters of what might be called the office-holding class in the old country. Between this office-holding class and the lay people, or masses, particularly during the larger first half of the nineteenth century a wide social gulf existed. The officeholding classes were thought to be, and in many cases were, overbearing, and the common people who emigrated to the United States were glad to get away from what they regarded as an oppression. They felt that they no longer had to stand in the ante-room of the office-holder with their caps in their hands. It was therefore natural that they should protest against any similar treatment from the sons of these office-holders who became their pastors on this side of the Atlantic. This was one reason why many either became followers of Elling Eielsen, who was a plain peasant, or connected themselves with the Methodist or Baptist churches, or, what was still worse, became religious tramps, not identifying themselves with any church.

As will be remembered, there was great demand in the Synod for ministers. Immigration went forward with leaps and bounds and Norway was unable to supply this demand. The 
Synod selected a committee to visit the various German Lutheran organizations in this country for the purpose of effecting an arrangement by which ministers might be educated here. This was in the latter part of the '50s. Indeed, there was an effort made at the same time to establish a connection between the Synod and the University of Wisconsin so that students might take the academic course at the university, in it be taught Norwegian, and subsequently take a course in theology in recitation rooms provided by the university, but under teachers paid by the Synod. This plan did not materalize, but the committee I have mentioned, and of which Rev. J. A. Ottesen was one, after visiting Buffalo, New York, and other places, came back full of enthusiasm for the great German Missouri Synod. This Synod under the leadership of the distinguished Dr. Walther had established a college at Fort Wayne, Ind., and a theological seminary, the Concordia, at St. Louis, Mo. The Missouri Synod was found to be the most orthodox Lutheran body on earth, and that honor belongs to it at the present time. The Missouri Synod received the emissaries from the Norwegian synod with open arms and offered to assist them in every way possible in educating ministers. As a result, Rev. Laur. Larsen was given a professorship at the theological seminary in St. Louis. The Synod ministers at once picked out the brightest lads they could find in their congregations and sent them, partly to Fort Wayne, Ind., and partly to St. Louis, to prepare for the ministry. My brothers-in-law, Rev. Reque and Rev. Torgerson and others, received their instruction in and graduated from Concordia. The arrangement, so far as the school in Fort Wayne was concerned, lasted only until the starting of Luther college at Half Way Creek in 1861.

The arrangement at St. Louis continued until the latter part of the '70s when the Synod bought the old soldier's orphans home in Madison, Wis., and converted it into its theological seminary. In the ' 80 s this property was sold and the theolog- 
ical seminary was moved to Robbinsdale, a little north of Minneapolis, and then again moved to its present magnificent çuarters at Hamline, midway between Minneapolis and St. Paul. But even since the Synod obtained its own theological seminary some Norwegian students have taken their course in theology at Concordia.

Prof. L. Larsen was sent to St. Louis for the purpose of giving the Norwegian students a proper equipment in the Norwegian language. After graduation these Norwegian students were to serve Norwegian congregations and hence they needed a thorough drill in the Norwegian language. After the founding of Luther college this instruction in Norwegian at St. Louis was no longer a necessity. Sudents came there from Luther college or from similar schools in Norway already instructed in their mother tongue. Hence it was that Prof. Larsen severed his connection with Concordia and was made the head of Luther college, a position which he held for more then forty years.

The connection between the Norwegian Synod and the German Missouri Synod proved to be a great blessing to the Norwegian Synod from a doctrinal point of view. Under Dr. Walther and the other professors at Concordia the Norwegian Synod acquired a thoroughness in Lutheran doctrine of which they had never dreamed before. But this picture also has its dark side. A considerable part of the Missouri Synod was domiciled in the south and St. Louis itself was in a slave state. A large number of the members of the Missouri Synod were owners of slaves. In 1860 Abraham Lincoln was elected president, in ' 61 he was inaugurated and after secession was proclaimed of course whatever other causes may have led to the war, slavery was the main issue. Throughout the north abolition was rampant. When the Norwegians settled in the United States nearly all of them affiliated with and became members of the democratic party. Then came William Lloyd Garrison, Wendell Phillips, Henry Ward Beecher, Horace 
Greeley, with his powerful "Tribune", and Harriet Beecher Stowe with her immortal 'Uncle Tom's Cabin.' The republican party was founded. The Norwegians looked with horror on the institution of human slavery, and, like a flock of sheep, they emigrated from the democratic into the new republican party. A large number of them voted for John C. Frenont and nearly all of them voted for Abraham Lincoln.

The first annual address delivered before the State Historical Society of Wisconsin, after moving into our present quarters, was delivered by Charles Francis Adams, a direct descendant of the presidents, John Adams and John Quincy Adams. In this address Mr. Adams gave it as an historical fact that the Norwegians who had settled in the Northwest were the primary eause of the rebellion. He showed that the Norwegians in Wisconsin, Minnesota, and lowa, joining the republican party made these states republican and that these states gave the majority to Lincoln in the electoral college. At least such was the contention of Charles Francis Adams.

But to get back to the Missouri Synod. Their seminary was locaied in the slave state of Missouri and, as stated, a large number of the members of this church were owners of slaves. We need not therefore be surprised that they took sides with the secessionists and defended slavery. They contended that slavery was sanctioned by the Bible, quoting in support of their contention numerous passages, both from the Old and from the New Testament. It seems that they easily converted Prof. Larsen. There were a number of Norwegian students at the Concordia seminary, and the Norwegians who had espoused the cause of abolition began to be suspicious of what was going on in St. Louis. Among those who expressed themselves most energetically on the subject were Col. Hans. Heg and John A. Johnson. Mr. Johnson published in "Emigranten," in Madison, an article calling upon Prof. Larsen to define his attitude on the slavery question, and on the rebellion. 
Prof. Larsen replied, defending slavery as having divine sanction and then a war broke out among the Norwegians which lasted for years and threatened to annihilate the Norwegian Synod. With their keenness as debaters, Prof. Larsen and Prof. Schmidt succeeded in convincing Rev. H. A. Preus, Rev. V. Koren, Rev. N. Brandt, Rev. B. J. Muus, Rev. J. A. Ottesen and the rest of the ministers in the Synod that the Missouri Synod was perfectly sound in its doctrine concerning slavery. The only minister who refused to be convinced was the Rev. C. L. Clausen of St. Ansgar. And with him, as the leader of the opposition, the war in the Synod was continued until 1868, three years after the surrender of Gen. Lee at Appomattox.

Speaking of Lee's surrender at Appomattox reminds me of an episode at Luther college in thie spring of 1865. It should have been told in connection with my story of Luther college, but the omission may be mended here. It goes without saying that the Norwegian Synod ministers who defended the institution of Slavery thereby made themselves very unpopular, not only among Norwegian-Americans, but among citizens of all nationalities. They were looked upon as "copperheads", as sympathizers with the rebellion, and at times it would not have taken much to make them the subjects of personal assaults.

The episode in Decorah to which I have alluded was as follows:

On the 9th or 10th of April, 1865, a report came to Decorah that Gen. Lee had surrendered and that the rebellion had collapsed. The report set the whole town wild. In the evening all Decorah was illuminated. Every tallow dip and every kerosene lamp was shining in the windows. All the people were out and making all the noise they possibly could. When people met they embraced each other. The saloons were filled and everybody was treating the crowd. I saw one man sitting on his horse in front of the bar inside of a saloon hurrahing for General Grant and the Union and for Abraham Lincoln and 
asking everybody to drink at his expense. It was the most exciting demonstration that I ever witnessed.

At Luther college, still located down town, all was noiseless and perfectly dark. The college did not in any way take part in the general rejoicing. The professors were busy looking for students in the crowds and sending them home. This gloom at the college made a deep impression on the citizens and revived talk about "copperheads." The day after some citizens called a mass meeting at the couri house and sent a demand to the professors to appear before this mass meeting and declare their attitude.

Prof. Larsen, Prof. Schmidt and Prof. Siewers were escorted to the court house where questions were put to them and each one had to state his position on the great subject that for four years had cost the country so much blood and treasure. They rcse in their places and replied that they meant to be perfectly loyal to the American government and were pleased to know that the north had conquered. They did not wish that their conduct on the evening above described should be interpreted as want of loyalty or as sympathy with secession. The replies were considered satisfactory. Had not such a meeting been held and the proper assurance been given there is no telling what might have happened to the school and its professors.

The Missouri Synod also took strong grounds in opposition to the American public schools. The Norwegian Synod agreed with the Missouri Synod. It was argued that the public schools were hosille to the Christian religion; that in their very nature they were inimical to the kingdom of God. At the Synod meeting in Manitowoc in 1866 it was resolved that in the Norwegian Synod, as was the practice in the Missouri Synod, the congregations should establish parochial schools, so that the children would not need to be sent to the public schools. To this program there was also much opposition among the rank and file of the Norwegians in this country. 


\section{CHAPTER XV.}

\section{AMBITIOUS PLANS.}

All this opposition to the Synod ministers on account of their aristocratic tendencies, on account of their defense of slavery and on account of their hostility to the American public schools, the naughty boy, now serving as a clerk behind the counter at Cleghorn \& Monte's store resolved to make use of in the conflict in which he was soon to be engaged. My first plan was to build a Norwegian school, that is, an academy or college, in distinct opposition to Luther college. My school was to be patterned after the best American schools of this order. Of course there was to be instruction given in the Norwegian language and its students were to be taught the rudiments of the Christian religion. The curriculum and the discipline was to be wholly different from that of Luther college. The plan required organization and funds. I proposed to make use of what knowledge I had acquired while at Luther college and also of what reputation or notoriety I had gained by my expulsion. I interviewed a number of more or less prominent Norwegians in and around Decorah, selecting such as I knew belonged to the opposition on account of the reasons which I have already stated. I met with considerable success. I found men willing to contribute the use of their names, much of their time and of their money for the cause. We organized the Norwegian-American Educational Society, the first society of the kind among the Norwegians of America. Erik Ellefson Sleen, who 
was called "the king of Big Canoe," was elected president. In all respects he was the most able and persistent opponent of the Synod ministers then living on the west side of the Mississippi river. Ole Noben, a successful mechanic in Decorah, was elected treasurer, and I was chosen secretary.

The society had more than a hundred substantial members who had signed its constitution and by-laws. This society decided to build a Norwegian-American college at some suitable Norwegian center, preferably in Minnesota, and to put me in charge of it. In the meantime, while the necessary funds were being gathered, the society was to defray my expenses as a student at Yale college in order that I might come back thoroughly educated and equipped for so important a position.

While I was busy with this work the other side was not idle. I was under age; I was a mere minor; I was a disobedient child; I was so lacking in moral character that I did not obey my mother, who was requesting me to come home. Of course we knew where she got her advice. I had just passed my twentieth year, and in a conference with the president Erik Ellefson Sleen, with the treasurer, Ole Noben, and a few other members of the society it was decided that our cause would be greatly strengthened and not much time lost if I should go home and remain there until I became of age. I took the advice of my friends and went home.

I may add here that Messrs. Cleghorn \& Monte dissolved partnership and Mr. Monte moved the store to Conover and took me with him. This happened after New Year's.

While in Conover I was equipped with a large sled and a pair of mules, and with these I took a stock of goods to sell in Howard, Mitchell and Worth counties, Ia. On this trip I visited Rev. Clausen in St. Ansgar and made my headquarters at his house while I canvassed his town and surrounding country. The town of St. Ansgar and the Norwegian settlement around it had been founded by Mr. Clausen in the early '50s. This 
trip as a peddler I made during the month of February, 1866, and I made good use of it in advocating the Norwegian-American Educational Society among the Norwegians that I met. Rev. Clausen was in full sympathy with the movement and agreed to give the matter his support. It was after the return to Conover from this trip that I had a conference with the officers and others of the society and acquiesced in their advice to go home and remain there until I should become of age. I returned to Koshkonong in the early spring of 1866.

On my arival home I found all plans perfected for making me a farmer. My only older brother Andrew had a farm of his own in Coodhue county, Minnesota, and was in easy circumstances, hence I would be in line to assume the management of the homestead. My mother, who had been a widow since 1860 , and who was getting on in years, was anxious to be relieved from the responsibilities of managing the farm. The plan was to sell the farm to me on easy terms and so, on the one hand, relieve my mother, and, on the other, rivet me to the soil and to agricultural pursuits. Our pastor, Rev. J. A. Ottesen, was a frequent visitor at our home during those days and exhausted his eloquence in urging me to become a farmer. Neighbors were also drawn into the scheme and exerted their influence to the same end. Several of those who took a hand in this matier had even gone a step further. They had selected what they called "the rose of Koshkonong Prairie" to be my partner and no opportunity of bringing that stunning young lady and me logether was neglected. There was a wedding; the "rose of the prairie" was bridesmaid and I had to serve as best man. A few young people engaged me to give lessons in German and the "rose of the prairie" was one of my pupils. I did not take either to the farm or to the girl. So far as the girl was concerned I had already seen the lass who later became my wife, Miss Bertha Karina Olson of Cambridge, Wis., and with me my intentions were not to be changed. Concerning 
the farm I finally yielded on the express condition that I should not be obliged to run it or even to keep it. This point was yielded as all hoped that matters would work out satisfactory, and so I bought without money the farm of 230 acres and became a farmer. 


\section{CHAPTER XVI.}

1.

\section{ALBION ACADEMY.}

Albion academy was located about in the center of the town of Albion, scarcely three miles from my home. Indeed, with the right kind of wind, we could sometimes hear the Albion academy bell. This school was one of the oldest higher inștitutions of learning in the state of Wisconsin, having been founded in the early '50s. I had had a keen desire to attend this school before I went to Milwaukee, but could not get the consent of my stepfather. The school had been founded and was owned by the Seventh Day Baptists, a large number of whom had come to Wisconsin, partly from Rhode Island, and partly from Alfred Center and vicinity in New York state, and had settled at Milton and in the town of Albion. These Seventh Day Baptists were very much interested in educational work; they had a university at Alfred Center, New York, and on account of some disagreement they founded two rival academies in Wisconsin, one at Milton (now Milton college) and the other at Albion. Both seemed to prosper and had a good attendance until the war broke out, when a number of the students enlisted. Among those who enlisted from Albion academy was Knute Nelson, from Deerfield, Dane county, at present United States senator from Minnesota. At the close of the war Knute returned to the academy and graduated. Of graduates of this academy I may have something to say later on. 
It was June, 1866. Albion academy was to hold its regular annual graduation exercises. These were held in a grove on the south side of the town. I decided to attend. Among the stucients there was one of Norwegian parentage, Peter Tjentland (Chantland) from the western part of Dane county. $\mathrm{He}$ afterwards became a prominent citizen of Fort Dodge, Iowa, where he died a few years ago. On a little investigation I found that the academy had had just three Norwegian students during the year now closing. While attending these graduation exercises a stream of thoughts and new ideas coursed through my mind. Here was a full fledged academy with a faculty of teachers; here were two large academy buildings, one for men and one for women, located on twelve acres of land in the very heart of this beautiful village. Several hundred students could easily be accommodated and instructed here. In spite of these facts the school was having an attendance of only 40 to 50 students. The school was located only three miles north of Edgerton; hence it was easily accessible to students from a distance.

Albion was an ideal village, removed from all the temptathons that surround young people in cities. There had never been a drop of liquor sold in Albion up to that time, nor has there since. I thought of our Norwegian Educational Society in Decorah and it flashed across my mind that right here could be realized all the purposes of the academy or college that this society had planned to build and equip, and here we could begin at once without the necessity of soliciting subscriptions. Here were the buildings and the teachers. To the north were the large Koshkonong settlements, beginning in Albion and extending clean into Columbia county. To the west and northwest were Primrose, Perry, Blue Mounds and a number of other populous Norwegian settlements. We did not have to go far south to reach the prosperous Norwegian settlements in Rock county and northern Illinois and for people from a greater 
distance we had ample transportation facilities to Edgerton. As I keep on saying, the conditions here struck me as being absolutely ideal for the realization of all the plans that I had conceived and worked out in connection with the organization of the Norwegian Educational Society in Decorah.

Dr. C. R. Head was the president of the board of trustees of Albion academy. I called on him and unfolded my plans to him with all the eloquence at my command. He became deeply interested. He said there was to be a meeting of the board of trustees that afternoon and requested me to be present. I appeared before this body and explained to them how they might more than double their attendance by adding a Norwegian-American to the faculty, that is by securing a person who could do the necessary missionary work and canvassing in the Norwegian settlements and persuade the parents to send their sons and daughters here. They asked me where such a teacher could be found. Without any hesitation I told them that I was their man and that I wanted the place. They claimed that they had no funds in the treasury with which to pay me for my work. I replied that I did not ask any fixed salary and that I would be content to receive the tuition money paid by Norwegian students that would come. So far as I now remember, the tuition amounted to $\$ 7$ a term for each student. They asked me what branches I could teach. With brazen effrontery I declared that I was able to teach any branch taught at Albion academy, and some others besides. I claimcd to be able to give instruction in English, German, French, and Norwegian, in fact, in any modern language; that I was competent to take advanced classes in Latin, Greek and Hebrew and that I was prepared to take charge of the department of mathematics and of the various classes in such sciences as botany, zoology, geology, astronomy and physics.

Although as the reader knows I had been at Half Way Creek and Decorah barely three and a half years, still I pre- 
tended to be an all-round man able to do work in any line where I might be needed. My statements almost took the breath of the venerable members of the board. They looked at each other and at the beardless boy with astonishment. The school had gotten pretty near to low water mark, partly on account of the war and partly on account of its rival at Milton and another rival at Beloit, and was in a life and death struggle for existence. The idea of bringing in scores of Norwegian boys and girls appealed to them. The fact that I did not ask any salary both astonished and pleased them. The claims I made in regard to my equipment confounded them. I left the board and a couple of hours later I was informed by President Head, that my terms had been accepted and that I had been clected professor of Greek and modern languages to begin the coming fall term.

This was one of the happiest days of my life. I had the news proclaimed from the housetops, I rented my farm to one of my neighbors, Martin L. Hollo, for three years. I immediately began a systematic canvass of the towns of Albion, Christiana, Deerfield, Pleasant Springs, Dunkirk and the village of Stoughton, made trips into Windsor and Vienna and succeeded in inducing a considerable number of boys and girls to come to Albion.

Then there was a hitch. In my absence tares had been sown among my wheat. I was requested to come to Albion as scon as possible. I went there. Dr. Head told me that it had become his unpleasant duty to inform me that I was not eligible to a position in the academy. The board of trustees had been made acquainted with my relations to Luther college. They had been informed of my expulsion. To employ me at Albion academy would be a distinct violation of the code of academic ethics; it would be an act of discourtesy for one school to give shelter and protection to a student who had been expelled from another. Dr. Head assured me that he was very sorry, but he 
knew no remedy. The shock to me was more violent than I am able to describe. It came as an utter surprise. Dr. Head did not tell me whence the board had obtained this damaging news concerning me; they had evidently received it in confidence. For my own part I had no doubt as to the source. I asked who the informant was, but could get no answer.

As a large majority of the board lived at Albion, I now demanded that the members be brought together and that they give me an opportunity to make a statement in my own defense. The Albion members of the board were quickly convened. I appeared before them and made as complete a statement in regard to my expulsion as has been made in the preceding pages of this work. I closed by saying that I had already secured more than a dozen new students for the fall term and that whether I was wanted or not I was coming all the same to take my place in the faculty. The story of my expulsion enlisted their sympathy and the remarks with which I closed seemed to fill them with wonderment. They passed a unanimous resolution that they could see nothing to hinder my continuing as a member of the Albion academy faculty.

I continued my canvass for students with all the energy possible. Albion academy became a subject of discussion throughout the Norwegian settlements in Dane county. When the fall term opened there were fifteen new Norwegian students, a much larger number than there had been at any one time at Half Wav Creek, a result most gratifying not only to me, but to the board of trustees of the academy. During the winter term the number increased to twenty-six, but in the spring term it dropped to eighteen.

During the year we had about twice as many Norwegian students at Albion academy as there were in attendance at Luther college during its first year's existence at Half Way Creek. 
At the Christmas recess the students made me a present of a solid silver goblet, and at the end of the year of a gold-headed cane. At the anniversary exercises of the academy I delivered an address on the subject "The Good Student," and received the degree of Bachelor of Philosophy. On the platform sat Governor Lucius Fairchild and Congressman L. B. Caswell. I thought it a great honor to be invited to dine with these distinguished men at the home of Dr. Head, the president of the beard of trustees.

The first year's work having been finished under such auspicious circumstances, I went to work during the vacation to arouse a still greater interest in the academy for the following year. I went out as the summer before, but extended my canvass to a larger territory. During my canvass I met Captain John Anderson of Milwaukee. He was the owner of the brig Montezuma. He thought I needed a little rest and recreation and so he invited me to take a trip with him from Milwaukee to Menominee and back. On our return to Milwaukee he sent me in a ship of one of his friends from Milwaukee to Buffalo and back. This gave me an opportunity of seeing Niagara Falls.

The first mate on the ship to Buffalo and back was a highly educated Finlander. Every day when he was off duty he gave me lessons in the Finnish language. When we parted I knew the elements of his tongue fairly well and he opened to my mind great vistas of Finnish literature, mythology, traditions and song and it was he that opened my eyes to the transcendant, the splendid and immortal beauties of the Kalevala, the Finnish epic, which suggested to Longfellow the poetic dress of his famous song Hiawatha. I am still able to give from memory snatches of song that this Finlander taught me.

I think I forgot to state heretofore that while I lived in Conover, Iowa, during the winter of 1866, I acquired a fairly good reading and speaking knowledge of the Bohemian language. 
Near Conover there was then and is still a large Bohemian settlement and in waiting on these people in the store where I clerked I soon became able to talk with them in their own vernacular. The Bohemian is one of the Slavonic group of languages; the Finnish is a Tshudic, or Ugro-Finnic form of speech, that is to say, Hungarian and Finnish are both daughters of the same original parent language. My knowledge of Bohemian served me a good purpose a few years ago when I, at the instigation of the present Judge J. C. Karel of Milwaukee, was invited to deliver the decoration day address at his old home in Kewaunee, Wis., where there is a large Bohemian population. When the city mayor had introduced me as the speaker of the day I began my address in Bohemian to the great delight and astonishment of the audience.

After the three weeks spent on the lakes the rest of the vacation was devoted to an industrious canvass for students. The great Norwegian newspaper "Skandinaven," in Chicago, was, by a mere coincidence, founded at the very time that I began my work at Albion academy in 1866. The founder of this paper was John Anderson, the editor was Knut Langland. John Anderson had come to Chicago from Voss, Norway, as a poor boy and had learned the printer's trade in the Chicago Tribune rooms and was well equipped for the business end of the enterprise. Knut Langland had come to America in 1837. He had received something more than a "confirmant's" education in Norway and was by nature a student with an unlimited thirst for knowledge. He had, with O. J. Hatlestad, bought "Nordlyset" in 1848 and had changed its name to "Demokraten." He had served one term in the state assembly as a representative of Racine county. He was a broadminded man and an ardent republican, a thorough-going abolitionist; in a word, he was in every way exceptionally well fitted to be the editor of "Skandinaven." He was a small, wiry person, not unlike Lyman C. Draper, the founder of the Wisconsin State Histor- 
ical Society, in his general appearance. He was my steadfast friend till his death, which occurred in the ' 80 s. His last letter before he died was written to me while I was in Copenhagen as minister to Denmark. I had read of his death before his letter reached me. I do not know of any Norwegian in this country who had a larger or more healthy influence on the Norwegian group of our population. 


\section{CHAPTER XVII.}

\section{REPLY TO A PROTEST.}

The president of the Norwegian Evangelical Lutheran church founded in 1846 by Elling Eielsen, Rev. S. M. Stenby of Clear Lake, Iowa, and Rev. Erik Morstad of the same church have both protested against what they deem a slur on the good name of Elling Eielsen when I say that he kidnapped a little girl that he had placed with a Catholic family in Muskego, Wis. I therefore take this opportunity of making a more complete statement of this incident.

The parents of two little girls had come to America in 1839 and had died from cholera on Jefferson Prairie near Beloit in 1844. One of these girls by name Giertrud became the foster child of Endre Glasmager in Norway, Ill. She afterwards married Ole A. Quam, who is still living at the age of 84born Jan. 17, 1830 - with his son-in-law, Thomas Edwards, in Ashland, Wis. Thomas Edwards is president of the independent telephone company in Ashland and a large dealer in cement. He is in easy circumstances and three of his boys are graduates of the University of $W$ isconsin. His only daughter is at present a student at the same university. The other little girl, Anna, first married a man named Goddard and settled in the province of Quebec, Canada. After Goddard's death she married Mr. Arthur Newell. Anna died in the '90s, leaving several children and grandchildren. One of her grandsons is a well known singer. 
Anna was the girl left by Elling Eielsen with a Catholic family. Having repented of this he tried to get her back from her new foster parents, but they refused to give her up. He afterwards took Gjertrud with him and she about sundown succeeded in finding her sister and taking her away from the home to where Eielsen was waiting for them with his rig.

A son of Ole A. Quam, J. A. Quam, of Sheridan, Ill., married a daughter of Peter $\mathrm{C}$. Nelson, the last male survivor of the sloopers of 1825. Peter C. Nelson came with his father, Cornelius Nelson, in the sloop and Cornelius Nelson was married to a sister of Kleng Peerson, the promoter of the sloop party. Ole A. Quam's mother was a sister of Ole Olson Hetletvedt, who also came in the sloop, while she came to this country later.

While I have no apology to make, I am entirely willing to admit and have no doubt that Elling Eielsen acted in perfect good faith and believed he was doing an act of kindness to little Anna when he found a nice home for her with a Catholic family and that he did his duty when he afterwards took her away from there, though he had to do this secretly. He acted from the purest motives.

For the facts as here stated I am indebted to Mr. Thomas Edwards, who, as the reader will have seen, is a son-in-law of Gijertrud. 


\section{CHAPTER XVIII.}

\section{MORE ABOUT ALBION ACADEMY.}

I had the good fortune of securing the enthusiastic support in my work at Albion of Mr. Langland and the paper he so ably edited. "Skandinaven" at once took a pronounced position against the Norwegian Synod, both in regard to the slavery question and the question of the American common school, a position which was maintained vigorously during Langland's long career as editor. Langland repeatedly called the attention of his readers to the work I had undertaken and was doing at Albion and recommended Albion academy most cordially. I also had the support of Rev. C. L. Clausen of St. Ansgar, Iowa. He sent one of his sons to the academy.

John A. Johnson, then county clerk of Dane county, Wisconsin, was also among my staunch friends. He too had served a term in the Wisconsin assembly from Dane county, his home being formerly in Pleasant Springs. We made fine progress and the attendance of Norwegian students the next year (1867-68) was more than double that of the previous year. The faculty was enlarged and I received a regular salary. Though it was very small, I was content.

But now I had to meet another attack from the enemy. It was an attack of a new kind. I was accused of being a deserter from my nationality. I was charged with being too proud to be a Norwegian and with using my position and in- 
fluence to make the Norwegians ashamed of their nationality and to become "yankeefied."

This charge was both base and false and I went to work to meet it as best I could. In the first place I began soliciting contributions for a Scandinavian library at the academy; in the second place I studied the few Scandinavian books I had. I particularly made as thorough a study of Snorre's "Heimskringla" as possible, a work of which I fortunately was the happy possessor. I found references to the discovery of America by the Norsemen in the tenth century, a fact which was not then mentioned in any text book on Arnerican history. I visited the State Historical Society at Madison and found there to my great delight all the works published by the Royal Antiquarian Society of Copenhagen on this subject. I copied everything and immediately prepared a lecture on the Norse discovery of America five centuries before Columbus and sandwiched into it the most enthusiastic eulogies of the viking age, of the Eddas, of the Scandinavian exploits, of the literature, music and art down to present times. I gave under hydraulic pressure a most glowing tribute to both the ancient and modern Scandinavians. This lecture took the wind out of the sails of my accusers. I delivered it at the acaderny, in school houses, in various parts of the county, in Chicago, and as far north as New Lisbon, Juneau county, Wisconsin. The lecture was in English, but was delivered before mixed audiences.

The delivery of this lecture that I have reason to remember best was at the old Norwegian Methodist church in Cambridge, Wis., in the spring of 1868 . After the lecture I went with Miss Bertha Karina Olson, who had helped furnish music for the occasion, to her home. She was the daughter of the shoemaker, Hans Olson, who had come to America in 1852 and settled in Cambridge. I had seen her at three different weddings, including my own sister's wedding, had visited her at Fort Atkinson and on this evening we became engaged. She 
had attended a select school in Cambridge and had herself taught district schools in the country and had made good use of such opportunities for education as were afforded in those pioneer days. I may here add that two of my younger brothers married two of her younger sisters, so that we are three brothers wedded to three sisters. As I may have something to say of my family life later on I will only add here, that Bertha Karina has been a good wife to me and a mother of rare tenderness and devotion to our children. 


\section{CHAPTER XIX.}

\section{MY THIRD YEAR AT ALBION.}

Before the end of the second school year an address was delivered at the academy by P. A. Chadbourne, then president of the University of Wisconsin. To A. R. Green, who took the president to the train at Edgerton, Mr. Chadbourne expressed himself as surprised at finding the academy in so flourishing a condition and inquired into the causes thereof. $\mathrm{Mr}$. Green told him that the school had gotten a new start in attendance since I became connected with it and gave him a general idea of the work I had done.

Immediately after the closing of the spring term, while I was planning my summer carnpaign I received a letter from President Chadbourne requesting me to visit him at once at his home in Madison, Wis. President Chadbourne then lived in the house which afterwards became the residence of the professor of astronomy. The president received me most kindly. $\mathrm{He}$ told me that he had acquainted himself with the work that I had done the past two years at Albion Academy and wanted to give me a larger field in which to operate. He was then making arrangements for his staff of instructors for the coming year and offered me a position as instructor. He said he knew that I had not a complete college training, but promised that I should have the opportunity of completing a college course and get my bachelor of arts degree at the university while I was serving as instructor. He urged me strongly to accept his advice and 
pictured to me a much greater field of usefulness with the university as a base and with the proper attention given to my studies than would be possible at Albion.

I was persuaded; I accepted the position he offered me with a salary of $\$ 400$ for the first year. I was to teach in the lower classes and be a student myself in the upper classes. My name was sent in to the board of regents and all was settled.

On returning to Albion, I explained what I had done and tendered my resignation. This was refused. Nobody could think of the idea of my leaving Albion at that time. The board of trustees held meeting after meeting and insisted on my remaining. Practically the whole village of Albion met in mass meeting and adopted a resolution begging me to continue my work at Albion academy. This was urged as my duty and it was claimed that in the end this would be of great advantage to me. My friends did not forget to quote Julius Caesar when he said he would rather be the first man in a small town in Spain than second in the great city of Rome. At Albion I could easily, they asserted, be the first, while at Madison and at the university my identity would be lost.

I fell. I presume I had my share of human vanity and I was unable to resist all the flattery, praise and blandishments heaped upon me. Albion had had a taste of prosperity and didn't see how to continue without me. I agreed to stay, but on condition that several changes should be made. The board of trustees, without any solicitation on my part made Prof. A. R. Cornwall and me joint principals of the academy, making us absolutely equal in authority. This I accepted. Then I asked that a number of prominent Norwegians be made members of the board of trustees. This was agreed to with alacrity. Rev. C. L. Clausen of St. Ansgar, John A. Johnson of Madison, Knut Langland, editor of "Skandinaven," and Jens Olson Kaasa of Chicago were elected as members of the board. 


\section{CHAPTER XX.}

\section{SWEDES SETTLE ON THE NORTH SHORE OF KOSHKONONG LAKE.}

In 1844 there had come from Sweden a band of remarkable Swedes who had settled on the north side of Lake Koshkonong. Several of these were men of high culture. One of them, Gustaf Mellberg, was a graduate in theology from the University of Lund, and an intimate friend of the poet $E$. Tegner. Another one was Thure Ludvig Kumlien, from Skara, Sweden. Kumlien was the scion of a distinguished Swedish family. He was a graduate of the gymnasium at Skara and had nearly completed his studies as a student at Upsala. He was a bosom friend of Gunnar Wennerberg, the author of both words and music of the immortal and inimitable students' songs "Gluntarne." At the university of Upsala Kumlien had made a specialty of natural history, particularly of botany and of ornithology. His teacher in botany was the distinguished Elias Fries, who was himself the favorite pupil of the father of modern botany, Carl von Linne. Though only a student, Kumlien had received a government stipend to make a botanical exploration of the famous island Gotland, in the Baltic. He performed this task with great credit to himself.

Anyone who will take the trouble to study the conditions in European countries in the beginning of the ' 40 s will find a peculiar restlessness pervading all classes, and this uneasiness sometimes found its outlet in emigration to foreign lands. In 
this way we explain how the theological graduate Mellberg, the nobleman Reuterskjold, such highly cultivated men as $\mathrm{Mr}$. Hammerquist, T. L. Kumlien and others got together and resolved to find homes in the wilderness of America. In the middle of the Atlantic Ocean they studied a map of the United States and on it they found Koshkonong lake, in Wisconsin, and decided to go there. Each one of this group of about a half dozen secured small pieces of land on the hills on the north side of Lake Koshkonong, built with their own hands their little $\log$ cabins in genuine pioneer style and remained there the rest of their lives.

I knew these Swedes in my earliest childhood. The most of them made occasional visits at the home of my parents. Kumlien worked his little farm, but he devoted a large part of his time to collecting specimens of plants, birds, reptiles and quadrupeds and sending these to European museums, particularly to Leyden, in Holland, and to Upsala, in Sweden. He was in constant correspondence with Elias Fries and with many others of the most distinguished naturalists of his time. He had much correspondence with the Smithsonian Institution at Washington. Koshkonong lake and surrounding country was in those early days a veritable paradise to the naturalist and Kumlien had the good fortune of discovering a number of new specimens of both flora and fauna. His son Ludvig, who inherited his father's tastes for natural history, was employed by the United States fish commission and served as naturalist in the Howgate arctic expedition. Ludvig died comparatively young as professor of natural history in Milton college. It was the delight of my boyhood to walk the three miles from my home to visit the home of Kumlien, which was filled with stuffed birds of all kinds. Once I brought him an owl that I had shot and he gave me a stuffed bluejay for it.

T. L. Kumlein in the '70s arranged a collection of Wisconsin birds for the University of Wisconsin and for some of our 
Normal schools. During his last years he was engaged by the Wisconsin Natural History Society of Milwaukee and supplied its museum with hundreds of specimens of Wisconsin birds. In the latter part of the ' 80 s he died in Milwaukee. In my association with him and the other Swedes who lived near Koshkonong lake I became intensely interested in Swedish history and literature. They seemed to know the Swedish poets by heart and through them I learned to appreciate and admire the great productions of Tegner, Runeberg, Geijer and a large amount of Sweden's song and story. On account of my constant intercourse with them during my three years at Albion academy I became as much interested in Swedish history and literature as in Norwegian or English. In the death of Kumlien, this charming, scholarly fine-grained man, I lost one of the dearest friends I ever had.

A second demand that I made to the board of trustees of Albion academy as a condition of my giving up my engagement with the university and remaining at Albion was that T. L. Kumlien should be dragged out from his obscurity near Koshkonong lake and given a regular professorship of natural history at Albion academy. This was also agreed to. When I visited him and informed him of his election it was difficult to convince him that I was telling the truth.

With these and other matters arranged I promised to remain at Albion and at once notified President Chadbourne that it was impossible for me to sever my connection with this school. Mr. Chadbourne expressed his disappointment, but did not neglect to tell me that I had made the mistake of my life. He was entirely correct as will soon be seen. 


\section{CHAPTER XXI.}

\section{ALL IS WELL.}

Everything pointed to a spendid year for Albion. I received reports of new students from every part of the Northwest. Boys and girls were coming from Chicago, from Milwaukee, from all parts of Wisconsin, from Iowa and from Minnesota. The fact was that there were more coming than we could possibly accommodate in our two buildings. I therefore resolved to put up a third building at the south side of the academy grounds. This building to be built of cream colored brick would cost completed and ready for use between $\$ 6,000$ and $\$ 7,000$. I went out among my Norwegian friends to raise this money and I was successful. Many of the farmers in Dane county gave me, some $\$ 25$, others $\$ 50$ and a few even $\$ 100$ each, and the necessary funds were soon in sight. I went to Chicago and got Jens Olson Kaasa, who was a contractor, to come to Albion and bring with him a sufficient number of men, bricklayers, plasterers and carpenters, and put up a building in a hurry and have it ready for occupancy for the winter term. I raiscd all the money, Mr. Kaasa put up the building and received his pay. This building is still standing. When taken into use it was named "Kumlien Hall."

Miss Olson and I were married July 21, of that summer, and the south half of the first floor of Kumlien Hall became our first home. During the balance of the vacation and during the fall term we had been boarding. 
Having secured subscriptions enough for the new building I devoted a part of my summer vacation and the fall term to collecting books and funds for a Scandinavian library. The books thus secured I kept in my own apartments at the south hall and never formally turned them over to the academy. The attendance at the academy was large and in the winter term still larger. We had over 300 students registered and every available room in the three buildings was rented. Boarding houses in the town had all the roomers and boarders they could accommodate. We had as many if not more Norwegian students at Albion academy than were in attendance at Luther college.

All the dreams of our little Norwegian-American Educational Society, organized in the late autumn of 1865 , at Decorah, now seemed more than realized, and there was no prouder man among the Norwegians on this continent than the 22-year old Rasmus B. Anderson. I now decided to rehabilitate this Norwegian-American society on a larger scale. I wanted to make Albion academy a pattern for similar work in other American educational institutions throughout the Northwest. The idea of creating Scandianavian professorships in the leading colleges and universities of the whole land had not yet dawned on my mind. What I now dreamed of was American academies and colleges in various centers for the growing Norwegian population, these to be supplied each with a Norwegian teacher like myself to attract Norwegian boys and girls. I had in my mind that there ought to be such a Norwegian teacher at the University of Wisconsin, another at Beloit college and others at similar schools in Iowa and in Minnesota. These schools would furnish teachers for the common school and educate the rising generation for all walks of life.

For the realization of this plan-of which only this bare outline can be here given-I consulted with Rev. C. L. Clausen, John A. Johnson, Knut Langland, Wilhelm Winslow and 
other friends. They approved my purpose and we decided to call a meeting of all who might be interested to be held at the court house in Madison in early March, 1869. A NorwegianAmerican educational society was there to be organized, equipped with constitution, by-laws and officers to raise funds and carry out the purposes of the society. 


\section{CHAPTER XXII.}

\section{DIP INTO THE POLITICAL SEA.}

A couple of other things happened in this to me so eventful year, 1868. One of these was that I took a dip into the sea of politics. There was to be a state election and a national election. I was an ardent republican, but had never taken any personal part in politics. A friend of mine in Albion, who was considered a very astute politician, told me he was going to have me elected a delegate to the state convention and possibly even to the national convention. I told him that it was impossible, but he insisted that I should not interfere, but simply let him manage it. I agreed. At the caucus in Albion I was elected a delegate to the assembly convention of that district. This convention was largely manipulated by my friend, the politician. From there he took me to the senatorial convention held at Cottage Grove and there I was with great unanimity elected a delegate to the state convention which was to elect delegates to the national convention to be held in Chicago. At this state convention Horace Rublee and Mr. Seymour of La Crosse, afterwards consul to China, were elected delegates at large. My friend, the politician, was lobbying among the delegates and insisted that the Norwegians in Wisconsin being practically all republicans ought to be represented at the national convention and I was elected Rublee's alternate. Thus I swung around the circle. I got my certificate and my badge and my transportation, went to Chicago, took part in all the delibera- 
tions of the Wisconsin delegation, heard all the arguments of all the visiting delegations from the various states presenting the claims of the various candidates and actually sat in the national convention that nominated Grant for president and Colfax for vice president.

Somewhere between Madison and Portage there lived at that time a somewhat prominent Wisconsin politician by name R. B. Sanderson. When the Milwaukee Sentinel came to Albion the name of this R. B. Sanderson was printed as that of Rublee's alternate. The successful man in politics always has his rivals and so I had mine and these had a jollification meeting at my expense, thinking that I was so green in the profession that I had heard R. B. Sanderson proposed and elected delegate and supposed it was myself. There was always a large crowd present at the postofice when the mail came from Edgerton. In a few days I recaived a large envelope containing my credentials, my badge and my railroad transportation and I took pains to open this envelope in the most conspicuous manner, and thus endad the R. B. Sanderson episode. Nevertheless I was the first Scandinavian-American sent to a national convention. 


\section{CHAPTER XXIII.}

\section{AM ELECTED REPRESENTATIVE TO THE ANNUAL SYNOD MEETING.}

That same summer the Norwegian Synod was to hold its annual meeting in Chicago. I was a member of Rev. J. A. Ottesen's East Koshkonong church and I was present and attended service there on a Sunday when a meeting was called at the end of the service to elect a representative to the annual meeting. My name was proposed. Rev. Ottesen knowing my position, particularly in regard to the slavery question and also in regard to the question of the common school, objected to my election. He first claimed that I was not a member of the congregation; that I had been absent for several years at Decorah. It was shown that I had been confirmed in his church and that young men attending Luther college did not thereby sever connection with the congregation from which they had been sent. Then Ottesen argued that I was too young and that the congregation ought to be represented by someone of older membership and years. It was argued on the other side that I had had several years' schooling at Decorah, that I was now a professor at Albion academy and that I, for such reasons, ought to be particularly well equipped for the position of representative to a church convention. I was overwhelmingly elected.

I attended this annual meeting. It was held in Our Saviour's church on the west side in Chicago. The great 
question to be discussed and settled was that of slavery. This troublesome question was now to be settled for all time to come. The chief person on the negative side was Rev. C. L. Clausen of St. Ansgar, Iowa. He and I were the guests of Mr. Jens Olson Kaasa, the one who the next autumn built for us the south hall at Albion. At this meeting I presented some resolutions on the subject of education. These resolutions may be found in the printed report of that meeting. In these resolutions I took the position that the Synod should secure the appointment of orthodox Lutheran teachers at as many American academies and colleges as possible, that the Norwegian youth should be sent to these schools so that our common schools where they are controlled by Norwegian Lutherans could be supplied with teachers belonging to the Lutheran church and the children attending these common schools not be subject to any irreligious or non-Lutheran influences.

My resolutions were not adopted, but were ordered printed in the proceedings. As an illustration of how I have sometimes been subject to snubs and incivilities I will here mention that one day during this Synod meeting our host, Mr. J. O. Kaasa, invited a few guests, mainly ministers, to take dinner with $\mathrm{Mr}$. Clausen and me. Among the guests invited was the Rev. B. J. Muus of Goodhue county, Minnesota, considered to be one of the profoundest theologians and ablest debaters in the whole Synod body. He knew me by sight, but at the dinner table he asked the host, Mr. Kaasa, who that gentleman was, pointing at me. Mr. Kaasa said:

"That is Professor Anderson of Albion academy; I supposed you knew him?" whereupon Rev. Muus in his deep, bass voice, remarked:

"It surprises me that an old congregation like East Koshkonong has so little appreciation of the proprieties as to send Rasmus Anderson as its representative." 
A portion of each day was devoted to the disagreeable slavery question. A committee furnished a series of more than a dozen theses as a basis for the discussion. The first one of . these stated the relations between employer and employe, and so the subject proceeded through the different stages of master and servant until finally the conclusion was reached:

"Therefore, slavery is not $\sin$ in itself."

Already in the third thesis, the intention of the whole series was plain enough to anyone who could read a little between the lines. I therefore arose and asked for the floor, my pastor, Rev. J. A. Ottesen, siting beside me, at the same time pulling at my coattail and urging me to sit down. I was recognized by the president, Rev. H. A. Preus, and I boldly stated that these first theses were evidently prepared for the purpose of stealing a march on the opposition. I argued that the approval of slavery had been adroitly smuggled into this third thesis and that those who voted for it thereby committed themselves to the approval of all the remaining theses.

One minister jumped up and proposed that the whole Synod should express its disapproval of my insulting remarks by a rising vote. The motion was promptly seconded. The president was about to put the motion to a vote when the same Rev. Muus, who the day before had snubbed me at a dinner party, arose and said that while he entirely disapproved of my utterances he did not think it would be proper to put such a limit to free speech and free discussion. The president dropped the malter there and no action was taken.

After a prolonged discussion this thesis No. 3 was adopted by an overwhelming vote and as soon as the president had declared it adopted, Rev. Clausen, two of his representatives and I stood up, got together in the aisle of the church and all four of us stated that we now severed our connection with the Norwegian Synod; we deplored the action that had been taken as an insult to truth, and as a lasting disgrace to the Synod, and 
then we solemnly, amid the breathless silence of the whole body, marched down the aisle and out the front door. This was the last discussion of the slavery question in any public meeting of the Norwegians in this country and Rev. Clausen's connection with the Synod was permanently severed. His congregations also left the Synod and so did his former old congregation on Rock Prairie, in Wisconsin.

The opposition gradually got together and organized what was called the Norwegian-Danish Conference of which C. L. Clausen was the first president. About thirty years ago the Norwegian Synod was split in two; a large party of so-called Anti-Missourians combined with the Norwegian-Danish Conference and organized what is now known as the United Church. A few years later this church also experienced a split, a large portion of the forner Norwegian-Danish Conference seceding and organizing what is now known as the Free Church.

Not wishing to do the ministers in the Norwegian Synod any injustice in regard to the attittide they took in the slavery question, I will here quote some of their statements on the subject.

At the synod meeting in Luther Valley, Rock county, Wis., in 1861, the ministers made the following declaration:

"Although it is not according to the word of God a sin to own slaves, still slavery is an evil and a punishment from Cod and we cilsapprove (fordömmer) all the abuses and sins connected therewith, and when our duty as ministers makes it necessary and Christian love and wisdom demand it, we will work for its abolishment."

At the Synod meeting in Chicago in 1868 the Synod adopted ten theses on slavery as a reply to Rev. C. L. Clausen's declaration. The first two of these theses read as follows:

(1) "The Synod agrees with Rev. Clausen in his statement that slavery means ownership, but it does not agree with him, when he claims that this ownership consists in one person's re- 
garding and treating another person not as a human being but as a chattel.

(2) "The Synod agrees with Rev. Clausen when he asserts that it is a sin per se for a person to regard and treat another person not as a human being, but as a chattel. On the other hand the Synod does not agree with Rev. Clausen, when he asserts that this is the proper interpretation of the ownership existing between the master and the slave."

At the Synod meeting in Spring Grove, Minn., in 1869 the Synod declared:

"The Synod is anxious to do all within its power to prevent misunderstanding by distinctly declaring, that it realizes that there certainly were many laws and practices in the American institution of slavery, which either directly permitted or at least did not punish sins committed. Thus the most disgraceful and most horrible sins were committed with impunity. The poor slaves were treated with cruelty, while the masters and the leading people as a whole were exposed to moral degradation. It follows as a matter of course, that when the masters took advantage of such laws and practices and abused their slaves, such conduct was a sin against God and against man, even though it was permitted by the civil regulations."

In giving an account of what happened in Decorah and of the controversies in the Synod I want it distinctly understood that I do not harbor any sentiments of malice or ill will toward the persons with whom I in those early years came in conflict. I know they acted in good faith. They are to be honored for the ability, earnestness and zeal with which they labored. They did so little for themselves and so much for us and their graves must not be forgotten or neglected by an ungrateful posterity.

These pioneers in our church and school work, A. C. Preus, H. A. Preus, J. A. Ottesen, Laur Larsen, B. J. Muus and the rest of them, were tenaces propositi viri, unbending in their 
purpose. They were not infallible, but their integrity and piety stand unquestioned. Nor do I claim infallibility for myself. If I have at times been tenacious and stubborn, I may with some justice claim that I was their disciple. If we had not been blessed with this quality of stubbornness, we might not have been able to accomplish those results to which we now point with pride. We did not in those days know how to trim and compromise.

The Norwegian immigrants were fortunate in securing leaders so well equipped in every way for laying a solid foundation for the spiritual, moral, and intellectual work to be done. May their memories forever be kept green among us! I am proud to have known these pioneer teachers and I cherish both for those dead and for those still living only sentiments of admiration and deep reverence. Their lives should be studied and imitated by many of our present generation. Some of the spirit of those pioneers might with advantage be infused into some of our present would-be leaders. 


\section{CHAPTER XXIV.}

\section{MEET OLE BULL.}

In January, 1868, I had the gocd fortune of meeting a man who was destined to have a great and important influence on my whole subsequent life. It was also the first time that I came in close touch with a person enjoying a world-wide fame. This person was Ole Bull, the greatest violinist in his day and the most widely known Norwegian. He had come to America in the autumn of 1867 and had been engaged for a concert tour from the Atlantic to the Pacific, from New York to San Francisco. In Wisconsin he was to play in Janesville, in Madison and in Milwaukee. His first concert in this state was given in Janesville. A large number of the Norwegian students at Albion went there to hear him. In one of the rigs was found room for me. We reached Janesville long before concert time. There I learned that Ole Bull was stopping at the Hotel Meyers. I was eager to meet him and decided to make use of the excuse that he and I were distantly related on my mother's side. Thus armed I sent my name up to his room. I told him that my mother was a von Krogh and he at once recognized the connections between the Bull and the Krogh families in Norway. He received me with the utmost cordiality. I had a ticket to the concert, but he insisted on my staying with him behind the curtain on the stage where we could talk when he was not playing. I told him of my life, of my experiences in Decorah and at Albion and he became deeply interested. $\mathrm{He}$ 
wrote out a short address, a sort of greeting to the Norwegian students at Albion academy which I was to read to them on my return to the school.

He was due that same night at Madison where he was to be received by a torchlight procession and he insisted on my going with him. There was no train from Janesville to Milton and therefore a carriage had to be hired to take Ole Bull and his party to that place. The party consisted of Ole Bull, Madam Varian, the soprano, Mr. Hoffmann, the pianist, Ole Bull's son Alexander, Mr. Widdows, his agent, and myself, three in each seat. I was squeezed in between Ole Bull and Madame Varian, and I felt that I had never before been in such distinguished company.

At Milton Ole Bull was met by a delegation from Madison, John A. Johnson, B. W. Suckow, and two or three others. At Madison a large number of Norwegians had turned out with torchlights and escorted their distinguished countryman from the West Madison depot to the Vilas House. In front of the Vilas House a speech of welcome was delivered by John A. Johnson to which Ole Bull responded. Ole Bull considered himself a greater orator than violinist, but he seldom attempted to speak without making some kind of break. I remember his saying at this time that the Norwegians honored themselves when they honored him. Of course what he meant to say was that he accepted such honors as intended more for his dear Norway than for himself. In my conversation with him at Janesville I had not forgotten to mention to him that I was studying and lecturing on the discovery of America by the Norsemen. In his response to the address of welcome he made a special point of calling attention to Leif Erikson as the real discoverer of this continent; in fact, he made use of the most of our conversation on this subject. The address of welcome was in Norwegian and Ole Bull responded in the same tongue. 
At the hotel he secured me a room next to his own and he appointed me his representative to whom visitors would have to apply for audience with his majesty, the king of the violin.

The next day the city was crowded, particularly with Norwegians from all parts of Dane and adjoining counties. The concert was to be given on the third floor of the city hall and the limited number of tickets were soon exhausted. Tickets held by speculators went up to fabulous prices. To meet this difficulty Ole Bull quickly decided to give a matinee in the afternoon at which the city hall auditorium was filled to its utmost capacity. Both at the matinee and the evening concert every available seat was sold. Between the matinee and the evening concert the Norwegians gave Ole Bull a banquet at the Odd Fellows hall. An address of welcome was delivered by Mr. Sanborn, then the mayor of Madison, and an address in Norwegian by John A. Johnson.

I had the honor of sitting next to Ole Bull at the banquet board. In conversation with him he asked me whether there were any Danes or Swedes present. He was himself intensely Norwegian and very much opposed to what was called Scandinavianism, that is to any closer union between Norway, Sweden and Denmark. He wanted Norway to stand on her own feet as she does now, and his anti-Scandinavian feeling kept him from giving concerts in Denmark or Sweden and sometimes led him to exhibit his animosity toward individuals representing those nationalities. When he asked me concerning the presence of Danes or Swedes at this banquet I pointed out to him Mr. Hans Borchsenius and Mr. Mathiesen, both Danes. I knew that there was a Swede at the table, but I was unable to locate him. When the time for Ole Bull to respond came he expressed his thanks for the honor shown him and in the course of his remarks he stated that he was particularly pleased to know that there, at this banquet, were present only two Danes and one invisible Swede. But such violations of the proprie- 
ties of life were always excused in Ole Bull. He had carte blanche to say anything he pleased and it gave no offense.

Perhaps I ought to mention here that for the first time in my life I was called on to speak at a banquet. I remember how embarrassed I was. Still I thought I must say something and so I attempted to draw attertion to Norway's contributions in the field of history, poetry, folk lore, painting and music and Ole Buil himself led the applause when I mentioned P. A. Munch, Asbjörnsen, Tidemand, Lindeman, Welhaven and Wergeland. I had made my maiden effort as a banquet speaker, but when I sat down I was more dead than alive.

At the hotel Mrs. Carr, wife of Ezra Carr, professor of chemistry in the University of Wisconsin, called on Mr. Bull. The Carrs lived on Gilman street in the stone house now occupied by the banker, J. W. Hobbins. Mrs. Carr invited Ole Bull to a reception at her home after the concert in the evening. This invitation was accepted.

At this reception, which was attended by the elite of the city, including the governor and other state officers, judges of the supreme court-all of these with their ladies-I had the honor of presenting Mrs. Thorpe and her young daughter, Sara, to Ole Bull. They were infatuated with him. Ole Bull had a habit of asking everybody that he met to visit him at his magnifcent home, Valestrand, on the Oster island, a few miles north of Bergen. He invited Mrs. and Miss Thorpe to pay him a visit in Norway. Mrs. Thorpe at once accepted and said that she and her daughier would go with him when he returned to Norway the next spring. They did not forget their promise.

When Ole Bull reached New York the following spring Mrs. Thorpe and daughter were there and went with him to Valestrand where they spent the summer. Ole Bull and Sara became engaged and on their return to America they were joined in marriage by Rev. Richards of the Congregational 
church at the Thorpe home, which afterwards became and is still the governor's mansion at Madison.

The next.day after this reception at Carr's Ole Bull went to Milwaukee and I returned to my work at Aibion.

I have divelt thus fully on my first meeting with the wizard of the bow, in the first place because it had an important influence on my whole subsequent career, and in the second place because it represents a hardly less important turning point in the remarkable career of Ole Bull himself. He was then a widower, 58 years old; Sara Thorpe was still in her teens, only 19 years old. Bull was in his full vigor. On the stage he was harmony not only to the ear, but also to the eye. In society he had every accomplishment and we need not be surprised that he was able to win the heart even of a maiden in her teens. But Ole Bull was a moody man which Sara soon learned to her sorrow. The marriage was decidedly a misalliance and a misfortune to toth the contracting parties. To me it was a blessing because it brought Gle Bull to Madison to spend much of his time the remaining years of his life and in this way brought me into the most intimate relation with this grand old man for about a dozen years. 


\section{CHAPTER XXV.}

\section{LETTER FROM A SCHOOLMATE.}

From a valued friend, who was my fellow student at Decorah, I have received the following interesting letter:

Bemidji, Minn., Feb. 16, '14.

Fricnd R. B. Anderson,

\section{Madison, Wis.}

Dear Sir:- Through the courtesy of a friend I am reading your "Iistory". I am much interested as I have known you, or at least known of you, since the fall of 1862 when we first met at Decorah. And so far I find only a few immaterial mistakes as to fact, but quite a few single letter misprints. On page 11 of No. 4 you say that: in 1863 a one-story building was erected as a study room \&c. Now the fact is that there was a second story with about 25 beds. When I arrived there for my second year, in the fall of '64 I was domiciled there and slept upstairs all the time. Both floors had but one room each. And it was from a remark of mine that the place received its nickname of "Hutetu". For one evening the boys were playing the piano, dancing and scuffling when I jumped out through the door and exclaimed: "Hutetu for leven!"

You will probably get into fractions with Ingrid Egge about her age. You say she was older than you. But I think the fact is anyway that you are 4 or 5 years older than she. 
I remember well the celebration of the 10th of April, 1865. I think there was a fairly good excuse for the college not being illuminated just then. The stage coming about supper time brought the news. And when the noise began the boys all struck down street and got so interested that they forgot studyhours and all. I know that was my case.

You mention the man on horseback. I remember well Dr. John Stiles (veterinary) on a white stallion. He first forced his horse to leap over or through a ten-fost high bonfire in the street. Then he rode into old Wagner's saloon, turned around and stopped in front of the bar. Then two more men mounted the horse and sat there drinking whisky. At the same time another elderly man stood on his head at the end of the counter.

When I came outside again one of our boys said they were talking about our establishment and were going up to speak to the professors. Some one on horseback led, and quite a crowd, mostly boys, formed an irregular procession going around the block so as to come up to our buildings from the west.

Both the buildings were in the dark sure enough. But after some effort Professor Larsen came out and was asked to make a statement. And while I can't repeat his little talk I know he said he thought we had a good government and even if it were a bad government he meant to honor and obey, considering all governments established by the Supreme Being \&c.

I never heard of the conference of the next morning that you mention.

The man that called on Prof. Larsen never left his saddle while at the college.

I have lived here since last July.

Yours truly

O. B. Stephens

alias Hustvedt. 


\section{CHAPTER XXVI.}

\section{PRIDE GOETH BEFORE A FALL.}

I have dwelt at considerable length on the year 1868 . In many respects it has seemed to me to be the most important year in my whole life. It was crowded with events of the greatest significance to me. It was all sunshine. During the whole year there was not a cloud visible above the horizon.

In 1868 I had revived the Norwegian-American Educational Society; I had made the acquaintance of Ole Bull; in that same year I had been the first of Scandinavian blood to occupy a seat in a national convention; in the summer of that year I had represented the old East Koshkonong congregation in the annual meeting of the Norwegian Lutheran Synod in Chicago; in that year I had received and accepted an appointment as an instructor in the University of Wisconsin, but soon afterward reconsidered my action and withdrew my acceptance; I had made a new deal with Albion academy and had been put at the head of that institution jointly with Prof. A. R. Cornwall; I had gotten a number of prominent Norwegians clected as members of the academy board. Norwegian boys and girls were seeking admittance to the academy in large numbers from all parts of Norwegiandom in America. Albion academy, as I then saw it, was going to be the chief center of education for Norwegians on this continent. I had drawn that splendid scholar and fine-grained gentleman Thure Ludwig Kumlien out of his shell and out of his obscurity and gotten him 
elected professor of botany and natural history at our academy. I had been honored with the degree of master of arts by Alfred Univcrsity of which I have spoken. I had begun giving lectures on the discovery of America by the Norsemen and on other subjects. I had made the beginning of a Scandinavian library as a source of information for all seeking a knowledge of Scandinavian history and literature. Before the close of the year I had added a third building to the equipment of the academy, the so-called South Hall. To crown it all I had found the girl who loved me and shared my interests and aspirations. We were engaged on April 11 and celebrated our nuptials at the parsonage of my brother-in-law, Rev. S. S. Reque, in Lemonweir, about three miles south of New Lisbon, Wis.

As stated, 1868, was all sunshine and it looked to me as if the foundations were laid for a splendid future for Albion academy and for an interesting and useful career for myself.

But how little we know of what is in store for us! In the northern mythology the three norns, or. wierd sisters, are Urd, the past; Verdande, the present, and Skuld, the future. They do not, like the Greek fates, spin the threads, but they weave the webs of our lives. Urd holds one end of the woof in the far east, Skuld sits at the other end and Verdande plies the shuttle beneath the midday sun. No historian has yet succeedcd in unraveling the mysteries of the past; even the present is largely wrapped in mist, and Skuld conceals from us the future, closing our eyes with her hands.

The heavy clouds gathering beyond the horizon in $1868 \mathrm{I}$ did not see nor suspect, and yet I was destined to encounter a storm of the greatest violence, and by it the work done at $\mathrm{Al}$ bion was to be completely wrecked, and therewith all my hopes and expectations frustrated. From the giddy height of arrogance and pride to which I had climbed I was to fall and be thoroughly castigated and humiliated. 
The winter term of the academy opened with as many students as we could possibly accommodate.

Before going any further I want to explain here a fact which in my youthful ardor I did not then understand. My colleague as joint principal, Prof. A. R. Cornwall, was utterly reckless in his domestic economy and in his financial relations. He incurred debts right and left, never considering that there would come a day when he would be called upon to pay. He borrowed and bought on credit wherever he could and, in short, was in debt to everybody, and he would borrow from Peter to pay Paul. When hard pressed he would hustle and get money wherever he could lay his hands on a few dollars to satisfy his creditors.

On opening the school the fall term of 1868 we appointed Prof. Josiah Beardsley treasurer, but at the end of the term, when he made his report, it was found that from a large number of students Prof. Cornwall had collected privately the tuition money and room rent and of course spent it. The result was that none of the teachers received all their pay and I did not get a dollar. To mend this difficulty it was agreed that I should take the treasuryship the next term, that is the first, or winter, term in 1869 and here the trouble begins.

Some of the students came to me to pay their tuition and room rent. A large number did not come. When I went to collect from these I was invariably told that they had paid Prof. Cornwall. If I had been an older and more experienced man I would probably have been able to find some businesslike way out of the difficulty, but I was only twenty-three years old and had never had any experience along these lines. With my youthful spirit of independence I simply became disgusted and with all the energy and vehemence of my nature I rebelled. I was angry and excited and while A. R. Cornwall collected money right and left I protested right and left. The situation produced a tremendous tempest. Ill-considered words were 
spoken, I presume, on both sides and in the midst of it all Cornwall was quoted as saying that there were "more Norwegians than white folks at Albion academy" and that it was not the kind of school he cared to be connected with.

In the heat of the conflict I handed in my resignation. I decided to try to obtain again the position I had refused at the State University and to have nothing to do with Albion academy. I took a train for Madison to see President Chadbourne. He chided me for being vacillating, but received me with much kindness. I explained the situation to him as I was able and he gave me his sympathy in full measure. He told me he had no place for me for the spring term, but promised me a position as instructor for the next year and advised me to attend the university during the spring term as a post graduate student with a view of getting a university degree later.

With this arrangement I felt that I had weathered the storm at Albion and had reached a harbor of safety. But my success with Chadbourne made the Albion people wild. They were determined to have me disgraced and so make my connection with the university impossible. They refused to accept my resignation and proposed instead to have the board of trustees dismiss me. Before they took any action they sent for Knute Nelson and for John E. Johnson. Both came and spent a day at Albion in consultation with Dr. Head, A. R. Cornwall and many others, but did not come near me. I have never been able to understand why these two gentlemen neglected to call on me and hear the other side of the case in which they were called in as advisers. I have never been able to excuse or fully forgive them for this.

After they had gone I was told that the board had held a meeting and had given me dishonorable dismissal to be spread on their records; they had also elected one of our most promising Norwegian students, John M. Engesether, of Vienna, Wis., 
to succeed me, not as joint principal with Cornwall, but as professor.

At this time there was an academy at Marshall, in Dane county, Wis. As had been the case with Albion just before I became connected with this school, the Marshall academy had a hard struggle to maintain its existence. I knew of this school, but had never met any one connected with it. In the battle now at its height at Albion it flashed upon my mind that the most of the Norwegian students at Albion might be transferred to Marshall to continue their studies there, that is, so far as they were not prepared to enter the preparatory department of the state university.

One of the most talented and the one farthest advanced in his studies among the Norwegian students at Albion was P. A. Flaten from Black Earth, Wis. He afterwards studied medicine and died in the midst of a successful career as a physician. I explained to Mr. Flaten the plan I had in my mind in regard to Marshall academy and he consented to accept a position as a teacher there if tendered to him. We got a horse and buggy and drove to Marshall, arriving there in the middle of the forenoon. Here I persuaded the principal of the academy to call a meeting of the board of trustees and of as many as possible of the leading citizens immediately so that I might have an opportunity of laying this matter before them. My address was listened to with the greatest interest and closest attention and within two hours, Mr. Flaten, whom I introduced to the audience, was elected a professor of Marshall academy and zuaranteed a salary of $\$ 400$ a year, which was considered good remuneration in those days. He was to begin with the opening of the spring term and we were now nearing the end of the winter term. Mr. Flaten and I returned to Albion with victory perched on our banners.

I had won two battles; I had secured a new appointment for myself in the university and had found a place for Mr. Flaten 
and our Norwegian boys and girls at Marshall and was now ready to depart from Albion. Before leaving I invited all the Scandinavian students to a reception and oyster supper given by my wife and me at our home in the South Hall. Our apartments were crowded to their utmost capacity. I there made a complete statement of all that had transpired, invited those who were able to come to the university and advised all others to continue their studies at Marshall academy. I am not exaggerating when I add that there were many tears trickling down the cheeks of that audience.

The next day these students held a mass meeting in which they, with great unanimity, applauded what I had done and resolved to leave Albion academy in a body at once. They also insisted that Mr. Engesether should not serve as a "tool of our enemies" and he had to acquiesce though perhaps somewhat reluctantly in this unanimous demand made upon him. Parenthetically I may add here that John M. Engesether came to the university the next year where at the beginning of the winter term he was taken down with smallpox. He was transferred from the South Hall to an improvised pest house at the Camp Randall grounds where he died, presumably from exposure, in a few days. He was one of the most gifted and promising young men among those who have been my pupils.

To meet the emergency created by this mass meeting of the students Prof. Cornwall called a meeting of students and citizens in the chapel early the next morning. The deputy sheriff came to me and said he had been appointed to stay with me and serve as my body guard and protector, saying that there was fcar that I might be molested. I would have liked to have gone to the chapel, but my body guard feared it might not be safe. Some hot-headed person might take a notion to do me bodily injury and so I stayed away from the meeting. I was told that Prof. Cornwall delivered a long and very denunciatory harrangue with R. B. Anderson as its main topic. But 
it did not help his side. There was about a week left of the winter term, but that very day all available teams and rigs were employed in taking students to the trains at Edgerton and to their homes. It is a remarkable fact that not only the Scandinavian students departed in a body, but also a large number of Americans and English joined the exodus. The school was practically suspended.

Efforts were made the following term and for a few years afterwards to maintain the semblance of an academy, but without success. The school kept dwindling and was finally closed. The buildings were unoccupied and the beautiful grounds uncared for and those halls that had resounded with the cheerful voices of ambitious students were used in time by neighboring farmers for tobacco sheds. Sic periat gloria mundi! So passes away earthly glory!

It so happened that the meeting to organize the NorwegianAmerican Educational Society was to be held in the court house at Madison the very same week in which all these troubles took place at Albion. I went to Madison, attended the meeting and returned the next day. Personally I was so discredited by the turmoil I was in that I kept myself entirely in the background and had not a word to say. The meeting was well attended and an organization effected, but the conditions at Albion academy, to which the meeting was to point with pride, put a wet blanket on the proceedings, which consisted mainly in adopting a constitution, electing officers and adjourning. No later meetings were held. The Norwegian-American Educational Society organized at the court house at Madison in March, 1869, was a stillborn child. 


\section{CHAPTER XXVII.}

\section{MORE ABOUT ALBION.}

About the middle of the ' 90 s the whole property of Albion academy was sold for a song to Prof. Peter A. Hendrickson on the condition that it should be used for educational purposes. Peter Hendrickson was a graduate of Beloit college. After graduating he studied theology in a Congregationalist seminary. He also spent a couple of years as a student in Europe. In order to meet the competition for Scandinavian students which I had created, first at Albion and later at the university, Hendrickson was elected a professor at Beloit college, a position which he filled with credit to himself for nearly twenty years. He was an able teacher, but did not seem to have any ambition to do any literary work outside of his teaching. In the middle of the '80s he was offered a position as editor in chief of "Skandinaven" and accepted it. He held this position for about seven or eight years, but as he several times admitted to me it did not suit him. For some reason or other he and the owner, John Anderson, were not in accord and he was succeeded in the early ' 90 s by N. A. Grevstad. Being without employment he conceived the idea of purchasing Albion academy. He opened the doors of Albion academy again, spent considerable time and money in cleaning house and giving it a presentable appearance again and was in a measure successful. His very able wife served as a most efficient preceptress. One of his 
sons was also a teacher. Together they made a comfortable living, but the outlook was not promising, and so after a few years of hard work Prof. Hendrickson decided to dispose of his interest in Albion academy.

Since the above was written I have received the following letter from my old friend, Prof. Peter Hendrickson. From a literary point of view it is a gem and it throws so much valuable light on our lives and on conditions in the '70s and later, that I at once asked for and obtained his permission to incorporate it in this volume. I am sure it will be read with more than ordinary interest. Here it is:

Foxcroft, Maine, Aug. 8, 1915.

My Dear Professor Anderson:-

I have recently returned from a visit to my old home and friends in and around Portland. I intended to write you a few words before going, but failed to do so. I wanted to tell you how very interesting I found your biography as I hastily read it through in "Amerika". In fact I rather had in mind to write you a semi-humorous contrast between you and me, for I think it would be hard to find two characters more diametrically unlike than we are. I would have classified you as of the warlike and me of the pacifist nature, or perhaps more appropriately, you of the do-something and me of the do-nothing type. The furious activity of your constantly battling career appalls me and fills me with admiration, while a glance at my own past fills me with shame not to say disgust. Well, regret is useless and reparation too late, so let that chapter pass. When I think of it all I am reminded of the words of Victor Hugo: "Peu de travail ennuie; beaucoup de travail amuse" or something like that. You certainly have had your full share of "amusement" and I heartily congratulate you on the number of victories you have scored, though your nature is in many respects wholly incomprehensible to me. As I was read- 
ing your story I very often was reminded of Theodore Roosevelt and the few other men of that stamp known to history.

I was at the same time reading the "Reminiscences of Lyman Abbott" who for constant activity and mass of work accomplished compares with you, but the two natures as different as peace and war. How grand such lives of activity are! When I read your book again I shall be able to study it with more care, and I may take the liberty to ask you some questions.

Now where do I come in? The "do-little folks" generally think they are and also seem to be quite busy. Until now I have most always been panting and puffing and struggling, yes even sometimes with an element of seeming heroism in it; but when I look back upon the now long path it looks like a blank where it is yet covered with heaps of neglected opportunities. My boy life at home on the farm was placid, goody, and a little bookish, something like a wild flower by the edge of the garden-nothing to spur, nothing to hinder.

At seventeen I went to Beloit, arriving there with just what was left of a five dollar bill my father gave me at the station. Four years in the academy without a cent of help from any source and only about half pay for my work at home on the farm in vacation. It was saw wood, do chores, run errands, or janitor work, at times almost "unto blood" and on the brink of despair. I did, nevertheless, come out of the academy at the head of my class, but I think with some of my physical elasticity strained. In college it was not quite so bad, for I had then "learned the ropes" and I got some help the last year and a half and graduated third in the class. But now comes the great mistake-I went right into a great fog. I had no definite purpose, no fixed ambition. I somehow thought the great batthe of life was all over and victory won. It was now to slip into a smooth rut and move gracefully along to easy triumphs. To stand before audiences, charm them with the grace and dig- 
nity of our manners, the elegance of our diction, and the force of our arguments was all there was to life, and all this we had "learned to perfection". In all these things I was pretty near at the top. I had talked to cows and horses and even pigs in barns hundreds of times and nearly as often to birds and rabbits in the woods, and always with the same "irresistible force of logic and eloquence".

I inherited a piece of property, sold it and had three years in Europe. I studied and read much and made many friends but all with the same want of a definite plan and purpose. But I am making you tired, if you have not already thrown this into the waste basket.-But, wait, I must add that I think I was a fairly good teacher at Beloit, and at Albion for seven years (by the way, you once published it as only five years-it was full seven) I worked hard, harder, hardest—nobody can ever know how desperately hard I worked and sacrificed. I earned over two thousand dollars in political campaigns and put it in; I sunk my \$5,000 life insurance in it, and even then, if it had not been for the splendid efficiency of my wife we would have been swamped. I got some of it back. I think you have also made the statement that I "made a fair living there"-yes, call it so, but at the expense of three-fourths of a nervous system.

But there is one thing I would like to make clear to you in regard to my education and its results. There was nothing in my boy days at home to awaken in me any interest in Norway or "überhaupt" in Scandinavian matters. Norwegian history or literature was not heard of in my surroundings. I occasionally saw and heard the earliest Norwegian preachers like the Preuses, Brandt, etc., and the easy, soft and kindly Stub, and a fool named Thalberg who confirmed me. But neither of them ever tried to interest me in anything human or divine (outside of the instruction for confirmation) and I never got any respect for them as men or as Christians. We had a couple of 
Norwegian teachers and we despised them as they richly merited. My mother was great-that is, religiously; she taught us from very infancy with wisdom and skill. She was a Christian: the preachers - in my estimation-were not. Well, my oldest brother, Hans, was a wonder-one of those precocious children that know more at ten than most mature men. From the age of three mother had taught him. He had a memory that let nothing drop. At the age of seven he could repeat the gospel of Mathew and many of the church hymns, etc., etc. Through Rev. Clausen he learned of the young Beloit college, and in 1849 became, I think, the first Norwegian boy at that institution. Like me, he got no help from homethat was not thought necessary in those times-but he performed the marvelous feat of passing entrance examination in a year and a half, and in the first three years in college he made a record that had never been equalled, according to the unanimous testimony of the professors. Shortly after coming home in long vacation he died of cholera-July 26, 1854. He was the oldest and I was the youngest in my mother's family of four. I was then twelve, and five years later I went to Beloit. My mother's teaching and my brother's example was what animated me and fixed my purpose. I had nothing to battle with except poverty; I knew nothing but friendship, encouraging words from teachers and fellow students buoyed me up; I was a "popular student"; everybody called me Peter, but I never heard anything about Norway or Scandinavian matters. Besides the classics, oratory and elocution monopolized the attention of all and in that line I got all the honors that lay in my path. Besides this, the great moral lesson I had gotten was: "Go out into life, be loyal to your convictions of truth and honor and take the first work that is placed before you, do it faithfully and well, and Providence will steer you all the rest of the way." 
The college and most of the community was composed of New Englanders: by these surroundings I was literally adopted, absorbed and transformed. When I graduated I was a New Englander in mind and spirit, nothing else. My first year in Europe I spent in Norway, not for any definite purpose, but mainly out of curiosity and also to please my parents, who seemed to have a pride in it.

In Norway I was disappointed. I have always been bashful and timid; I did not push myseif forward, I was really not "discovered" till I had been there six months. Then I suddenly became popular and was somewhat feted as the first emigrant boy who had gone through an American institution and revisited his native land. But I did not value these attentions very much. The cultured life, and especially the student life did not please the "Puritan New Englander" in me. The lectures seemed dull and clumsy and hard to get interested in; and the students led a wild and often riotous life-drunken, dissipated and vile were many of them. A relative of mine, a very fine, brilliant young man, just past his "Anden Examen" was going to study theology and did actually become a preacher, but was now a notorious "rangler" with whom I soon refused to associate.

The very first week I was in Christiania I got switched onto a sidetrack which has very much influenced my later life. A Danish professor, Rasmus Nielsen, was then delivering a course of lectures on "Tro og Viden". He was a disciple of Sören Kierkegaard, a brilliant lecturer, and I soon fell to reading Kierkegaard and Martensen and all the philosophers of that time with almost feverish zeal. Nothing had ever taken such hold of me.

And now I will cut this whole lingo short by confessing that I have never yet known whether I was a philosopher or a fool. I am reading philosophy now all the time as diligently as if for an examination. Nothing else for the past three years. The- 
osophy - oriental religions, Buddhism, etc. Now very busy with the writings of William James which captivate me very much. In fact I am struggling to work out a "Weltanschauung" of my own. I enjoy it. Time is not heavy on my hands. I should be very happy and contented if, on looking back, I could see a little larger results of my life.

Pardon me for sending you all this stuff.

Yours truly,

Peter Hendrickson.

The Norwegian Synod congregations in southern Wisconsin and northern Illinois had held several meetings on the question of establishing an academy of their own. At their meetings they received bids from Beloit, from Deerfield, from Cambridge, from Stoughton and from Madison. Prof. Hendrickson offered to sell them his interest in Albion academy. On account of its favorable location, I and others urged the purchase of Albion academy and our arguments finally carried the day. The property was turned over to the Norwegian Synod, was immediately opened by it and Albion academy still continues to be conducted under its auspices. It has an able corps of teachers and a reasonably good attendance. I feel a deep personal interest in its welfare.

It would be unfair to Albion academy if I should omit calling special attention to the great work done by this institution from its incipiency in the early ' 50 s down through the early pioneer days in Wisconsin. It was indeed a lamp of inestimaable value to guide the early settlers. It furnished a large number of district schools with efficient teachers. By awakening an interest in literature, it brought sunshine into many homes. Many of the farmers and business men of Dane and surrounding counties owed all they possessed of higher training to this academy. 


\section{CHAPTER XXVIII.}

\section{ALBION STUDENTS.}

Some of the students and alumni of the Albion academy that practically closed its doors in March, 1869, have become prominent in various walks of life. I will mention a few of these with an apology to those whom I may not remember.

There is Knute Nelson who was the first Norwegian to be elected to a seat in congress, serving the "bloody fifth" of Minnesota in that capacity for several terms. He was also the first Norwegian to fill the office of governor, being twice elected to that office in Minnesota. Likewise he was the first Norwegian to be elected United States senator, in which position he has recently been reelected to the fourth consecutive term. He has a wonderful hold on the good will of the people of his state and has attained high rank among his colleagues in the senate. All his education was received at Albion academy. After graduating at Albion he studied law in the office of John C. Spooner's father at Madison.

While discussing Knute Nelson's career I seize the opportunity of giving this somewhat interesting episode from his life in Wisconsin.

In 1868 Knute Nelson had been elected a member of the assembly from the eastern half of Dane county. In that way he became at once a representative Norwegian in the state.

Before the state convention the following year a number of prominent Norwegians held a meeting in the Dane county court 
house for the purpose of securing the nomination of a Norwegian on the republican state ticket. This group of our citizens had not been represented on a state ticket since the days of Hans $\mathrm{Hcg}$, he having been twice elected state prison commissioner before the war at which time the commissioner was a regular state officer. As heretofore stated Hans Heg resigned to raise and organize the Fifteenth regiment of Wisconsin volunteers for the war.

Knute Nelson was at the above mentioned meeting in the court house. He was called on to speak, but was not willing to commit himself. The meeting was asking for a Norwegian for the office of secretary of state, but Knute Nelson had evidently promised to support an American friend of his, a Dane county man by name Spencer, for that place on the ticket. It may be added that it was Spencer who had helped Mr. Nelson to be elected assemblyman. Mr. Spencer was at this time serving as assistant secretary of state and was a candidate before the state convention for the office of secretary. The Norwegians convened at the court house, wcre steered mainly by John A. Johnson, and adopted a resolution recommending Col. Ole C. Johnson, a brother of John A. Johnson, to the state convention for the nomination of secretary of state.

Ole C. Johnson had served as an officer in the Fifteenth regiment, had been a prisoner of war, had suffered all kinds of hardships, had escaped in a miraculous way by cuiting a hole through the floor of a freight car and lying down between the ties, had let the whole train pass over him, badly tearing his clothes, and after that reaching the union lines by perilous night marches. Near the close of the war he had been appointed colonel of a regiment which did not, however, see much active service. The Norwegians of Wisconsin now wanted Col. O. C. Johnson to be their political Moses to lead them into Canaan's happy land of political offices. 
At the state convention the next day the court house resolutions were read. Both O. C. Johnson and Mr. Spencer were placed in nomination for secretary of state, but Spencer won by a substantial majority. Knute Nelson, who was a delegate, voted for Spencer.

The campaign had not progressed far when it appeared that Mr. Spencer, as assistant secretary of state, was guilty of irregularities in his accounts. A special meeting of the state committee was immediately called. Mr. Spencer's name was taken off the ticket and that of Llywelln Breese of Columbia county substituted. It seemed to me that it would have been good politics if the committee had given the place to Col. Johnson although this might have irritated some of Spencer's friends on account of the previous contest. Mr. Spencer refused point blank to acquiesce. He declared himself innocent of any irregularity in the office from which he had been removed and decided to make the run as an independent candidate. Knutc Nelson loyally supported him. Spencer was overwhelmingly defeated at the polls in November and both Spencer and Nelson were politically dead. It ended Nelson's political career in Wisconsin. He moved to Cambridge, in the eastern part of Dane county, and hung out his shingle as an attorney, but there was not much for a lawyer to do in that small. village and so Knute Nelson gathered up his personal effects and moved with his family to Alexandria, Minn., which has been his home ever since and where he soon entered upon the brilliant political career which has since been his good fortune.

Another Albion student who has made his mark in the world is J. Q. Emery. I remember him from the day of his graduation. The following year he was my colleague as a professor at the academy and I gave him private lessons in Latin. $\mathrm{He}$ afterwards became county superintendent of schools, then city 
superiniendent of schools in Fort Atkinson, Wis., thereupon president of our Normal school at River Falls, then elected and reelected state superintendent of public instruction, and has now for years held the position of state dairy and food commissioner with great credit to himself and to all concerned.

One of Albion's distinguished sons is Alva Adams. He came from Black Earth, Wis., moved to Colorado where he has accumulated a fortune, where he has repeatedly been elected governor, although he is a democrat, and where he would years ago have been elected to a seat in the United States senate had his party been in control of the legislature. He is an orator and writer of rare ability and a gentleman of charming personality.

C. V. Bardeen was the son of a prominent tobacco grower midway between Albion and Edgerton. He practiced law successfully for many years in Wausau, Wis., was elected circuit judge in that part of the state and then served several years until his untimely death as a member of the supreme court of Wisconsin.

W. C. Silverthorn of Wausau is eminent as an attorney, has seen service as circuit judge and has been the democratic candidate for governor.

Louis R. Head, the son of Dr. C. R. Head, president of the board of trustees of Albion academy, has held various high positions as physician, was for some years superintendent of the Mendota hospital, Madison, Wis., and since his retirement from that position has built up a large practice of medicine in Madison, where he is a leading citizen.

E. L. Greene, a graduate of Albion of 1866, has had a wonderfully successful career as a botanist. He was reared in the Seventh Day Baptist church. In the '60s he became a preacher in the Methodist church; later he became a pastor in the Episcopal church and finally identified himself with the 
Catholic church of which he is still a distinguished member and a professor in its great university at Washington, D. C. His first steps in the study of botany were taken under the guidance of T. L. Kumlien. Later he went to the far west where he hecame the discoverer of countless hitherto unknown members of our American flora. He became a close friend of the dislinguished Asa Gray and many other American and European botanists and is today himself one of the great botanists of the world. E. L. Greene is without any doubt the most noted scicntist that Albion academy has produced and would be a credit to any university or any nation.

Good things could be said of a number of others who received their education at Albion academy and have since attained prominent positions in their respective communities. There are the brothers Sylvanus and A. R. Ames, the former now superintendent of schools in the eastern district of Danc county and the latter a prominent real estate man of Madison, and I. P. Ketchum, business manager of the Madison (Wis.) Democrat. I had the honor of giving I. P. Ketchum his first lessons in bookkeeping.

Of Norwegian Albion students who subsequently made their mark in life I may here mention Christ Melaas, the merchant prince of Stoughton, Wis., P. A. Flaten and A. L. Hollo, who both became well known and highly respected physicians; P. O. Nolen, who died as a prominent attorney in Duluth and my brother Abel Anderson, who is a Norwegian Synod ministcr in Montevideo, Minn.

But this sketch of Albion academy students would be sadly defective if I did not mention Elias Molee. His father came from Tin, Telemarken, Norway, in 1839 and settled in Muskege. One of his aunts was married to Col. Hans Heg and another aunt was married to Elias Stangeland, a man who became widely known as a Norwegian journalist in Madison, Wis., and as a publisher of a Norwegian edition of Luther's 
sermons, a book nearly the size of Webster's unabridged, a Herculean undertaking among the Norwegians of the ' 50 s in this country. I presume he lost money on this venture. The book was published in Madison. Elias Molee was sent to Luther college in Decorah. There he and I became intimate friends and he followed me to Albion. He graduated at Albion in 1868 and afterwards became my pupil at the University of Wisconsin. He was a young man of extraordinary ambition. While yet a student at Decorah he began deploring the multiplicity of languages and insisted there ought to be only one universal tongue and this one tongue ought to be simple and absolutely regular. As a student in Albion he had the idea of becoming the creator of such an universal language. He entered Luther college under the name Elias Johnson. This was also his name at Albion academy, but he thought there were too many Johnsons and that it would not be easy for him to establish his identity and make his mark in the world with so common a name. Therefore, in order to distinguish himself from the other Johnsons he inserted a " $t$ " and called himself "Johnston." But this did not serve his purpose. His correspondents seemed to overlook the " $t$ " and write his name, as before, "Johnson." He envied such men as Clay, Webster, Lincoln and others who seemed to have gotten names that would easily be remembered and serve as identification. He studied the problem and wishing to have a name that nobody else bore he coined the word "Monololo" and for a time he used that as his surname. It was "Elias Monololo".

From the university he went to Houston county, Minn., where for two terms he was elected county treasurer, but under the name Elias Johnson. In Spring Grove, in that county, he met a widow with two grown daughters and considerable property. The widow's name was Velo. I think Mrs. Velo courted him. At all events they were married. Elias now thought his time had come to create a new language for the 
whole world. He thought Velo would be an excellent name for him to be known by and so he applied to the state legislature of Minnesota to have his name changed from Elias Johnson to Elias Velo. This was done, but the transcribing clerk had made the "l" look like an uncrossed " $t$ " and so the governor remarked that he did not care to veto the bill changing "Johnson" to "Veto".

Elias and his wife were not compatible. He was the essence of good nature but she seems to have looked upon him as a shiftless person who wanted to dabble in literature at her expense. So they agreed to separate. They went together to the judge in Caledonia, the county seat of Houston county, and asked for a divorce, but as neither one was able to give a sufficient cause the judge refused to grant it.

Mr. and Mrs. Velo than agreed that one would have to strike the other so as to establish a cause for the desired divorcc. Elias said it would not look well for a large able-bodied man like himself to assault a frail woman and so it was agreed that she should strike him. She did so and with this evidence they went a second time to the judge and then obtained their divorce. Elias then went to Bristol, S. D., engaged in farming and in working on his universal language. He accumulated some property and then went to Minneapolis where he fell in with another widow who had several children and some property. This woman also got tired of supporting Elias, who spent his time and money in linguistic pursuits of which she had no appreciation.

After a couple of years they also agreed to separate and since that time Elias has enjoyed the blessedness of single life. For many years he has lived in Tacoma, Wash., which is still his home. He has published a number of pamphlets and several books, all on the one subject of his universal language, a form of speech entirely distinct from Volapuk or Esperanto. His first book was published by "Skandinaven" in Chicago, his 
second by Rand, McNally \& Co. of Chicago, and his last one by the great Trubner publishing house of London. He calls his language "Tutonish". It is made up of roots from the Germanic languages. It is entirely regular and he uses no capitals.

A few years ago he went to Europe solely in the interest of his language. He visited Christiania where he organized a Tutonish language society, getting the support and cooperation of a number of the most distinguished scholars in that city. He also visited Berlin, Leipsic and other German cities and as he has writen me he was well received. The best proof of distinguished attention lies in the fact that he secured the Trubners as publishers of his last book. This gave him a distinct standing in the world of books and writers.

After his separation from his second wife he assumed the name Molee based on his father's farm name in Tin, Norway, which was "Moyli". He has reflected great credit on Albion academy and earned an honorable position among its most distinguished sons. He has made the name elias molee immortal.

I would like to give a list of all the 303 students that attended Albion academy during the year 1868-69, but it would take too much space. In addition to those already mentioned. I think I ought to mention: H. C. Adams, from Cottage Grove. He afterwards served our district as member of congress and died in the harness; Halsten O. Brager from Black Earth; Albert J. Berge, Mt. Horeb; Ole Bilstad, who is now a prospcrous druggist in Cambridge, Wis., and whose son is a wellknown physician in that city; S. M. and H. A. Bue from Deerfield, Wis.; Charles P. W. Clausen, who has repeatedly becn elected to state office in the state of Washington. He is a son of the late Rev. C. L. Clausen. F. W. Coon, who is a publisher and leading citizen in Edgerton, Wis. Geo. W. Currier, who became a prominent journalist and citizen of Stoughton, Wis. Edwin A. Drotning, the present postmaster 
in Stoughton. E. T. Farnes from DeForest. He afterwards took a full course in the state university, and then studied theology. Michael S. and Thomas Frawley. Sina C. Johnson of Christiana. H. M. Langland of Lucust Lane, Iowa. O. H. Lee of Christiana. He afterwards married Sina C. Johnson. They now reside in the state of Washington. L. K. Lier of Christiana. L. K. Luse, now a prominent attorney. Chas. Olson (Kittel Onsgard) of Albion, now a prosperous farmer in Burke, Wis. D. N. Rothe, Deerfield. C. A. Sjolander from La Crosse. Nels O. Starks, who died as a successful real estate dealer in Madison. H. O. Texley of Cambridge. T. G. Thompson of Deerfield. He has served a term as assemblyman. E. A. Weigen, who died seeking gold in Alaska. O. P. Swerig, now a citizen of Minneapolis. Jessie Brodahl, daughter of Rev. P. M. Brodahl of Perry, Wis. Julia Ingebrigtsen of Stoughton and her sister Betsey. Julia afterwards married the well-known Prof. J. D. Jacobson of Luther college. Florence Taylor of Cottage Grove. Her father William R. Taylor served one term as governor of Wisconsin. Th. W. Evans, now a well-known physician in Madison, had charge of the bell. D. J. Whittet, the father of Assemblyman L. C. Whittet.

I hope to be forgiven by those whom I after this long stretch of years may have forgotten to mention in this list of Albion students.

Besides meeting Ole Bull I desire to mention here that I once heard T. H. Brand give a violin concert in the chapel of Albion academy and I thought his music the finest I ever heard or would ever hear. In Janesville I one night heard John B. Gough, the great temperance orator, and he gave his famous passage on water with a full glass of water in his hand. I also heard the country's most distinguished senator, Charles Sumner, deliver his address "Are We a Nation?" in Janesville. At the hotel I was allowed to shake hands with him and look at 
the scar on his head from the wound after the assault made on him by the southerner Preston S. Brooks of South Carolina.

The student making a study of pioneer life in Wisconsin will not fail to find that it contained many virtues that are sadly lacking in our day. It is true that the pioneers as a whole were deficient in what is called education, culture and refinement; but they were industrious, serious and ambitious. Whether occupied in tilling the soil, in selling goods or in the practice of various professions they applied themselves with great diligence and singleness of purpose, and their children, whether in the common school or later in the academy, college or university, exhibiled those same traits of industry and ambition. Every pupil was determined to get the best results possible from the time he was allowed io attend school. In this way alone can be explained the large percentage of successful men and women in the various walks of life. 


\section{CHAPTER XXIX.}

\section{LEAVE ALBION.}

After March, 1869, Albion, with its academy became for years a mere story of what it had been. On the fatal day which has been described nearly all the students returned to their homes, the academy buildings were empty and the town was deserted.

I loaded my few belongings consisting mainly of my books and a few modest pieces of furniture on a wagon and sent them to Cambridge where they were stored. With these goods I also had the library which I had gathered during the previous twelve months. For my wife, who was soon to become a mother, I found temporary shelter in the home of her parents in Cambridge. All this done as well as circumstances permitted, I went to Madison to study at the university during the spring term. I was offered a room and board at the house of my good friend, John A. Johnson. I sawed and carried his wood, did little chores and helped take care of his little daughter Ida. Mr. Johnson was at that time associated with Williams, Hoyt, Proudfit \& Gernon in the handling of Walter A. Wood's reapers and mowers in the Northwest. In this business he laid the foundation of his later wealth. His home was at that time on the north side of West Main street midway between Broom and Bassett streets. Before this time he had served several terms as county clerk and he was, all things considered, probably the best known and most influential Norwegian layman in Amerca at that lime. 


\section{CHAPTER XXX.}

\section{MORE TROUBLE.}

When the spring term opened at the university I was on hand to register and to determine which classes I could attend. President P. A. Chadbourne sent for me to come to his office. Imagine my consternation when he informed me that I could not be admitted to the university even as a student and that my engagement as instructor for the next year had been cancelled. He explained that he had full information in regard to me, both concerning Albion academy and Luther college and he regarded my record at both places to be of so serious a character as to entirely exclude me from the university.

It seemed as if the floor were sinking beneath my feet. My future seemed a mere blank. But I braced up and gathered up all the courage there was in me and with all the emphasis that I could command I demanded an opportunity of presenting my side. He had heard the representations of my worst enemies and I urged that he had no right to pass judgment without also hearing the other side. My appeal to him was so earnest and passionate that he could not refuse me a hearing. He therefore appointed an hour on the next day when he would be pleased to listen to me and hear what I had to say in my defense. Accordingly the next day I came to his office and gave him a complete history of my life, including a detailed account of my 
expulsion from Luther college and of the circumstances that culminated in mý departure from Albion.

It may be immodest on my part to mention it, but I do believe that I was really eloquent in this narration of my life story to President Chadbourne. It was an eloquence produced by the feeling that my whole future depended on the effect of my words. President Chadbourne listened to me with increasing interest. My story made a deep impression; he arose and told me that he was convinced that I had been much wronged. $\mathrm{He}$ told me that I might enter the university and that my engagement as instructor would not be cancelled. I remember that he patted me on my cheeks, telling me that I should look upon him as my friend and that I should feel free to come to him with my troubles. This interview dispersed the clouds and brought sunshine back into my life. I devoted the most of my time during that term to the study of Latin, Greek and history and in hearing lectures by President Chadbourne on botany.

At the end of the spring term I rented a small cottage on West Main street opposite John A. Johnson's home and brought my little family to Madison. The library which I had begun collecting while at Albion I now turned over to the University of Wisconsin library, calling it "Mimer's Subdivision". It consisted of several hundred volumes, many of which were of but little value, but this Mimer's library became the nucleus of that splendid collection of Scandinavian books now found at the university.

In order not to have to refer to my flitting again I will now state, once for all, that Mrs. Anderson and I lived only two months in that cottage on West Main street. From there we moved into a small house on East Washington avenue below Blair street, thus becoming a near neighbor of Halle Steensland. The next summer we rented a house owned by Col. O. C. Johnson on East Gorham street nearly opposite the second 
ward school house. In the fall of 1871 we rented a cottage built by Prof. J. W. Sterling at what is now called Sterling Court, near the university. Three or four years later we rented a house owned by Alexander Gill on West Washington avenue below Broom street. In 1881 we purchased a house at 316 North Carroll street and this has been our home from that time to this.

In these our various homes we have had the pleasure of entertaining a number of distinguished guests among whom I may here mention Ole Bull, Björnstjerne Björnson, Kristofer Janson, Edward Everett Hale, John Fiske, Edward Remenyi, Paul B. Du Chaillu, the celebrated explorer of Africa, Knut Hamsun, the Danish minister Bille, the Norwegian minister Bryn, Halfdan Koht, Captain Angell, Mrs. DickVaaler, C. L. Clausen, V. Koren, H. A. Preus, J. A. Ottesen, Sven Oftedal, Sven Gundersen, Prof. L. Larsen and scores of others, particularly Scandinavians of prominence in this country. 


\section{CHAPTER XXXI.}

\section{AT THE UNIVERSITY.}

My first year at the university as an instructor consisted chiefly in hard work. I had four classes per day, five days a week. I keenly felt that my teaching would be scrutinized as it never had been before. It seemed like beginning life over again and that what $I$ had done heretofore was without value. I also realized that the atmosphere was filled with prejudice against me and that it was up to me to make good. I was a sort of supernumerary and had to take such classes as were assigned to me. If an instructor were needed in mathematics, I had to take the class and so on in the different departments. During my first years in the university I taught Latin, Greek, German, Anglo-Saxon, ancient history, English grammar, arithmetic, and several other subjects, and I was kept pretty busy in studying my lessons before appearing in the class room.

The idea of a chair of Scandinavian languages, literature and history in the university had begun to take shape in my mind, but had not yet matured. There were but few students of Scandinavian parentage in attendance and I saw but little opportunity of organizing a class in Scandinavian studies, and as I keep on indicating I was exceedingly timid on account of all my recent troubles. Of the fact that my Norwegian enemies had not laid down their arms President Chadbourne furnished the proof. One day shortly before Christmas he asked me to 
come to his office. He then informed me that he had received letters from Norwegian-Americans who protested vigorously against my being employed as a university teacher and urged that my services be discontinued. The president did not inform me from whom he had received such letters, but he said he wanted me to know the fact, at the same time assuring me that his personal relations to me had undergone no change. $\mathrm{He}$ advised me not to pay any attention to my enemies, but to concentrate all my energies on my university work and leave the rest to him, he would take care of me.

President Chadbourne's kind words gave me the kind of encouragement of which I was much in need, but all is not gold that glitters and my future in the university was not, by far, so secure as the reader may have been led to suppose. There was a serious flaw in President Chadbourne's assurances of protection. I knew that I could depend on his good will, but it was already being talked all over the state that Chadbourne would sever his connection with the university the next spring, and if he left who would take his place as my protector? The fact is, and I may as well state it now, that President Chadbourne did resign at the end of this school year and leit the university and Wisconsin for good. Prof. Sterling took his place during the interregnum, then the regents committed the egregious blunder of electing the unexperienced, clumsy, impractical Methodist preacher, J. H. Twombly, as president.

The regents soon discovered their mistake, demanded Twombly's resignation and elected as his successor Prof. John Bascom of Williams college, decidely one of the brainiest men who ever set foot on Wisconsin soil. John Bascom was a great man, a great teacher and a great university president. No teacher in our university has been more beloved and respected by the students, and he left an impression on all who came under his influence. In him I found again a warm friend. He took an 
intcrest in my university work and in my literary activities and aspirations.

But to return to my first year in the university. Already the second term of that year the number of Scandinavian students had increased and so I was able to organize a small class in Norwegian. With this as a basis, I gradually began to urge the addition of Scandinavian languages, etc., as an elective study in the university curriculum. I wanted these languages and literatures formally recognized. The whole university faculty refused to listen to me. They were, all of them, totally ignorant of Scandinavian literature and had only the most superficial knowledge of Scandinavian history. They said I had Scandinavian languages on my brain; they regarded this as a form of disease and pitied me. Imagine a man coming to the university today and insisting it was absolutely necessary to establish a chair in Patagonian, imagine him claiming that Patagonia is the cradle of all our libertics and of the laws out of which all modern civilization has poured, imagine him urging that Patagonian is more important than any of the studies now offered in the university curriculums, imagine what sort of reception this Patagonian would receive, and you have a clear idea of my position as an advocate, champion and apostle of Scandinavian siudies. My efforts hardly left an impression.

The university had few books to which I could refer to furnish evidence of the correctness of my contentions. I was but poorly armed and equipped for the contest. To please President Chadbourne, to show my appreciation of what he had done for me and to make my bow to the public as a writer I translated a small pamphlet by Chadbourne into Norwegian. I set the type myself, working nights in a printing office owned by B. W. Suckow. He was publishing at that time an Illustrated monthly called "Billedmagazin," edited by Svein Nilsson, afterwards for many years editor in chief of "Skandinaven." In 1868 this same "Billedmagazin" had contained an 
cxtended account of my work at Albion academy, with pictures of the academy buildings. Chadbourne was a sincere Christian. The subject of the pamphlet which I translated and published was "The Relations Between Science and Christianity", the author's object being to show that there is no conflict bctween the teachings of Christianity and the teachings of science.

My chief object in translating the booklet was to show that the Norwegian Synod ministers were mistaken when they denounced the American public schools as godless and destructive of the Christian faith. The booklet produced a great deal of discussion, pro and contra, in the Norwegian-American press and thus my main purpose with this my first literary attempt was fully realized. It was published in 1869 . 


\section{CHAPTER XXXII.}

\section{CHADBOURNE LEAVES THE UNIVERSITY.}

In the summer of 1870 President Chadbourne resigned and went to Utah and from what I have already stated about all his kindnesses to me his leaving was a very great loss to me. There was no one left in the faculty to whom I could go and discuss my aims and aspirations. Outside of the faculty I had Ole Bull, and John A. Johnson. Indirectly Ole Bull was a tower of strength, but he was not equipped for doing any personal work, either with the university faculty or its regents. John A. Johnson, on the other hand, was an experienced politician, and he knew how to approach the people in authority in my behalf and in the interests of the cause. He also knew all the state officers and the members of the board of regents and his word had great weight with them.

While Prof. Sterling, as acting president, and his successor, President Twombly, were without any interest in or appreciation of the Scandinavian languages as a branch of university instruction, still they knew that there was a large and growing Scandinavian population in the Northwest; they noticed that a considerable number of Scandinavian students were attending the university, and so they came to look upon it as a matter of good business policy to give this group of our population some sort of recognition in the department of instruction in the university. I attribute to this, that as one year after the other ended I was not dropped as an instructor, 
In the meantime two things were uppermost in my mind. The one was to do as well as I was able the teaching assigned to me; the other to make the university well known among the Scandinavians and to get as many as possible of their children to enter it as students and make it the center of education for the whole Scandinavian population of this country. I organized classes in the Scandinavian languages and persuaded as many as possible to join these. I also induced a number of students who were not of Scandinavian extraction to learn one or more of the Scandinavian tongues. As a text book I used Björnson's "Synnöve Solbakken" and Tegner's "Fridtjof's Saga".

Outside of the university I took every opportunity to urge the tremendous importance of Scandinavian history and literature as an element of culture, and in this I was splendidly supported by Ole Bull. After his marriage Ole Bull made Madison his American home and spent much of his time there. I was in almost daily intercourse with him and I think I may safely attribute it to him that my eyes were opened to the need of a vast amount of work in the line of presenting Scandinavian antiquities, history and literature to American readers. Somebody would have to do on a large scale for the other departments of Scandinavian culture what Jenny Lind and Ole Bull had accomplished in music. In the early ' 70 s very little had been done in the English language. In this country George P. Marsh had translated Rask's "Icelandic Grammar"; Longfellow had translated Tegner's "The Children of the Lord's Supper" and Bayard Taylor had published a book on his travels in Scandinavia. An obscure Dane by name Sinding had published in New York a very flimsy history of Scandinavia. It is fair to say that at this time Scandinavia was among the cultivated Americans an unexplored country.

This petit done and undone vast constantly occupied my mind, but how to get it done, there was the rub. I wanted to 
do it, but knew only too well that I lacked the education; that I did not have access to the necessary books; in a word, that I did not have the necessary equipment. But where there is a will there is a way. If I could not do all, I could at least make a beginning and blaze the route for others, and so I went to work and applied myself industriously with the limited means at my command. For some reason or other, I had arrived at the conclusion that Norway outclassed all other countries in the field of folk-lore, or nursery tales. The German folk-lore tales had teen collected by the Brothers Grimm. In Norway Asbjörnsen and Moe had performed a similar task. As a boy still on the farm in Albion I had read a small volume of Asbjörnsen and Moe's folk-lore tales. Now in 1871, I conceived the idea that these stories ought to be read by all Norwegian children in America and that a collection of them would serve admirably as a text book in teaching the Norwegian language in the university.

Accordingly I went to work, selected what I thought to be the most characteristic of these stories, furnished them with a glowing preface or introduction and the "Skandinaven" published them for me in a little volume called "Julegave" (Christmas Gift). I builded more wisely than I knew. The book served me well as a textbook in the university and became very popular with the general public. This little book has been published in eight editions and is still selling. I think I can say without exaggeration that no other book hitherto published in the Norwegian language in this country has done as much to create and preserve an interest in our Norwegian inheritance in America, that is to say, outside of the work done by the church and its religious books.

"Julegave" was published in the autumn of 1872 . While nothing in it was original, except the introduction, still it was the first book within the domain of secular, cultural literature 
in any Scandinavian tongue printed on the western continent, and thus I became the pioneer or pathfinder, in this field of endeavor, just as I was the first Norwegian-American to teach in an American academy in 1866 and the first NorwegianAmerican to serve as instructor in an American state university, in 1869, where in $1875 \mathrm{I}$ was to occupy the first chair of Scandinavian languages established on this continent. I like to impress upon my readers the fact that the securing of recognition of Scandinavian culture involved a tremendous struggle. The great majority of the Norwegians themselves were either ignorant or indifferent in regard to their inheritance. It was necessary to do a lot of missionary work among them in order to arouse in them enthusiasm for their ancestors and respect for their language and literature. I wanted them to be good Norwegians and loyal Americans at the same time, and I wanted to impress the Americans with the fact that they were greatly indebted to the north of Europe for their liberties, laws and institutions. Along these lines I conducted my campaigns. 


\section{CHAPTER XXXIII.}

\section{MY FIRST VISIT TO NORWAY.}

I was poor; I had sold my farm, but the proceeds for many years went to paying my debt on that farm; my salary was small, only $\$ 400$ the first year, $\$ 600$ per annum the next two years; then $\$ 800$ the fourth year. Our little daughter, born April 18, 1869, died on April 18, that is on Easter Sunday, in 1870. Thus the reader will see that I had much with which to contend, and still I was in no way disheartened. Now and then I would secure a new book either for my own private library or for the university library, or I would get Mr. Lyman C. Draper, the founder of the State Historical Society, whose friendship and good will I had won, to purchase books that I wanted to use, for the great library that he was creating.

In the spring of $1872 \mathrm{I}$ conceived the idea of going to Ole Bull for assistance. I requested him to give a concert for the benefit of the Norwegian (I did not dare to say Scandinavian) library in the University. He responded with alacrity. He chose the 17th of May, Norway's fourth of July, for the concert, and we secured the assembly chamber in the capitol for this great festival. We had this celebration advertised far and wide. A choir came from La Crosse and assisted at the concert. A large delegation came from Chicago. The assembly chamber was crowded to its utmost capacity. President Twombly of the university presided. At the end of the con- 
cert there was an informal reception at which Governor Fairchild, John A. Johnson, Ole Bull, I and others spoke.

The music played by Ole Bull at that concert was Norwegian and so were the songs sung by the choir.

I spoke mainly on the significance of the 17th of May in Norwegian history. The enthusiasm was great and by this event the Norwegians were raised materially both in their own estimation and in that of their American fellow citizens. It was surely the greatest 17 th of May celebration ever held in America up to that time. Besides the proceeds of the tickets, which were $\$ 1$ apiece, I secured some outside subscriptions so that the day after the concert I had about $\$ 750$. Mr. Iver Lawson of Chicago, father of the well known Victor F. Lawson, then contributed about $\$ 250$, sufficient to make the whole fund an even $\$ 1,000$. This was all to be invested in Scandinavian books for the university library.

Then Ole Bull, in his great generosity, proposed that I should go with him to Norway and purchase the books. He offered to defray all my expenses, I to be on the whole journey his guest. He wanted to assist in educating the Norwegian instructor at the university. He was anxious that I should sec Norway, its mountains and valleys and fjords and the people living amid those romantic environments. He also wanted me to meet as many as possible of Norway's scholars, authors and artists, so that I might speak and write of those things with a more intimate knowledge of them. He promised my wife to take good care of me and obtained her consent.

There were at that time somewhat strained relations between Ole Bull and his wife and the Thorpe family. Mrs. Bull and her mother, Mrs. Thorpe, decided to remain in Wisconsin, but it was arranged that Mr. Thorpe and the son Joseph, a young man who some years later married one of the daughters of the poet Longfellow, should go with Ole Bull, presumably to keep an eye on his movements and acts. We spent a few days in 
New York. While there Ole Bull took me with him to call on John Ericsson, the inventor of the Monitor. Ole Bull had himself during the past couple of years invented a piano with a new kind of sounding board. The frame for this piano had been made in John Ericsson's laboratory and the visit had reference to this work. We found John Ericsson in a blouse full of work. He was a medium-sized, thick-set, fair-faced, grayhaired man with keen, sparkling eyes. I thought it a great honor to be permitted to shake hands with this greatest of living inventors, with the man who had invented the propeller for steamers and the world-famed warship, the "cheesebox" called the Monitor, and to watch him and Ole Bull visit together as if they were two turtle doves.

John Ericsson was no "invisible" Swede to Ole Bull. Ole Bull realized what a charming man he was and that he had compelled the world to destroy its old commercial and naval fleets and build new ones from his pattern. All the old style ships became worthless with his inventions and new ones had to be propelled by Ericsson's screw. This visit was the only glimpse I ever had of this great and modest man, but I can never forget it.

To show how utterly reckless Ole Bull was in money affairs an instance or two will serve. He had in his trunk a large amount, many thousands of dollars of American paper currency. This he wished to change into British gold. He took the money out of the trunk and wrapped it up carelessly in one of the large daily newspapers, handed it to me and asked me to go with him. We went to a bank near Trinity church. In the bank Ole Bull relieved me of the bundle and laid it on the ledge between a couple of the interior windorws. The tellers at the bank were busy and could not wait on him at once, so he calmly lit his cigar and went out of doors to take a walk up and down the sidewalk, giving no thought whatever to the bundle of money. Of course I had horse sense enough to stay 
near the money. I do not believe he had the least idea how much the package contained.

When he re-entered the bank he finally succeeded in shoving the package into the hands of the cashier and telling him he wanted it changed into English gold. This he received in a fair-sized canvas bag which he let me carry back to the hotel. At the hotel he took a good handful of the gold, handed a part of it to me and put the rest loose in his inside vest pocket. The bag containing the balance of the gold he threw carelessly into his valise among his linen and underwear.

Ole Bull and I got a stateroom together on the White Star line steamer Atlantic, supposed at that time to be the finest ship afloat. It was new and its record between New York and Liverpool was ten days. J. G. Thorpe and his son secured berths in another part of the steamer.

Perhaps it should have been stated before that Norway had reached in this year the thousandth year of her existence as a monarchy and great preparations had been made for the celebration of this anniversary. Norway had been united into one kingdom at the battle of Hafersfjord, near Stavanger, in the summer of 872 by Harald Fairhair. On his grave, near Haugesund, a monument had been erected. This was to be unveiled with royal ceremonies on the 18 th of July.

The event was the occasion of drawing many NorwegianAmericans to Norway that summer. Many of the trans-Atlantic steamship lines advertised excursion rates to Norway on account of the celebration. Of such excursionists there were a considerable number on board the Atlantic. They were all in a part of the steerage which had been fitted up for their special accommodation. Among these Norwegian passengers were Halle Steensland and B. W. Suckow, of Madison, Wis. I had many pleasant visits with them, both on board the steamer and later in Norway. 
Ole Bull seemed to know everybody; he had been intimately acquainted with Daniel Webster, with Henry Clay and with many of the other old-timers, and be enjoyed an intimate acquaintance with Longfellow, Lowell, Holmes, in fact with all Americans of note, in journalism, in art, in science and in literature, and they all loved him.

Among the passengers on the Atlantic on this trip were Cyrus W. Field and General W. B. Franklin. General Franklin's brother, Colonel Franklin, had been for a year professor of military tactics at the University of Wisconsin. For this reason I easily became acquainted with the general.

Ole Bull was a passionate whist player and he got Mr. Field, General Franklin and me to form a whist club. We played assiduously a great share of the time until we reached Liverpool.

About mid-ocean Ole Bull was persuaded to give a concert for the benefit of sailors' widows. I still have the invitation which was signed in red ink by all the officers and first class passengers on board. Tickets were sold at any price the purchaser cared to pay and the concert produced a very substantial sum for the sailors' fund. 


\section{CHAPTER XXXIV.}

\section{AN OLE BULL EPISODE.}

A little incident occurred on this my first journey to the old world and I will tell it wholly for the reason that it throws a sidelight on the life of the famous Ole Bull. If it did not involve him it would be of no interest to the reader. As already stated Ole Bull's father-in-law was a passenger on the Atlantic. There was no intercourse between the two on board the steamer. I saw and talked with Mr. Thorpe every day. In the middle of the Atlantic ocean he decided not to go direct to Norway, but to make a hurried detour to London, Paris, Switzerland, take in a few cities in Germany and then swing up to Norway later. He knew that I could speak German and a little French and besides preferring to have company he invited me to go with him wholly at his expense. This seemed to me an offer that I could not afford to decline. I told Mr. Thorpe that I would be more than glad to go with him, but being Ole Bull's guest I would have to have his consent.

Ole Bull and I had the same stateroom, he occupying the lower and I the upper berth. In the evening I, with all the diplomacy at my command, suggested that I would like to take a run to London, Paris, Berlin, and Copenhagen and join him later in Bergen, assuring him that I would get to Norway in ample time for the unveiling of the Harald Haarfager monument, the 18th of July. I also urged that I might remain a 
little longer in Norway in the autumn. But Ole Bull's suspicions were at once aroused. In his own mind he saw every string in this deep-laid plot. He at once started piling up reasons to show how foolish it would be for me to waste my time chasing through the streets of those large cities staring at the buildings. To my answers he did not pay the least attention. Neither he nor I mentioned Mr. Thorpe, but it was clear that he understood that the proposal had come from his father-inlaw and that was what worried him.

I was pretty stubborn and tried to persuade him that my plan was a reasonable one, but assured him that I could not think of making this sidetrip without his approval.

Ole Bull had put on his nightshirt and sat barefooted on his berth. In spite of the fact that I had yielded he continued to scold and ridicule me all night long and until after breakfast time in the morning. Neither he nor I got a wink of sleep. He told me what interest he had taken in me and of all the things that he wanted to do for me. He reminded me that he had promised my wife to take care of me, but if I was going to act in this manner we better part for good. He said that we should have our misunderstanding committed to writing in duplicate and we were to sign this document which he was to frame in the presence of witnesses. I informed Mr. Thorpe the next day that Ole Bull was obdurate and that it was impossible for me to accept his generous offer.

I have given this episode to show how even great men can become worked up over trivial things and make mountains out of molehills. 


\section{CHAPTER XXXV.}

\section{LAND IN THE OLD WORLD.}

I can never forget the strange feelings that overwhelmed me when for the first time I planted my feet on the historic soil of Europe. At every step I seemed to be treading on sacred ground.

At Liverpool we dined and took a drive with Mr. Lucius Fairchild, who had just reached that city as American consul. He had been appointed by President Grant. From Liverpool Fairchild went to Paris as our consul general and from there he was sent to Madrid as our minister to Spain.

One day while in Liverpool Ole Bull and I went to hear an organ concert by Mr. Best, on one of the world's most powerful organs, and Ole Bull said that Mr. Best was the greatest organist then living.

From Liverpool we proceeded by rail to Hull and there we embarked for Norway. On the North sea we struck a gale. I had not been seasick a minute and Ole Bull, who had traveled by water so much was supposed to be seasick-proof and was anxious to be so considered. I too was ambitious to be considered a good seaman. We had left Hull about midnight and had plunged into the midst of the gale. For breakfast there appeared only the captain at the head of the table and Ole Bull and I, one on each side of him. I did not feel well, but would not admit there was anything the matter. Ole Bull's 
complexion was exceedingly fair, but I noticed traces of unusual paleness. I tried to keep up with him in eating and remained till the meal was finished. I then hastened to my room and gave my breakfast to goddess Ran. I noticed that Ole Bull did not smoke his cigar, but neither would admit to the other that there was anything the matter.

At dinner the same trio put in their appearance. All the other passengers were invisible. Ole Bull appeared paler than ever, and his accustomed smile was gone, but of course there was nothing the matter with either one of us. I was determined to eat all that was set before me, but when I had finished the soup I had to take my leave suddenly and without ceremony and again pay my respects to goddess Ran. I had remained for some time in my stateroom when I thought I was in condition to pay a visit to my friend. I entered Ole Bull's stateroom and found him exerting all his energy in turning his dinner over to Aegir. His humiliation was indescribable. I think he would rather have lost his best violin than be seen in this predicament.

When we came in sight of Norway Ole Bull sent for me to join him on the deck. There he stood with his head uncovered and with tears streaming down his cheeks as he pointed out to me those mountains of his native land that he loved so well. When King Frederick VII of Denmark once asked Ole Bull who had taught him to play he replied, "the mountains of Norway, your majesty". I once asked Ole Bull what had inspired his weird and original melodies. His answer was substantially that from his earliest childhood he had taken the profoundest delight in Norway's natural scenery. He grew eloquent in his poetic descriptions of the grand and picturesque, flower-clad valleys filled with soughing trees and singing birds; of the silvercrested mountains from which the summer sun never departs, of the melodious brooks, babbling streams and thundering rivers; 
of the blinking lakes that sink their deep thoughts to star-lit skies; of the far penetrating fjords and the many thousand islands on the coast. His face lighted up with inspiration when he talked of the eagerness with which he as a boy had devoured all myths, folk-tales, ballads and popular melodies; "and all these things", he said, "have made my music".

These things did make his music, not only by their influence upon his mind, but also by the impression they had made upon several generations of his ancestors who had contemplated them. Ole Bull's forebears had for many generations been people of culture and refinement. When we see a beautiful and thoughtful face we sometimes forget to consider how much the ancestors of that man or woman must have suffered and labored and thought before such beauty and intelligence became possible.

I am unable to describe the feelings with which I for the first time in my life beheld Norway floating on the horizon. Behind these mountains my forefathers had lived for ages. Norway had become to me next to America the dearest land on earth and this country was this very year celebrating its thousandth anniversary as a kingdom. On the 18th of July a monument was to be unveiled on Harald Haarfager's grave at Haugesund. Harald was to be honored as the creator of a united Norway.

I did not feel and did not share in this admiration for the famous Harald; I looked upon him then as I still do, as a tyrant and usurper. Behind these mountains at which I was looking lay the cradle of modern free institutions. Before the days of Harald the Norwegians had been a free people, making their own laws and electing their own rulers. Harald, encouraged by the girl whom he had asked to be his wife, determined to destroy the liberties of Norway and make himself the despot of the country. He had learned of the system of Charlemagne and had made up his mind to impose it on Nor- 
way. He made war on the thirty-odd ancient republics and conquered them one by one until he fought the last bloody batthe at Hafersfjord, near Stavanger, presumably in July, 872. This battle of Hafersfjord, which was this summer to be celebrated by the unveiling of a monument to the victor, you do not find mentioned in our encyclopedias, nor in our universal histories, but to my mind it is the most important battle of all mediaeval and modern history, judging it not by the number of people engaged in it, nor by the number of heroes who there found a watery grave, but by the results which followed to bless mankind.

In the battle of Hafersfiord Harald conquered the last of those who opposed his subjection of Norway and the usurpation of its freedom for his crown; but the proud freemen of Norway, though conquered, disdained to give up their timchonored independence and be degraded. They resolved to abandon those homes in the beautiful Norwegian valleys which they could now no longer call their own and resolved to emigrate and found new homes. Harald's victory resulted in an exodus from Norway the like of which has never been scen in that or any other land. Whither should they go? Not less than 70,000 went in their ships to Iceland. Cther large numbers went to the Faroes, to the Shetland isles and to the Orkncys and Hebrides.

In Iceland they established a republic which flourished for about 400 years, and it was during this republic's existence that the immortal Eddas and Sagas were committed to writing by the Icelanders. We do not have any words of praise for Harald, but we thank him that he made this exodus to Iceland necessary. It was Harald Haarfager's tyranny and usurpation of power that made Norway pour her best blood out of her loins. A band of these emigrants found their way to France where they took possession of one of the fairest districts and 
called it Normandy and the Normans became the leaders in France in the various industries, in architecture, in art and in literature. Descendants of these Normans founded kingdoms and principalities along the Mediterranean, in Italy and in Sicily; and it was they who led the van in rescuing Jerusalem and the Holy Sepulcher from the heathens.

The leader of the Norwegians that founded Normandy in the year 912 was Gange-Rolf (Rollo). He was the first Norwegian known in history to accept the Christian faith and be baptised. He received the daughter of the French king Charles the Simple for his wife and was made by him duke of Normandy. His great great grandson was William the Conqueror, who won for himself the crown of England at the battle of Hastings on the plains of Senlac in the year 1066, and it is proper to add that from this conquest of England by the Normans from France the pride and glory of Great Britain descended. The English trace their free institutions back to this conquest. Putting all this in a nutshell we may say that of the tree of liberty that had thrived for ages in the secluded valleys of Norway Rollo and his companions brought seed to France where it flourished in the fertile soil of Normandy. William the Conqueror and his Norman heroes planted scions of this Norwegian tree of liberty throughout England where it budded in the Magna Charta and the many bills for the advancement of human rights. Our pilgrim fathers carried seed of this same trec with them in the Mayflower and scattered it in the virgin soil of New England where the tree unfolded the world's fairest blossom in the Declaration of Independence and produced the ripest and sweetest fruit in the Constitution of the United States.

The fruits of Harald's usurpation were the settlement of Iceland, the discovery and settlement of Greenland in 983, the disçovery of America (Vinland) by Leif Erikson in the year 
1,000 , the founding of Normandy and the spreading of the idea of individual liberty and independence throughout the world. On this basis, I say, the struggle at Hafersfjord was the most important battle fought in the history of Europe.

The land with this wonderful history I now had before my eyes and was soon to put my feet on its soil and to mingle with its people. Our steamer landed in Christiansand. Here Ole Bull and I parted. He went north to his home, Valestrand, north of Bergen, and he sent me east to Christiania where I was to purchase books for the library of the University of Wisconsin. Ole Bull furnished me with letters and cards of introduction to people whom he wanted me to meet and some of whom were to assist me in selecting books for the $\$ 1,000$ I had with me. From his inside vest pocket he took a handful of gold to defray my expenses.

Ole Bull had given me a letter to his friend, the poet Bjönstjerne Björnson, the celebrated writer of Norway's most popular national song. I was familiar with his poems, stories and dramas and had a keen desire to see him. During the wceks that I spent in the capital of Norway I was a frequent guest at his house. He was a man of great personality, a commanding figure, with the head of an Apollo. He was Norway's lion, both in appearance and in his unique position as a national character. In his intercourse with people he was exceedingly arrogant and superbly reckless. He thought aloud and did not hesitate to give expression to anything that came to his mind. He was not so handsome a man as Ole Bull. When Ole Bull stood on the stage he was harmony both to the eye and to the car. Björnson too was fascinating but he lacked the polish and amiability of the wizard of the bow.

Björnson was eloquent as a public speaker and in private circles a most charming conversationalist and story-teller. He received me at his home with the utmost kindness and was de- 
lighted with my deep interest in everything Norwegian. I had some special business to transact with him.

Shortly before I left America there had been trouble in the office of the "Skandinaven" of Chicago. John Anderson, the publisher, and Knut Langland, the editor, had fallen out and the latter had resigned. He, with John A. Johnson of Madison, and Iver Lawson, had started a new organ called "Amerika". These three gentlemen, with all of whom I was on most intimate and confidential terms, had asked me to secure correspondents for "Amerika" in Norway and they had authorized mc to pay Björnson $\$ 300$ a year for four letters annually. Björnson accepted this engagement with the greatest enthusiasm. He was having trouble with newspapers and with his publishers in Norway and so he wrote out a contract agreeing for $\$ 300$ a year not only to correspond exclusively for "Amerika", but also to send all his poems, stories and dramas for publication in "Amerika" before they appeared elsewhere. This contract I brought with me to America.

As is evident from Björnson's writings, he was a keen psychologist. In his presence it seemed as if he could read your thoughts. On one of my visits this incident occurred: While we were drinking the afternoon coffee the mail carrier brought the post. The maid handed to Björnson a large package and a big letter. Sitting near him I saw that both the package and the letter were covered with American postage stamps. Björnson opened the letter and found in it a photograph and a long cpistle from Walt Whitman. Then he opened the package and found in it a large book called "Leaves of Grass" by Walt Whitman. He asked me to read the letter which contained a lot of nice things about one of Björnson's stories which Whitman had read in an English translation and he begged him to accept the photograph and "Leaves of Grass" with his compliments. 
I was an American and here was an American of whom I had never heard even the name before. I was a teacher at an American university and thought that it would be a disgrace to the University of Wisconsin and to my country if I exposed this ignorance of mine to the great Norwegian author and his family. I was unable to lay my hands on the book and the letter which I had read and translated gave me no clue to Whitman's identity. What I feared happened. Björnson asked me what I thought of Walt Whitman. I hesitated. I wanted to make an answer that should not expose my ignorance.

The title "Leaves of Grass", I thought, might fit a work on botany, a subject in which I was deeply interested, but the only American botany that I knew was Gray's. Upon reflection I thought it would be safe to say that the opinion in regard to Walt Whitman's merit and standing was divided.

Biörnson looked at me, he became wild; he got up and paced the floor like a raging lion. He told me that I knew nothing about Whitman, that I was only trying to deceive him. He said that we Americans did not appreciate our greatest men; that we let our most gifted poets starve to death, and while he was abusing me and attacking the Americans he kept sandwiching in something that sounded to me like "Democratic Wits". He declared that no poet's fancy had ever soared so high and no poet's thoughts had ever sunk so deep as W/alt Whitman's, and as he paced the floor he kept on shouting, "Walt Whitman! Democratic Wits! Walt Whitman! Democratic Wits!" and said that we Americans ought to be ashamed of ourselves.

There was nothing for me to do, but to make a clean breast of it and confess my total ignorance of Walt Whitman; but I made a faithful promise that on my return to America I should read his books. On my return to Madison I tried to secure a 
copy of "Democratic Wits", but no bookseller knew of any such book. I finally, however, secured a copy of a pamphlet by Walt Whitman entitled "Democratic Vistas" and this Björnson had read in a Danish translation.

I wrote a letter to Walt Whitman giving him an account of this episode and received from him in return a copy of "Leaves of Grass", a copy of "Democratic Vistas", Whitman's photograph, with his autograph and a package of unfavorable criticisms of his writings. While publishers reproduce the nicest things said of their books Walt Whitman ignored all praise, but reprinted on slips the unfavorable criticisms and sent these leaflets broadcast.

I may not have occasion to speak of Walt Whitman again, so I will add that in 1877 I had the honor of paying this charming old man a personal visit at his home in Camden, New Jerscy. He was an old bachelor living with his brother. He had a striking appearanice and talked in the same kind of endless wave sentences that one finds in his "Leaves of Grass". He told me he had been present at the unveiling of the Edgar Allen Poe monument in Baltimore and added that he was the only "Poet" there. 


\section{CHAPER XXXVI.}

\section{PROF. SVEN OFTEDAL.}

With the reader's permission I will here make a digression and give a brief outline of the activities of one of the Norwegian-American churches of which I was at the time a member. The discussion of the slavery question in Chicago produced a small split in the Norwegian Synod. Rev. C. L. Clausen and scveral congregations left the Synod. These united with what was then called the Augustana Synod and organized the Norwegian-Danish Conference. This Conference later became a part of the United Lutheran church, but irouble soon sprang up and those who had been leaders of the Norwegian-Danish Conference seceded and formed what is now called the Free church, with headquarters at Minneapolis. This Frce church has its own college and theological seminary and its own organ, "Folkebladet".

Having left the Synod in Chicago, I was instrumental, together with John A. Johnson and others, in organizing an independent Lutheran congregation in Madicon and Rev. C. L. Clausen accepted our call as its visiting pastor. The Norwegian-Danish Conference purchased the academy at Marshall. Wis., the school at which P. A. Flaten had become a teacher after we left Albion. This school was turned into an academy and theological seminary for the Norwegian-Danish Conference. I was elected principal of the academy, but declined the 
election. At the head of the theological department was Prof. A. Wenaas, a graduate of the University of Norway. When Wenaas came to Marshall he succeeded Clausen as our pastor in Madison and later he was succeeded by Rev. M. Falk Gjertsen, who lived in Stoughton.

And now to run back to Christiania for a moment. I there received a call from a man of about my own age by name Sven Oftedal, a brother of the well known preacher and politician, Lars Oftedal. Sven Oftedal wanted to talk with me about America and we soon became fast friends. He, with Georg Sverdrup and Sven Ruud Gundersen, formed a brilliant triumvirate of theological students. They were fresh from the university where all three had taken high honors. Cundersen had gotten a position as teacher in a reform prison in Christiania. He was married and kept house, and at his home this triumvirate met frequently. Sven Oftedal wanted me to know the other two members of this coterie and so I met them several evenings at Cundersen's home. All three expressed a keen desire to go to America and find work among their countrymen there. They overestimated the position I held at the University of Wisconsin and wanted me to find similar positions for them. I agreed to keep my eyes open and not to fail to inform them if $\mathrm{I}$ succeeded in finding suitable positions for them. I also engaged all three as correspondents for the Chicago paper "Amerika". They were to write without pay, but I urged that this would be an excellent way to make themselves known among the Norwegians in America. The arrangements were carried out. Oftedal spent the following winter in Paris and from there he sent letters to "Amerika". Gundersen sent the paper news from Norway and all of them corresponded privately with me.

During the fall and winter of 1872-73 the Norwegian-Danish Conference grew ambitious and decided to build a college 
and theological seminary in Minneapolis and at the same time to close their school at Marshall. They expected to grow and so to need additional instructors and professors. Professor Wenaas moved to Minneapolis to be president of the college and seminary. At the annual meeting of the Conference in the spring it was decided to engage two or three additional professors and Prof. A. Wenaas and Rev. M. Falk Gjertsen were elected a committee to proceed at once to Norway to find suitable candidates. On their way to Norway they visited me at Madison. I at once called their attention to Oftedal, Sverdrup and Gundersen. I described them as the three ablest and most promising young men in all Norway. I assured them that they could get them and insisled that they must go directly to them and seek no further. I armed them with letters of introduction and in private letters to Oftedal, Sverdrup and Gundersen I strenuously urged them to accept the positions that would shortly be offered to them and tried to show to them what a great career of usefulness there was before them on this side of the Atlantic.

As will be shown later I went to Norway again with Ole Bull, in 1873. I had no knowledge of this journey when I talked with Wenaas and Gjertsen. The decision to go was taken one day and I started for Norway on the next. In Norway I parted with Ole Bull in Christiansand and went as the year before to Christiania. I was there to fetch Björnson and bring him with me to Bergen. Björnson decided that we go by land across the mountains as he was a poor sailor.

He and I and Mrs. Björnson proceeded to Drammen, where there was at that time being held a national exposition. At this particular time there was also being held in Drammen a large conference of Norwegian ministers. At this conference I found Sven Oftedal. He had already been seen by Wenaas and Gjertsen and had taken their call under advisement. The 
plan was that Oftedal was to go to Minneapolis in the autumn of 1873, that he was to be followed by Gundersen in 1874 and then by Svercrup in 1875, thus increasing the faculty pari grassu with the growth of the school.

Björnson and I were to go to Bergen by the way of Hallingdal, Hemsedal, Lerdal and the Sognefjord. The first stretch of our journey from Drammen was by rail north to Krödern. Oftedal had never met Bjönson and would like to be introduced to him, so I invited Oftedal to accompany us as far as Krödern in crder that he might have an opportunity of visiting with his distinguished countryman. He accepted the invitation. When we had left Oficdal Björnson advised me not to put too much faith in that fellow. He thought him "foxy".

Oftedal's home was in Stavanger. There lived his aged father, a venerable, fine-looking old schoolmaster. There also lived his brother Lars, the great revivalist, philanthropist and politician.

In Bergen I arranged a series of concerts to be given by Ole Bull for the benefit of the Leif Ericson monument. The first concert was given in Bergen, the second in Stavanger. In Stavanger Ole Bull, Mrs. Bull and I were the guests of Mrs. Kielland at her beautiful home. In the afternoon I went to seek Sven Oftedal and found him at home. He introduced me to his fiancee. He expressed a desire to meet Ole Bull. I therefore asked him to go with me to Mrs. Kielland's where it would give me pleasure to introduce him. Mrs. Kielland invited him to a cup of coffee with Ole Bull. In parting with him I handed Oftedal tickets for himself and his fiancee to the Ole Bull concert. I am giving all these details for a purpose, as the reader will see later.

In the autumn I left Bergen to return to the United States. My steamer for Newcastle was to stop for an hour at Stavanger. I telegraphed to Oftedal requesting him to meet me at the 
wharf. On going ashore in Stavanger I found Oftedal waiting for me at the landing and he now introduced me to his wife, they having been married just the day before. I handed Mrs. Oftedal a sovereign as my wedding present. Oftedal now informed me that the calls received from Minneapolis had been accepted and that he was to depart for America so as to reach his destination by Christmas. I invited him and his wife to stop off at Madison and be our guests for a week or ten days in order that we might discuss from Dan to Beersheba the whole situation of Norwegian America, socially, politically and in reference to schools and churches. I desired to give him as a newcomer the benefit of all my knowledge anent these matters. I had navigated the Norwegian-American seas for several years and thought my experience and knowledge of dangerous places might be of benefit to him. He accepted my invitation and toward Christmas he came and spent about ten days at our modest home in Madison, with his wife and maid. During those days Rev. Gjertsen of Stoughton was an almost daily visitor and together we discussed every phase of Norwegian-American history, present conditions, and future prospects. We mapped out a campaign for work that needed to be done.

Oftedal then went to Minneapolis to begin his work there with Wenaas immediately after the holidays. Some time later, I think it was in the spring of 1874 , I happened to be sitting in the editorial rooms of "Skandinaven og Amerika", the two papers having then been consolidated. The mail came. In it was a large envelope. The editor, the old Svein Nilssen, opened it and seeing that it was from Wenaas and Oftedal he handed it to me to read and give him my opinion of it.

The document I read was the notorious "Aaben Erklæring" (Public Statement). It was a document signed by Wenaas and Oftedal giving their view of the religious work hitherto done among the Norwegians in this country and outlining what 
reforms were needed. They posed as great progressives. I found that the publication of such a document was premature and that many of its statements were not in accord with the facts. I asked the editor not to print it for the present. I told him that Wenaas and Oftedal were friends of mine and I at once wrote to them that I had taken the responsibility of requesting the editor not to publish the public statement. The editor agreed to it until he should hear from the authors. In their eagerness to bring their statement before the public they at once upon receipt of my letter telegraphed to the editor of "Skandinaven og Amerika", saying that if their article did not appear immediately they would have it printed elsewhere. The article was sure to create a sensation and the "Skandinaven og Amerika" wanted the benefit thereof. It appeared. I looked upon this article as an undeserved depreciation of all the hard work that had up to that time been done for the advancement of our people and as an insult to those who had done this great work. I felt that I more than anyone else was responsible for Oftedal. He had been engaged on my recommendation. It was widely known that he had been my guest in Madison and therefore must have been coached by me. I was myself on a war footing with many of those people against whom the "Public Statement" was directed and it would be natural therefore to infer that I shared its sentiments. So I immediately wrote and sent a brief reply attacking the "Public Statement", pointed out that it contained unwarranted charges and protested against it as a document that ought to be recalled. My name was signed to this protest which was at once published by "Skandinaven og Amerika" and was the first public reply to the "Public Statement". I wanted to wash my hands and clear myself of all responsibility in connection with this unfortunate publication.

Not long afterwards I received from Prof. Sven Oftedal the following letter: 
"From the first moment that I met you I have known you, I repeat that I have known you. You are a person whose aim has been more to become somebody than to be somebody. Your relations with Ole Bull and Björnstjerne Björnson have caused you the loss of everybody's respect in Norway. Oh that you would abandon your mania for popularity and in quiet, earnest work devote yourself to an idea.

Yours, Sven Oftedal."

The reader will now see why I have been so particular in giving the details of our various meetings and I need not call attention to the fact that he insists in his letter that he had had the same opinion of me all the time since we met in Christiania in the summer of 1872. In his letter to me from Paris he smothered me with praise; he could not understand how I could have learned many things with which I was familiar. In one of his letters from Paris he breaks out: "When you and I shall fight side by side in America how the fur will fly!" (hvor det skal sprute omkring os!).

I made a copy of the letter given above and sent it to him telling him that he must have written it hastily, in anger, and that in looking it over calmly he doubtless would like to recall it.

He replied: "I am not a man who says one thing today and another tomorrow."

The bonds of friendship between us were severed.

S. R. Gundersen came to Minneapolis the next year and during the Christmas holidays he and his wife came to Madison to visit us. I laid all the facts before him and he fully agreed with me. He proposed to take Oftedal in hand and compel him to make the amende honorable. In this he failed utterly and this failure caused a breach between Cundersen and Oftedal. Gundersen soon resigned as a professor at Augsburg and accepted a call from the Hauge Synod's seminary at Red 
Wing. After teaching there a while he accepted a call as pastor at Crimstad, in the southern part of Norway and returned to his native land.

Then came Sverdrup, the third member of this triumvirate and he and Oftedal seemed to pull together remarkably well. It can be truly said of Sverdrup that he was one of the most gifted and best edicated scholars that Norway has given to America.

The following summer (1875) I came late to supper one evening and found to my utter surprise seated at the table with my family Prof. Sven Oftedal and Rev. M. Falk Gjertsen. There was a vacant chair for me. I took supper with them. After supper Oftedal took a large rocking chair in the parlor. An Icelander, Jon Bjarnason, and his wife Laura were living at our house. He and Gjertsen were familiar with the relations existing between Oftedal and me, so they took their hats and went out for a stroll, thinking Oftedal and I might want a "twa-handed" chat. I fully expected an apology from Oftedal and I waited for him to begin. As we sat there looking at each other he started the conversation by asking me if I had lately heard from Björnson and what literary work he now was engaged upon. I replied that I did hear from Björnson occasionally, but that he did not reveal to me his literary plans. Then he asked me where Ole Bull was keeping himself. You see he was talking to me about the very two people who, in his opinion, had caused me the loss of everybody's respect in Norway.

I told him I did not know where Ole Bull was just at that time, but I asked him whether there was not something else he and I ought to talk about. He shrugged his shoulders in a manner peculiar to him and replied that there was nothing so far as he knew. 
This was more than I would stand. I told him that he had then come to insult me in my own home and that was something I could not permit. He was a larger and stronger man than I was, but I took hold of him vigorously, led him to the front door and pushed him out, telling him never to set foot on my premises again. I went in and got his hat and handed it to him at the gate. This ended for all time my intercourse with Sven Oftedal.

But the matter had other consequiences. Rev. Gjertsen was my pastor. Oftedal was a most conspicuous teacher in the Norwegian-Danish Conference. Rev. Gjertsen had gone daft on Oftedal. In his mind Oftedal could do no wrong although he knew all the facts as I have here stated them. He vigorously defended Oftedal and blamed me. For this reason I refused to recognize him any longer as my pastor. I left his congregation and became once more a religious tramp.

From that time until late in the '90s I was not identified with any church. What bearing all this had had upon the history of Norwegiandom in America the intelligent reader will understand. 


\section{CHAPTER XXXVII.}

\section{BACK TO NORWAY.}

After this lengthy digression let us return to Christiania in the summer of 1872 . While in the city I found a number of my wife's relatives whom I frequently visited, and one day I engaged a photographer and drove with two of Mrs. Anderson's cousins and their wives a few miles east of Christiania where we visited her uncle Ole and photographed a house near by in which my wife was born. The little cottage was still standing, but occupied by people of no particular interest to me.

In Christiania several of the university professors aided me in selecting books that I was to purchase with the $\$ 1,000 \mathrm{draft}$ in my pocket. Björnson was also very helpful to me in this matter. I had the honor of meeting the great linguist, Ivar Aasen, the distinguished lexicographer, Knud Knudsen, the historian, Sigvart Petersen, whose text book on Norwegian history I had studied at Luther College, and many other men and women of note. Being recommended by Ole Bull, I was admitted everywhere. Some of the well-to-do people made contributions of books to the Norwegian library at the University of Wisconsin, and I had every reason to be well pleased with my sojourn in the capital of Norway.

The most prominent business man in all Norway at that time was the banker, Thomas Johan Heftye. His ancestors had come from Switzerland and he represented Switzerland in Nor- 
way as consul. He owned the finest mansion in the city, a finc country seat, "Sarabraaten", on the east side of Christiania, and another on the west side called "Frognersæteren". Ole Bull had recommended me to him most cordially, and he entertained me most royally. In fact, he was looked upon as Norway's viceroy, performing the social duties of king when the real king was in Stockholm. He took me to "Sarabraaten" and to "Frognersæteren". He entertained me at his palatial residence in the city. There he had an old engraving of my great great grand uncle, Gen. George Frederik von Krogh, and this he gave to me to take with me to America. 


\section{CHAPTER XXXVIII.}

\section{THE MILLENNIAL CELEBRATION.}

The time for the millennial celebration was approaching. A steamer had been fitted up to take Prince-Regent Oscar, his suite and invited guests to Haugesund. Consul Heftye was on the committee on arrangements and invitations. He said he had looked over the names of the guests, but that he found no American among them. He therefore gave me an invitation to be one of the guests to accompany Prince Oscar to Haugesund. I could not resist. I had no full dress suit, or uniform, but Mr. Heftye told me that such things were not necessary. He was not going to Haugesund himself, but he took me on board the steamer and there introduced me to Norway's prime minister, Frederik Stang, who in turn presented me to his royal highness Prince Oscar. Later I was introduced to the members of the king's cabinet and to the various Norwegian and foreign guests. Among the latter was a son of the great English commoner W. E. Gladstone. Really it seemed as if the boy born among the Indians around Koshl:onong lake had now reached the top round of the ladder. With how much modesty and dignity I maintained myself this book fails to tell. All I can say is that I felt it incumbent on me to act as if I had never known other surroundings.

I had been told that I must not approach the prince and talk to him and that it was his prerogative to come to me if he cared to, and he did come to me on several occasions and engaged me in conversation, asking me all sorts of things about 
the Scandinavians in the United States. I answered his questions as well as I was able. A story was circulated that I had informed his royal highness that I too was a prince and that for this reason I said "thou" to him. This story was made out of whole cloth. The only foundation for it was that I did inform Prince Oscar that it was the first time in my life that I had the honor of talking to royalty and that I begged him to pardon me for my awkwardness in addressing him as I did. A man born and raised in the woolly west does not become a Chesterfield in one week.

The trip to Haugesund was a series of great ovations and receptions to Prince Oscar. Wherever there were forts salutes were fired and replied to by our steamer. We stopped at Arendal, Christiansand and Stavanger. All of these places were gay with flags and bunting; the wharves and streets were crowded with people in their best dress; there was music; there were poems and public addresses. All the way from Christiania to Haugesund was what the Swedes would call an "ericksgata", that is, a procession of triumph.

Hundreds of ships and tens of thousands of people and many regiments of soldiers were gathered around the Harald Haarfager monument at Haugesund on July 18. Prince Oscar delivered the unveiling speech which was brief and to the point. His voice had splendid carrying qualities. His first sentence was, and he spoke in Norwegian: "Harald Haarfager has with a mighty hand united this kingdom."

It should probably be mentioned that neither Björnson nor Ibsen was recognized in connection with this national celebration. The poems, or songs, on the program were written by Jonas Lie, he having been preferred to the other two. Björnson took no notice of the celebration in any way, while Ibsen sent from his exile, a lengthy, most pathetic, though partly sarcastic poem. It ranks today as one of the greatest poems in any Scandinavian tongue, 


\section{CHAPTER XXXIX.}

\section{STAVANGER AND VICINITY.}

Having witnessed this celebration I at once left Haugesund for Stavanger, that ancient city near which the literties of Norway had been slain just a thousand years before at Hafersfjord; that city from which the Norwegian Mayflower, the sloop "Restaurationen", had set sail with its precious cargo for the land of freedom in the west on the fourth of July, 1825; that city from which my own father and mother and two eldest brothers had sailed for America in the spring of 1836, this city so crowded with interesting memories I was now to visit.

I had no relatives or acquaintances there, but I made use of the time in visiting the different parts of the city and surroundings. The great industry in sardines, fish balls, cod roes, and ptarmagans, which has made Stavanger so widely known throughout the civilized world had not yet been started. I knew that the father and brother of my stepfather were farmers a few miles from Stavanger and so I engaged a liveryman to take me out to see them. On the way I met a man carrying an immensely large salmon. This I bought of him for one dollar.

I found my aged stepgrandfather, Amund Goa, living with his son Ole and they were glad to receive a visit from one who could tell them so much of their deceased son and brother in Wisconsin. Ole's wife served a splendid dinner consisting chiefly of boiled fresh salmon and boiled potatoes in the jackets. 
All in all, this was one of my red-letter days in Norway in 1872.

The pastor of one of the principal churches in Stavanger was the Rev. Welhaven, a brother of the celebrated poet, J. S. Welhaven. Mr. S. R. Gundersen, one of the trio that I had met in Christiania, was married to his daughter and had written to his father-in-law about me. When Rev. Welhaven learned that I was in the city he called on me and invited me to visit him at his home to meet his family and a few friends. I spent a delightful evening at his house. Mr. Welhaven also wrote poetry and had published a volume of poetical selections. At the dinner he presented me with a copy of this volume with the following inscription. I quote it because it was the first poetry cver written in my honor:

Da jeg ved, De er glad

I sange og kvad

Helst som de synges i Norden,

Saa bærer jeg frem

Bogen til Dem.

At ogsaa jeg

Paa sangernes vei

Nævinet er vorden,

Maa vist nævnes med ret

En vansirende plet.

Og hörer til bogens uorden.

At the hotel in Stavanger I met Halle Steensland, my friend and neighbor from Madison, and he and I at once took a steamer for Vikedal, his birthplace and also the birthplace of my parents. The emotions, with which I stepped ashore on this venerable ground I am unable to describe. I felt as if I wanted to kiss the ground under my feet. 
Mr. Steensland immediately went to his birthplace in the northern part of Sandeid. I went first to Westbö, in Sandeid, where I found my uncle Sören, my uncle Bernhard, my aunt Dina and several cousins. The old home where my mother was born was now occupied by my uncle Bernhard. I spent several days most delightfully with these relatives of mine. I visited the old church where my mother had been baptized and confirmed. I had the graves of my grandparents pointed out to me and I plucked from them flowers which I took back to America and presented to my mother.

One day accompanied by my cousins I took a walk around the mountain to Vikedal and visited Kvelve where my father was born, but I found no near relatives there. One of my father's nephews by name Rasmus Danielson was then, and is still living,* at St. James, Minn., and his brother Ole I afterwards met in Bergen where I also met my mother's brother Christian von Krogh. Recently I have had an oil painting of Kvelve and Kikedal made by the Norwegian artist, Lars Haukaness.

Mother's oldest brother, Sören, had a cane which had belonged to Gen. Georg Fredrick von Krogh. He was determined that I should have some souvenir of my visit, and so he insisted on my accepting this relic. The handle is a dog rampant in bronze taken from the coat-of-arms of the von Krogh family. The stick was in bad shape, so I Americanized the cane by substituting a stick of genuine American hickory.

From Sandeid Mr. Steensland and I proceeded to Bergen. There we met Mr. B. W. Suckow. Mr. Suckow was an old friend of Ole Bull's and Steensland was also acquainted with the wizard of the bow, and so both Suckow and Steensland went with me to Ole Bull's celebrated home Valestrand, on

${ }^{*}$ Rasmus Danielson has died since this was written. 
Oster island, some miles to the north of Bergen. There we were all most hospitably entertained at his magnificent home.

Ole Bull was very fond of his Arabian horse, Karages, - (lightning), which he had imported from Russia. He had it saddled and showed it to us, offering us a ride. The only one who dared to accept the invitation was I, but I was soon through and I deemed myself in luck that I did not break my bones.

Karages treated me like a cowboy's broncho, while he was happy and docile with Ole Bull in the saddle.

Valestrand was an extensive estate on which Ole Bull had spent thousands upon thousands. He had built near the seashore facing the south a splendid residence which he had furnished with costly imported curtains, tapestries, rugs and furniture. On the second floor he had a large music hall, most artistically designed. In fact, the building was well nigh royal in all its appointments from the well-supplied wine cellar to the garret. Costly paintings decorated its walls, and all the money had been made by his invincible bow. On the estate he had devoted much attention to a system of drainage of his own invention and the whole estate was covered by a system of splendid roads. He had also built one of the finest barns to be found in all Norway. He wanted his dear Valestrand to be ideal in all respects and to this guiet country seat he returned now and then to spend a month or two in a luxurious far niente. The loyal Knut took charge of the farm and Martha was his faithful housekeeper. Steensland and Suckow returned to Bergen the next day, but I remained for a few days to make my report to my benefactor of how I had spent my time since I left him at Christiansand.

One day while I was at Valestrand Ole Bull received a visit from a young man who was already then looked upon as the coming leader of western Norway. This young man was Wollert Konow, born at Stend, in Fane, near Bergen in 1845, 
less than a year older than I. We soon became such warm friends that we addressed each other as "Wollert" and "Rasmus". Wollert invited me to visit him at Stend, an invitation which I eagerly accepted.

In a few days I said goodbye to Ole Bull, returned to Bergen and from there I proceeded at once to Stend, in Fane. Stend is one of the largest estates in western Norway and has long been the property of the Konow family. Wollert still owns it and has greatly increased its value. At this time his parents were living and at the home were Wollert's two sisters, like himself unmarried. The Konows originally came from Cermany. They had prospered and many of this family are prominent in the annals of Norway. Wollert's father, whose name also was Wollert, was a writer of distinction, had been a member of the Norwegian Storting and his good wife was the daughter of Denmark's greatest poet Adam Oehlenschlæger. The three days I spent at Stend with these charming people were among the most delightful of my visit to Norway in 1872 .

The young man whom I here call "Wollert" has since served a long time as member of the Storting, has been cabinet officer and for a period Norway's prime minister. After the death of his father his mother and sisters made prolonged visits in Copenhagen and there I had the opportunity of renewing my acquaintance with them and talking over auld lang syne. Notwithstanding their wealth and distinguished ancestry and connections, the Konows were exceedingly democratic and Wollert has been a consistent leader of the liberal element in Norway's politics.

What particularly interested the Konows in me was that although I was born among the Winnebago Indians in the far west I was able to recite to them many of the choicest pieces of Norwegian poetry. The poet Oehlenschlæger had looked upon the cultivation of the Norwegian dialects with contempt, 
and had gone out of his way to ridicule Henrik Wergeland. Oehlenschlæger had in turn been lampooned by Wergeland, but when I declaimed snatches of poetry from Vinje and Aasen I saw tears trickling down the cheeks of the daughter and granddaughters of Denmark's greatest skald. A cousin of Wollert, also named Wollert Konow, from Hedemarken, has had a career very similar to that of our Wollert from Bergen.

It is necessary to make an end of this my first visit to the land of my forebears. After my three days' visit at Stend I returned to Bergen where I called on my uncle, Christian von Krogh, on my cousin, Ole Danielson, a son of my father's only sister, and my cousins on my mother's side, the Beyers. Frederick and Morten Beyer owned the principal publishing house in Bergen. In the city I met Mr. Steensland and Mr. Suckow again and we three decided to go to Christiania over land. We first took a trip through the Hardanger fjord, visiting every nook in this most beautiful district of Norway.

From Hardanger we went to Voss. This beautiful district has supplied America with several prominent citizens. From this district came Senator Knute Nelson, John Anderson, the founder of "Skandinaven", and Canute Matson, a soldier in the war of the rebellion, for many years connected with the Chicago postoffice and in the '80s sheriff of Cook county, Ill. Matson was the sheriff at the time when the anarchists were executed in Chicago.

Near Vossevangen, on the way to Stalheim, is a mountain called Lönehorgen. At the foot of this mountain lies the farm Löne, where my old friend and teacher Knut Henderson, now living near Cambridge, Wis., was born. Knut Henderson deserves to be remembered as the first Norwegian to teach and publish music in America. He came to this country as a young man with his father, who settled near Cambridge. Knut took a deep interest in music and in Chicago he took lessons in harmony from the distinguished song composer Geo. F. Root and 
other teachers. In 1853 he organized a singing school in the East Koshkonong congregation. My sisters and I were members of this class. A similar school which he maintained at Cambridge was attended by my wife. In this way a number of young people of Koshkonong learned the rudiments of written music. Later Knut Henderson published a volume of Norwegian songs and still later a hymnal, being the pioneer in this field. He is now a prosperous farmer near Cambridge, has an interesting family and is hale and hearty in his eightysecond year.

From Voss we went by way of Stalheim to Gudvangen, at the head of Neröfjord. From Stalheim you descend by a zigzag road by the side of a beautiful waterfall into the Nerö valley.

This short valley, with its lofty, perpendicular mountains on either side seems like a mere gorge and hardly wide enough for two vehicles to pass each other. In the middle of this valley we met going the opposite way Rev. J. A. Ottesen, his wife, his son and his two daughters, from Koshkonong, Dane county, Wisconsin. This delightful meeting was entirely unexpected, as we did not know that they were in Norway. It appeared that Rev. Ottesen's father had recently died and had left him some property. He and his wife were making use of this inheritance to visit their native land and to show its glories to their children.

Speaking of this unexpected meeting, I may here mention that I had a good friend by the name of Jurgens, who in the early '70s was a banker in La Crosse, but before that had lived in Madison. From La Crosse he moved to Chicago. At present he is living in Norway.

In 1873 Björnstjerne Björnson, Sven Oftedal and I were on a train going north from Drammen. At a station we met the southbound train. In the coupe opposite the one we occupied I saw Mr. Jurgens and was able to shake hands with him be- 
fore the train left. In 1885 I was on a train from Stockholm to Malmö, in Sweden. At a station we met the northbound train and in the coupe opposite me sat Mr. Jurgens. We shook hands. In 1886 Consul Tönsberg, the old bosom friend of Henrik Wergeland, had invited me to visit him at his home in Christiania, saying he would meet me at the wharf. While the steamer was being towed to the landing I stood on the deck looking for Mr. Tönsberg, but the first faces I discovered were those of Mr. and Mrs. Jurgens, who were still living in America.

In the early '90s I was invited to speak at a celebration by the Norwegians in Chicago of an Ole Bull's birthday, February 5. I had a box ticket and when I entered the box to take my seat there sat Mr. and Mrs. Jurgens opposite me. Such are coincidences in life.

Rev. Ottesen had sccured a landau carriage at Gjövik, in the eastern part of Norway, and used this as their conveyance to Lerdalsören, thus changing only horses and driver at each station. He was to send this rig back to its owner in Gjövik and he now generously offered it to Steensland, Suckow and me. At Gudvangen we took a steamer to Lerdalsören through some of the grandest, most majestic and awe-inspiring fjord and mountian scenery of Norway. At Lerdalsören we secured the Ottesen landau and proceeded like princes of the blood through Lerdal, Borgund, over the mountains, down through the different parts of Valdres, through Vardal to Gjövik, the people standing at the different stations awe-stricken at the millionaires from America who could afford so sumptuous an equipage. They took off their caps to us, but did not venture to speak to us.

The station on the top of Filefjeld is Nystuen, the uppermost farm in Valdres. The Nystuen station is situated at the foot of a mountain rising a few hundred feet on its north side. We could see the station a mile or more before we reached it. It 
was in the latter part of July; the days were still long and though it was about 9 o'clock in the evening the sun had not yet set on the other side of the mountain. I intended to go on the mountain top until I reached Nystuen where I expected to descend and join Steensland and Suckow again for the night. It seemed so easy. The distance was greater than I had calculated and the road was not so smooth as it looked from a distance, and what was worse I had not gone far before clouds had gathered around me and the snow was falling thick and fast. I was in despair. I decided to try to find my way back, but for a while the snow fell so thickly that I lost the points of the compass. Fortunately the clouds broke again and I could see the road in the valley to the south of me. I returned as nearly as possible to the place where I had ascended and fortunately found a place where I could get down on the plain again.

At the tavern they had grown very anxious about me, fearing that I might perish. They had planned to send parties out to search for me. I had been on this expedition about four hours and reached the wayside inn about 1 o'clock in the morning. In the register in the hotel the traveler reads on the first page this caution: "Tourists must not climb the mountain from Nystuen without a guide; it is dangerous." I saw this and I wrote underneath it: "I tried it and can testify that the above is good advice."

The trip through Valdres and Vardal to Gjövik was uneventful. From Gjövik we went to Eidsvold and inspected the building in which the constitution of Norway was adopted May 17, 1814. This building corresponds to Independence hall in Philadelphia, and is kept in the same manner, open to visitors. From there we proceeded by rail to Christiania. Here Steensland, Suckow and I parted. I had to hurry back to America. I said goodbye to the friends I had met, took a steamer to Hull and went from there to Liverpool. In Liver- 
pool I went by the Allan line to Quebec. As we were about to enter the straits of Belle Isle we were caught in a dense fog. The temperature of the water showed that we were near icebergs. For twenty-four hours the steamer kept going slowly in a circle, but then the fog lifted and we found ourselves in the midst of an immense number of icebergs, a wonderful sight.

Just in time to begin my work at the university I returned to Madison. 


\section{CHAPTER XL.}

\section{THE PETIT DONE AND THE UNDONE VAST.}

The goal to which all my efforts were now concentrated was to get a professorship of Scandinavian languages, history and literature established at the University of Wisconsin. The obstacles to overcome were immense. There was no professorship of this kind either in this country or in England. The professors at the University of Wisconsin knew but very little about Scandinavia and its claims to recognition in a university curriculum and cared less. I had come to the university very poorly equipped for promoting such a thing, but on my return from Norway I felt that I had added materially to my efficiency. Before leaving for Norway I had my enthusiasm and my energy, but against me I had not only my lack of knowledge, but also my unfortunate experiences at Decorah and at Albion, and besides I had the active opposition of the most influential men in the church. On the other hand I had the warm support of John A. Johnson, of Knut Langland and his paper "Amerika", and I had the cordial backing of the famous Ole Bull. I had already placed the nucleus of a Scandinavian library in the university and to this there would now be a material addition, the proceeds of Ole Bull's concert on the 17th of May.

I had now been in Norway; I had written a series of letters about my first visit to Norway for the columns of the "Amerika" which I have heretofore mentioned. In Norway I had traveled not a little and had made the acquaintance of a number of men of note, including the reigning prince, Björnstjerne Björnson, Ivar Aasen and others. All this helped to give me 
a certain prestige. I was one of the few in the Madison of those days who had crossed the Atlantic. The number of boys and girls of Scandinavian descent attending the university was increasing and I left no stone unturned in my efforts to secure a recognition of the Scandinavian languages and literatures.

Still, so far as the university faculty at that time was concerned, I might as well, as I have said, have been advocating the establishing of a professorship of Patagonian. It was necessary to do something to draw special attention to the importance of what Scandinavia had contributed to the progress and culture of the world.

Having a better library at my command than I had had before, I went to work and prepared and published a sixteen page pamphlet on the historical, linguistic and literary value of the Scandinavian languages. In this pamphlet I quoted H. W. Longfellow, O. C. Marsh, Benson Lossing and Bayard Taylor among American authorities, Samuel Laing, Max Muller, Robert Buchanan and a number of other British and German authorities. I dedicated this pamphlet to Ole Bull and printed a thousand copies which I distributed as extensively as possible among the most cultured people not only in Madison, but in the whole state of Wisconsin and elsewhere.

Ole Bull, who returned to Madison late in the autumn, was delighted with this little pamphlet and talked about it to his friends.

During the winter I was invited to lecture in the city hall on the Norse discovery of America. I had a packed house; the applause was most generous and in a long review of the lecture the next day in the State Journal all the claims I had made were fully endorsed. This lecture also made Lyman C. Draper my staunch friend during the rest of his life. He from that time labored most assiduously for my recognition and advancement at the university. 


\section{CHAPTER XLI.}

\section{THE JOHN A. JOHNSON FUND.}

In the course of time I persuaded John A. Johnson, who had been very successful in his business in a partnership with Chauncey Williams, M. E. Fuller, A. E. Proudfit and L. W. Hoyt in promoting the sale of Walter A. Wood's reapers, to create a fund at the university of $\$ 5,000$, the income of which was to be used to assist Norwegian students attending the State University. Until the end of the century the income was to be given exclusively to students of Norwegian descent, but after the year 1900 the proceeds were to be open to all regardless of nationality. Thus a Norwegian American established the first scholarship fund in the University of Wisconsin. By this my position was also materially strengthened, but I was still far, very far from my goal. It was still the petit done and the undone vast. 


\section{CHAPTER XLII.}

\section{THE LEIF ERIKSON MONUMENT.}

Late in the fall of 1872 Ole Bull returned to Madison. I was engaged in teaching his wife Norwegian and I devoted much time, partly to reading aloud to Ole Bull books of interest to him, and partly in taking notes with a view to writing for him his autobiography and also his views upon the violin. I took down voluminous notes concerning his career and he also dictated to me his views in regard to the various old makes of violins, such as Gaspar da Salo, Stradivarius, Guarnerius, Amati and others, who have made old Cremona famous and also concerning the most distinguished violin players.

After the death of Ole Bull I turned all these notes over to Mrs. Bull and she published them, partly in her own name and partly in the name of Dr. A. B. Crosby, as her biography of her husband. The book was published by Houghton, Mifflin \& Co. in 1882.

During this same time I talked much with Ole Bull about the Norse discovery of America. I argued that Leif Erikson should be honored with a monument. Christopher Columbus, who was merely the rediscoverer of this continent, had had much honor paid to him in the way of monuments, paintings and otherwise. It was time Leif Erikson should receive similar recognition and honor. In this matter Ole Bull was an "easy mark". He had given but little attention to the details of the Norse discovery, but his enthusiasm was easily aroused 
for anything that would redound to the fame and glory of his dear fatherland. What we proposed to do was to raise funds sufficient to erect a suitable Leif Erikson monument on the campus of the University of Wisconsin in front of the main building. There Leif should stand proclaiming his discovery of Vinland and this would help us to make the University of Wisconsin the chief center of Scandinavian study in the United States. It would help make Madison the Mecca of Norwegiandom in America. We took John A. Johnson with us in our councils. He fully approved of our plans and purposes, and so, early in 1873, we three organized ourselves into a Leif Erikson monument committee. Mr. Johnson and I elected Ole Bull president, Ole Bull and I elected John A. Johnson treasurer and Ole Bull and Mr. Johnson elected me secretary.

Our thought was that the necessary funds, say $\$ 25,000$, should be contributed by the Norwegians in this country and that such an enterprise, if carried out, would be of great benefit to them in many ways. This triumvirate prepared an address to the Norwegians on this side of the Atlantic and asked for contributions from 25 cents up. Ole Bull, Mr. Johnson and I subscribed $\$ 100$ each. We published the address in "Skandinaven" and in the other Norwegian-American papers. It seems incredible,--but the truth must be told-this call for voluntary contributions to so magnificent a cause did not produce one single response. Not one cent was received from anybody.

Ole Bull felt humiliated and angry; he decided to take the bull by the horns and raise the necessary funds himself with the aid of his invincible bow. He ordered me to proceed at once to arrange a series of concerts for the benefit of the Leif Erikson monument fund. The only ones to appear on the program were Ole Bull, Mrs. Ole Bull as accompanist and R. B. A. to talk to the audience between the musical numbers. 
I arranged concerts in Madison, Stoughton, Cambridge, Fort Atkinson, La Crosse, Prairie du Chien, MacGregor, Ia., and Decorah, Ia. At all these concerts we had packed houses. I opened with a few introductory remarks, then between the first and second and second and third appearances of the great master I sandwiched in the story of the Norse discovery of Vinland, condensed under hydraulic pressure. I am unable to give the exact amount realized from these concerts, but it was in the neighborhood of $\$ 2,500$, and this money was turned over to our treasurer, John A. Johnson.

Ole Bull was going back to Norway and requested me to go with him to help hin arrange a series of concerts there for the benefit of this fund. Of course I could not say no. This year Mrs. Bull, her father, J. G. Thorpe, and her brother Joseph also accompanied Ole Bull to Norway.

Let me here make a brief digression. In his youth Ole Bull had fallen in love with one of the most charming spots in all Norway. It was an island called Lysöen, some fifteen or twenty miles to the south of Bergen. In 1872 he had succeeded in purchasing this island and he had engaged an eminent architect to build a large villa on it in Turkish or oriental style. This villa had been completed and we were going to Norway to occupy it. It had a large music hall decorated throughout with Norwegian woodcarving. From the cupola there was an extensive view in all directions over sea, islands and mountain ranges. To the east seven ridges of mountains rising one above the other could be seen. When we reached Norway the house had been complctcly furnished, partly from Valestrand, and that summer Ole Bull made his headquarters at Lysöen. 


\section{CHAPTER XLIII.}

\section{MEET THOMAS A. EDISON.}

The journey to Norway that summer was by the usual route, by the W/hite Star line to Liverpool, thence to Hull, thence to Christiansand, and was uneventful. I say uneventful, but to this I must make an important exception.

On the steamer Celtic, from New York to Liverpool, there was a young passenger, then unknown to fame, but whose name is now a household word throughout the civilized world. This young man was 26 years old, that is he was a year younger than I. His name was Thomas A. Edison. He had formerly been a newsboy on a railroad train in Michigan, but had at the same time learned to hold down a telegraphic instrument. He later became a telegraph operator in Boston and had made various improvements in telegraphy. His last discovery, in 1873, was a method by which he could transmit four messages over the same wire at the same time. It was called quadruplex telegraphy. His invention had been pattented, both in America and Europe, and he was now on his way to England to make personal demonstrations.

Edison had not then paid much attention to the amenities of life. It was noticed that he was very fond of his fine cut and he was so full of inventions that he wanted to talk about them continuously. The eagerness with which he wanted to tell everybody all that he knew about electricity and its possible uses made many of the passengers actually shun him. There 
was, however, one passenger who never wearied of listening to Edison and that was Ole Bull. I think one of the reasons why Ole Bull became so interested was that he did not really comprehend what Edison was talking about. The more obscure and hazy the subject was the more it appealed to Ole Bull's imaginative mind. At least this is my interpretation of it. In this connection I may refer to the fact that Ole Bull made me read to him by the hour from Helmholz' scientific work on sound and sound waves, and I know that he understood no more of it than I did. It was a sealed book to me.

You cast your bread on the waters and it will return to you after many days.

A few years ago I was to reap a peculiar benefit from having crossed the ocean with Edison in 1873. More than thirty years afterward I was sitting on my porch one afternoon and was considering what new thing I might do to promote an interest in this country in Scandinavian culture. It came to me like a flash from a clear sky, first, that we had no Scandinavian music on the phonographs, and second, that I knew Edison, the inventor of the phonograph. I therefore immediately wrote him a letter telling him of all the beautiful melodies to be found in the grand old North and telling him also that there were millions of Scandinavians scattered throughout this country who would become good customers if they could get the folk songs and best melodies of Norway, Sweden and Denmark for reproduction on their phonographs. I received immediately a reply from Edison's secretary thanking me for the suggestion and stating that it would be attended to at once. The result is that we now can get any Scandinavian music of merit for our phonographs. I was the first one to call attention to these Scandinavian records in my paper "Amerika" and I look upon this as one of my most important services in this line of promoting Scandinavian culture. 


\section{CHAPTER XLIV.}

\section{IN NORWAY AGAIN.}

On reaching Christiansand Ole Bull and his wife proceeded at once to Bergen, but he handed me a handful of gold and sent me to Christiania. The plan was to give the first concert in Bergen, and this entertainment was to have on its program Norway's greatest trio. Ole Bull was to appear as violinist, Edward Grieg as pianist, and Björnstjerne Björnson as orator. A more artistic combination could not then be found in Norway. I was to make a few opening remarks and state the puipose of these concerts.

I vent to Christiania to see Björnson and bring him without fail to Bergen, his expenses to be paid to Bergen and back to Christiania. I succeeded. Björnson was unwilling to go by boat. He was a poor sailor and did not care to make the long sea voyage around the coast, but was willing to make the inumey over land. It was on this journey that we met Sven Oftedal in Drammen. Mrs. Björnson accompanied us as far as to this city. From Drammen Björnson and I proceeded by rail to the lake Kröderen, then by steamer to the lower end of Hallingdal, then through this valley and Hemsedal to Borgund in Sogn and hence down to Lerdalsören where we took a steamer through the romantic Sognefjord around to Bergen.

And now another digression. At Borgund we took a look at the old Borgund stave church with its wierd architecture. It is one of the oldest remains of church architecture in Norway. 
At this antique church we met the pastor of that parish, the Rev. Schellerup. He was pleased to meet Norway's greatcst poet and invited us to go with him to the parsonage where his wife served us with refreshments. To meet Björnson meant controversy. The pastor and Björnson were soon plunged into a violent political and religious discussion. At such times Björnson was loud, vehement and even bitter. After we had enjoyed the hospitality of the parsonage for an hour or more we left for Lerdalsören. We had to remain in Lerdalsören all the rest of that day and until late in the afternoon of the next before our steamer departed for Bergen.

During that time Bjönson and I made a careful inspection of this old town. He had a notebook. In it he made, first, a psychological description of Rev. Schellerup, of his wife and of their two daughters. He described their outward appearance and their manners and their mental characteristics. He made a diagram of the road from Borgund to Lerdalsören and a very minute sketch of the town and he said to me:

"Here I have the plot for my next novel."

He carried this sketch with him to Rome the following autumn and there produced his remarkable story "Magnhild". "Magnhild" is an orphan rescued from a landslide and reared at the above parsonage. As a compliment to his American fellow traveler he lets his heroine go to America and there uscs Mrs. J. M. Rusk, wife of the late governor of Wisconsin, as his model, I having talked to hin about her, she being a Norwegian-American girl who had married an American of great prominence. I once asked Mrs. Rusk whether she had read Björnson's story "Magnhild". She said she had not done so. I told her she ought to read it because the anthor had made use of her as one of the characters in the book. 


\section{CHAPTER XLV.}

\section{BJÖRNSON AS A FELLOW TRAVELER.}

You ask me about Björnson as a traveling companion. This question is not easily answered. I may say that he was very moody, but upon the whole charming. In traveling through Hallingdal and Hemsedal it was a bitter disappointment to him that nobody seemed to know him even by name or reputation. He had a most striking appearance which made people dread to approach him. They would come to me and ask me who that man was. I would tell them that he was Norway's most distinguished living writer, that he was the author of "Synnöve Solbakken", "Arne", "A Happy Boy" and their great national song, "Yes we Love with Fond Devotion", but these were things that the people in Hallingdal and Hemsedal had not yet heard of. They said they knew a man by name Peter Björnson, a road engineer, who had done some work up there, but had never heard of "Björnstjerne". By the way this Peter Björnson happened to be B. Björnson's only brother and he seemed to be well known to all the people in this part of Norway. This ignorance of him made Björnson rave against the narrow valleys of Norway. He was disgusted with them and he exclaimed:

"Give me the broad "bygds'. There I am known."

At one time he fell to congratulating himself on his fine appearance and his commanding presence. "Oh, Anderson!" 
he said, "you have no idea what it means to be a great personality like me! It gives so much weight to everything I say." At one station where we stopped we took a walk into the fields. He sent me several rods away and then he made a speech to show me the great carrying qualities of his voice and the splendid acoustic qualities of the Norwegian mountain air. Sometimes he would amuse himself by showing me how easy it was for him to produce rhymes about the objects around us.

Between two stations we had a girl for our driver and during that time she monopolized his attention.

While Henrik Wergeland and Robert Burns looked upon every flower and blade of grass and insect or bird as a fellow sentient being, Björnson did not seem to care much for either flora or fauna. He was above all the keen psychologist. His fellowmen was what interested him. He wanted to read their inmost thoughts and be their leader. 


\section{CHAPTER XLVI.}

\section{OLE BUIL, EDWARD GRIEG AND BJÖRNSON.}

The entertaimment in Bergen by Ole Bull, Edward Grieg and Björnson was a decided success. Björnson recommended the monument to Leif Erikson in glowing terms. The day after a banguet was given in honor of this trio at one of the wea!thiest homes in Bergen. At this banquet stewed eels were served. Mirs. Ole Bull liked them so well that she accepted a second dish. She asked me, sitting opposite her, what it was that tasted so nice. Not suspecting that I was doing any mischief I told her it was eels. She at once left the table and did not return.

At this banquet there were toasts in honor of Ole Bull, in honor of Edward Grieg and in honor of Björnson. They were praised as the three most brilliant stars then visible above Norway's horizon, and when all these toasts had been responded to other guests were called upon for speeches and my turn came too. I responded by proposing a new coat of arms for the city of Bergen. Bergen's coat of arms is the three mountains surrounding the city resting on seven balls. Bergen is known as the principal market of the dried codfish (ludefisk) and is also renowned for it continuous rains. Every person you meet on the street carries an umbrella because it may rain at any moment. I therefore proposed as a new coat of arms a 
dried codfish under an umbrella in a shower of rain. Guests all applauded.

Edward Crieg left the table but soon returned having fetched his umbrella and this he presented to me as a reward for my brilliant suggestion. I am sorry that this is one of the treasures that I have lost.

Björnson left his place at the table, came over to clink his glass with mine and drink "dus" with me, that is, hereafter we were to address each other with the more familiar "Du" instead of "De".

On the north side of the city overlooking the harbor Edward Grieg had a cottage. It contained only one room and in it he had a Chickering piano. To this cottage he retired every day to do his composing. He wanted to be alone in a well lighted room with fine views from the window's. These things helped to inspire him. When lie presented me with his umbrella he invited me to visit him in this retreat. I went there the next day. In the course of my chat with him I told him that I had often watched Ole Bull when he improvised melodies on the violin and told him that I wondered how Grieg managed to get those melodies and harmonies on paper. He said:

"I will show you."

Getting some music paper and pen and ink which he placed on a small table in front of the piano, he seated himself at the instrument, assumed a very serious, almost superhuman look, whistled a little; then played what he had whistled and then wrote down what he had played; whistled another phrase, played another phrase, wrote down another and kept on in this manner until he had filled two pages. These he gave to me as a souvenir of this visit. I asked him to dedicate the music to my wife rather than to me, which he did. This piece called "Humoresque" is found in all editions of Grieg's collected works. 
A couple of days later Ole Bull, Mrs. Bull and I left Bergen for Stavanger, Christiansand and Christiania where concerts were given for the benefit of the Leif Erikson monument. The proceeds of the four concerts, as I now remember, were between $\$ 1,500$ and $\$ 2,000$ and this money was turned over to our treasurer John A. Johnson in Madison. 


\section{CHAPTER XLVII.}

\section{PROF SVEN LOVEN.}

I came near forgetting an interesting little incident at the Hotel Scandinavie in Christiania where the Thorpes, father and son, and I were stopping. On a visit to Thomas Heftye's summer resort "Sarabraaten", I had made the acquaintance of a German poet, from Breslau, Heinrich Traunann. He too was stopping at the same hotel. Among the guests at the hotel I had noticed a distinguished looking person that seemed to attract the attention of everybody. On inquiring I learned that this fire-looking gentleman was the famous naturalist, Prof. Sven Lovén. He was in Christiania visiting his scarcely less distinguished colleague, Prof. Georg Ossian Sars of the University of Christiania. When dinner was served in the dining room I had at my left J. G. Thorpe, Sr., on my right the poet Traumann and next to him sat a Norwegian to whom I had been introduced. With Mr. Thorpe I conversed in English; with Mr. Traumann in German, and with the Norwegian beyond him I spoke Norwegian, these three speaking only their own vernacular. Directly opposite me at the table sat Dr. Lovén and his daughter, a young lady in her teens. The daughter seemed to watch me with interest. At last I heard her whisper in her father's ear in Swedish, saying:

"What man is that, papa, that knows so many languages?"

Prof. Lovén answered his daughter in a low voice: 
"That I do not know. It must be an emigration agent." Having heard this I looked at the professor and said to him in Swedish:

"I believe the gentleman opposite me is a Swede. Am I not right?"

He answered: "Yes, Sir, I am a Swede. Can you talk Swedish too?"

I answered that I was no expert in speaking Swedish, but that I was very much interested in everything that concerned Sweden, and then I continued about as follows, speaking in Swedish as well as I could:

"I know who you are, Sir. You are the distinguished Dr. Lovén, professor of natural history in the Upsala University. I have long known you by your great reputation." Then I added: "I have a splendid Swedish friend in America where I live. He too is a great naturalist and I am greatly indebted to him for my interest in Swedish culture. I am referring to a man that knows you well, Dr. Lovén, and I have no doubt you know him. His name is Kumlien."

Dr. Lovén dropped his knife and fork and raising both his hands and his eyes sparkling with joy and wonderment he exclaimed:

"Thure Ludwig Kumlien! Koshkonong Lake! Do you really know him?"

I told him I had known him from my infancy. He then got up from his chair, walked around the table and came to me to take me by the hand. I quickly rose, told him who I was and chatted with him about Kumlien. He apologized for having insinuated that $I$ was an emigration agent; then he invited me to his room in the hotel where I met him and his daughter and had a most interesting visit. He insisted on my visiting him in Upsala. Unfortunately this never became convenient, but I brought most hearty greetings from him with me to Kumlien. 


\section{CHAPTER XLVIII.}

\section{RETURN TO AMERICA.}

As I have already in a former chapter given some of the incidents in connection with this visit to Norway and do not intend to refer to it again hereafter, I will only add that I took a trip with Joseph Thorpe across the country via Drammen, Kongsberg, Bolkesjö, Rjukanfos, through all the districts of Telemarken down to Skien, thence up to Siljord, through Vinje, across Haukelid, down to Roldal, thence to Odda in Hardanger, and from there by steamer to Bergen. Here I bade goodbye to Ole Bull and his family, took a steamer via Stavanger to New Castle, going from New Castle to Edinburgh, from Edinburgh to Glasgow and from Glasgow to New York and home. Mrs. Bull sent four large trunks of baggage with me to Madison.

On the trip through Hemsedal with Björnson a fine old Hemsedöling, Mr. Bjöberg, made me a present of a pair of reindeer antlers of unusual size. These I took with me and I still have them.

When I reached the steamer in Glasgow all my baggage was lost, although it had been checked in the usual way. All the employes of the steamship line were made busy hunting for my baggage. Telegrams were sent to Edinburgh, to New Castle and to Liverpool, but no trace could be found. The steamer was about to leave and I had made up my mind to wait for the 
next steamer, but a few minutes before the boat was to leave a stevedore reported that he had seen reindeer antlers in the hold of the ship with the luggage of the steerage passengers. This proved to be my lost baggage and I embarked happy.

We had a pretty stormy voyage. Among my fellow passengers were Prof. A. Wenaas and Rev. M. Falk Gjertsen, who have been mentioned heretofore. As soon as Prof. Wenaas landed in New York he received the sad tidings that his wife had died during his absence in Norway. Rev. O. J. Hjort of the Norwegian Synod, near Lansing, Iowa, also had the misfortune of losing his wife while on a visit to Norway the same summer. She was a sister of Rev. J. A. Ottesen. She was burned to death by the explosion of a kerosene lamp.

In New York I was for the only time in my life "taken in" by a confidence man. I had taken a room in a small hotel, had taken my bath and was sitting on the porch smoking my cigar when a well-dressed young man spoke to me by name and asked me how we were getting on at Madison. I explained to him that I was on my way home from Norway and consequently had no fresh news from Madison. He then asked me how soon I was going to leave town. I told him that same day. Then he asked me if I would not be kind enough to take with me a small package for a friend of his employed in the American Express office in Madison. He had previously explained to me by way of introducing himself that he had recently come from Madison and had been a clerk in the American Express office there. He told me that the package he wished to send was so small that I could carry it in my pocket. He claimed to know me by sight and reputation. Of course he had found my name and residence in the hotel register. I told him to bring the package and that I would be glad to serve him.

Then he said that he was working in an office only half a block from the hotel and invited me to take a walk with him there. I went. We ascended a flight of stairs, went through 
a long narrow hall and then entered a room furnished only with a table and a couple of rude chairs. There werc two other gentlemen in there when we entered, but one of these went out. My friend then asked if this was the office of the Havana lottery; the other fellow said yes. My friend then said that he had a ticket and understood that he had won a prize and gave the number of his ticket. The other gentleman opened a book, looked in it and said:

"Yes, you have drawn $\$ 5,000$."

By this time I was getting anxious. I rose and went to the door, but found the door was locked. I gathered up all my viking strength, braced my knce against the side of the door, pullcd with all my might, broke the lock, got out and hurried away. 


\section{CHAPTER XLIX.}

\section{MORE ABOUT THE LEIF ERIKSON MONUMENT.}

But to return to our Leif Erikson monument enterprise. Beyond the proceeds of the contents of which I have given an account, nothing was done. The work did not progress. Ole Bull was absent much of the time during the year 1874 and 1875. John A. Johnson was immersed in his business and I was busy getting the professorship of Scandinavian languages established.

In 1876 Ole Bull rented the home of the poet, James Russell Lowell, who was then our American ambassador in London. While at Cambridge Ole Bull succeeded in interesting a number of Massachusetts friends in the monument project. The matter was launched at a grand reception given to the distinguished artist in the music hall in Boston, Dec. 8, 1876. At this reception Edward Everett Hale in an address said that he supposed it was known to all who were present that Ole Bull had spent almost the whole of his active life in knitting those lies which connected his country with ours and that he hoped that there might be erected a physical memorial to the early Norse discoverers of this country. Mr. Hale thought that such an enterprise ought to appeal to Massachusetts men and he suggested that the committee that had arranged this reception should also be a committee of New England to take this matter in special charge. 
The committee was a large one and included Thomas G. Appleton as chairman, the governor of Massachusetts, Alexander H. Rice, the mayors of Boston and Cambridge, James R. Osgood, Oliver Ditson, Henry W. Longfellow, John G. Whittier, E. N. Horsford, Oliver Wendell Homes, James Russell Lowell, James T. Fields, Charles W. Eliot, Edward Everett Hale and many others renowned throughout the world in science, in letters and in the arts. In fact, no American enterprise ever had a more distinguished committee as its promoters. This committee meant success. The necessary funds came forth speedily. John A. Johnson sent what was in his keeping to Mr. Thomas C. Appleton.

The eminent American sculptress, Miss Whitney, was engaged to make the statue of Leif Erikson in heroic size, and in the second half of the '80s it was unvailed with suitable ceremonies, Prof. E. N. Horsford delivering the principal address. It was not placed on the campus of the University of Wisconsin, as was first intended, and as might have been, but it stands with a Viking ship for a pedestal on Commonwealth avenue in Boston, overlooking the Boston Back Bay. At the request of the committee I wrote the inscription, both with runic letters and in English. I was invited to speak at the unveiling, but could not at that time be absent from my post in Copenhagen.

The statue is subject to criticism. Miss Whitney made a figure more or less resembling Ole Bull. Leif Erikson has a smooth face, and upon the whole it is in all its outlines more a Roman then a Norse work of art, but is a great work of art nevertheless. In a conversation with James Russell Lowell he said to me that he considered Miss Whitney's Leif Erikson the high water mark of American sculpture at that time.

Ole Bull died in the summer of 1880 and so did not see his favorite project entirely realized, but he was remembered at the unveiling. A wealthy lady in $\mathrm{W}$ isconsin, Mrs. Gilbert, a relative of the Thorpes, secured a replica of this monument and 
gave it to the city of Milwaukec where Leif Erikson on a plain pedestal stands in Juneau park shading his eyes with his right hand looking for land.

Such was the result of the initiative taken by Ole Bull, John A. Johnson and myself in the early part of 1873 .

In the 'SOs the Norwegians in Chicago organized a Lcif Erikson monument committec. They had better luck than Ole Bull, Johnson and I and succeeded in the course of time in unveiling a Leif Erikson monument in Humboldt park.

The fact is the Scandinavians have been very enterprising in later years in erecting monuments and statues. They have put up a Thorvaldsen monument in New York, a Linné monument in Lincoln park, Chicago, an Ole Bull monument in Minneapolis, a Wergeland and a Gange-Rolf monument in Fargo, N. D., an Ivar Aasen and a Hans Nielsen Hauge monument in Moorhead, Minn., a Hans Christian Andersen monument in Chicago, and possibly others that I do not now think of. 
Sir the wintion of $18.73=4, \cdots$, Q haidi Noisinian did not necifan

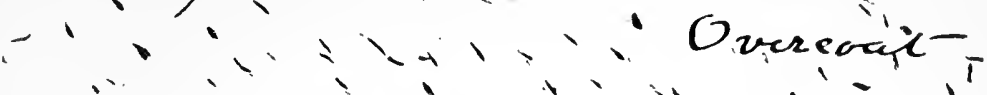

- 


\section{CHAPTER L.}

\section{STRENUOUS DAYS.}

\section{"America Not Discovered by Columbus."}

As indicated, I had strenuous days before me at the university. The professorship of Scandinavian languages was not yet in sight. There was yet very much to be done. The large field in Scandinavian literature had not yet been opened to American readers. Fully aware that my equipment was limited, I decided to make a beginning. I chose as my first subject and as the one I thought I could best handle, the discovery of America by the Norsemen. I had lectured somewhat extensively on this subject and could make use of my lecture as the basis of a book. I wrote a little book of something more than a hundred pages, gave it a thoroughly sensational and defiant title, "America Not Discovered by Columbus", thus challenging the claims of Christopher Columbus to this honor. I appeared as a fearless iconoclast, well aware of the prejudices to be overcome. What I meant by this aggressive title was not to detract in any way from the great honor belonging to the Italian navigator, but to insist that he did not discover, but only rediscover the western world. To belittle the services of Columbus would be the part of a crank and none of my critics have ever called me a crank. Indeed the great scholar and historian John Fiske published an article in the Atlantic Monthly on the subject of "Cranks", and he begins this article 
by telling his readers that " $\mathrm{R}$. B. Anderson is not a crank" and then goes on to show why Marie Brown, George Francis Train and others must be put in the category of cranks.

I had my manuscript ready, put it in my pocket and went io Chicago to secure a publisher. I called on the well known publishing house of S. C. Griggs \& Co. That patriarchal publisher, Mr. Griggs, with a great beard extending down to his waist, received me very cordially, but told me that he was very sorry that the book I offered him was not in his line. He did not think it would sell. He said that American readers did not care more about who discovered America than about who had first seen Goat Island at Niagara Falls. But I had acquired the knack and habit of being persistent. I answered him that he must publish the book. He finally agreed to print it if I would buy of him at wholesale price the first 500 copies. That meant $\$ 300$, more money than I could lay my hand on with a salary of only $\$ 800$ a year.

I went to my friend, Victor F. Lawson. I had known him since he was a child. With John A. Johnson and Langland, Victor Lawson's father had become part owner of "Skandinaven". The father, Iver Lawson, who had contributed so liberally to the Norwegian library at the university, was dead and Victor was now the business manager of "Skandinaven". My readers know how he has since risen to eminence as a publisher and business man.

I laid the facts before Victor. He decided to help me out and at once agreed to buy from S. C. Griggs 500 copies of "America Not Discovered by Columbus", and gave me the agreement in writing. He expected to sell that number to the readers of "Skandinaven". Griggs was satisfied and now the manuscript passed into his pocket. In the evening it went home with him as he forgot to leave it at his office. That night Chicago had its second great fire. The immense Criggs publishing house and book store was entirely consumed. The only 
thing combustible that was saved was my manuscript which Griggs had forgotten to take out of his pocket.

And so it came to pass that when S. C. Griggs \& Co. opened their business again mine was the first book to be published. This book was the first one in English written by a NorwegianAmerican. It is on account of this and my other books that followed in rapid succession that I have been called "the father of Norwegian literature in America".

The book was remarkably well received. Long and favorable notices were given it in the leading newspapers and magazines, both in this country and in England. The demand was so large, particularly in the east, that the first edition was soon exhausted, and Griggs had to buy books back from Victor Lawson to supply his customers. This book has passed through half a dozen editions in this country. The "Skandinaven" published a Norwegian translation. It has been translated into Danish, German and Russian. Before this book was published not a single text book of American history contained any reference to the Norse discovery. Today all such text books contain something about the early Norse discoverers, and I think I may claim that the recognition accorded to the Norsemen in this field is largely attributable to this little book of mine. 


\section{CHAPTER LI.}

\section{FIRST CHAIR OF SCANDINAVIAN}

LANGUAGES.

My little book, "America Not Discovered by Columbus", served to strengthen me in my position in the state university. I then determined to make my next effort in the line of Scandinavian mythology, thinking this was a subject that would appeal, both to scholars and to the general reader.

We were now nearing the end of the year 1874 and the university had gotten a new president, John Bascom, formerly of Williams College, a distinguished author, a great scholar, orator and teacher. In him I found a friend. After writing a few chapters of Norse mythology I obtained permission to read parts of it to him. He became deeply interested. The subject was new to him, but he liked my way of presenting it. $\mathrm{He}$ said to me:

"I am going to recommend to the regents to establish a chair of Scandinavian languages, history and literatures for you, so that you can put this your position under your name in your forthcoming book."

The regents responded to Bascom's request with alacrity. The chair was created at the annual meeting of the board of regents. This chair still exists and the example here set has since been followed by the University of Minnesota, the University of North Dakota, the University of South Dakota, the University of Illinois, the University of Iowa, by Columbia and Harvard, the University of Washington, and in a measure by several other universities and colleges. 


\section{CHAPTER LII.}

\section{"NORSE MYTHOLOGY."}

I collected in my little library in my modest home on Washington avenve all the works relating to Scandinavian mythology within my reach.

The work of writing was done chiefly by lamp light, many a night I kept on writing until dawn came peeping in at my window. I first wrote enough to make a book of about 200 pages. Then I started again, wrote it once more and more than doubled its size.

Early in the autumn of 1875 my manuscript was finished. I had suddenly grown ambitious. I wanted an eastern publisher. It was supposed to be more creditable to have one of the great houses of New York or Boston as a publisher than a more or less obscure publishing house in the undeveloped west. I now wanted either the Harpers or James R. Osgood \& Co., the publishers of the leading writers of the country. I wanted to trot in the same class with them.

Ole Bull was not here, so I went to John A. Johnson and talked the matter over with him. He sympathized with me and he gave me $\$ 100$ to pay my expenses to Boston and back. At the end of the fall term of 1874 I packed my grip and started for Boston. I went first to Ithaca, N. Y., where I visited the distinguished scholar Willard Fiske. He had visited the Scandinavian countries, was now the senior professor in Cornell University and was well versed in Scandinavian lan- 
guages, history and literatures, and was particularly interested in the old Norse and Icelandic. I acquired his friendship which I retained to the end of his life. He paid me a long visit later in Copenhagen. I read to him from my work on Norse mythology and he was pleased with it. He gave me a letter to H. W. Longfellow, whom he knew well.

From Ithaca I went directly to Cambridge, Mass. Longfellow occupied a splendid mansion near Harvard University, the celebrated house in which George Washington had his headquarters when he took command of the American army. Longfellow was now a widower for a second time.

With the permission of the reader I may state that I rang his door bell with the greatest timidity. I believe I heard my heart beat. I found the poet at home and was conducted into his library. In his presence I soon forgot my timidity. His manner was so democratic. He knew how to put himself on the same level with me. I told him my errand and I handed him Fiske's letter. He immediately gave me permission to read to him and to his two daughters the opening chapter of my manuscript. He praised it with enthusiasm and said he wanted his friends to enjoy this reading with him, and so he fixed an evening when I was to come and read for an hour from my Norse mythology to him and such friends of his as he might invite.

On the evening of the day after his parlor was well filled and I had in my audience many of the most distinguished writers then living in Cambridge and Boston, among them the president and many of the professors of Harvard, Oliver Wendell Holmes, Eben Norton Horsford, James T. Fields, Thomas G. Appleton and others. My reading was applauded and I was smothered with compliments from my hearers as they bade me goodnight. Longfellow invited me to dinner and to tea. He gave me permission to dedicate my work to him. Then he gave me a letter to James R. Osgood, his own publisher. 
The present name of the house is Houghton, Mifflin \& Co. Mr. Osgood said that a recommendation from Longfellow was sufficient and that he would be pleased to publish the work at once. I told him that I would like to take the manuscript home with me and give it one more careful revision.

When I informed S. C. Griggs of what I had done and of my plans to have my book published by Mr. Osgood he became furiously jealous and took the first train for Madison. He insisted that it was he who had been at the trouble and expense of getting me advertised and that I had no moral right to desert him as soon as I could get another publisher. He offered to lay the matter before President Bascom and John A. Johnson as arbitrators between us. $\mathrm{He}$ also argued that he not having so big a list of publications could give to each book more attention, and assured me that he could handle "Norse Miythology" more successfully for me than any of the eastern houses who rarely paid any special attention to any of their books.

I agreed to leave the matter to Mr. Johnson. So we went together to lay the question before him. Mr. Johnson found Mr. Griggs' arguments reasonable and gave it as his opinion that it was my duty to allow Griggs to continue as my publisher and do the work that he had so well begun. I yielded. I immediately informed James R. Osgood and he consented to the change with great courtesy.

I then went to work and gave the book a second revision, rewriting various parts and making important additions. All I expected in the beginning was to give a brief synopsis of the religion of our forefathers, but now that I had secured a publisher in advance I wanted the book to be as complete and exhaustive as any work on that subject in any language.

The book appeared early in August, 1875. In June I had been elected professor of the Scandinavian languages in the University of Wisconsin and thus was able to state this fact 
under my name on the title page. I got the American artist, James R. Stuart, who had come to Madison from the south, to make a representation of Thor for the back of the book, and of Odin, with his ravens and wolves for the front cover and "Thor Fighting the Giants" for a frontispiece.

I am not overstating the matter when I say that "Norse Mythology" was remarkably well received by the scholars and by the press generally of this country and of other lands. E. P. Whipple, the great American critic, wrote in the Boston Globe:

"A masterly work ***. No American book of recent years does equal credit to American scholarship or is deserving of a more pronounced success."

The great professor, William Dwight Whitney of Yale College, wrote:

"I have been struck with the warm glow of enthusiasm pervading it and with the attractiveness of its descriptions and discussions. I sincerely wish it a wide circulation and careful reading."

Prof. F. Max Müller of Oxford sent me a letter in which he said:

"I like it decidedly. A mythologist must be not only a scholar, but a bit of a poet; otherwise he will not understand the petrified poetry out of which the mythology of early nations is built up. You seem to me to have that gift of poetic divination, and therefore whenever I approach the dark runes of the Edda I shall gladly avail myself of your help and guidance."

The Bibliotheca Sacra, edited by the professors of Yale College, stated:

"We have never before seen so complete a view of the religion of the Norsemen. The myths which Prof. Anderson has translated for us are characterized by a wild poetry and by suggestions of strong thought. We see images of singular 
beauty in the landscape of ice and snow. Sparks of fire are often struck out from these verses of flint and steel."

The Presbyterian Quarterly and Princeton Review contained an extended review in which the following was found:

"Prof. Anderson is an enthusiastic as well as an able scholar and he imparts his enthusiasm to his readers. His volume is deeply interesting as well as in a high degree instructive. No such account of the old Scandinavian mythology has heretofore been given in the English language. It is full and elucidates the subject in all points of view ***. Prof. Anderson's interpretation of the myths throws new light upon them and are valuable additions (as is the whole work) to the history of religion and of literature. *** $*$ It deserves to be welcomed not only as most creditable to American scholarship, but also as an indication of the literary enterprise which is surely growing up in our northwestem states."

The reviewer in the New York Tribune said:

"Prof. Anderson has produced a monograph which may be considered exhaustive in all its relations."

Commendations of this kind might be multiplied with quotations from all the leading magazines including Harper's Magazine and the Atlantic Monthly in this country, and the great quarterlies in England. The poet Longfellow wrote the review for the Boston Advertiser.

I presume I may say without exaggeration that by the publication of this work my reputation as a Scandinavian scholar was established throughout the English-speaking world.

I have a copy of the will of an old wealthy bachelor in Melbourne, Australia, in which he has set apart 500 pounds to be used for distributing "Norse Mythology" and "America Not Discovered by Columbus" in Norway after his death.

I will add here that the book has been reprinted in England, has been translated into French by Jules Leclerc and published in Paris. It has been translated into Italian by the 
Italian poet and scholar Tomaso Cannizzaro of Messina. Mine is the only work on the subject in French and I am singlehanded fighting Jupiter and Mars and the other ancient Roman divinities in Italy.

I think it was in 1877 that my "Norse Mythology" was used as a text book for subjects in preparing the floats in the Mardi Gras festivities in New Orleans.

But what is perhaps most remarkable in this connection is the fact that both "Norse Mythology" and "America Not Discovered by Columbus" have been translated into Danish, and published in Christiania and Copenhagen. This went beyond all my dreams and nost sanguine expectations. In "Verdens Gang" in 1881 the poet Björnson wrote:

"Anderson's scientific work rests on an unlimited industry in the acquisition of knowledge. What he has been able to gather and with what unusual memory he controls what he has gathered challenges the respect of all who are familiar with the circumstances under which Prof. Anderson has worked. In my whole circle of acquaintances there are only one or two similar examples. The fact is attributable, in addition to his intellectual endowments and strong physique, to a strictly moral life and an iron will. A recognition like that given him by the Icelandic skald Mathias Jochumsson who says "his "Norse Mythology" is the best Scandinavian mythology ever written', cannot be set aside."

In this same article in "Verdens Gang" Björnson says a number of other nice things about me. I take the liberty of quoting further:

"Anderson has one single purpose in life: To make the Norwegians honored in America. * * * When I gather in my memory all the splendid people I met in the west, all the good, loving men and women, with the marked qualities of honest minds,--Prof. Anderson is and will remain No. 1. I prefer to remember him walking. Few things reveal a per- 
son more perfectly than his walk. Whoever observes Prof. Anderson's walk gets into good humor by noticing the energy with which he makes his way. All men resemble animals and he resembles the Norse fjord-horse which is equally splendid in running or in pulling, on the level or up the side of the mountain."

All the eulogistic reviews of "America Not Discovered by Columbus" and particularly of "Norse Mythology" did not fail to make an impression on the professors, my colleagues at the University of Wisconsin. They began to think that there must after all be something of value in the traditions, history and literature of Scandinavia. I have heretofore dwelt on the fact that there was not one professor in the university who had even paid the slightest attention to this field of investigation and there was no one to assist me in defending the cause of which I was the advocate and apostle. Still there were members of the faculty who recognized my earnestness and extended to me considerable sympathy. Among these I like to remember in these memoirs particularly Prof. W. F. Allen and Dr. S. H. Carpenter. They were always willing to extend to me a helping hand and to aid me in getting suitable work in teaching. Then there was one professor, whose name I dare not mention, whose heart overflowed with kindness and who was always ready to help me with all sorts of advice and suggestions. If I happened to mispronounce a word he would immediately take me to one side and inform me how the word ought to be pronounced. If I had said "advertisement" with the accent on the third syllable and the long sound of "i." he would take the first opportunity of telling me that I must say "advertisement," with the accent on the second syllable. If I gave the long sound to " $\mathrm{i}$ " in "direction" he would tell me that the word was pronounced "derection." This became a habit with him. When he had seen the many reviews of the two books above mentioned he grew exceedingly attentive and 
patronizing. One day I met him in the lobby of the postoffice. He at once approached me and asked me what my next book would be. I answered him that I was trying to make an English translation of the "Elder Edda". Following his old habit he told me that the correct pronunciation of the word in English was "Eldorado".

When we consider that this professor was himself a graduate of a prominent American college this example illustrates the dense ignorance in regard to Scandinavia cven among the scholars of the land. In those days there were not many university professors who could explain after whom the days of the week were named. 


\section{CHAPTER LIII.}

\section{MORE ABOUT OLE BULL.}

During our visit to Norway in 1873 the relations between Ole Bull and his wife and her family grew gradually more and more strained. I think Mr. and Mrs. Bull might have gotten on harmoniously if she could have been divorced from her mother, but Ole Bull could not endure Mrs. Thorpe. Ole Bull wanted to make his home at Lysöen. Mrs. Thorpe wanted her daughter in America. Of course Mrs. Thorpe and the rest of her family knew well the history of Ole Bull's life with his first wife. They were aware that he was not very domestic in his habits. He was an artist and as such he had visited all parts of the civilized world, appearing before large audiences and overwhelmed with applause and attentions of every sort. In the midst of all these ovations and honors heaped upon him, finding society revolving around him as its center, he very easily forgot that he had a home, a wife and children. Naturally enough Mrs. Thorpe did not like to see her only daughter left alone at Lysöen and her husband flitting from one city to another. The question between them now was whether Mrs. Bull should obey her husband and make her home with him in Norway or he accommodate himself to the wishes of his mother-in-law and live in America.

One of the reasons that led Mrs. Bull to decide to go back to her mother was the fact that her physical condition was such 
that she thought she might need her mother's special care. As heretofore indicated Mrs. Bull sent with me when I returned to Madison several trunks filled with her personal possessions, clothes and other articles, as she had determined to leave later in the autumn.

Toward Christmas Mrs. Bull returned to Madison alone. She was very much depressed. The ocean voyage had proved disastrous. She came to see me almost daily, appealing to me to find some way of bringing about a reconciliation. I sympathized with her, but I also had much sympathy for Ole Bull. I studied the matter carefully and finally hit on this means of getting the two reunited. I knew Ole Bull's great enthusiasm for everything that would in any way spread the glory and fame of his dear old Norway. I saw how I could kill two birds with one stone. He too was anxious to diffuse an interest in Norwegian literature. I therefore selected the story "The Pilot and His Wife", by Jonas Lie, as a book that I would help her translate into English. With this book in her hand I felt sure that Ole Bull would take back his wife with enthusiasm and forget all about her desertion. Besides this work would keep her mind occupied and help her forget her troubles.

I casily secured S. C. Griggs in Chicago as her publisher, both for this book and later for "The Barque Future", another novel by the same author.

The next autumn when "The Pilot and his Wife" had left the press Mrs. Bull put a dozen copies of the book in her trunk and went to Norway. As I had expected Ole Bull was so delighted that he received his wife with open arms and the reconciliation was complete. She brought him back to Madison, but this again brought him more or less in contact with Mrs. Thorpe.

It is not an agreeable task, but it is a duty, both to Ole Bull and to his wife, to state that Mrs. Thorpe, while we admit her many excellent qualities, did grate on Ole Bull's nerves, and it 
may be said without stretching the truth that he did not hesitate to show that he did not like her.

While in Madison in 1874 and 1875 the family reached a compromise, agreeing to settle in Cambridge, Mass., where Ole Bull could associate with Henry W. Longfellow and many other of his distinguished friends in Cambridge, in Boston, and in the east generally. They rented the furnished home of the poet James Russell Lowell, who was at that time our minister to England. Here Ole Bull seemed to be very happy. He was in close touch with friends; he gave a concert now and then; spent his summers in Norway at his favorite Lysöen; came to Madison now and then and seemed fairly happy and contented. But his health was gradually failing; he complained of his stomach; now and then he would have violent spasms of vomiting. These spasms became more frequent and more violent. The last time I saw him was early in the year 1880 . He looked very discouraged; he said he must go to Norway for his health. He was sure that the balmy air and ozone of Lysöen would make him well. He had lost much flesh; the vigorous grasp of his hand had departed and I felt I was bidding him goodbye for the last time.

As soon as Ole Bull and his wife could get ready they started for Norway. They got as far as Liverpool where they had to remain for a time and it looked for a time as if Ole Bull would end his days there. He improved a little and proceeded under great difficulties to Hull and thence to Bergen and Lysöen. There he, was put in a bed in his great music hall. His wife gave him the most delicate attention. Fresh heather flowers were brought to him every day. Mrs. Bull played the choicest music that she knew for him at the piano, but death had knocked at his door and entered his home and he soon passed away. This was in the month of August, 1880, and he was then in his seventy-first year, having been born February 5 , 
1810. An autopsy showed that his disease had been cancer of the stomach.

There was the greatest funeral ever seen in the city of Bergen. King Oscar telegraphed his grief at the loss of so distinguished and beloved a citizen. The principal speaker at the grave was Björnstjerne Björnson, who began his remarks by saying:

"Ole Bull was beloved. That we all see today." In vigcrous language he told the vast throng whose idol Ole Bull had been what a great loss the world and Norway, and particularly Bergen had suffered, and he called upon his hearers to be kind to his widow, who was there prostrated with grief.

While in Madison Ole Bull occupied what is now the governor's mansion on Gilman street. The wealthy lumberman J. G. Thorpe, Mrs. Bull's father, had bought this home from George P. Delaplaine. After the marriage of Ole Bull to Sara Thorpe Mr. Thorpe deeded the house to his daughter and some time after her husband's death she sold it to the state of Wisconsin. To this home were brought many treasures from the Ole Bull home Valestrand in Norway. Among these were three large parlor mirrors, framed in carved birchwood.

Much hospitality was dispensed at the Ole Bull home in Madison. There were frequent entertainments attended by the leading citizens of Madison, including the governor and other state officers, the judges of the supreme court, and the president and professors of the state university. To all these parties Mrs. Anderson and I were regularly invited.

Ole Bull was passionately fond of cards and billiards. In the middle of his lawn he built a billiard hall and there he spent much time playing billiards with his neighbor C. S. Mears, father-in-law of J. H. Palmer, the prominent Madison banker of today. A frequent visitor there was the artist James R. Stuart. At the entertainments Ole Bull usually gave a short musical program with his wife as accompanist, but sometimes he 
was balky and could not be induced to touch his Guarnerius. His chief motive in refusing to play was to plague his motherin-law.

I saw him nearly every day; I would call on him at his home; take dinner with him; then he would go home with me, take supper and spend the evening until midnight at our house, and then I would escort him home again. At our house he got anchovies, which he swallowed whole, head and all, and he was particularly fond of Mrs. Anderson's broiled quail on toast.

I presume I may tell here without offending any one of the living that at one time Mrs. Thorpe had made elaborate preparations and invited many guests to a swell entertainment at which Ole Bull, of course, was to be the great star and the chief attraction. But Ole Bull was not in the mood for social duties. He said he was tired of being put on exhibition. In the afternoon he took me with him for a long walk. He insisted on going to our house for supper and to spend the evening there. At the entertainment they waited in vain for Ole Bull to appear. After 12 o'clock Ole Bull and I returned to the Bull mansion and at the head of Mifflin street we met Mrs. Bull. I never heard Ole Bull laugh more heartily than when he met his wife. Mrs. Bull said they had been searching for him and had been grcatly worried about him.

On another occasion a large number of distinguished people had been invited and had been distinctly promised that Ole Bull would play. At this time he did not leave the house but he refused absolutely to produce his violin.

It was arranged between Ole Bull and me that I was to write his biography and in connection with it publish a separate chapter, giving his views of the violin, of the different old Italian Cremonas, the Gaspar da Salo, the Stradivarius, the Guarnerius, the older and younger Amati and of some of the later makers and players. The makers of the varnish used by 
the old Italian makers was a lost art which he claimed to have rediscovered. He had his own views about the bridge and the sounding post, and while in Madison he invented a chin resi. Of all these things I took notes from his dictation. Then he turned over to me his biography written in Norwegian by Henrik Wergeland, another one written by Winther-Hjelm and a large amount of newspaper and periodical sketches gathered in England, Germany, France, Italy and many other countries. Out of all these I was to construct the story of his life, adding such new matter as he and I together could supply. Much of this work had been done when he left Madison and settled in Cambridge, Mass.

The notes on the violin I took at his house and he always had one of his violins in his hands while he dictated. When he was at our house I had to read to him. I read newspapers, magazine articles, and books to him. He was very fond of poetry and listened with eagerness to every new book that I rcceived from Norway. This also helped me keep from getting rusty.

In the spring of 1873, three men, one of whom was Syver Holland, from Moscow, Wis., called at our house one evening. They wcre a committee to invite me to deliver the 17th of May oration at Moscow, a little village in Iowa county, some thirty milcs southwest of Madison. There was no railroad and the country to be traversed was very hilly. When the three men came to our house Olc Bull happencd to be there. I introduced them to him. In course of time they broached their errand saying they were making preparations for the celebration of Norway's day of independence and had come to invite me to be the orator of the day. Instead of replying to them I turned to Ole Bull and asked him whether I should accept the invitation. Ole Bull said:

"Certainly, you must; you cannot refuse to speak on the 17th of May." 
I answered him:

"I will go to Moscow, if you go with me."

"Of course, I will go with you."

The committee could hardly believe their own ears. The idea that they were to have at Moscow the most distinguished Norwegian that ever lived at their 17th of May festival was more than they could take in. I can still see how Syver Holland sat rubbing his hands together with joy. They were too full for utterance. I presume they would have liked to hurry back to Moscow that very night to proclaim the great and good tidings.

One trouble they had after they got home was to get the people out there to believe them when they told that Ole Bull was coming. People thought it was a trick for the purpose of drawing a crowd. I invited John A. Johnson to accompany Ole Bull and me to Moscow. Mr. Johnson got a double seater and he served as coachman. We had been invited to go to O. B. Dahle in Perry, near Moscow, on the 16th to stop over night and proceed the next morning to Moscow.

Mr. Johnson having been much in county politics was supposed to know the way. We had gotten within a few miles of O. B. Dahle's when the road forked and Mr. Johnson did not know which of the two roads to take. Several rods from the road on the left hand side stood a small farm house and I went there to inquire as to which road to take. I could not get anyone to hear me knocking at the front door, so I went to the back door and there I found an old man chopping wood. I said to him:

"I am going to Dahle's, but there are two roads and I do not know which one to take. Shall I take the one to the right or the one to the left?"

The old gentleman looked at me, examining me from head to foot, and then replied:

"Are you the one who are to speak in Moscow tomorrow?" 
"Yes, I am he", I answered. "Will you kindly tell me whether I am to take the road to the right or the one to the left."

The gentleman again looked at me earnestly and then replied:

"Are you really Rasmus Anderson that I have seen so much about in the newspapers?"

"Yes, that's my name, shall I take the road to the right or the one to the left?"

The gentleman still looked inquiringly at me and then replied:

"Is Ole Bull with you?"

"Yes, he is", I said; "shall I take the road to the right or the one to the left. I want to get to O. B. Dahle's before it gets dark."

The gentleman then again replied:

"Yes, I will tell you which road to take," and so he walked on ahead of me up to the road. Standing by the carriage he took a survey of the man in the front seat and of the one in the rear seat. After examining both carefully, pointing at the one in the rear seat he said:

"Is that Ole Bull?"

I said: "Yes sir, it is."

He was struck dumb with astonishment.

Then I asked him: "Will you now tell me which of these roads I am to take?"

The man pointing at the gentleman in the front seat replied again saying:

"Who is that fellow there?"

I told him that was John A. Johnson, a young man whom he had probably voted for several times; "shall we take the road to the right or the one to the left?"

After looking Mr. Johnson all over and telling him how well he knew him by reputation he drew a long breath and said: 
"You have to take the road to the right."

The genteman here described reveals a not uncommon trait among his countrymen. In other words, I mean to say that while men in other nations have to be made the Norwegians are born diplomatists.

This sturdy farmer, who told us to take the road to the right, spoke in his pure Sogning, one of the most musical dialects of Norway, and this gave to his conversation a piquant flavor, which unfortunately is not reflecied in my English translation.

The old fellow showed us the road; we were handsomely entertained until the next morning by the Dahles. Then we drove on to Moscow where we were met far outside of town by a large body of celebrators headed by a brass band. They escorted us to the celebration grounds where there was music and speaking.

I delivered my speech, our coachman, John A. Johnson, also spoke, and Ole Bull talked on the violin. He did not have his own violin with him, but an old fiddle was produced and on this he played a few Norwegian melodies. This fiddle belonged to Peter Holt, who died this year, 1914, at the age of 87 years. His son Ole now owns the fiddle. It has received the best of care and is still exhibited as a curiosity, having been actually played upon by the world's greatest violinist. I do not think the owner would part with it for a farm.

Ole Bull did not like to play on any other violin than his own. He had his own ideas about the sounding post and especially in regard to the bridge and strings. He whittled down the bridge so as to make it nearly level on the top, the $A$ and $D$ strings being but very little more elevated than the $E$ and $G$ strings. This enabled him to play upon all four strings at the same time. Expert musicians did not understand how he managed to play "Home, Sweet Home", for instance, in four parts. To play on four strings at the same 
time and not allow any of them to touch the finger board required enormous strength of muscle and a steady nerve.

Ole Bull would never touch the Hardanger violin which is the national instrument of Norway because it has a shorter neck and less space between the notes than the Italian violin and he did not want to give his fingers the wrong habit. So it was not from pride that he refused to play on any instrument that might be handed him. His nerve and muscle enabled him to play staccato equally well on the down or up stroke of the bow and in harmonics he has never been excelled, if equalled. Well might Strakosch say of him:

"Ole Bull's right hand is invincible."

Ole Bull's appearance at Moscow the 17th of May, 1873, has ever since been one of the choicest traditions in that village and the surrounding country. The fact that he was willing to take that long journey over a rough country and that he condescended to play on an old common fiddle reveals one of the most beautiful and lovely traits in Ole Bull's character. It showed him to be, as he always professed to be, a true democrat in full sympathy with the rank and file.

Here we have a man, who had stood before all the crowned heads of Europe and been entertained by the various aristocratic circles of the old world, associating with and taking his position on the same level with the common immigrants from Norway. By this he proved himself truly great.

A number of stories could be told about Bull showing the eccentricities of genius. Out of the many that I have heard I may tell one which I have on most excellent authority. Iver Lawson of Chicago, father of the well known Victor F. Lawson, was a warm friend of Ole Bull's and to some extent his financial manager or guardian. Iver had invested some of Ole Bull's money in two lots on North Clark street in Chicago; but there was one lot between his two. All three lots were vacant. Business had been extended beyond these lots 
and so Iver Lawson advised him to build stores on his lots in order that he might derive an income from them. It would be easy to get the stores rented. Ole Bull replied:

"All right; you may build on my lots."

Then Mr. Lawson suggested that if he could buy the lot between Ole Bull's two he could put up one building on all three lots and in this way the construction would be more economical.

"All right; buy the lot," said Ole Bull.

In a few days Mr. Lawson informed Ole Bull that the owner of the lot in question demanded a so exorbitant price that he could not advise him to buy it. Then Ole Bull, as if he had received inspiration from on high, burst out:

"Build over him, and let him keep his lot!"

He had conceived the idea that he could build up say one story on his iwo lets and then unite his buildings over the other man's property and it was difficult for Mr. Lawson to get Ole Bull to understand that the other fellow owned the space above and below the lot as well as the surface. 


\section{CHAPTER LIV.}

\section{ODDS AND ENDS.}

In this story of my life I am not dwelling much on my speeches and lectures. It is probably sufficient to say that I lectured in a great many different places on a variety of Scandinavian subjects and that I rarely failed to speak somewhere on the 17ih of May and on the fourth of July. But a couple of instances of this sort now come to my mind and these are of such a character that I wish to make a special record of them.

One of these occasions was in Chicago July 4, 1875. It was the fiflieth anniversary of the departure of the sloop "Restaurationen" from Stavanger July 4, 1825. The celebration gotten up by the Nora Samlag society in Chicago was held in the open air in a park on the northwest side of the city. It was one of the largest assemblies I ever addressed. On the platform sat nearly all the then surviving members of the sloop party. I think I made a decided hit with my address, which was immediately printed in a large edition and sold at 25 cents per copy. Nora Samlag banquetted me in the evening and as a souvenir of the event presented me with a gold-headed cane.

Another occasion was the winter before I went to Denmark. I was invited, as I had been before by Mrs. May Wright Sewall, to give parlor lectures at her spacious home in Indianapolis and she had made engagements for me to lecture 
at the University of Indiana and at the various colleges in that state.

My lectures in Mrs. Sewall's parlors were attended by such notables as Mrs. Benjamin Harrison, Mr. and Mrs. Thomas A. Hendricks, Charles Dudley Foulke and several other distinguished people. At the DePauw I was introduced to the audience by the very popular historian, Clark Ridpath. At the University of Indiana where I delivered three lectures I was a guest at the home of its president, David Starr Jordan. These invitations were entirely a recognition of my services to Scandinavian literature, my diplomatic appointment not having been even dreamed of at that time. 


\section{CHAPTER LV.}

\section{J. C. DUNDAS.}

One of the most original and most interesting Norwegians that ever came to America was Dr. J. C. Dundas of Cambridge, Wis. He was a direct descendant of the famous Nordland poet Petter Dass and J. C. Dundas was everywhere known as "Dr. Dass." In Norway he had been intimately acquainted with the poets Welhaven and Wergeland and had fallen desperately in love with Wergeland's sister, afterwards the distinguished Camilla Collett.

Mr. Dundas came to Cambridge in the latter part of the ' $40 \mathrm{~s}$ and built up a lucrative practice in medicine and surgery. $\mathrm{He}$ was a passionate hunter and very fond of horses and horse racing. With his long duster he could be seen at every county fair. He wrote poetry by the yard. Many of his poems were published from time to time in the Norwegian newspapers, but the large bulk of them have never seen the light of print.

Dr. Dundas had traveled in many lands. He had lived and studied in Holland, England, Germany and Scotland and had gone as ship physician to China and Japan. When he was in his full dress he wore a vest of Chinese silk in many colors. After his death which occurred in Madison this remarkable vest was given to me.

Dr. Dundas and Ole Bull were fast friends and enjoyed each other's company very much. When Ole Bull gave his concert in the Methodist church in Cambridge for the benefit 
of the Leif Erikson monument, Dundas had on his Chinese vest and was on the street the whole day waiting for his distinguished guest.

The Methodists did not want a violin concert given in their church, but Dr. Dass had secured the key to the church door and the church was soon filled in spite of them. A suit was threatened, but did not materialize. The day and night that Dundas had Ole Bull as his guest was surely the happiest day of his whole life; and Ole Bull was happy too.

What I have of souvenirs of my intimate relations with Ole Bull consist mainly of a few letters received from him at various times. These letters are full of enthusiasm and very characteristic of the writer. Then I have an unabridged Webster's dictionary which he handed to me as a Christmas gift, a flyleaf of which he has covered with a unique presentation. On leaving Valestrand in 1872 he gave me the autograph copy of Henrik Wergeland's wonderfully beautiful poem to him, written to him in 1843, when he was about to leave for America. The title of the poem is "Norway to America", written on the occasion of Ole Bull's departure for his first visit to this country. In this poem Wergeland shows a remarkable knowledge of American geography and expresses his opposition to the American institution of slavery. The poem reads as follows:

Norge til Amerita.

ved Ole Bulls didreise.

O Amerika, betro'd

har jeg dig med ængstlig anen

ham, min fattigdoms klenod,

ham, mit hjertes bedste blod!

Lad platanen

kicerligt ham imödebruse,

Alleghannen 
ham i venlig grotte huse,

Susquehannen

som en dxmpet harpe suse

ham, min elskling, ham inod!

Han med buens lette spil

kan til dans din panther tvinge,

og (hvad der skal mere til)

slave-eieren til smil.

Han kan bringe

Carolinas arme neger

til at springe

gladere end barn, som leger,

sig at svinge

snellere end hjulets eger

$o$, han kan det, om han vil.

Men, som om hans bue blev

pludselig med tordner svanger, som om den i luften skrev trylleformlet frihedsbrev, skræk og anger

fylder herrens hjertekammer som med slanger, tusind blik i mulmet flammer hos hans fanger

Ve ham, ve ham! Slavens jammer

klagende min Bull beskrev.

Far da hen, far hen, min sön!

lad din tryllebue skjænke

arme negers suk $\mathrm{i}$ lön

styrken af en bonhort bön,

saa hans lænke 
for dens strög maa sönderbriste!

Da sig sænke

signende platanens kviste,

og jeg tænke

kan med stolthed, dig at miste,

Olc Bull, min sön, min sön!

Thi hist vest, did du vil fly,

cr min egen friheds kjerne

voxet i plataners ly,

baaret hid paa svanger sky.

Derfor gjerne

vilde jeg taknemlig sende

til dens fjerne

fosterland ved havets ende

herlig stjerne,

og af dem, som hjemme brænde,

straaler ingen med dit ry.

In this connection I think I may properly tell what part I had in securing from Longfellow his poem on the Four Lakes around Madison. A committee here of which Mrs. J. G. Thorpe was chairman had raised a considerable sum of money and had engaged the distinguished artist Thomas Moran to paint Madison's four lakes in four separate pictures. These were to be a part of Wisconsin's exhibit at the centennial exhibition in Philadelphia in 1876 and then presented to the state university. The ladies wanted the subject of the paintings immortalized in a poem. In an interview with Mrs. Thorpe I suggested that through my acquaintance with Longfellow I might induce him to write such a poem though he had never seen the Madison lakes. Longfellow responded promptly and sent in his own handwriting the following poem: 


\section{The Four Lakes of Madison.}

Four limpid lakes_-four Naiades

Or sylvan deities are these,

In flowing robes of azure dressed;

Four lovely handmaids, that uphold

Their shining mirrors, rimmed with gold,

To the fair city of the west.

By day the coursers of the sun,

Drink of these waters, as they run

Their swift diurnal round on high;

By night the constellations glow,

Far down their hollow deeps below,

And glimmer in another sky.

Fair lakes, serene and full of light,

Fair town arrayed in robes of white,

How visionary ye appear!

All like a floating landscape seems,

In cloudland or the land of dreams,

Bathed in a golden atmosphere.

I gave the original manuscript to the committec who had it suitably framed and hung together with Moran's paintings in the university art gallery in the old Science Hall. About 1883 Scicrce Hall was destroyed by fire and the Moran pictures, together with the manuscript of the above poem, were reduced to ashes. I might as well tell here that in his poems of places Longfellow included this poem and also published my translation of Andreas Munch's wonderfully beautiful poem, "The Bridal Party in Hardanger".

Ole Bull's daughter Olea, now dead, was just three months younger than our daughter, Carletta, now Mrs. Vedel, in 
Aarhus, Denmark. Carletta was born Dec. 4, 1870, and Olea Bull March 4, 1871. While the Bulls lived in Madison these two little girls and later on our son George, born in 1872, were constant companions cither at the Bull home or at our liome. The Bulls had horses and carriage and Mrs. Bull freģuently took Mrs. Anderson and our two ehildren with her for long drives. Mrs. Anderson taught these children little pocms by Wergeland and Hans Christian Andersen. 


\section{CHAPTER LVI.}

\section{SURVEY OF FIELD IN THE SEVENTIES.}

Back in the ' 40 s, when this story begins, there was only a handful of Norwegians in this country and these were lacated in small settlements mainly in southern Wisconsin and northern Illinois. Enigration from Norway kept increasing through the ' 40 s and ' 50 s and by 1860 we find them scattered throughout the northwest even to the borders of what is now the Dakotas.

Immigration subsided somewhat during the dark days of the rebellion, but after the close of the war it took a fresh start and down through the rest of the '60s and all of the '70s the Norwegians came by the thousands every year. The '70s were strenuous years in forming settlements and starting enterprises of all kinds. A person visiting them, say in 1880 , would find them well established in every line of activity.

There were prosperous farmers scattered in large and small settlements throughout the Northwest even to the Pacific coast. The several church organizations were continually creating new congregations, building new and costly churches and parsonages and establishing colleges, academies, theological seminaries, hospitals, old people's and children's homes and publishing church organs and religious books, pamphlets and tracts of all kinds.

Prominent among the churchmen were Rev. V. Koren, Rev. J. A. Ottesen, Rev. B. J. Muus, Prof. L. Larsen, Rev. N. 
Brandt, Rev. H. A. Preus, Prof. S. Oftedal, Georg Sverdrup, A. Wenaas, and many others from the University of Christiania. Besides there was a large group of ministers who had been educated in this country. The Norwegian Synod had its college in Decorah, Iowa, and its theological seminary at Madison, Wis.

Hauges Synod had its college and seminary at Red Wing, Minn., and the Conference (now the Free Church) had its college and seminary at Minneapolis.

In 1880 a considerable number of Norwegians had been clected to both branches of the legislatures of various states and to state and county offices, particularly in Wisconsin, Minnesota, Iowa, and Dakota. Knute Nelson was a member of congress; Hans B. Warner had been elected secretary of state in Wisconsin and J. S. Irgens to the same office in Minnesota. It would take too much space to mention here all the Norwegians who down to the year 1880 had been elected to important public offices even if I were able to do so, and the good work begun has gone on without interruption, so that we now, in 1914, can point to three Norwegians, who are, or who have been, members of the U. S. senate, to three who have served as United States ministers abroad, a dozen or more members of congress and a large number of United States consuls. In Wisconsin J. O. Davidson, in Minnesota Knute Nelson, and in South Dakota C. N. Herreid and Andrew Lee have served as governors.

In 1880 the Norwegian press was well established. There were large and influential Norwegian papers in Chicago, in Decorah, in St. Paul, in Minneapolis and at Fargo. These papers wielded much influence in promoting the political interests of the Norwegians.

The importation of Norwegian books had become a prosperous business. Both "Skandinaven" and I. T. Relling were successful booksellers and each church organization had its 
own publishing house and book business. There being no intcrnational copyright law to interfere a considerable number of Norwegian books were reprinted in this country, particularly by "Skandinaven" and by the various churches. The production of Norwegian books by authors on this side of the Atlantic did not make much headway until later. Large numbers of the Norwegian-American youth were flocking to the schools, both to those built and maintained by the Norwegians and to the American universities, colleges, academies and normal schools. Hundreds of Norwegian young men and women were engaged as teachers in our public schools. In the higher schools, besides myself in the State University of Wisconsin, we find Peter Hendrickson had been for many years professor at Beloit College, Mr. Breda was a professor in the University of Minnesota and Hjalmar Hjorth Boyesen was a professor at Columbia College in New York.

Mr. Boyesen made his debut as an author with the story "Gunnar" only a few months later than I with my "America Not Discovered by Columbus", and when he died a little more than fifty years old, about the year 1900, his published works filled a whole shelf of books.

All the Norwegian settlements and the cities having a considcrable Norwegian population were well supplied with physicians and surgeons, partly from Norway and partly educated here. Conspicuous among them was Dr. Knut Hoegh, for several years located at La Crosse, but now living in Minneapolis, Dr. E. Hansen, of Koshkonong, who afterwards returned to Norway, and the doctors Paoli and N. Quales of Chicago.

So far as I have been able to learn, the first regular graduate of the medical department of the University of Norway, who came to America to practice medicine was a man by name Brandt from Drammen. I do not know his first name. I was told by Dr. J. C. Dundas that he first practiced a while in Chi- 
cago, then in the Norwegian settlements in Illinois, then bought a farm in Iowa, and finally settled as a regular practitioner in Indiana. I have not been able to learn what year he came to America, or what finally became of him. Dr. Brandt was followed by Theodor Schjötte and Gerhard C. Paoli. Both of these came to Koshkonong. Dr. Schjötte returned to Norway and became a government physician in Finmarken. Dr. Paoli moved to Chicago where he continued to practice medicine until he died at an advanced old age. Dr. Madsen was a medical student from Norway. He settled in Cambridge, Wis., and died there. Dr. J. C. Dundas came to America in 1850 and settled in Cambridge, Wis. He died in the beginning of the eighties. After him came Dr. E. Hansen, who settled near Utica on Koshkonong, but eventually returned to Norway where he became the government physician in Romsdal, where he died a very old man. While in America he wrote and published a book under the title: "Menneskelighed og Orthodoxi” (Humanity and Orthodoxy). It was provoked by the discussion of the slavery question.

In the legal profession there were hardly any who had studied jurisprudence in Norway. Among the more prominent ones who had acquired a reputation before 1880 I may mention Knute Nelson in Alexandria, Minn., Andreas Ueland in Minneapolis, Louis R. Larson, who was the first Norwegian to graduate from the University of Wisconsin, and John W. Arctander, also of Minneapolis; but it must be admitted that the Norwegian-Americans have not acquired any great prominence in the legal profession in this country.

The cultivation of the fine arts, music, painting and sculpture was reserved for a later date. I cannot think of anything original in these lines prior to 1880 . Of course I do not think of Ole Bull as a Norwegian-American.

In mercantile pursuits, in banking, and in manufacturing the Norwegians had made considerable progress. They had 
stores of every description scattered throughout the Northwest and a few were engaged in banking and manufacturing.

In Chicago Iver Lawson and others were large dealers in real estate. Chicago also had some prominent vessel owners and sea captains. Paul O. Stensland had built up a large dry goods business and the Johnsons operated a large furniture factory.

The Norwegians have persistently kept their hands off the brewing industry, leaving this to the Germans. If you had visited Milwaukee at this time you would have found Mr. Saveland and other well to do vessel owners, the brothers Joice as large ship chandlers and John Thorson, the wealthy lumberman. In Manitowoc, Wis., we find the leading merchant of that city to be Ossul Torrison. His oldest son Thomas is at present the head of the large Torrison estate; one son, Isaac, married to a daughter of Rev. V. Koren, is the Synod minister in Decorah; one son, Oscar, is a municipal judge in Chicago; another son, George, is a leading physician in the same city, and Mrs. Adolf Bredesen, who recently died, was a daughter of Ossul Torrison. His widow is still living.

In Green Bay we find a large pea canning industry founded by two Norwegians.

Proceeding westward we find Gilbert Anderson, the leading clothing merchant in Whitewater, Wis.

In Beloit John Thompson is the owner of one of the largest plow factories in the West.

In Stoughton, Wis., T. G. Mandt had come to the front as a manufacturer and inventor of wagons and sleighs. The oscillating sleigh knee was invented by him. In Stoughton we also find Mathew Johnson and Chr. Melaas the leading merchants in that city.

In Madison, Wis., the two most prominent Norwegian business men were Halle Steensland and John A. Johnson. Steensland early became one of the leading grocers, and in 
1880 he ranked as one of the most prominent business men in the city. John A. Johnson had acquired a fortune as a dealer in agricultural implements and was engaged in organizing the Fuller \& Johnson Mianufacturing Company. In the early '70s Mr. Johnson and Mr. Steensland, together with others, on my suggestion, organized the Hekla Fire Insurance Company, which for many years did a prosperous business and was the forerunner of the present Savings Loan and Trust Company of Madison, Wis. B. W. Suckow had for years owned and operated a large book-bindery, one of the very few in that line of business among the Norwegians in America. Torgrim Olson from Valdres, who is now the head of the Olson \& Veerhusen Co., had forged to the front as a clothing merchant. Another leading clothier was Gilbert Winden.

In La Crosse we find Mons Anderson, the largest drygoods merchant, and Charles Solberg, the largest grocer west of the lakes.

In St. Paul and Minneapolis a number of Norwegian business men and some bankers were gradually coming to the front, and there were prosperous merchants in Rochester, Fergus Falls and Albert Lea in Minnesota, and in Fargo and Grand Forks, N. D.

Of country storekeepers who acquired prominence by their remarkable success, O. B. Dahle of Perry, Wis., was a fine example. His son Herman B. has served two terms in congress.

We have hit only some of the most conspicuous heads in this attempt to show the progress which the Norwegians in this country had made at the close of the ' 70 s and have no doubt that the reader will easily be able to fill in the rest of the picture. 


\section{CHAPTER LVII.}

\section{MYSELF AGAIN.}

Having now for some time, and doubtless to the great satisfaction of the reader, kept myself in abeyance, I shall again return to the chief subject of this story and try to carry my own life forward down to about the year 1880 .

I may say in general that the '70s were perhaps the most strenuous years of my life. I was working hard in the university, and am not overstating it when I add that we who then were employed as teachers had to do more for the small compensation then received than the far better paid professors have to do now.

I have told how I published my first English pamphlet and a translation into Norwegian of a little pamphlet by President Chadbourne. Later I published Norwegian translations of two of John Bascom's baccalaureate addresses. In 1872 I published "Julegave", a collection of Norwegian folk-lore stories, a book which I also used in my classes of beginners in Norwegian. 


\section{CHAPTER LVIII.}

\section{LANDSMAAL IN NORWAY.}

Before publishing "Norse Mythology" I wrote a small book called "Den Norske Maalsag", and of this the "Skandinaven" was my publisher.

As is known, Norway was for about 400 years prior to 1814 subject to the king of Denmark. Norway had no university; Norwegian young men seeking an education had to go to Copenhagen and Norway was flooded with Danish office holders of all kinds, including the pastors of the congregations. The result was that Danish was the only language that appeared in print, that was taught in the elementary schools, that was heard from the pulpit and in all public proceedings. During all these 400 years Norway had no parliament and conseguiently no way of asserting herself as a distinct nation.

In 1814 Norway got rid of the Danish yoke. She had already a few years before started her own university and now in her union with Sweden she obtained her own parliament. But she was still under the yoke of a foreign tongue. The Norwegian language was still spoken throughout the land, particularly by the peasantry, but it did not appear in print or in writing. Men of large views saw the impropriety of this. Henrik Wergeland wrote a most interesting essay, showing how absurd it was that the Norwegians should be compelled to use Danish instead of their own tongue. There were two 
ways by which the people might now get rid of the Danish language. One way was to gradually graft Norwegian words into the Danish parent stock and continue in this manner until the whole was Norwegian and nothing left of the Danish. This sems to have been the view of Wergeland, Knudsen and others. The other way was to take several of the least corrupted dialects in the mountain districts and make them the basis of a new Norwegian national language.

The great poet A. O. Vinje produced a vast amount of splendid prose and poetry, using mainly his mother's tongue as he learned it in the remote valleys of Telemarken. But his contemporary, Ivar Aasen, was not only a poet, but developed into one of the most learned philologists of his time. He gathered together all the dialects of Norway and on the basis of these he constructed or created a new language for Norway.

While the official language is called the "Rigsmaal", the language created by Aasen is called the "Landsmaal". Aasen wrote an exhaustive dictionary and also a grammar of this "Landsmaal" and these were published on account of their profound scholarship and linguistic value with the aid of appropriations by parliament, and the author received from parliament a stipend for life. This "Landsmaal" soon got prominent advocates; gifted authors such as Kristofer Janson, Henrik Krohn, Christopher Brun and others adopted it as the vehicle of their writings and it has steadily grown in popularity to this day. In fact the Storting has by a recent law placed the "Landsmaal" on an equal footing with the "Rigsmaal".

In 1872 and again in $1873 \mathrm{I}$ had the honor and pleasure of being presented to the great peasant scholar, Ivar Aasen. I visited him several times in his bachelor quarters and saw him in his slippers and long study gown smoking his meerschaum with a stem reaching to the floor. He was one of the most venerable men that I have ever met. I had become fond of the 
"Landsmaal" before I ever met Aasen, but after talking with him I became its advocate. And so it happened that in 1874 I wrote my ambitious book in defense of the "Landsmaal", that is, "Den Norske Maalsag". As an appendix I reprinted one of Kristofer Janson's stories, "Per og Bergit". The book sold slowly, but the edition has long since been exhausted. It received an enthusiastic review from the pen of Arne Garborg, published in the "Landsmaal" periodical called "Fedraheimen", and Kristofer Janson wrote in high praise of it. I am the only one who has published a book on this subject in America. 


\section{CHAPTER LIX.}

\section{MORE ABOUT THE SEVENTIES.}

In this story of my life I have already touched the year 1880 and am anxious to get through what still properly belongs to the 70 s. I am not sure that I shall give the following episodes in their chronological order, but there remain a few things that I do not think I ought to leave unnoticed.

I devoted all my spare time to literary work, and in 1881 I had published "Viking Tales of the North", containing G. Stephens' translation of Tegner's "Fridtjof's Saga", made under the poet's auspices, together with two Icelandic sagas, that is, Thorstein Vikingson's Saga and the saga of Fridtjof the Bold, and also the life of Tegner and an introduction to the saga literature of Iceland. This work I dedicated to Iceland's great American friend, Prof. Willard Fiske.

The two greatest poetic productions in the Swedish tongue are without question Tegner's "Fridtjof's Saga" and Runeberg's "The Ensign's Stories" (Fänrik Stal's Sägner). "Fridtjof's Saga" had been translated into many modern languages and into English at least twenty-two times.

Then I made a more complete translation of the "Younger Edda" than had ever appeared before in any language. Together with Auber Forestier, I now made a somewhat extensive selection of Norwegian folk melodies, national airs and modern compositions of Norway and these were published in a large quarto volume by Oliver Ditson \& Co., Boston. The words 
were all given in the original and in translations, either by myself or by Auber Forestier. This work has done much to make the American people acquainted with Norwegian music and is still having a considerable sale. This work was dedicated to the memory of Ole Bull.

There was great need of a history of Scandinavian literature. No such work had yet appeared, either in England or in America. The great Danish scholar, Frederik Winkel Horn, with whom I was in close touch, wrote a condensed history of Scandinavian literature in German and had it published in Leipsic. I secured his consent to translate this book into English on the condition that I be permitted to make such additions as I might find desirable. I more than doubled the size of the original work; parts of the additions being supplied in manuscript by Mr. Horn and the rest by myself.

This work contains: Part I, the old Norse and Icelandic literature; part II, Denmark and Norway; part III, Sweden, including the Finlanders, who wrote in Swedish. This work was published in 1883 and I got my friend Thorvald Solberg in Washington, D. C., to prepare for it a bibliography of all works in English relating to Denmark, Norway, Sweden and Iceland.

Solberg was born of Norwegian parents in Wisconsin. He was for many years connected with the Library of Congress at Washington and is at present the register of copyrights. Mr. Solberg has done much valuable work in the line of bibliography. One of his great achievements in this line is his "Bibliography of Literary Property", which paved the way for our present international copyright laws. I have frequently met Mr. Solberg in Washington and through him I made the acquaintance of Frances Hodgson Burnett, author of “'That Lass o' Lowrie's", and also of the famous negro orator and diplomat, Frederick Douglass. With Solberg I had the honor of taking dinner both with Mrs. Burnett and with Fred 
Douglass; with the latter at his home in Anacostia, where Solberg then lived. In the ' $80 \mathrm{~s}$ Mr. Solberg visited me in Copenhagen. 


\section{CHAPTER LX.}

\section{ST. JOHN'S DAY.}

One summer during the '70s a St. John's festival was celebrated by the Norwegians in a beautiful grove on a high hill a few miles east of Lodi, in Columbia county, Wisconsin. I was invited to deliver the address of the occasion. A Madison brass band was engaged. The weather was exceedingly fine and a large number of people came to the festival, not only Norwegians, but also of other nationalities. An elaborate stage had been built. This was decorated with flags and bunting.

At this time there lived with an unmarried daughter in Lodi a widower by name Frederick Brown. He was a brother of the celebrated John Brown of Ossawattomie and Harper's Ferry fame. He was a large, smooth-faced, white-haired man, with a somewhat florid complexion and a very sweet, intelligent and benevolent countenance. He had come to attend this St. John's festival and there I was introduced to him. John the Baptist and John Brown were instantly connected in my mind and I requested the president of the day, Hans Grinde, to invite Mr. Frederick Brown to take a seat on the stage, which he did. Mr. Brown soon occupied a seat by my side.

St. John's day was in ancient times in Norway a midsummer festival corresponding to the Yule festival in midwinter. After the introduction of Christianity the Yule festival was 
turned into Christmas in honor of the birth of Christ and the midsummer festival was assigned to St. John the Baptist. St. John's day is still celebrated every 24th of June throughout Scandinavia, and Shakespeare's "Midsummer Night's Dream" shows that the day was formerly popular in England.

Having Frederick Brown by my side on the platform I dccided to make this a day not only in honor of John the Baptist, but also of our great John in American history. As soon as I had been introduced as the speaker I called attention to the fact that there was sitting on the stage a brother of the martyr patriot John Brown. I pointed out that John the Baptist was the forerunner of our Saviour; that he was the voice of Christ crying in the wilderness, preparing the way for the greater One who was soon to appear. I showed how John the Baptist gave his life for the cause which he had espoused and how Christ died on the cross for the salvation of man.

Paralleling this, I showed how John Brown was the forcrunner of Abraham Lincoln, how he might truly be characterized as Lincoln's voice crying in the Kansas wilderness and how he too lost his life in the cause which he advocated. Then came Lincoln, who carried forward to completion the work of striking the shackles of millions of bondsmen by his emancipation proclamation, giving freedom to the slaves in our southern states. He too had to sacrifice his life on the altar of his country.

I hope none of my pious readers will look upon the parallels here drawn as in any way blasphemous.

With similar remarks I asked Frederick Brown to stand up and I introduced him to the audience as the only living brother of John Brown. He was greeted with prolonged applause. The whole audience stood up and cheered him. He took his seat again. Then I addressed myself to the band and requested it to play "John Brown's Body Lies Moldering in the Grave; But His Soul Goes Marching On". While the band 
played this piece the whole audience remained standing and the stalwart Frederick Brown stood by my side, the tears streaming down those venerable cheeks. Then I asked him to talk to the audience. He said he was no orator, but with much feeling he gave a heart-to-heart talk, telling what he remembered about his brother while they still were together under the parental roof. The whole festival was an event never to be forgotten by those who were present.

After that I met Frederick Brown several times. He used to call at our house in Madison. It was agreed between us that I was to write for him a history of his family and particularly of his brother, John Brown. We were to be joint owners of the book. But we never got started. It all ended in talk. He always had some excuse, either ill health, or something else, and he soon left Lodi and I lost track of him. Mr. A. O. Barton tells me that he moved to Kilbourn City and died there, as he has bcen told. 


\section{CHAPTER LXI.}

\section{MORE ODDS AND ENDS.}

The publication of my books, especially of "Norse Mythology," brought me many invitations to give public lectures and parlor readings. I read lectures before a large number of literary clubs, in Chicago, Milwaukee and in other cities. One winter I was one of the speakers in a course of lectures given at Quincy, Ill. But the greatest distinction that I achieved in this line was in February, 1877, when I delivered by invitation a course of four lectures at the Peabody Institute in Baltimore. This invitation was distinctly a tribute to the author of "Norse Mythology." I gave one lecture on "The Norse Discovery of America," one on "The Odinic Religion," one on "The Viking Age" and one on "Our Teutonic Epic." The last one I myself consider to be the best lecture that I have ever written in English. My only effort in this line that I might regard as superior to "Our Teutonic Epic" is my lecture in Norwegian entitled "Vor Fædrenearv" (Our Norse Inheritance). Neither of these lectures has ever been published.

Perhaps I ought to explain that the subject treated in "Our Teutonic Epic" is the story of Sigurd and Brynhild, both in its original Norse form as found in the Edda poems and in the Volsunga saga, and in its later German version, particularly in the middle high German "Niebelungen" lied. In this lecture I try to show that our story of Sigurd and Brynhild is the greatest, the profoundest, the most sublime, the most comprehensive of the 
world's five popular epics. The other four popular epics are (1) The Iliad, and Odyssey (Greek); (2) The Mahabharata and Ramayana (Hindooic); (3) The Sha-na-meh (Persian); (4) The Kalevala (Finnish).

I hold that our Teutonic Epic contains the virtues and merits of the best epics of art and popular epics combined.

During the two weeks that it took to deliver this course of lectures I made visits to Philadelphia and to Washington. It was on one of these visits that I called on Walt Whitman in Camden, N. J., and made the acquaintance of Thorvald Solberg, Mrs. Burnett and various other people of note in those cities.

During the $70 \mathrm{~s}$, besides teaching and writing books and lecturing, I wrote extensively both for the Norwegian and American press. My contributions to "Skandinaven" alone would fill several volumes if published separately. I became a regular contributor to the columns of "The Nation," published and edited by E. L. Godkin and W. P. Garrison. Mr. Garrison was a son of the distinguished abolitionist, William Lloyd Garrison. "The Nation," which was afterwards consolidated with the New York Evening Post, founded by William Cullen Bryant, has long been regarded as the high water mark of journalism. It is still published as a weekly edition of the New York Evening Post. It was said of E. L. Codkin that he never had his equal in skilful use of quotation marks. Woe be to his opponent who became a victim of E. L. Godkin's quotation marks. It meant confusion and defeat.

It is a strange fact that while "The Nation" soon reached a circulation of 10,000 it has never been able to get far above this mark. It is still taken only by America's upper ten. In my opinion "The Nation" should be read with considerable caution. A constant reader of this publication is very apt to lose the habit of thinking for himself and letting "The $\mathrm{Na}$ tion" do the thinking for him. One finds constant readers of 
"The Nation" accepting all its statements without question and "The Nation" supplies them with their whole stock of knowledge of current events. All they care to know is what "The Nation" says on the subject. As tame fowls have lost the art of flying from not using their wings, many of the readers of "The Nation" have lost the art of independent thinking. My department was to review books published in Scandinavia and books published in other countries on Scandinavian subjects. In this way I got an additional channel for creating an interest in Scandinavia.

I also secured positions on various encyclopedias, writing for them articles on Scandinavian topics, especially biographies. In this way I found an opportunity of presenting the leading authors, poets, composers and artists of the past and present in Scandinavia to the encyclopedia readers. I succeeded in securing the recognition of many Scandinavians whose names had never before been seen in the pages of an American encyclopedia.

My work in this field in the '70s and since that time includes Johnson's, Kiddle \& Schem's, McClintock \& Strong's, the American Supplement to the Britannica, Chambers' and several others.

While I am on this subject I might as well add now that I served in later years as a contributor to the Century Dictionary, edited by W. D. Whitney, and that I am one of the editorial staff on the Standard Dictionary, published by Funk \& Wagnalls. In the Standard Dictionary I had charge of the words connected with Scandinavian mythology, antiquities and history, and in this work place was found for more than 150 names and words that had never before appeared in any dictionary of the English language.

In the first place all the old Scandinavian divinities were introduced and defined, and in the next place words of direct Scandinavian origin, such as "ski," "fjord," "fjeld," "foss," 
ctc., were inserted. I also secured recognition of the pronunciation "viking" (veeking), instead of "viking" (vieking). In my encyclopedia article on "viking" I was the first one to suggest or point out that the word is not derived from "vik," a bay, but from "veida," to slay, so that the etymology of the word "viking" is not "bay-ing" but "slayer," that is, warrior. This suggestion of mine was endorsed by Norway's greatest linguist, Sophus Bugge. While I do not claim to have fully established the derivation from "veida," I have certainly shown the absurdity of the old supposed derivation from the word "vik," a bay. Before the word "viking" was known outside of Scandinavia the old Norsemen themselves regularly made use of the phrase, "at fara i viking," which meant "to go abroad," to gather fee and fame-i. e. wealth and culture. 


\section{CHAPTER LXII.}

\section{HOW BUTTERFIELD SAW ME IN 1879.}

Before leaving the 70 s for good I insert here a slightly abbreviated sketch of me from "History and Biographical Annals of the University of Wisconsin," written by C. W. Butterfield and published by the University Press Co. in 1879. It supplies in a nutshell a review of my literary work down to that year, and it is so much easier to let some one else sing your praises.

Mr. Butterfield's sister was the wife of Pere Hyacinthe, the famous Dominican and Carmelite monk, who from 18,64-1868 preached to immense audiences in Notre Dame in Paris. $\mathrm{He}$ took issue with the dogma of infallibility and left the Catholic church, styling himself old Catholic and tried to organize an independent Catholic church. Pere Hyacinthe and his wife visited C. W. Butterfield and wife, our neighbors, in Madison.

This is the sketch:

In June, 1875, Rasmus B. Anderson, A. M., was elected professor of Scandinavian languages in the University of Wisconsin. He was born the twelfth of January, 1846, in Albion, Dane county, Wisconsin, of Norwegian parents,--his father having been, in 1836, the leader of the first large company of emigrants that came from Norway to the United States, arriving in Wisconsin in September, 1841. The son received such common school instruction as the pioneer settlement afforded. At the age of fourteen, he left home, leading a some- 
what unsettled life for the next two years. He then entered an Iowa college, where he studied over three years, at the expiration of which time he returned to Wisconsin and, in June, 1866, was elected professor of Greek and modern languages, in Allion academy, in his native county. This position he held for nearly three years, drawing into the institution a large numLer of Scandinavian pupils.

Professor Anderson then entered as student the post-graduate course in the University of Wisconsin, where he remained during the spring term of 1859 . In the summer thereafter, he was appointed instructor in languages in that institution, contiming in the position until the summer of 1875 , when, as before stated, he was called to the chair of Scandinavian languages, - the first native-born citizen of Wisconsin to be honorea with a full professorship in that institution. This office he continues to fill with credit and ability. He was appointed librarian of the University in 1877, which position he still holds. He has established, in the institution, a Scandinavian Mimer's library, the best one of the kind in the United States. It contains over one thousand volumes. In the founding of this library, he received much assistance from Cle Bull, the worldrenowned violinist, who, on the seventeenth of May, 1872, gave a concert in Madison, Wisconsin, in aid of the enterprise.

Professor Anderson is, for his age, one of the most prolific writers of the country. As a contributor to the periodical press and as an author of books for general reading, no other citizen of Wisconsin has gained so extended a reputation. He early began to feel an especial interest in Norse literature,-collecting works upon subjects connected therewith, the result being the accumulation, at this time, of a large and unique private Scandinavian library. His first contributions to the press were made in 1865, at the age of nineteen, Since then he has contributed exiensively to newspapers and magazines published in the Norwegian language, in the United States and Norway. 
These articles are, to some extent, upon history and belles-lettres, but the larger portion are polemic. Among these contributions are to be found "Runer;" "Folkefrihedens Vugge stod i Norge;" "C. C. Rafn,-Biografisk Skisse;" "Oplysningens Nytte i timelig Henseende;" and numerous others of recognized ability. The burden of his controversial articles has been an ardent defense of American institutions, particularly of the common school. The gist of his sentiments with reference to this cherished institution of our country is to be found in this terse, and rather startling motto adopted by him: "Whosoever, directly or indirectly, opposes the American common school is an enemy of education, liberty, and progress. Opposition to the common school is treason to our country."

In the English language Professor Anderson has supplied papers to be found in the Atlantic Monthly, The Nation, The Christian at Work, Inland Monthly, Frank Leslie's Sunday Magazine, Robinson's Epitome of Literature, The Library Table, and others; to the English press, articles to be found in various periodicals, especially in The London Academy. His contributions to the daily papers, east and west, in the United States, have been numerous. His connection with "Osszehasonlito Irodalomtortenelmi Lapok" (Journal of Comparative Literature) has been interesting and quite extensive. This polygot journal is published by the professors of the Royal University of Hungary. In it, he has published a number of articles both in poetry and in prose. It is a periodical circulating among scholars in every quarter of the globe.

Professor Anderson began his successful and enviable career as an author of books, by giving to the world, in 1872, "Julegave,"-a work in Norwegian. It is a collection of Norse folk-lore stories and has reached its third edition. Of the work, The Nation of Feb. 20, 1879, says: "The 'Julegave' (Christmas-gift), of fairy tales and stories to children of the Norwegian settlers on our continent, consists of selections chiefly from the 
charming collections of Asbjörnsen and Moe, and owes its existence to a desire to provide the little ones with entertaining reading in the language of their fathers. Among the tales, we recoguize such common property of the Aryan race as 'Little Red Ridinghood,' 'Faithful John,' and 'The Master Thief;' while others bear a more distinctively Norwegian stamp. We can heartily recommend them to both young and old."

In 1874, Professör Anderson published another Norwegian Loak, - his second effort for public favor. The work was entitled "Den Norske Mlaalsag;" it being an account of the movement to restore a national language in Norway. Says The Nation: "The written language of Norway, as is well known, differs widely from the spoken dialect, and 'Den Norske Maalsag gives an interesting account of the efforts that, since the separation from Denmark in 1814, have been made by an evergrowing number to supplant the Danish of the press and literature of the 'Alntiemaal.' To the book is appended a story in Norwegian by Krostofer Janson, one of the foremost champions of the movement." The London Academy, while opposing the project thus illustrated and supported by Professor Anderson, admitted that his book said everything that could be said in favor of the movement. The journal added: "Mr. Anderson supplements his clever little book with a specimen of the new language."

Professor Anderson now entered upon a larger field of literature, which he has since cultivated with even more success than the other. His first book in the English language was "America Not Discovered by Columbus;" third edition, in 1877. This work has been received with marked attention at home and abroad. It has been reviewed in many languages; and, with one notable exception, these notices have all been commendatory. This history is an attempt to place (what the author believes to be) the facts of the Norse discovery of America in the tenth century, within the reach of all; and to show, 
by a chain of circumstantial evidence that Columbus, before sailing upon his famous voyage in 1492, was in possession of knowledge of the Norse discovery. Of the work, the London Notes and Queries says: "It is a valuable addition to American history. * * * The book is full of surprising statements, and will be read with something like wonderment." The book has been twice translated into the Norwegian language,- - once, into modern Norwegian, and again into the tongue advocated by the author's "Maalsag."

The idea of erecting a monument to Leif Erikson, claimed to be the discoverer of America, was first suggested by Professor Anderson, who has interested himself greatly in the undertaking, securing the cooperation of Ole Bull and John A. Johnson. From the attention called to the supposed discovery by the publication of "America Not Discovered by Columbus," also from Ole Bull's efforts and influence, and from the contributions of others, a sum sufficient has been raised.

In 1875, Professor Anderson published his "Norse Mythology." This is his largest work and the one upon which rests, to a great extent, his excellent literary reputation. It is an exhaustive and systematic presentation of the Odinic religion of the old Teutons, based on the Icelandic Eddas and Sagas. Few books have been more extensively or more generously noticed by the press of America. In Europe, its reception has been equally cordial:-English, French, German, and Scandinavian journals gave it, and are still giving it, elaborate and most favorable notices. Says the Christian Era: "It is full of matter at once entertaining and instructive. What Hans Christian Andersen was to the children, Professor Anderson is to the 'children of larger growth.' He is a guide into the most famous fable-land of the globe, and a translator of the most marvelous traditions among men." This, from the Hartford Post: "Professor Anderson's 'Norse Mythology' is without a peer in the English language. There is none so thorough 
and complete, so appreciative and enthusiastic, so really fresh and vivid as a tale by Dickens, and enchants one by the beauty and simplicity of its strange conceptions. At the same time, it exhibits all the earnestness and purity of ancient northern thought and purpose." The New York Tribune has words equally commendatory: "Professor Anderson has produced a monograph which may be regarded as exhaustive in all its relations. His work gives evidence of wide research." Says Scribner's Monthly: "Professor Anderson's work is incomparably superior to the already existing books of this order." Prof. Max Müller writes thus to the author, of his work: "I like it decidedly; and, whenever I approach the dark runes of the Edda, I shall gladly avail myself of your help and guidance." "We say in all sincerity," is the language of the Boston Globe, "that no American book of recent years does equal credit to American scholarship, or is deserving of more pronounced success." And thus the Boston Daily Advertiser: "The volume is rich in poems from the Eddas; and the myths are as wonderful, as fantastic, as exciting, as any of the Greek fables, and have the additional elements of ice and frost to enhance their wildness and mystery." The book, some time ago, reached a third edition, and a fourth will soon be issued.*

Professor Anderson's "Viking Tales of the North" was issued from the press in 1877. It is a literary study of Tegner's celebrated Fridthjof's Saga, giving, in an English translation, the Saga material, out of which Tegner fashioned his poem; giving, furthermore, an introduction on Saga literature; also, a biography of Tegner; and, by way of an appendix, Professor Stephen's English translation of the poem:- the whole carefully annotated by Professor Anderson. Says the Boston Commonwealth: "This work will vie in interest to

\footnotetext{
* Some of these notices appeared in a previous chapter in connection with my own account of "Norse Mythology".-R. B. A.
} 
scholars with the Vedas of the East." And thus, The Nation: "Professor Anderson's book is a very valuable and important one. The 'Saga of Thorstein, Viking's Son,' * * * teems with magnificently dramatic situations, the impressiveness of which is rather increased by the calm directness and dignity with which they are related. And these features are as characteristic of the English version as of the Icelandic originals. The translator shows an intimate acquaintance with all the intricacies of that cruelly inflected language, and an enthusiastic appreciation of its epigrammatic pith and vigor. * * * Tegner's celebrated poem 'Fridthjof's Saga' is sufficiently novel in its theme and abounding in melody and rhythm to yield a large measure of enjoyment." Thus, the Boston Traveller: "It is impossible to describe these writings; but the reader will find himself immeasurably repaid by their perusal." Says The Churchman: "This work, as a whole, will please and instruct all classes of readers, and especially those who wish to searcin out the antiquities of Scandinavian literature. But every one will be struck with the majesty and force of that old poetry of the north."

Professor Anderson is now at work, with Ole Bull, upon a book to be entitled "Violins and Violin Makers." He has in hand, also, a transiation, from Icelandic, of the Elder Edda and the Younger Edda, in all three volumes; "A Guide into Teutondomm," one volume; and "Folk-lore Stories, from the Norse," one volume. He has, likewise, other literary enterprises under way, prominent among which are an English version of the Finnish national epic "Kalevala," and an extensive and thorough study of the Magyar poet, Petöf, whom he hopes soon to introduce to the English-speaking public.*

The chief of Professor Anderson's prose translations is "Charcoal Burners," from the Swedish. This has already

*Some of these literary plans were either modified or died in embryo.-R. B. A. 
been noticed as a work annotated and published, in the English language, by Professor Nicodemus. From the Norwegian, Professor Anderson has translated for the Smithsonian institute among other articles, an account of the Norwegian North Sea exploration, by Prof. Georg O. Sars. He has translated a large number of poems from Norwegian, Swedish, and Icelandic; some have been printed in musical publications; one, in Longfellow's "Poems of Places"; several, in the Hungarian Journal of Comparative Literature; others, in various periodicals at home and abroad. His translation used by Longfellow is from the Norwegian poet, Andreas Munch, and is entitled

\section{A Bridal Party on the Hardanger Fjord.}

There quivers a glittering summer air

Warm o'er Hardanger Fjord's fountains,

Where high 'gainst the heavens, so blue and bare,

Are towering the mighty mountains.

The glacier shines bright, the hillside is green,

The people are clad in their Sunday clothes clean;

For look! o'er the blue billows rowing,

The wedding-folks home are going.

A beautiful princess from times of old, With crown and with scarlet and crimson, Sits high on the boat-stern so fair to behold, Than fjord and the daylight more winsome.

The hat of the bridegroom, how happy it flies!

For home he is bringing his loveliest prize;

He sees in her eyes reflected

The hopes of his life perfected. 
Hardanger's weird instruments now pour forth

Strange tunes o'er the billows resounding,

The mountains give back ev'ry gun's report,

And echoes of joy are rebounding.

The maids of the bride of sport get their lot;

The man of the feast, he has not forgot

To serve unending potations,

And honor the bride's relations.

And thus they row onward with music gay, Their way o'er the bright waters wending;

And boat after boat makes up the array,

The guests all in gladness contending.

The clefts all look blue, the mountain-tops shine,

Sweet fragrance comes down from the apple and pine;

The bells in the church-tower ringing,

Rich blessings from God are bringing.

And just at this moment, so soon to depart,-

The drops on the oars are still gleaming,

The artist has caught, with his loving heart,

The picture, with beauty beaming.

He shows to the world the work of his hand,

That all may observe our glorious land,

And learn the wonderful stories,

That add to our Norse fjord's glories.

Hardanger's weird instruments now pour forth strange tunes; there is feasting and revelry; the bells of the church-tower ring; at that favorable moment, an artist catches

"The picture with beauty beaming,"

which is afterward shown to the world, that all may see the glories of Hardanger Fjord and learn the wonderful stories of the northland. 
Professor Anderson has published a number of pamphlets in English and Norwegian, upon various subjects. One of these, entitled, "The Scandinavian Languages; Their Historical, Linguistic, Literary, and Scientific Value," is worthy of special mention. Besides his numerous other literary labors, he has charge, as assistant editor, of the department of pre-Columbian history, in The American Antiquarian. He has under his supervision, also, the Scandinavian department of McClintock \& Strong's Cyclopedia of Biblical Literature, and the Kiddle \& Schem's Cyclopedia of Education, and has contributed articles to Johnson's Cyclopedia. His books have been extensively quoted by writers on American history, on northern literature, and on mythology. He reads, besides the English, Norwegian, Swedish, and Icelandic, the Anglo-Saxon, Modern, Middle, and Old High German; also, French, Latin, and Greek. As a lecturer, he has gained considerable reputation. $\mathrm{He}$ spoke in the house of the poet Longfellow, in 1875, to a select audience of literary celebrities, on the subject of Norse mythology. In 1877, he delivered a course of four lectures upon Norse history and literature at the Peabody Institute in Baltimore. These lectures were attended by large numbers and attracted general attention. Because of his translations, works, and lectures, Professor Anderson has been frequently (and with justice) called the father of Norse literature in America. He has twice visited Europe, once in 1872 and again in 1873 , --both times in company with Ole Bull. These trips were made chiefly for the purpose of extending his acquaintance with men and things in northern Europe. In 1875, he was made an honorary member of the Icelandic Literary Society. $\mathrm{He}$ was appointed delegate to the international congress of Americanists that assembled at Luxemburg in September, 1877, but professional duties prevented his attendance. He was also appointed at that congress a member to the session to be held at Brussels in September, 1879. 
Several short biographies of the Professor have been published: one, in the Chicago Times; one, in the Cincinnati Enquirer; another, in the Nordiske Blade; a fourth, in Heimdal, Chicago; a fifth, in Dagbladet, Christiania, Norway; a sixth, in Robinson's Epitome of Literature, Philadelphia; a seventh, by the Petöfi society, in Hungary; an eighth, in the "History of Madison, Wisconsin;" and a ninth, in Illustreret Familieblad, Chicago, in January, 1879. He has been the recipient of many flattering testimonials from literary and scientific men at home and abroad. The following poetical tribute, in the Norwegian language, is from Munch, the poet-laureate of Norway. A free translation into English is subjoined:

Norway in America.

(To Professor Rasmus B. Anderson.)

To western fields from thy lap are going, My fatherland, how many lads and lasses! Thy stony soil but poorly pays their sowing And dreary toil, among those mountain masses.

They hope in western lands to gather A golden crop, a life that's free from worry. It may be Heaven hears their prayers rather There; but their hearts still long to be in Norway.

To you be therefore praise, since you are bringing A word to them in tones so homelike sounding, As though 'mong Norway's mountains they were ringing. Ancestral wisdom to our sons expounding,

Our language's praise with poet's voice you're singing, In far-off zones, across the billow bounding.

The number of Scandinavian students in the University of Wisconsin has been large and constantly increasing since Prof. Anderson became connected with it. There are more of that 
nationality in attendance at this institution than in all other American colleges combined, except in such as are strictly Scandinavian. The bequest by John A. Johnson, and the Mimer's library, already referred to, have been largely instrumental in swelling the numbers. As a teacher of Scandinavian languages, Prof. Anderson is painstaking, thorough, and very enthusiastic. He is popular with the students under his instruction and has a happy faculty of filling their minds with the zeal so characteristic of himself as an educator and writer.

\section{A Page from "History of Madison."}

I also reproduce here a page from "History of Madison," written by C. E. Jones and published by W. J. Park \& Co. in 1876. I print this extract on account of the lucid statement it contains in regard to the "Johnson student's aid fund":

"The Scandinavian library known as 'Mimer's library,' was a contribution from private individuals in 1868, through the agency of Prof. R. B. Anderson. The collection now aggregates about one thousand volumes of Scandinavian literature, and its value can hardly be stated. The world-famous Ole Bull was induced by Mr. Anderson to increase the library fund by giving a concert in the assembly chamber, and the sum thus obtained was very advantageously expended in Norway by the professor, who made a voyage thither in 1872 for the purpose, and procured at the same time valuable contributions from some of the ablest professors and most distinguished Norwegian scholars. The books obtained by the several means indicated render the Scandinavian library one of the best in the United States. The 'Johnson student's aid fund' was in part due to the same agency. The sum given by the Hon. John A. Johnson, some time senator for this district, is $\$ 5,000$, the interest of which is to be applied from the time of the donation, 1876, until the end of the present century, to assist indigent Scandinavian students, with sums not to exceed $\$ 50$ per annum in any indi- 
vidual case, nor to aggregate more than $\$ 200$ in the aid offered to one person; with this further proviso, that in every case the student assisted shall understand that the advance is a loan, and not a gift, and that whenever it may be in his power, he shall be expected to repay the sum to the fund, to increase its efficiency for future operations. On and after the end of this century the fund will be available for all students, irrespective of nationality, on precisely similar terms. Clearly, the object of the donor is to break down whatever barriers may at present exist, to the complete unification of the Norse element in our population with the great body of the people, made up of all nations of the world. It would be difficult to imagine a form in which enlightened munificence can more elegantly express itself, than by such contributions to the improvement of the state university, and it is gratifying to observe that other persons are preparing to follow in the path thus nobly indicated. Most of the universities and scholastic institutions in Europe have been enriched by just such acts of individual munificence, generally by way of bequests, taking effect upon the death of the donor." 


\section{CHAPTER LXIII.}

\section{THE ICELANDERS.}

In 1856, Lord Dufferin, who afterwards became governorgeneral of Canada and viceroy to India and who occupied nearly all of the most important British ambassadorships, including St. Petersburg, Constantinople, Rome and Paris, while yet a young man, made a voyage in his yacht to Iceland and Jan Mayen. In Iceland he was most royally entertained. On his return he followed the coast of Norway, stopping at various points. This journey led him to make a fairly thorough study of Iceland and its interesting history, and of this visit he wrote one of the most charming books of travel ever produced.

In this work he takes occasion to tell of the discovery and settlement of Iceland and of the causes that led to that tremendous emigration from Norway. He also touches briefly on the discovery and settlement of Greenland, and then gives an outline of the voyages to Vinland. The title of his book is, "Letters from High Latitudes." It overflows with good will to Iceland and to the Icelanders.

This book has been printed in many editions on both sides of the Atlantic. While Lord Dufferin was governor-general of Canada an American publisher asked him for permission to reprint this very popular book. He graciously granted this permission, but said that he would like to give the book a revision. This was in the '70s. He wrote to me and said that he had read my "America Not Discovered by Columbus" and "Norse 
Mythology" and asked whether I would be willing to revise for him his "Letters from High Latitudes." A new edition was about to be published and he was too busy a man to undertake the revision himself. He knew that his book contained misspelled names, some wrong dates and other minor errors. I answered him that I would be delighted to render him this service. I said I would correct and eliminate such faults as it was possible for me to find, adding that I did not regard myself as any authority. He sent me a copy of his book. I gave it as thorough a revision as I was able and returned it to him. For the pains I had taken he sent me his hearty thanks and a draft for $\$ 300$. This was my first big money for literary work and it made me feel rich.

From that time on my relations with Lord Dufferin were most cordial. He repeatedly invited me to visit him and be his guest at the government mansion in Ottawa. But as I have more than once stated my life was at that time exceedingly strenuous and my means very limited. I continued to postpone this visit until it became too late. Lord Dufferin left Canada for higher posts of honor in the old world. Still he now and then found time to write me a short letter. He was particularly pleased when he found that I too had been called into the diplomatic service. He then addressed me as his "dear colleague."

But the heading of this chapter is "The Icelanders," and I have apparently drifted away from my topic. Let me return to it. Sitting in my chair and dictating this to Mr. Barton I shall not be able to give accurate dates, nor is this necessary. It all happened during the '70s. Even before the '70s a few Icelanders had emigrated to America. They were of the working class and found employment here and there among their Norwegian cousins.

The first one of these Icelanders whom I saw came to our house in 1871. He was working on a farm near Madison. 
His name was Bergman and he came from Akureyri in the north part of Iceland. I had not learned old Norse or Icelandic at Luther college. In my study of the discovery of America and of Scandinavian mythology and history I became most painfully conscious of my need of understanding old Norse. I got text books from Norway, Sweden and Denmark and studied these books most industriously, and now you may imagine how glad I was to get hold of an Icelander who could actually read and understand my old Norse books. I made him read aloud to me; then I read aloud to him. I do not know whether it was a blessing or a misfortune that this Icelander knew neither English nor Norwegian. He had been sent to me by Madison people because they could not converse with him and they thought I might be able to do so.

This Icelander brought three or four of his countrymen to see me and we soon all became fast friends. I looked upon these sons of Iceland with wonderment and they all had to help me to read correctly and to talk Icelandic which is practically the same today as it was in the days of Leif Erikson. It is the only vernacular that has continued more than a thousand years with practically no change of utterance. When you talk with an Icelander you are hearing the same words, the same accents that you would have heard had you listened to Harald Haarfager at the battle of Hafersfjord in 872 .

Later, in 1871 , I received a prolonged visit from the Icelandic poet Jon Olafsson. He was a fugitive from Iceland. At about this time, that is to say, in the latter part of the ' $60 \mathrm{~s}$ and the beginnings of the ' 70 s the relations between Iceland and Denmark were exceedingly strained. The Icelanders were clamoring for home rule. They wanted their own parliament, a demand which the Danes later very wisely granted. I may add here that Iceland with its scattered population of about 70,000 has absolutely no illiteracy. Although there are no schools outside of Reykjavik, the capital, in the south, and 
Akureyi on the north coast, the children are taught to read and write by their parents in the long winter nights and there is not to be found in the whole island a single man or woman of normal mind who is unable to read and write Icelandic, while a large percentage of the population can read Danish and English and some of them even German and French books. It is also a remarkable fact that Iceland has no executioner and hence a person guilty of a capital crime cannot be executed. Not a criminal has been executed in the past one hundred and fifty years.

Jon Olafsson was charged with high treason. Though but a young man in the early ' 70 s he was very precocious and had already written enough to make a substantial volume. Among other things he had written a patriotic song breathing defiance to Denmark, and it was for this that he was to be arrested and tried for treason. He escaped to Norway in a Norwegian tramp vessel. From Norway he made his way to America and when I first heard of him he was working on a farm in the Norwegian settlement called Muskego in Racine county, Wisconsin. I invited him to visit me and I remember he went with me to Moscow, Iowa county, Wisconsin, where we both spoke on the 17th of May.

Young Olafsson was highly educated. He was well versed in the ancient classics and spoke fluently both Danish and English. With him I took a strenuous course in Icelandic, reading long parts of the eddas and sagas and also of modern Icelandic literature. He remained with us about two weeks and then returned to his work in Muskego. His career in this country was most remarkable. He had conceived the idea that it would be a splendid thing for the Icelanders to emigrate in a body to Alaska. In emigrating from and abandoning Iceland they would escape Danish tyranny and besides find better soil and a finer climate than in Iceland. But how to carry out this idea, that was the great problem. Prof. Willard Fiske of 
Cornell University and I equipped him with letters to Washington, but after getting there he would have to fight his own battles. After he got to the seat of our government he elbowed his way to members of congress, to United States senators and members of the cabinet and even got an audience and interview with President Grant. He told all of them that he wanted the 70,000 people in Iceland to leave the homes they and their forebears had occupied for a thousand years and settle in Alaska. He made it appear that the idea was perfectly practicable. And what happened? Jon Olafsson received an appointment from President Grant to take two other Icelanders with him and proceed at once to Alaska to select a site for a settlement. A United States revenue cutter was placed at his service and provisions made for the necessary travel in Alaska.

Jon Olafsson and his companions made the journey. Of the trip and of the Alaskan country in general Olafsson wrote in Icelandic a ponderous report. It was a large octavo pamphlet of, I think, not less than 200 pages. This was ordered printed by the government in an edition of several thousand copies. In the meantime Jon Ofalsson through diplomatic correspondence had received full pardon for his treasonable poem and so could return to Iceland unmolested.

The president of the United States sent him to his native land with a cargo of his pamphlet on Alaska. On his arrival home he at once began to agitate in favor of emigration to Alaska and distributed his pamphlet. But neither his preaching nor his pamphlet had any other effect than to make him the butt of ridicule. His audiences hissed him and he was, by way of disparagement, called "Jon Olafsson Alaska-fari," i. e. "Alaska-farer". The whole enterprise was a colossal failure and fell flat. Not a single Icelander was found willing to give up his Iceland home in exchange for one in Alaska.

Jon Olafsson remained in Iceland, started a newspaper and lived there until in the early ' 90 s when he again visited America, 
living most of the time in Chicago and then a short time in Madison, Wis. Here he edited a Norwegian paper published by O. A. Buslett. Then he returned to Iceland where he still lives.

As above indicated Iceland obtained home rule in 1874 and Jon Olafsson has for many years been a leading and very influential member of the Icelandic parliament.

The settlement of Iceland by people from Norway on account of the tyranny of Harald Haarfager dates from the year 874 , and in 1874 the Icelanders celebrated their millennial. The king of Denmark attended the celebration in person and brought with him as his millennial gift a new constitution for Iceland providing for home rule. The celebration was attended by many distinguished visitors, among whom was Bayard Taylor from the United States. Willard Fiske of Cornell in the east and $I$ in the west made a large collection of books which we sent to the library at Reykjavik in honor of the millennial. No other people in the world appreciate books more than the Icelanders. On his return home Bayard Taylor published his very readable book on his journey to Iceland and I made all this aid me in the campaign I was conducting to get the Scandinavian languages, including Icelandic, recognized at the University of Wisconsin.

Icelanders came to America in increasing numbers. Early in the ' 70 s we find a whole colony located on Washington island outside of Green Bay. Quite a number had located in Mil. waukee and others had found their way into various Norwegian settlements on both sides of the Mississippi. Among these there were bright and ambitious young men who wanted to attend school and such were assisted by Synod ministers and sent as students, first to Luther college, and thence to St. Louis to study theology. I kept one of these young men by name Thorlaksson, who afterwards became a pastor in Canada, in foot- 
wear during his course at Decorah and then St. Louis. I had promised to take care of his "understanding."

Then, I think it was in 1874, Luther college added an Icelander to its faculty. This was Jon Bjarnason. He was a graduate of the college at Reykjavik, in Iceland, a gifted man and ripe scholar. Unfortunately, he was found by Rev. V. Koren of the Synod and by his colleagues in the faculty to entertain theological views that were not strictly orthodox. He was thought to be too liberal. This caused friction and at the end of the school year he lost his position.

With me it was still the petit done and the undone vast in Icelandic, as in many other things, and so I invited Prof. Bjarnason and his wife, Laura Pjetursdottir, to come and make their home with us for a year or pending his finding some other position. Laura was a daughter of the organist at the Reykjavik church, a musician of note. She too was an able musician and an expert on the guitar. She assisted Mrs. Anderson in doing the housework, while Bjarnason gave me a rigid course in reading, translating and speaking Icelandic and in assisting me in various ways in my literary work. He helped me prepare for publication my "Viking Tales of the North." Before the year was out he got a position as editor of a Norwegian paper, published in Madison by Lars J. Grinde, but Jon and Laura continued to live at our home. The next spring I got him a position on "Skandinaven" in Chicago. He worked there a short time and from there was called to be editor in chief of "Budstikken" in Minneapolis. Then he went to serve as one of the pastors of the Icelanders who had settled in Manitoba where he has done a great and noble work in building up the Lutheran church among his countrymen. He is now the president of the Icelandic Synod in Manitoba and North Dakota and the editor of its official organ. A few years ago 
I had the pleasure of visiting Jon and Laura in their splendid home alongside of their magnificent church in Winnipeg. ${ }^{*}$

I now want to add by way of self-praise that through the help of all these Icelanders, particularly Jon Olafsson and Jon Bjarnason, I became so proficient in Icelandic that when soon after my arrival in Copenhagen as United States minister the Icelanders connected with the university and others in that city gave me a reception I was able, to the great and agreeable surprise of my entertainers, to respond to Prof. Finnur Jonsson's address in their own vernacular. Prof. Jonsson in his address to me not suspecting that I would understand Icelandic spoke in Danish.

* Since the above was written, Rev. Jon Bjarnason has died. 


\section{CHAPTER LXIV.}

\section{MORE ABOUT THE ICELANDERS.}

I have already mentioned the Icelanders in Manitoba. How did they get there? In most of what I have already stated I have intended to lead up to the answer to this question. It was largely with this end in view that I introduced Lord Dufferin to my readers. I have shown how deeply he was interested in Iceland, its people and its history. I have given an account of Jon Olafsson's and President Grant's abortive enterprise to get the whole population of Iceland to emigrate to Alaska.

As stated, the Icelanders continued to emigrate in increasing numbers from year to year. But they had failed to find a large body of unoccupied land where they could settle together and preserve their Icelandic language and traditions and maintain schools, churches and newspapers. I believe it was sometime in the summer of 1878 that three sturdy middle-aged Icelanders visited me to discuss this matter with me. We considered North Dakota, the Pacific coast and Texas, where suitable large tracts of land might be available. But the fact was that the Icelanders had no money to buy even the cheapest land on the market. Then it suddenly occurred to me that Lord Dufferin was governor general of Canada; that in Canada there were large tracts of unoccupied land; that Lord Dufferin was a friend of the Icelanders and that I knew him. I therefore suggested that these three Icelanders should go to Ottawa and 
find out what Lord Dufferin might be able and willing to do for them. I gave them a letter to the governor general.

Lord Dufferin received them most royally as if they had been ambassadors from some foreign potentate. He entertained them at the government mansion. His fertile mind soon found a way. He selected a strip of land some thirty miles in length and perhaps ten miles in width on the west side of Lake Winnipeg in the province of Manitoba and in a message to the Canadian parliament he recommended that this strip of country be set aside for an Icelandic settlement and that the land be sold exclusively to Icelanders and on very easy terms of payment. The recommendation was adopted with alacrity by the parliament.

Here the Icelanders would find a climate not unlike what they had been accustomed to in their native land; they would find a soil immensely more generous than that of Iceland, and besides they would have the sea, that is, Lake Winnipeg, on the side facing the rising sun. This lake would supply their tables with fish.

In the space of a few years several thousand Icelanders located on this land. Take your map of Manitoba and you will find in this little American Iceland a number of names of Icelandic origin, such as, Icelandic river, Geyser, Arne, and the chief town Gimli, the heaven in Norse mythology. Besides maintaining churches and schools and an official organ of the church, they publish, in Winnipeg, two ably-edited political papers, and several Icelanders have had seats in the Manitoba parliament and one is now serving as a member of the cabinet of Manitoba.

From Manitoba a number of Icelanders have drifted down into Pembina and Cavalier counties of North Dakota, and Icelanders in this state have found their way into the North Dakota legislature. There is a large body of Icelandic students at the University of North Dakota, and in Grand Forks and 
other cities they are ably represented in the legal and medical professions. Then there is an Icelandic congregation in and around Minneota, Lyon county, Minnesota. Several Icelanders have found employment in some of the most prominent American libraries. Both Canada and the United States have abundant reason to be proud of their Icelandic immigrants.

Perhaps one of the most interesting Icelanders that has landed on our shores in recent years is A. H. Gunnlaugsson. There were two brothers, one of whom had gone to Paris, lived and died there as a prominent writer on economic subjects. The father of Gunnlaugsson was a high Danish official in Iceland, but it is of the Gunnlaugsson who came to America that I am to speak. As a young boy in Iceland he was captivated by the Catholic religion. Catholic missionaries came to Iceland and took the young man with them to Rome where he was placed in the Propaganda College and served as an acolyte or altar boy to the pope. He showed a wonderful talent for languages and learned in a jiffy all the leading ancient and modern tongues, Hebrew, Sanskrit, Greek and Latin, Italian, Spanish, German, French and English. The plan was that he was to be made a missionary to Iceland to bring the Icelanders back into the fold of the Catholic church. But young Gunnlaugsson lost his faith in the Catholic religion and ran away from Rome. In course of time he became settled in London where he enjoyed the intimate acquaintance of Lord Beaconsfield, became the tutor of Queen Victoria's daughter, Princess Christian, and did editorial work on several of the English quarterlies and some of the most prominent British monthlies. But his health failed him; he suffered from a nervous breakdown. $\mathrm{He}$ imagined that he was being persecuted by the Jesuits and cther Catholics for having deserted the propaganda school in Rome. One would think that he must have read Eugene Sue's "The Wandering Jew." At all events he considered 
himself in great danger of being waylaid and assaulted or thrown into some dungeon.

In this state of mind he became unfitted for work and he fled to America, coming first to Chicago. Here a prominent Dane, Prof. N. C. Frederiksen, took an interest in him, furnished him with food and clothing, of both of which he was greatly in need, and then brought him to Madison and left him, so to speak, on my hands. I was supposed to be the friend of all Icelanders. I got him a room at the corner of Carroll and Johnson streets, in Madison. We soon got classes of young ladies for him to teach. He taught the daughters of General Lucius Fairchild and some of their friends, and in this way he managed to make a living. But he still had spells of suffering from his suspicions of being persecuted and this interfered very much with his success as a teacher. I gave him some literary work to do and he helped me translate Horn's history of Scandinavian literature. Then he decided to return to Chicago where he eked out a miserable existence and finally moved to Tacoma, Wash., where he still lives and where I met him a few years ago.

This tall, slender, emaciated Icelander was no less interesting in his general appearance than for his remarkable history. Though poor as Job's turkey he was proud and independent as a millionaire, and he liked to boast of how Disraeli depended solely on Albert H. Gunnlaugsson for his foreign policy. The Englishman never ventured to take a step without Gunnlaugsson's advice and consent. A Al in all he was a unique specimen of humanity.

Of course I met a number of distinguished Icelandic scholars in Copenhagen and there I received a visit from Iceland's greatest poet, Mattias Jochumsson. He has honored me with a beautiful poem in which he lauds me for what I have done for Icelandic literature, history and mythology and for the interest I have taken in the Icelanders. While in Copenhagen I was 
invited to visit Iceland, to be entertained by the Icelandic people, but unfortunately the time never became opportune.

I had one opportunity to serve an Icelander in Iceland. Every year there came to the west coast of Iceland a fleet of American fishermen from Gloucester, Mass.; but there was no American consul resident in Iceland. An Icelandic merchant on the west coast of the island became ambitious to become American consul. He came to see me about it, as Iceland was included in my jurisdiction as minister. I recommended his appointment to our state department at Washington and this worthy Icelander was duly made U. S. consular agent. As a souvenir this consular agent made me a present of the largest and clearest specimen of Icelandic spar that I have ever seen. I still have it and cherish it as one of my choicest treasures. It is a thing of beauty in itself and represents to me the capstone on my connection with Iceland.

With the introduction of Christianity, which brought pens, ink and parchment to the Icelanders, about the year 1000, Iceland entered upon a literary career well nigh without a parallel in history. In the eleventh, twelfth and thirteenth centuries Iceland became to Europe what Greece had been during the centuries immediately preceding the birth of Christ. We might almost say it became the Patmos where our Teutonic past was recorded. The eddas give us a well nigh complete exposition of the pre-Christian religion of the Teutons and the sagas give us a minute history of the Scandinavian north from the year 860 and shed much light on contemporary European history. The saga period culminated with Snorre Sturlason, who died in 1241 , and then there is a period of inactivity until the time of the reformation which produced a revival which has continued with increasing vigor to the present day. But during this lethargy, from 1250 to 1536 , while Iceland was for nearly three centuries wrapped, so to speak, in intellectual darkness there shines through this gloom a single bright star. This star 
was visible in the second half of the fourteenth century. I refer to the remarkable skald Eystein Asgrimsson and his wonderful poem, "Lilja." Eystein was a monk. In some way he had offended the bishop and for this reason he was thrown into a well 100 feet deep. He was supplied with writing material. While in this well, so the story goes, he began writing a poem. When he had written three stanzas he found that he had risen three feet from the bottom of the well. This made him vainglorious and the next stanza was written in a haughty spirit and he found himself in the bottom of the pit again. The haughty stanza was destroyed and the poem was continued in the meek spirit of the first stanzas. He continued and with the one hundredth stanza he had written himself out of the well.

This poem, called "Lilja," is a sort of messiad and is written in a rhythm and rhyme of its own called the Lily. The poem is so beautiful that there is not an Icelandic poet who would not like to have been its author. It is known that Milton got his idea of "Paradise Lost" from the Dutch poet Vondel's "Lucifer," but what I here want to point out is that Eystein Asgrimsson treats the same subject long before him and it has been claimed, with much probability, that Vondel received his inspiration from Eystein. Eystein's "Lily" is without question, both as to rhythm, rhyme and contents the most beautiful pocm in all Icelandic literature, and the remarkable thing is that it should have been produced while Icelandic culture was at its low water mark, at its nadir, so to speak.

Herewith I take my leave in this narrative of that wonderful island with its grand eddas and sagas and its interesting people. 


\section{CHAPTER LXV.}

\section{CONTROVERSIES.}

Life is war and war is life, but I may safely assert that I have had more than my share of controversy. I got into war as a student at Luther college. My connection with Albion academy ended in war; and to have a fight on my hands of some kind secms to have been my fate to this very day. I would like to have it understood that at least from my standpoint my battles have been waged for the betterment of man's estate. It has never been my purpose to throw my fellowmen into the gutter, but, if possible, to help lift them out of it. I may at times have been severe and defiant, but I may say truthfully that I never considered my own personal advantage or popularity. As Robert Burns would put it: I would rush into the thick of the fight "uncaring consequences." In a controversy I have seldom known the word compromise. When I was sure I was right the only terms I could offer was unconditional surrender, as General Grant put it.

The Norwegians in America have not been above criticism, and it has often seemed to me that in the absence of other critics it was my duty to step into the breach. In this way I have lost many friends and have had to forego much personal popularity.

The controversies to which I here refer are too numerous to be presented in detail in these memoirs. A narrative of them 
would be monotonous and tedious. Furthermore, many of those with whom I have had public conflicts are either still living or they have near relatives in the best of standing among us and it would seem cruel to parade such troubles before the public again. Still some of the conflicts have been so farreaching in their consequences, not only to me personally but also to the public in general, that it does not seem to me proper wholly to ignore them. In entering upon this subject I shall use all the discretion I yet may possess and present the facts absolutely without malice.

In a general way, it may be here stated that among the early immigrants to this country from Norway there was a sprinkling of men of a more or less educated class. Of these some had left their country for their country's good. They had committed some error or other in Norway and had come to America to make a new start among their countrymen who were not familiar with their past records. They frequently courted the gcod will of the Norwegian ministers, expecting, no doubt, through the latter to gain the confidence of the plain people. I am exceedingly sorry to have to add that some of these ministers lacked the courage of their convictions and backbone to shake them off. Some ministers even went out of their way to be nice to these fugitives from justice. They helped them in all sorts of ways to get to the front, in business, in politics, and in church affairs. If the minister had an unworthy cause he would find these educated men with tainted characters willing tools to advance it. Fortunately conditions have now changed and practically all of those to whom the above remarks apply have been gathered with their fathers and their names have passed into oblivion or at least into obscurity.

As an illustration I shall now give an episodc. I choose the name Fleischer because there are no relatives of his now living to have their feelings wounded by the tale. 
K. J. Fleischer belonged to the so-called conditioned, that is, educated class in Norway. In Norway he had committed forgery and for this he had been sentenced to serve ten years in prison. At the end of three years of his imprisonment he was paroled on condition that he leave the country. He was well dressed, had polished manners and not a little ability. He soon found his way to the parsonages and ingratiated himself with the ministers and thus he also soon got widely acquainted with the rank and file. He very quickly became connected with "Emigranten," the paper established at Immansville, largely by the help of Rev. C. L. Clausen and his brother ministers. From Immansville Fleischer moved to Madison, Wis., where he was engaged in selling emigrant tickets. In those days a large number of the emigrant tickets were purchased here and sent to friends in Norway. He prospered and was looked up to as a leader among the Norwegian-Americans. Then he wanted to be vice-consul for Sweden and Norway and for this appointment he was cordially endorsed by nearly all, if not all, the Norwegian ministers.

The recommendation was sent to the Swedish-Norwegian legation at Washington and in due course of time he received his commission from Stockholm, Sweden. It is possible that if Norway had had her own government, as she now has, instead of having all her foreign affairs attended to at Stockholm, Fleischer's record in Norway would have been looked up, and his appointment refused.

This vice-consulship added materially to his dignity and to his standing and influence. He belonged to the Norwegian Synod. If you will take the trouble to read the reports of the annual meetings of the Synod you will find that Fleischer was regularly there in some capacity or other. He was sometimes elected auditor of the Synod's finances and accounts, its receipts and disbursements. In a word it was Fleischer here and Fleischer there and Fleischer everywhere when anything of im- 
portance was doing. And now comes the episode which proves his undoing, an episode which shows that Nemesis is not dead though she may take long naps.

I have already stated that during my first year at the University President Chadbourne informed me that he had received letters from Norwegian Americans who protested vigorously against my being employed as a university teacher and urged that my services be discontinued. President Chadbourne did not inform me from whom he had received such letters. It is true that I had my suspicions, but I was not in possession of the necessary proof. I was on speaking terms with Fleischer and he usually went out of his way to be nice to me. His very politeness to me was suspicious. In my early boyhood I attended not only the common school, but also a Norwegian Lutheran parochial school which was maintained by the congregation to which we belonged. This school flitted from house to house, the neighbors taking their turns in furnishing a room for the school and board for the teacher. Our teacher was a semi-educated crank from the eastern part of Norway. He had done the very same kind of work for many years in his native parish in Norway. Besides being parochial teacher he also served as "klokker" in the East Koshkonong church. The "klokker" offers the opening and closing prayers of the service, announces the hymns, leads the singing and on the great church festivals he puts the robes on the minister before the altar. The name of this old teacher was Anders Anderson. He was a teacher emeritus before he left Norway in the 50 s and in course of time he became unfit for further service in this country. He retired and lived on a small patch of ground a quarter of a mile west of the East Koshkonong church. In spite of his many oddities and shortcomings I was very fond of this old teacher. Whenever it was convenient I would pay him a visit and he seemed very proud of the 
various marks that his quondam pupil was making and in my controversies he always took my side and gloried in my victories. He was in rather poor circumstances, having a hard struggle to support himself and family. 


\section{CHAPTER LXVI.}

\section{THE FLEISHER EPISODE.}

Once while I visited this venerable and amiable gentleman, Anders Anderson, we fell to talking about his having been a teacher in Norway, and I asked him how it was that he who had given so many years to that service did not get a pension. He said he believed he was entitled to a pension, but had never applied for it.

"Apply for it now, then," said I.

So we drew up the necessary papers, had them signed and witnessed and I took them with me to Madison where I turned them over to Vice-Consul Fleischer, whose duty it was to do the rest. After considerable time my old schoolmaster received his pension consisting of several hundred dollars and his heart overflowed with gratitude to me. Before the pension had arrived I called at Fleischer's office to make inquiries in regard to it. The vice-consul was not present, but his clerk opened a book containing copies of all the correspondence of the office to show me what letters had been written. In turning over the pages he happened to open a page where there was a copy of K. J. Fleischer's letter to President P. A. Chadbourne. I read it and it was a letter protesting against my being employed as a teacher in the university and severely attacking my character.

I informed my friend John A. Johnson of this and he immediately prepared an article exposing Fleischer's antecedents 
in Norway and his conduct in this case. Before sending this article to "Skandinaven" Mr. Johnson went to Fleischer and read it to him. Fleischer became very meek and begged Mr. Johnson, on his knees, so to speak, not to publish the article. He offered to do anything in his power to mend the wrong he had committed and assured Mr. Johnson that he now had the very highest opinion of $R$. B. Anderson's character and ability.

There was much of the milk of human kindness in Mr. Johnson's heart. He felt very sorry for Fleischer and agreed that the matter should not be published. Meanwhile Mr. Johnson thought that he had given Fleischer a good lesson. The matter was dropped and I continued to be on speaking terms with Fleischer, though our cordiality was more or less strained.

A few years later we had a maid by name Marit Bach, a newcomer from the Trondhjem district in Norway. One day I was to pay her wages for several weeks' service. She asked me if I would be kind enough to go to the vice-consul, Fleischer, and hand this money to him on her account with him. I asked her how she came to be in debt to Fleischer. She explained that the train on which she and other immigrants had traveled through Michigan had been wrecked and she and some of her fellow passengers had been injured. For the injuries sustained they wanted indemnity from the railroad company. Marit Bach with others had put the case in the hands of Fleischer. In course of time Fleischer reported that he had received as an indemnity for her from the railroad company $\$ 40$ which he paid her. But Marit Bach had her betrothed in Norway and wanted to send him a ticket to come to this country. The price of the ticket was $\$ 60$ and so Fleischer offered to take that $\$ 40$ and give her credit for the twenty until she might be able to pay it. I now understood the case and it was these \$20 I was to pay Fleischer. I called on him and said:

"You have, Mr. Fleischer, an account with Marit Bach. She owes you some money which I am to pay." 
He opened his ledger and there he showed me the account exactly as stated to me by Marit. But showing considerable nervousness he said he was very sorry that he had lost the papers from the railroad company. He said he had carried them in a note-book in his inside vest pocket and must have lost this note-book while taking a nap in his hammock in his garden. He said he did not like to give me extra trouble, but that if I could come in again the next day he would make a thorough search for that note-book and the papers so he would be able to show me the report from the railroad company. Had it not been for our somewhat strained relations I would have told him that such search was unnecessary. As matters stood I agreed to call the next day.

What happened the next day? Fleischer seemed exceedingly nervous. As soon as he saw me, he stated that he had searched everywhere for the papers, but in vain. Therefore to satisfy me he had telegraphed to the office of the railroad company in Detroit, Michigan, and, said he, "I have received this answer."

He held a telegraph blank in his hand and read: "Marit Bach was allowed as indemnity $\$ 40$." This was signed by one of the officers of the railroad company. I stood by the side of Fleischer looking at this telegram. Suddenly he turned fiercely toward me and exclaimed:

"Do you think I am a scoundrel?"

I answered: "That will do, Mr. Fleischer. I am not going to settle Marit Bach's account with you today," and I left him.

The fact was that Fleischer had simply taken a telegraph blank and forged all that was written upon it. I discovered at a glance that the pretended telegram was in his own chirography and this fact was fully confirmed by Fleischer's exceedingly nervous conduct. 
I told Marit that I had not seen fit to settle her account with Fleischer and that I proposed to make some investigation. Then I wrote a letter to the office of the railroad company in Detroit and asked how much indemnity had been paid to one Marit Bach, who had had her shoulder dislocated in a railroad wreck of which I gave the date. I promptly received an answer informing me that the company had paid to the viceconsul at Madison for Marit Bach $\$ 80$. Thereupon I requested two men in Stoughton who, Marit had informed me, had been in the same wreck, to come to me at once and bring with them all correspondence in their possession from Fleischer in connection with this wreck. They came. Marit did not have a word in writing, but these two men from Stoughton had everything in black and white. Both of them had been severely injured. Fleischer reported that he had gotten $\$ 200$ for one of them and $\$ 250$ for the other. He said they ought to have had more and regretted very much that these indemnities were not larger, but recommended their acceptance rather than going into expensive litigation with a rich corporation. To give emphasis to his sympathy for them he explained that he did not have the heart to charge any commission for his services, another very suspicious fact.

I wrote to the railroad office in Detroit and immediately received a reply that one of these men had been awarded $\$ 400$, the other $\$ 500$ and that they had the vice-consul's receipts in full for these amounts.

What to do next was a serious problem. I did not want to Le particeps criminis. Fleischer was clearly guilty of a most serious offense. I laid the matter first before John A. Johnson, then a conference was called at which John A. Jchnson, B. W. Suckow, Nils Michelet and I were present. We considered and debated the question from early in the evening until broad daylight the next day. It was finally decided to 
show the old man some mercy. He was not to be taken into court, but this is the sentence we passed upon him:

First, he was to reimburse the three individuals that I have mentioned with interest. Second, he was to resign his office of vice-consul. Third, he must discontinue his business as ticket agent, and fourth, he must leave Madison. With all these conditions he complied with the greatest alacrity.

When the office of vice-consul thus became vacant Halle Steensland's friends united in recommending him for the position to the Swedish-Norwegian legation at Washington. $\mathrm{He}$ easily received the appointment and filled it for many years with great credit to all concerned.

During my long life I have had a number of experiences of an equally exciting character. It seems to have been my lot to go into the breach when anybody needed public criticism, and on account of this I have sometimes been called "the fraud extinguisher." Interesting as some of these episodes might be to the reader I shall have to pass over many of them in silence. My desire is to spare so far as possible the feelings of the relatives and friends of those with whom I have been obliged to wage war. 


\section{CHAPTER LXVII.}

\section{KRISTOFER JANSON.}

I have already given an account of my interest in the Norwegian "landsmaal" and how I in 1874 wrote and published the only book that has appeared on that subject on this side of the Atlantic, viz., "Den Norske Maalsag." This little book brought me into very intimate correspondence with the Norwegian poet Kristofer Janson, who was at that time one of the most talented of that group of writers who made use of the "landsmaal" as the vehicle of their poems and stories.

Kristofer Janson had with Christoffer Bruun established in Gausdal, in Gudbrandsdal, one of those popular high schools of which Grundtvig had caused so many to be founded in Denmark. Janson also had the reputation of being one of Norway's most popular orators.

I was constantly considering what could be done to awaken a larger interest in Norwegian language, history, literature and tradition, and I conceived the idea that much could be achieved in that direction, if Kristofer Janson could be induced to speak to his countrymen in the various cities and settlements in this country. I corresponded with him on this subject until I finally got him persuaded and he agreed to come. This was in 1879. I served to a large extent as his impressario and financial agent. I advertised him as thoroughly as possible and made engagements for him throughout the northwest. He had his headquarters at our home in Madison. After giv- 
ing scores of lectures in halls, churches and schoolhouses he returned to Norway with fully $\$ 3,000$ net proceeds, a sum which it would have taken him many years to accumulate in Norway.

Kristofer Janson, was at that time, though somewhat tainted with Grundtvigianism, thought to be fairly orthodox in his theology. In his addresses he abstained rigidly from touching upon religious topics. He was accordingly hospitably received at all Norwegian Lutheran parsonages and he was permitted to speak in a large number of Norwegian Lutheran churches. He was received and entertained as one of Norway's distinguished sons and his visit did much to promote an interest in Norwegiandom on this side of the Atlantic. After him came a still more renowned son of Norway in the person of Björnsterne Björnson, kut before I tell of the visit of the latter I must finish my story of Kristofer Janson.

When Björnson was here in 1881 both he and Kristofer Janson had abandoned the faith of their fathers. Georg Brandes of Denmark, of Jewish descent, became the great interpreter and promoter of modern liberal European ideas, first in Denmark and then in Norway and Sweden. He brought the ideas of John Stuart Mill, Taine, Ernst Renan and Zola to the attention of his Scandinavian readers. In 1879 Björnson, who up to that time had been an energetic and enthusiastic defender of the Christian faith, went over into Georg Brandes' camp bag and baggage. And there he remained to the close of his life. With his strong personality and great eloquence he took many of the lesser lights with him.

Though I never formally identified myself with this movement, still I too was carried away by it. I thought I saw in Brandes, in Björnson, in Ibsen and in the rest of them, the sun of a new day rising in Scandinavia and while I myself wrote very little that might be called prejudicial or damaging to the Lutheran church or the cause of Christianity, still I kept in close touch with the Scandinavian leaders and did all I could to se- 
cure them readers and admirers in America. And while I am taking my readers into my confidence I may as well make a clean breast of it and add that I remained a pretty full-fledged agnostic in religious matters until toward the close of the ' 80 s. I had worshipped these leaders of liberal thought at a distance, and distance, you know, lends enchantment to the view, but after spending several years in Copenhagen in close contact with these eminent representatives of modern ideas and observing the effect of their broad views on their own lives and on their surroundings I began to think that this new preaching was not the dawning of a new day, but rather the twilight of a coming night. In my associations with Bishop Monrad, Bishop Fog, the estimable and learned P. A. Vedel and others my suspicions against the new cult were strengthened, and when I returned to America I, by the grace of God, brought back with me the faith in which I had been confirmed as a boy before the altar of the Lutheran church.

While Björnson was in America during the winter of 1880 - 81 he repeatedly urged me to find a position for Kristofer Janson among his countrymen in America. Janson had abandoned his Lutheran faith, but instead of following Björnson into agnosticism, or what may be called Ingersollism, he accepted the views of the great Swedish scholar Victor Rydberg and became a Unitarian. Janson was an exceedingly lovable character. He was mild mannered, gifted as a poet and speaker and with his long soft hair and beard he had the appearance of an evangelist. Indeed he had a great resemblance to the conventional portraits of our Saviour. Björnson believed that there were enough of liberals among the Norwegians in this country to support Kristofer Janson as their spiritual adviser.

While I was not so hopeful and enthusiastic in this respect as Björnson, still I promised to do all in my power to find an opening for Kristofer Janson. And this is what happened. 
One day in the spring of ' 81 I met in the capitol park in Madison Rev. Jenkin Lloyd Jones and the Rev. H. M. Simmons, both prominent ministers in the Unitarian church. Rev. Mr. Jones is now in Chicago and Mr. Simmons died while pastor of a church in Minneapolis. I knew both of them well and so I suggested to them that if they cared to have any missionary work done for Unitarianism among the Norwegians in America I had the right man for them. I then exhausted my eloquence in eulogizing Kristofer Janson as a man, as a theologian, - he being a graduate in theology from the University of Norway, -as a speaker, novelist and poet. Mr. Jones and Mr. Simmons approved with ardor what I had proposed and said they were going to Boston to attend the annual national meeting of the Unitarian conference and would lay the matter before that body with their hearty recommendation. I urged that the conference should guarantee Kristofer Janson a salary of $\$ 1,000$ a year for three years. They had no doubt that they would succeed in securing this guaranty and agreed to write me from Boston.

I at once wrote a letter to Kristofer Janson in Norway and said that if the matter turned out as I expected I would cable to him one word "Come!" In due course of time Jenkin Lloyd Jones informed me that the conference in Boston had voted Kristofer Janson a salary of $\$ 1,000$ a year for three years. I cabled the word "Come" to him and he immediately packed his grip and came.

On his arrival in Madison that same year we canvassed the matter of location and decided that Minneapolis would be most central for his headquarters. He therefore located there. He succeeded in organizing a congregation and building a church in that city. He established another church in Brown county, Minnesota, and gathered a small congregation in Hudson, Wis. In addition to his preaching he devoted considerable time to lecturing and to writing. 
The next year, 1882, he brought his wife and children. Two of his sons are physicians and one a dentist in Seattle, Washington. It pains me in this connection to have to record that after several years of successful work as a Unitarian preacher and lecturer in this country, Kristofer Janson turned spiritualist. He was no doubt perfectly sincere in the matter, but his congregations became greatly displeased and lost their confidence in him. Mr. Janson would sit on his porch and hold conversations with Napoleon and other celebrities of the past and even with Christ and His apostles. His Minneapolis congregation called a meeting to investigate this matter. At this meeting one of the members asked the question:

"Does Kristofer Janson believe in spirits?"

To this Janson replied: "Yes; I have myself talked with spirits."

But to this picture there is a still darker side. A woman who was a fanatical spiritualist, a Miss Benson, invaded the Janson home and his family was broken up. Without going into further details I may add that Kristofer Janson and his wife, with whom he for so many years had lived an ideal life were separated and Janson afterwards married Miss Benson. Mrs. Drude Janson, who was an exceedingly gifted woman and able writer, went to live in Dresden, in Germany, where she has since died.

Kristofer Janson, with his new wife, returned to Norway in the early '90s and still lives in Christiania. He still continues, in spite of his three score and ten, to preach, lecture and write.

Janson was one of the small number of poets in Norway that received what is called "digtergage," that is an annual stipend of 1600 crowns from the storting. This stipend he gave up when he emigrated to America, but after his return to Norway in the '90s the storting renewed it. By his charming stories and beautiful lyrics he has won for himself a per- 
manent place in Norway's literature. Some of his songs are as popular as the best of Björnson's and Ibsen's. With all his faults I love him still. 


\section{CHAPTER LXVIII.}

\section{KNUT HAMSUN.}

On the second day of December, 1902, Björnstjerne Björnson celebrated his 70 th birthday. The day was remembered by groups of admirers in all parts of Norway. The whole press of Norway on that day was devoted to Björnson. It was filled with eulogies, poems, portraits and congratulations. Christiania, where Björnson spent the day, turned out in a tremendous ovation and in the evening one of his dramas was given before a packed house at the theater, where Björnson was present. Between the acts the white-haired poet was called out and he appeared on the stage to express his profound gratitude for all the honor that had rained upon him from his countrymen in connection with his three score and ten. In his remarks he stated that he wished to present his thanks to the Norwegian people through the medium of one who was not present at the theater and whose name was Knut Hamsun. A poem by Hamsun in honor of Björnson had appeared in one of the Christiania papers of that day. Of this remarkable character in the most recent Norwegian literature I some years ago gave to the press a narrative which attracted much attention.

Half a dozen years ago I sat one day in the editorial sanctum of "Normanden" in Grand Forks, N. D., smoking a corncob pipe of peace with the editor, Kjetil Knutson. Our conversation drifted to Norwegian literature and Knut Hamsun was mentioned. I think Mr. Knutson asked me what I 
thought of him. I answered by giving an account of my personal experiences with him. Mr. Knutson took no notes during our conversation, but several months later he published in the magazine "Eidsvold," of which he was the editor, an extended report of our interview. This report is given in the form of a dialogue and my answers to Knutson's questions are quoted. On account of the great prominence achieved by Hamsun the Knutson article attracted a very wide attention. It was reproduced in scores of papers in Norway, in many paners in Denmark and also in some Swedish papers. It provoked much controversy and a personal protest from Hamsun limself. The article supplied much material for the cartoonists. Hamsun timself claimed that the article was full of absurdities and that I had simply drawn on my imagination for my statements. I wish to state here that while the late Mr. Kowtson's article contains a few immaterial inaccuracies and errors, still it is upon the whole a wonderfully faithful reproduction of our conversation as I remember it.

One day during the summer of 1882, I think, while my family and I were seated at the dinner table we heard the doorhell ring. The maid being engaged in the kitchen, I went to the door myself. On opening it there stood before me a tall, slender, smooth-faced young man with a large growth of hair on his head. You could not look at this youth with a forest of brown hair without thinking of Björnstjerne Björnson in his palmiest days. This young man held his hat in one hand and with the other he handed me a letter, after asking me if I was Professor Anderson. I opened the letter and found it was written to me by no less a personage than Björnstjerne Björnson himself.

In this letter Björnson says in substance that he herewith sends to me a young man by name "Knud Pederson." $\mathrm{He}$ adds that "he is not without literary talent" and requests me to take an interest in him and do what I can for him. 
I asked "Knud Pederson" to walk in and learning that he had not had any dinner that day a place was found for him at the table. At the dinner table, after some conversation, I put the question to "Knud Pederson":

"Well, my young friend, what do you intend to do in this country?"

He replied at once: "I have come to write poetry for the Norwegians in America. Björnson told me that his countrymen here needed a poet, and I have come to supply this want."

I then asked him what he had been doing in Norway, what education he had and how much experience in the practice of the art of poetry. He told me that he had not attended any but elementary schools; that he had done various kinds of work and that for a time he had served as a clerk in a store in Gjövik, on Mjosen. He had written some poems, some of which had appeared in print, and told me how he at one time when King Oscar was in Christiania had gone to the palace and asked for an audience. He did not succeed in seeing the king, but he was able through the chamberlain to hand his majesty a couple of poems. By the chamberlain King Oscar had sent him ten crowns (about $\$ 2.50$ ).

The fact that he had only attended the elementary schools struck a responsive chord in me as I well knew by experience what it meant to be an autodidact, or self-taught scholar. I tried to impress upon my new friend that I did not think he could make a living by writing poetry for the NorwegianAmericans and suggested that he had better make use of his Brage-gift as a side line; but he insisted that he had an inner call and that Björnson had assured him that such a field was open among his countrymen here.

About at that time I was in the midst of my agitation in the Norwegian press urging all Norwegians wherever it was possible to drop their names of "Olson," "Larson," "Johnson," "Peterson" and the whole aggregation of "sons," and substi- 
tute the name of the farm from which they or their families came in Norway. I persauded Paul Olson of Chicago bank fame to change his name to Paul O. Stensland. My own name would have been "Kvelve," but I felt that my name Anderson had been too extensively advertised to warrant my dropping it at this late date; but I recommended the change wherever possible.

After dinner I had some further conversation with Knud Pederson. I asked him whether he did not have a farm name that he could use. I told him that the Pedersons were so numerous that it would be difficult to acquire enough reputation for identification. He then informed me that his family had lived on a farm by name "Hamsund" and that he would have the right to use this name. I found "Hamsund" a splendid substitute for "Pederson" and advised him by all means to drop "Pederson" and call himself "Knut Hamsund." This advice he at once accepted.

I had lately met a Norwegian merchant in Elroy, Wis., and understood that he needed a clerk. As Hamsund had some experience in this line of work $I$ at once sent him to Elroy and gave him a letter to my friend there. Hamsund was accepted as clerk and for a while seemed to give satisfaction, but after some time he began turning up later and later at the store in the morning. He seemed to have spent his nights writing poetry and so overslept in the morning. The merchant called him to task several times, but as this did no good he discharged Hamsund. Hamsund then came back to Madison and I had him on my hands again. He lived at one of the cheap boarding houses of the city.

Kristofer Janson had been successful in Minneapolis and his church at Madelia, Minn., had been organized. He was getting more work than he could do and his church was growing. $\mathrm{He}$ therefore wrote to me and requested me to find for him some bright student at the University of Wisconsin that he 
might prepare for the ministry. He said he needed assistance. If I could find among the university students some young Norwegian who would like to become a Unitarian preacher I was to send him to Minneapolis. Kristofer Janson agreed to take him into his own family and keep him and instruct him in Unitarian theology if any such thing may be said to exist. I had not found any one, but now I had Knut Hamsund on my hands and I must try to find something for him to do. I therefore asked Hamsund (he later dropped the " $\mathrm{d}$ " in his name) how it would suit him to become a Unitarian preacher. I do not think he had the slightest idea of the meaning of the word "Unitarian," but he at once replied that he was sure he had in him the making of an excellent preacher, and he was perfectly willing to go and live with Janson in Minneapolis. Armed with a letter from me he at once took the train to Minneapolis. Kristofer Janson was well pleased with him and Mrs. Drude Janson was delighted if not to say infatuated with him. She said to me that it was bracing and invigorating both mentally and physically to be in the same room with Knut Hamsun.

Well, Janson gave Hamsun daily lessons in Unitarian theology. Hamsun was appointed a teacher in Janson's Sunday school and before long he was permitted to occupy the pulpit in Minneapolis when Janson himself had to preach in Madelia, Minn., or in Hudson, Wis. I once heard Hamsun preach, but I must confess that I did not have the slightest idea of what he talked about. It seemed to me like nonsensical and incoherent twaddle. There was a superabundance of words that gushed from him like peas poured from a bag.

Hamsun was industrious, but he was in failing health. In the spring of 1885 he had to take to his bed. About that time I paid a visit to Minneapolis shortly before I started on my mission as minister to Denmark. While in Minneapolis I called at the Janson home. Kristofer Janson was not at home, but Mrs. Janson told me that Knut Hamsun was very sick and not 
expected to recover. He was in bed upstairs and she wished me to go up and see him. I went upstairs and found him in bed. He was pale, emaciated and utterly despondent. He told me, as I had also been told by Mrs. Janson, that he had quick consumption and did not have many more days to live. The day before he had sent for Prof. A. Wenaas at Augusburg seminary. Wenaas had come to him and to him he had made his last confession and received the last sacrament from him. Of this Hamsun himself gave me a full account.

I looked at Hamsun and considered his case as well as I was able. I said to him:

"My dear Hamsun; you are not as sick as you think you are. The weather is beautiful. Get up and dress yourself and go out with me for a walk."

He shook his head and declared that he was not well enough to take a walk; but I insisted. I got hold of his feet and in that way pulled him out of bed. I helped him dress and then I led him downstairs and told Mrs. Janson that we were going out for a walk. We walked around a couple of blocks, he leaning on me. The weather was fine; the air was bracing, but Hamsun would talk of nothing but death. He repented his treason to the Lutheran faith, but he had now, with the aid of Wenaas, made his peace with God, so he did not fear to die. One wish was uppermost in his mind and that was to get back to Norway so he could be buried beneath Norwegian soil. If he, contrary to his expectation, should get his health back, he would devote the rest of his days to the spreading of the kingdom of God among his fellow men.

"How I long to get back to Norway," he said, "but I do not have the price of a ticket!"

I assured him that this matter could easily be arranged and told him that I would immediately get the necessary transportation for him. I then called on several of my friends in Minneapolis and easily gathered enough money to defray 
Hamsun's expenses to Norway. With this money he started at once on his journey home. The walk in the open air and the encouragement I gave him seemed to revive him in a wonderful manner.

When he got back to Norway his health improved rapidly. He had promised to serve God and I understand he found work as a teacher of children in religion. It seems that he regained his health completely, and that in the same degree as he found his health he again lost his religion. "When the devil was sick; the devil a monk would be. But when the devil got well, the devil a monk was he."

By the way, in 1896, Mr. John Lind was independent candidate for governor in Minnesota. He had always been a republican and had represented the republicans in congress. In 1896 there was a split in the republican party in Minnesota and so the democrats picked up the republican Lind as their candidate, just as the democratic national party gave the nomination for president to Horace Greeley in 1872. That same year, 1896, W. J. Bryan had flourished his crown of thorns and cross of gold and had been nominated for president by the democrats and endorsed by the populists.

During the campaign in Minnesota John Lind persistently declared himself a political orphan without affliation with any party and appealed to members of all parties for their votes. He was elected. After the election the democrats of Minnesota held a ratification and jollification meeting in Sleepy Eye. John Lind, the governor elect, was present and delivered a rousing speech in which he declared that their victory was due to their peerless leader, William Jennings Bryan. In commenting on this speech in my paper "Amerika" I quoted the above lines and applied them to John Lind. A subscriber in Minnesota became wroth. He wrote me a letter stopping his subscription, adding that he was well acquainted with John Lind and that John Lind was no more "monkey" than I was. 
How long Hamsun remained in Norway I do not know, nor have I been informed how he spent his time except as to his teaching and even this I have only by report. But he was well again and for some reason or other he again emigrated to America. Where he lived and what he did on this second visit to America I am unable to state in detail. All I know about it is what I heard from his own lips. And this is how we met.

In 1888 I obtained from the state department leave of absence to pay a visit to my home in Madison, Wis. I went to bring my family with me to Copenhagen. I had secured transportation by the steamer Thingvalla of what is now the Scandinavian-American line. Shortly before my vacation had expired our youngest child, Rolf, was taken down with measles. I went to Washington and asked Secretary Bayard to extend my leave of absence for a month. This he was willing to do, but informed me that I would have to forego my salary for that extra time. This I could ill afford and on my return to Madison the doctor decided that it would be entirely safe for Rolf to travel.

I mention this because the steamer that I would have taken had I obtained an extension of my leave was the Geyser, which on that very trip collided with the Thingvalla on the latter's return trip off the south coast of Nova Scotia near Halifax. Nearly all the passengers of the Geyser perished in this wreck. And so I may safely say that had I taken an extension of my leave of absence my family and I would have found a watery grave and I would not now be telling the story of my life.

I may be pardoned if I here give my readers some idea of my industry. Sweden's foremost scholar, novelist and poet in the second half of the last century was without comparison the great Victor Rydberg. I had the pleasure of enjoying his personal acquaintance. I met him at various times and one summer I took my son George with me and visited him at his 
beautiful summer home on one of the islands outside of Gottenborg. His wife was as charming as himself. In the ' 80 s Victor Rydberg wrote an exhaustive work called "Undersökningar i Germanisk Mytologi." This is the most scholarly and thorough investigation ever made of this important subject. All previous writers on Scandinavian mythology have made Snorre Sturlason's younger, or prose, edda the basis of the system.

Victor Rydberg discarded the younger edda altogether and went back to the elder edda and to all sorts of fragments of old Norse and old Teutonic poetry, inscriptions and traditions and out of these he constructed a new Norse mythology as unlike those of his predecessors as Greek mythology is unlike the Roman, and immensely more profound, sublime and interesting. I arranged with Rydberg to translate this great work of his for Swan Sonnenschein Co. of London, Rydberg to furnish me with advance sheets while the work was in press. It is a work of more than 700 large octavo pages. I gave it the English title "Teutonic Mythology." I decided not to go to bed any night before I had translated 20 pages. When I started for America on my vacation there still remained 200 pages to be translated, and by working diligently several hours every day I had the last page translated before I landed in New York. While the steamer stopped in Christiania and at Christiansand I did not go ashore, but stuck faithfully to my work.

For my return trip I had an even more arduous work before me. I had undertaken to translate into English "Blandt Menneskeædere" (Among Cannibals), by the Norwegian traveler, Carl Lumholtz. Mr. Lumholtz had traveled four years in Australia and had spent much time in camp life with the aborigines of Queensland. I had agreed to translate this work for the publishers, John Murray, in London, and Charles Scribner's Sons, in New York. This was a ponderous work 
of 400 large octavo pages. I was determined to have this translation completed before landing in Copenhagen, and so assumed the task of translating 40 pages per day from the time I embarked on the Thingvalla in New York. I was kept busy morning, afternoon, and night, in all kinds of weather and never retired till the 40 pages were done. And the whole book was translated when I landed in Copenhagen less than two weeks later. I saw nobody except my family. 


\section{CHAPTER LXIX.}

\section{MORE ABOUT KNUT HAMSUN.}

While somewhere in the middle of the Atlantic ocean I took a walk through the different parts of the ship for a little recreation. I visited the steerage. There in a corner by themselves sat four young men playing cards. The cards were ragged and filthy and in front of each player lay a few pennies and small silver coins. The four young men seemed to be badly in need of a washing and their clothing had seen better days. One of these young men was Hamsun. I immediately exclaimed:

Why, Hamsun, are you here! I thought you were dead long ago, or, if not, then teaching the children religion in Norway."

In my further conversation with him and in answer to my questions he told me that he had spent the last year or two in America; a part of the time he had been one of a threshing gang in North Dakota; then he had spent a winter in the pineries logging; but his last work in America had been that of a street car driver in Chicago.

"And now you are going back to Norway?" I said.

"No," he answered; "I am on my way to Copenhagen."

I asked him what his object was in going there. He said he had written a book and was on his way to Copenhagen to find a publisher. The title of his book he said was "Det Amerikanske Aandsliv" (American Culture). He then produced 
from an old dilapidated satchel a huge mass of manuscript, enough, it seemed to me, to make a book of 1,000 pages. The manuscript consisted of paper of every description and color and was in the same condition as his hands and face and apparel and satchel. He wanted me to read it, but I told him that I positively did not have the time, a statement which is easily confirmed by what I have told you about the work I had on hand.

I took him with me to the upper deck and let him meet my family who also remembered him. I had noticed that he wore a small bow of black ribbon on the lapel of his coat. I tenderly asked him for whom he wore mourning, inquiring whether he had recently lost his father or mother. He said no, but with a sort of brazen effrontery he added, that he wore the black in honor of the anarchists who had been executed in Chicago in 1887. This was the last I saw of him on board the Thingvalla. I kept at my work and I presume he continued with his card playing. But from that moment Knut Hamsun was in my mind an anarchist and I had no use for people of that ilk.

I do not remember that I spoke to the captain of the ship or to anyone else outside of my family about the occurrence, though I may have done so; but the fact is that on reaching Copenhagen Hamsun was reported to the police headquarters and from that time he was shadowed every moment by day and by night. I do not suppose Hamsun was aware of this himself.

Before leaving Chicago he had ordered all letters and papers to him addressed in my care. I wanted nothing to do with him so I gave strict orders to my secretary to hand Hamsun his mail when he appeared at the door, and if he asked for me to tell him I was not at home. After the first few calls he ceased asking for me. 
How he lived in Copenhagen I do not know; but, of course, he soon got out of funds. I heard of his offering his soiled and ragged manuscript to various publishers, but they would not even condescend to examine it. I suppose they knew that he was an anarchist and therefore would have nothing to do with him. The doors of the American legation were closed; nobody would purchase his manuscript and his funds were exhausted! His case was desperate.

"Be an author and live in a garret" became literally true in his case. He found a small garret near St. Hans Torv (St. John's Market) and paid his last copper for rent; he had nothing left for food. He had to starve. At the end of each day he put down on paper all the sensations he experienced from hunger. From day to day the inward cries for bread became louder. How many days he lived without food I do not know; but his manuscript contained a faithful record of his sufferings. Finally he wrote as a heading or title in big letters the word "Sult" (Hunger), put the manuscript in his pocket and managed to get back into the city where he entered like a ghost into the sanctum of the publisher Philipsen and laid "Sult" on the table before him. Philipsen was struck with astonishment. He looked at the word "Sult" and at the emaciated man before him. He pitied him. He asked Hamsun to take a seat and rest himself. Then he gave the manuscript to the editor of the great magazine "Tilskueren" (The Observer) of which he was the publisher and the result was that Hamsun received a good price for his manuscript and the story appeared in the next issue of the magazine.

The publication of "Sult" made Hamsun the lion of the day, not only in Copenhagen, but also in Norway and to a considerable extent in Sweden. He became at once the most talked of personality in all Scandinavia. The story in the magazine was the first chapter of what was afterwards extended into a large book. All Copenhagen was asking: 
"Who is this Hamsun?" Where does he live?"

When it was learned that he was living in a garret at St. Hans Torv the distinguished authors of the city, such as Georg Brandes, Erik Skram, and others went to look him up. They found this skeleton Knut Hamsun, who when standing was over six feet tall.

Hamsun's success was established. He had made his fame in a day. The leading authors of Copenhagen and other citizens invited him to dinner. They wanted to put flesh on his bones again. I remember particularly a dinner given in his honor by the distinguished couple Erik and Amalia Skram. Georg Brandes and a number of other celebrities were invited to meet the new author. I too was invited to that dinner.

As the guest of honor at the dinner table, around which sat the representatives of the highest culture in Denmark, was seated beside his host this quondam thresherman from the $\mathrm{Da}$ kota prairie, this logger from the American pineries, this street car driver from Chicago, a man who during the past week had been under the constant surveillence of the police on account of the black ribbon bow he wore on the lapel of his threadbare coat, and who a few days before had been at the point of starvation in the garret of St. Hans Torv. And how conscious he was of his own importance! He walked among the other guests and talked with them with the greatest assurance as if he had been to the manor born and had a ready made opinion on every question under the sun.

I say his success was assured. "Sult" was published in book-form and had a tremendous sale. He had not the least trouble in getting Philipsen to publish his ragged, soiled manuscript on American culture. While this book received high praise from the eminent literary critic, Georg Brandes, and others, I must say that to me it seemed from beginning to end to be nothing but silly twaddle. The only reason that I can conceive why the book was well received by the Scandinavian 
critics is that Hamsun tried in this work to ridicule everything called American culture. He represented such writers as Emerson, Longfellow, Lowell, and the others of the group beneath criticism. Of course Hamsun knew little or nothing about these writers and his opinion had been formed simply from hearsay. In this book he ridicules Americans for saying "how do you do?" and translates the greeting into "hvorledes gjör De gjör?" thus showing that he does not understand that the one "do" is an auxiliary and the other the principal verb.

Then Hansum went back to Norway where he was received with ovations. He began by touring the country giving lec-

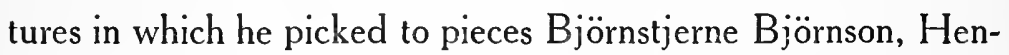
rik Ibsen and all the other noted writers of Norway. $\mathrm{He}$ treated them with supreme contempt. He published books in rapid succession and made money, but spent this mainly in Christiania and in Copenhagen in a most reckless and dissolute life. In order to be odd he would buy drinks for ten crowns and give a hundred crowns to the waiter, throwing his money away while it lasted right and left. Stories of his escapades in the streets and at the cafes in Christiania and in Copenhagen are too disgraceful to be described in these pages. If the reader cares to be further informed I would refer him to Steen Drewson's article in "Minneapolis Tidende" for Sunday, Feb. 15, 1914. While his books have found willing publishers and many readers they seem to me utterly uninteresting and there is nothing in them to arouse in the reader a desire for higher ideals or a better life. There are passages in his books too coarse and indecent to be read aloud even where only men are present. Such writers as Hamsun are a disgrace to the country that tolerates them. Just think of Björnson making this man his messenger to carry his greeting to the people of Norway on his 70th birthday! 
Note.-Mr. L. H. Lund of Chicago has informed me that Knut Hamsun's article Sult (Hunger) consisted of 30 pages and that it was not published by Philipsen in "Tilskueren," but by Mr. Hauberg in his periodical called "Ny Jord" (Virgin Soil). The article was enlarged into a book of 300 pages and this was published by Philipsen. I am obliged to Mr. Lund for sending me this correction. 


\section{CHAPTER LXX.}

\section{CARL LUMHOLTZ.}

Carl Lumholtz, whom I mentioned above as the author of the very pretentious work, "Among Cannibals," frequently called on me in Copenhagen. As a student in Christiania he was threatened with tuberculosis and was advised to take a sea voyage. This is how he came to go to Australia in 1880 . He spent several years there and in accordance with his claims in his book he lived for four years with the aborigines of Queensland, adopting their life and making himself one of them. Of this experience he wrote his book "Blandt Menne. skeædere" which appeared simultaneously in Danish, German, French, and English. I was persuaded to furnish the translation into English. In more recent years Lumholtz has traveled extensively among the aborigines in northwestern Mexico and is at present doing similar work in Ceylon and neighboring islands. He seems to have no trouble in getting publishers for his books and finances for his travels.

I cannot say that I admire him as a man or have much confidence in him as a scholar. It seemed to me while translating his book, "Among Cannibals," that he was either plagiarizing from other travelers or making his stories out of whole cloth, a sort of forerunner of Dr. Frederick Cook of Arctic notoriety. I think that anyone who will take the trouble to read "Among Cannibals" critically will find an abundance of internal evidence to bear me out in what I have here said. 
Lumholtz is a man of an infinite amount of brass and the very personification of self conceit. Let me give one example: Lumholtz happened to be present at the splendid festivities in connection with the unveiling of the Leif Erikson monument in Boston, Mass. There were a number of eminent speakers on the printed program, but among these there was no Norwegian or Scandinavian. Lumholtz was in the hall; he arose and said:

Mr. President," and he was recognized. He said in substance:

"Mr. President and Ladies and Gentlemen! My name is Carl Lumholtz, and I being the most distinguished Scandinavian present here tonight conceive it my duty to say a few words," etc., etc.

Incredible as this may appear it is nevertheless a cold fact. He was constantly promising to museums and to others boomerangs that he said that he had brought with him from Australia, but he never kept his word. In Boston his boomerang came back to himself. 


\section{CHAPTER LXXI.}

\section{THE BUSY SEVENTIES.}

As heretofore stated, the '70s were busy years. I found work to do in many directions. It was during those years and the first couple of years of the ' 80 s that I prepared for the press in rapid succession "Julegave," "Den Norske Maalsag," "America Not Discovered by Columbus," "Norse Mythology," "Viking Tales of the North," "The Younger Edda," "Horn's History of Scandinavian Literature," and a number of pamphlets. Besides I wrote a large number of articles, many of them being of the controversial sort, for our Norwegian-American press. In addition to this I did considerable work preparing articles on Scandinavian topics for several encyclopedias.

Early in the '70s I became connected with "The Nation." I wrote practically all the reviews of Scandinavian publications that appeared in "The Nation." At the office of "The Nation" once during the '70s I met Theodore Roosevelt, then a fresh graduate of Harvard, with a very promising future. By the aid of this acquaintance I was able to induce the State Historical Society of Wisconsin to invite him to give one of our annual addresses. He accepted the invitation. Our friendship continued and I am the possessor of quite a number of personal letters from him. He wrote to me at least half a dozen times while he occupied the White House at Washing- 
ton. Our friendship continued until he committed what I deem to be treason to his friend, ex-President Taft. By his conduct to $T$ aft he forfeited, in my judgment, the confidence and good will of his fellow citizens. In my ethical code loyalty to friends is a cardinal virtue. I cannot endure a person who shows himself disloyal or ungrateful. 


\section{CHAPTER LXXII.}

\section{HUNGARIAN LITERATURE.}

In the second half of the '70s there was founded in Kolozsvar (Klausenburg) in Siebenburgen, in the eastern part of Hungary, a polyglot periodical "Osszehasonlito Irodalomtortenelmi Lapok," which means a periodical for comparative literature. It was edited by Dr. Samuel Brassai and Dr. Hugo Meltzl, the former the president and the latter a professor in the Royal University of Klausenburg. On this periodical I at once became a member of the editorial staff, and to it I made a number of contributions. The review had editorial writers in Germany, France, England, Russia, Italy, Spain, etc., and even in Iceland and in China. The purpose was to exhibit both the resemblances and the differences in the literatures of various countries. It was through this journal that I became acquainted with the Italian scholar, author, and poet, Tommaso Cannizzaro of Messina, Sicily, who afterwards translated my "Norse Mythology" into Italian and also published a biography of me with my portrait in a small book. While I was in Copenhagen he sent me casks of wine from his own vineyard. Since the great earthquake in Messina I have not been able to get in touch with this dear Italian friend, and I fear that he must have perished in that terrible catastrophe.

To give an idea of the kind of work that I did for this polygot review I may state that it printed my translation of An- 
dreas Munch's poem "The Bridal Party on the Hardangerfjord," of Runneberg's national hymn, "Our Land, Our Land; Our Native Land," and of Carl Ploug's "Long was the Glorious Folk Tree of Northland Split Into Three Small Withering Shoots." Then I wrote extended articles on the Swedish poet Tegner and on Finland's bard Runeberg. I contributed one article on what ought to constitute the boundaries between nations. I urged with great fervency that nations are not made by the accidental flow of a river or by mountain ranges; that the one thing that should be the test of national land-marks is the blood and the language. People of the same blood, with the same traditions and the same tongue should be permitted to live under the same roof as a nation, while those of different languages should not be compelled to obey the same laws and institutions.

The Greeks have been struggling for generations to realize this idea. They have succeeded in securing the independence of Greece proper, but there are outlying districts and many islands that still are subject to foreign dominion. To eventually secure the union of all Greece under one government, "The pan-Hellenic League" was organized, and as an appreciation of my article in the "Lapok" on what should constitute national boundaries I was elected one of the vice-presidents of this league.

Later I had an even more agreeable surprise. I had stumbled on a Reclam edition of the great Hungarian national poet Alexander Petöfi's strange story, "The Hangman's Cord," and had read with wonderment some of his poems. I had also obtained other snatches of Hungarian literature and to sum up my impressions I wrote an article for "Lapok" in which I eulogized Petöfi as more than the Robert Burns of Hungary, and lauded a number of Hungarian writers. I ended by declaring that if I had not courted, won, and wed the goddess Saga and so owed to her my devotion and work I surely would 
put on my best garments and try to win the favor of beautiful Hungaria. With this the faculty of the University of Kolozsvar were so delighted that they conferred on me the honorary degree of Doctor of Philosophy, and I had a charming letter from the venerable Dr. Samuel Brassai inviting me to come to Kolozsvar in order that he might himself have the opportunity of placing the laurel wreath on my brow. I am sorry it was too long and too expensive a journey for me to take. 


\section{CHAPTER LXXIII.}

\section{REMENYI AND PETÖFI.}

My interest in Hungarian literature paved the way for me to an intimate and exceedingly interesting acquaintance with the great Hungarian violinist, Edouard Remenyi. Whenever he came to Madison to give concerts he was sure to come to our home. Through him I obtained a knowledge and appreciation of Hungarian popular music which would otherwise have remained a sealed book to me. We were mutually interested in the Hungarian poet Alexander Petöf, whose weird story I had translated into English though I have not yet published it.

Petöf was a lyric and national poet of extraordinary talent and he was a Hungarian patriot. In a way he kindled the flame that produced the Hungarian revolution for independence in 1848. The way he did it was as follows:

In the third story, or attic, of a building on one of the principal streets in Buda-Pesth he had a small hand-press. $\mathrm{He}$ wrote his stirring revolutionary song beginning, "Rise, Hungarians, Rise!" to a familiar Hungarian melody. As fast as he could print the song on his hand-press he flung copies of it out of the window into the street. The passers-by picked them up and in a few days, so to speak, the entire Hungarian nation, men, women, and children, was singing "Rise, Hunga- 
rians, Rise!" I know of nothing to be compared with this unless it be the French "Marseillaise" by Rouget de Lisle.

The revolution broke out and so far as I know we have here the only instance of record where a poet becomes accredited to the army. The armies are furnished with surgeons and chaplains and fifers and drummers, but the revolutionists of Hungary appointed Alexander Petöf to accompany the army and write songs for the soldiers to stimulate their bravery on the field of battle.

In the battle of Schassburg his patriotism got the better of him and he picked up the arms and ammunition of a fallen comrade and rushed into the thickest of the conflict, and this was the last ever seen of Petöf Sandor. 


\section{CHAPTER LXXIV.}

\section{MORE ABOUT REMENYI AND PETÖFI.}

Petöf was born in 1823 and so he was only 26 years old when his career ended; but the literary work he had accomplished is simply astounding. There are Petöf societies everywhere in Hungary and new Petöf poems are frequently discovered. In quantity Petöf must have written fully as much as Robert Burns though he died eleven years younger, and his poetry, so far as I have been able to examine it, in English and German translations does not exhibit any lack of vigor or maturity. The Hungarian people were loathe to believe that their favorite poet really was dead. They conceived that he must have been taken prisoner and carried away to some foreign land and there kept in captivity. They demanded that the government should go and find him. The pressure on the government became so strong that the diet at Buda-Pesth had to appropriate funds and send men in search of Petöf in the same manner as Stanley went to find Dr. Livingston, or as navigators have been financed to seek the poles. The search was made; even the Russian exiles in Siberia were visited, but $\mathrm{Pe}$ töfi was not to be found.

My friend Edouard Remenyi had also taken part in the Hungarian revolution. He was a personal friend and a great admirer of Petöf. After the revolution Remenyi was exiled, but his violin was polyglot and could speak the language of 
every country. He located in London where he soon was honored with the title of violinist to the queen. As a violinist he ranked easily with Vieuxtemps, Sarasate, Wilhelmij, Ysaye, and I would like to add Ole Bull. He was a composer of note and is particularly celebrated for his great masterpiece, "Hymn to Liberty," in which he has given immortal expressions to the Hungarian patriotism.

In the course of time the Hungarian exiles were given amnesty by Austria and so Remenyi was able to return to his fatherland that he loved so well. He proposed a monument to the memory of Petöf. He gave concerts in every nook and corner of his native land and with his bow and violin he accumulated more than $\$ 100,000$. Other contributions were added to this fund and in Buda-Pesth may be seen today the Petöf monument, the greatest in all Hungary and one of the finest in all Europe.

I may give you an idea of Petöf's power over his readers by the following incident.

Once in the '70s I visited New York. One evening I walked into Steiger's book-store. I scanned the titles on the backs of a long line of the little books published by Philip Reclam in Leipsic and on one of them I saw "Petöfi: Der Strick des Henkers" ("The Hangman's Cord"). I paid my dime and put the book in my pocket. At the Astor House on going to bed I made the mistake of reading the first chapter of this little book; but it had taken such a hold of me that I could not lay it down again before I had finished it in the small hours of the morning. The next day I returned to Steiger's and bought the only other copy he still had of this book. This copy I sent to a literary friend. She afterwards wrote me that she had begun reading it after retiring at night and had put out the light and lit it again three times and did not close her eyes until she had finished the book. 
One evening at home I tried this book on Ole Bull. It made so powerful an impression on him that he would not go home until I had gotten to the end.

One Sunday morning Rev. M. Falk Gjertsen came to our

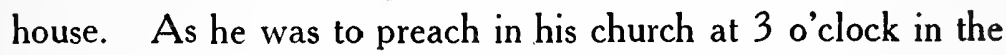
afternoon he asked to sit in my library to study his sermon. I was in the room and had picked up this Petöf book which was bound in a yellow paper cover. Mr. Gjertsen remarked that he was surprised to see me reading yellow-covered literature. I told him that this was a remarkable book and asked him to look at it. He insisted that he had no time for such literature and besides he had to study his sermon. I told him that in return for the use of my library and for the dinner that he was to get he must do me the favor of reading the first chapter of "Der Strick des Henker's," which would not take him over ten minutes. He read the first page.

"Why," he said, "this is blasphemy," and threw down the book.

I kept insisting that he must read two pages more and finish the first chapter. He picked the book up again. When he had finished the first chapter he looked at me and asked: "What became of Rosa?"

I answered: "I am unable to tell you; but you can easily find out by reading a few more pages."

He read on and on; he swallowed his dinner in a hurry and succeeded in finishing the book just in time to go to church.

I remember one cold clear night that we took Remenyi after his concert up to the university observatory to look at the moon and how enthusiastic he was. He kept on shouting: "Colossal!" "Co-los-sal!" with great accent on the last syllable. At another time he came to our house after the concert and Mrs. Anderson served a Dutch lunch. After the lunch he played a number of Hungarian melodies, but the maid was clearing the table in the dining room and in a passion he rushed into the 
kitchen and told the girl that he didn't want any accompaniment of knives and forks. At his concerts he couldn't brook the least noise or disturbance. He would stop in the midst of his piece and wait until absolute stillness was restored.

Remenyi was not prepossessing in his appearance. He didn't have Ole Bull's splendid physique. He was stout, perhaps even corpulent, and his manners were not at all graceful as compared with many other artists who might be named. $\mathrm{He}$ was well aware of this defect himself and to take some of the edge off it he made his clumsiness more conspicuous than it really was. He once said to me:

"I send my soprano out to sing; her voice is cracked; she is passe, a wet blanket on the audience. Then my pianist plays a solo, something that the audience cares nothing about; another wet blanket. Then Remenyi comes out himself, corpulent and clumsy, looking like an old monk. The audience sighs distress and says, 'That can't be Remenyi; that fellow can't play; but then I begin to play, and I stir--r them up, stir-r-r them up."

The last time he visited Madison I invited him for a drive. On this drive he took me into his confidence; he told me that a friend of his, a distinguished author in New York, was writing a book on the world's greatest four geniuses and he asked me whether I could name them. I had talked enough with Remenyi to know whom he considered the four greatest intellects that had ever lived, but I made up my mind to tease him just a little. I began, in answer to his question, with Homer.

"Correct!" he said.

Then I said, "Michael Angelo."

"Correct!" he shouted.

Then I said, "Petöf Sandor."

"Correct," he replied.

Then I gave as the fourth Shakespeare.

"Oh no!" he said. 
I suggested Goethe, then Raphael, Mozart, Beethoven, Byron, Burns, and several other names, but all were wrong, and getting impatient he broke out, pointing his finger at his breast:

"It is me! It is me! And do you know for why? Because I write "Hymn to Liberty!' "

He regarded "Hymn to Liberty" as the world's greatest musical composition and it must be admitted that in many respects it is a marvelous work. It contains climax upon climax. When you think the last possible climax has been reached there are still several in store for the hearer. The theme is wonderfully constructed out of the most beautiful popular Hungarian melodies.

A few years after we had taken this drive Remenyi died in the harness. He fell dead on the stage while playing before a large audience in Oakland, Cal. But my meetings with him I shall always cherish among my sweetest recollections. 


\section{CHAPTER LXXV.}

\section{BIRTH OF THE MISSOURI SYNOD.}

With Mr. Barton's permission I am going to make a digression. Within a few hours it will be the 19th of February which may be regarded as the most important date in the history of the Lutheran church on this continent.

On the 19th of February, 1839, just 75 years ago, four steamers from New Orleans arrived in St. Louis. This metropolis of nearly a million inhabitants was then a city of only 12,000. From these four steamers there went ashore $750 \mathrm{Ger}-$ mans, who had that same year emigrated from Saxony. They were Lutherans and had left their native land to find a home where they could worship God according to the dictates of their own consciences. The church in their fatherland had drifted away from its old moorings into indifference and false doctrine. It was in some respects a repetition of the old familiar story of the Puritans and the Mayflower, and reminds us of the sloop "Restaurationen" with its precious cargo.

These Saxons had left Germany in five ships for New Orleans. The four arrived after stormy voyages safe in $\mathrm{New}$ Orleans and those who arrived first waited for the others. The fifth ship named Amalie was never heard from. It was lost with all on board. The passengers of the four ships embarked in four river steamboats and reached their destination at St. Louis at noon on February 19th, 1839. How happy they must have been when they at length arrived in the Canaan of 
liberty in the remote west. They did not come as mendicants; they were well supplied with money and had with them all kinds of furniture and household utensils. Dressed in their German national costumes, they must have made a deep impression on the citizens of St. Louis. The great majority of these 750 were ordinary laborers, artisans, and farm hands, but there was a large sprinkling of men of culture. Among them were seven ordained ministers and eight candidates ready for ordination. There was one school teacher and three normal school graduates; there were three doctors, one doctor of laws, and one lawyer. Besides there were several of the office holding and commercial class. They had with them a large library, a church organ and three church bells and various articles serviceable for equipping a church.

All the artisans, farm hands, and ordinary laborers, parents and children, young men and young women, aged and youthful scattered through the city and found homes and work as best they could. The cultured members of this party rented a large building on Broadway street and in it they all lived pretty much as one family.

In this party was the learned Dr. C. F. W. Walther, who was destined to become the greatest and most influential Lutheran on this continent. On that day, Feb. 19th, 1839, he organized these people into a congregation which became the corner stone of the great Missouri Synod, with its fully 4,000 congregations at the present time. This Synod has built for itself a large number of monuments in this country in the form of churches, seminaries, colleges, academies, parochial schools, hospitals, homes for the aged and for orphans. It has established great publishing houses and from its presses have poured forth a constant siream of books and periodicals. It was from Dr. Walther and the Missouri Synod our Norwegian Synod received aid when it was in need of ministers. The Norwegian Lutherans in America owe to the Missouri Synod a greater 
debt than they perhaps yet realize. Surely tomorrow will be a great day of rejoicing throughout the Missouri Synod and I have here attempted to contribute my little mite.

$* * \%$

Much of my time and energies throughout the '70s was, as those who read the newspapers of that time are well aware, given to controversies that attracted the widest attention and to write the story of my life without giving the main facts of these controversies seems to me very much like playing Hamlet and leaving Hamlet himself out. I have considered the matter with much care and find that I could not give even a superficial account of these matters without running the risk of wounding the feelings of people who on the one hand are entirely innocent and whom on the other hand I hold most dear. Times have changed; the old sores are healed, and I could give the stories entirely without malice, but I think I must here apply the old saying that "discretion is the better part of valor" and so avoid hurting anybody's feelings. Nor would there be any use of entering upon this phase of my life unless I did so with sufficient details to make the subject clear to those of the present and perhaps also of future generations. 


\section{CHAPTER LXXVI.}

\section{BJÖRNSON VISITS AMERICA.}

At Ole Bull's funeral in Bergen in August, 1880, Björnstjerne $B$ jörnson was the principal speaker, and in his address he asked his hearers to give their sympathy to Ole Bull's widow who was standing near the open grave.

Between Ole Bull and his children and their immediate friends there was much irritation on account of Ole Bull's marriage to Miss Thorpe. All this ill will would now in all likelihood be centered against Mrs. Bull. She, therefore, delighted with the reference Björnson had made to her at the grave, sought him for protection against Ole Bull's children and their backers. She conceived the idea of inviting him to go with her to America where she would introduce him to Ole Bull's choice friends in the east, such as Longfellow, Lowell, Holmes, and the rest of the elite in American literature, art, and science. She was going to have him lionized. She also secured Björnson's promise that he would immediately write Ole Bull's biography. Björnson was comparatively poor in purse, while Mrs. Bull had an abundance of money. She offered to defray Björnson's expenses to America and Mrs. Björnson was made to believe that her husband would be greatly benefited by such a journey. He would get rest, recreation, and his horizon would be widened by coming in touch with the best in 
American life. And it must not be forgotten that Björnson was at that time a full fledged republican.

Mrs. Bull had no idea of letting Björnson visit his plain countrymen in the Mississippi valley and the far west. She and the distinguished writers in the far east were going to have him all to themselves and she was going to be his manager to whom all would have to come, if they wanted the honor of meeting the great lion from Norway.

The first part of the program was carried out. Björnson came with Mrs. Bull to Cambridge, Mass. I had to telegraph a story of 500 words to the "Literary World," then edited by Lyman Abbott, to inform the American people who the distinguished visitor was who had come from Norway to our shores. And Björnson was received with marked distinction on all hands.

But Mrs. Bull soon learned to her sorrow that she had a real elephant on her hands and that she was utterly unable to manage him. Björnson got tired and disgusted with all her plans of making him a subject of exhibition. He would not be handled in this way. He was bound to "gang his own gait" and was not willing to put on full dress at the bidding of Mrs. Bull. Nor was he able to endure the American customs of visits, dinners, and receptions. There was a rigidness about them unbearable to a man of Björnson's antecedents and temperament. At times he could not help being what was thought positively rude. I being the one he knew best in the west he wrote to me again and again complaining most bitterly and telling me that his life in Cambridge and Boston was unendurable. I invited him to come to Madison and told him I would arrange a series of lectures for him among his countrymen in America, just as I had previously done for Kristofer Janson.

Finally it came to a break between him and Mrs. Bull and her family. There was a terrible scene, Björnson swearing vengeance on all of them. He fled. He had money enough 
to take him to New York; there he visited his old Danish friend, Clemens Petersen. It was Petersen who first introduced Björnson to his Danish readers. Petersen was looked upon as one of the most gifted esthetical writers that Denmark ever produced. In America he mastered the English language completely and did much encyclopedia and magazine work.

From Clemens Petersen Björnson borrowed money to take him to Madison.

Mrs. Bull, Mrs. Thorpe and Mr. Thorpe got frightened and wanted to make peace with Björnson. They traced him to Chicago. Björnson was at the Palmer House and Mrs. Bull and the Thorpes at the Grand Pacific. They wanted me as a mediator. They telegraphed for Mrs. Anderson and me to come to Chicago at once and there was all this muss and trouble to be straightened out. I tried to pour oil on the troubled waters, but Björnson was utterly implacable. Only the thought of Mrs. Bull and Mrs. Thorpe made him rave like a tiger. I advised Mrs. Bull and her mother to drop the matter. No compromise with Björnson was possible. The only thing was to give him time to become occupied in other directions and so forget all about it. The advice proved to be correct for Björnson soon got busy with other work and forgot all about Mrs. Bull, Mrs. Thorpe, and Cambridge and Boston.

The idea of Bjornson writing Ole Bull's biography had to be abandoned and Mrs. Bull decided to undertake this work herself. She knew that I had a lot of notes and printed material and so a few days after this meeting in Chicago she and her parents came to Madison to secure my biographical material. I gave her all I had, and what was done with it I have already told in connection with my reminiscences of Ole Bull.

I met Björnson at the Palmer House in Chicago. He at once asked me to arrange addresses for him to his countrymen and made me his minister of finance. He made Madison his 
headquarters and lived at the Vilas House, but of course he was a daily visitor at our home on the south side of West Washington avenue between Broom and Bassett streets, the house owned by Alex. Gill. He liked to smoke his pipe, but he talked so much that the light frequently went out and he instructed Mrs. Anderson to have matches all over the house wherever he happened to be when he wanted one.

Björnson was of the peripatetic kind. Like Aristotle of old, he always walked while he talked. He was a man of large frame, tall, with heavy eyebrows, a woman's lips, a finely chiseled nose, a broad and high forehead, the head crowned with a veritable forest of hair, pompadour.

While Björnson was here a terrific war was being waged in Norway as to who should be the speaker on the following 17th of May at the unveiling of the Henrik Wergeland statue in Christiania. Björnson always had had his share of enemies, but these had vastly increased in number since he, in 1879 , publicly abandoned his Christian faith.

One evening while at our house Björnson received a cablegram from Norway informing him that he had been chosen as the speaker at the Wergeland festival, though by a narrow margin. It made him dance with joy. He was happy and acted like a little child that gets what it wants. At our house I showed him a poem by the Norwegian poet Theodor Caspari. This he interpreted as a reflection on himself, and he at once asked for paper and pen and sat down and wrote a lampoon in verse, addressing the first part of it to Theodor Caspari's father, Prof. Caspari, a distinguished member of the theological faculty of the University of Christiania. In it he slurs the old professor in regard to his religion and theology and then smothers him with sarcastic pity for being the father of Theodor.

I had the opportunity of observing Björnson's way of composing poetry. He wrote his lines wide apart. After finishing the poem he went over it at least half a dozen times and each 
time he struck out words and substituted others in the intervening spaces. He kept on in this way until he became entirely satisfied with the rhyme, meter, and diction. I have had prose compositions of Björnson's treated somewhat in the same manner. The next day he sent his lampoon to a paper in Christiania where it was published and I believe lost him many friends. His attack on the poet's father was uncalled for and utterly indefensible.

It was arranged that Björnson should speak in all the principal Norwegian centers from Chicago as far west as Fargo, N. D. I at once published a notice requesting all who wished to hear Björnson to write to me in order that I might give them a date. The price of each address was $\$ 100$ and half of the profits over that amount. I insisted that he must abstain rigidly from discussing religious topics as he well knew the vast majority of his countrymen were loyal to the church and he ought not, in my opinion, utter a word to wound their religious feelings. To this he agreed. He chose for his subject "The Norwegians, Swedes and Danes." In his address he gave a rapid historical sketch of these peoples and then pointed out the chief distinct characteristics of each of these nationalities. He did this with such consummate skill that the Norwegians in his audiences thanked God that they were Norwegians; the Swedes were delighted to know they were from Sweden and the Danes would rather be Danes than anything else in the world. $\mathrm{He}$ made no invidious comparisons. Equipped as he was, with a magnificent physigue, with a halo of fame, with a clear sonorous voice, and with great talent for speaking extemporaneously, it must be admitted that Björnson was one of the greatest, if not the greatest, orator that Norway has ever had. As was said of Nestor in Homer, "words flowed from his lips sweeter than honey."

But the leaders in the Norwegian churches would not leave Björnson in peace; they knew that he had forsaken the Chris- 
tian faith and that in Norway he had made severe attacks on the church. They did not want him to visit Norwegian-Americans and instill into them agnosticism and religious doubt. So they attacked him publicly both in the secular papers and in the official church organs. They urged people not to attend his addresses, but this seemed to serve only to increase his audiences. These attacks coming to Björnson's notice irritated him in the extreme. He had promised me not to refer in any manner to religion, but as these attacks on him continued he could not constrain himself any longer and he swore that he would lecture to his countrymen about the prophets. And so whenever he got the opportunity he would give his regular address and then arrange a second free talk on the prophets. He wanted to get even. I think this was a mistake on his part, but it was in harmony with his general makeup and temperament which if I should attempt to describe with one word that word would be recklessness. No other man I ever knew could be more provokingly reckless than Björnson and of this I could give numerous examples were it necessary. He spoke twice in the City Hall in Madison and the second time on the prophets. As he was bound to speak on the prophets I refused to introduce him or to occupy the stage with him and so he got John A. Johnson to do this instead.

In his farewell address in Chicago he went out of his way to ridicule and to speak ill of his countrymen in America. He described them as ignorant, uncouth, and as unfit for cultured people to associate with. He spoke of how the atmosphere became unbearable in the halls where they assembled more or less intoxicated and their clothing reeking with all sorts of bad, odors. His complaints were vastly exaggerated and came with little grace from one who had been received with so much hospitality and honor.

The winter of ' 80 and ' 81 was one of the severest known in the west. Much of the time there was so much snow that rail- 
road travel had to be abandoned. Björnson got on one trip to Nora Springs, a very small town in Iowa, and there he was snowbound for more than a week. The frequent blizzards made several rearrangements of his route necessary. While in Nora Springs he spent his time writing articles for the papers in Norway, but I can imagine how this imprisonment in a small country hotel must have annoyed him.

In spite of the unfavorable weather conditions, his trip was a pronounced success financially. When he returned to Madison I had more than $\$ 10,000$ in the bank to his credit. Of this amount he urged me to take 20 per cent, or $\$ 2,000$ as my commission, but I did not accept a single cent. Björnson was at the time up to his eyes and ears in debt. He had bought a large farm, Aulestad, in Gudbrandsdal, and lost his home in Christiania by foolishly going security for a friend and there was no prospect that he ever would be able to liquidate his debts. Excepting what he needed for traveling expenses I sent the $\$ 10,000$ to Consul Th. J. Heftye, who had charge of Björnson's finances in Norway. Heftye applied the money to appease some of Björnson's most pressing creditors.

While Björnson was in Madison he appointed me as the translator of his works into English and I secured Houghton, Mifflin \& Co., in Boston, as his publishers. I at once went to work and my translation of Björnson's stories appeared in rapid succession in seven volumes. Owing to want of copyright laws they were all reprinted in London. In Christiania, in 1886, I handed Björnson about $\$ 500$ as his share in the royalty paid me by Houghton, Mifflin \& Co., and the same day he scattered this money among the poor of that city, sending his wife out to make distributions.

Björnson possessed most generous impulses and with all his great faults I could never help loving him. It seemed to me as if I loved him on account of his faults. 
I arranged with William Dean Howells to have my translation of one of Bjornson's dramas published in the Atlantic Monthly simultaneously with its publication in Denmark in the original. Björnson sent me his drama "En Handske" (A Glove). I received it in manuscript, and translated it; but the editor of the Atlantic Monthly refused to print it on account of its naturalistic tendency. The publishers returned to me the manuscript and sent me $\$ 100$ for the work I had done. This helped to open my eyes to the immoral course which the Ibsen and Björnson literature had then taken. Whatever sympathy I may have had for this trend in modern literature, I got entirely rid of in my more intimate intercourse with its promoters while I resided in Copenhagen. 


\section{CHAPTER LXXVII.}

\section{ARNE KULTERSTAD.}

The following incident which I have told in my introduction to my translation of Björnson's novels throws much light on Björnson's character. That part of the incident which occurred in Madison took place in my presence.

While Björnson was stopping at the Vilas House in Madison in the beginning of January, 1881, an elderly man came in to see him. At the sight of Björnson the man was very much moved; tears choked his voice, while he attempted to greet the great skald of the north. Björnson also appeared deeply touched by the sudden appearance of his guest and grasping his hand he exclaimed:

"Why are you here, my dear Arne?"

The scene of the meeting was intensely affecting and the reason for it will be evident from the following explanation:

This Arne was not the "Arne" of Björnson's novel by that name, but Arne Kulterstad, a man whose life he had saved about twenty years previously. Arne was now a man about 50 years old, had a large, powerful frame and in his younger days must have been the very picture of strength and manly beauty.

About the year 1855 Arne, who had been a sergeant in the Norwegian army and as such had become noted for his athletic strength as well as for his kindly disposition and honest 
character, had a serious feud with one of his neighbors in his mountain home in Valdres, a valley in the central part of Norway. According to Björnson's testimony Arne's enemy waj a dissipated, mean, cringing, base villain who at a party succeeded in getting Arne drunk and then in persuading him to sign papers by which he lost his old homestead. The feud grew in bitterness from year to year. One day when business had brought them together at the same place it came to blows between them and his foe drew a knife and gave Arne severe wounds in his hand and arm, the marks of which Arne exhibited to me.

There were many other aggravating circumstances among which may be mentioned as the worst the fact that upon the farm of which his enemy had obtained possession, Arne's father lived and received his annual allowance according to Norwegian law. When the father lay upon his deathbed Arne visited him and learned that he had been ill treated and that his death had probably been hastened by the cruelty of the owner of the farm. This so enraged Arne that revenge was a mere question of time and opportunity.

The opportunity was not easily found for the villain feared Arne and carefully avoided meeting him. He never went out alone. One morning early he had, however, deemed it safe to go a short distance from home with his team. But it so happened that Arne too had gone out that morning with his rifle to hunt, when on returning he saw his enemy and at once determined to give him a mark at least as severe as the one he bore himself. He raised his gun to take sight. He was one of the best marksmen in the country and had brought down many a bird on the wing: but unfortunately as his enemy was walking by the side of his team he happened to stumble at the very moment when Arne pulled the trigger and instead of giving him a severe wound in the arm as he intended the bullet entered his breast and he soon expired. 
Arne Kulterstad was convicted of murder and sentenced to death. This was in the lower court. The case was appealed. Mark now the remarkable incident which occurred!

Having been sentenced to death by this lower court Arne was to be transferred to an adjoining bailiwick. The bailiff who had him in charge knowing his prisoner's honesty and truthfulness did what probably no other bailiff ever did. The bailiff had some errand to attend to, and Arne knowing this told him that there was no necessity of his going with him or sending any guards, for he would go alone and place himself in the hands of the officer of the next bailiwick; and such confidence had the bailiff in Arne's uprightness and integrity that he unhesitatingly sent him alone without any guard and Arne promptly did as he had agreed!

The sentence of the lower court was confirmed by the supreme court without any recommendation to pardon. As there was no direct evidence in the case, Arne's lawyer had advised him to deny everything. The effect of a confession was now resorted to, but without avail. He was locked up in his cell and in a few days he was to be beheaded.

The young, ardent poet Björnson was at this time in Christiania. He had heard of the case; had read all that had been said about it in the press and had become so deeply interested in it that he went to the prison partly to see this remarkable criminal, partly out of curiosity to see a man standing at the threshold of execution. He had a long talk with Arne and was much affected by his manner and by his story of the aggravating circumstances which had led to this great crime. As he was about to leave the prison cell, Arne arose, stretched out both arms to Björnson and beseeched him in the tones of deepest agony:

"Oh, save me!"

These words rang in the ears of the poet and he determined to move heaven and earth if this were possible to procure a 
pardon. He immediately set himself to work and wrote for the press what he still in 1881 considered the most masterly article of his life, and we all know what Björnson could do with his wonderful pen. This article set the whole community, the whole land, in commotion. The wives and daughters of the very judges who had pronounced the sentence and the wives of the members of the king's cabinet were the first to sign a petition to the government for Kulterstad's pardon. The death sentence was changed by the king to imprisonment for life.

For twenty long years Arne had to remain in prison, but in 1880 he was paroled with the understanding that he would leave the country. By this time his wife had died and his family was scattered. After twenty years of confinement within the walls of a prison liberty itself scarcely seemed a boon. He came to Wisconsin where he had a married daughter, Mrs. Andrew O. Grinde, near Mt. Horeb. Hearing of Björnson's arrival in Madison he immediately came to visit him and the meeting of these two men was indeed a most affecting scene.

"You are my second father, Björnson, and I cannot tell you how much I love you; I owe my life to you," said Arne to his benefactor.

Arne was poor and felt at home nowhere. America seemed no place for him. With his usual kindness Björnson received him as cordially as a brother. He offered to care for poor Arne in his old age and directed me to furnish Arne with the necessary funds to defray his expenses back to Norway where he was to have a home and employment on Björnson's farm, Aulestad. This pleased Arne very much, but before I could get him started on his journey information in regard to this plan had come to the knowledge of the authorities and protests were received here against his returning. The supposition was that if he went back to Norway he would lose his parole and be sent back to prison. 
All must admit that this incident sheds a pleasing light on the character of $B$ jörnson.

Arne Kulterstad spent the rest of his days in the vicinity of Mt. Horeb, Wis. His long life in prison seemed to have undermined his character as a man. His neighbors did not seem to think very highly of him. He was even suspected of crime. A daughter of Arne's was for a time our maid. She was a fine looking, well bred girl, but she did not seem to care for or take any interest in her father. Of course she was a mere infant when her father was sent to prison and she looked upon his coming here as a misfortune. She afterwards married John Mennes of Mt. Horeb, Wis. Arne died several years ago. 


\section{CHAPTER LXXVIII.}

\section{MORE ABOUT BJÖRNSON.}

On his return to Norway Björnson translated and published as a tract which sold for less than three cents Col. Robert G. Ingersoll's lecture, "Mistakes of Moses." He gave it the title "Tænk Selv" (Do Your Own Thinking). Then he had a Mrs. Amalie Möller translate Waite's large work on the gospels in which the author attempts to show that these were written centuries after the death of Christ. In fact from that time on he did all in his power to eradicate Christianity among the Norwegian people. His books contained more or less overt assaults on the Christian religion and several of them fairly reeked with indecency. He had begun as a romanticist and ended as an extreme naturalist.

I have not much more to tell of my meetings with Björnson. I met him a few times while I resided in Copenhagen. He was there one year and lectured in all the principal cities in Denmark on one of his great hobbies, "Engifte og Mangegifte" (Monogamy and Polygamy). It was a plea for sexual purity.

I have stated that Björnson was a great orator. I want to modify this. He was not an orator of the kind we have in our minds when we think of Daniel Webster, Charles Sumner or Henry Ward Beecher, but he was of the revivalist order. He was an eloquent exhorter. We hit the nail more squarely on the head if we compare him as a public speaker with the 
Norwegian Hans Nielsen Hauge or the American Dwight L. Moody. The preacher and exhorter were prominent in his whole manner when he addressed the public. While I wholly disapproved of the course he took in the last period of his life there was never any break in our personal relations. When Americans visited him at his dear Aulestad he always hoisted the big American flag that Mrs. Anderson and I had given him and invariably sent us his greetings. His widow has published Björnson's correspondence. In that connection she asked me for the letters that I had received from her distinguished husband, but I declined to loan them to her for the reason that they contain aspersions on the character of people still living or whose children are living. These letters should not be published during the life of the present generation. I have rigidly abstained from quoting from them in these memoirs. 


\section{CHAPTER LXXIX.}

\section{LIFE INSURANCE.}

In the fall of 1883 I received a very tempting offer to engage in the life insurance business to solicit insurance for the Equitable Life Assurance Society of New York. The Equitable signed a five year contract to pay me $\$ 2,500$ a year salary and in addition to that 40 per cent commission on the business I secured. This offer was too tempting for an impecunious man like me, with a family on my hands, to resist.

I had been teaching continuously nearly twenty years. The recognition of the Scandinavian languages was an accomplished fact. Others could now easily carry on the work which I had inaugurated. A few years devoted energetically to moneymaking would put me in a position to devote the rest of my life to the literary field which I had opened. I wanted an income so that I could give my whole time to study and writing. But there is many a slip twixt the cup and the lip as the sequel will show. I went to New York and in the office of the Equitable I signed a contract and from there I sent my resignation as professor of Scandinavian languages to the president, John Bascom, of the University of Wisconsin. 


\section{CHAPTER LXXX.}

\section{PAUL DU CHAILLU.}

I think this is as good a time as any to speak of my acquaintance with that remarkable piece of humanity known throughout the world as the discoverer of the gorilla. I mean Paul Belloni du Chaillu. He brought the first live gorilla to Europe.

Paul du Chaillu was born in New Orleans of French parents in 1831. As a boy he was sent to Paris to be educated. While yet a young man he persuaded his father to furnish him means to explore central Africa. Of his explorations there he published a voluminous report of indifferent scientific value, but he made use of his experiences in producing five books for children, among them "Lost in the Jungle" and "My Apingi Kingdom." These five volumes were published in this country by the Harpers in New York and had a phenomenal sale. The author became the favorite of the children throughout the world and was a very successful lecturer. He was a small, utterly bald-headed, wiry and exceedingly vivacious fellow, and could make himself look like a real monkey. But Paul grew tired of Africa and turned his attention to the extreme north of Europe. He traveled in every nook and corner of the Scandinavian countries, became everybody's pet from the king down to the humblest peasant and of his travels he published "The Land of the Midnight Sun" in two sumptuous volumes.

In the winter of 1877 I had given a course of lectures at the Peabody Institute in Baltimore and one of these, "The Viking 
Age," I repeated in Chicago on my way home. Without my knowing it, Paul du Chaillu was one of the audience. At the close of the lecture he came and introduced himself to me and complimented me on my lecture. We became fast friends at once.

Paul never married; hence he was free to go and come to suit himself. I invited him to go home with me to Madison. He accepted the invitation and the next night after midnight we entered our little home on Washington avenue and I put him to bed. He remained at our house more than a week, the delight of a large number of Madison children.

One day while we were seated at the table our little boy George stole behind him and impressed a kiss on his bald head. One afternoon he gave a lecture to the school children of Madison in the auditorium of the city hall. There was a stream of children calling at our house to shake hands with $\mathrm{Paul}$ and get his autograph.

When Paul was not traveling he made his home in New York city. When I went to New York to sign a contract with the Equitable, John E. Burton, later of Gogebic fame, was with me. Burton represented the Equitable and had a contract with the company covering Wisconsin, northern Michigan and Minnesota. I was to report to his agency. While in New York I suggested to Burton that we go together and call on Paul. We went and found him at home. As Paul had emjoyed a week's hospitality at our house, he desired to get even in a way and so he invited Burton and me for a drive. I suppose he wanted to show these two men from the woolly west the great city of New York. He took us through the principal streets, to Riverside and Central Park and finally to a Delmonico restaurant for a sumptuous dinner. He ordered everything of the best without asking the price. He gave a signal to the waiter that he wanted the tickets; but how he wilted! The bill called for $\$ 77$ and the poor fellow didn't have a third of this 
amount in his purse. He had ordered three small bottles of old Burgundy and these came to $\$ 48$ in the bill.

Paul was at his wit's ends. He didn't like to confess that he who did not come from the woolly west, but was familiar with the ways of the great cities, was unable to pay. Mr. Burton and I saw his dilemma and so between us we loaned him $\$ 60$, knowing that we could get money, if we needed it to go home, from the Equitable. The next morning Paul came to our hotel and reimbursed us, making all sorts of apologies. This was surely one on Paul.

I met Paul again in Copenhagen. When I arrived there he was living in that city writing his great work "The Viking Age," two volumes, published afterwards by Murray in London and the Harpers in New York. When I got to Copenhagen he was living in sumptuous quarters in the finest part of the city. There was with him a millionaire bachelor from New York and together they had a high time, the bachelor millionaire footing the bills.

Paul had as his secretary the distinguished American scholar Samuel Kneeland, but he (Kneeland) was one of those straight-laced, correct living Americans and got tired of the extravagant carousings of Paul and his friend. After my arrival Kneeland left and a year or two afterwards I read of his death in Hamburg, Germany. Then Paul's millionaire friend also left him and he had to paddle his own canoe. He was gathering materials for his "Viking Age" and was having hundreds of expensive cuts made. The whole subject was an unexplored country to him, but he shrewdly got an Icelandic student at the University of Copenhagen to help him and his work kept slowly progressing.

I took Paul with me and introduced him in many of the most prominent families as the distinguished discoverer of the gorilla, and I even brought him into diplomatic circles. Then his funds gave out. He became utterly destitute. Like Knut Hamsund 
he moved into cheaper quarters and he avoided the expensive restaurants. Then he came to me in great embarrassment and asked me to lend him 100 crowns Danish money. I said:

"Paul, you can have all the money you want; had you not better take 500 or 1000 crowns?"

"No," he expected money from New York and from London and 100 crowns was all he wanted. Then he insisted on giving me his note for that amount. He got paper and pen and wrote, "For value received, I promise to pay," etc., and signed his name. In a couple of weeks he came again looking very much abashed, explaining that the money he expected had not come and asked for a loan of another 100 crowns. It was impossible to persuade him that he ought to let me give him more, and again he went through all the formality and gave me his note. No money came either from New York or from London. He came to me a third time, a fourth time, a fifth time, all the intervening times, and at last the fifteenth time, each time refusing absolutely to borrow more than 100 crowns and each time insisting on giving me his note. He explained that I had a family; that he might die and that for my family's sake I ought not to lend him money without having something to show for it. I now had a stock of fifteen of his notes.

At length, in the summer of 1889, "The Viking Age" made its appearance and with it Paul got money. From his first remittance he reimbursed me and got his notes back. He insisted on giving me a large amount as interest, but this I, of course, declined to accept.

One of our mutual friends, the well to do, highly educated and large hearted F. P. Möller, Ph. D., decided to celebrate the publication of "The Viking Age" as an event of importance to Scandinavia. Möller invited a number of Copenhagen savants, among them the distinguished George Stephens of the University of Copenhagen, author of the monumental work on the northern runes in two magnificent folio volumes. Paul was the 
guest of honor at this swell banquet given in one of the principal dining rooms of the Hotel Phoenix. There were speeches galore and $\mathrm{Paul}$ was smothered with eulogies. In responding to the toast in his honor he made a clean breast of the straitened circumstances in which he had been and told how I had come to his relief. He made a full statement concerning the fifteen notes. For this the host chided him. He said that impecunious scholars should not borrow money from each other, but should come to their friends who had money and get what help they needed. Möller ended by making the demand that whenever the authors Paul du Chaillu and R. B. Anderson were out of funds, they should draw on him and he would not fail to honor their drafts.

The last time I met Paul was at a banquet given by the Scandinavians of Chicago at the Auditorium in honor of the Arctic explorer Fridthjof Nansen. Paul had come all the way from New York to be present at that festival, where by the way I was one of the speakers. Not long thereafter he went to Russia and the papers contained a telegram that he had suddenly expired while walking on one of the streets in St. Petersburg.

All in all Paul was an exceedingly interesting personality. While he did not seem to know any language thoroughly he conversed readily in a number of tongues, including Norwegian. The last he acquired after he was forty years old. Even his English was very broken. 


\section{CHAPTER LXXXI.}

\section{LEAVE THE UNIVERSITY.}

President John Bascom did not fail to tell me that he thought I had made a great mistake in resigning my professorship, but the step had been taken and what was done could not be undone. The Norwegian students at the University held a meeting and passed resolutions which were nicely engrossed and presented to me. Grief over a departed friend is not felt so keenly at the moment and during the excitement of the funeral, but takes possession and tortures later on, and so it was in my case, and it took me considerable time to become reconciled to the fact that my ingoings and outgoings at the University had ended for all time. Many of the students whom I had the opportunity to instruct have since become prominent in various walks of life, some in science, others in education and many have attained high positions in the public service. I can't help looking upon my old pupils, both at Albion academy and at the University of Wisconsin, as in a certain sense my children, as if they were of my kith and kin. Of course I am particularly proud of the Norwegians who have since established careers for themselves. A large number of these would probably never have gotten a university education but for me. It might be interesting to mention some of them by name, but this might cause invidious distinctions. It would seem best not to mention any when I cannot call attention to all, as one not eulogized might wonder why I bestowed praise on others rather than on 
him. I shall therefore have to confine myself to referring all those who may be interested in this matter to the various University of Wisconsin catalogues, especially to the alumni catalogues.

It might seem that I ought to say something about how the work which I established with so much difficulty has been carried forward since my resignation, but for reasons that $I$ do not care to discuss in this story of my life, I shall have to avoid any reference to it here. 


\section{CHAPTER LXXXII.}

\section{LIFE INSURANCE CONTINUED.}

In the writing of life insurance I achieved extraordinary success. The people did not run after me to get their lives insured, but if I had sized a man up as insurable he was pretty apt to become my victim. For the year 1884 the Equitable divided the United States into four districts and offered a prize to the most successful agent in each district. I won the prize in the northwest quarter. It was an Equitable emblem made by Tiffany in New York with a substantial purse added.

I worked for the Equitable seventeen months and in that time I wrote over a million and a quarter of insurance and earned in salary and commissions more than $\$ 17,000$. I wrote the first $\$ 100,000$ policy in the west.

There was a difference between earning $\$ 150$ a month as a professor and more than $\$ 1,000$ per month writing insurance.

I was in Eau Claire, Wis. I was insuring people right and left. One evening a number of people, the most of whom I had insured, were gathered in Andrew Hollen's clothing store. They were surprised at my success in getting business, but Mr. Hollen knew one man whom he was certain I could not insure. If I succeeded in insuring that man he would give me the best hat in the store. If the man was insurable I agreed to have his application inside of 24 hours; if not I would send Mr. Hollen a barrel of apples. 
The man in question was Casper Syverson, a leading grocer on the east side. Hollen knew that Casper Syverson had been insured in the Charter Oak, a company that had failed. Having lost his money there he had determined never to invest another penny in life insurance. Mr. Hollen further knew that Syverson was a very great admirer of Prof. Sven Oftedal; that Sven Oftedal always was Syverson's guest when in Eau Claire and that Syverson entertained a corresponding contempt for R. B. A. on account of the relations between Oftedal and me. Of all this I was informed and I had a difficult task before me the next day.

In the middle of the forenoon the following day I went empty-handed to Casper Syverson's store and found him at his desk. I said:

"Is this Casper Syverson?"

He replied: "It is; what can I do for you, sir?"

I answered: "I don't suppose you know me. My name is R. B. Anderson and I would like to have an interview with you."

The name R. B. Anderson seemed to give him quite a shock, but he answered quite gracefully that he was busy and could not give me much time. Then I took a little book out of my pocket and addressed him about as follows:

"I am at present, as you may have heard, engaged in writing life insurance, but I am trying to kill two birds with one stone. I am also interested in gathering historical material concerning the Norwegians in America and in connection with my insurance work I am gathering data in regard to Norwegians who have been successful in this country, and you are one of these, Mr. Syverson. I would like to put down in this little book the principal facts of your life, if you will permit me to ask you a few questions." 
Barkis was willing. I took down carefully in my note-book the date of his birth, the place where he was born, the year of his emigration and the other chief facts of his life.

"Now, Mr. Syverson," I said, "when you left Norway you were poor like the most of the emigrants, but you have prospered. You had native ability and knew how to manage. I do not wish to pry into your private affairs, but I presume you own this building and this stock of goods and that you have no objection to my putting you down as a well-to-do citizen."

This waked Mr. Syverson up. He was anxious to give me the best possible impression of himself. He took me to the front door and pointed to a building across the street which he said he also owned. Then he owned his home and this he wanted me to see, and so he took me to his house. He told me he had two daughters and these he had sent to Christiania, Norway, in order that they might learn the Norwegian language thoroughly. For this I praised him. Then he showed me letters received from his daughters to have me see how they had been improving in writing the Norwegian language. On the table in his parlor was an album containing photographs of these girls. He handed me the album. The first portrait in the album was one of his idol, Sven Oftedal. I turned the leaf over and on the next page was Prof. Georg Sverdrup. With a twinkle in his eye, he asked me what I thought of Oftedal. I told him I considered Oftedal an exceedingly brainy and bright man, but turning the leaf over I added that I liked Sverdrup better. Like little George Washington I could not tell a lie. Then Casper Syverson asked me to take dinner with him. I told him I had another engagement, but perhaps some other time I might have that pleasure. In parting with him he urged me not to fail to come and see him whenever I had the opportunity. He said I was the kind of fellow he liked to talk with. Then I warned him not to be too liberal with his invitations to me. 
"As I have told you, I am in the life insurance business and I might get to talking with you about insurance," I said.

"Oh, insurance," he replied; "I have had all the insurance I want, and I am not afraid of any insurance agent, but I like to see you anyway."

Late in afternoon I returned to the store and found him at his old place at his desk. I had my grip in my hand. He realized what that meant. He seemed half frightened out of his wits and before I could say a word he burst forth:

"You may write me for $\$ 1,000$. I don't want any insurance, but will take a small policy for your sake."

I thanked him and told him that people ought not to make insurance a burden to themselves by taking more than they could easily pay for. He gave me a seat at his desk and I filled out his application. When I had it ready for his signature I said:

"I have made a mistake, Mr Syverson; I am so used to writing applications for $\$ 5,000$ that without thinking I have made yours for $\$ 5,000$; but I can change it."

He then said: "How much will a $\$ 5,000$ policy cost a year?"

I told him. He said he guessed he was good for it and at once signed the application for $\$ 5,000$.

I got my hat. In less than two years after that Casper Syverson died. His family promptly received $\$ 5,000$ from the Equitable and for this they were indebted to the above incident. 


\section{CHAPTER LXXXIII.}

\section{INSURE PROF. SVEN OFTEDAL.}

I am disposed to give my readers one more peep or two into my career as a life insurance agent. I may say in a general way that success in any agency work where canvassing is necessary depends largely on concentrating your mind on your business. It is the strong will that prevails. You go to a man with a view of insuring his life and concentrate on him all the energy and power of your will in your attack. He may be the possessor of a far stronger mind than yours, but his thoughts are occupied with his various business affairs and he resists you with only a fraction of his mental strength. The result is that you, with your whole mind, soon conquer the fraction that he employs in resisting you and he easily becomes your victim. At least I think this was my experience during the seventeen months that I was engaged in this business.

I also made extensive use of the fact that I was an ex-professor and author and a lecturer. Coming, for instance, to Red Wing, Minn., I spent fully a week without mentioning life insurance. I visited the few people I knew and they introduced me to others so that I got acquainted with all the leading people of the city. Then I was invited to give a lecture one evening in one of the principal churches. The lecture was free and all were invited. The result was that I got a full house. I demonstrated beyond the least doubt that the honor of discovering America belonged to the Norsemen and the following 
days the Norse voyages were being discussed with great animation in every Red Wing home. All this done, I got out my blank applications and other insurance literature and insured well nigh every man I tackled. In a few days I wrote more than $\$ 100,000$ insurance in Red Wing.

But the other incident that I was about to narrate happened in Minneapolis. In that city I made my headquarters at the Scandia bank. In a comparatively short time I wrote about a quarter of a million of insurance.

As the reader will remember, the last time that I met Prof. Sven Oftedal I ordered him out of my house. My relations with that gentleman were known by the officers of the Scandia bank. The Augsburg school, with which Prof. Oftedal was connected, was not many blocks from the bank and the professor passed the bank when he went to take the street cars for up town. Besides he was a patron of the bank and occasionally called there on business. Particularly the president and cashier of Scandia kept teasing me and when they saw Oftedal go by they said:

"Why do you not insure him?"

I answered that if they didn't stop harping on this I would have to insure him.

One day Oftedal came into the bank with a subscription list. He was raising money to help a poor family. The president Haugan and cashier Sunde both subscribed. Oftedal had seen me inside of the bank, but did not speak to me. As he was about to leave I spoke to him and asked whether he would not accept a contribution from me too. He looked at me and then he said, yes he would. I handed him a ten-dollar bill. He thanked me. I declined to write my name on his list. Nothing more was said.

Now the problem was how to get him insured. I could not go to his house after having ordered him from my premises, but he was a frequent caller at Prof. Sverdrup's. One day while 
I was on the lookout I saw him enter the Sverdrup home. Soon afterwards I rang the door bell. Mrs. Sverdrup came to the door and invited me to come in. I told her I would like to see her husband. She told me that he was in the library engaged with Prof. Oftedal. Of course she did not think I would care to meet the latter. I told her that I would be very glad to see both of the professors, so she showed me into the library.

Prof. Sverdrup gave me a seat and after some conversation about glittering generalities I began talking about life insurance, addressing myself wholly to Prof. Sverdrup. I was using my whip on the dashboard, but meant the horse. Prof. Oftedal listened. After a while he asked me how much a $\$ 5,000$ policy would cost him. Knowing his age I turned to him and explained. He at once answered that he would take that policy. I wrote his application. He signed it. On my request he went with me to the bank. I sent for Dr. Bendicke. Oftedal was examined. He paid me $\$ 165$ and this ends the story. I never saw him to talk with him again. I made 40 per cent on the $\$ 165$ and felt amply reimbursed for my $\$ 10$ contribution and my friends in the bank were dumbfounded.

Writing life insurance may seem to many easy; but I can assure everybody that it means the hardest kind of work and much of it. The life insurance agent works the hardest when he seems to be idle. It takes much study to pick out your victim and great diplomacy and persistence to conquer him, and then there is the logical or rather psychological moment to get his ink on the paper. Many go beyond that moment. 


\section{CHAPTER LXXXIV.}

\section{THE MADISON LITERARY CLUB.}

A prominent and flouishing institution in Madison today is the Madison Literary Club, counting among its members the elite of the men and women of Madison engaged in any kind of literary work, or with literary, artistic or scientific tastes and inclinations. The society meets once a month during the school year in the homes of the members. At each meeting a paper by one of the members is read and discussed.

How did this club get started? It was back in the '70s. The founders were Ella A. Giles, Dr. Joseph Hobbins and I. To which one of us the greatest share of the honor belongs it would be difficult to "figure out." Ella Giles had published her "Bachelor Ben," and if I remember correctly also her "Maiden Rachel," and had spent her royalty in a visit to Boston to make the acquaintance of some of the eastern writers. I had published my book on the discovery of America and my "Norse Mythology," and both these books had been extensively read in the east. When literary people in the east whom Miss Giles met learned that she was from Madison, Wisconsin, they asked her about the author of "Norse Mythology;" but she was unable to give any account of him. She did not know that there was any such book as "Norse Mythology" or any such person as R. B. Anderson. She told me that she felt deeply humiliated at this ignorance and decided to mend the matter as soon as she returned home. The first thing she did 
after getting back to Madison was to look me up. She came to our house and told me of her embarrassment and made many apologies. After that we saw each other frequently and we talked a great deal about how nice it would be if those in Madison who had literary tastes and interests could meet occasionally and cultivate each other's acquaintance. Dr. Joseph Hobbins was our mutual friend. He lived on West Main street and we frequently visited each other through our back yards which were adjoining. Miss Giles lived with her father, Hon. H. H. Giles, a prominent Wisconsin pioneer, on West Wilson street, three blocks away. Miss Giles and I occasionally called on Dr. Hobbins together and he was very much in favor of bringing together the literary forces in the city and organizing them into a literary club. He had had some experience of this kind while he lived in Boston and he was ready to assist us in every way possible. Our main object was, as stated, to have all the literary people in the city get acquainted with each other, but another object of no less importance in the minds of Miss Giles and myself was to have an organization that would be able to invite and entertain in a modest way distinguished persons, lecturers, musical artists, actors and actresses, etc., when they visited Madison, so that we might have the honor of meeting them.

Madison had been visited from time to time by such people as Frederika Bremer, Horace Greeley, Bayard Taylor, and Wendell Phillips, but only a few had the opportunity of meeting them.

Dr. Hobbins was a sort of patron and friend of all those who showed any literary ambition. He was old enough to be our father and on account of his social standing Miss Giles and I thought it would come with better grace if the idea and suggestion emanated from him, and we therefore asked him to take the lead. This he was willing to do. He talked with a number of people and the outcome of it was that a number of us met 
in the parlors of the Vilas House and organized the Madison Literary Club, its membership to be limited to people of decided literary tastes. At this meeting were present, as I remember, Sarah Fairchild Dean, Prof. William F. Allen, Charles Noble Gregory, and several others, of course including Dr. Hobbins, Ella Giles and me. Membership also included wives and husbands. Dr. Joseph Hobbins was unanimously elected president. The membership fee was $\$ 1$ a year, to pay for refreshments. Meeting at the homes of members was not then contemplated. That came later. This was the beginning of the club which has since grown into so prominent an organization of culture in the city of Madison. Many years ago I was elected one of its honorary members and I have read a number of papers at its meetings.

Through Ella Giles I got acquainted with the other Ella, whose name is now so well known throughout the Englishspeaking world. Ella Wheeler, now Ella Wheeler Wilcox, lived at Windsor, near the city. Her education was only of the elementary sort, but she had a decided literary ambition and much of the divinus afflatus. She would bring her early essays and poetry to Ella Giles, who introduced her to Prof. S. H. Carpenter and to me. Either Carpenter or I would read her little poems, correct them and give her lessons in rhyme and rhythm. Our friendship has never been marred by any discordant note. She never comes to Madison without paying us an old-fashioned friendly visit.

Another Madison girl that yearned to make her mark in the world was a daughter of Joseph Hobbins. She decided to leave home, to carve out a career for herself in journalism. The doctor brought his daughter Alice to me and asked me to give her a letter of recommendation. I wrote a letter to "whom it may concern" thinking she might find people who knew of me through my literary work. She achieved immediately a pronounced success and she rewarded me by writing for a leading 
Cincinnati daily a glowing account of R. B. Anderson. Alice afterwards married the eminent journalist and statistician, Robert P. Porter, and with him she has visited all the principal countries of the world, including China, Japan, India, and South America. Mr. Porter was the chief of the census bureau of 1890; he founded "The New York Press" and has been editor-in-chief of the "London Times." He has written many books and recently published a ponderous volume on Japan. Mr. and Mrs. Porter invited me to dine with James G. Blaine in Washington and they never fail to call on us when they visit their friends in Madison. 


\section{CHAPTER LXXXV.}

\section{YGDRASIL.}

In the latter part of the '90s I found that Madison was the home of a number of Norwegians either by birth or descent who had more or less of an academic education and I suggested that all these should meet once a month for a smoker. For such a meeting one of the number should come prepared to make a talk or read a paper to be discussed for an hour or more. As president of the Wisconsin Life, I offered the rooms of this company for our meetings. I suggested the name "Ygdrasil" and this was adopted. On my motion, Peer O. Strömme was elected the first president. He was at that time the editor of "Amerika." There were to be no dues and no constitution or by-laws. The only rule we adopted was that the members who were to give papers or addresses should steer clear of religion and politics. All other subjects were admissible. We were surprised to find how many there really were in the city of this nationality who had actually acquired more or less of an academic training.

At first we met at the office of the Wisconsin Life. After I had assumed the editorship of "Amerika" we met in the "Amerika" office on the second floor of the "Democrat" building. Then Mr. Halle Steensland invited us to hold our meetings at the office of the Savings Loan and Trust Company, and for a considerable length of time we met there; but in course 
of time the society followed the example of the Madison Literary Club and has ever since met at the homes of the various members.

While the meetings were held in the offices that I have mentioned they were quite informal and being smokers ladies were not present. The wives of the members of Ygdrasil therefore decided to organize a similar society for themselves. They were not willing that their husbands should gather learning and wisdom and they remain in darkness and ignorance. They resolved to organize and hold their meetings at the homes of the members and have a regular literary program, particularly to post themselves on Scandinavian history, literature, and art. At each meeting they read and discussed a paper on some phase of Scandinavian culture. The promoter, I may say mother, of this society was my wife, and I may add that I suggested the name "Gudrid," which the members adopted.

"Ygdrasil" is the all-embracing, heaven-aspiring, world-tree of Norse mythology, with its roots penetrating into the lowest regions of the universe, and Gudrid, the wife of Thorfin Karlsefne, was the first white and Christian woman who planted her feet on American soil and the mother of the first pale-faced child born on this continent. She is to the descendants of the explorers from the north more than Queen Isabella is to the descendants of the explorers from the south of Europe.

In course of time I severed my connection with "Ygdrasil." My reason for so doing was that the rule we had adopted at the first meeting in regard to religion was repeatedly violated. I protested against such ignoring of what I deemed a vital principle and my protest being unheeded I ceased to attend meetings. My action in connection with "Ygdrasil" complicated matters for my wife in the "Gudrid" society and soon led to her withdrawal therefrom. I am sorry to have to record that for these and similar reasons my relations with my fellow citizens of Norwegian blood and academic education have for 
years been considerably strained and I do not see how they can be mended. Certainly I am not willing to make any improper concessions or compromises. I am not the least disposed to make any sacrifice of my self-respect. It is not a matter of vanity or egotism, but simply a question of right on one side and wrong on the other. 


\section{CHAPTER LXXXVI.}

\section{A TERM AS DIPLOMAT.}

The first one to suggest to me a diplomatic appointment was my friend Col. William F. Vilas. Vilas was a graduate of the University of Wisconsin, served in the war of the rebellion, was an eminent jurist, was professor of law, and member of the board of regents of the University of Wisconsin. He. served as postmaster general and as secretary of the interior in President Cleveland's cabinet and then was elected as United States senator from Wisconsin. He was an orator of great force and eloquence. Observing my efforts in Scandinavian literature and being well aware of the many difficulties I had to contend with on account of my impecuniousness he, on various occasions, suggested that I ought to secure an appointment as minister, either to Copenhagen or to Stockholm. Such position, he said, would not involve much official work and would afford me some time for study in a suitable environment. I would there have the opportunity of consulting the great Scandinavian libraries and of associating with the leading Scandinavian scholars. I invariably answered him that I did not consider myself in line for any such honor, but that I did expect that he would some day be elected president and then he would be able to give me such a diplomatic appointment. This he said he would certainly do should he ever become president.

Vilas said enough to set the diplomatic bee buzzing in my bonnet. I actually began to think that there might be a posi- 
tion of this kind in store for me. I talked about it with my bosom friend, Ole Bull. He approved of the idea with the greatest enthusiasm and even said that he would get me the appointment. He knew personally many of the leading statesmen and he thought it would be sufficient for him to ask for my appointment.

At this time the famous William Maxwell Evarts was secretary of state under President Hayes. Ole Bull was an intimate friend of Evarts. He wrote a long letter to him recommending me in the most flattering terms and asked to have me appointed minister either to Stockholm or to Copenhagen. $\mathrm{He}$ prepared this epistle with the greatest care, made two copies of it, sent one to Evarts and gave the other to me as a keepsake. I still have it and regard it as one of the most charming souvenirs of the Norwegian wizard of the bow.

But nothing came of it. Ole Bull received a very polite letter from Mr. Evarts in which Mr. Evarts regretted that it was not possible for him at that time to comply with the request. This was as I expected, and I may say truthfully that I extracted this diplomatic tooth with but little pain. But there was this ghost of Banquo that would not down. In looking over the diplomatic history of this country I found that there were a number of literary men who had been appointed largely as a compliment for their literary services and to afford them larger opportunities for study and literary work. I thought of Washington Irving as minister to Spain, of Motley as minister to The Netherlands, of Bayard Taylor and George Bancroft as ministers to Berlin, of Nathaniel Hawthorne as consul general to Liverpool, of James Russell Lowell as minister to the court of St. James, and others, and might it not be possible for me to be sent to one of the less conspicuous posts in Scandinavia?

Administrations at Washington came and went, but I saw no opening for me and I gradually abandoned all hopes I might have had and tried to forget the matter. 
My father was an ardent Whig and died four years before the republican party was born. Had he lived until after 1854 he surely would have been an enthusiastic member of the republican ranks, and an energetic advocate of the republican cause. I became a republican long before I was old enough to vote. The New York Tribune and its account of the trial and execution of John Brown at Harper's Ferry had made me an abolitionist. The whole war of the rebellion confirmed me in my faith in the republican party. I admired Lincoln. My first vote for president was cast for U. S. Grant. I voted for Grant again and for Hayes.

In Wisconsin I had become acquainted with and admired Senator Timothy O. Howe, Senator Matt. H. Carpenter, General Fairchild, Jeremiah Rusk, Horace Rublee and many others of the popular leaders in the state. In spite of all this I voted for W. S. Hancock for president in 1880 and for Grover Cleveland in 1884. I was in the University of Wisconsin and the faculty of this institution was honeycombed with free trade sentiment and opposed protection.

I naturally became imbued with sympathy for free trade. My teacher was the distinguished John Stuart Mill. I read his book and was unable to resist the force of his arguments. I became a full fledged free trader. Then I thought the republican party was making too liberal use of the reminiscences of the civil war and maintaining sectional hatred. In its campaigns it was constantly shaking the bloody garment and rehearsing all the wrongs committed by the rebellious south.

I desired to be cosmopolitan and I conceived the idea that a nation, like the individual, should buy where it could buy the cheapest and sell where it could get the highest price. I did not believe in putting restraints on trade and commerce, but of this idea I became thoroughly cured after I had investigated and found how labor was compensated in other countries. Under directions of the state department at Washington I made 
a report on the wages and domestic life of the artisans and common laborers in Denmark. I made similar observations in Norway, Sweden, Germany, Belgium, Holland, England, and other countries that I visited and I everywhere found that the position of the laborer in all these lands was far below that of his brother in the United States. I went to Denmark an ardent free trader. I returned an enthusiastic protectionist and have remained so ever since.

During the campaign of 1884 I was very much occupied with my life insurance business, but still I was drawn into the contest more or less and made a couple of speeches. There was great opposition to the republican candidate, James G. Blaine, on account of his Mulligan letters and his dealings in Ft. Smith and Little Rock railroad stock. Many of the leading business men in Madison and throughout the state refused to vote for Blaine. The Norwegians remained, as a whole, loyal to the republican ticket, but there were some prominent exceptions. Among them was Hon. John A. Johnson of Madison. He had always been a leading republican, but had no confidence in the personal integrity of Blaine. He had long been very sorry to see me voting with the democrats and had done all he could to bring the prodigal son back.

I remember that Mr. Johnson and Ole Bull's father-in-law, J. G. Thorpe, once called on me to persuade me to give up my free trade notions and come back into the republican fold. I replied that I would give the matter careful consideration. This was early in the year 1884 . The fact was they feared, and justly so, that a democratic victory might greatly disturb and injure American industries. Some time after that, on a visit at Mr. Johnson's home, where I went well nigh daily when I was in Madison, I made this proposition to Mr. Johnson: If Mr. Blaine should not be nominated I would agree to vote the republican ticket, providing he would agree on his part to support the democratic ticket if Blaine should be nominated. 
"That's a bargain," said Mr. Johnson and we shook hands. Then we put this agreement in writing, each one keeping a copy of it. In the agreement it was stipulated that the one who had to change his party affiliation should do so publicly over his name, either in the "State Journal" or in the "Madison Democrat" and give his reasons for the benefit of the public.

Blaine was nominated, an outcome that Mr. Johnson had considered utterly impossible. I soon called on Mr. Johnson. and showed him our contract. Like the man of his word, which he always was, he toed the mark and not long afterwards he published, I think in the "Madison Democrat," his carefully written epistle announcing his bolt, giving several reasons why he could not support the republican national ticket. His announcement made a deep impression, I might say a real sensation, in Madison, in the state and throughout the northwest where Mr. Johnson always had been known as a republican among republicans. He delivered a number of public speeches for the Cleveland ticket.

In the life insurance business I was intimately associated with Mr. John E. Burton, later known as "Prince John," of Gogebic fame. Mr. Burton was not only a great admirer of Blaine, but also his personal friend and had had business relations with him, having at one time sold him some stock for which he was then agent. It worried Mr. Burton to see so many leading citizens deserting Blaine's banner. He knew my intimate relations with John $\mathrm{A}$. Johnson and very greatly deplored the stand he had taken. I told Mr. Burton of my agreement with Mr. Johnson. Burton was anxious to get me to come out for Blaine, hoping that this might influence others. $\mathrm{He}$ insisted that Blaine was entirely innocent of the charges made against him and that he was the greatest living statesman.

I_et me here give in a nutshell one of the public charges made against the "plumed knight," as Colonel Ingersoll styled him. As a member of congress, Mr. Blaine had sold to his friends in 
Maine $\$ 100,000$ of the Fort Smith and Little Rock railroad stock and had guaranteed that it would bring the purchasers at least a 10 per cent annual dividend. The enterprise failed utterly. Blaine was up against it. He went to his friends and bought back all the stock he had sold them, paying them par, that is, reimbursing them with the $\$ 100,000$. The question arises: Where did Blaine get the money? At a directors' meeting of the Union Pacific railroad held in Indianapolis just $\$ 100,000$ of Fort Smith and Little Rock railroad stock was found in the assets of the Union Pacific. Mr. Henderson, of Missouri, one of the directors, asked how this corporation had gotten this stock. Tom Scott, of Pennsylvania, another director, replied that this was a private matter and that he would explain it to Mr. Henderson later. Senator Edmunds of Vermont openly charged Blaine with having transferred this worthless Fort Smith and Little Rock railroad stock to the Union Pacific and in this manner gotten funds to reimburse his friends in Maine, and Senator Edmunds added, that whenever he or Senator Thurman had attempted in the senate to bring the Union Pacific to time, James G. Blaine had always jumped up behind Jay Gould's breastworks, musket in hand.

I told Mr. Burton that I was willing to waive the indelicacy on the part of Blaine as a member of congress selling stock of a company that was asking the government for a land grant. What I objected to particularly was that he, through Tom Scott, unloaded this worthless stock on the Union Pacific. Mr. Burton insisted that I was mistaken.

"Very well," I said, "I am now prepared to make a contract with you similar to the one I made with Mr. Johnson, and we will leave the matter to be decided by James G. Blaine himself. Blaine is your personal friend and you may write to him and ask him what became of the $\$ 100,000$ Fort Smith and Little Rock railroad stock after he bought it back. Ask him if he still has it, or if not, how did he dispose of it. If he still has it, 
or if he did not turn it over to the Union Pacific, I agree to vote for Blaine and come out for him publicly."

Mr. Burton then wrote a long letter to Blaine explaining to him the great disaffection among republicans in Wisconsin and telling him what an important factor I was in the case. Then he explained that I would come out publicly in his favor if I could see over his own signature such a statement as I have already indicated. In a few days Mr. Burton received a letter, not from Mr. Blaine, but signed by his private secretary, stating that it was not customary for presidential candidates to answer letters in their self-defense. Burton wrote again, guaranteeing that no public use or mention would be made of the letter. It would be seen only by Mr. Burton and me and would remain in his keeping, but insisted that the letter was most important and that he must have it. He got another letter, not from Blaine, but from his secretary, saying that Mr. Blaine was at Bar Harbor taking much-needed rest, and he sent out under another cover an armful of printed documents emanating from or relating to James G. Blaine. He asked Mr. Burton to hand these documents to me. I looked them over carefully, but found in them nothing to throw light on the question I had asked. Burton too became impatient. He too began losing faith in his greatest statesman, at least he did not think his way of handling this matter showed much statesmanship. He sent a third, pretty breezy letter to the "plumed knight" at Bar Harbor and tried to show him that it was absolutely necessary for him to answer these questions confidentially, and that he, that is Burton, would be left badly in the lurch if he did not answer. He got a third letter, not from James G. Blaine, but from his secretary. This letter read, as nearly as I can remember, as follows :

"Have Prof. Anderson come to Bar Harbor at our expense and we will satisfy him in regard to the information he desires." 
I thought I understood this letter, but I may have been mistaken. I took it to mean that if I would come for a personal interview I would get the promise of an appointment to some desirable position. But this was not the kind of stuff I was made of and I flatly refused to go to Bar Harbor.

Blaine was not elected, but four years later he became secretary of state in President Harrison's cabinet. I take it that he had a splendid memory because when he took up the slate for new diplomatic appointments my head was the very first one to be chopped off. He did not start with England, or France, or Germany; but went to little Denmark and at once sent me a cablegram asking me for my resignation. As a matter of fact, my resignation had already been written and sent to the President before I received Blaine's dispatch. It may be that Blaine was taking the ministers in alphabetical order and of course "Anderson" headed this list. I do not mean to do the distinguished statesman any injustice; but it is still my opinion that he remembered this Burton episode and that it irritated him when he found my name among the diplomats of the previous administration. An incident of which I expect to give a full account later prevented Blaine from carrying out his plans in regard to my removal. Something happened that made it necessary for me to remain at my post in Copenhagen almost to the end of the year. I was not relieved by my successor before late in the aztumn. I had the honor of sending many dispatches to Secretary of State Blaine and of receiving a number of dispatches from him. When I afterwards met him in Washington he was very cordial, complimented me on my work done in Copenhagen and did not exhibit the slightest ripple of resentment or ill-will. When I met him he was in failing health. I never saw him in his palmy days. I admire him for his brilliant parts, but my opinion in regard to the $\$ 100,000$ Ft. Smith and Little Rock stock remains unchanged. 
In that campaign the political waves ran high. Many prominent newspapers and business men deserted Blaine and openly supported Grover Cleveland. There was disaffection in the republican ranks in every state in the Union. Every inch of ground was most hotly and in many cases most bitterly contested. The outcome trembled in the balance. While Blaine's integrity as a man was assailed Cleveland's private character was not spared, but made the subject of most violent attacks.

Perhaps the little thing that determined the way the scales finally tipped were Rev. Mr. Burchard's sensational three r's, "Rum, Romanism and Rebellion!" Mr. Burchard, at a mass meeting in New York City made use of these three r's as a characterization of the democratic party. If he had used only two r's, "rum" and "rebellion," the republican party might still have stood up under it, but it was the third r, "Romanism," that aroused the united resentment of the whole Roman Catholic church and its friends. Ready as Blaine was to meet every emergency, he on this occasion lost his presence of mind. $\mathrm{He}$ should have protested at once, but he neglected to do this until after the whole country had gone wild. Then it was too late. The day after election the result was still uncertain. Everything depended on New York. The ballots in that state had to be re-counted which took several weeks and Grover Cleveland won out by a very small margin.

I spent the autumn and winter in piling up life insurance and gave no heed to politics. The most of the time I spent in Minneapolis, St. Paul and other Minnesota cities. About the first of March I came home and I confess I did have some intention of speaking to my friend, Colonel Vilas, about some diplomatic appointment, but he was not to be found. He had gone to Washington at the request of the president-elect and what hopes I might have cherished went glimmering. I made no application, nor did I ask anybody to recommend me or make 
any application in my behalf. I had no more expectation of being appointed to a diplomatic post than I have today of being made governor of $\mathrm{W}$ isconsin.

One day soon after the inauguration I had been in the outskirts of Madison looking after some insurance business. Toward evening I was on my way home to supper. That same afternoon the "The Journal" contained in bold headlines the news that R. B. Anderson had been named by the president as minister to Denmark. I had not seen the "State Journal," but people whom I met on the street had read the paper and one after another wanted to shake hands with me and congratulate me. The way in which they did it convinced me that they were not joking or poking fun at me, but still I could hardly believe my own ears. I kept hastening my steps and hurried home. There my wife stood at the front door looking for me. In her hand she held a telegram from Col. Vilas: "The president has today appointed you minister to Denmark. I congratulate you. You will, of course, accept." This settled it, and I was no longer in doubt.

But I was bound by a written contract for the coming three and a half years to serve the Equitable. I concluded that the first thing for me to do would be to telegraph to President Hyde, notify him of my appointment and ask him to release me from the contract.

President Hyde had anticipated my desires and before I could get my telegram sent I received a message from him, felicitating me on my appointment and stating that I could be released from my contract if I so desired. He said in the dispatch that he regarded my selection for a diplomatic post as a great honor to the Equitable Assurance Society. The coast was now clear and I telegraphed my acceptance and my gratefulness to Col. Vilas.

Perhaps I ought to have stated for the sake of completeness that Col. Vilas had been made postmaster general in Cleve- 
land's cabinet. He had recommended me to the President and to Thomas F. Bayard, the secretary of state. In Washington I asked Mr. Vilas why he had not mentioned the matter to me so that I could have been prepared for the event. He told me that he had had the matter in his mind for some time, but did not expect to be able to secure my appointment. $\mathrm{He}$ did not wish to awaken expectations in me to be followed by disappointment. A surprise would be better than the chagrin of failure. One reason why I mention this fact is that it shows a most charming trait in the character of Mr. Vilas.

As a matter of course I received a very large number of congratulations, both by wire and by letter, from friends, far and near, in fact many more than I was able to reply to, as I had not yet any secretary to assist me. Then came invitations to banquets. I accepted invitations from Minneapolis, from La Crosse, from Chicago, two from New York and one from Brooklyn. A number of invitations had of necessity to be declined. But the banquet with which I was most pleased was one given me by my old Madison neighbors April 24, 1885, at the Park Hotel. This was the first send-off of this kind ever given to an appointee in the foreign service in Madison.

I was the third Miadison citizen chosen for the diplomatic service. Before me Horace Rublee had been made minister to Switzerland by President Grant and General Fairchild had been our minister to Spain, but no farewell banquets had been given to either of them.

In those days full dress suits were exceedingly scarce in Madison. President John Bascom of the University of Wisconsin never owned a full dress suit. The Prince Albert was his limit. I do not remember that at that time there was a single professor or student in the state university that owned a swallow-tail, nor were there many people outside of the university in this city that had such a thing in their wardrobes. But it now became necessary for me to provide myself with a full 
dress suit. It would take the place of a uniform in Copenhagen and the sooner I began getting accustomed to it the better.

I went to Klauber's and got measured for a $\$ 65$ suit and this I wore for the first time at the Park Hotel banquet. I felt like a fish out of water. In the first place I did not know how to act in such strange garments and in the next place I was the only one in full dress at the banquet.

This banquet was attended by the state officers, the judges of the supreme court, by many of the university professors, by Madison lawyers, doctors, ministers and other prominent citizens. Ex-Minister and ex-Governor Lucius Fairchild, with his one empty sleeve, presided; in fact it was he who had taken the initiative and promoted the whole affair. The only regretable feature was that it was for gentlemen only; it was a stag party and smoker. I am sufficient of a woman's rights man to believe that on such occasions the ladies should be invited as well as the gentlemen, and in this I hope every one of my gentle readers agrees with me. The committee sent Mrs. Anderson a bouquet of flowers in honor of the occasion. There was an elegant menu and a lengthy program of music and speakers. Among the latter were John A. Johnson, Charles Noble Gregory, John Bascom, who spoke for the university; E. W. Keyes and several others.

The hit of the evening was made by D. K. Tenney, who made an exceedingly humorous address on the Norwegians in Dane county, the group of citizens to which the guest of the evening belonged. As to myself I was too embarrassed to be able to make any sort of reply beyond saying, "Thank you!" I never was in a worse "pickle" in my life. The Madison daily papers the next day contained extended reports of this banquet.

On my way to Washington the Scandinavians in Chicago gave me a fine banquet at the Palmer House, with speeches by Prof. Peter Hendrickson, Ingolf K. Boyesen, Prof. Svein Nils- 
son, Prof. Edward Olson and a poem by M. Salomonsen sung to the tune of "Marching Through Georgia," each stanza having the refrain "Hurrah, hurrah, for Diplomaten A!" alternating with "Hurrah! hurrah! for Excellencen A!"

At the banquet in New York given by the Scandinavians of that city the principal speech was given by the NorwegianAmerican author Hjalmar Hjorth Boyesen.

In Brooklyn a banquet was given at General Christensen's splendid home, he being the host and serving as toastmaster. By this time I was getting somewhat used to this sort of "hostilities" and was able to respond with less embarrassment. - I have never yet been able to face an audience without great nervousness until I get a few minutes under way.

There were three dinners given me in New York before I sailed for Denmark which I ought not to pass over in silence. One of these was by the chief officers of the Equitable Assurance Society. This dinner was given at a Delmonico restaurant and at it President Henry B. Hyde of the Equitable presided. One of the guests was Dr. Curtis, brother of George W. Curtis. By order of President Hyde the Equitable saluted the steamer in which I sailed as we passed out of New York harbor by dipping the flag on the roof of the Equitable building. The captain of the ship in which I was a passenger returned the salute in the same manner.

The second dinner was given by Jane Cunningham Croly, known in American literature as "Jenny June." For over forty years she held editorial positions on various journals, was the first woman on the staff of a daily paper and for years was the editor of the very popular "Demorest Magazine." She had been our guest a whole week at our home in Madison and now she entertained me by giving me a brilliant dinner at her beautiful New York home.

The third dinner was given me by the distinguished John Bigelow at his palatial residence on Gramercy Park. Mr. 
Bigelow was himself an ex-diplomat, having been our minister to Paris from 1864 to 1867 . He was at one time with William Cullen Bryant joint proprietor of the "New York Evening Post" and for years its managing editor. $\mathrm{He}$ was also Samuel J. Tilden's literary executor and edited his correspondence and literary remains. The dinner at Bigelow's was a family affair and I spent the evening with him, with Mrs. Bigelow and with their two charming daughters, one of whom was deeply interested in the Danish author Paludan-Müller's writings.

The reader will have observed that Mrs. Anderson has not been with me in any of these festivities. The fact is that we decided that I should go to Denmark alone, at least for the first year. We had children attending school in Madison and did not like to disturb them in their courses of study. For this and other reasons it was thought best that Mrs. Anderson should remain at home, at least until I became initiated in my new duties, got my bearings and could provide a suitable home for the family in Copenhagen.

I was going to Copenhagen as an entire stranger. The reason why I did not visit Denmark in 1872 or in 1873 was Ole Bull's radical anti-Scandinavianism of which I have spoken heretofore. He himself avoided Denmark in his travels and concert tours and he would not give his consent to my visiting Copenhagen. Such was Ole Bull's ultra-patriotism. In the meantime I had, of course, studied Danish history and literature with the Dane, F. Winkel Horn. I had published our history of Scandinavian literature and I had corresponded, more or less extensively, with the famous Danish archæologist, J. J. A. Worsaae, with the eminent critic Georg Brandes, with the renowned runologist George Stephens and various other Danish writers and scholars, so that I had persons to whom I might go when I located in Copenhagen. 


\section{CHAPTER LXXXVII.}

\section{DANGEROUS SHOALS AND BREAKERS AHEAD.}

"The course of true love never did run smooth." Trouble of some kind or other seemed determined to pursue me, no matter how bright the sky appeared. The troubles that I am now about to describe came to me like a clap of thunder from a clear sky. I supposed that all was lovely and plain sailing. I had been regularly appointed by the president and the secretary of state, Thomas F. Bayard. My name had been sent to the senate. Although this body was republican, my neighbor and friend, Senator John C. Spooner, moved my confirmation and my appointment was unanimously approved by that august body.

My appointment had been reported to Denmark both offcially and unofficially; the Danish dailies contained a dispatch from America that one "Rasmus Andersen" had been chosen minister to Denmark. "Rasmus Andersen" is a very common name in Denmark, though perhaps not quite so common as "Peter Sörensen," the latter being nearly the equivalent of "Ole Olson" in Norway. The Danes naturally thought one of their emigrated "Rasmus Andersens" was now returning to Denmark clothed with the dignity and authority of an American minister. They were wondering which one of the "Rasmus Andersen" emigrants it might be who had worked his way up to become the representative of that great country across 
the Atlantic. It made them feel jealous and inclined to protest.

In Waupaca, Wisconsin, there lived at that time a Danish Lutheran minister by name Rasmus Andersen. He afterwards moved to Brooklyn, N. Y., where he still resides. Rev. Rasmus Andersen had already at that time published books and pamphlets about the Danes in America, particularly about their church work in the United States. It was reported that the new minister to Denmark had also been dabbling more or less in literary work. Furthermore the information was supplied that the diplomatic representative who was coming was also from Wisconsin. Putting these facts together the conclusion was naturally drawn that the person in question must be Rev. Rasmus Andersen of Waupaca, Wis. Then his record was looked up and it was found that he had exhibited liberal political proclivities in Denmark before he emigrated. The administration circles in Denmark which were at that time extremely conservative did not like to have to extend the hand of welcome to a liberal emigrant who had made his life successful in the American republic. There were mutterings of displeasure and disaffection along the whole conservative line and these grumblings found their way into government circles, into the foreign office and clean into the palace.

My predecessor in Copenhagen was Col. Wickham Hoffman. He had served as secretary of legation both in Paris and in St. Petersburg and had recently come to Copenhagen to fill a vacancy. The minister before him was M. J. Cramer, brother-in-law of U. S. Grant, who had formerly been minister to Switzerland, but on account of his unpopularity had been transferred from the legation at Copenhagen to the consulship at Leipsic, a demotion.

Mr. and Mrs. Cramer, and particularly the latter, had made themselves socially very unpopular in the capital of Denmark. They were both very zealous Methodists and were continually 
talking religion. This was particularly the case with Mrs. Cramer. She even tried to convert the Danish court to her particular religious views. Mr. Cramer had been a professor in a Methodist seminary in New Jersey and both he and his wife would have been more in their proper sphere in the missionary field than in the diplomatic. When ex-President Grant made his celebrated journey around the world we all know that attentions were shown him at all the capitals that he visited. The one exception was Copenhagen and for this his own sister and brother-in-law were to blame. Festivities for Grant would involve conspicuous attentions to Mr. and Mrs. Cramer and these the Danes wished to avoid at any cost. When Grant came to Copenhagen he was received by the Cramers privately, almost incognito. With the exception of an audience with the king there was not a single public demonstration, in singular contrast with the great ovations in his honor everywhere else, including Christiania and Stockholm.

Colonel Hoffman had expected to remain in Copenhagen at least during Blaine's term had Blaine been elected. He had been in Copenhagen only a few months and Cleveland's election was a bitter disappointment to him, even more so to his vain and silly wife. If my coming could be frustrated in some way Hoffman's diplomatic life would be lengthened. He would remain until his successor arrived and was received at court. It seems that the Hoffmans soon found out that the Danes were on the wrong track and that they were looking for the squirrel in the wrong tree. They therefore undertook an independent investigation. They got into touch with Americans who knew something about me and through them they learned that I had been an apple peddler in Milwaukee; that I had been expelled from Luther college and dismissed from the faculty of Albion academy, and had sized me up as an uncultured fellow from the woolly west, a sort of bull in a china shop. 
These facts, if they may be so called, they circulated most industriously throughout the corps diplomatique and in the highest Danish government and social circles. Minister Hoffman told what he knew to the minister for foreign affairs and Mrs. Hoffman kept her tongue wagging in the diplomatic circles and the queen of Denmark being very hard of hearing she shouted into her ears, "Why, it would be a disgrace, he has been an apple peddler!"

Thus it will be seen that a storm was gathering about me and that there was little hope left that I would be received at the Danish court. Simultaneously with my case the man from Virginia whom Cleveland had appointed minister to Austria was refused on account of an article that he had written in his paper many years before criticising the Catholic church and casting aspersions on the pope. American diplomacy was being scandalized and in all the diplomatic circles in Europe they were having fun largely at my expense. The European press was busy belittling President Cleveland's appointments and in citing me as an illustration.

The state department in Washington was duly informed by the Danish minister at Washington, acting under instructions from his superiors in Copenhagen, that the newly appointed minister would not be persona grata and our government was asked to send some other representative. Our state department asked for reasons. These the Danish government was not obliged to furnish, but it condescended to give the principal ones. Among the reasons given the chief one was that I was a Dane and that this would hinder my usefulness as a minister. As I was born in Dane county, Wisconsin, some bright editor had written as a headline concerning my appointment, "A Dane to Denmark!" and a newspaper with this headline had found its way to the Danish foreign office and was quoted in the protest presented to the secretary of state at Washington. 
As I was still in this country while all this was going on I received an order to come to Washington where I could be heard in my defense. Colonel Vilas went with me to Secretary Bayard, and then to the White House, where he presented me to President Cleveland. Colonel Vilas and I were able to show that the Danish government was clean off in its premises. I was not born in Denmark and had not even set foot on Danish soil. Colonel Vilas could testify in regard to my long service as a university instructor and concerning my standing in the world of letters. It was plain that the protests from Denmark were a case of mistaken identity; that while some things might apply to me yet the bulk of the objections pertained to a totally different person. A long dispatch was sent to Copenhagen. It took all the wind out of the Danish sails and a reply was received apologizing for the mistake and assuring the state department that I would be well received. 


\section{CHAPTER LXXXVIII.}

\section{DANGEROUS SHOALS AND BREAKERS}

\section{AHEAD.}

I have neglected to state that immediately after my appointment by the president a number of democrats in Madison held an indignation meeting in the offices of a local attorney and resolutions were adopted and promptly sent to Colonel Vilas at Washington. The tenor of these resolutions was that I was not a democrat, but only a mugwump, and that I was not entitled to any such recognition from the party. The country was then full of very hungry democrats and they wanted all the appointments that the administration had to bestow. But this little episode had nothing whatever to do with the rumpus that had been kicked up in Copenhagen.

Having seen the dispatch from the Danish government explaining that it was a case of mistaken identity and assuring Secretary Bayard that I would be well received, I proceeded on my journey with a lighter heart. Before leaving Washington Mr. Adee of the state department gave me a desk near him and brought me all the recent correspondence between Washington and Copenhagen. This gave me an insight into the nature of diplomatic correspondence and put me in touch with matters then pending between the two nations. I was at the time only 38 years old and was the youngest in years among all the diplomats in the whole world. Outside of the United States men 
rarely become ministers before they are old and gray. They serve as attaches and secretaries until there are vacancies by death or otherwise. A diplomatic career is in this respect identical with a career in the army or navy. 


\section{CHAPTER LXXXIX.}

\section{AMERICAN DIPLOMATS.}

I am digressing somewhat but I might as well state here that in spite of this fact the American diplomats have held their own. While they are selected from well nigh all walks of life and usually serve through only one or two presidential administrations, and while they may be more or less deficient in the etiquette and amenities of the service, still the history of the last century and a quarter shows that American diplomacy has not only well maintained its position by the side of the diplomacy of any other country, but has even shown marked superiority. The fact is, it requires a rare equipment for a European diplomat to flit as an attache or secretary from one capital to another attending banquets and drawing rooms and balls, turning night into day and day into night, and at the same time maintain an interest in his studies and in international problems. He becomes a finished courtier, an indifferent student. His knowledge of the world is apt to become very superficial, and by the kind of life he leads his physical and mental energies are sapped. This is not the case with our American diplomats. They are as a rule men in their best time of life, full of energy and eager to make marks for themselves.

In this connection I want to point out the fact that some of the most important reforms in the diplomatic service have been brought about by American diplomats. Let me give an example or two. It was the American minister Benjamin Franklin who succeeded in doing away with the secrecy connected 
with the service. Before the days of George Bancroft ministers were received at the foreign office according to their rank, the minister having to wait for the envoy and the envoy for the ambassador. George Bancroft, as minister to Berlin, got tired of sitting in the waiting room and letting the ambassadors precede him and went back to his legation. This drove Prince Bismarck to take the bull by the horns and announce the rule, "first come, first served," and, thanks to George Bancroft, this system has since been universally adopted.

\section{Henry Wheaton.}

As further proof let me mention Henry Wheaton. He was from 1827 to 1835 chargé d' affaires at Copenhagen, where I had the opportunity of perusing his notes and dispatches, and from 1835 to 1846 our minister in Berlin. What I wish to emphasize is that in 1836 he published "Elements of International Law." This work has been translated into nearly all civilized languages and in this statement I include Chinese and Japanese, and in many countries, including England, it is used as a text-book for those intending to enter the diplomatic service. A candidate has to pass his examination in Wheaton's "International Law" before he receives his appointment as attaché. To American diplomacy the world is indebted for the abolishment of the Sound dues of Elsinore, for the incorporation of the most favored nation clause in all treaties between nations, and surely an investigation of the records will show that the American diplomats have more than held their own.

It pained me while in Copenhagen to find in the archives from 1827 to ' 35 that this distinguished scholar, this great jurist and historian, Henry Wheaton, several times was reprimanded by the secretary of state at Washington for not leaving the necessary margin and writing straight lines in his dispatches. Of how well he was trained in the nice points of court etiquette I have no information. 


\section{CHAPTER XC.}

\section{LEAVE NEW YORK.}

From Washington I went to New York where the dinners already noted were in store for me. A group of friends came to the dock to see me off as I took the steamer "Nevada" of the State Line for Glasgow. It was a slow steamer and I wanted the time to myself to study the personal instructions handed me by the secretary of state, to ponder on the difficulties I might have to overcome in Copenhagen and to see whether I could think of anything by which I might make myself useful as a representative of my country.

I intend, at the risk of wearying some of my readers, to give a pretty full account of my experience as a United States minister. In the first place I was the first one of the Scandinavian group in our population to be honored with a diplomatic appointment. I became the pathfinder in this line of activity. It was an exceedingly important chapter in my own life and opened a new field for ambitious Norwegian-Americans. Every new step made a vivid impression on my mind and I cannot therefore resist the temptation of making a fairly complete record thereof in this story of my life.

\section{Glasgow.}

I landed in Glasgow and proceeded thence to Edinburgh. In Edinburgh I went to hear W. E. Gladstone deliver a political speech, the only time that I ever saw or heard that great 
statesman, scholar, and patriot. His address was largely devoted to the question of home rule for Ireland. I cannot say that he impressed me as a finished orator. As an orator he would not rank with our Webster, Sumner, Calhoun, and others that might be named. Oratory does not seem to flourish in Europe as it does on American soil. A republican form of government is required to encourage and develop a people's oratorical endowments. The United States alone has more accomplished public speakers than all the European countries combined. I should have liked to have been introduced to Mr. Gladstone to thank him for the very nice letter he wrote me in praise of my "Norse Mythology," but that opportunity never presented itself. I wanted very much to meet and shake hands with a man who ranked with Bolingbroke, Chatham, Pitt, and Fox as an historic orator. He was first made prime minister in 1868 and resigned his fourth premiership in 1894. 


\section{CHAPTER XCI.}

\section{ARRIVE IN COPENHAGEN AND CALL ON WORSAAE.}

From Edinburgh I proceeded by steamer to Copenhagen where I arrived early on Monday, the second day of Pentecost. I put up at the Hotel d'Engleterre.

Before leaving New York I had made up my mind that the first people to see in Copenhagen were not Minister Wickham Hoffman and his wife, both of whom had done so much to embarrass me. One of those whom I wished to see first was J. J. A. Worsaae, the great archæologist. I had had considerable correspondence with him anent northern antiquities and mythology and I had made arrangements with him to translate into English a book in this line on which he was then at work.

Mr. Worsaae was chamberlain to the king and was a frequent visitor at court where he was intimately acquainted with every member of the royal family. I very much wanted his help and guidance and I felt sure that he would be perfectly willing to give a good account of me to the royal family.

After breakfast I looked up Mr. Worsaae's address and took a carriage and drove to his home. He received me most kindly and when I told him why I was in such haste to meet him he explained to me that he had heard of the gossip about me and that he already had a long talk with his majesty, the king, and also with the queen and set things right. He assured me that both of them had become deeply interested in the work I had done to promote Scandinavian culture in America and that they would receive me most cordially. Mr. Worsaae re- 
peatedly invited me to his home where he kept planning and arranging the work that he was writing and which was to be published simultaneously in Copenhagen, in London, and in New York. Our plans did not materialize. A few months after my arrival in Copenhagen this brilliant scholar was cut off in the prime of his life, only 64 years old. Worsaae had published in 1849 "Primeval Antiquities of England and Denmark" and in 1852 "The Danes and Norwegians in England." The work I was to translate was "Pre-History of the North." It was not finished by him, but with some additions edited and published by other hands after his death. With his death and with the unfinished condition of the work I lost my personal interest in it and would have had trouble in securing suitable publishers in England and America.

\section{P. A. Vedel.}

The other man I wanted to see was Mr. P. A. Vedel. Mr. Vedel was a man with all sorts of titles and was the director general of the Danish ministry for foreign affairs, a position which he held for about 40 years. He was an eminent jurist and statesman, and the relations between Denmark and all the nations were confided to his hands. The minister for foreign affairs was the ornamental figure. A new one came in with each change of ministry, but Vedel maintained the continuity of Denmark's relations to other nations and, as stated, for forty years through all kinds of ministries he was always there. In his younger days he had been a professor of jurisprudence in the Copenhagen University. He was an extraordinary, or reserve, member of the supreme court, who could sit on the bench in the absence of one of the other judges. He had the title of "Geheimelegationsraad" and was the private adviser of the crown prince, keeping the latter posted in regard to all Danish and foreign affairs. He usually spent a part of one afternoon a week with the crown prince. 
Mr. Vedel was a direct descendant of the famous Anders Sörensen Vedel, one of the founders of Danish literature and history, and an intimate personal friend of the great Danish astronomer Tycho Brahe. A ring given to the writer Vedel by Tycho Brahe has been worn by the oldest son of the Vedel family through all the succeeding generations and is now worn by our son-in-law, Peter Andreas Vedel, harbor engineer in Aarhus, Denmark.

I knew that Mr. Vedel, who was an author of great prominence, could not fail to take some interest in the work that I had done and was intending to do. I wanted to see him, too, before I made any move to be received as the American minister and there was no time to lose. In the afternoon of this same day I got the address of his residence and took a carriage to his home. He received me with the utmost cordiality. He introduced me to his family and insisted on my taking dinner with him and ordered my carriage and driver discharged.

Mr. Vedel seemed to know everything about me. He knew about my work at the University of Wisconsin and about the books I had published. After dinner he took me into his splendid library and there he gave me a thorough course in court etiquette explaining to me everything that was in store for me in connection with my reception at court and telling me in detail all about what calls I had to make on Danish officials from the premier down, and on my diplomatic colleagues. It was like going to school and what a splendid schoolmaster Vedel was to me! His wife was as charming as himself. There were three sons and one daughter, making with their parents an ideal family. I having left my wife and children in Madison, the Vedels insisted that I should consider their house my home while in Denmark. From that time on I regularly dined with them nearly every Sunday. In Vedel I had a friend at court and he wanted me to feel free to come to him whenever I needed information in regard to my official or social duties. A better friend and guide could not be desired. 


\section{CHAPTER XCII.}

\section{RECEIVED AT COURT.}

According to the rules and regulations of diplomacy it was Wickham Hoffman's duty to post me and coach me in my first steps into my official position, but with such a friend as Vedel I needed no assistance from my predecessor. The only use I made of his services was to invite him to ride with me in my carriage to the foreign office in order that he might personally introduce me to the minister of foreign affairs. Not to do this would have been a breach of etiquette on my part. He donned his colonel's uniform and drove with me with his chapeau on his lap to the ministry for foreign affairs and there, in a pompous manner, presented me to the minister, Baron Rosenörn-Lehn. After that I saw but little of him and he left the city without saying goodbye to me. The court knowing how Mr. and Mrs. Hoffman talked about me before I left America and that our relations therefore could not be particularly agreeable had changed the customary practice of receiving the outgoing and incoming ministers at practically one function and arranged for our audiences separately. The court wanted to avoid giving me any personal annoyance and for this I was indebted to my friends Vedel and Worsaae, especially the former.

I sent to the minister for foreign affairs the official note informing him of my arrival in Copenhagen and enclosing an unsealed copy of my letter of credence from President Cleveland to his majesty, King Christian IX, and asking his excellency 
when it would be convenient for his majesty to receive the original. A king cannot receive a letter without being informed of its contents in advance, hence this unsealed copy. His excellency sent me a note in reply that his majesty would be pleased to receive me the first of June at 11 o'clock. I engaged a carriage, driver, and footman and drove to the entrance of Amalienborg. There stood the king's body guard in two lines between which I passed escorted by an officer, the soldiers presenting arms and the royal band playing "King Christian Stood by the Lofty Mast." I walked with my head uncovered. On reaching the entrance of the palace another officer took me in charge and escorted me to the foot of a stairway. There this officer was relieved by an officer of higher rank, who in turn escorted me to the head of the stairway. There I was turned over to an officer of still higher rank and escorted to the rooms of the king's grand marshal, Count Lövenskjold. There I was invited to take a seat and await the pleasure of his majesty.

The grand marshal engaged me in conversation most affably, but every once in a little while he went and peeped through a tiny hole in the door to see whether the king had arrived in the receiving room. Finally Mr. Lövenskjold said:

"The king is now waiting for you, Mr. Anderson," and he escorted me to the door which he opened and presented me to the king. When he had done this he took his leave and went back to his own room.

In this great reception room none but the king and I were present. Both the king and I stood near a table. After he had taken me by the hand and bid me welcome I began delivering the speech which I had prepared, a copy of which I had to send together with the king's reply to the state department at Washington. It began thus:

"I have the honor, your majesty, of handing you herewith my letter of credence from his excellency, the president of the United States." 
About at this time the king interrupted me, saying in substance and speaking Danish to me, that he had been told that I could speak Danish; that he was more at home with Danish than with English and that he would like it better if I would talk in Danish. I replied:

"Yes, your majesty, I can speak Norwegian, but an act of congress in my country requires me to use the English language in presenting to your majesty my letter of credence."

The king then hemmed and hawed a little, said he was not aware of that fact, begged pardon and asked me to continue in English. I then finished my stereotyped address as I had prepared it in English. Then the king said:

"But that law of yours does not compel me to speak in English to you."

After that both of us spoke in Danish and had a long heartto-heart chat about glittering generalities. The king asked about my family, inquired about the kind of voyage I had had and then he said he understood that I was interested in Scandinavian history and literature and assured me that if he could be of any assistance to me in any way that I must feel at liberty to come to him at any time. He assured me that every avenue of research should be opened to me. I thanked him for his royal good will.

King Christian was not a scholar; he did not read many books, but he was a kind-hearted man and always ready to give help and encouragement to others. It is plain to all who can read between the lines that the king had been seen by Mr. Worsaae and by Mr. Vedel and that in his complimenting me on my interest in Scandinavian culture he took his cue from these gentlemen. While they coached me in court etiquette they had not forgotten to coach his majesty in regard to the proper way of receiving the new American minister, and he showed himself a fairly apt pupil. 
The ordeal that I had dreaded the most was now over. The reception by the king was rapidly followed with audiences with the queen, then with the crown prince, next with the crown princess; then with Prince Waldemar and finally with the king's brothers, Wilhelm and Hans, all separately. 


\section{CHAPTER XCIII.}

\section{COURT ETIQUETTE.}

Having taken instructions from my friend P. A. Vedel in court etiquette and having now passed through the first ordeal, I went to work and prepared a pocket edition of the code, a sort of a court catechism. It contained among other rules the following commandments:

1) Wait until you are spoken to; you must not go to a royal person and say, "How do you do?" and enter into conversation with him.

2) Do not change the topic of conversation; royalty has the right to determine what subjects are to be talked about.

3) It is the prorogative of royalty to determine when the interview is to end; you must not apologize for taking too much time.

4) Be careful never to turn your back on royalty; if necessary get into a corner of the room.

5) Do not be seated if you see any royal person standing; when royalty rises, all must rise.

6) At a reception or drawing room where royalty is present you must remain until the royalties have taken their leave.

7) Whenever royalty passes ladies must make a curtsy and gentlemen a bow.

8) Do not offer your hand to royalty, but wait until royalty offers the hand. 
9) If a queen or princess offers her hand you must raise it to your lips and kiss it.

10) At a court dinner if the king wishes to drink your health you rise in your place, make a bow, lift your glass in salute, empty it, lift it in salute again, bow again and sit down.

Once when I was on a visit at the house of our American minister in Berlin, George H. Pendleton- "Gentleman George" as he was called in the United States-Mr. Pendleton and his daughter became so much interested in this court catechism of mine that they made me give them a copy of it for their own consumption.

I need not remind my readers that Mr. Pendleton was a presidential candidate in 1868 and United States senator from Ohio, 1875 to 1885 ; but it may not be so well known that his deceased wife was a daughter of Francis Scott Key, who wrote our finest national anthem, "The Star Spangled Banner." This poem was written during the British invasion of 1814 at the attack on Baltimore which Key witnessed while detained on an English man-of-war. While he was watching through the gray dawn which flag floated over the ramparts of Fort McHenry he wrote those stirring words which have become immortal and will preserve his own name from oblivion. It was interesting to meet the grand-daughters of this justly celebrated poet. Mr. Pendleton had himself as a young man received his education at the Heidelberg University in Germany, so that he felt quite at home in German society.

In my audience with the queen of Denmark I made a break. When the interview was ended she extended her right hand, of course simply as a waving of goodbye. I had not yet learned this particular commandment in my catechism. In my confusion I supposed she was offering me her hand to say goodbye, and I grasped it and shook it, but did not kiss it. The queen mentioned this faux pas to her friends and it soon spread like a wildfire through all "diplomatdom." I knew better after that. 
The queen remembered this incident and the last time I met her just before taking my leave from Denmark she came smiling to me and said she wanted me to take her hand again which I did and smothered it with kisses and she added that she hoped I would not forget her. 


\section{CHAPTER XCIV.}

\section{THE CZAR.}

At another time I deliberately violated this well established code of court etiquette. Czar Alexander III of Russia was a giant in stature, but well proportioned. In drawing rooms he walked from one person to the other with a solemn and majestic tread. One might well imagine it was Atlas carrying the whole world on his shoulders. His movements were slow; his thoughts were slow; and his conversation was exasperatingly slow. On one occasion he came toward me. He knew by my not wearing a uniform that I was the American minister. He gave me his hand slowly and deliberately. Then he examined the ceiling of the drawing room; slowly he brought his head down again and said:

"You like-to-live-in-Copen-hagen?"

I replied: "Yes, your imperial majesty; I find much in Copenhagen of interest to me, and I have made good friends here. I think your majesty too must like Copenhagen pretty well. I have observed that you frequently make visits here and always remain a long time when you come."

The czar took a good look at the ceiling to collect his thoughts, then bringing his head down slowly again he uttered these inspired words:

"Yes, I - like - Copen - hagen - very - much."

There was a long pause. The czar gazed for a long time at the ceiling waiting for inspiration and trying to find something important to say to me. Bringing his head down slowly again 
until our eyes met he gave utterance to this profound royal sentiment:

"We - have - a - very - nice - American - minister - in - St. Petersburg, - Mr. - Mr. - " observing that he was trying to think of the minister's name I fell in and suggested, "Mr. Lathrop, is it not, your majesty?" After some pause he replied: "Yes, - Mr. Lathrop."

I answered: "You are very kind, your majesty, and I am glad to hear from you that the American president has been successful in finding the proper person to reside near your court."

The same pause; the same look at the ceiling, the same slow descent and then these profound words from the royal lips:

"Yes, - I - like - Mr. - Lathrop - very - much."

This ended the conversation, but the czar remained standing before me without speaking a word. He looked at the ceiling and he looked at me, but seemed unable to find a new subject for our conversation. As he did not leave me I took the risk of violating the rules and tried to find some topic with which to entertain the czar. I remembered that during the war of the rebellion while England sympathized with the rebels Russia, the old foe of England, gave her whole sympathy to the North. In the midst of the war the czar of Russia sent a warship to New York with a secret message to President Lincoln and, as it is generally understood, offered to take care of England if she should become troublesome to us. It is said that President Lincoln expressed his gratitude for Russia's good intentions, but did not think her services would be needed. The sequel to this is Alaska. After the war the United States government desired in some way to give expression of our indebtedness to Russia for her good will in the time of our great distress. The United States would not offer Russia a check on its treasury as a gift, but knowing that the vast regions of Alaska were practically of no value to anybody our government decided to purchase Alaska from Russia for about 
$\$ 7,000,000$. At the time this was considered equivalent to a gift, both by the giver and the receiver.

As the czar seemed utterly unable to find something more to talk about I ventured, as I have said, to violate the rules and so I said to him:

"It is a long way, your majesty, from Russia to the United States, the Atlantic ocean, the North sea and the Baltic lie between us, but, your majesty, on the other side we are neighbors; we shake hands in Alaska. It is a cold hand, your majesty, but it comes out of a warm heart."

With this piece of American eloquence the czar seemed entirely overcome. He took a long view of the ceiling and after much reflection uttered this profound sentence:

"Yes, - it - comes - out - of - a - warm - heart."

This ended our interview and he continued on his way to shake hands with the other guests.

The reason for the czar's frequent and long visits to Copenhagen was that he was a son-in-law of Christian IX. The czarina and her children liked to visit their parents and grandparents and other relatives. Czar Alexander II had been assassinated and it is not to be wondered at that the fear of assassination by the nihilists made Alexander III prefer to be visiting in Copenhagen to living at home in St. Petersburg. But even Copenhagen was filled with Russian detectives, while the czar remained there on his prolonged visits.

On Bredgade in Copenhagen, near the great Marble Church, is a beautiful little Russian church. This beautiful Greek Catholic church, with its gilt cupolas, was built by the czar as a gift to Denmark in return for the king's daughter. It was supplied with a Russian priest. Here the Russian legation held service every Sunday and here the czar and his family worshiped during their stay in Denmark.

In the Greek Catholic churches there are no pews or seats or benches to sit down on. The audience remains standing 
throughout the service. I sometimes got permission from the Russian minister, Count Toll, to attend service there in order that I might see the czar and his family worship. Of course, they, like other mortals, stood on the floor of the church during the entire service. But this is what I wish to tell in order to show how carefully the czar's life was guarded, even in the peaceful city of Copenhagen.

On Saturday evening the whole church was most thoroughly examined; not a nook or corner was left unexplored. The floor was lifted to see that no dynamite bomb, or infernal machine, lay hidden beneath it. Finding everything in order, a cordon of detectives was placed around the church and this continued its watch during the whole night and until the end of the Sunday service.

There cannot be much pleasure in being the autocrat of Russia, and this probably explains why this powerful giant of a man lived to be only 49 years old. His son, Nicholas II, born in 1868 , small and puny, is an old man at 46 , and the czarowitz is an invalid who will probably never grace the Russian throne. Such are the fruits of Russian autocracy and absolutism on one hand and nihilism and anarchy on the other, a terrible quartet.

I well remember the present czar as a young man in his teens. I frequently met him at court. I remember him particularly as a prestidigitateur. He had some Danish coins. He came over to me, showed me a two-crown piece in his hand and then the coin suddenly disappeared. He asked me where it had gone to. I told him I could not tell. He said:

"Can't you feel that it's in your nose?"

I said: "No."

Then he would take my nose between his two fingers, pinch it a little, and there was the coin in his hand. With this trick he would go from one to the other and amuse himself with the ladies and gentlemen. I think this coin trick was his whole repertoire. 


\section{CHAPTER XCV.}

\section{OFFICIAL CALLS.}

After being received at court the next important duty was to call on all the members of the corps diplomatique and of the king's cabinet and on the various high military, naval, civil and ecclesiastical officials. If any of my readers should ever get a representative post abroad I can give them this piece of gratuitous advice: Do not be stingy with your cards. Be sure you leave enough wherever you call. One card too many will scarcely be noticed, but if you do not leave enough to go around to wife, daughters and sons you are liable to commit a mortal offense. You are presumed to know how many members of the household are entitled to cards. Scatter cards freely. 


\section{CHAPTER XCVI.}

\section{ESTRUP.}

The only call out of the hundred or more I had to make that I care to speak of particularly at this time is the one I made on the Prime Minister, Estrup, a man who at a ripe old age died in the latter part of 1913.

Estrup was often called the Bismarck of Denmark. Shortly before my arrival a great political war had broken out and Denmark was on the verge of a revolution. The Danish parliament has two chambers, the lower house being elected directly by the people just as members of parliament are chosen in England, while the upper house consists partly of members appointed for life by the king and partly of members chosen by a select class of electors. The upper house therefore is always ultra-conservative like the house of lords in England, while the lower house may be extremely liberal.

In the early ' 80 s the relations between the conservatives and liberals became strained almost to the breaking point. The liberals were determined to have what is known as parliamentarism adopted. The lower house, that is the "Folketing," was the voice of the people and their wishes should prevail. The king was asked to choose his ministers from the ranks of those in sympathy with the majority in the Folketing, as is the practice in England. The king refused to yield, claiming that the selection of his ministers was a right, a prerogative that he 
could not surrender. About this time the parliamentary form of government had won out under the leadership of Johan Sverdrup in Norway and this added much fuel to the flames in Denmark. The king stood firm. Estrup was his premier and he selected a cabinet of conservatives.

Now the Danish constitution provides distinctly that taxes must not be levied or collected until the budget has been adopted by both the Landsting (upper house) and the Folketing (lower house). The break came. The Landsting passed the appropriation and the Folketing firmly refused to approve it unless Estrup retired and the king chose a new liberal ministry in harmony with the majority in the Folketing. Estrup, despite the constitution, proceeded with the levying and collecting of taxes.

When I came to Denmark the constitution of the country was, as a matter of fact, suspended and a provisional government had been substituted. This provisional government continued during all the time that I resided in Copenhagen and for years afterwards.

The chief issue between the right and the left was the fortifcation of Copenhagen. The conservatives wanted to spend millions for the army and navy as a protection against Germany in case of war, say between France and Germany, in which event Denmark might be able to recapture Slesvig-Holstein and help France to recover Alsace and Lorraine. The left was opposed to this program and did not want to squander the nation's money in preparations for war. As I said Denmark was on the verge of revolution and the provisional government employed a large army of gendarmes in blue uniforms to watch over the peace of the country. The popular waves of indignation ran high and the life of Premier Estrup was threatened. One afternoon an artisan came to his residence bearing a concealed revolver and emptied its contents at Estrup. One bullet struck a button of his coat over his breast, but was deflected 
by the button. I saw the prime minister about an hour after this had happened. The would-be assassin was sent to prison for life. A song was written to the American tune, "Oh, Susanna, Don't You Cry For Me," and carrying the refrain, "Down With Estrup!" People caught singing this song, whether they were men or women, young boys or young girls, were sent to prison, some for a few days and others for longer periods.

The great leader on the liberal side was Christen Berg, president of the Folketing. He was the would-be Johan Sverdrup of Denmark, but while Sverdrup was a graduate of the University of Norway, Christen Berg had received all his training in the elementary schools. But perhaps his prestige was all the greater for that very reason. $\mathrm{He}$, too, with two of his party friends, was arrested and incarcerated.

This political condition made my position more delicate than it otherwise would have been. Being able to speak Danish and being interested in everything Danish, I naturally liked to mingle with people of all parties. But I had to keep a padlock on my mouth and be very circumspect lest I might give offense to the provisional government. A diplomat has to be very careful not to express any opinion of things occurring in the country whose guest he is. Least of all must he exhibit any sympathy for the opposition to the government. It is difficult for an American to be perfectly neutral and above suspicion in such countries as Russia, Turkey, Spain and others I might name. But for me to be neutral where I felt so much at home and where I had so many personal friends in all parties was peculiarly difficult.

I made my call on Premier Estrup. I had great curiosity to meet this slender, wiry Bismarck of Denmark, with his tremendous moustache. He received me with the greatest familiarity, gave me a seat and we immediately got into a heart-to-heart conversation. He began talking about the sad political condi- 
tions that the diplomats to Denmark had to witness, but he hoped there would soon be a change for the better. I told him, in substance, that $I$ was not at all interested in politics; that $I$ had no knowledge or experience in such things. I stated that I had no knowledge whatever of diplomacy and international affairs. The president of the United States had sent me here because the relations between Denmark and the United States were so friendly that a skilled diplomat was not needed. The president knew of my interest in Scandinavian history and literature and had given me this position in order to improve my opportunities in my chosen field of work.

"I have come here," I said, "to sit for a few years at the feet of your great scholars and to visit your great libraries in order that I may increase my knowledge of Scandinavian history, literature and culture. If any trouble should arise requiring the presence of a real diplomat it is my purpose to resign and return to America and the president will then find some one equal to the emergency to take my place."

Mr. Estrup smiled, put his hand on my shoulder and said I must not think of resigning.

"I am an old diplomat," he said, "and if you should get a case too difficult for you to handle you just come to me and I will help you out."

I said: "That is very kind of you, Mr. Estrup, and I shall not forget your promise, but I do not feel at all certain that my government would like to have you handle both sides of a case between the two countries."

"Ah!" he said, "I thought you said a minute ago that you were not a diplomat; but this remark of yours is very diplomatic. Anyhow I hope you will remain with us for many years; and if I can be of any service to you you must not fail to call on me." 


\section{CHAPTER XCVII.}

\section{CARLOS BUTTERFIELD \& CO.}

Did Estrup keep his promise to help me out in case I should run into some diplomatic snag? He did; and I shall now show how gracefully he did it. To lead the reader up to it I shall have to tell a chapter of unwritten Danish-American diplomatic history.

We shall have to go back to the year 1854. In that year two ships floating the stars and stripes entered the harbor of St. Thomas in the West Indies. As we all know, the little group of islands consisting of St. Thomas and St. John islands and a number of lesser neighbors, in the West Indies, belong to Denmark. The two ships were the steamer Benjamin Franklin and the barque Catherine. Both of them had been damaged in a storm at sea and came into St. Thomas for shelter and repairs and asked for the assistance of the citizens. At this time a revolution was in progress in Venezuela. It was found on examination that both vessels were loaded with arms and ammunition. The authorities in St. Thomas believed the war materials to be intended for the rebels in Venezuela. They desired to maintain absolute neutrality and so they issued orders that no citizen in St. Thomas should give any assistance to the vessels. Meanwhile they gave them shelter and permitted them to make such repairs as they could attend to with what. help they had on board. In course of time the most necessary repairs were effected. 
There is an old Danish law that no ship must leave the harbor after sundown without a night passport, but this law does not apply to ships carrying mail.

One night after sundown the Benjamin Franklin was seen steaming out of the harbor of St. Thomas; but suddenly a cannon ball from the fort at the entrance of the harbor came tearing through the cabin. There was one passenger on board, an English bishop, and he, of course, was frightened out of his wits. The steamer being damaged by this cannon ball had to return to the dock and be laid up for new repairs.

There is some discrepancy in the testimony in regard to this shooting. The captain of the Benjamin Franklin testifies that it was the second shot from the fort that came breaking into the cabin; that he had heard the first shot and stopped as soon as the momentum attained by the ship permitted. The commandant at the fort testifies that he first fired a shot behind the Franklin, then a second in front, but as these were not heeded he sent the third shot through the body of the ship. He had rot been notified that the Franklin carried mail; in fact, it was not in any ordinary sense a mail steamer and had no mail or government flag. The regular mail steamer had been delayed and the Franklin took this one parcel of mail merely as an accommodation. These are the premises in the case.

Both the Benjamin Franklin and the Catherine were owned by Carlos Butterfield \& Co., United States citizens in New York. On the premises here given they sent a claim for damages to the state department at Washington. They protested that the authorities in St. Thomas had refused to grant them the hospitality to which they were entitled at the hands of a friendly nation. They denied that the war materials in their ships were intended for the rebels in Venezuela. They made out a large bill for actual damages, for loss of time, for want of hospitality and for insult to the flag and asked our government to collect these damages from Denmark. 
The state department examined the claim and approved it. The American minister to Copenhagen was instructed to lay the matter before the Danish government in Copenhagen and demand payment. Then began a long and tedious investigation and correspondence, and as I have already shown there was considerable discrepancy between the American and the Danish testimony. The correspondence was continued through the Buchanan administration, but no agreement was reached.

Then came our great civil war and during all this time the Butterfield claim was neglected, if not wholly forgotten. I presume the Carlos Butterfield Co. did not neglect to press its claims, but it doubtless failed to get the ears of the administration. We did not hear anything about this claim again before during Crant's term as president. President Grant was very much in favor of purchasing the Danish West India islands, claiming that they would be of inestimable value to the United States as a coaling station and also as a naval station in case of war. Negotiations were conducted between Washington and Copenhagen and the result was a purchase treaty duly signed by the two contracting parties. Our Wisconsin senator, James R. Doolittle, was made a special envoy to Copenhagen to make the treaty. The United States agreed to pay the sum of seven million dollars and it was understood that in this deal the Butterfield claims should be liquidated and forgotten. The treaty was promptly ratified by the Danish parliament. The Danes did not wish to sell the people in St. Thomas and St. John as chattels, but provided for a plebiscite of the citizens in those islands. This vote was taken and showed an overwhelming majority in favor of the change of allegiance from Denmark to the United States. Thus all was settled on the Danish side.

In Washington the relations between President Grant and Senator Charles Sumner were exceedingly strained, and Mr. Sumner was the chairman of the committee on foreign relations 
in the senate. I do not know how far Mr. Sumner was personally opposed to the purchase of these islands; but he was doing all in his power to block anything that President Grant advocated, anything to humiliate and defeat Grant. One thing that probably did more than anything else to dampen the ardor of the American people to become the owners of these islands was the fact that during the negotiations St. Thomas and St. John were visited by a severe earthquake. The American press took advantage of this to sneer more or less at the purchase treaty. Senator Sumner put the treaty into a pigeon-hole and there it remained. It was never presented for ratification. I regret to add that only a small, powerless nation like Denmark would submit to this kind of treatment. In this whole transaction the United States have much to be ashamed of and nothing of which to be proud. Remember that the treaty was ratified by the Danish parliament and a plebiscite taken on the islands! Denmark felt herself particularly weak at that time, having so recently emerged from her unequal war with Germany and had lost her two splendid provinces, Holstein and Slesvig.

The Butterfield claim was taken up again and called to the attention of Denmark by the Hayes and Arthur administrations, but largely as a matter of form. No vim or vigor was put into the negotiations.

I had not been in Copenhagen many months before I received a large package of mail from the state department. Along with it came a dispatch from the secretary of state informing me that all the papers relating to the Butterfield claim against Denmark had been sent me and stating that President Cleveland had determined that this claim must now be settled forthwith. Secretary Bayard instructed me to present the matter to the Danish government without delay. I opened the large package which contained copies of all the testimony and all the correspondence relating to the subject from 1854 down. 
It would take me weeks, if not months, to read and digest it. I thought to myself: Anderson, you are up against it! This is more than you can handle. You better resign and go home. I remembered my first call on Premier Estrup; but surely he would have to give his best services to Denmark.

It so happened that I that same day had an invitation to dine with the king. I went to the palace. There I met Mr. Estrup. He asked me how I was getting on. I told him not very well. He asked:

"What is the matter?"

I told him that it was new matter to me, but one that he was probably very familiar with.

"The fact is, Mr. Estrup, that if you had not offered to assist me in case I got any difficult matter to handle my resignation as minister to your country would probably already have been in the hands of the president."

"What is it then?" he said.

I told him: "It is something called the Carlos Butterfield claim."

"Is that all?" he said; "why, that's a case thirty years old. The Carlos Butterfield Co. never had any just claim and if they did have it it is long since outlawed. All witnesses in that case are now dead and gone; they can't be called from their graves. The case itself was buried in the St. Thomas purchase treaty. You write to your government that the Carlos Butterfield claim is outlawed."

I looked Mr. Estrup in the face and asked him if that was the way he was going to help me in my present dilemma, adding that if that was all the comfort he could give me I had better resign at once. He saw the force of my remark, and asked me to study the matter as well as I could. $\mathrm{He}$, on his part, would think the matter over and do the best he could.

I gave the matter all the thought and consideration possible. I remembered how our Alabama claims had been settled by 
arbitration and it seemed to me that if there ever was any international claim suitable for arbitration this certainly was one. The claim with expenses and interest added amounted now to more than half a million dollars.

I went to my friend Mr. Vedel in the foreign office. I wanted to discuss the matter orally as much as possible before committing anything to writing. Vedel took the same position as Estrup had taken and in a teasing manner asked me if I meant to declare war against little Denmark on account of this claim. I kept repeating that, "the president of the United States says this claim must be settled," and I hinted that there were means of reprisal without actually going to war. Then I suggested arbitration as the proper remedy and solution.

Mr. Vedel said: "Consenting to arbitration would be an admission on the part of Denmark that there are two sides to the question and a possibility of a claim, the very thing that Denmark denies."

I had several conferences with the learned, wise, able and humane Mr. Vedel. He in turn discussed the matter with the minister for foreign affairs, Baron Rosenörn-Lehn, and finally I obtained their individual consent to arbitration, but the matter would have to be acted upon by the cabinet.

Having gotten thus far I prepared an official note addressed to the minister for foreign affairs and presented the case in accordance with instruction from my government, stating the position of President Cleveland. The day before I had sent a cipher cablegram to Secretary of State Bayard asking for his consent to have the Butterfield claim submitted to arbitration. Secretary Bayard cabled me that the United States would cheerfully acquiesce in such course. In my note to the foreign office I proposed arbitration and was assured that such a disposition of the case would be agreeable to the president of the United States. 
In due course of time a special meeting of the cabinet was convened to consider my proposition. At this meeting Baron Rosenörn-Lehn made his little speech, explained to the king and to his cabinet members that he had promised the American minister to recommend arbitration and that he now did so. The members of the cabinet shrugged their shoulders and made long faces showing how displeased they were with the suggestion. They all seemed ready to put on record an emphatic no. At this point Prime Minister Estrup stood up and ad. dressing the king and the cabinet said:

"The first time Minister Anderson called on me I took a liking to him. He told me that he had come to Denmark chiefly for the purpose of studying our history and culture and consulting our libraries and he made the remark that he would resign if any difficult diplomatic matter should come up. I, no doubt foolishly, asked him not to resign, but to come to me and I would help him out, and now I do not see how I can keep my word to that amiable minister without asking you all to vote for submission of this old disagreeable case to arbitration."

The cabinet voted unanimously in accordance with the recommendation of Prime Minister Estrup and Baron RosenörnLehn. Estrup kept his word and I had achieved what I still look upon as a great diplomatic victory.

The arbitration treaty was duly framed and signed with all the formality and ceremony usual on such occasions. The treaty was ratified by the Danish parliament and by the United States senate. All this was done without much delay, but it took much time, much correspondence and much haggling and bickering to agree on an arbitrator.

Different sovereigns were proposed by both sides, but objections were raised. Finally Denmark proposed the queen of England and the United States consented. The queen of England appointed Sir Edward Monson to act on her behalf. He had been my colleague and good friend in Copenhagen, 
but was at this time British minister to Athens. Later he became ambassador to Paris. Two able attorneys were engaged by the United States while Mr. Vedel took charge of the case for Denmark. Their briefs were submitted to Sir Edward Monson. He gave his opinion to Queen Victoria and she decided the case in favor of Denmark.

Mr. Vedel's brief, printed in French, opens by paying a glowing tribute to me, stating that the submission of the matter on the part of Denmark was wholly on account of the esteem in which I was held by the Danish government. At all events this was the end of the thirty-year old Butterfield claim. It deserves to be remembered as one of the few cases submitted to arbitration up to that time and therefore is entitled to a place among arbitrated cases. 


\section{CHAPTER XCVIII.}

\section{A WEDDING IN HIGH LIFE.}

My first year in Copenhagen was too crowded with events for a beginner in the diplomatic service. It didn't rain, but it poured.

During the summer of ' 85 there was the biennial visit of the czar of Russia and his whole family. This brought the prince of Wales and his wife and children, King George of Greece, with the queen and all their children and many other royal guests. That summer Copenhagen was visited by two American warships, the old Kearsarge and the Pensacola, under Rear Admiral S. R. Franklin. The Pensacola was commanded by George Dewey, the present Admiral Dewey of Manila fame.

Immediately after the arrival of the royalties I have mentioned a great wedding was held at the Russian legation. One of the daughters of the Russian minister Count Toll was to be married to the Russian prince Koudachoff. The greatest preparations were made. Every member of royalty then in Copenhagen was invited. The whole corps diplomatique, all of the Danish high officials in state, army, navy, etc., were included among the guests. I too had to be invited. The czar of Russia was best man and there was a great line of bridesmaids and groomsmen. It was without exaggeration as great an aggregation of royal personages and statesmen, with their ladies, as could possibly be gathered under one roof in all Europe, or 
all the world for that matter at that time. The men were in their gayest uniforms and the ladies in their richest gowns, and the whole assemblage in a blaze of diamonds and other precious stones. I was there in my plain full dress suit. I was a lookeron in Venice; I kept myself as much as possible in the background so as to be sure to avoid showing my back to royalty. I had the greatest difficulty when going from one part of the room to another to keep from treading on the long trains of the ladies' dresses. In going through a door Princess Maud, now queen of Norway, came running and collided with me. I apologized and she insisted it was her fault.

I was invited to go and see the wedding presents which were collected in a separate room and guarded by uniformed detectives. There were jewels seemingly without end; gifts of every description. I was told that the total value of the wedding presents amounted to more than a million crowns.

The bridal knot was tied by the priest of the Greek Catholic church residing in Copenhagen. I came there without a gift. I was a stranger to the contracting parties and any gift that I could have made would only have served as an exhibition of my poverty.

This wedding festival took place in the middle of the day and lasted only a couple of brief hours. Then all the guests departed in their splendid equipages. I returned to my modest legation quarters and made haste to get back into my business clothes.

I reflected on where I had been and on what I had seen. It was a long steep hill from the farm in Albion, Wisconsin, to this wedding party. I said to myself:

"Rasmus, you have today been to the very top of this world's social ladder and seen society in its greatest splendor. How would it be to take a look at the other side and see how they have it there? You have been at the zenith. Had you not better also make a visit to the nadir?" 
I put on my hat, went to the bank and got 500 crowns, partly in 5 -crown bills and partly in 10-crown bills. The whole 500 crowns would not have made an impression as a gift to the bride, but they might give comfort to many in the slums. Then I went to the chief of police, told him who I was, and that I wished to visit incognito the most wretched people to be found in Copen hagen. I asked him to give me a policeman to guide and protect me. The chief of police looked very much surprised at the request I made, but he granted it. The policeman did not know who I was, but he guided me into the most squalid, poverty-stricken homes. I shrink from describing them. There would be basements without floors, with three families having a kitchen and cookstove in common, with half-naked, half-starved children; with straw on the bare ground for their beds. I would hand the mothers five or ten crowns according to the size of the family and so I continued with my police escort to visit basements and garrets until my last five- and ten-crown bill was gone.

The poor mothers could not understand what good angel it was who visited them; many of them sobbed aloud with joy. They were profoundly grateful. In no case did I reveal my identity; but I want to say now with all the emphasis that I can pack into so many words: I never spent a happier afternoon in my whole life on account of the happiness that I was able to give to the most unfortunate among my fellow men. Thus I saw the zenith and the nadir of human society on the same day. 


\section{CHAPTER XCIX.}

\section{THE KEARSARGE AND THE PENSACOLA.}

I had not been many weeks in Copenhagen when I was instructed by the secretary of state to ask the Danish government for permission for two men-of-war to enter the harbor of Copenhagen for a short visit. The permission was granted with alacrity. I did not know how soon these ships would arrive, but one morning two officers, one a captain, the other a lieutenant, called on me at the legation telling me they had been sent by Rear Admiral Franklin to inform me of his arrival and to ask me when it would be convenient for me to receive a visit from the admiral in person. It took my breath away, but I braced up and decided to be as democratic as possible and I answered that I would be pleased to receive the admiral at any time when it might suit his convenience.

I soon found that I had a great advantage in the fact that I was well acquainted with two brothers of the admiral. In 1872 I had crossed the Atlantic in the same ship with one brother, Gen. B. F. Franklin, and had played whist with him nearly every day from New York to Liverpool. Another brother of the admiral had been in the close of the '60s professor of military tactics and commandant of the battalion at the University of Wisconsin, and so had been my colleague. This fact made me feel more at ease and almost acquainted in advance with the admiral. It afforded me something about which to talk with him. 
The admiral came to see me the same day. We soon became fast friends and laying aside all ceremony I made my return call by going back with him in his launch to the Pensacola. Here the salute due a minister was fired, the band played in my honor, all of which I listened to with my head uncovered.

I remained on board and took dinner with the admiral and Mr. Dewey. I gave the admiral, Dewey and the principal officers of the two ships a swell dinner at the d'Engleterre, had the admiral presented at court, took Franklin and Dewey for a long drive and met them daily during their ten days' visit in Copenhagen.

One day the admiral gave a magnificent dinner on board the Pensacola to which the generals and admirals in the Danish army and navy, the crown prince and several of the diplomats, including myself, were invited.

From Copenhagen the admiral was going to Stockholm. He invited me to go with him. For this I got permission by cable from Washington and thus I became a real viking on the Baltic. On board I occupied the same stateroom with $\mathrm{Mr}$. Dewey.

In Stockholm I shared in the festivities and the admiral and I went together and paid our respects to Sweden's most famous living son, Baron Nordenskjold, the first one to double Cape Tscheljuskin and sail around Asia from North Cape to Bering's strait. He did for the northeast passage what our famous south pole discoverer, Roald Amundsen, afterward did for the northwest passage. We had a delightful visit. Nordenskjold was as charming and unassuming personally as he was distinguished as an explorer.

The official ceremonies were like those in Copenhagen and a description of them would be monotonous. While in Stockholm I looked up a sister and two brothers of my Koshkonong friend, Professor Kumlien. The brothers were prominent architects, and the sister, unmarried, was a teacher in one of the 
public schools. You can imagine how pleased they were to see me and get so much personal information concerning their brother who had left them in 1844.

From Stockholm the Kearsarge and Pensacola returned to Copenhagen to take in a supply of coal, and so I got another week of hob-nobbing with Admiral Franklin and Captain Dewey. Franklin was a man of imposing stature and a most dignified appearance. Dewey was a pigmy beside him. No one supposed, and I suppose Dewey, least of all, that he was slated for any particular fame. His chief claim to recognition when I knew him was that he had served under Admiral Farragut, hero of Mobile Bay, and he never failed to let this be known. 


\section{CHAPTER C.}

\section{POSTAL MONEY ORDERS.}

During my four and a half years in Copenhagen I met a large number of people known to fame and the time was filled with incidents that were new and of great interest to me. An account of all these things would fill a pretty stout volume. In this story I shall have to try to make a selection; but I hardly know where to begin or where to end. As I am relying wholly on my memory and am not consulting newspaper files or books, or records of any kind, I shall wholly abandon any attempt at chronological arrangement. I shall pick up episodes as they occur to me without regard to what year of my sojourn in Denmark they belong.

Already while on the Atlantic ocean I tried to think of something that I might do as minister and I think I felt like young Alexander of old weeping because his father was leaving him no countries to conquer. It seemed to me that there was nothing for me to do; but while I continued to explore the field I found that there was no postal money order treaty between the Scandinavian countries and the United States and there I thought I had found something to do, with a fair prospect of success.

My good friend Col. W. F. Vilas was postmaster general and if I could get him enlisted in the cause the battle would be half won. I therefore wrote a long letter to Vilas from Edin- 
burgh, laid this matter before him and asked him to write me and let me know whether he was willing to assist me. I told him that such a treaty would be of great value to the thousands of Scandinavians in America who were constantly making remittances for all kinds of purposes to their home countries.

In Copenhagen I received a letter from Vilas informing me that he was in favor of such a treaty. More than that he had talked with President Cleveland and with Secretary Bayard and both were in favor of the measure. In course of time I took the matter up with my friend, Director General Vedel, and he seemed greatly pleased with the idea and advised me to lay the matter before the chief of the Danish postal service, Mr. Petersen. I said to him:

"All postal money orders between Denmark and the United States now go by way of Germany. Germany has a large pair of shears with which she amputated Alsace and Lorraine from France and cut off Holstein and Slesvig from Denmark; but she has another pair of tiny scissors with which she clips off a small fraction of every money order passing between the United States and Denmark; but these little fractions make in the aggregate a large sum. This sum might be saved to the Danes on both sides of the Atlantic by transacting this business direct. There is no need of paying Germany a commission for this service."

Mr. Petersen admitted that all this was true. Then I informed him that I was authorized by the postmaster general, by the secretary of state and by the president of the United States to propose to him a treaty providing for the direct exchange of money orders on the exact gold value of the American dollar and the Danish crown.

In less than an hour I had the chief of the Danish postal service as enthusiastic and eager for the proposed treaty as I was myself. I got the treaty framed and sent it to Washington for approval while Mr. Petersen took care of the Danish end of the 
business. After a few months the treaty had been properly engrossed; I was made envoy extraordinary and minister plenipotentiary for the occasion and in the most formal manner the treaty was signed and sealed by Baron Rosenörn-Lehn and me. This treaty was duly ratified by the Danish parliament and by the United States senate. I bought postal money order No. 1 and also No. 2 and sent them to my wife at Madison, and I now felt that $I$ had been of some real service to my country.

I went a step further. I made a copy of this treaty, substituting in it the names Sweden and Norway in lieu of that of Denmark. Sweden and Norway were also paying a little tribute to Germany on their postal money order business with the United States. I sent this copy to minister McGee in Stockholm, telling him what I had accomplished in Denmark and assuring him that the measure would be favored at Washington. I also wrote a letter to Mr. Vilas. In a few months Mr. McGee had the opportunity of signing the same kind of treaty in Stockholm and he too felt that he had been of some service to his country. In honor of the occasion the chief of the postal service, Mr. Petersen, gave a grand dinner at which I was the guest of honor. 


\section{CHAPTER CI.}

\section{A CASE OF EXTRADITION.}

One of the most delicate and complicated cases that I had to deal with was one involving two American fugitives from justice.

There landed in Copenhagen two well-dressed, rather dashing gentlemen, but with something in their appearance and general conduct which made the Scotland Yards detectives suspicious of them. They did not have the map of Ireland on their faces, but still they might possibly be Hibernians. At all events the Scotland Yards detectives thought it possible that they might be dynamiters who were abroad to do something to promote the cause of Ireland. From the day they landed in Copenhagen they were shadowed. The Scotland Yards detectives and the Danish police never left these two men out of sight, so to speak, either by day or by night. The two men gave their surnames as "Frank," evidently assumed names. They seemed to have an abundance of money and sent long cipher telegrams to America. The police secured copies of these cablegrams and found the key with which to translate them. They did not stop at any hotel, but at so-called "pensionats," a kind of boarding houses, and every few days they. would change their lodgings. When they dropped letters into the postoffice letter boxes attached to the lampposts the police would wait till the letter carrier came and then secure these letters. 
This continued for some time. Finally the "brothers Frank" sent their baggage by steamer to Newcastle and they themselves bought railroad tickets to Hamburg. The Scotland Yards detectives had no doubt that the Frank trunks were filled with dynamite and infernal machines. They therefore seized them before the steamer left port. The "brothers" were arrested at the railroad station and sent to jail. Then the trunks were broken open for examination. Not a trace of dynamite was found. What the police did find was a lot of clippings from American and Canadian newspapers describing the escape of two land grabbers and swindlers from the Pacific coast. They had been found guilty in a lower court and were to be tried again in the federal district court in San Francisco. They had escaped by way of British America and from Canada they had come to Copenhagen. Several of the newspaper clippings contained crude portraits of the criminals, whose correct surname was Benson.

The Danish police had made a tremendous blunder. It had arrested these two men and seized and opened their baggage without cause. The two men had committed no offense whatever in Denmark or against the Danish government. Under Danish law they could not be held more than twentyfour hours on suspicion. It was Saturday night and Sunday night they must be liberated again, and being innocent of any offense against Danish laws they might be entitled to damages. The chief of police was at his wits' end. It appeared from the contents of the trunks that they were American criminals and as such might be wanted in the United States and it was decided to report the case to me; but there was no time to lose. It was already after midnight and the next day was Sunday.

In the small hours of the morning there was a tremendous noise out side of my legation. The janitor was awakened and he came to me and said that the chief of police wished to see me at once. I got up from bed and in my night robe received this 
exalted Danish official. He explained to me with much frankness the mistake that had been made and the dilemma in which he now was placed. He showed me the newspaper clippings and the portraits and assured me that there was no doubt about their identity and he suggested that I take charge of the prisoners and take the responsibility of their incarceration. I told him that I could do nothing without instructions from Washington, but promised to cable for instructions at once. But the trouble was it was Sunday and the Sunday would begin six hours later in Washington. I suggested that the Danish 24-hour habeas corpus law did not include Sunday.

The chief of police replied that he would hold the prisoners until 6 o'clock Monday morning. I agreed to report at the earliest possible moment.

I dressed immediately, prepared a cipher dispatch and went to the telegraph office and cabled it to Secretary Bayard. I described the prisoners in accordance with the newspaper clippings and asked for instructions. All diplomatic messages have the right of way. The question was whether the secretary of state could be found on Sunday.

Sunday evening I had received no reply. The American consul, Mr. Ryder, sat up with me and kept telling me that I had made a great mistake. I did not retire that night, but sat up anxiously waiting for a reply from Washington.

At 3 o'clock a message was brought me signed "Bayard" saying, if sure of identity request detention of prisoners.

Early Monday morning the chief of police called. I told him the contents of my instructions. Then I went to the jail with the chief where he arranged to give me an opportunity of getting a square look at the prisoners without their knowing who I was.

I was made sure of their identity and then prepared a request for their detention which was granted. 
But there was no extradition treaty between Denmark and the United States and it was thought that the prisoners knew this fact.

On Monday I went to the foreign office and was asked whether the Danish government would be willing to extradite the prisoners in the absence of a treaty. This required considerable red tape. A special meeting of the cabinet had to be called to consider this grave question. The cabinet met Monday noon, decided to extradite and so informed me. I then cabled to Bayard:

"Danish government willing to extradite without treaty. Do you want the prisoners?"

I received a reply that the court in California did not believe that I had correctly identified the prisoners and wanted more evidence. I then made a more complete statement of all the facts in my possession and the federal judge in San Francisco was satisfied.

Extradition was then arranged for and the prisoners were held, but well treated, pending the arrival of a United States marshal from California.

How well I remember the day when this United States marshal walked into my office and told me that he was on a wild-goose chase and was certain that I did not have the prisoners that he was looking for. I invited him to go with me to the prison and when he and the "Frank brothers" met they immediately greeted each other as old acquaintances. The United States marshal at once took the Bensons with him to California and my course was fully vindicated. From the state department I received a letter of thanks for the intelligent manner in which I had handled this case. I am glad that I did not have another experience of this kind during my diplomatic career. 


\section{CHAPTER CII.}

\section{PEDER SORENSEN.}

One of the most pleasant recollections that I have from my brief career as a diplomat is my acquaintance with Peder Sörensen of St. Louis. The name "Peder Sörensen," as I think I have stated before, corresponds in Denmark to "Ole Olson" in Norway and to "John Smith" in this country. This is my story about Peder Sörensen in St. Louis:

One morning I received a letter well covered with stamps from St. Louis, Mo. I opened it. It was from Peder Sörensen. He did not know me, but he had seen that one Rasmus Anderson was at that time United States minister to Denmark. Judging by the name he assumed that this Rasmus Anderson was a Dane and so his countryman to whom he might appeal for assistance. Then he told the story of his life. As a young man he had been a soldier in the war with Germany in 1864 . While in his uniform he had deserted and had made his way by night marches down through Slesvig and Holstein to Hamburg. There he had secured passage for New York. In the United States he had been industrious and successful. He had for many years been a clerk in the postoffice in St. Louis and had recently been promoted to a superintendency. He was not married. His childhood home was in Jutland where he still had near relatives. He had saved up a considerable amount of money. There was in his breast an intense yearning to visit his friends and relatives in Jutland, but he did not 
dare set his foot on Danish soil for fear he would be arrested and shot as a deserter. Desertion from the army, particularly at the front, in the face of the enemy, is never outlawed. The fact that he was now a United States citizen was no protection to him in Denmark. What he wanted of me was that I should intercede for him and as twenty years had elapsed secure, if not his pardon; then a permit to visit his old home unmolested for a stated number of weeks or days. He would simply pay his folks a visit and return to St. Louis. He also, somewhat naively, intimated that his friends in Jutland would be financially benefited by such a visit if it could be arranged.

This letter, the open confession of desertion, the modest request and the apparent excellent character of the writer, touched my heart and I at once decided to do all in my power to get Sörensen's request granted.

I went as usual to my good friend Vedel, showed him the letter and he was as deeply affected by its contents as I was. $\mathrm{He}$ went with me into the office of the minister for foreign affairs and there the matter was thoroughly canvassed. But it was decided that the foreign office had no authority in the case. The person to see was the minister of war, Colonel Bahnson, and I was advised to go to him. I called on the minister of war and laid the matter fully before him. He expressed great sympathy for Peder Sörensen, but he feared that such a pardon would be setting a bad example and be an encouragement to desertion. Anyway he said he would be willing to act in accordance with an opinion from the minister of justice, Mr. Nelleman. Mr. Nelleman was a heartless skeleton, weighing not much over 100 pounds. He made me think of Richelieu and Marat. I expected nothing from him and was not disappointed. He read Sörensen's letter with the utmost indifference, handed it back to me and said he regretted that he was not able to recommend even a temporary pardon for my client. I left him in despair; I had exhausted all the channels for relief 
and so I wrote to Peder Sörensen. I urged him, using a Danish phrase, to have that tooth extracted and think no more of coming to Denmark.

Then this happened: One bright Sunday morning I was taking a walk alone through the beautiful walks in Kastelvolden to which all diplomats had tickets of admission. While walking through these shady grounds I met his majesty, the king. He too was out enjoying the balmy morning air accompanied by his two pug dogs. He saluted me and asked me to join him in his walk. He entered into conversation with me and in course of our talk he asked me about my work and he said he supposed that there was no diplomatic work to give me any special annoyance. Here I thought was my golden opportunity. He had asked me about my official work and here was a chance for me to reply. Of course I knew that I must not discuss international questions with the king. I had no right to embarrass him in any way, but here we were alone. I resolved to tell him the story of Peder Sörensen. I gave him a fairly full statement of my efforts in Sörensen's behalf and I succeeded in touching the king's gentle heart. He said:

"I will see to that, Mr. Anderson. I will pardon Peder Sörensen."

I thanked him most cordially. Nothing more was said of it. I did not expect much, but sure enough in a few days I received a full pardon for my stranger friend signed and sealed by his majesty, King Christian IX.

This pardon autographed by the king himself I without delay sent to the state department at Washington with instructions to forward it to Peder Sörensen in St. Louis. As soon as he had received it he secured leave of absence from the postoffice and at once started for Denmark where he spent about a month with his relatives and friends in Jutland. He called on me at the legation in Copenhagen, but, unfortunately it was also my 
vacation which I was spending at Ramlösa, near Helsingborg, in Sweden, and so I did not meet him at that time.

But I met him several times later. The first time was in the early '90s. I was in St. Louis on business and went to the postoffice and inquired for Peder Sörensen. As he was not in I left a note for him and the name of the hotel where I was stopping. In the evening he called on me. I went with him to his bachelor's quarters. Our mutual pleasure in meeting cannot be described. As the saying goes: "We were too full of joy for utterance," and I will not swear that we did not shed tears.

His rooms were neatly kept. He had a large graphophone and was very fond of music. He made this instrument play a number of the choicest records he had. In one corner of his. bedroom he had an iron safe. This he opened. Out of an inner lock box he took a large package. This consisted of about $\$ 12,000$ in United States 4 per cent bonds. He wanted to show me that he had been industrious and saving and that he had accumulated enough to take care of him the rest of his days. Out of the innermost recess of the safe he brought forth the pardon which I had secured for him from the king of Denmark. This gave him a clean bill of health and he prized it above all his other earthly possessions.

I spent several days in St. Louis and every morning I received from him a box of cigars.

I have stopped in St. Louis twice since and Sörensen never forgot to send me a box of cigars every morning. He was determined to have me smoke entirely at his expense while I was in St. Louis. 


\section{CHAPTER CIII.}

\section{HEINEMAN SENDS PORK TO NEW YORK.}

The following diplomatic stunt may be of interest to my readers:

Either hog cholera or some other disease had broken out among the Danish swine. Hog-raising is one of Denmark's chief industries. On account of this disease all the European markets were closed against Danish pork. I had reported the matter to our government at Washington, but no official action had been taken. Coal is not sent to Newcastle and I suppose that our government did not think it necessary to place an embargo on pork from Denmark, none being exported to the United States from that source.

One night I was at a swell dinner at the home of the wealthy banker, Mr. Lorck. I think there must have been forty people at the table, all Danes excepting myself. I was Mrs. Lorck's escort to dinner. At one end of the long table, as Mrs. Anderson was not there, Mr. Lorck took with him to his end of the table the venerable Hans Peter Holst, who might be in a way considered the poet laureate of Denmark. The great sculptor, Albert Thorvaldsen, died in Holst's arms at the Royal Theater in Copenhagen. Holst was born in 1811 and had become exceedingly popular by his 'The Little Trumpeter," giving in verse episodes from the Danish war of 1848 to '50, a sort of parallel to Runeberg's "The Ensign's Stories." 
He was a very distinguished looking and charming old man when I met him; but he had become very hard of hearing.

A diplomat must be wary of his tongue, but he must keep his eyes and ears open. In a way, without using the word in an offensive sense at all, he is a sort of spy. The Danes, with whom I mingled frequently, forgot that I was the representative of a foreign country and associated with me with perfect abandon, as if I were one of them.

As stated, Mr. Lorck took the poet Holst to dinner and Holst was hard of hearing. While I sat at the other end of the table with Mrs. Lorck I suddenly heard some conversation at the other end of the table about the disease raging among the Danish swine and about the embargo placed upon Danish pork in Germany, England, Sweden and Norway and other countries. The poet Holst became interested. Pork being one of the chief Danish exports, Danish commerce and the Danish money market were seriously affected. In my seat I heard Banker Lorck shout into the ears of the poet that the packer Heineman had just sent a whole cargo of pork by one of the Thingvalla steamers to New York. Heineman was the Phil Armour of Denmark in the packing and exporting business. I heard Mr. Lorck explain that Heinemann had done this because there was no embargo on Danish pork in the United States.

I became very uneasy. I had heard something of great importance to my country. Immediately after dinner I went to my host and hostess and begged them to excuse me from the balance of the entertainment as I had some important business to attend to, and I bade them goodnight. I went home, found my cipher code, prepared a dispatch to the secretary of state at Washington, giving all the facts that I had obtained and calling attention to my previous dispatches concerning the plague among swine in Denmark. 
When the cargo of pork reached New York the discharging of it was prohibited. The ship had to carry every pound of it back to Copenhagen. Mr. Heineman became fiercely angry. He raged like a tiger. He suspected me and went to the minister of foreign affairs and demanded that I should no longer be recognized as United States minister. Mr. Vedel told Mr. Heineman that in the first place there was no proof that I had had anything to do with the case and in the second place that if I knew about the matter it would be my plain duty to report it to my government.

Before I left Copenhagen in the fall of 1889 I informed Mr. Vedel how I had obtained my knowledge and what use I had made of it. Mr. Heineman used to be very nice to me and at one time I introduced him to Mr. Phil Armour, who happened to be visiting in Copenhagen, but after he got his cargo of pork back from New York he never knew me. Heineman claimed that the plague among the swine had been brought to Denmark from the United States by way of Sweden in the following remarkable manner:

American hams had been shipped to Malmö, Sweden, in large boxes. These boxes had been used for shipping chickens to Copenhagen; then these empty boxes had been sold to Danish farmers who raised pigs. They had used the boards of the boxes for mending the pigpens and in this way the pigs had caught the plague. This version was actually endorsed in print by the faculty of the Danish agricultural college with the eminent scholar, Mr. Fjord, at its head! 


\section{CHAPTER CIV.}

\section{OLAF POULSEN.}

The Danes are a happy-go-lucky nation and brim full of wit and humor. They quickly see the funny side of any statement or situation. The language is full of what is called "brandere," that is "scorchers." They can parallel almost any serious statement with one ridiculous. These "brandere" are not translatable. If, for instance, you say in English "pickles are hard to digest," and you get in reply, "I hope you will not die just yet," this illustrates about what I mean by the ready wit and humor of the Danes.

I shall try, however, to tell a couple of stories to illustrate this charming side of the Danish character.

The most distinguished comic actor in the Danish theater was Olaf Poulsen. He could keep the whole audience roaring with laughter. But he was a dangerous man to meet outside of the theater. The restaurant where the actors frequently took their lunches and refreshments was one called "Aporta," near the Royal theater.

One of the wealthiest men in Copenhagen in the ' 80 s was Mr. Gamel. His father had become very rich as a coffee vender and the son had added much to the wealth. Mr. Gamel furnished dogs to our Greeley for his Arctic expedition. Mr. Gamel financed Fridtjof Nansen for his expedition across Greenland. Mr. Gamel had given much to Danish churches and he was a very public-spirited man. But he stuttered. 
One day he entered the Aporta restaurant and taking his seat he called a waiter and said:

"Gi-gi-gi-give-m-m-me- a - c - c - cup-of-cof-cof - coff - fee, but it must be Ga-ga-Gamel's." He wished to help create a demand for his coffee.

Olaf Poulsen sat at another table and overheard this. $\mathrm{He}$ then called the waiter and said to him:

"Gi-gi-gi-gi-m-m-m-me a c--c-c-cup of cof-cof-fee; but it must not be Ga-ga-ga-Gamel's."

This made Gamel angry; in fact so angry that he could not speak at all. With his fist closed he went over to Poulsen, but could not utter a word. Then he reported Poulsen to the police. It is against the law in Denmark to insult a man in a public place. Poulsen was brought into court. In the examination by the judges he stuttered worse than ever. One of the judges said to him:

"We frequently hear you at the Royal theater and then you never stutter. This must be put on."

"N-n-n-n-no," said Poulsen, "th-th-th-then I-I pl-pl-play com-com-com-comedy."

The judges decided that Poulsen should pay the cost and then fixed a day and an hour when he was to call at Gamel's residence and apologize. Gamel was happy. For the day of the apology he invited a number of his best friends to dinner in order that they might be witnesses to the naughty Poulsen's humiliation. He looked at his watch and said:

"Poulsen is due here now. I will myself open the door for him and I want all of you to hear him beg my pardon."

Poulsen rang the bell; Gamel opened the door; the guests were looking on; then Poulsen said:

"I am looking for Peder Sörensen; does he live here?"

Gamel said, "No! I l-l-live here, Ga-ga-ga-Gamel."

"I am very sorry and beg your pardon for troubling you," said Poulsen. The laugh was on Gamel. 
Another millionaire in Denmark, in crowns, if not in dollars, was $\mathrm{H}$. Mansfeld-Büllner. He had acquired his great fortune as a manufacturer of "Brahma-Elexir." He too was a publicspirited, but at the same time exceedingly vain, man. Once going on the train from Copenhagen to Elsinore I was in the same coupe with Gamel and Mansfeld-Büllner. I sat between them chatting now with one and now with the other. I whispered to Mansfeld-Büllner, asking him whether I might introduce him to Gamel. He said he would be delighted. Then I whispered to Gamel asking him whether I might make him acquainted with Mansfeld-Büllner.

Gamel answered: "No," adding: "I can buy a dozen Mansfeld-Büllners."

I did not introduce them.

Mansfeld-Büllner later received the appointment of Turkish consul general. As such he left no opportunity unimproved to display his gold-embroidered Turkish uniform.

Perhaps the readers will enjoy another Olaf Poulsen story. The queen of Denmark had a sister by name Augusta, who was far from being a beauty. She fell desperately in love with an officer in the Danish army by name Blixen-Finnecke. Blixen-Finnecke had to be divorced from his wife in order to marry Princess Augusta. By Augusta he later had two sons; one of them became an officer in the Swedish army; the other got a place in the Danish army.

While their mother was a sister of Queen Louisa these boys were not counted royal, but made barons in order to be ranked above the common herd. I knew Princess Augusta and attended her funeral, and the son in the Danish army was my neighbor whom I frequently met. And now for the story:

One day while Olaf Poulsen was sitting in his accustomed place at Aporta's in came Baron Blixen-Finnecke with two boon companions and sitting down at a table called a waiter and said: 
"Have you a bottle of champagne on ice?"

The waiter said: "No, baron, we have not; but we can put a bottle on ice and it will soon get cold."

The baron exclaimed: "That's great, isn't it!" Then he said: "Waiter, have you a bottle of rhinewine on ice?"

Waiter: "No, baron, but we can put one on ice; it won't take long."

The baron to his companions: "Isn't that great!"

All this roused Poulsen's sense of humor. He called the waiter:

"Have you a half bottle of beer on ice?"

The waiter: "No, Mr. Poulsen; we have not;" but entering into the humor of the situation, he added: "we can put one on ice. It won't take long."

Poulsen burst out: "Isn't that great!"

This made Blixen-Finnecke angry. He went over to Poulsen and addressed him about as follows:

"I know who you are. You are Olaf Poulsen of the Royal theater; but you have no right to make fun of me. Perhaps you do not know who I am; but I'll tell you. I am Baron Blixen-Finnecke. Princess Augusta is my mother. The crown prince is my cousin. The queen is my aunt and the king is my uncle."

Poulsen: "Isn't that great!" 


\section{CHAPTER CV.}

\section{THE JACOBSENS.}

Two of the most public-spirited men that Denmark ever produced were the two brewers Jacobsen, father and son. The father founded the great brewing industry called "Gammel Carlsberg." The beer he brewed was known by that name. His gifts amounted to millions upon millions of crowns. He was opposed to decorations. When he made a great gift it became necessary for the king to recognize it by offering him a decoration, but he persisted in declining to receive it. He had, however, a weak point in another direction. He was fond of the so-called "split flag" which belongs exclusively to the government. On special occasions Jacobsen would display a split flag on his flagstaff. The police would make him take it down. He would hoist it again on another occasion, with the same result. But he was bound to get the better of the police and this is how he did it:

He wrote his check for one million crowns and sent it as a gift to the "Royal Danish Scientific Society" of which the king is president. It became the duty of the king to pay Jacobsen a personal visit and thank him for this handsome gift. Mr. Jacobsen was prepared for this royal visit. The king came in his carriage and was ushered into Jacobsen's palatial residence. Parenthetically it may me stated that the chief competitor of the "Gammel Carlsberg" was a beer called "Tuborg." After the king had been seated Mr. Jacobsen asked the king whether 
he might offer him a glass of champagne. The king, Christian IX, intending to be particularly gracious, replied:

"No, I thank you, Mr. Jacobsen, but I would be pleased to drink a glass of Tuborg."

Jacobsen answered: "I am sorry, your majesty, that I do not have any Tuborg on hand, but I may offer you a glass of Gammel Carlsberg instead."

The king saw his mistake and quickly responded:

"Yes, yes, Mr. Jacobsen, Gammel Carlsberg is what I meant to ask for." And the right beer was produced.

The king said over and over again:

"That was a splendid gift you gave to the Scientific Society, Mr. Jacobsen. I assure you that I appreciate it and I beg you to accept my thanks for it. I know there is no use in my offering you any decoration for you will not accept such honors, but that was a handsome gift and if there is any way in which I can show my appreciation of it I would be glad to avail myself thereof."

Mr. Jacobsen, looking at the king as a child might look at his father, said:

"I have only one wish, your majesty, and that is, I would like to be permitted to hoist a split flag on my flagstaff."

The king replied: "That was a handsome gift you made to the Scientific Society, Mr. Jacobsen; I assure you I appreciate it very much, and you shall be permitted to float a split flag over your residence."

When the king took his seat in his carriage to drive away, Mr. Jacobsen had touched an electric button and sixteen split flags were waving in the breeze in an instant.

The father and son Jacobsen did not agree. The younger Jacobsen, Carl, married a Scotch girl against his father's wishes. To prevent this marriage the father had even gone so far as to slander the girl. This made Carl angry and he never 
spoke to his father again until he met the latter on his deathbed in Rome. There they were reconciled.

Without a penny from his father Carl started an opposition brewery called "Ny Carlsberg." He developed a larger business than his father's and outdid his father by millions in wealth and in public donations. He gave to Copenhagen the famous "Glyptotek," one of the largest and finest collections of sculpture in the whole world.

I met the elder Jacobsen a couple of times and became well acquainted with Carl Jacobsen and his estimable wife. Mrs. Anderson, our daughter Carletta and I, once spent a whole day at their beautiful home. 


\section{CHAPTER CVI.}

\section{SARAH BERNHARDT.}

After these more or less humorous episodes perhaps a story with a slightly tragic tinge may be appreciated. Everybody knows Sarah Bernhardt, at least by reputation. She is French in every fibre. She has violated the rule in recent years, but if we go back to the ' 80 s she was so intensely patriotic that she refused to appear or show herself in Germany. She hated the Germans. She would make her journey hundreds of miles longer in order to avoid traveling through Germany. She declared that she would never let her dainty feet step on German soil. Her reason for this hatred was that the Germans had taken Alsace and Lorraine from France in 1870. Denmark had a similar reason for not liking Germany. She had been robbed of her two fine provinces Slesvig and Holstein. The loss of Alsace and Lorraine to France and of Slesvig and Holstein to Denmark made Denmark and France companions in misfortune.

It goes without saying that Sarah Bernhardt aside from her great reputation as an artist was greatly admired in Denmark. She was invited to come to Copenhagen to act the part of Ophelia in Shakespeare's "Hamlet" at the Royal theater. All Copenhagen, I might say all Denmark, wanted to welcome her. Many days before her arrival every available seat in the Royal theater was sold at an advanced price and every night the theater was filled to its utmost capacity. The royal box 
was full; the members of the royal family leading in the applause. All the seats reserved for the diplomats were occupied and they too joined in the great ovation to the celebrated actress.

The German minister at this time was a bachelor, Herr Ernst. He seemed to be the leader in the applause among the diplomats. The fact is, the poor fellow had become smitten. The next day he called on the French actress at the Hotel d'Engleterre. He sent her his card and she received him most graciously and told him when he left that she would be pleased to have him call again. She evidently looked upon him as her victim.

The German minister conceived the idea of giving a banquet at the Hotel d'Engleterre in honor of the "divine Sarah." She consented to be his guest of honor. The minister engaged the large dining room of the hotel. It had a capacity of more than a hundred guests. He invited all his colleagues and many of the elite among the Danes to meet the "divine Sarah" at this feast. Of course all accepted the invitation.

In the anteroom the guests were all introduced to Sarah. Then came what was probably the proudest moment in the German minister's life. He gave his arm to Sarah and led the procession into the dining room where he and his guest of honor took their seats at the head of the table. It was a brilliant affair. A great orchestra played during the dinner; the table was loaded with la France roses. The time came for the champagne, also a product of France. The German minister stood up and said:

"My friends, I have the honor of requesting you to join with me in emptying a glass to the health of my honored guest this evening, the world's greatest interpreter of the dramatic art."

All arose, bowed to the guest of honor, drank to her health and sat down again. Then there was a lull; the guests watched the head of the table and observed an earnest tete-a-tete be- 
tween the host and the guest of honor. We may assume that she was urging him to propose a toast in honor of her native land, France, a serious matter for the representative of Germany. The tete-a-tete ended in the German minister's rising, and taking his glass, he said:

"I have the honor of requesting you to join with me in drinking this glass in honor of the native land of my honored guest, of France."

At this moment Sarah Bernhardt stretched out both her hands in the most beseeching manner and said in a voice that could be heard by every guest in the large dining hall:

"A la France entiere, Monsieur!" That is: "To the undivided France, Sir!" meaning that Alsace and Lorraine were to be included in this toast.

The German minister did not express any consent, nor did he object. He was too much confused. With these premises the guests stood up, bowed to the great actress and emptied their glasses. It was a solemn moment, but more solemn in its consequences. Somebody had reported what had happened to Berlin. The next morning the German minister received a dispatch from Prince Bismarck discharging him from the service and within three months a report was received in Copenhagen that Herr Ernst had died in an insane asylum.

This may remind the student of history of a similar occurrence. It will be remembered how Napoleon had taken Germany's great fortress Magdeburg and thereby had given to Prussia a crushing humiliation. Later at a dinner his lady was Louisa of Prussia. To show her some attention he gave her a rose. Louisa said to him:

"Is Magdeburg included with this rose, your majesty?"

Napoleon had more presence of mind than our poor German minister in Copenhagen and he replied:

"Madame, it is mine to give and yours to take what I offer." 
In this case it was the fair one that died broken-hearted not long afterwards, but Nemesis never sleeps. She was the mother of the great William, who in 1870 humiliated France and took Alsace and Lorraine away from her.

The occurrence at Copenhagen may thus be said to be one in an interesting chain of coincidences of historical significance. 


\section{CHAPTER CVII.}

\section{BISMARCK.}

In all Holstein and in the south part of Slesvig the German language is spoken. The population is German. In the north half of Slesvig the population is almost wholly Danish. The German element in these two duchies demanded more home rule than they had. The situation was in many respects a parallel to that of England and Ireland. If Denmark had been wiser she would have listened to the demand of these two provinces and accorded to them all the home rule they might desire except absolute independence. As Denmark was stubborn Holstein and the southern part of Slesvig rebelled. They turned to Prussia for support and received it. This led to the war of 1863 to ' 64 and Denmark was beaten. The penalty of the war was the loss of Holstein and Slesvig.

At the treaty of Vienna, 1864, in which these two provinces were ceded to Prussia, it was provided as a concession to Denmark that there should be held a plebiscite in the north half of Slesvig and so give the inhabitants an opportunity to choose for themselves whether they would be Danes or Germans. If such a plebiscite could be held the sentiment would be practically unanimous in favor of belonging to Denmark, and during the fifty years since the signing of the treaty of Vienna the loyalty to Denmark and the desire to be again incorporated with Denmark has not diminished. The Danish sentiment is as strong as ever and that in spite of every effort on the part of Germany 
to curb it. If a vote could be taken today nine-tenths of it would be for Denmark. The feeling is very much the same toward Denmark in North Slesvig as it is in Alsace and Lorraine toward France. I cannot help looking upon Germany's treatment of all these provinces as a great mistake, wronging the inhabitants of the provinces and injuring Germany in the estimation of all fair-minded people outside of Germany.

But why has not this plebiscite been held in North Slesvig? The people of that province and the government of Denmark have asked for it again and again. They have pointed to the treaty which provides for such an election to be held, but in the treaty there is a loop-hole and of this Bismarck and the German government have constantly taken advantage. The treaty states that such an election is to be held, but does not specify when. So whenever a compliance with the treaty has been asked Bismarck, beginning, and his successors, following his example, have answered:

"Yes, yes; you are right; there is to be an election, but the treaty does not say when, and the opportune time has not yet arrived."

Germany evidently wants all Danish sentiment eradicated in North Slesvig before arranging for the promised plebiscite, and she treats the inhabitants most harshly. She has forbidden the singing of patriotic Danish songs and the use of the Danish language at public meetings. Not long ago Norway's most distinguished living son, Roald Amundsen, the discoverer of the northwest passage and of the south pole, was to lecture on his discoveries in Flensborg and desired to speak in Norwegian, his own tongue, but the president of the province interfered and forbade it. This refusal occasioned a great deal of indignation the world over and particularly in the Scandinavian countries. The matter was referred to the government in Berlin and the emperor found it necessary to rescind the refusal and 
make an exception of Roald Amundsen's case. In many ways the German government makes itself offensive in North Slesvig.

As minister to Denmark my attention was frequently called to the conditions in North Slesvig. Even before I left for Denmark I received an address signed by Danes in the United States requesting me to do all in my power to induce Germany to grant the election solemnly pledged in the Vienna treaty of peace. Of course I could do nothing. Nor would I have been able to meddle with the matter even if $\mathrm{I}$ had been minister to Berlin. Diplomatically the affair does not concern the United States.

But in another way I came face to face with Germany's harsh treatment of the people in Slesvig. Emigrants from Slesvig to the United States, people who had sought an asylum of liberty from Bismarck's cruel government, would return to Slesvig to visit aged parents, relatives and friends, or to look after inheritances or other business in which they were interested. They had taken both their first and second papers in America and were full-fledged citizens of the United States. They therefore expected that the stars and stripes would afford them ample protection on such errands. It may be that some of them were unable to abstain from making remarks that were unfriendly to Germany.

North Slesvig is thoroughly policed by an armed soldiery called gendarmes, and these gendarmes regularly gathered the visitors from America and marched them at the point of the bayonet across the border into Denmark. Then these poor victims would come to me as the United States minister and state their grievances to me, expecting me to be able to furnish them with the desired relief. I was unable to help them. I explained to them that I was minister to Denmark and those who had any cause for complaining of the Danish government or people would naturally come to me; those who had suffered at the hands of Germany must lay their case before Mr. Pendleton, 
our American minister in Berlin. But they could not get to Berlin; they must not again set foot on German soil.

These expelled American citizens from Slesvig came to me, in large numbers and I had a keen desire to help them if I could find any way to do so.

My German colleague in Copenhagen was the distinguished Baron von Stumm. He was an exceedingly wealthy man, owning large iron industries in Germany, and he was a bosom friend of Bismarck. His wife was formerly Miss Hoffman, the daughter of a wealthy banker in New York. Baron and Baroness von Stumm had also become my special friends. I was a frequent visitor at their house and took many family dinners with them. Mr. Stumm was anxious to learn all he could about Danish culture and at his request I arranged calls for him and me on a large number of Danish professors, authors, poets, artists, musicians, etc. We called together on Georg Brandes, Holger Drachmann, Prof. J. N. Madvig, on the composers Gade and Hartmann, and on many others. After such a call Mr. Stumm regularly invited those we had called on to take dinner at his house and I was always invited to dine with them. Of these calls and visits Georg Brandes gives an account in his autobiography published a few years ago.

On account of this close friendship with Mr. Stumm I felt entirely free to discuss these exiles from Slesvig with him, and secure his good offices, if possible, in their behalf. Stumm was a man with a large heart and broad mind and he became interested. Together he and I framed a special passport for me to issue to the exiles. With this passport they were to go by the shortest route from Copenhagen to Berlin and there exhibit the passport to Mr. Pendleton and lay their grievances before him. But Mr. Stumm said it would be necessary for me to go to Berlin and get this passport approved by Prince Bismarck. He wrote to Bismarck himself in regard to the matter and I took the draft of the passport with me to Mr. Pendleton. 
On Mr. Pendleton's invitation I stopped at his house over night and he proposed to take me with him to call on the great German chancellor the next day. Mr. Pendleton was in full accord with me and promised to assist me in securing the approval of the passport and in getting some relief for the SlesvigAmericans who came to visit their native province.

The next morning about 11 o'clock Mr. Pendleton presented me to the great Prince Bismarck, the man with the bald head and heavy eyebrows. I was surprised to find him a very much smaller man in stature than I had expected. I felt quite nervous before meeting him, but after being presented my mind was so much occupied with the speech I was going to make that my nervousness wore off.

Bismarck rose from his chair and remained standing. He did not ask Mr. Pendleton and me to take seats. Mr. Pendleton then informed the prince that I had come to Berlin on a special errand and indicated that he would like to have me state the case. I did not forget to inform Prince Bismarck that this visit had been suggested to me by his good friend, the German minister in Copenhagen, Baron von Stumm. He told me that Mr. Stumm was a man well worth knowing.

Then I blundered.

After stating the facts in regard to these expelled American citizens I entered upon the argument that inasmuch as they were American citizens in good standing and furnished with passports from the secretary of state at Washington it seemed to me they should have the right to live or travel in Germany. I stated that all Germans in good standing enjoyed that privilege in the United States.

At this point Prince Bismarck brought his closed fist down on the table with all his strength and exclaimed:

"I want to say to you, Mr. Anderson, that I am master of my own house and that I admit and refuse to admit, and expel whomsoever I please!" 
I thought my case was lost. I waited awhile and then I apologized. I told him that I had not come to dispute his authority; that I had said more than I really intended. Then I proceeded, with his permission, to read to him the passport that Mr. Stumm and I had drafted and asked his permission to issue such passports to people who had been expelled from Slesvig in order to enable them to come to Berlin and present their grievances to Mr. Pendleton.

Prince Bismarck read this passport himself very carefully and approved it without a single change. He then made an agreement with $\mathrm{Mr}$. Pendleton that he should investigate each case separately and if he found no objections he might recommend that these people be permitted to spend three weeks with their friends in Slesvig, but at the end of that time they must depart. Of course the Berlin foreign office would also make an investigation of the merits of each individual case. This ended the only interview I ever had with the noted Bismarck, and I must say I had no special desire to meet this man of iron again.

With this passport I afterwards succeeded in making many Slesvig-Americans happy. I had it printed so that I only needed to insert the name, age, color of hair, eyes, etc., and then signed my name, dated and affixed the seal of the American legation in Copenhagen. 


\section{CHAPTER CVIII.}

\section{JOHAN SVERDRUP.}

Distance lends enchantment to the view. Some American ladies secured an opportunity of being presented to President Thiers in Paris. One of the ladies whispered to her friend:

"What a small man he is!"

Mr. Thiers had good ears. He had heard the whisper and remarked:

"Never mind, ladies; I look larger from a distance."

This about distance lending enchantment is generally true, both in a literal and in a figurative sense. We read of the men who are doing things in the world and imagine they are not only large physically, but also in their ordinary intercourse with their fellow-men.

I thought General Grant must be a giant, but found him hardly medium-sized. I had the same experience with Gladstone and with many others.

In the eyes of the Norwegians Johan Sverdrup loomed up. as of no less ability, consequence and size as man and statesman than Gladstone in England or Bismarck in Germany. He was a leader and representative of the common people, the great advocate of parliamentarism in Norway. He gained his point and became the first prime minister under the new system.

I had met Sverdrup a couple of times and one summer while I was spending my vacation at Ramlösa, near Helsingborg, 
King Oscar of Sweden came to spend a few weeks at his summer palace, Sophiero, in the outskirts of Helsingborg. King Oscar sent his adjutant to me inviting me to call on him, setting the time for my visit the next day.

I had had some literary correspondence with King Oscar. He had written a couple of letters to me with his own hand and he now invited me to call on him. I had to wait in the antechamber while he finished his interview with one or two Swedes, but when he had dismissed them he sent for me, gave me a cigar and asked me to take a walk with him in the park surrounding Sophiero. He chatted with me about Paul du Chaillu, about Victor Rydberg, Björnstjerne Björnson and other persons whom I knew; but I soon discovered he was leading up to Johan Sverdrup. He was evidently much worried over conditions in Norway. He knew well that I had met both Björnson and Sverdrup and that I was likely to meet them again and he naturally supposed that things that he said to me I might find occasion to repeat to them. Anent Björnson he said that he regretted that $B$ jörnson seemed to cherish ill-will toward his king and that people thought that he might be jealous of Björnson as a poet. He said:

"I write verses, but I do not pretend to be a 'storskald" (a great poet) like Björnson, and there is no one who admires Björnson more than I do."

$\mathrm{He}$ expressed a similar affection and admiration for Johan Sverdrup. He said:

"My great mistake was that I did not make Sverdrup prime minister much sooner than I did. Much of the bitterness between the parties in Norway might then have been avoided."

I did not fail on my part, on the one hand, to put in a good word for Björnson and Sverdrup to King Oscar, and on the other to report my interview with the king to these gentlemen the first time I met them again. 
Johan Sverdrup was a disappointment to me. In 1884 he was in the midst of his great battle for parliamentarism. The Norwegian-Americans were all with him. It was understood that Sverdrup was as poor as Job's turkey and the NorwegianAmericans gathered subscriptions and sent him financial aid. On the 17th of May, 1884, I was the speaker at a great celebration in Eau Claire, Wis. Much of my speech was devoted to Johan Sverdrup. At the close of my speech I suggested to the immense audience that they all spend a little less that day for cigars and refreshments and make a contribution to Sverdrup. I appointed a number of persons to pass their hats around. I too went among the people with my hat. The contributions amounted to about $\$ 750$. Then I got $\$ 50$ from J. G. Thorpe, and Sigvald Quale added enough to make the gift an even $\$ 1,000$. The next day, the 18th, Quale and I bought a draft and sent this money together with a eulogistic letter to Sverdrup. Quale also sent him Blaine's "Twenty Years in Congress." I am sorry to say that we never received one word of thanks from Mr. Sverdrup.

In the spring of 1886 I made a short visit to Christiania. I stopped at the Hotel Victoria, which is near the premier's apartments. I had a desire to meet the man whom I had eulogized in my Eau Claire address and to whom Quale and I had transmitted the thousand-dollar gift. I imagined him to be the great commoner of Norway, a man whom anybody could approach informally.

I went to the premier's residence and announced myself. I was on foot and in my traveling suit. It was only a few minutes' walk from the Hotel Victoria. The janitor opened the door and announced me. I waited at the foot of a long stairway. It was about 11 o'clock in the morning. After a little while a young man came down the stairway and greeted me and informed me that Minister Sverdrup was not at home, but would be pleased to see me at 2 o'clock in the afternoon. The young 
man was Sverdrup's son. That Johan Sverdrup was at home I afterwards learned, but he did not care to receive me in an informal manner.

At 2 o'clock in the afternoon I again walked over to the ministerial residence and rang the door-bell. The janitor opened the door and the same young man, a son of Sverdrup, again met me and ushered me upstairs into a huge reception room. There he left me saying that the minister would soon come to see me. Presently a rear door was opened; in comes a little man in full dress suit with a silk hat in his hand and greeted me, not without cordiality; at least he said he was pleased to receive me. $\mathrm{He}$ did not enter into conversation with me, but pulled off a long, loud address, the main part of which was on America and American institutions, pointing out to me a number of things that needed reform, if America was to be to the Americans themselves and the rest of the world what it no doubt wished to be. He gave a number of instances from our federal, state, and local administrations where he thought we were sadly in need of reform.

I was not minister to Norway. This formal reception was utterly out of place. He said nothing about the gift from Eau Claire. I wanted to meet him in an informal, democratic manner and have an old-fashioned twa-handed chat, but I was sadly disappointed.

The next day, about noon, a porter came to my room in the hotel with a card on a silver plate. The porter himself was quite excited. The card was from Prime Minister Sverdrup. I asked the porter to show his excellency to my room. The porter said that the minister was in his carriage in the street. I then took a democratic tack, ran down the stairs bareheaded and out into the street to invite the premier to come in. But just as I got to the sidewalk he was driving away, so that I saw only his back and his equipage. 
I called on Mr. Sverdrup only once more. That was a year or two later, with Hon. John A. Johnson of Madison. Mr. Johnson came to see me in Copenhagen. From there he went to Norway; but he could not feel that he had seen Norway unless he also met Sverdrup whom he so greatly admired. Sverdrup was to Mr. Johnson the major part of Norway. To come away from Norway without seeing Sverdrup was to him the same as seeing Shakespeare's Hamlet with Hamlet left out.

I went with Mr. Johnson to Norway. The day after our arrival in Christiania I informed Mr. Sverdrup's son that there was a distinguished Norwegian-American with me who desired to pay his respects to his father and requested him to find out and let me know whether he could be received and if so at what time. Young Sverdrup reported that his father would be pleased to receive us the following day at 11 o'clock.

Mr. Johnson had a lot of nice things that he wished to say to the great Norwegian statesman, but he did not get an opportunity to unburden his mind. The visit was in all respects a' repetition of my visit that I have already described.

$\mathrm{Mr}$. Johnson and I were ushered into the large reception room where we waited awhile. Then comes from a rear door the premier in full dress and silk hat in hand. He shook hands with both of us cordially and then he went on in a loud voice as if speaking to an audience of a hundred or more and delivered practically the identical speech that he had made to me alone, telling how he hoped a lot of reforms might be attained in the United States and dwelling on how sadly they were needed. At the end of his harangue he thanked us for our visit, said farewell and retired. I shall never forget the expression of disappointment and disgust in Mr. Johnson's face. He had no desire to meet Norway's great representative again. 


\section{CHAPTER CIX.}

\section{THE CZAR IS HUMBLED.}

The facts that I am now going to relate have been persistently kept in abeyance, but the story is too interesting to be left untold.

When a royal person arrives it is customary for the high officials of the country and the ministers from foreign lands to welcome him at the railroad station or at the dock where he lands.

I attended many meetings of this kind. The czar of Russia, Alexander III, came over the sea in his imperial yacht "Derschava." On his anchoring in the Copenhagen harbor all the cannon in the Danish forts and on the Danish warships boomed in his honor. Then the czar and czarina and their children came ashore in launches. They always landed at an open place near the custom house. The place was furnished with carpets and a canvas stretched over it as a protection against the sun or rain. Nearest the landing stood the Danish and other royalties; next in order were the members of the Danish cabinet. Following them stood the diplomats in the order of their seniority of service; on the left hand side facing the landing stood the ladies and on the right hand the gentlemen. Outside of these lines stood the royal carriages to take the royal persons to the palace.

All these people were assembled in this manner at the custom house landing at least an hour before the czar arrived. This time was consumed by the royalties in going up and down the 
lines of ladies and gentlemen greeting them and engaging them in conversation.

The occasion of which I am now speaking was the arrival of the czar and his family in the late summer of 1885 . The royalties had taken their strolls up and down the lines of the members of the cabinet and their wives and of the diplomats and their wives. Cannon had boomed; the king of Denmark was approaching the landing with the czar and czarina in his launch. All eyes were centered on the imperial rulers of Russia. The czar and czarina landed; there was much handshaking and embracing and kissing between them and their Danish relatives. Then the czar shook hands with Prime Minister Estrup and all the members of the Danish cabinet and their wives. But with-. out recognizing or even deigning to look at the members of the corps diplomatique, this tall and imposing autocrat of all the Russians walked rapidly down the center of this alley of foreign representatives and took his seat in the royal carriage waiting for him. The czarina took her time. She greeted everyone of the diplomats and their ladies and presented her hand to be kissed. She had a friendly word to everyone. Then she went and took her seat in the same carriage with her husband immediately followed by the king and queen of Denmark. The other royalties got into their respective carriages as rapidly as possible and then this whole cortege of royal equipages proceeded through the streets filled to their utmost capacity with people and in a blaze of flags to the palace.

The diplomats were deeply offended. Before departing in their carriages they gathered in a little circle for a little conference. They discussed what had happened. The neglect on the part of the czar to recognize them they regarded as an insult not only to themselves, but to the sovereigns and countries that they represented. They declared that they would make a report of this insult to their own governments and that they would not subject themselves to a similar snub a second time. 
Then comes the year 1887. The czar was to come with his family for his usual visit. The diplomats had been invited as usual to be present at the custom house landing. The preparations were all the same as two years before. The ministers from the various countries met and considered whether they would go or not. The Russian minister could not as a matter of course be absent. The Princess of Wales was there and the British minister thought he ought to be there in deference to her. It was finally agreed to have the matter laid before the Danish minister for foreign affairs, by the doyen or dean of the corps diplomatique. He did so. The minister for foreign affairs said he would regret it very much if the diplomats were not present. He promised to do all he could to prevent a recurrence of the scandal. After all these negotiations it was decided to go to the landing and assist in the reception of the czar and see what the result would be.

The czar landed. The ceremonies were the same as in 1885. There was the same handshaking, embracing and kissing. Then the czar shook hands with all the members of the king's cabinet, but when he got as far as the corps diplomatique he looked neither to the right nor to the left, but walked directly to the carriage waiting for him. The czarina seemed to understand the situation and did all in her power to make amends for the arrogance of her husband. She took much time, stopped and talked with everyone of the diplomats and their wives, and was as gracious as possible. She let her husband wait till she got ready. Then all the royalties departed.

The members of the corps diplomatique again formed into a circle, looked at each other in disgust; one of them saying: "Are we mere lackeys?" and positively declaring that this should be the last time that the czar would have an opportunity to insult them in this manner. I have no doubt that they all made caustic reports to their respective governments. 
We now pass to the czar's next visit in 1889 . The diplomats were invited as usual. Through their doyen the Swedish minister, Baron Beck-Fries, they reported to the minister for foreign affairs that they very much regretted that they could not assist in the reception of his majesty, the czar of Russia. They had been snubbed twice and did not care to subject themselves to a third insult, declaring that in remaining absent they were sure that they were acting in accordance with the wishes of their home governments.

This action was reported to the king and the king of course was exceedingly sorry. His majesty sent his court marshal, Lövenskjold, to call on all the ministers to request them as a personal favor to the king to be present on the arrival of the czar at the custom house landing.

A minister cannot refuse to grant a personal request from the king. Such a refusal would involve a departure from the country. Of course the grand marshal stated that the king would do all in his power to make the czar recognize the members of the corps diplomatique. On these terms there was nothing else for the ministers to do than to put in their appearance a third time and abide the result.

The "Derschava" arrived, the cannon boomed, the king brought the czar and czarina in his launch to the landing. The usual hand-shaking, embracing and kissing followed. The diplomats all had their eyes focussed on the czar. After the czar had greeted his relatives he shook hands with all the members of the king's cabinet and just before he reached the diplomats a grandson of the king, Carl, now king of Norway, hurried over to his side and said something to him. He probably told him that the king had something to say to him. Then the czar went back to where the king was standing and we observed that they were engaged in very earnest conversation. There is no doubt that the king was pleading with his exalted son-in-law not to omit speaking to the diplomats and probably 
explaining to him how it had come to pass that they were not absent.

The czar left the king, walked down the line, hesitated and looked sulky. He reached the corps diplomatique and like a naughty schoolboy, who has been forced to do something that he did not want to do, he took each of us by the hand and said: "Bon jour, Bon jour, Bon jour," and so on down the line. He did not utter a word to express his pleasure, satisfaction or gratitude. He only, shall I say, grunted his "bon jours" and then took his seat in the carriage. The diplomats had won a decided victory and the autocrat of the Russians had been humbled.

Smaller things than this arrogance of the czar have sometimes led to serious international complications and even to war and there is no telling what might have been the consequences to Europe, had not the czar mastered his arrogance and condescended to show the diplomats some recognition. The czar acted more wisely than he himself knew, when he decided to give up the position he had taken and comply with the wishes: of his large-hearted father-in-law. 


\section{CHAPTER CX.}

\section{CLAUDE McDONALD.}

The first British minister with whom I became acquainted was Sir Edmund Munson. He was a very agreeable, highly cultured and very able diplomat. I am indebted to him for much hospitality and many acts of kindness. In connection with Queen Victoria's semi-centennial jubilee in 1887 there were great doings in Copenhagen on account of the close relations between the English and Danish royal families. Sir Edmund Munson gave a magnificent entertainment at the Concert Palais, one of the finest public halls in the city, in honor of the occasion. He invited the distinguished scholar and runologist, the then venerable George Stephens, to respond to a toast to England. He requested me to respond to the toast "Scandinavia" and he proposed himself to respond to "The United States of America." Both I and Mrs. Anderson attended this magnificent banquet. In responding to the toast "Scandinavia," I said in substance:

"We in America are a young nation and while we have received immigrants from every country in Europe we look upon ourselves as a daughter of Old England. Our own written history takes us back to the landing of the Pilgrim Fathers and to similar colonizations. We do not get at the root of our customs and institutions by stopping at the Pilgrim Fathers in 1620. There is much beyond this that we wish to know. When we are in doubt about the origin and significance of any 
of our laws and customs we go to our mother England and from her we usually get an entirely satisfactory answer and explanation. But sometimes our questions refer to things in the hoary past even beyond the beginnings of England. Our dear mother England then scratches her gray hair and says, 'really I do not quite remember, but I think that if you will ask my mother in the Scandinavian North she may be able to tell you.' We then go to our grandmother, the old white-headed Scandinavia and there we never fail to get a satisfactory answer. Scandinavia has preserved the memory of the religion of our forebears and of our social and political institutions."

In this manner I eulogized Scandinavia in connection with Queen Victoria's semi-centennial jubilee. I know my little speech pleased Sir Edmund Munson and Sir George Stephens.

But I wrote Claude McDonald over this chapter. Sir Edmund Munson was transferred to Athens and was succeeded in Copenhagen by Claude McDonald as British minister. $\mathrm{He}$ is the same Claude McDonald that we read so much about as minister to China at the time of the rebellion of the Boxers about 1900. Mr. and Mrs. McDonald were both very nice to Mrs. Anderson and me.

On the last day of December, 1888, we and the more prominent English families of Copenhagen were invited to dine with them and to watch the old year out. After dinner the gentlemen went into the minister's library to smoke. While there I looked at some portraits hanging in the drawing room. I saw some that had a very familiar look. They reminded me of portraits of the von Krogh family of which I had seen a considerable number and of which family I was, as the reader knows, a sprig. I told Mr. McDonald, pointing to the portrait, that it looked as if it might be one of my own mother. Mr. McDonald said:

"I am a Norwegian on my mother's side." 
This was a picture of his mother and he then explained to me that she was a Norwegian lady by name von Krogh. On investigation we found that McDonald's father and my mother's uncle had been, one the British and the other the Swedish-Norwegian consul to Algiers. Consul von Krogh had a wife and daughter. Consul McDonald was a bachelor and married Miss von Krogh, my mother's cousin, and so it appeared that the British minister, Claude McDonald, and the American minister, Rasmus B. Anderson, were second cousins. We shook hands as blood relations. He then invited Mrs. Anderson for a walk through the drawing room to look at his mother's portrait and asked her if she had ever seen anyone look like her. She immediately replied, without knowing anything about McDonald's conversation with me that it looked as if it might be a portrait of her husband's mother. $\mathrm{Mr}$. McDonald was then fully satisfied and explained to Mrs. Anderson that the portrait was one of his mother and that he and I were cousins. British and American ministers at the various capitals usually greet each other with a "Good morning, cousin," "Good evening, cousin," "Good bye, cousin," and so on, but after this occurrence Mr. McDonold and I always put special emphasis on the word "cousin" whenever we met. McDonald's eldest son was about the same age as our eldest son, George Krogh, and they were both named after the same ancestor.*

* Since the above was written Sir Claude McDonald has died. His death occurred in London in September, 1915. 


\section{CHAPTER CXI.}

\section{DEMOCRACY.}

Switzerland does not send a diplomatic representative to Denmark. She sends ministers to only a limited number of countries. In accordance with an agreement between Switzerland and the United States, I, as American minister, was to represent Switzerland also. Wherever a country does not have its own representative it usually puts its interests in that country in the hands of the representative of a friendly nation.

As representative of Switzerland I had neither uniform nor salary. I was entitled to make an annual visit to Berne at the Swiss government's expense to make a verbal report on conditions in Denmark so far as these might affect Switzerland.

In the spring of 1887 I decided to take advantage of this opportunity to make a journey to Switzerland at that country's expense. I went. I stopped at some of the more important cities on the way, among them Hamburg, Cologne, Strassburg, Basle and Zurich. I came to Berne late one afternoon, and went to the "Bernerhof," the leading hotel in the city, located rear by the statehouse. The next morning, at 11 o'clock, I put on my Prince Albert and walked the short distance to the statehouse. I wanted to call on the minister for foreign affairs, announce my presence and find out when it might be convenient for the president of the Swiss republic to give me an audience. I had by this time become quite familiar with all this sort of red tape. I did not find the minister for foreign affairs, but I read 
on the door, "President's Office." It was very much like the governor's chambers in a capitol in the United States. It was open to the public. I therefore walked in to look around and if there was an opportunity to talk with some of the clerks. There I met the president's private secretary. I told him who I was and why I had come. The secretary said they were looking for me because they had received a letter from me that I was coming. I fell to talking with the secretary about how to proceed to get an audience. He took me to a window and said:

"Do you see that house on the right hand side of the square, with two stories and a mansard roof?"

I said: "Yes," and added, "looking at it from here it is an exact duplicate of my own house in Madison, Wisconsin."

The secretary continued:

"The president is at home, and he would like to have you come to his house."

I hesitated. 'I asked whether this would be proper. The secretary said that he was sure the president would prefer to have me come to his house.

I walked across the square and went to the house that looked exactly like my own home and rang the door-bell. A maid opened the door and I handed her my card which she took to the president. In a few moments the president, whose name was Deutscher, came himself to the door, shook hands with me, bade me welcome and invited me into his little library. Here we sat down and soon were engaged in conversation, part of the time in English and a part of the time in German, he plying me with questions concerning Denmark. It had gotten to be nearly 12 o'clock. If Mr. Deutscher had been king I would not have dared suggest that perhaps I was interfering with his lunch or other plans, but as he was merely president of a republic I arose to excuse myself for having taken so much of his time. 
"Not at all," he said; "if you have no other engagement, I would like to have you take lunch with me and my family."

I answered that I did not know but what I was transgressing the rules of society there, but that I could not refuse such an invitation. He then introduced me to his wife and two daughters and we all proceeded to the dining room for lunch. This is what I call democracy.

The next day, shortly before noon, a Bernerhof porter brought me President Deutscher's card, telling me that the president was waiting in the office of the hotel to see whether I was in. I hurried down. The president went with me to my room where he stayed and chatted with me. It got to be lunch time. I said:

"I do not know, Mr. President, what your customs are, but yesterday you asked me to take lunch with you. Would it be proper for me to invite you to take lunch with me today?"

"Most assuredly," he answered, "and I shall be pleased to lunch with you."

I had lunch served on a table in my own room and there we two sat for a couple of hours eating, drinking and smoking, and discussing the affairs of Denmark, Switzerland, America and the rest of the world. I asked him what salary he received as president. He told me that as president he received 17,500 francs $(\$ 3,500)$ and that this did not include a house to live in or any other perquisites. The house he lived in was his own.

The president of Switzerland is elected for only one year and cannot succeed himself. Representatives from all the Swiss cantons meet in Berne and form a sort of senate called the "Bundesrath." On the first of January they elect one of their own number president, both of the Bundesrath and of the Swiss republic. The members of the Bundesrath receive a salary of 15,000 francs $(\$ 3,000)$ and the one elected president receives 2,500 francs $(\$ 500)$ extra. It will be seen that he gets less salary than the president of a college or university or of an 
American governor. This is what I call democracy, a kind of democracy that might be imitated with advantage by every other state or nation in the world.

While in Berne I did not fail to call on the American minister, Boyd Winchester of Kentucky. From him I learned that the diplomats were invited to only one state dinner each year. This was given not by the president or any other high. official, but by the state. The president presided at this dinner, but it was paid for from the national treasury. This is also as it should be.

I went to see the bears in their deep pit. An English tourist had recently been killed by one of these bears. Engaged in feeding them he had fallen into the pit.

Berne is a city of no great importance, but lying on the top of a hill it furnishes one of the finest views of the Alps to be gotten anywhere. From my window in the Bernerhof I had before me the most stupendous view imaginable of the Alps, with innumerable peaks aspiring to heaven itself. It was indeed an awe-inspiring sight.

I received a check for 1,000 francs to defray my traveling expenses and after a week spent in the Swiss capital I bade goodbye to the president and to the American minister and started on my journey back to Copenhagen. 


\section{CHAPTER CXII.}

\section{MUNICH.}

\section{Prof. Konrad Maurer.}

I decided to stop on my way at Munich, the capital of Bavaria. I had several reasons for stopping in Munich. There lived the distinguished scholar, Prof. Konrad Maurer, without question the greatest then living authority in old Norse language, history and literature. At one time this man was invited to lecture on old Scandinavian laws at the University of Christiania. This might seem like shipping coal to Newcastle, but Konrad Maurer brought a better grade of coal to Norway. I had read his books while I was a professor in the University of Wisconsin and had received many charming letters from him. Now I wanted to see him in person. I wanted to thank him for his kindnesses to me and for the great service he had rendered to the cause of old Scandinavian culture. He was a charming old man, as unpretentious as a common laborer, but every inch a scholar and gentleman. I could not help comparing him with the great Norewegian linguist Ivar Aasen. But Ivar Aasen was a recluse while Conrad Maurer liked society and had every accomplishment thereto belonging. I went with him to lunch and so we had the opportunity of discussing many topics of interest to both. He was one of the most interesting scholars I ever came in personal contact with. 


\section{Count Werthern von Beichelingen.}

Before leaving Copenhagen on this journey the German minister there, Baron von Stumm, told me that the Prussian minister at Munich was an intimate friend of his; that he was a man of literary bent, and he wanted me to meet him. His name was Count Werthern von Beichelingen. The next day after visiting Professor Maurer I went to present my letter to Count Werthern von Beichelingen. I found him at home. I was ushered at once into his office and he received me in a most friendly manner. After a little he said to me:

"Just before you came in I was reading a book written by one of your fellow citizens. It is a most interesting book and if I knew the author's address I would like to send him a letter and thank him for the pleasure his book has afforded me."

He handed me the book. It was "Ragnarok," by Ignatius Donnelly. I pointed out to him that this book "Ragnarok" was in fact founded on my "Norse Mythology" and von Beichelingen was most agreeably surprised when I showed him that my book was regularly quoted throughout "Ragnarok" at the foot of the pages. I told him how I was well acquainted with Mr. Donnelly personally and what a charming man he was to meet. I gave his address as Hastings, Minn., and said that $\mathrm{I}$, too, would write and inform him that he had a distinguished admirer in Munich.

Then von Beichelingen stated that he was going to have a grand reception at his residence that same evening and he insisted that I, too, must come. Of course I accepted. I never refused such things.

I went to my hotel, "Die Vier Jahreszeiten," and a little later put on my full dress for the reception. There I met a number of the most prominent people of that city, including government officials, diplomats, professors, artists, authors, actors, actresses, opera singers and so on ad libitum. For the 
buffet I was given the Countess von Frankenstein to wait upon. Her husband was at that time the president of the Bavarian parliament. She was a woman of great dimensions, abominably corpulent. She was very communicative and inclined to tease me because I was an American. She evidently looked upon America as the home of humbug and she was tactless enough to speak disparagingly of my country to me. She began by asking me how much I had seen of Munich and what I thought of it. I spoke in glowing terms of praise of the city. She asked me if I had seen any of their grand parks. I said I had. Then in a teasing way she asked me whether we had any such large parks in America. She added that she had heard so much about Central Park in New York, but she knew that it didn't amount to anything.

Then I answered: "We have a park in the United States; I do not know the exact dimensions of it, but I think it is nearly as large as the kingdom of Bavaria."

At this she staggered and hesitated. When she had recovered she asked me if we had any such great trees in America as they had in Munich.

I said: "Your grace, if one of our great American trees lies on the ground and happens to be hollow the largest man you have in Bavaria can sit on the largest horse to be found in Bavaria and ride plumb through the tree."

"Ach!" she said, "sie können gut aufschneiden!" ("You can spin big yarns").

But, oh, with what an appetite this countess was blessed!

My objection to this kind of parties is that you meet so many people at once that you hardly get acquainted with any of them. It is all show and no substance. 


\section{CHAPTER CXIII.}

\section{HENRIK IBSEN.}

Another episode belongs to this visit in Munich, but in order to tell it I must return to Copenhagen to pick up some circumstances preceding it.

It was in the middle of the summer of 1885 . One evening on my way home to my legation I passed by the "Hotel d'Engleterre." Near the front entrance I saw a gentleman and a lady about to say good-night to two ladies. I looked at this man and the more I studied him the more it appeared to me that it was either Henrik Ibsen himself or his double. I had not heard of Ibsen's being in Copenhagen. I had never met Ibsen personally, but had had some correspondence with him, particularly concerning a translation of his "Pillars of Society," and I had had some interviews with the great American actor, Lawrence Barrett, in regard to the presentation of this drama on the American stage. Barrett finally decided that he could not act in ordinary costume.

Well, I thought I would find out who this man was. I asked him if this was Dr. Ibsen. He said it was. Then I handed him my card. He tried to read it, but it was getting late in the evening and there was not light enough. He handed the card to his wife. She could read it and told him who I was. At once Ibsen threw both arms around me and pressed me to his hosom, telling me how happy he was to meet me. His only 
son was at the time attache to the Swedish-Norwegian legation at Washington and this was a tie binding Ibsen to America.

Ibsen's besetting sin was his vanity. He would not have received me so gushingly had I not been United States minister. Did I say Ibsen was vain? To prove this, I may mention that he never refused a decoration from any potentate and he even wore these decorations pinned onto his overcoat when he walked the streets in Rome or in Munich. The three ladies were Mrs. Ibsen, her mother, Magdalena Thoresen, herself a writer of great prominence, and a young relative whose husband was a consul at Archangel. My wife and I later saw much of the gifted Magdalena Thoresen.

After Ibsen and his wife had said good-night to the other two ladies, Ibsen told his wife to go to her room and go to bed, and then he took me by the arm and led me into a small dining room in the hotel where we sat down. He ordered two bottles of champagne and a box of cigars. He did not smoke himself, but asked me if I smoked. He evidenly had had a drink or two before I met him. I let him drink the most of the champagne while I did the smoking. This man famous for his taciturnity became very communicative. He talked continuously, telling me over and over again how his books henceforth should become more and more aggressive. What he had done, he said, was hardly a beginning; but he was going to turn society inside out before he got done with it. He talked of all society as rotten and needing a thorough renovation. He continued talking until far into the small hours of the morning. It must have been about 3 o'clock a. m. when Mrs. Ibsen came down in her nightrobe, took her husband by the arm, said goodnight to me, and to her husband, "come with me." Such was my first meeting with Ibsen.

The next day a carriage stopped in the street in front of my legation quarters which were on the second floor, No. 50, Store-Kongens Gade. I looked out the window and there 
sat Ibsen in the carriage. He had both driver and footman. I saw him hand a card to the footman. Mr. Ibsen having been so exceedingly friendly the night before I thought I would return the compliment. So I hurried down stairs and went to the carriage in the street to bid him welcome. I was as cordial and gushing as possible. Mr. Ibsen had not intended to leave his carriage, but I persuaded him to walk into my parlor if but for a moment. He consented. I took him by the arm and escorted him upstairs. I offered him a chair in my reception room, but he refused to sit down. I asked him if he would take a glass of wine, but he declined. He had nothing to talk about, but said that he only came to pay his respects. He had several orders pinned on his breast, I presume as a compliment to the diplomat. In less than five minutes his visit was finished and he said goodbye.

I saw Mr. Ibsen only once more during his visit to Copenhagen in 1885 and that was at the home of his publisher, Hegel, proprietor of the well known Gyldendal publishing house. Hegel gave a banquet in honor of Ibsen and to it were invited the creme de la creme in Danish literature, art and other lines of culture. There was Georg Brandes, Sophus Schandorph, the dramatist Hostrup and many others. Mr. Hegel also invited me. I studied Ibsen closely. I observed his taciturnity. Nobody, not even Brandes, could get him to talk. He was silent as a sphinx.

At the banquet Mr. Hegel himself made a short speech of welcome and then called upon Georg Brandes to respond to the "skaal" to Henrik Ibsen. It was a fine address. Brandes always shines in his dinner speeches. He lauded Ibsen to the skies and thanked him on behalf of all the world for his service in exposing the wrongs in human society. I remember Brandes saying:

"We thank you, Dr. Ibsen, for laying bare our faults so that we may see them and mend them." 
When Brandes sat down all the guests joined in calling for a speech from Ibsen. After much urging he finally rose to state that he was not able to make a speech and so would have to decline; he wished, however, to say in reply to Brandes that it wasn't the world about him that he had attempted to expose, but that he had only laid himself bare to his readers; that he had written wholly from a study of himself. Then he sat down. What he meant to say was a mystery to all who heard him. It was probably symbolism of which they had no comprehension. Ibsen himself being unable to speak extemporaneously probably did not know exactly what he was saying.

And now let us return to Munich.

The next day after attending the reception at Count Werthern von Beichelingen's, at which reception, it may be here noted, Henrik Ibsen was not present, I remembered that the distinguished Norwegian poet was domiciled in that city. I remembered his address, "Maxmilian Strasse, No. 1, second floor," that is what the French call "belle etage." I secured a carriage and drove to that number. I discharged my driver, went upstairs and rang the bell. A maid came to the door and I asked her if Dr. Ibsen was at home. She answered:

"No, he is not at home."

I looked at her earnestly and asked again:

"Are you sure he is not at home?"

She blushed and hesitated; then I said:

"Take this card with you and if Dr. Ibsen is at home hand it to him and I will wait here until you return."

She did not return, but instead came Henrik Ibsen himself, bade me welcome and invited me in. In the sitting-room we met Mrs. Ibsen. She also greeted me cordially. In the middle of the room was a round table. On this table stood a server with two decanters of wine, one of sherry and one of port. There were two glasses on the table and also a tray with cakes. At the table were two chairs. I having come in Mrs. Ibsen 
brought a third glass and a chair for me. We drank wine, ate cake, and of course, I smoked. It was about 11 o'clock in the forenoon. I said:

"Is this your daily custom to drink wine and eat cake at this time of the day?"

Mrs. Ibsen assuming a very earnest and serious look said:

"No, it is not our daily custom; but it is my husband's birthday today and we are celebrating it in this way. I am glad that you have come to join us in the celebration."

It was the 21 st of March, 1887. He was that day 59 years old and had long before reached the zenith of his fame.

Would not this make a subject for a painter? Henrik Ibsen and his wife; he the famous author of "Brand," "Peer Gynt" and "Kongsemnerne," no doubt the three greatest dramas written in the nineteenth century. Here we have Munich, the city of culture, the home of Paul Heyse, and the whole galaxy of distinguished writers and artists, and Henrik Ibsen celebrating his birthday in the utmost obscurity, all alone with his wife, this solitude only interrupted by a literary wanderer from far off Wisconsin.

Throughout his life Ibsen was a recluse and adopted the habits of a hermit. Much as I admire the dramas I have mentioned, including also "Hærmændene paa Helgeland," I have no sympathy whatever with his so-called social dramas, beginning with "Et Dukkehjem" and ending with "Naar vi döde' vaagner." Aside from the improprieties and offense against good morals that are found in them, they seem to me mere twaddle and all the symbolism which they are said to contain I regard as a mere opinion of his readers and admiring critics. It is said that language was given to diplomats to conceal their thoughts, but an author has no right to present his thoughts so ambiguously, vaguely or obscurely that intelligent readers have to guess at the meaning. And such is surely the case with Ibsen. Of his drama, "Bygmester Solness" there are at least 
a dozen different interpretations by as many distinguished literary critics, including Georg Brandes, where there should be but one, if the author had used his words and phrases in the proper manner. But it became a fad to search for all kinds of hidden meanings in Ibsen's prose dramas. If Ibsen should look out of the window, see the snow falling and happen to remark: "It is snowing," his admirers would look at each other in despair and wonder what the great sphinx actually meant by this profound remark. One would argue that it was an expression of Ibsen's pessimism; and that he meant to indicate that all virtue and kindness and sweetness in life were being buried under a carpet of cold snow. Another one would suggest that he disagreed wholly with this interpretation. $\mathrm{He}$ would say:

"When our great seer Ibsen has uttered the profound remark that "it is snowing," he has thereby indicated that the world is taking on a dress of purity; everything unclean, vicious and wicked is being buried under the whiteness and purity of snow. A third one would suggest:

"When our great master has said that 'it is snowing,' he has had a glimpse of the future when the swords will be beaten into plow-shares; when all wars will cease and man, figuratively speaking, will be clad in snow-white angelic robes. It is the white flag of truce which puts a stop to war and bloodshed of which our great master has just had a vision."

It is no exaggeration when I say that much of the ecstacy of the Ibsen critics is of the very kind and nature that I have here suggested.

Before I left Copenhagen Ibsen again visited that city on his way to Norway. I attended a grand dinner given him by the wealthy old friend of Hans Christian Andersen, Mr. Henriques, and met him on one or two other occasions; but did not have much conversation with him. The fact was that I had already begun drifting away from the Ibsen, Björnson, Bran- 
des, Garborg school in Scandinavian literature. I was struggling to find my way back to my old more conservative moorings. 


\section{CHAPTER CXIV.}

\section{GEORG BRANDES.}

The most eminent literary critic that all Scandinavia ever produced is unquestionably Georg Brandes. He is a man of wonderful intellectual endowment and of indefatigable industry. He is a highly-gifted orator, and if he speaks to an audience of culture he holds his hearers spell-bound. He would be unable to harangue the masses as Björnson did. $\mathrm{He}$ would not be able to find a suitable topic and would shoot over the heads of his audience. What he talks on is literature, art and, to some extent, on peculiar social problems. His whole library of published works consist, I might say, almost exclusively of literary criticism. He treats with equal skill English, French, German and Scandinavian modern literature and he lectures in the languages of all these countries in his frequent visits to them. He has sometimes been called the Taine of the North. As I see him I would call him corrosive-sublimate. When he has finished an author there remains nothing left but the skeleton. The blood and flesh, sinews and muscles are all gone. In religion he is an agnostic; in literature he favors the naturalistic school of which Emile Zola was the promoter and head. It was Brandes that promoted infidelity and naturalism among the writers and artists of the North.

I met Brandes frequently, particularly at the home of our mutual friend, director general of the foreign office, P. A. Vedel. But we also exchanged visits to our respective homes. 
During the year 1888 there came to Denmark a German journalist by name Max Bewer. He was the correspondent from Copenhagen for several papers in Germany, and he was a man of great arrogance and pretensions. In that year Emperor William I of Germany died and also his son Frederick III, the latter at once being succeeded by the present emperor William II. An article had appeared giving an estimate of the character of the two deceased emperors and discussing the effect of their deaths upon the future of the German empire as well as upon the whole world. The article attracted much attention and discussion. Its author was not known.

A few of the most intimate friends of Brandes knew that he was the writer. But Brandes did not want it known that he had written it, because on account of certain statements, it might embarrass him on his visits to Germany. The German government is known to be very sensitive in regard to criticisms of their ruler or institutions. The Danish writer, Herman Bang, visited Berlin and sent from there to a paper in Bergen, Norway, a correspondence in which he made some humorous reference to the fact that the people in Berlin made an idol of their emperor and that the emperor's portrait was hung in well nigh every window to be looked at by passers-by. No doubt the German vice-consul in Bergen sent a copy of the paper containing the correspondence to Berlin where it was read. Immediately two "gendarmes" called on Mr. Bang at his boarding house and escorted him to the railroad station and sent him out of the country.

This was during the life time of the old emperor. Georg Brandes naturally feared that a similar fate might be in store for him if he became known as the author of the article concerning the two deceased and the new emperor and this he wished to avoid. He was accustomed to having the emperor in his audience when he lectured in Berlin. 
In some way Max Bewer had ferreted out that Brandes was the author of the article in question and in a correspondence to a German paper he made this fact known over his signature. Brandes did not like this and he was all the more incensed because he had been nice to Max Bewer.

After the publication of Bewer's correspondence in Germany we gave a small dinner at our house in honor of Georg Brandes and his wife. At that dinner, among others, were present Consul Mann and his wife, both Germans, residing for a short time in Copenhagen. Mr. Mann had been a consul, but was not now connected with the service. He was in easy circumstances and a gentleman of leisure, most of the time waiting on his wife. Mrs. Mann was a blue stocking; she had come to Copenhagen to translate the cream of Danish bellelettres into German and was trying to become a correspondent for various German dailies. She claimed that she had the entree in the most prominent Copenhagen homes and so could get valuable news at their very source.

One of our guests was a rising German poet by name Friedrich, who was also sojourning in Copenhagen. He had come there to see the great Dane, Brandes.

After the dinner we had Mr. and Mrs. Algot Lange. Lange was the great operatic singer at the Royal theater and his wife was a leading pianist, who gave lessons to the then crown princess Louise.

The Manns and Brandes were fast friends and Brandes was helping Mrs. Mann in the selection of suitable Danish literature for translation into German. I may here add that she also translated and published in Germany my book on the Norse discovery of America. The Manns were also intimate with Max Bewer, helping him find news for his journalistic work and I have a strong suspicion that Mrs. Mann was the one who had revealed to Max Bewer the fact that Brandes had 
written the article about Germany and which had made much commotion.

At the dinner table Brandes sat directly opposite Consul Mann. In course of time the conversation turned on the rights of an anonymous author. Dr. Brandes insisted that the public was not entitled to know who had written an article that was not signed. He considered it highly improper to go on a hunt to discover the author of an anonymous book or article. If the writer wished to be unknown that was his privilege.

The discussion was animated and in the course of it Brandes denounced the journalist tramp for having named him as the writer of the much-discussed article. He spoke with great passion. Consul Mann said:

"You have a remedy, Dr. Brandes. Why don't you make use of it?"

"What do you mean?" said Dr. Brandes.

"I say you have a remedy," said Mr. Mann.

Brandes: I do not know as I understand you. I know of no remedy in the laws. Do you mean that I should challenge him to a duel?"

Consul Mann: "That is exactly what I mean," and he too was very much impassioned.

In the midst of this heated discussion the dinner was finished and we retired to the parlor to be entertained by Mr. and Mrs. Lange. The matter was not referred to again that night.

The next night Mrs. Anderson and I had retired and gone to sleep. Then we heard a racket at the door. I arose and without dressing opened the door and there stood Dr. Georg Brandes before me in a state of great excitement. He came in. It was about midnight. He begged me not to dress, but he wanted an interview with me. I got a light in the room and we sat down at the table. He told me that Max Bewer had challenged him to a duel. He said he did not believe in duels and had no experience in that line, but he took out of his pocket 
a long article on the subject "Max Bewer" and this was to be published in the liberal paper "Politiken" the next morning. He read the article to me. It was full of corrosive sublimate. I urged him not to print it. I argued that Max Bewer, hitherto an obscure fellow, was trying to get notoriety by getting his name linked with the distinguished name of the greatest Danish critic. I insisted that the name Georg Brandes was too great and good to be yoked up in public print with that of Max Bewer, a mere literary tramp.

But Brandes was evidently so well pleased with the caustic article he had written that he could not be persuaded to keep it out of print. It appeared in "Politiken" the next morning.

We then discussed the matter of the duel. I proposed to go to the home of Brandes the next day and be present when the seconds of Max Brewer came with the formal challenge, and I was there. The seconds came. One of them was Consul Mann; the other I do not now remember. Consul Mann was spokesman. In the most solemn manner he informed Dr. Brandes that he and his companion had been duly appointed Max Bewer's seconds and had come to present a challenge to a duel on Max Bewer's behalf and requested Brandes to name the time and the place and to choose his seconds and the kind of weapons.

At this point I protested. I objected to any duel growing out of a dinner at my house and asked Consul Mann to inform Max Bewer that I personally assumed all responsibility for every word spoken at our dinner. If he wanted to challenge anybody he must therefore challenge me; but to this Consul Mann refused to listen. The seconds left.

I not only requested but I distinctly forbade Brandes engaging in any scandal as a result of a dinner which had been given in his honor at my house. He said he neither could nor would take part in any duel. 
Then I received an insolent letter from Max Bewer demanding of me a statement of what had been said at the dinner. It may be unnecessary to add that I did not even answer this epistle.

The duel did not take place, but Brandes reported Max Bewer to the police. Duels are prohibited in Denmark. Max Bewer was arrested, tried, sentenced and had to pay for his insolence with 90 days in jail. The whole affair produced quite a flood of articles in the newspapers throughout Europe. The circumstances were telegraphed everywhere and published with sensational headlines. It was what we would call in this country "first page matter."

Max Bewer had gained one point; he had gotten his name linked with that of Georg Brandes and so Max Bewer became a household word wherever the great Danish writer was known. I have to regret to add that my name too appeared in all these telegrams and correspondence from the fact that the affair had started at our dinner to Brandes. The kind of notoriety that I was getting out of this did me only harm. The episode also furnished first class matter for the cartoonists. In one of the cartoons I was presented as a North American Indian chief with my hair covered with feathers and my left arm loaded with books. 


\section{CHAPTER CXV.}

\section{AUGUST STRINDBERG.}

It is probably no exaggeration when I say that during my residence in Copenhagen I met personally well nigh all the Scandinavians of that day eminent in literature, in science, in the various arts, in the learned professions, and in statecraft. To mention them all would require many more pages than have been allotted to this story of my life. Furthermore, while there were many whom I met casually or even repeatedly I cannot say that they had any perceptible influence upon my own life. They did not become, as it were, any part of myself. They were not all men and women whose lives and works had become of any special interest to me. Sometimes I met some of these prominent people under more or less strange and interesting circumstances and such I mention mainly on account of these.

I assume that the reader is so well acquainted with the works of Ibsen, Björnson and Brandes, that he does not care to have me give a list of the books they have written; but would rather get in a single line my estimate of their worth and then some episodes concerning my own association with them. Keeping this in view I shall now proceed to mention some other people of note that I met.

There is, for instance, Johan August Strindberg, unquestionably the most prominent figure in modern Swedish literature. I was a member of a society in Copenhagen in which only English was spoken and occasionally had to read a paper or speak 
at its meetings. One night after attending the meeting of this society with the well known Danish novelist Pontoppidan he and I went down stairs into a large restaurant where we sat down at a table for refreshments and a chat. While we sat there two men entered and took their seats at another table. I asked Mr. Pontoppidan whether he knew either one of those gentlemen who had just taken seats. He said he did not. I said to him:

"Notice that man with the long hair, thin, pale face, almost invisible mustache and those long, thin, bony fingers. He looks as if he had had nothing to eat for a year; but look too at that pair of eyes. Note how they pierce. From pictures that I have seen that must be August Strindberg. If it is we must get acquainted with him. I will introduce you and you can introduce me."

This was agreed to. I then went over to the other table and asked the gentleman I have described whether he was not August Strindberg. He said he was and asked who I might be. I told him that a gentleman and I at another table had agreed that if he was August Strindberg I was to invite him and his friend to jcin us at our table. He and his friend consented. I then introduced him to the poet and novelist Pontoppidan. Pontoppidan introduced me and before long we got into a conversation about all things between heaven and earth.

Strindberg was wonderful. He spoke only in flames and with these he seemed to burn up and lick up everything sacred in human society. He spoke almost entirely in paradoxes, but seemed intensely in earnest. I never heard anyone equal to him in sweeping over all conventional social, religious and political institutions with such bitter and stinging satire.

This session was prolonged until after midnight. This emaciated form never seemed to get exhausted and he held his little audience spell-bound every moment. At this particular time Strindberg had written his, as I see it, exceedingly immoral 
drama called "The Father." It was being played at the Casino theater in Copenhagen night after night to crowded houses. He continued in this vein until near the close of his life when he turned a complete somersault and confessed his unwavering faith in the Christian teachings of his childhood. In his death the whole Swedish nation honored him more than if he had been their king. Sweden had lost in the death of Strindberg her most gifted and distinguished son. 


\section{CHAPTER CXVI.}

\section{GOLDSCHMIDT.}

With Aaron Meir Goldschmidt we go back to the first half of the last century. He was a contemporary in Denmark with Adam Oehlenschlæger, in Sweden with Esaias Tegner and in Norway with Henrik Wergeland. Like Brandes he was an Israelite. Wergeland's heroic fight for the rights of the Jews in Norway endeared the Norwegian skald to Goldschmidt. One of the finest tributes ever penned in honor of Henrik Wergeland was written by Goldschmidt. Goldschmidt himself ranked well up among his contemporaries as an essayist and novelist, and many of his stories, including "Recollections and Results of My Life," will live as long as the language in which they are written.

I knew Goldschmidt from his celebrated works, and now living in the same city with him I had an eager desire to meet this man who was born in 1819 and had been a friend of Wergeland. It seems that Goldschmidt became prematurely old. When people asked me whom I had met and whom I had yet to meet and I mentioned Goldschmidt among the latter they said:

"You better keep away from him. He will talk you to death about Nemesis."

In his declining years he was making a hobby of Nemesis and he was finding Nemesis everywhere. He regarded Nemesis as the controller of all things physical and spiritual. Nemesis 
is present at your birth and stays with you every moment of your life. You do not understand Nemesis by simply looking about you and pointing your finger at the culprit as he reaps his penalty. Nemesis is omnipresent and has maintained and maintains the equilibrium of all things, material and spiritual, in this world. Nemesis is above all physical and moral forces, nay, God himself is governed by Nemesis.

In spite of the warnings I had received I knocked at Goldschmidt's door. I was ushered into his library and what an elegant and distinguished looking man there greeted me! He had examined my card and knew who I was. He invited me to be seated. Then he brought me a cigar and lit one himself. A maid left some refreshments on the table. I began by assuring him how I was delighted to meet face to face with a man so distinguished as himself in the world of thought and literature. I informed him that my first glimpse of him while I lived in the far west near the Mississippi river was the tribute he had written to Henrik Wergeland, and that I had read many of his stories with unusual interest. But he soon interrupted me. He said:

"Mr. Anderson, there is one subject which surpasses all others in interest and that is Nemesis. I have for years been making this force in the world my chief subject of investigation. She is indeed the great goddess of justice. People call her the goddess of retribution, but that shows only a superficial knowledge of her real character. Nemesis presides over all nations and over all individuals with unwavering justice. She is the chief principle in the administration of this world in which we live. I have been studying Nemesis in the history and literature of a number of peoples and always with the same general result. At present I am deeply engaged in investigating Egyptian antiquities to learn exactly to what extent this principle was comprehended by the ancient Egyptians." 
In this strain he continued. I will not say he was not profound and interesting, nay, scholarly, but no end was in sight. I suggested that I was taking too much of his valuable time. He would not listen. I intimated that he might be getting tired. He said he could discuss Nemesis till doomsday without getting weary; the subject was of such absorbing interest to him. Finally I told him, looking at my watch, that I was going to be late to meet an engagement I had made. He assured me that Nemesis never failed to keep everything in the proper balance and see that all appointments were kept exactly as they must be. I got up; he held me by the hand; he had so much more to say, but I finally released myself, thanked him for the pleasant visit and took my leave.

But the more difficult dilemma was to come. In a couple of days Dr. A. M. Goldschmidt returned the visit. He called on me. I supplied the cigars and the refreshments. I was determined, if possible, to guide the conversation into the field of modern European and particularly Scandinavian literature. I began by plying him with questions concerning a number of well known authors. I struck the attitude of a disciple sitting at the feet of his master and desiring the benefit of his knowledge and opinion of the different great writers of the day. But with the adroitness of a prestidigitateur he soon managed to weave into his reply a statement that the kind and quality of literature now, as in all ages, was determined exclusively by that remarkable goddess Nemesis. She determined the fates of nations and all authors depended on the grace and favor of this benign and just divinity. He soon got full swing and began lecturing Nemesis among the Hindoos, Japanese and Chinese. He was my guest. I could not turn him out. He could not stop. What was I to do?

After a long session I had to inform him that there were people in the waiting room who had business to transact with me and that he must excuse me for their sakes. I never saw him 
again. He grew more and more feeble and two years afterwards, in 1887, he was gathered unto his fathers. In spite of the Nemesis episode I must confess that Aaron Meir Goldschmidt was one of the most gifted, scholarly, poetic and lovable persons that it has ever been my good fortune to meet. He reminded me in his general appearance, in his whole manner, in his simplicity and in his cordiality of our American poet $\mathrm{H}$. W. Longfellow. 


\section{CHAPTER CXVII.}

\section{COUNT CARL VON SNOILSKY.}

The greatest lyric talent in Sweden in modern times is Count Carl Johan Gustaf von Snoilsky. It may be safely stated that there are but few parallels to Snoilsky in any land or age. At any rate he ranks in the domain of lyric song with Wergeland and Vinje in Norway, with Christian Winther in Denmark, with Heine in Germany, with Shelley in England, with Burns in Scotland and with Petöf in Hungary. His life spans the years between 1841 and 1903.

Snoilsky was intended for a diplomatic career and was given a position in the foreign office in Stockholm. In the meantime he was pouring forth poems of exquisite beauty. Then there was a tragedy in his family life. A lady friend was a guest of Mr. and Mrs. Snoilsky. Snoilsky fell deeply in love with the guest and the two fled. They went to Italy and Spain. The abandoned Mrs. Snoilsky died of a broken heart. The pair spent years and years in exile, Snoilsky in the meantime sending to his native land the sweetest poetry that had ever found expression in the Swedish tongue. The whole Swedish nation read these poems with the profoundest delight. It was making the author the most popular man in his native land with the assurance that whatever mistakes he might have made this would be forgotten and that a most hearty welcome was in store for him. He came. Besides being the favorite poet he was also a nobleman. He landed in Stockholm, had himself properly announced at court, but there every door and avenue was 
closed. The palace could not receive Mr. and Mrs. Snoilsky on account of the past, and for this the queen was chiefly responsible. But the people of Sweden had heard of Snoilsky's arrival and so they organized throughout the land to receive him in the grandest fashion. There were parades, banquets, receptions, and speeches of welcome without limit, from one end of Sweden to the other. It was a procession of triumph, a veritable "Eriksgata" such as has never before or since been accorded to a Swedish citizen.

One of the grandest receptions to Snoilsky was the one at Göteborg. At the head of this were the distinguished journalist and statesman Sven Hedlund, the great scholar and poet Victor Rydberg, and the very distinguished Swedish writer Karl Warburg, a trio of which the greatest nation might be proud. To this magnificent Snoilsky ovation Hedlund and Rydberg invited me from Copenhagen. I could not say no. What an opportunity to meet and see and hear the flower of Swedish culture!

I have mentioned Snoilsky, Rydberg, Hedlund and Warburg, but there were many others that a student of Swedish would be glad to meet. At the banquet Sven Hedlund presided, with Carl Snoilsky and Mrs. Snoilsky on his right and left. I was seated beside the man dearest to me in all Sweden, Victor Rydberg. There were eloquent addresses by Hedlund, by Snoilsky, by Victor Rydberg, by Warburg, and by many other distinguished guests. I had feared that I might be called on to say a word and for that reason had tried to make a little preparation and I was determined to speak Swedish as perfectly as possible. I carried in my valise a volume of Carl Snoilsky's sonnets and committed to memory from it his wonderful poem on Benvenuto Cellini. There is no doubt that Snoilsky intended this sonnet as a description of his own life and of the sacrifice that he had made in order that he might produce finished products of the poetic art. 
In the course of the banquet I was called on. I responded in the best Swedish I could command and then quoted a part of "Benvenuto Cellini," making an application thereof to the guest of honor. The poem quoted showed that Cellini had put too little metal in the crucible for the statue of the Zeus which he was that moment casting for his king. He at once seized whatever precious ornaments from antiquity he could lay his hands on in his studio and threw them without hesitation into the crucible that the statue might not be marred for want of metal. It shows what sacrifices must be made in life or in art to attain completeness and perfection. The whole audience rose and gave three cheers for the American minister who could respond in Swedish and quote from the choicest lines of the guest of honor.

Sven Hedlund owned a magnificent summer resort near Göteborg. On one side of this resort was a mountain presenting a perfectly smooth and perpendicular wall. On this wall Mr. Hedlund had cut, like runes of old, in letters at least a foot high, the names of the most distinguished guests whom he had had the honor of entertaining at this resort. There were the names of the king and queen of Sweden, the names of $A$. E. Nordenskjold, Victor Rydberg, Paul B. du Chaillu.

To this resort a group of the banqueters were invited by $\mathrm{Mr}$. Hedlund the next day. Of course Count Snoilsky was the chief one of this group. On our departure Count Carl Snoilsky's and Rasmus B. Anderson's names were added on the mountain wall to stand there together to the end of time.

This was the end of my Göteborg visit at this time. On his return to Italy the poet paid me a charming visit in Copenhagen and he never forgot to write me about his new poems and books of which he regularly sent me copies. The old saying is: "See Venice and die." I think many a Swede would paraphrase this with "see Carl Snoilsky and die," so greatly was that man beloved. Carl Snoilsky died in 1903. Sven Adolf Hedlund died in 1900. 


\section{CHAPTER CXVIII.}

\section{RANDOM NOTES.}

The second half of the nineteenth century gave Scandinavia great prominence in the field of science, literature, and art. There was a great intellectual activity in all directions. If we go back to the ' 80 s some of the celebrities of this golden epoch in intellectual endeavor in Scandinavia had but just spread their wings for flight. Others were in the meridian of their activity and some had begun to stoop toward the grave. As I have said, I met a very large number of them, but it would increase these pages beyond all reasonable bounds if I should give incidents touching my personal association with them all. I must therefore cut this part of my story short and merely mention a few of the most conspicuous ones whom I met.

J. C. Hostrup was the greatest dramatic writer in Denmark since Ludvig Holberg; in fact, it may be said that the mantle of Holberg fell on Hostrup's shoulders and that he wore it most gracefully. His comedies always filled the Royal theater and kept the audience roaring with laughter. He died in 1892.

The first time I met the poet Carl Ploug was at a students' annual banquet where I had been invited to deliver the regular address. Near me at the table sat the then venerable Carl Ploug. While we were seated at the table I wrote out with pen and ink my translation of his well known Scandinavian song: 
Længe var Nordens

Herlige stamme

Spaltet i trende

Sygnende skud;

Kraften, som kunde,

Verden beherske,

Tyggede sul

Fra fremmedes bord.

Atter det skilte

Böier sig sammen,

Engang i tiden

Vorde det et.

Da skal det frie,

Herlige Norden

Före til seir

Folkenes sag.

My translation runs as follows:

Long was the mighty

Folk-tree of Northland

Split into three small

Withering shoots.

People who might have

Conquered the whole world

Sought for their food

From tables abroad.

Now are the parted

Shoots reuniting;

Yet in the future

Will they be one.

Then shall the glorious

Folk-tree of Northland

Lead on to victory

Liberty's cause. 
Having written this in my best Italian hand and signed my name to it as translator I handed it to Carl Ploug with my compliments. Carl Ploug, who was a good English scholar, read it aloud, and it produced the greatest enthusiasm. Then the poet proposed a toast in my honor and when my health was drunk he came to my side and put one arm around my neck while we clinked and emptied our glasses. He was the pro-Scandinavian par excellence, the very opposite of Ole Bull. To Carl Ploug there were no invisible Swedes or despised Norwegians. The great national poet died in 1894 .

The leading writer of humor in Denmark in this epoch was the inimitable Erik Bögh. His comic songs and his burlesques are among Denmark's most precious literary gems. His death occurred in 1889.

Holger Drachmann was the greatest lyric talent among his Danish contemporaries. He was an exceedingly prolific writer of poems and dramas and a most striking personality. He died in 1907 and lies buried out on the Skaw, the north point of Jutland, where his lyric mind loved to watch the undulations and breakers of the sea, his own soul's counterpart.

I had heard that the famous Finnish poet Zacharias Topelius was paying a visit to Copenhagen and I could not rest till I had seen the author of the wonderful cycle of romances called "The Surgeon's Stories" and of so many charming poems and stories for children. I found him at his hotel and he graciously returned my visit. J. L. Runeberg and Z. Topelius are two literary ornaments to poor Finland of which any country or any age might be proud. Topelius died in 1898.

During this period Denmark had Frederik Liebenberg, the great text critic of Holberg and other Danish literature; P. Hansen, the translator of Goethe's "Faust" into Danish, the author of a life of Goethe and also of a splendid illustrated history of Danish literature; and J. N. Madvig, the world's greatest Latin scholar of the nineteenth century. In matters of Latin texts 
and in determining the oldest, or parent, in a series of ancient manuscripts, Madvig was the highest authority and his decision was final. In the political distress of Denmark in the early '80s he was impressed into the service of his country and was compelled to do duty as a cabinet officer. I exchanged calls with Madvig and told him that I had learned his Latin grammar, and I attended his funeral at the Church of Our Lady in 1886. The year before I had escorted the blind old scholar to the funeral in the same church of our mutual friend, the archæologist J. J. A. Worsaae.

Speaking of Worsaae's death in 1885 , leads me to give my readers a little glimpse of court life for the diplomat. At drawing rooms it was important that the royalties should have something to say to each individual diplomat. It seemed as if the different members of the Danish royal family must have held conferences and considered what particular topic might be appropriate for the various ministers.

Worsaae had died and I was due at a drawing room. The king came to me and said:

"That must have been a great blow to you, Mr. Anderson, when Worsaae died."

I answered: "The death of Worsaae, your majesty, was an untimely loss not only to Denmark, but to the whole world. In him I lost a personal friend, as you probably know."

The queen comes to speak to me and she says:

"I have been thinking so much of you, Mr. Anderson, since our dear Worsaae died. His death must be a-great personal sorrow to you."

I assented. Then the same condolence was expressed to me by the crown prince, the crown princess, Prince Waldemar, and all the rest.

At another time a report had just been published in the Danish papers about the Johnstown flood. At court all of the royal personages told me how shocked they were to see such 
bad news from America and begged me to be assured of their sympathy.

The Norwegian writer Camilla Collett, Henrik Werge-. land's sister, the author of "Amtmandens Dötre" ("The Magistrate's Daughters"), the first Norwegian book to espouse the cause of the women, and of a large number of other works, spent much of the ' $80 \mathrm{~s}$ in Copenhagen. She died and was cremated in 1895 .

Of the Norwegian Sinding brothers there were three, Stephan, Otto, and Christian. Stephan was the sculptor. He lived in Copenhagen and had the wealthy brewer, Carl Jacobsen, as his patron. Being treated so well in Denmark he became a Danish citizen, thereby greatly displeasing his Norwegian compatriots. He took the grand prix at the world's exhibition in Paris in 1889. Among his most famous productions are "The Captive Mother," “The Barbarian Croup," "A Human Pair," and "The Oldest of the Race." Dr. and Mrs. F. P. Möller and Mrs. Anderson and I went to congratulate Stephan Sinding the day he received the grand prix. He was simply wild with excitement and joy. He declared that he would no longer be modest. He could see yellow streams of gold pouring in upon him from all sides and he could demand any price he pleased for his work henceforth.

Otto was the painter. He died in the year 1909. He had won many gold medals. He painted expressly for me thirteen pictures of the land of the midnight sun which are among the most precious possessions in our home at Madison, Wis.

Christian is a musical composer of renown. His symphonies and other compositions rank high in the world of music. Sinding wrote the music for "Der skreg en Fugl" and for Sivle's "Vi vil os et Land." He wrote music for Björnson's poem on "Molde." For the publication of this in Norwegian, German, and English in Berlin I furnished an English translation. 
There is a sister of these brothers, Johanna Sinding, born 1854. She had acquired considerable reputation as a sculptress.

I had the pleasure of meeting both Japetus Steenstrup and his son Johannes, the former ranking as Denmark's greatest scientist in the ' $80 \mathrm{~s}$, and the son distinguished as an historian, being the author of a four-volume history of the Normans and of a work on the "Danelag." The father was also a great ethnologist. Our P. A. Chadbourne had gone to Copenhagen only to see and consult with Japetus Steenstrup. The old man died in 1897 , at the age of 84 .

The most popular novelist living in Denmark at this time was Sophus Schandorph, who died in 1901. He was in Danish literature what Jonas Lie was in the Norwegian. Socially he was joviality personified. When his friends gathered round him he was always the chief center of attraction and entertainment.

During the '80s the Norwegian poets John Paulsen, Nils Collett Vogt and Alexander Kjelland spent much of their time in Copenhagen and I met them regularly. Kjelland had a hard time of it to make both ends meet and I had to exercise all my persuasive powers to keep him from carrying out his resolution to become a farmer in North Dakota. He kept on writing until he became, first mayor of Stavanger and then amtmand in Romsdal and from that time he never wrote a line. He died in 1906. A brilliant writer was spoiled to make an indifferent office-holder.

Norway's brilliant critic of art, architecture and culture in the last half of the nineteenth century was Lorenz Dietrichson. $\mathrm{He}$ is an authority on wood carving and on pictures of Christ. $\mathrm{He}$ also wrote the history of Norwegian poetry.

Among Danish artists I would like particularly to mention Lorenz Frölich, who has probably never been excelled by any Scandinavian. He illustrated Hans Christian Andersen's sto- 
ries, made a series of immortal etchings for Oehlenschlæger's "The Gods of the North" and made the grand fresco "Gefion Ploughing Sealand Loose from Sweden" on the ceiling of Frederiksborg palace. For my four-volume English and American edition of Snorre's "Heimskringla" he made at my request a drawing to be reproduced on the front of the cover. The picture represents a viking ship floating on the boundless sea of time beneath a blaze of northern lights. In the boat sit Saga, the goddess of history, and the Icelandic historian Snorre. Saga is in the attitude of telling and Snorre conscientiously putting down every word. The picture was suggested by me and now hangs over the desk at which this story is being written. Frölich exhibited this work of art at the great annual Danish art. exhibition and it won the first prize. Frölich died in 1909 at. the age of 79 .

Speaking of painters I may also mention the greatest Norwegian artist of this period, Fritz Thaulow, who died in 1906; but had then reached the point when he could set his own price on his paintings. I am sorry to have to record that he belonged to the extremely modern, or naturalistic, school.

Denmark still had with her at this time her two greatest composers of music, J. E. P. Hartmann, born 1805, and N. W. Gade, born 1817. They easily rank with the best composers of their time.

Denmark had a great runic scholar in Ludvig Frands A. Wimmer and Norway her profound linguist in Sophus Bugge.

I had the pleasure to meet while in Copenhagen two charming old maids, the daughters of the founder of the Royal Danish Society of Antiquaries, C. C. Ravn. They often entertained Mrs. Anderson and me, gave me autographs and other mementoes of their distinguished father and were kind and hospitable in the extreme. Once Willard Fiske came to Copenhagen from his home in Florence, Italy, to spend a part of the 
summer and he went with us to visit the Ravn sisters at their summer resort.

The great Swedish traveler Sven Hedin came to Copenhagen to lecture before the Geographical Society. He was then a young man brim full of life and energy and after the lecture I joined him and some of the officers of the Geographical Society for several hours at a restaurant. His stories of hair-breadth escapes almost made our hair stand on ends.

I first met Fridtjof Nansen in Copenhagen. The generosity of the coffee vender Gamel had enabled him to cross Greenland on skis with five companions in 1888. Having been financed by a Dane, the only proper thing was to make his first appearance and report of his expedition in Copenhagen. He received a tremendous ovation a la Dr. Cook's in more recent years there and lectured before the Royal Geographical Society. Mrs. Anderson and I attended the lecture and while at Copenhagen he called at our house. I afterwards met him after his "Farthest North" in Madison and at the great banquet given him at the Auditorium in Chicago I was one of the speakers.

I happened to be in Christiania at the time when the Storting was discussing the Alexander Kjelland stipend question. Amtmand Michelet, whom I had met, and who was a member of the Storting, took me with him to one of the sessions and gave me a seat in the diplomatic box near where the cabinet officers sat. Michelet acted as my host. He brought the king's cabinet to me one at the time to introduce me, then he would select some of the most prominent members of the Storting and bring these to me. Among these members the most interesting one was probably the then aged Sören Jaabæk, or, as they sometimes called him, "Neibæk" (No bæk). He kept the strings of Norway's purse tied and was sure to object to any extravagance. 
The Kjelland stipend was defeated largely as a protest against the reckless school to which Kjelland belonged, but this was not the reason why Jaabæk voted no.

I saw Johan Sverdrup to shake hands with him, but he was too busy with his parliament to stop for conversation. I also met here a son of the renowned peasant leader Ole Gabriel Ueland, a brother of my good friend Andreas Ueland, in Minneapolis, at present John Lind's law partner.

The eminent Swedish writer, Anna Charlotte Edgren, sometimes visited Copenhagen and I first met her at the Ibsen ban-. quet given by his publisher, Hegel. This gifted woman died in 1892 , only 43 years old.

The celebrated author of "Gluntarne," those rollicking stu . dent songs, the Swedish poet, the friend and fellow student of Thure Ludwig Kumlien, Gunnar Wennerberg, was still living over in Sweden, not far from Copenhagen. I had special greetings to him from Kumlien, but I regret to say that something always prevented me from delivering my message. $\mathrm{He}$ died in 1901, at the age of 84 . Like Bellman of old he wrote both the words and music to his songs.

For many years Johan Svendsen directed the music at the Royal Opera in Copenhagen. His name does not stand out like that of Edward Grieg. He was a Norwegian and three years older than Grieg. He wrote beautiful songs, but his great fame rests on his symphonies. Some critics claim that Svendsen was an even greater musical genius than Grieg. I knew both him and his wife well. 


\section{CHAPTER CXIX.}

\section{STANDARD OIL.}

In the petroleum market the United States has an aggressive competitor in Russia. The Russian oil is of an inferior quality, but bears with the same refining a higher fire test. In the ' 80 s a Swedish company was making great efforts to create a market for the Russian product in Denmark. A Danish sub-company was organized and the country was flooded with literature advertising and recommending Russian petroleum. The Russian oil was cheaper, but it was not so clean as that brought from the United States nor did it give so good a light. On account of its inferior quality the promoters of the Russian product did not make much headway. But then they suddenly took a new tack.

Taking advantage of the higher fire-test withstood by the Russian oil, they put their heads together and offered to the Danish parliament some novel legislation. The bill introduced provided that no kerosene or petroleum could be handled by Danish merchants that did not stand a given fire-test. This test was higher than the American standard oil would bear but below that of the ordinary Russian product. To compete with it the American oil would have to be refined up to the water white point before it could be sold on the Danish market. The fact is that if the bill introduced in the parliament by the Russian company should become a law American oil would be excluded and the Russian dealers would have a monopoly. 
I faithfully reported all the facts that I could secure to the state department at Washington and kept the American government as well informed as possible.

One day an American gentleman called on me. He was a representative of the Standard Oil company in the United States and he handed me a letter from Secretary of State Thomas F. Bayard. In this letter Secretary Bayard requested me to assist the Standard Oil representative in any way that I might be able.

The Standard Oil company did not like to lose any part of its European market and the representative was here to see what could be done to prevent the passage of the pending bill. $\mathrm{He}$ concluded that the matter had better be left with me to handle alone. He gave me full instructions and explained to me in detail all the essential facts concerning the two kinds of oil. He urged me to leave no stone unturned and assured me that the Standard Oil company would be pleased to reimburse me for any expense that I might find necessary.

The bill was pending and every effort was made by its friends to get it passed. After consultation with various Danish offcials, I decided to take a somewhat extraordinary course. I invited the whole committee of the Rigsdag to a sumptuous dinner at the hotel d'Engleterre. In the course of the evening I informed them that I had invited them in order to confer with them anent the petroleum bill committed to them. I pointed out that the passage of this bill would saddle a Russian monopoly on Denmark. I suggested that if they wished to secure more safety of life and property they could attain this by abolishing the use of glass lamps. I claimed that nine-tenths of the accidents were attributable to the use of fragile lamps. With well made brass or metal lamps they could burn any grade of oil with safety.

To cut the story short the chairman of the committee thanked me most heartily for the sumptuous dinner and for the enter- 
tainment in general. He complimented me on being able to confer with the committee members in their own tongue and he added that he had no doubt that the reasons that I had offered against the bill were sound and would be carefully considered. The committee recommended to the Rigsdag that the bill be not passed.

I reported every step I had taken in the matter to the state department and received Secretary Bayard's thanks.

This story has an appendix. In the spring of 1888 I came to America on leave of absence, my purpose being to take my whole family back to Copenhagen. While in New York I called at the Standard Oil office and made a verbal report of how I had handled the attempted petroleum legislation in Denmark. John D. Rockefeller happened to be present and he heard my story with great interest. He then invited me to dine with him and the principal officials of the company at Delmonico's. The table was loaded with everything good to eat and drink and I was given the place of honor next to our host.

While we all feasted on the good things set before us $\mathrm{Mr}$. Rockefeller contented himself with a glass of milk diluted with water and a couple of pieces of toast. It occurred to me that I would rather have my stomach than Rockefeller's millions. Of course I received Rockefeller's thanks for the satisfactory manner in which I had served the company in Denmark. 


\section{CHAPTER CXX.}

\section{THE KING OF PORTUGAL AND HIS MINISTER.}

The Portuguese minister represented Portugal both in Copenhagen and Stockholm and for some reason or other he spent most of his time in Stockholm. Occasionally he would come to Copenhagen for a few weeks.

One early autumn King Louis of Portugal came to Copenhagen to pay his respect to the king of Denmark. King George of Creece was there at the same time. Mrs. Anderson and I were still spending our vacation at Ramlösa, a watering place near Hensingborg, in Sweden. We had not been informed that King Louis was expected. To make the matter worse we had, that same week accepted an invitation from the dean of the corps diplomatique, Baron Beck-Friis, and his lady to their country seat, Bosjö Kloster, far in the interior of Sweden. On reaching Bosjö Kloster Baroness Beck-Friis looked astounded. "Why," she said: "tomorrow evening there is a grand dinner at the palace in honor of King Louis of Portugal and of King George of Greece, and you must be there, Mr. Anderson. Have you not been notified?"

I declared that I had not received any notice.

Baron Beck-Friis, whom we expected to meet, had remained in Copenhagen on account of this dinner, which was for gentlemen only. We figured out that we could take an early train for Ramlöso and then I could go by boat from Elsinore to 
Copenhagen and reach there just in time for the half-past five p. m. dinner.

At Ramlösa I found the instructions to come to dinner. They had reached there immediately after my departure. Mrs. Anderson packed my full dress in a dressing case and I lost no time in making my way to Elsinore where I caught a steamer for Copenhagen. But it never rains but it pours.

It so happened that the Copenhagen schools were to begin the next day and so all the summer resorters, with their children, were homeward bound. At each station along the coast there was a long delay in taking passengers and luggage on board. We were getting dangerously near half-past five and had not yet reached the city. When we finally reached the Copenhagen dock the clock marked half-past five.

A messenger from the foreign office had been sent with a carriage to take me from the boat to the palace. He was all excitement and every few minutes he would exclaim:

"Just think, your excellency, there are three kings, three kings, and you are late; they have already sat down to the table, and you are not even dressed!"

The case was indeed serious.

The messenger drove me to the palace and there stood in readiness for me a private room for dressing. A court lackey waited on me and helped me to dress. I finally was made ready and was escorted into the dining room where the dinner had been begun, the soup being finished. My place at the table waited for me. As soon as I entered the door and walked toward my place at the table I was greeted with handclapping and after the dinner I had to answer a stream of questions about where I had been and how I had managed to get there. My story challenged their admiration.

King Louis of Portugal was a short, very thick-set individual with a very small, rather bald head perched in the top of his shoulders. I do not wish to be guilty of lese majeste, but I 
cannot help comparing King Louis with an old-fashioned bag of wheat with a string tightly tied at the top. He was the impersonation of sluggish pomposity and very taciturn. If he spoke, his words, like those of the Russian czar, were few and far between.

At the dinner King Christian IX of Denmark arose, seized his glass of champagne and proposed the health of his honored guest, King Louis of Portugal. Of course all the guests rose with the king. King Christian was no orator, but he did manage to say in French that he was pleased to have so distinguished a guest at his table, that he hoped King Louis would take pleasant memories home with him and that circumstances would permit a repetition of the visit, and thanked him for coming. Then we all drank the health of King Louis.

It was necessary for the Portuguese monarch to respond. The man whom I have described as a bag of wheat rose, took his glass, and after long pondering he uttered these winged words:

"Jai propose - que - nous - bivions - un - ver - a la - sanite du - Roi - et - de - la - Re - i-n-e."

We drank to the health of the king and the queen and then his Portuguese majesty sat down.

But this story has a sequel. The following summer the corps diplomatique decided to go on a picnic to a lake several miles out in the country in Seeland. The ladies were to furnish the eatables and the gentlemen the wines and cigars and we were to have no servants with us. At the picnic grounds the ladies decked the tables. The gentlemen served the wine.

My colleagues very well knew how lame I was in French. I never attempted French if I could avoid it. - To tease me they agreed among themselves that I must toast the ladies and thank them for the splendid dinner they had served. I tried to beg off, but the more I objected the more my colleagues insisted. 
"Well," I said, "if I must I must," so I seized a glass of champagne, struck as serious and important an attitude as I could, commanded attention by hitting my glass and then I gave utterance to the following inspired words:

"Jai - propose - que - nous - bivions - un - ver - a - la - sanite des - les - dam - es!"

The Portuguese minister happened to be with us. He was a small, thin fellow with his wrists covered with bracelets loaded with precious stones and with rings set with gems on nearly all bis fingers. He looked to me like my conception of the missing link. On hearing my toast he exploded. He became violently angry. He came to me and declared that I had insulted his sovereign; he would report me, not only to his king, but also to my government. "I have you recalled. You insult my king and the Portuguese nation. I not allow you to make ridicule of king of Portugal."

I replied by insisting that I had not intended to give any offense to his sovereign or his people. I explained to him that I had been compelled to toast the ladies; that it was necessary to do this in French and that I was a very poor French scholar and had used all the French I knew. He broke out and said:

"No, you have been repeating my sovereign's speech. I am his representative and will see that you be recalled."

Then I insisted that he ought to consider it an honor if I made use of his sovereign as my model and tried to speak like him. Others of the ministers came to my assistance and assured him that I had not reflected on the character of his sovereign and begged him to drop the matter. I never heard of the affair again, but surely there is a divinity doth hedge about a king. 


\section{CHAPTER CXXI.}

\section{ODDS AND ENDS.}

The princes Christian, now King Christian X, and Carl, now King Haakon, were confirmed on the same day in the Royal Chapel by the king's confessor, Rev. J. P. M. Paulli, July 27, 1887. Prince Christian had to wait until Carl reached the proper age. The confirmation was an exclusive affair attended only by the royal family, the members of the cabinet, the foreign representatives, and a few other high officials, of course, including the wives of all these representatives. I do not blame the boys for being embarrassed in the presence of so august an assemblage. Whether they knew their lessons or not I am unable to tell, but I want to give my readers some idea of the kind of examination to which they were subjected. Rev. Paulli asked only leading questions. He went on about in this way:

"Prince Christian, there are three persons in the God-head, are there not?"

Prince Christian: "Yes."

"These are Father, Son, and Holy Spirit, are they not. Prince Carl?"

"Yes."

And so on through the whole catechism. Then they were lauded by the pastor for the very satisfactory examination they had passed and for the splendid testimony they had given of their Christian education and faith. 


\section{CHAPTER CXXII.}

\section{LECTURES.}

During my residence in Copenhagen I was much in demand as a lecturer. I lectured before various societies in Copenhagen and in various places in other parts of the country. I had an advantage over my colleagues in being able to speak in Danish, and perhaps the most interesting aspect of it to the Danes was that I lectured exclusively on old Scandinavian topics. At the university I lectured on northern mythology, on the Viking age, and on our Teutonic epic which dealt with Sigurd the Volsung and the heroes and heroines of the Niblung story.

On one occasion I was invited by the Royal Geographical Society to lecture on the Norse discovery of America in the large hall of the Exposition building. It is the largest auditorium in Denmark and it was filled to its utmost capacity. The whole royal family was present excepting the queen, who was hard of hearing. She sent me her regrets. At the close of the lecture the king came to me, took me by the hand, saying:

"That was a very interesting lecture, Mr. Anderson. I enjoyed it very much. I want you to come and take dinner with me and the queen tomorrow."

This was the king's way of showing his very special appreciation. Of course I accepted the invitation.

In my lecture I contended that Christopher Columbus had full knowledge of the Norse discovery. As evidence of my contention I pointed to Gudrid's visit to Rome, to the testimony 
of Adam of Bremen and to the visit of Columbus to Iceland in 1477. This lecture was extensively discussed in the Scandinavian press and gave the subject of the Norse discovery of America a new impetus.

My book, "America Not Discovered by Columbus," was translated into Danish by Dr. Frederik Winkel Horn and published with my portrait by the Gyldendal publishing house, and soon afterwards the Norwegian professor Gustav Storm published his volume on the Vinland voyages. Excepting the large quarto published by the Royal Antiquarian Society in three languages, old Norse, Danish, and Latin, mine was the first book on this subject in the three Scandinavian countries, as it was also the first in Germany and in Russia. The little book that I published in Chicago in 1874 has had a wider circulation both in America and in Europe than any other book treating of the Norse discovery of America. 



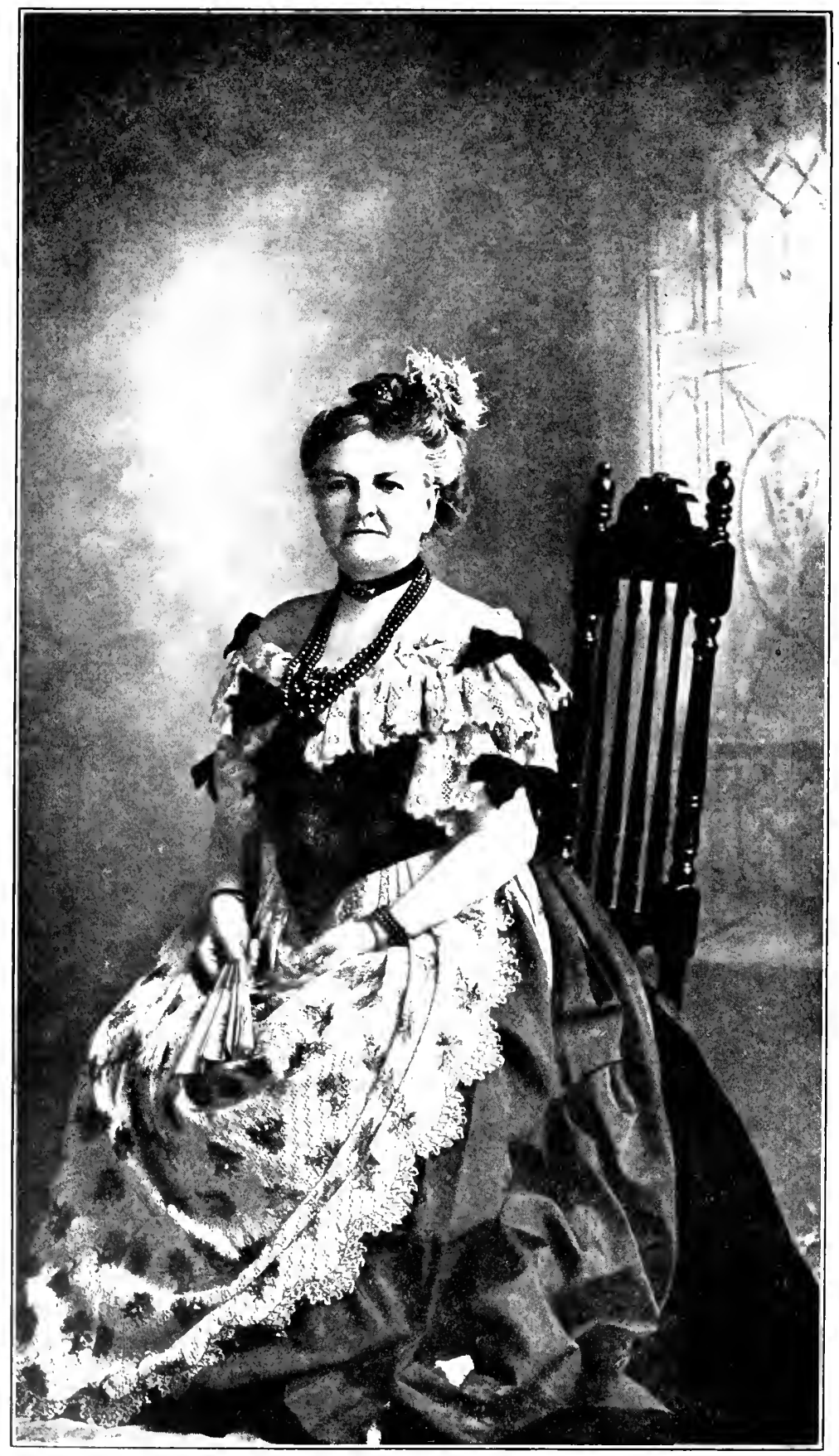

Mrs. Bertha Karina Anderson

In gown worn at the summer residence, Bernstorff, of the king and queen of Denmaik, at the reception in honor of the queen's birthday, September 7, 1886. 


\section{CHAPTER CXXIII.}

\section{ROSENBORG WINE.}

Dinners at court are as a rule very formal affairs. Everybody appears in gala, the gentlemen in their gold embroidered uniforms and the ladies in their richest, long-trained decollette gowns, in a blaze of jewels. It takes skill for the ladies to handle the long trains and for the gentlemen to avoid stepping on them. For the dinner proper the men and women are matched according to their rank. The king and queen are at the head of the table, which is usually in the form of a horseshoe or quadrangle. The waiters are attired in the most gaudy uniforms, wearing tall caps surmounted with an immense bouquet of artificial flowers.

There were three dinners a year of especial prominence. These were given, the first on New Year's day, the second on the king's birthday in April, and the third on the queen's birthday in September. At these three dinners Rosenborg wine was served. What is Rosenborg wine? It is rhinewine just 200 years old. In the cellar of the Rosenborg palace, which is now a historical museum, there are kept 200 tiers of wine bottles. The oldest of these is 200 years old and the newest is of the last year's vintage. Thus in 1914 the tier of wine from 1714 will be consumed and a fresh tier of this year's vintage will be installed. There is much superstition in connection with this wine. If a person is sick and all remedies have failed the last thing resorted to is a bottle of Rosenborg wine. If this 
can be obtained the patient will recover. But for a man in the obscure walks of life it is most difficult to obtain this precious liquid. It takes an enormous lot of red tape. There are a lot of papers to be signed. It is handled very much like a registered letter. Each one receiving the package has to give a receipt, so that if it does not reach its destination it can be traced to the last one that receipted for it.

Rosenborg wine is served at the three court dinners which I have just mentioned. Among the glasses there stands a tiny one about the size of a liqueur glass. This you fill to the brim with granulated sugar. Then comes the solemn moment. Complete silence pervades the dining room. The waiters walk behind you noiselessly. With bottles wrapped in napkins they bend down at your side and pour a few drops of this ancient liquor into the glass filled with sugar and with the solemnity of a minister of the gospel before the communion altar the waiter says, "this is Rosenborg wine," and passing to the next guest he again pours in a few drops and repeats, "this is Rosenborg wine."

When all the glasses are filled the king and queen rise and all the guests at the table rise with them, and then all saluting their majesties a little moisture is extracted from the sugar. But still the Rosenborg wine has the flavor of vinegar. The celebrated Rosenborg wine is all sentiment and nothing else.

When the king wishes to pay his respects to you he sends his waiter to you and he whispers in your ear and says:

"His majesty wishes to drink with you."

"You then at once seize your champagne glass, rise, salute with your glass and bow to the king, who remains sitting; then you drink, salute the king with your glass again, make your bow and sit down. It was said that King Christian usually had water instead of wine in his glass. At court dinners there are no post prandial speeches. There is simply a tete-a-tete between yourself and your table companion. 
American ministers are sometimes in awkward positions from the fact that they have no uniform. One of our American ministers in Vienna attended a court party outside of court where the waiters were attired in the conventional full dress. The American minister also appeared in full dress. One of the distinguished ladies present walked up to the American representative and asked him to be so kind as to fetch her a glass of water. He, of course, got it and brought it to her. When she learned that she had ordered the American minister to wait upon her it broke her all up and she made most humble apologies.

At the garden parties in Copenhagen the royalties usually appeared in plain full dress without decorations, while the guests wore their uniforms. It happened to me once at a garden party at Charlottenlund, the summer home of the crown prince, Frederick, that a lady twice in passing me curtsied and saluted me, "Your royal highness." She was a lady from Stockholm and took me to be one of the royal family on account of my appearance in full dress suit. 


\section{CHAPTER CXXIV.}

\section{CALLERS.}

A large number of Americans called on me as the American representative. I have already mentioned some of these. I was also pleased to receive visits from a number of my Scandinavian-American friends. Among these were John A. Johnson and his daughter Ida, Halle Steensland and his daughter Helen, Mr. and Mrs. H. T. Lerdall, Mr. and Mrs. Torgrim Olson, all of Madison; Ossul Torrison and his son George of Manitowoc, Wis.; Rev. H. A. Preus of Columbia county, Wis.; I. T. Relling, Paul O. Stensland, and Mr. Jevne, of Chicago; A. C. Haugan of Minneapolis; Mr. and Mrs. Sören Listoe of St. Paul; Mr. Saugstad of Baldwin, Wis.; Captain Grinager and his son Alexander, the latter remaining to study painting, and others. 


\section{CHAPTER CXXV.}

\section{A DANISH-AMERICAN PAPER ATTACKS THE ROYAL FAMILY OF DENMARK.}

At one time the Danish paper "Den Danske Pioner," edited by Sophus F. Neble, contained some very scurrilous and scandalous attacks on the royal family of Denmark, particularly on the crown prince, Frederik. A large number of copies of the paper were sent from Omaha, Neb., and distributed broadcast in Denmark. At court they were very much worried and excited over this.

In Europe they have what is called the lex magnatum, prohibiting any attack on a royal person. In Europe the king can do no wrong and no criticism whatever is permitted.

In the United States there is no lex magnatum and the only way to reach Mr. Neble was for the injured party to bring suit just like any other private individual. The crown prince complained bitterly to Mr. Vedel in the foreign office and requested him to bring the matter to my attention, thinking that the United States government might take the offender to task and punish him.

At the request of the crown prince I called on him and heard his tale of woe. I explained to him as well as I could the legal situation, assured him of my sympathy, but did not feel that I could recommend him to institute a personal suit in the American courts, though he doubtless would win an easy victory over 
his calumniator. "Den Danske Pioner" was excluded from the Danish mails. The copies that arrived were destroyed.

After my conference with the crown prince I laid the whole matter before Secretary Thomas F. Bayard in Washington and recommended to him that he write his views on the subject in the form of a personal letter to me, which I might read to the crown prince and then hand it to him to keep. Mr. Bayard acted on my suggestion.

In due time I received an eight-page letter on the subject. In this letter Mr. Bayard strongly recommended the crown prince not to go into court; for that he was too exalted a person. He requested me to remind the crown prince that the lightning usually strikes the tallest trees in the forest and that assaults of the kind made by the Omaha editor were among the penalties of greatness.

I asked for an audience with the crown prince and got it. I took Bayard's letter with me and read it to him. When I came to the passage about the lightning striking the tallest trees and of the penalties of eminence the crown prince burst into tears and fairly smothered me with his kind words of appreciation of what I had done. He asked me if I would not let him have a copy of that letter. I said:

"The original is yours, your royal highness, if you care to keep it."

I handed it to him and I am sure he took good care of it, and thus ended the episode. 


\section{CHAPTER CXXVI.}

\section{LITERARY WORK.}

During the four and a half years of my diplomatic service I published (1), "Eminent Authors," by Georg Brandes; (2), "Among Cannibals," by Carl Lumholtz; (3), "Teutonic Mythology," by Victor Rydberg; (4), I was joint author with Canon Farrar and other English authors of a book published in London on "Non-Christian Religions." For this work I wrote the chapters on Scandinavian mythology.

(5), Then I published in London and New York in four volumes a thorough revision of Samuel Laing's translation, published in 1844, of Snorre Sturlason's "Heimskringla" or "Sagas of the Kings of Norway." This work sold in England for four guineas per copy. The publisher in London, John C. Nimmo, sent me a copy for presentation to the king of Denmark. This he received most graciously. I had then presented my letter of recall and was no longer in the service. The king therefore decided to confer on me the great cross of Danebrog, but as I do not believe in this sort of frippery I declined the honor with thanks.

Besides translating these works I was a regular, but anony-: mous, contributor to "The Nation" of New York, and contributed the annual survey of Scandinavian literature to the January columns of "The Literary World" in New York.

Thus it will be seen that with translating the above books; with writing for "The Nation" and for "The Literary World;" 
with lecturing in Copenhagen and elsewhere in Denmark; with seeking the personal acquaintance of the representative men and women in the Scandinavian countries; with attending to my diplomatic and social duties, my time was well filled. 


\section{CHAPTER CXXVII.}

\section{DIPLOMATS MUST NOT TALK.}

The fact that I associated with many of the more liberal people attracted some attention at court. The court was conservative and Denmark was on the verge of a revolution. I came from a republic and might easily be suspected of sympathy with the opposition, but I kept my lips sealed.

One day at court the crown princess found me in a corner of the drawing room and stretching out both hands in front of me she said:

"Mr. Anderson, you are now my prisoner," to which I replied:

"You are very kind, your royal highness."

Then she said: "I would like to know what you think of the political conditions in Denmark."

I answered: "I have no opinion. I did not come here as a diplomat, but as a student, to sit as a disciple at the feet of your great scholars."

She said: "But you associate with a large number of our people and I do not see how you can help having an opinion about what is going on here."

I answered: "Even if I should have an opinion, your royal highness, my government does not permit me to express it." 
She continued: "I know that, but this is private; only between you and me. You are a republican and I should think it would be natural for you to sympathize with those who are opposed to our government."

I answered: "I came from a republic which is more conservative than any country in Europe. Our country has had the same constitution since 1778 and no matter what faults it may have it is almost impossible to get any amendments passed. So far as government is concerned the Americans are probably the most conservative people in the world."

"Oh dear, Mr. Anderson," she said, "you are more of a diplomat than I thought you were," and she left me.

At another time the king's youngest brother, Prince Hans, tried to tease me in a similar manner. He said he had heard about my visits at the homes of prominent liberals and insinuated that $I$ as an American must be popular in that kind of circles. 


\section{CHAPTER CXXVIII.}

\section{EMPEROR WILHELM II.}

Once while in Berlin, Germany, I took a walk on the famous street Unter den Linden. I thought the linden trees were rather scrawny. In passing by the palace I saw a very old man sitting at a window. Passers-by took off their hats to this man and saluted him and the aged man now and then would return the greeting with a nod of the head or a wave of the hand. I was told that this aged gentleman in the window was the Emperor Wilhelm I, who in 1870 had made one empire of all Germany. This is as near as $\mathrm{I}$ ever came to him. His son, "Unser Fritz," I never saw although I had traveled close behind him in Norway in 1873 and at Bolkesjö, west of Kongsberg, I occupied the same bed as he had slept in the night before. But I was a day too late to see him. Both Wilhelm I and Frederick III died in 1888, the father March 9 and the son June 15, and the latter was followed by his son, the present emperor, Wilhelm II. Some witty fellow has called Wilhelm the First "der Greise Kaiser;" his son Frederick "der Weise Kaiser" and the grandson, Wilhelm II, "der Reise Kaiser."

Soon after Wilhelm II had ascended the throne he set out to pay visits to his colleagues among the rulers of the nations. If I remember correctly he first went to Vienna and paid his respects to the emperor of Austria. Thence he went to St. Petersburg to visit the czar of Russia. His next stop was at Stockholm where he was the guest of King Oscar II. From 
Stockholm he came to Copenhagen. He was accompanied by Count Herbert Bismarck, son of the iron chancellor. As United States minister I assisted in receiving him at the custom house landing and was one of the guests at the grand dinner given in the kaiser's honor by the king.

The streets through which he was driven from the custom house landing to Amalienborg palace were crowded with people anxious to get a glimpse of the new emperor of Germany. In the crowd hisses were heard, but of this no mention was made by the press. It probably would not have been safe for a newspaper to record such a fact. By some people even in court circles it was thought that the young emperor had North Slesvig in his pocket and intended to give it to King Christian as a souvenir of his visit, but in this they were greatly mistaken and disappointed. The emperor left nothing, but the ordinary fees to the lackeys.

In the drawing room before entering the dining room King Christian personally presented all the guests to the kaiser. This is how I fared:

King Christian:

"This is the American minister, Mr. Anderson."

Emperor Wilhelm gave me his hand and said: "I am a great friend of your country, Mr. Anderson."

I answered, "You are very kind, your majesty, and I can assure you that your sentiments are reciprocated by the president and the people of the United States."

Kaiser Wilhelm: "You have a great country and I am its friend."

To this I replied: "If our country is great the large number of German-Americans have helped to make it so."

At the dinner I sat within plain sight of the emperor and his royal host. As is well known, the emperor has only one developed arm. His left arm is abortive and is of no use to him. $\mathrm{He}$ carried with him some of the utensils that he used at the 
table for carving his meat and for other purposes. When the champagne was served King Christian arose and all his guests with him. The king of Denmark made a neat, carefully prepared speech in German. He thanked the young emperor for his visit. He wished him abundant success and much happiness in the responsible position to which he had been elevated; hoped that he would enjoy his sojourn in Denmark and that he would repeat his visit. We drank to his health. Then the emperor immediately seized his glass, which had been refilled, and responded with a torrent of oratory. It was a perfect Niagara of words. Instead of thanking the king of Denmark for his magnificent hospitality and paying his respects to a man old enough to be his grandfather; instead of exhibiting the modesty due from a youth in the presence of his seniors and saying that he was willing to learn from those who had more experience, he took the opposite tack. His whole harangue consisted in assuring the king of Denmark that he was his friend and that if any emergency should arise Denmark and its king needed only to turn to him and the necessary aid and protection would be forthcoming.

All the Danes and many of the other guests were thoroughly disgusted with the arrogance, I might say impudence, of this newly fledged monarch. Everybody felt sorry for King Christian that he should be treated in this insulting manner by his guest, but there was nothing to do but act as if everything was lovely and make the best of it. 


\section{CHAPTER CXXIX.}

\section{LINCOLN.}

At the dinner I sat next to a commander in the German navy. I have forgotten his name, but he was a man I should say near the '70s. He told me that during our war of the rebellion he had been sent to America to observe the war. For this he needed a permit from President Lincoln. He then went on to tell me about his visit at the White House in Washington. He explained that he had been shown into the president's office or study. On entering he had found a man with long, awkward limbs, with slippers on his feet and both his feet resting on a desk in front of him. The German officer was in his uniform dressed for an audience with the president of the United States.

At this point I began thinking that I ought to make some protest against his speaking disparagingly of the great Abraham Lincoln. I presumed he noticed that I was getting ready to say something. He said:

"Wait till I am through. The president turned around, looked at me and asked: 'What can I do for you, sir?' I handed him my letter. He read it and then wrote a permit for me to go to the front in the army. Then he asked me to sit down and he entered into conversation with me and when I left I felt that I had been in the presence of the world's greatest man. I look upon Abraham Lincoln as the greatest statesman that the world has produced." 
I then told my neighbor that at first I felt like protesting, but now I was pleased with what he had told me about the saviour of our country.

I think the Danish court were pleased to have Emperor Wilhelm II take his departure the next day and he has not visited Copenhagen again from that day to this. His annual visits to Norway are well known. 


\section{CHAPTER CXXX.}

\section{THE PRINCE OF WALES.}

I met the Prince of Wales, the late King Edward VII, on several occasions in Copenhagen. The Princess of Wales, late Queen Alexandra, usually came, with all her children, early in the summer and remained until late in the autumn. The Prince of Wales would come for a couple of weeks and then leave again. He had a wonderful faculty of adapting himself to his surroundings. He was able to put himself completely on the same level with the person he met, whether king, scholar or laboring man. Nobody felt embarrassed in his presence. He had been in almost every part of the world, had associated with all kinds of people, and spoke readily seven different languages. And he was a well-informed man. He could discuss in an interesting manner science, art, literature, agriculture, sports, navigation, and politics. This accounts for his wonderful popularity. The one thing that worried him was that his mother would neither die nor resign. It looked as if she might even outlive her son, so that he would never have the opportunity to show the British people and the world what a splendid king he was going to be. His reign lasted only nine years, from 1901 to 1910.

I once met him half way up the stairs in the Hotel d'Engleterre where he was going to call on one of the diplomats. He recognized me, slapped me on the shoulder by way of putting himself on a familiar footing and at once plunged into a con- 
versation about American affairs. He seemed as familiar with the leaders in American politics as with those of his own country. He said he had just come from the German watering place, Homburg, where he had met our American statesman James G. Blaine. He said he had had a fine time with him, that Blaine was a very clever statesman; but, with a twinkle in his eye, he added:

"He will never be president of the United States."

This was his prediction, and it proved true.

At another time I played whist with him at court. The players changed partners at the end of each game. The stake was one crown per point. I was lucky that night and won 100 crowns from his royal highness, the Prince of Wales. I played whist a whole winter with the German, Austrian, and Japanese ministers. We did not change partners. The Jap and I played against the German and Austrian and beat them. I heard the Prince of Wales speak when the corner-stone was laid of the English church (St. Albans) in Copenhagen and again at the dedication of that church. He had a fine dog with him. In dancing quadrilles at court the Prince of Wales sometimes withdrew from the dance and let this well trained dog take his place and the dog made no mistakes.

While at Bernstorff palace on the queen's birthday the Prince of Wales put this dog in his place in the dance and asked me to introduce him to Mrs. Anderson with whom he talked about the wide diffusion of the English language until the dance ended.

Queen Victoria never came to Copenhagen and I never was presented to her. Once in $1888 \mathrm{I}$ saw her in a carriage driving through Oxford street in London. 


\section{CHAPTER CXXXI.}

\section{MY DIPLOMATIC CAREER ENDS.}

On the fourth of March, 1899, I cabled my resignation to President Benjamin Harrison and in a couple of days I received a dispatch from Secretary of State James G. Blaine informing me that my resignation had been accepted by the president and that John A. Enander of Illinois had been appointed my successor.

During the interval between the election in November, 1888, and the inauguration of President Harrison in March, 1889, strenuous efforts were made, both in Scandinavia and in the United States, to have me left undisturbed in my position as minister to Denmark in order that I might continue my work in the field of Scandinavian literature. During the four years already spent in Copenhagen I had, as the reader has seen, published eight volumes. But I had a number of other works planned and partly under way. The Scandinavians were interested in seeing this work done. They liked to have Scandinavian history, literature, and culture made known to the English-reading public and were pleased with the energy and industry that I was putting into this work. It was decided by a group of Scandinavia's most eminent authors, artists and statesmen to unite in sending to President- elect Harrison an address requesting him to permit me to remain at my diplomatic post. In this address they say in part: 
"It is generally known that a large number of the Scandinavians who have emigrated to America have always been able to go to Minister Anderson and there obtain valuable advice and assistance. We would regard it as a great loss if a new man, not familiar with the conditions in the North, should relieve the minister who now for four years has become identified with our life and has so often been found to be so valuable a connecting link between us and the United States. To this must be added that the northern countries cannot overestimate the value of the literary work that Professor Anderson has done. By his scientific and literary activity he has made a series of products of the northern mind, both from ancient and modern times, accessible to the great American public through translations and compilations. It would be a source of deep regret to us if Professor Anderson should be called away from the North in the midst of his work, which, as a matter of course, can best be carried on in a city like Copenhagen where the necessary advantages both as regards libraries and literary connections in the professor's special literary studies, are to be found.

"For these reasons, which cannot, in our opinion, fail to meet with your approval we have taken the liberty urgently to request you to permit Professor Anderson to continue in his present position."

This address was signed by the following: C. Berg, leader of the liberal party in the Danish parliament; Björnstjerne Björnson, Norwegian poet; Carl Bloch, eminent artist, and professor at the Academy of Art; Erik Bögh, distinguished author and censor at the Royal theater; Georg Brandes, eminent critic; C. Carstensen, distinguished editor; Jonas Collin, eminent scholar; Holger Drachmann, poet; Anna Charlotte Edgren Löffler, Swedish writer; Loorg Feilberg, editor; Niels W. Gade, the composer; Konrad Gislason, professor at the university, eminent Icelandic scholar; J. Gluckstad, bank president; P. Hansen, author of the "History of Danish Literature"; 
J. P. E. Hartmann, the composer; Jacob Hegel, publisher; Carl Hostrup, great dramatist; Harald Höffding, Denmark's greatest philosopher; Sofus Högsbro, statesman; V. Hörup, Danish statesman and journalist; Henrik Ibsen, Norwegian dramatist; Carl Jacobsen, brewer and founder of Glyptothek; William Horum, eminent jurist; Alexander L. Kielland, Norwegian novelist; N. J. Larsen and F. Bojsen, members of the parliament; F. L. Liebenberg, great Danish text critic; Jonas Lie, Norwegian novelist; F. Peckel Möller, doctor of philosophy; Sophus Möller, R. Bang, the two chief officials of the Royal Northern Society of Antiquaries; C. V. Nyholm, supreme court judge; Gustav Philipsen, publisher; Carl Ploug, Danish poet; E. N. Ritzau, chief of telegraph bureau, Copenhagen; Victor Rydberg, Swedish poet and scholar, member of Swedish Academy; Otto Borchsenius, publicist; Sophus Schandorph, Danish writer; Fr. Winkel Horn, Danish encyclopedist; Ludvig Schröder, eminent Danish teacher and author; $\mathrm{Kr}$. Erslev, professor of history in University of Copenhagen; Hans Gude, Norwegian painter; Otto Sinding, Norwegian painter; Edward Grieg, Norwegian composer; Stephan Sinding, Norwegian sculptor; Carl Snoilsky, Swedish poet; J. V. C. Steen, Norwegian statesman, afterwards premier; Henrik Strandvold, Danish journalist; August Strindberg, Swedish writer; George Stephens, great runologist; Johan Svendsen, Norwegian composer; F. Tutein and Harald Holm, members of Danish parliament; O. Thommessen, L. Holst and F. M. Wallen, three eminent Norwegian journalists; B. Wulff, Danish journalist; $\mathrm{O}$. Wergeland, Norwegian general, brother of the renowned Henrik Wergeland.

This address was executed in duplicate; one was sent to President-elect Harrison and the other, beautifully bound in morocco, was given to me as a souvenir of the good will and friendship of the signers. It is one of my most precious possessions. 
Prof. George Stephens wrote a long personal letter to Benjamin Harrison telling him of the things I had accomplished and urging that it would be a misfortune to disturb me in the midst of the work in which I was then engaged.

It has been insinuated that this address was prepared on my instigation and written and signed at my request. In reply to this insinuation I wish to state with all the emphasis possible that I am not guilty. The preparation of it did not originate with me and I had absolutely nothing to do with it in any shape or manner. When I first heard of it it had already been sent to all the persons above mentioned for their signatures. The same is true of the letter sent by George Stephens. After he had mailed it he handed me a copy of it in his own handwriting. A similar letter was sent to President-elect Harrison by Paul du Chaillu and of this I had no knowledge until he handed me a copy which he had made of it for me.

Long after my successor had been appointed I was told by my good friend P. A. Vedel that his majesty, King Christian IX, through the Danish minister at Washington, Mr. Lövenörn, had sent a personal message to President-elect Harrison informing him that it would please him greatly if he would permit me to remain American minister to Denmark, stating that I was very much liked, both by the court and by the people.

The winter before I went to Denmark I gave, as the reader may remember, a number of lectures at colleges and universities in Indiana. These lectures were arranged by May Wright Sewall, eminent promoter of women's organizations, both national and international. On her own initiative and without even informing me of what she was doing she prepared an address to President-elect Harrison very much like the one sent from Scandinavia. This address was signed by the presidents and professors of many of the leading American universities, including Harvard, Yale, Johns Hopkins, Columbia, Princeton, Cornell, University of $\mathrm{W}$ isconsin, and the University of 
Michigan. It was also signed by a considerable number of the most distinguished American writers, including James Russell Lowell, John G. Whittier, George W. Curtis, Oliver Wendell Holmes, Samuel L. Clemens (Mark Twain), and many others.

May Wright Sewall took this address to the house of President-elect Harrison in Indianapolis. She has since told me that when she entered the parlor Mrs. Harrison embraced her and kissed her and then led her into the library to the president-elect. Mr. Harrison took the address, glanced over it and then said:

"You have many splendid names on this petition, Mrs. Sewall, and it shall receive careful consideration at my hands."

Indeed Mrs. Sewall had no doubt that she had carried her point, and that she had an interesting surprise in store for me. She also relied greatly on the fact that Mrs. Harrison had been one of my audience when I gave parlor lectures in the Sewall home in Indianapolis.

One would think that all this would have produced the desired effect, and that I would have been permitted to continue at my diplomatic post and in my literary work. But hereby hangs a tale, which I do not need to tell again. It is only necessary to remind the reader of John E. Burton's negotiations with James G. Blaine in the campaign of 1884 . It has been said of. Blaine that he never forgot either a friend or an enemy. I see him in my mind taking his seat as secretary of state March 4, 1889. I see him pick up a list of the diplomats appointed by President Cleveland. They are all to be beheaded. He finds the name of R. B. Anderson and mine was the first head to be chopped off. The first diplomat appointed by the president was John A. Enander of Illinois to be minister to Denmark. 


\section{CHAPTER CXXXII.}

\section{WHAT BECAME OF ENANDER?}

In due course of time I received from Mr. Enander a letter written in Swedish informing me that he had been appointed my successor and that he expected to sail from New York about the first of April. I took this letter with me and went to the foreign office where I called on Mr. Vedel, the director general. I told him that I expected my successor about the middle of April. Mr. Vedel answered me in substance:

"You must not begin to pack your household goods right away. It will not be possible for Mr. Enander to get here as soon as that."

I replied: "Here is his own letter. Do you know better how soon he can come than he does himself?"

Mr. Vedel continued: "Mr. Enander has a newspaper to dispose of, and then he has his home to turn over to somebody and he cannot do all this in so short a time. You are going to remain with us for some little time yet."

I thought Vedel's arguments were reasonable and did not give the matter any further attention.

After about two weeks I received a second letter from Mr. Enander beginning as follows:

"I consider it my duty to inform you that I have been attacked by a sickness which threatens to end my life and therefore have been compelled to postpone my departure for Den- 
mark. My physician insists that I would not be able to stand the Danish climate at present."

Our daughter, Carletta, now Mrs. Peter Vedel, was standing at my side while I was reading Enander's letter written in Swedish. She said: "That man is not sick, father. He could not write such a fine hand if he were sick."

I found much sense in my daughter's remarks.

The next day I again called at the foreign office and had Enander's letter with me. I showed it to Mr. Vedel.

"Did I not tell you," he said, "that you did not need to look for Mr. Enander so soon?"

"But you did not know that he was going to be sick, did you, Mr. Vedel?"

If I had been more alert I might have noticed, perhaps, that my question embarrassed him a little, but he continued in his old vein and told me to go on about my work and not worry about getting ready to leave Copenhagen. I again dropped the matter there.

Not long after that I attended a dinner at court. The king came to me and said:

"I am very sorry you are going to leave us, Mr. Anderson, and I can only hope that your successor will be as well liked as you are."

"I have no doubt of that, your majesty, my successor is a highly educated Swede living in Chicago. He is an able journalist and he is thoroughly acquainted with Scandinavian life and culture."

The king: "But there is something that I esteem higher than education and that is character."

This put me in an embarrassing position. On the one hand I must be loyal to my country and on the other I must not contradict his majesty. I attempted to escape from the dilemna by answering: 
"I know Mr. Enander only by reputation, your majesty, and have no knowledge concerning his personal character."

Then the king shrugged his shoulders and said, as it were in triumph: "Then it may be that I am misinformed."

That same evening I left court in company with Mr. Ravn, the secretary of the navy. We chatted about various things. Then he suddenly looked up into my face and said:

"What do you hear about your successor, Enander? Is he in some kind of trouble?"

I answered: "The last I heard from Enander was that he was very ill and had to postpone his departure from America. But I had a conversation with the king this evening that was a surprise to me. Perhaps you, Mr. Ravn, can throw some light on it."

Mr. Ravn answered: "I fear I have been saying things to you that do not concern me. I spoke without thinking."

Then he closed up like an oyster and not a word further was spoken about Enander.

Some days later I called on the doyen of the corps diplomatique, the Swedish minister, Baron Beck-Friis. $\mathrm{He}$ invited me into his library and gave me a cigar. In the course of our conversation he said:

"I hear so much about your successor, Mr. Enander. What is the matter with him?"

I answered. "Really, Mr. Beck-Friis, I am beginning to be curious. The king made a strange allusion to him the other evening when we were at court. On our way home the secretary of the navy made a remark about him and then suddenly refused to talk further. Others have asked me questions that I do not understard and statements that the director, Vedel, in the foreign office have made to me now seem wrapped in mystery. If you can help me clear up this mystery you will do me a great favor." 
Then Baron Beck-Friis said: "The only thing I can do is to apologize to you for speaking of Mr. Enander to you. I supposed you knew."

This was all I could get out of him and it made the matter more mysterious than ever.

The American minister in Stockholm, Mr. Magee, of Indiana, had been relieved by his successor and was now on his way home. He stopped for one day in Copenhagen at the d'Engleterre. In the course of the day he called on me to say goodbye. When he left me I went with him back to the hotel to pay my respects to his family. Walking down Bredgade he stopped and made some remarks about Mr. Enander, criticising President Harrison for appointing such a person a minister. I told Mr. Magee that all I knew was that Mr. Enander's departure from America had been postponed, but that I had not heard anything detrimental to his character. Then Mr. Magee broke out and said:

“Now, come, Anderson, don't you play diplomat with me because I happen to be out of the service while you are still in it. That's no reason why you should keep diplomatic secrets from me."

I answered: "I am not keeping secrets from you. The subject of Enander is wrapped in mystery to me. All I have heard is insinuations and when I have pressed those making them for further information they have closed up like clams and left me in the dark. All I know is from a letter that I received some time ago from Enander telling me that he was dangerously sick and had to postpone his departure from Chicago."

Said Mr. Magee: "Sick! I should think he would be sick! A man with such a record as his."

I then begged Mr. Magee to let me know what the trouble was, if he was in possession of the secret, assuring him that I was entirely ignorant of it. 
Mr. Magee then took from his pocket a certified document showing that Mr. Enander, before emigrating from Sweden, had served a term in prison for appropriating property that did not belong to him. I saw this document with my own eyes.

My interviews with the king, with $\mathrm{Mr}$. Vedel, with $\mathrm{Mr}$. Ravn and with Baron Beck-Friis became plain to me. The whole mystery was cleared up.

I went with the Magees to the railroad station and there bade them goodbye.

The next day I again called on the director general at the foreign office, Mr. Vedel. I told him that I had come to inform him that I was now just as wise as he in regard to Mr. Enander; that I had seen Mr. Magee and that he had told me all.

Mr. Vedel said he was sorry. It had been the purpose of the Danish government to keep the American government and the American minister in Copenhagen wholly out of the matter. The course they had taken was as follows:

They could tell by his name that Mr. Enander must be a Swede. They had therefore confidentially instructed the Danish minister in Stockholm to have Mr. Enander's record looked up. The Danish minister in Stockholm had reported in a confidential dispatch, the facts, as I learned them from Mr. Magee. Then the foreign office in Copenhagen had instructed the Dan. ish minister in Washington, Mr. Lövenörn, not to inform President Harrison or Mr. Blaine, but to write to the Danish consul, Mr. Dreier, in Chicago, and to instruct him to call on Mr. Enander personally and inform him that his record had been investigated and that he could not be received in Copenhagen. This probably made Enander sick, and it was immediately after Consul Dreier's visit to him that he wrote me the letter about his serious illness. He also immediately sent his resignation to the state department at Washington, giving sickness as his reason for resigning. 
Here the matter would have ended had not an accident occurred. It had been decided not to let the king into this secret for fear that he might not be able to hold his tongue. How, then, did the king find it out? The minister for foreign affairs. made it a practice to take the dispatches from the Danish ministers abroad under his own arm once a week and read more or less of them aloud to his majesty. He took the bundle containing the Enander dispatch from Stockholm under his arm and went to the palace to read from them to the king. The king said:

"I happen to have another engagement today at this hour, so you will have to excuse me; but if you will leave the dispatches on my table I will read them myself when I return."

The minister for foreign affairs forgot all about the dispatch concerning Enander and left the whole bundle on the king's table.

The reader will now easily understand how the king could in a triumphant manner shrug his shoulders and say to me:

"Then it may be that I am misinformed!"

He had been informed by a dispatch from his own trusted agent in Stockholm. The king had not held his tongue and this explains the remarks made to me by the secretary of the navy, by the Swedish minister, and by one or two others. The king had let the cat out of the bag.

This Enander episode became the basis of an agreement between Copenhagen and Stockholm on one side and Washington on the other. Both in Denmark and in Sweden they were anxious to prevent the recurrence of such an incident.

It is well known that the European countries do not like to receive their own emigrants back clothed with the dignity and authority of ministers. Germany, for instance, would not accept an emigrated German as ambassador to Berlin. An emigrant returning is also apt to have too many blood entanglements with the rank and file and diplomats like to look upon them- 
selves as satellites revolving around the throne and living in an atmosphere far above the common herd.

Taking this Enander incident as a basis, the Danish foreign office submitted to me an agreement by which the state department in Washington should pledge itself not to appoint as minister to Denmark any person born in Denmark, Sweden or Norway. A copy of it was submitted to the foreign office in Stockholm. I informed the Danish minister for foreign affairs that I could not sign such an agreement without first submitting it to our secretary of state, James G. Blaine. I did submit it, Mr. Blaine approved it and sent me instructions to sign it which I did. It was not put in the form of a treaty to be ratified by the rigsdag in Denmark and the senate in Washington. It was simply a solemn agreement between the American department of state and the Danish foreign office.

The Norwegian foreign office has been created since, but there can be no doubt that the agreement will be considered applicable between Norway and the United States, between every country in Europe and the United States for that matter. In view of this sentiment the United States, for instance, would never think of sending an English emigrant back to England as its ambassador.

The first time I visited Chicago after my return I stopped at the Palmer House. I sent a communication to Mr. Enander, who had then recovered his health and was editing his paper, "Gamla och Nya Hemlandet," and invited him to come to the hotel and dine with me. Some Swedish journalists in Chicago, who evidently had some bone to pick with Mr. Enander, called on me to interview me concerning his failure to go to Copenhagen. I had Mr. Enander in my room and when his Chicago friends knocked at my door I told them that Mr. Enander was my guest and had no doubt he himself would be pleased to see them, but that I had no statement to make. Of course, they refused to meet Enander. For this courtesy Mr. Enander ex- 
pressed himself greatly pleased. He has now rested in his grave several years; the statement I have made can do him no harm, but it does throw an interesting light on the Danish manner of handling a delicate diplomatic matter so as not to do anybody any personal injury.

Mr. Enander carved out a splendid career for himself as a citizen, journalist, and author in this country. His life in America was without reproach. The mistake he made was that he did not apply for the mission to some country outside of Scandinavia in which case his mistake as a young man in Sweden would probably never have been looked up. 


\section{CHAPTER CXXXIII.}

\section{CLARK E. CARR.}

Enander having resigned, the president appointed in his stead Mr. Clark E. Carr of Galesburg, Ill., but I being at that time in the midst of negotiating the Carlos Butterfield arbitration treaty the state department asked him not to qualify until further notice and requested me to remain at my post pending the negotiation of that treaty. Mr. Blaine appeared to have abandoned his eagerness to get me displaced. This explains why I remained in Copenhagen until late in the autumn of 1889. My last act was to sign the treaty making Queen Victoria arbitrator of the Butterfield claim and this finally opened the door for Clark E. Carr.

Clark E. Carr was a good fellow, but he had his shortcomings, and while he is a man of high standing in Illinois I do not overstate it when I say that he was more or less of a joke as a diplomat. In the first place he could not speak a word of any other language than English. In the next place he had never been outside of the United States before and his greatest claim to recognition as an office-holder was his services as a campaign speaker. The government would have acted more wisely if it had given him some lucrative and responsible position at home instead of sending him abroad. I have said he was a good fellow. He was more than that; he was a splendid fellow. He was so eager to please that he was continually overdoing it. $\mathrm{He}$ 
had an abnormal abdominal development. He could not see his feet. He floated on the water like a rubber ball. And now there is not a particle of malice in it when I tell you some little episodes in connection with his advent to the capital of Denmark.

At the time when I was to present my letter of recall and Mr. Carr his letter of credence the whole royal family had moved out to Fredensborg some twenty miles distant from Copenhagen. The king and queen of Greece had arrived; the princess of Wales, with her sons and daughters, were there; the czar of Russia, with his family, were expected in a few days, and also the prince of Wales. The king not caring to go to his palace in the city to receive Mr. Carr and me invited us to come to Fredensborg. The party consisted of Mr. Carr, Mrs. Anderson, and me, and we were escorted by the minister for foreign affairs, Baron Rosenörn-Lehn. The king sent his private railroad car to take us to the Fredensborg railroad station and back and he sent his private carriage to take us from and to the station at Fredensborg.

At the palace we were given a room each, with servants to assist us in dressing. We were invited to dinner and, of course, everybody was in full dress and gala. As soon as we were dressed the king received Mr. Carr and me separately to deliver our letters from President Harrison to him.

Before going to dinner there was general, informal visiting in the large drawing room, all the royalties and their children being present. Mrs. Anderson and I had met all these people before and were treated as old acquaintances. Everybody looked at the newcomer, Mr. Carr. His great rotundity amused them. The young princes and princesses would get behind their mothers and steal a look at him and laugh.

Before we left Copenhagen Mr. Carr had said to me that he was afraid he would put his foot in his mouth. I had told him that he need not worry about that as he could not even see his 
feet. I had assured him that the royalties were plain, commonsense people, human like ourselves, and that it was only necessary to act naturally as in any well-bred society. I had gone over my court catechism with him and I thought he was immune from any serious faux pas. I had called his special attention to the fact that the queen of Denmark and the princess of $\mathrm{W}$ ales were very hard of hearing and that if he spoke to them he must answer slowly and bring his mouth in the vicinity of their ears. Mr. Carr had asked me whether I thought his majesty would appreciate a good story or a joke. I advised him not to attempt anything of that sort.

During the informal visiting the king of Denmark, having his daughter, the princess of Wales, on his arm, approached Mr. Carr and said to him:

"Mr. Carr, this is my daughter, the princess of Wales."

Mr. Carr bowed and said he was pleased to meet her. Then he bent his head toward her ear and shouted so that it could be heard by all the people in the room:

"We call your husband the prince of whales in America."

Sarcastic smiles were visible everywhere.

A few days later all the royalties, high Danish officials and foreign representatives were at the custom house landing to receive the Russian czar and his family. Mr. Carr having then been received was there as the representative of the United States. Mrs. Anderson and I had been specially invited to be present.

Under the canvas at the landing I stood by the side of Mr. Carr. I thus had the opportunity of introducing him to many whom he had not yet met. The king's brother Vilhelm came and shook hands with me. I at once presented to him my successor, Mr. Carr. The prince shook hands with him and said he was pleased to make his acquaintance. Mr. Carr said:

"I am most happy to meet you, sir. You must come and see me. Come and see me often." 
Prince Vilhelm looked dumbfounded at this exhibition of American hospitality.

The prince of Wales, as was his custom, had arrived in Copenhagen incognito. He could not bear to have the court and all the official dignitaries come to meet him when he arrived or left. He was under the canvas to assist in receiving the czar. Walking along the line of the diplomats and shaking hands with them, with a cheerful word for each, he came to me. He had not yet met Mr. Carr, who stood beside me, but he looked at him. He put his hand on my shoulder and said:

"I am very sorry you are going to leave us, Mr. Anderson. You change your ministers too often in America. This is something you ought to mend."

I answered: "You are very kind, your royal highness. It will be a pleasure to me to remember that I have met you and to know that I have your good will," and then I added: "I now have the honor, your royal highness, to present to you my successor, Mr. Carr."

The prince of Wales shook hands with Mr. Carr and said he was glad to meet him. Then looking at him for a moment he said:

"Say, Mr. Carr, I have been told that you call me the prince of whales. It seems to me you look more like a whale than I do." And as he said this he pointed at Mr. Carr's and at his own abdomen.

Shortly before sailing from Denmark my cousin, the British minister, Sir Claude McDonald, invited me to a farewell lunch. $\mathrm{He}$ also invited a number of the English gentlemen sojourning in Copenhagen. On a hint given by me he included Mr. Carr among his guests. At this luncheon Mr. McDonald bid me goodbye in a very neat little speech assuring me that I would be missed by all the English-speaking residents of the Danish capital. I had to reply and expressed my thanks for all the 
forbearance and kindness shown me by my English friends. Then I continued in substance, first, asking Mr. Carr to rise:

"I have the honor to present to you my successor, Mr. Carr, who is to take my place in your attentions and affections. This is Mr. Carr. I say his name is Carr. He is a freight car. He comes loaded with good will to all of you. $\mathrm{He}$ is a palace car; he is a gentleman from head to foot. He is a dining car; you may safely invite him to your dinners. He will appreciate them. $\mathrm{He}$ is a smoking car; you must have good cigars after your dinners; and now, my friends, you see that this gentleman easily fills the small space that I leave vacant in retiring from Denmark."

Turning to Mr. Carr and tapping him on the shoulder I said:

"In the language of our great national game, go me one better."

There was much merriment over this. Mr. Carr responded with much humor and good feeling and was well received. The only thing that I regret about it is that the sobriquet "the American dining car" seemed to stick to him here and there throughout his residence in Denmark.

Perhaps I ought to apologize for giving so much space to my experience in Denmark; but it was a unique chapter in my life. Everything was new to me and consequently made the deep impression that only new things can make. Besides what I have told is not copied out of books or newspapers, but is wholly original, being my personal recollections dictated from my easy chair to Mr. Barton. I have made no references to written or printed documents worth mentioning.

The last days were spent in getting ready to sail and in making farewell visits. Mr. Carr took our legation quarters and bought our furniture. He moved in at once and we took rooms at the Hotel Phoenix.

Among those who were particularly kind to us during these last days were the director general of the foreign office, $\mathrm{Mr}$. 
P. A. Vedel, our family physician, Dr. Stockfleth, Dr. F. P. Möller, Mr. H. Mansfeld-Büllner, and their amiable wives and families.

While I left Copenhagen with much reluctance I might have remained there at least for a few years to finish various literary enterprises that I had either partly under way or planned. Among these were the translation of a second volume of "Teutonic Mythology" by Victor Rydberg, a complete English version, with notes and vocabularies, of the elder edda, a more exhaustive work on the Norse discovery of America, the translation of Asbjörnsen and Moe's Norwegian folk-lore stories and of a few of the Icelandic sagas that had not yet appeared in English. To be able to do this work fairly well it was necessary to live in Copenhagen within reach of its great libraries and where specialists could be consulted. In order to enable me to do this my wealthy friend, H. Mansfeld-Büllner, offered me a stipend of 12,000 Danish crowns for a year, providing I would continue to live in Copenhagen and devote my time to these literary enterprises. Other rich men were willing to contribute to this stipend.

From Mr. Mansfeld-Büllner I received the following letter:

\section{Translation.}

May 1, 1889.

Office of the Imperial Turkish

Consul General, Copenhagen,

Mr. Minister R. B. Anderson:

The information, that you are to leave your post as minister for the United States, and that your meritorious activity in the domain of Old Norse literature is to be so suddenly interrupted, was received by me with a sense of deep regret. I can assure you, Mr. Minister, that this regret is shared by all true friends of this field of endeavor and as is well known this view has found its public expression in the address, which has emanated 
Clark E. Carr.

561

Det keiserlige tyrkiske General-Consulat.

KJOBENHAVN.

Qen Hifaci_- ssg-

$\rightarrow \vec{i}-2$

Ni S!

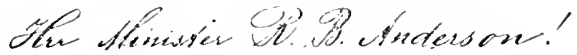

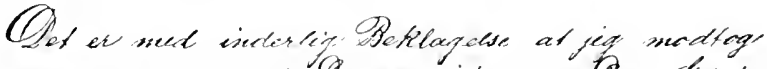

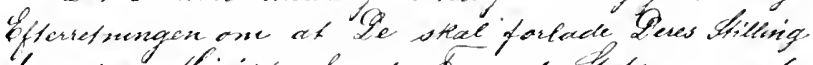

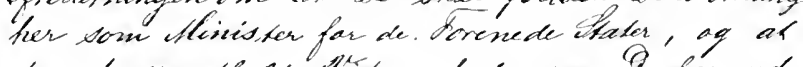

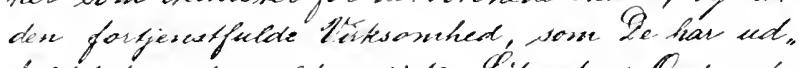

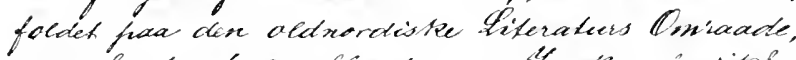

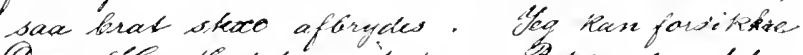

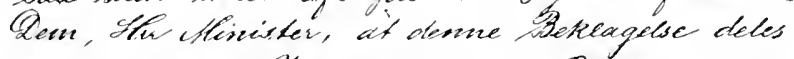

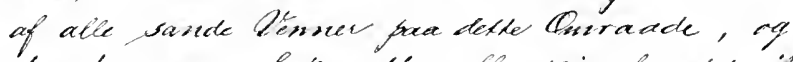
den hav, wase betyerids. afferescig fuender sith

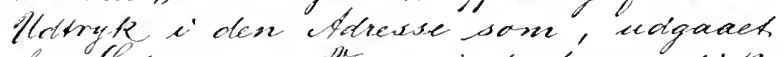

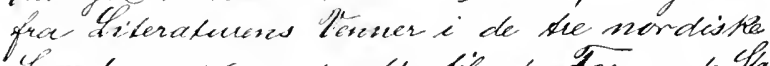

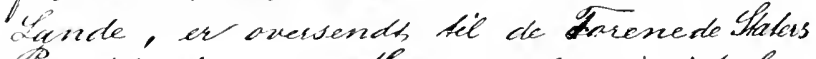
Prasidents. Alase a denfor iorigh bes

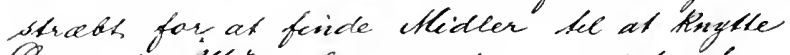

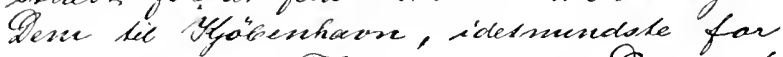
et sad langt Tidasum som Dei ansér for moduendigs til s' The at fulataic de migtige liencere Alacider, der forberedes under Beres Yaand.

Somer Bbeves para Oprizrigheden of

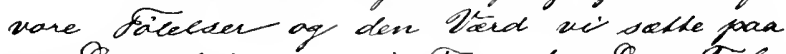

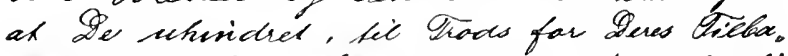
ectiadelse fra Mleinisterposten han fuleafais

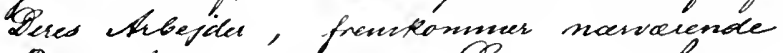
Brev for at ticlayder Den en Sim of 12000 Shoner, fivictien Shm stilles Dem

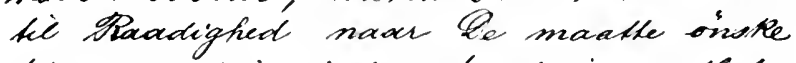
det, og ided jeg i' dene Anledneing wdeder mig Peres oude Beshentrig, bedw

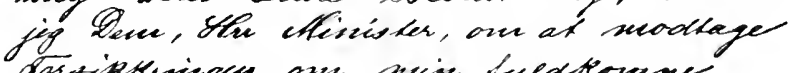

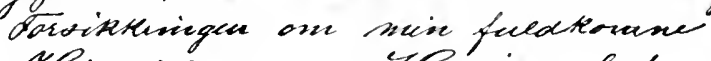

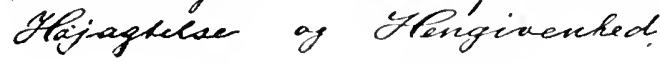

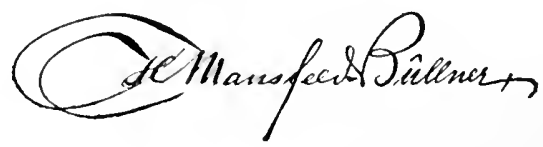

36 
from the friends of literature in the three countries of the North and sent to the president of the United States. Great efforts are therefore being made to find the means of retaining you in Copenhagen, at least for so long a period as you may deem necessary to enable you to finish at your leisure the important literary enterprises you now have in hand.

As evidence of the sincerity of our sentiments and of our appreciation of the importance of affording you an opportunity to finish your work unhampered in spite of your recall from your post as minister, this letter is sent you to offer you the sum of 12,000 kroner, which amount is placed at your disposal, whenever you may desire it. Respectfully requesting you to inform me what you may decide in this matter, I beg you, Mr. Minister, to accept the assurance of my perfect esteem and devotion.

H. Mansfeld-Büllner.

I was sorely tempted to accept this gift from my generous friend; but there were some obstacles in the way. In the first place I did not think it would be treating my successor right if I should remain there and have to share with him attentions that were his prerogative. I had an advantage over him by being classed as a Scandinavian scholar and being able to speak the Scandinavian tongues. In the second place it grated on my feelings to be the recipient of a gift even though the giver was entirely disinterested in every way except to promote the literary reputation of his country. I preferred to stand on my own feet and be the architect of my own fortune. Last, but not least, we had three boys who ought to be striking roots in their own native soil instead of growing up as exotics in a foreign atmosphere. Our daughter, too, though older than the boys, would probably be better off living at home than abroad. So taking all these things into consideration, I declined MansfeldBüllner's gift with thanks. 
Our friends insisted on entertaining us at dinner nearly every day up to the time of the sailing of the steamship "Norge" when they all came to the dock and loaded us with baskets and bouquets of flowers and with their good wishes and affectionate farewells. 


\section{CHAPTER CXXXIV.}

\section{MR. BARTON AND I TAKE A REST.}

Mr. Barton and I have now (end of March, 1914) devoted our evenings to this work with all the industry possible since early November, 1913. We have devoted all our winter evenings to this story and some more. We are now going to take a rest. There remains twenty-four years to bring the story up to date. How to treat these twenty-four years is not at this time clear to me. The work has not been fatiguing and perhaps it may even have been rejuvenating to live my life over again in memory and get its chief facts arranged and committed to writing. When we have had a few weeks of rest Mr. Barton and I will probably resume our work and try to condense the balance of the story into as few pages as possible. We will cross the bridge when we get to it.

In the remaining chapters I shall give some account of political, religious, and educational affairs among the NorwegianAmericans; of my experiences as editor and of a few prominent people whom I have met during the past twenty-four years. 



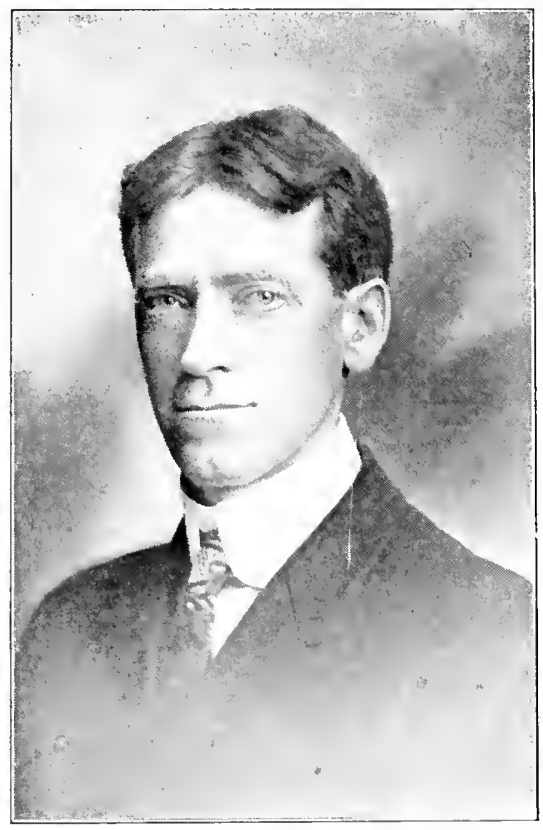

Albert O. Barton 


\section{CHAPTER CXXXV.}

\section{MR. BARTON AND I RESUME WORK.}

\section{Urged to Return to the University.}

The literary stipend offered me in Copenhagen by MansfeldBüllner and others I declined to accept for the reason heretofore stated. During my absence from Madison my friend and benefactor, President John Bascom, had resigned and had been succeeded by T. C. Chamberlin, a graduate of Beloit College. From Mr. Chamberlin I received a letter urging me to return to the university and resume my former position as professor of Scandinavian languages. He claimed, in his letter, that the university ought to have the benefit of the reputation I had made, both as a diplomat and as a writer, and he assured me that my salary would be made equal to that of the other professors. I replied that I was not willing to take the position away from the person that was then doing the work of the Scandinavian department. I received a second letter again urging me to return to the university and assuring me that the person then taking charge of the Scandinavian department would be given other work in the university so that he would not suffer financially.

I still declined. Then I received a letter from President Chamberlin asking my permission to print my name in the catalogue as a lecturer on Scandinavian languages and literature without salary. To this I agreed. Why this was not done has to this day remained to me an unsolved mystery. 
The president of the Equitable Life Assurance Society, in New York, wrote me that the doors of the Equitable were wide open and that they would be pleased to have me enter their service again, offering me a better position than the one I had before going to Denmark. I was inclined to accept this offer with a view of devoting a few years more to the acquisition of financial independence. 


\section{CHAPTER CXXXVI.}

\section{GO TO WORK AGAIN IN AMERICA.}

But while I was considering the proposition of the Equitable my friend Dr. Franz Peckel Möller came to me and asked me what I was going to do on my return to America.

Dr. Möller was the only son of the celebrated Peter Möller of Norway, and Peter Möller was the inventor of cod liver oil prepared by a steam process. Peter Möller put on the market an absolutely pure cod liver oil for which he had created a large and constantly growing demand in all civilized countries. At the various world exhibitions Peter Möller's cod liver oil had taken the first prize.

Dr. F. P. Möller was now the sole owner of this enormous business, including a large factory at Stamsund in the Lofoten islands, a principal business office in London and warehouses in Christiania. The son had also improved the quality of the oil by having it produced under a current of carbonic acid gas and so keeping it from contact with the oxygen of the air while it was being extracted from the livers. A perison taking this oil in China got it as fresh as the day when it was extracted from the liver of the cod.

Dr. Möller's agents for the United States and Canada were W. H. Schieffelin \& Co. in New York and he now proposed to make me his personal representative to the physicians of the United States and Canada. He offered me a salary of $\$ 5,000$ 
a year and traveling expenses and gave me carte blanche to travel as much or as little as I pleased, or saw fit. My relations with Dr. Möller were so intimate and his offer was so generous that $I$ accepted it.

Shortly after returning to my home in Madison I reported myself to W. H. Schieffelin \& Co., in New York, and talked over with them the modus operandi.

I packed my grip and in the course of four years I had visited every city with a population of 5,000 or more, both in the United States and in Canada, east of the Rocky mountains. I called on the most prominent physicians and discussed with them the merits of Peter Möller's product. I attended a large number of medical conventions, both state and national, and frequently obtained an opportunity of addressing the convention for half an hour, telling my hearers of my visit to the Lofoten islands and describing to them the Peter Möller establishment at Stamsund. I visited, I think, every medical college east of the Rockies in the United States and Canada and in a large number of them I was permitted to address the medical students on the subject of cod liver oil.

I had been minister to Denmark, but as Möller's representative I was now "minister to grease." "There is only one Cod and Mohamet is his prophet." This was easily changed into: "There is only one cod (liver oil) and Möller is its profit."

I prepared a considerable amount of advertising material which was generously distributed and wrote a small pamphlet on the Lofoten islands. This little booklet was published by the Schieffelins in five million copies, said to be the largest edition ever printed of one document at one time.

The business prospered and the demand for the Möller product increased in a very satisfactory manner. At the world's Columbian exposition in Chicago we had a fine exhibit of which I took charge. 
Being almost constantly on the road, I had but scant opportunity for systematic literary work. While living at hotels in New York, Boston, Chicago, St. Louis, New Orleans, and other places I managed to write sketches for some of the leading newspapers. I prepared a number of articles for the Chicago Tribune and the Chicago Record. I wrote an elaborate illustrated article on "The Land of the Mid-day Moon" for "Scribner's Magazine." I kept up my connection with "The Nation" of New York and kept this journal fairly well supplied with reviews of new Scandinavian books.

In some of the cities that I visited I was invited to address literary clubs and I also delivered lectures at a number of colleges and universities. When I got a few weeks off to spend at home I was busy catching up and in doing work on encyclopedias and in political campaigns, doing some speaking, particularly in Wisconsin, but also in other states.

I was expecting to accumulate enough money to become able to devote all my time the balance of my life to Scandinavian literature. But this hope was not to be realized. I had been investing my funds in the Scandia bank of Minneapolis. I owned our home free from debt, had built two small cottages in Ashland, Wis., and owned stock to the value of $\$ 25,000$ in the Scandia bank.

My friend, Dr. Möller, was ill, and having been on the road continuously so long we mutually agreed that I should retire, at least for a time. Before that time expired Dr. Möller was gathered to his fathers and in his death I lost one of the best friends I ever had. My wife was ill and required my constant attention.

With the crisis in 1893 the Scandia bank stood the first shock; but the panic continued. Real estate values kept declining and many of the strongest financial institutions were shaken to their foundations. Men who were rich one day found themselves the next day penniless. I knew a man who came to Min- 
neapolis with $\$ 100,000$ cash and bought with it $\$ 200,000$ worth of real estate, paying 50 per cent down. When the crash came his 50 per cent equity was more than wiped out.

The cashier of the Scandia bank owned $\$ 600,000$ worth of real estate in Minneapolis, much of it unoccupied. One block for which he had paid $\$ 100,000$ he mortgaged in order to raise money to pay his taxes. He struggled on for a couple of years in this way and finally lost all. Before the panic Scandia bank slock found ready buyers at $\$ 250$ per $\$ 100$ share. After the panic there were no buyers and one morning I was notified that the bank had been closed. All that I had accumulated was swept away in the twinkling of an eye. I was left stranded and had to begin over again.

In the midst of this disaster I had one great satisfaction and consolation. The legislature of Minnesota appointed a committee to investigate the score or more of bank failures in St. Paul and Minneapolis. It was claimed that many of the failures were due to reckless or crooked practices on the part of the officers and directors.

This committee after investigating all the failures in the twin cities made its report and therein stated that the only bright spot they had found was the Scandia bank. In it they had found nothing to criticise. This report was particularly gratifying to me because I had served, not only as a director, but also as vice-president of the bank.

What caused the bank to fail was simply that the bottom fell out of its securities and collaterals, a thing that not even the shrewdest or wisest business men could foresee.

The day after this calamity occurred one of my wealthy friends (Mr. J.) came to me and expressed his sympathy and then gave me a long and very interesting lecture on the proper way to invest money, showing me in fact how I ought to lock my barn now that my horses were gone. He forgot to ask whether I needed any assistance to keep the wolf from the door. 
Another well-to-do friend (B. J. S.) sent for me. He too was sorry for me and said he wanted to know if $I$ was in need of funds, in which case he would be pleased to furnish some. I was deeply touched by his kindness, but told him I was not in need of any help just then.

Governor Upham also expressed a willingness to give me financial assistance. I was still in what I considered the best years of life; my health was good and I was not disposed to make myself an object of charity. Many of my plans for usefulness in my chosen field of intellectual activity had to be abandoned and for some time all my thoughts were concentrated on what to do to support my family. 


\section{CHAPTER CXXXVII.}

\section{LIFE INSURANCE.}

In 1896 W. H. Rogers, L. M. Fay, and Col. A. R. Bushnell had conceived the idea of organizing in the city of Madison a life insurance company. Without my knowledge they had agreed among themselves to offer me the position of president. They knew of my success as an agent of the Equitable of New York. The Natural Premium Life Insurance Company was organized; I was elected a director and president, and accepted. It was originally an assessment company; but as soon as the assets permitted it was changed into a regular so-called old line company under the name of The Wisconsin Life and I have been its president from the day of its organization until the present time. The company has had the mumps, the measles, chickenpox, and all the other diseases to which children are subject, but is today in a sound and prosperous condition with nearly half a million dollars assets.

Although my income from this source has been insignificant, still it has helped me to make both ends meet in my struggle for existence.

While the insurance company was being organized the affairs of the Scandia bank in Minneapolis were being wound up by its receiver. The court in Minneapolis decided that all my obligations would be liquidated by my paying $\$ 1,000$. I received a letter from my good friend Judge Andreas Ueland stating that if I could send him \$1,000 I would receive a receipt in full 
for all my obligations to the stockholders. I did not have $\$ 1,000$. I called on Halle Steensland and dropped Ueland's letter on his desk in front of him without saying a word. $\mathrm{He}$ read the letter and in a few moments he turned to his son Edward and said: "Make out a draft for \$1,000 for Mr. Anderson," and turning to me he said: "I suppose that is what you want?"

I replied: "Yes, Mr. Steensland; but I hesitated about requesting you to lend me the money."

Against his protest I gave him my note for a year. At the end of the year I was able to hand him $\$ 1,070$, but he positively declined to accept the $\$ 70$. He refused to take interest on this loan, a kindness that I cannot forget and do not want to be forgotten in these records. 


\section{CHAPTER CXXXVIII.}

\section{BECOME A JOURNALIST.}

In 1898 there was a fierce political conflict in Wisconsin between La Follette and his friends on one side and Spooner and his friends on the other. Major Scofield, by a narrow margin, received the republican nomination for governor and John C. Spooner was a candidate for the United States senate. $\mathrm{Mr}$. La Follette had ingratiated himself with the Norwegian voters and he had secured the ardent support of "Skandinaven," the most widely circulated Norwegian paper in the country. It was well known that I was a warm friend of Spooner. Then it so happened that the newspaper "Amerika," which in 1884 had been founded in Chicago had been consolidated with another Chicago paper called "Norden" and being in a moribund condition had been in 1896 moved to Madison where it absorbed another Norwegian paper called "Normannen." The paper was put in charge of Peer Strömme as manager and editor, but did not thrive. During the two years of Strömme's editorship it ran behind several thousand dollars and the owners were willing to sell for the debt then accrued.

The Spooner and Scofield side needed a paper to counteract the influence of "Skandinaven" and Mr. Spooner suggested to me that I ought to purchase "Amerika." The debt of "Amerika" amounted to $\$ 4,100$. This amount of money was raised by Mr. Spooner among his friends and with this money I bought 
the paper. Mr. Strömme had been nominated for the office of secretary of state by the democratic state convention.

I took this wreck of a journal; I took my son George in as my partner and from that day to this he and I have been issuing "Amerika" every week. There has been no profit in it, but we have succeeded in keeping it afloat and now after sixteen years I am proud to state that "Amerika" does not owe anybody a single penny.

Scofield was triumphantly elected governor and Spooner got a seat in the senate.

Of the general policy of the paper and the work done through its columns I shall probably have something to say later. 


\section{CHAPTER CXXXIX.}

\section{RUBBER.}

In 1904 there was organized in Madison the Wisconsin Rubber company for the purpose of developing a rubber plantation in Chiapas, in the southern part of Mexico. The promoters held a meeting and decided to invite me to serve as director and president. The prospects were most promising. The company owns about 7,000 acres of land, 4,500 acres of which are planted to rubber. On the 4,500 acres nearly $3,000,000$ trees have been planted from seed. The oldest trees planted in 1905 are now being tapped and the plantation has reached a point where it is easily self-supporting. But we are confronted by two important difficulties, the one being the revolution in Mexico and the other the great decline in the price of crude rubber. Three or four years ago the price of crude rubber reached $\$ 3.20$ per pound, while we are now getting less than 50 cents a pound. But that is not after all so serious a matter as the political conditions in that revolution-ridden country. Fortunately the revolution has not thus far affected our part of Mexico excepting our war taxes and the loss of some of our labor which has been drafted into the army. Our Wisconsin rubber plantation has a larger number of rubber trees than any other single rubber plantation in the whole world so far as I know. With a return to peace in Mexico the Wisconsin rubber plantation should be a profitable investment even if rubber does not bring more than 50 cents a pound. 
Our plantation represents an investment of $\$ 1,200,000$ divided into 4,000 shares at a par value of $\$ 300$ each. Just before the revolution broke out in Mexico and while crude rubber brought about $\$ 3.00$ a pound we sold the plantation in London for $\$ 3,200,000$, or $\$ 800.00$ per share. The London syndicate was to send a representative to Chiapas to investigate our title and verify our invoice and if these were found to be as represented they were to hand us $\$ 50,000$ in earnest money and pay the balance in monthly instalments. But unfortunately Mexico became involved in revolution; the old patriot Porfirio Diaz was banished; De La Barra became acting president and was followed by Francisco Madero. The London syndicate wanted to wait until normal conditions were reestablished in Mexico. In the meantime the price of rubber declined and political conditions have been growing worse from that day to this. The sale did not materialize. 


\section{CHAPTER CXL.}

\section{VISIT MEXICO.}

On the coldest day of the winter of 1904-05, in the month of February, I started for Chiapas, Mexico. Ex-Mayor Hall of Brandon, Manitoba, had been elected as inspector to visit our rubber plantation and I decided to go with him. As I say, it was the coldest day of that winter. In Chicago we put up at the Brevoort, on Madison street, and got a room with two beds on the third floor. Some time after midnight we were awakened by a considerable noise and running to and fro in the halls of the hotel and water was dripping through the ceiling on our floor and on our beds. We got up and found that the hotel was burning. I dressed as rapidly as possible, but Mr. Hall took the matter with an alarming coolness. He seemed to be in no haste whatever. Out in the hall were water hose leaking at the joints; men and women were running hither and thither in their night-robes frightened almost out of their wits. Here could be seen a woman with one of the bedquilts wrapped around her; there one with a bedsheet, all, both men and women, barefooted and in terrible excitement.

Mr. Hall's coolness helped to make me keep cool. When he got his things packed in his valise and had put the last finishing touch on his toilet we both took our grips, went down the two flights of stairs and out into the cold street. There we found another motley crowd of only partially dressed, excited people. We went to the hotel across the street, but not a bed was to be 
had there, so we proceeded to the southeast corner of Madison and Clark streets where we succeeded in securing the last room.

The next day we continued our journey to St. Louis, thence to San Antonio, and Laredo, where we crossed the Rio Grande and entered Mexico.

The cold wave which I have mentioned stayed with us until we reached Austin, in Texas. From that time on we had summer weather. When one gets into Mexico one enters a new world. Everything is different from what one may have seen either in the United States or in Europe. This applies particularly to the vegetation and to the life, manners, and dress of the people. The men wear their huge sombreros which add an ell to their stature, and both the men and the women shine in their gaudy serapes, which the men throw over their shoulders, and the women wind around their waists for skirts. When you get into the genuine tropics the children under six or seven are found stark naked. I may add here that the Mexicans, including the peons, who are utterly illiterate, are scrupulously cleanly. They bathe as often as they have the opportunity; they are continually washing their hands and feet and after every meal you find them rinsing their mouths with water and scrubbing their teeth with their fingers. In respect to cleanliness they remind us of the Dutch in Holland.

The most striking feature of the vegetation are the many kinds of cactus, the agave of which the maguey plant produces the pulque, the beer of the Mexicans, and the henequen, in Yucatan, produces fibre for binding twine, and other purposes. The juice of the maguey plant is gathered by the peons in large bags made of pigskin. The henequen leaves are run through a machine resembling a sorghum mill. In this way the juice is squeezed out, leaving a bunch of fibre from three to five or six feet in length.

But what perhaps strikes one the most in the tropics is the great variety of brilliant flowers. The church walls in the cities 
are covered with the beautiful bougainvilleas. Then there are a large number of trees covered with bright red flowers not unlike Chinese poppies. Add to this the groves of stately cocoanut palm trees and of the royal palm and the countless orchids hanging on the branches of the trees and the vines of all kinds, making the tropical jungle, and you have a landscape differing as much from a Wisconsin landscape as summer differs from winter.

On the way between Laredo and the City of Mexico we made short stops at Monterey, celebrated for its wealth and for its mineral springs, said to have been discovered by the daughter of Montezuma ; at San Luis Potosi, from whose mint comes annually three million silver dollars and at Queretaro, where are found Mexico's rich opal mines. It was on the edge of this town that Emperor Maximilian was shot June 19, 1867. A beautiful little chapel stands on the spot where the emperor with his two faithful generals, Miramon and Mejia, fell. Miramon and Mejia dropped dead at the first shot, but Maximilian required a second shot. Before the execution he handed each one of the soldiers a gold coin and asked them to shoot straight at his heart in order that his mother might look upon his face after he was dead. He inquired about his wife, the poor Carlotta, who is still living a mental wreck in Brussels, and was told that she was dead.

"Then," said Maximilian, "there is one bond less that binds me to this world."

The faithful Carlotta pleaded with the pope to intercede. The American government protested against the execution. The princess Salm-Salm rode on horseback 160 miles to San Luis Potosi, where she fell on her knees before President Juarez beseeching him to spare Maximilian's life. But all was of no avail. President Juarez said:

"It is not I, but Mexico, that demands the life of Maximilian." 
It was the intention that Maximilian should stand in the middle between the two generals, but Maximilian stepped to the right, leaving General Miramon in the middle, saying:

"A brave soldier must be honored by his monarch even to the last moment. Permit me, therefore, to give you the place of honor."

Then it was that he went to the seven soldiers, handed each one of them a gold coin, and said:

"My dear boys, aim well; aim here," pointing to his heart.

As the soldiers fired he shouted: "Viva Independencia! Viva Mexico!" Miramon and Mejia repeated the same words and thus died the last Mexican empire.

At Queretaro I purchased a handful of opals. They represent the tragedy of Mexico. They are the precious stones of sorrow.

The City of Mexico is the cleanest and most beautiful city that I have ever seen. The principal streets are not swept, but scrubbed. If you get up at daybreak you will see hundreds of men and women on their knees scrubbing the streets as we would scrub our floors.

I visited the great and venerable cathedral near the government buildings in the city. I drove out to the famous Gaudeloupe church and walked through the graveyard where so many of Mexico's illustrious sons are buried. I also took that splendid boulevard drive in Chapultepec, the white house of Mexico. I twice saw President Porfirio Diaz with his family driving in their splendid equipage.

I visited the magnificent botanical gardens where I saw Mexico's flora in all its grandeur.

On San Francisco street there is a store dealing exclusively in orchids. I found one that suited my fancy and wished to buy it, but the price was $\$ 300$ Mex. (about $\$ 150$ gold) and that was too rich for my blood. I have learned not to bother with a stone that I cannot lift. 
One of the most interesting places to visit in the City of Mexico is the museum of Mexican antiquities. There may be seen a great variety of things illustrating the Aztec and other civilizations.

From the City of Mexico to Vera Cruz you descend more than 8,000 feet. The distance is about 300 miles. Every hour as you descend the temperature rises and there is a corresponding change in vegetation. There are two railroads, one narrow and one broad gauge. Outside of the City of Mexico you pass some ancient pyramids. They are not made of hewn stones like the pyramids of Egypt, but are constructed of adobe. Then you have around you those skyscraping, snow-capped mountains, the Orizaba, the Woman in White, and Popocatepetl, the highest on this continent, excepting only Mt. McKinley in Alaska.

What particularly attracted my attention in the old city of Vera Cruz was the great number of buzzards. When they were not soaring on their wide-spread wings they were strutting about on the streets where they served as scavengers. They served as the city's board of health and were protected by the city's laws. To hurt one of them was a crime. Their persons were sacred, like the persons of kings. I asked my traveling companion, Mr. Hall, how many buzzards he thought there were in Vera Cruz. He said:

"I might safely put them at two for every ordinary citizen."

Vera Cruz having a population of 35,000 humans, there must, according to Mr. Hall, one of the keenest men of Manitoba, have been at least 70,000 buzzards. I did not learn that this buzzard nobility was any burden to the city.

The buzzards are ultra conservative and will brook no change, no reform, no progress; their black garments are exactly the same today as when Cortez landed at Vera Cruz. They eat the same kind of food in the same manner and use the same means of transportation. When they are to perform their work 
as a board of health they condescend to walk in the streets, but the rest of the time they consider themselves too good to live on the same level with humanity. One of their ancestors invented a flying machine which at the same time serves as their black gown or uniform and they have kept this invention secret and it is their monopoly.

At the Grand Hotel in Vera Cruz, the weather being intolerably hot for one who had just left a temperature of at least 30 below zero, I left my window facing the Gulf of Mexico open, to let in some breeze from the salt sea. I knew the board of health was on guard outside so that nothing harmful to my health could enter. I fell asleep and promptly I was enraptured by the sweetest music. I heard my friend, Jacob Hjort, from Minneapolis conducting a mighty chorus of several hundred voices, singing Reissiger's music to Björnson's "Olaf Trygvason," my own son Hjalmar directing the accompaniment by a magnificent orchestra. But suddenly I felt a lot of needles piercing my flesh in my face, on my neck, on my hands, on my whole body. I awoke, and it did not take me long to discover that it was not Jacob Hjort's and Hjalmar's chorus and orchestra, but that the music came from a genuine Mexican chorus and an equally genuine Mexican orchestra; both belonging in Vera Cruz. They had read in the daily papers that I had come to the city and was stopping at the Grand Hotel and they had resolved to give me a serenade of genuine national melodies. Unfortunately my window was open and so they came in and began to help themselves to such refreshments as they could find. They are very fond of human blood; they had excellent instruments for lancing and it was their needle pricks that made me awaken. Like President Wilson I issued a declaration of war and the battle began at once. I lit a candle and delivered a thundering speech to these natives. I did not, like Admirals Fletcher and Badger, have a lot of dreadnaughts with me. I had only one cannon and that was my "Flor de Basca" which 
I had purchased the day before for 25 cents Mex. It is the best cannon made in Mexico. With this I bombarded the whole chorus and the whole orchestra and it will no doubt please my American fellow citizens to learn that I won a glorious victory over all these greasers. My cannon was loaded with the best leaf growing in Vera Cruz, but my enemies must have thought that it was dynamite, for they all took flight. I shut the gates of my fort, extinguished the light and retired again. During the battle some of them had hid under my bed and now they stole out again, but the most of these had to pay for their impudence with their blood, the same blood that they had taken from me. I won a glorious victory over these evil spirits of our day, but as in the most of the battles in which I have been engaged I had to fight the enemy single-handed.

In the steamer "Cometa" I continued my journey to Frontera, stopping on the way for a half day at Coatzocoalcos, now called Port of Mexico. From there the British have a railroad across the Isthmus of Tehuantepec to Selina Cruz. This railroad has an immense traffic and has automatic loading and unloading of cargoes at both terminals. It has for years been doing the great bulk of the carrying which will henceforth be done by our Panama canal.

Frontera is at the mouth of the Grijalva, Mexico's greatest river, named after the Spanish navigator, Juan Grijalva, who discovered Mexico. The Grijalva, and its tributaries, the Usumacinta, the Tulija, the Mexcalapa, the Jalapa, and some others have a combined navigability of more than 3,000 miles and support a large fleet of steamers.

In Frontera, where I stopped a week, one of my friends invited me to a bull-fight. I had refused to see one in the City of Mexico, but my friend insisted that it would be a disgrace to come back to Madison without having seen Mexico's most national institution for amusement. The tickets were $\$ 2.50$ apiece. I was persuaded to go. We occupied, the six of us, 
some of the choicest seats. I watched the people assemble, the women all dressed in their best gowns. I saw the bullfighters in their highly colored uniforms come in and salute their lady friends in the vast audience. There was the toreador, the picador and the bull. Meanwhile a band entertained the audience with music. I saw one of these bull-fighters hurl his bandarillas in a blaze of bright ribbons into the shoulders of the poor bull, causing him the greatest agony.

I had seen enough of this most brutal popular sport; I got up, said goodbye to my five friends and returned to my hotel. I had seen all I cared to see and all I ever expect to see of this barbarous amusement which should be abolished by law.

At Frontera the Tabasco-Chiapas Trading \& Transportation company have a shipyard. While I was stopping in the city this company launched the steamer "Mexcalapa," and I was invited to be a guest at the launching. This festival was attended by all the prominent people of the city, including a number of Americans, Englishmen, Germans, and Frenchmen. It was intimated to me that I would be called on for a few remarks.

For the festival they had engaged a native German, who was a polyglot, speaking, besides his own tongue, English, French, and Spanish, or Mexican. At the festival he stood beside the speaker and taking the words out of his mouth translated them to the guests, from one of these languages either into Spanish or into English.

In the morning before the festival I wrote out a five-minute speech in English. This I took to the head bookkeeper of the transportation company and got him to translate it into the classical Castilian of Spain. I rehearsed the speech several times with the translator and then I went into a cocoanut grove below Frontera and practiced it until I knew every word by heart. 
At the launching festival I was called upon to speak. I had a glass of champagne in my hand and the interpreter stood by my side prepared to translate my sentences into Spanish. Imagine the surprise of the guests and of my interpreter when I launched out in the most classical Castilian Spanish which had to be turned by the interpreter into English. I stated that I had been so enraptured by the scenery, the climate, the vegetation and particularly by the gorgeous flora of the tropics that I was now eating and drinking and speaking and thinking and sleeping and dreaming exclusively in the beautiful language of Cervantes and that I had utterly forgotten the vernacular of the immortal English writer Shakespeare. I predicted a great future for the city of Frontera, saying that the time was not far distant when it would have to annex the city of San Juan, a hundred miles up the river, as one of its suburbs. I am simply telling the truth when I say that with this little speech, the preparation of which was a profound secret, I made a decided hit at the launching festivities of the "Mexcalapa." 


\section{CHAPTER CXLI.}

\section{AM WRECKED.}

I had spent a week with Mr. Robert Hall inspecting our rubber plantation. The regular steamer was to take us back to Frontera. My son Rolf was working on our plantation and he told me that there would be a tramp steamer, the "San Jose," the next day and he begged me to spend another twenty-four hours with him and wait for this tramp steamer. I did so. The next day the "San Jose" came. I was given the best stateroom on board and we proceeded down the Tulija and then up another tributary on the Grijalva to a town called Macuspana on the river of the same name.

In this part of the world there is no twilight, but only day and night. It is dark until the sun rises and darkness sets in again immediately after sunset. But such brilliant sunrises and sunsets as are here seen are found nowhere else in the world so far as I know. As we entered the Macuspana the sun had set. I lit my cigar and seated on the deck watched first the glowing sunset effect and then turned my eyes toward the different constellations, most prominent among which was the celebrated southern cross. It corresponds in some ways to the dipper in northern latitudes. On this evening the southern cross appeared in all its effulgence as if it wanted to show me as a souvenir of my first visit to the tropics how brightly it can shine.

I presume I ought to have stated heretofore that while I was in this part of the world I became the man without a shadow at the noontide of every day, the sun being directly above my head. 
Having finished my cigar I retired to my stateroom and lay down on a steel mattress. There were no bedclothes. As a reminder of my experience in Vera Cruz, I found that a large number of Macuspana's musicians and singers had entered my apartment to surprise me with a serenade. They sang and played with all the energy they possessed. They were not playing spring dances or hallings or "Sæterjentens Söndag," but the well known national Mexican mosquito march, and as a refrain to each performance the chorus sang:

Ja, vi elsker denne Kvelve,
Som han ligger her
Drömmende om Norges fjelde
Og om rubbertrær.
Elsker, elsker ham og sænker
Syle i hans kjöd,
Miedens glade vi os bænker
Om det blod, der flöd.

I arose, delivered an address of welcome to the musicians and thanked them for the serenade. The music seemed familiar to me; it appeared to me like a melody from home. I was sure I had heard the tune before, but where the musicians had gotten the words was a mystery I could not solve. Then one of the serenaders came buzzing into my ear and whispered that they had received the text from the publisher of "DecorahPosten" and the melody from Norway, both by wireless. Another of the serenaders whispered in my other ear that this beautiful song was to be sung at the annual meetings and banquets of the Norwegian-American Press Association.

The only thing I could offer my guests was my blood and perfume from my cigar. Some of these guests treated themselves to portions of my blood and filled their bread baskets till they were ready to burst. My cigars were too large for the small, delicate mouths on the faces of this Mexican nobility and I had no cigarettes. But they enjoyed my smoke second hand. 
There are no roses without thorns. I have crossed the Atlantic eight times; I have sailed up and down the coast of Norway, I do not know how many times; I have crossed the North Sea again and again and have been a viking on the Baltic; I have sailed on all our American great lakes and on the Gulf of Mexico; but it was reserved for me to be wrecked on a pitch dark night between the 9th and 10th of March on the great Grijalva.

The steamer San Jose was to arrive at San Juan Bautista, the capital of the state of Tabasco, soon after midnight. Here I was to take another boat for Frontera. I had retired early, but did not intend to rise before morning. About midnight I heard a great racket on board, but I supposed we had reached San Juan and that the racket was caused by the leaving of passengers and discharge of cargo. I tried to go to asleep again, but suddenly the cabin boy broke my door open and shouted:

"Salva te, signor. A profundo! A profundo!' ("Save yourself, sir. We are drowning!")

I hurried up; put on my coat; grabbed my satchel and rushed out. It was dark as pitch and the San Jose was full of water. The Grijalva is many miles wide and there was no sign of land anywhere. I was told that we were 15 miles from San Juan. The captain had secured a couple of cayucas (canoes) and in these some passengers that we had taken on board at Macuspana had been taken ashore. Looking at me he said:

"Don't be afraid; there will be a cayuca for you."

The sailors were busy baling out water and throwing the cargo overboard. Before leaving the upper deck I had handed my baggage to the machinist and he had put them in a cayuca that had gone ashore, I did not know where. The San Jose could not go anywhere because the water had put out the fire under the boiler. The boat had struck a snag which had made a big hole in its bottom. It was an old, rotten hulk which should have been put out of commission long ago. While I stood there not knowing what to do and while the men 
were baling out water and throwing cargo overboard a cayuca came alongside of the "San Jose." In it stood a large, powerful man who asked me to come into his boat.

"I am Port Rican," he said. "I speak English. You get in my cayuca. I take you ashore."

There was much water in his cayuca and I got a large tin box for a seat. I was in one end of the boat and the black Porto Rican in the other, with his oar twenty feet long. But the people on board busy throwing cargo into the river threw some large sacks filled with beans into the cayuca. At the same moment the machinist shouted to me:

"Salva te, signor. A profundo!" I gave him my hand and he threw me back onto the deck of the sinking ship. I lay sprawling on the deck. The cayuca and the Porto Rican had disappeared. The captain spoke to me and said:

"Don't be 'fraid; there will be another cayuca for you."

The "San Jose" was rapidly sinking. Suddenly a shout arose from the captain and sailors:

\section{"Vapor! Vapor!" (meaning steamer.)}

In the distance was discovered a light growing gradually more distinct. It was the light of a steamer coming down the river from San Juan. It proved to be the steamer "Usumacinta" on its way to Frontera. The captain took the lantern suspended from the ceiling of the lower deck and swung it to and fro as a signal of distress, hoping to attract the attention of the captain of the Usumacinta. The sailors kept shouting at the tops of their voices:

"Salva nos! Salva nos!" (meaning: "Save us!") and in this shout I joined with all the wind I had in my lungs.

The captain of the "Usumacinta" had discovered our signal of distress and to our great joy we could see that he was coming to our rescue.

The "Usumacinta" laid up alongside of the "San Jose" in the very nick of time as we were on the very point of sinking. The Usumacinta had an empty barge in tow and this would 
easily furnish room for any cargo that had not already been thrown overboard.

The excitement on board the "San Jose" was turned into joy. I can say, without any exaggeration, that the arrival at our side of this steamer was the happiest moment that I ever experienced. I had fully made up my mind that I must go to the bottom with the San Jose and now I was saved.

On a narrow plank I was assisted on board the "Usumacinta." The captain, whose name was Fabre, stood at the gunwale to receive me. He escorted me to his own cabin and then he addressed me in this fashion:

"I do not speak German; but I speak a little English. You are the German ambassador to Mexico and I take care of you. You stay here in my room."

A waiter brought me a bottle of claret wine and a tray of cake and the captain asked me to help myself.

Now the fact was that the German ambassador to Mexico was traveling in this part of the country and had been visiting the celebrated Palenque ruins near the Wisconsin plantation and Captain Fabre and others had come to the conclusion that I must be that individual. Having been several years in the diplomatic service and conscious that I had some royal blood in my veins I quickly decided to play the part of the German ambassador to Mexico for the time being. I did not claim to be that person, but I allowed the captain to think I was.

Then I got to thinking about my baggage. The last I knew about it was that the machinist had put it on board a cayuca and sent it ashore. I sought Captain Fabre and told him that I was anxious concerning my baggage. Captain Fabre replied:

"You are the German ambassador to Mexico. You go to my room. I find your baggage."

And sure enough, in about an hour a couple of Mexicans brought me my luggage. I handed them a Mexican peso each. How the captain was able to find my baggage in this darkness 
and confusion is to this day to me an unsolved mystery. I had a box containing about two dozen Mexican pineapples, but this had been thrown overboard along with other cargo.

The hole in the bottom of the San Jose was more than one foot square, but this hole was mended so that the Usumacinta was able to take the San Jose in tow and bring her to San Juan where she was lifted onto the bank of the river.

As indicated, the Usumacinta, instead of continuing to Frontera, returned to San Juan, where we arrived soon after daybreak. The following evening she was to leave again for Frontera. I secured a stateroom and then went ashore to see the sights in the capital of Tabasco. I visited the plaza and the market. At the market I saw hundreds of turtles; the males sold for $\$ 1.00$ and the females for $\$ 1.25$ Mex.

While I was examining the various products on sale at the market a gentleman in uniform came to me and said in English:

"If I am not mistaken, you are the German ambassador to Mexico. The governor of Tabasco, his excellency, Abraham Bandala, desires to see you and has sent me to find you and to escort you to his office."

The gentleman in uniform was, as I learned, the governor's secretary. I said nothing, but went with him. He took me to the governor's office and presented me to the governor. Governor Bandala did not speak English and so communicated with me through the secretary. He said:

"You are the German ambassador to Mexico and I am sorry that you were wrecked last night in the San Jose. I am at your excellency's service. All is yours. You only need to make your wants known."

I could not continue to act the part of the German ambassador. I thanked the governor for his kind attention and good intentions, but said that it was my duty to inform him that I was not the German ambassador, but only a plain American citi- 
zen; that I was interested in a rubber plantation in Chiapas and in a transportation company in Frontera and I added that the transportation company had named one of its steamers for him.

"Ah," the governor exclaimed; "I know; mi Bandala; fine vapor!"

On returning to the steamer I met some of those who had been my fellow-passengers on the San Jose. In true Mexican fashion we embraced each other without regard to sex, color or previous condition. I had experienced the realization of the Latin phrase which I learned at college "dulce commune naufragium," ( a shipwreck in common is sweet). I do not know as a shipwreck is particularly sweet, but I realize the relation of friendship among those who have shared dangers and trials.

San Juan is a typical tropical city containing about 15,000 inhabitants. From San Juan I proceeded on board the Usumacinta to Frontera. I explained to Captain Fabre who I was and begged his pardon for permitting him to treat me as the German ambassador to Mexico.

In Frontera I found my fellow traveler, Robert Hall, from Brandon, Manitoba. We took a steamer for Vera Cruz; thence we went by rail to the City of Mexico and after spending a couple of days there we hastened back to Madison, Wis. The only stop of any importance that we made was at San Antonio, Texas, where we made a visit to the famous Alamo, the Thermopylae of America, where David Crockett lost his life in 1836.

On this trip I had come out fire proof from the Hotel Brevoort and water-proof from the shipwreck on the Grijalva, There is a ruler above who has numbered the hairs on our heads and without whose consent not a sparrow falls to the ground, and I have an idea that $\mathrm{He}$, in His infinite wisdom and mercy, had some purpose in bringing me safe, both from the fire and from the shipwreck. I have to thank Him for the protection He has thus far given me. 


\section{CHAPTER CXLII.}

\section{THE BENNETT LAW.}

On my return from Denmark in 1889 I found the people of Wisconsin up in arms against the Bennett law. A similar law had been enacted in Illinois and the people of that state were also greatly agitated on account of it.

The Bennett law was a school law. It was intended as a means to compel parents to send their children between the ages of seven and fourteen to school. So far as I know the republican party had not announced any intention of enacting any such law in their state platform. It must have been an afterthought. As I understand it, some persons had become interested in the Illinois law and gotten it into their heads to get a similar one adopted by the Wisconsin legislature. At all events the bill was framed and Mr. Michael J. Bennett of Cobb, Wis., was induced to father the bill. By gumshoe tactics the legislators were induced to vote for it without scrutinizing its contents and wording. It provided for the education of children and this seemed to be a good thing. Governor Hoard signed the bill with great enthusiasm and so people waked up and found it to be the law of Wisconsin.

But the law did not bear a careful scrutiny. On examination it was found to contain some very unjust and offensive provisions. Whether these provisions were intentional on the part of its promoters or not I have never been able to find out. What I do know is that when the opposition to it broke out 
Gov. W. D. Hoard espoused it, and became its most valiant defender. He worked himself up into such enthusiasm for it that he at last looked upon it as the greatest question that the whole American nation then had to settle. Just as Abraham Lincoln had become the saviour of our country as our president during the civil war and had become the emancipator of the slaves in the South so Mr. Hoard was going to be elected president on this issue and become the redeemer of our country and the emancipator especially of the children of foreign-born parents. Mr. Hoard expected that the issue contained in the Bennett law would spread rapidly into every state in the union and that the waves of this agitation would carry him as its chief champion into the white house at Washington.

The opposition to this law came from the Catholic and Lutheran churches and so far as I know this is the only time from the Reformation of Luther to the present time when Lutherans and Catholics have joined hands and been united in a common cause. What I mean to say is that it is the only instance within my knowledge where Lutherans and Catholics have combined to abolish a law that they found objectionable or offensive. From this viewpoint alone the Bennett law is an exceedingly interesting historical episode.

What were the features in the Bennett law that were found to be so offensive to Lutherans and Catholics? Let me try to make this matter plain. While the Bennett law contained many excellent provisions for the education of children and made their attendance in school for a given number of days a year compulsory, it also required that children between the ages of seven and fourteen must attend some public or private day school so many days a year in the city, town or district, in which they happened to reside. This was construed, and that properly so, as a stab at the parochial schools. The Catholics, and particularly the German Lutherans, maintain parochial schools in which the children receive religious and secular instruction. 
These children therefore do not attend the public schools. But as the reader will readily see, these parochial schools are not always located in the district in which the child resides. In many places the children attending a parochial school may come out of three or four public schools districts. In compliance with the law such a parochial school would have to be divided into three or four separate schools built in the various districts where the parents resided. Three or four teachers would be required instead of one and as any fair-minded person must see this provision of the law, if submitted to, would destroy a large number of parochial schools in Wisconsin.

There were other objectionable features in the Bennett law, such as those requiring certain branches, arithmetic, for example, to be taught in English when they might as well be taught in any other language. But the requirement that a child must attend school in the district where his parents resided was the one that caused the most opposition. The provisions in this law in regard to English were unnecessarily and offensively nativistic. They showed a reawakening of the old Know-Nothing spirit, but the part of it relating to the district wherein the child resides was flagrantly vicious and destructive of the rights of parents to educate their children where and in the way they pleased.

Many of the cooler and wiser heads in the republican party saw the storm that was coming and were willing either to repeal the Bennett law or to amend it by striking out the offensive provisions; but Governor Hoard was obstinate. He stood for the Bennett law as it was written and as he had signed it. $\mathrm{He}$ would not yield a hair's breadth. I heard him deliver an address at a state teachers' convention at Waukesha in which he said:

"So long as I am governor not an " $i$ ' is to be dotted and not a ' $t$ ' is to be crossed in the Bennett law." 
I did not hear him say it, but I heard him quoted as proclaiming that on his gravestone he desired no other inscription than this:

"Here lies the hand that signed the Bennett law."

The democrats made the Bennett law their chief issue for the state campaign in 1890 and nominated George W. Peck as their standard bearer. I was a democrat; at least I had served as minister under a democratic administration; but I had been reared as a republican and had many warm friends in the republican party. The fact is, I was not a full-fledged democrat, but belonged to the now extinct genus yclept "mugwump."

Among my best friends in the republican party were John C. Spooner and Jeremiah M. Rusk. I had several conversations with Mr. Spooner and I called his attention to the weak points in the Bennett law and particularly to that fatal requirement in it in regard to "the district in which they reside." Mr. Spooner agreed with me. He found the law too nativistic and that in regard to the district he regarded as utterly unjust. He said the law should at least be amended, if not repealed.

I visited Washington where I was the guest at the home of Mr. Rusk, then member of President Harrison's cabinet. I discussed the matter fully with him and like Mr. Spooner, he agreed with me. I stated that if the republicans would agree in their state platform to remove the objectionable features of this law I would support the ticket and make a few campaign speeches. I regarded this as my duty because I had for years championed the American public school among the Norwegians.

The Norwegian Lutherans had made many severe and unjust attacks on the American common school, denouncing it as godless and hostile to Christianity and for this I had frequently taken them to task. I had said in public print: 
"If the Lutheran church cannot exist alongside of the public school then let the Lutheran church perish, and I will say "peace be with its ashes.'"

On the upper right hand corner of all my letter paper I had printed over my name these words:

"Whosoever directly or indirectly opposes the American common school is an enemy of education, of liberty, of progress. Opposition to the American common school is treason to our country."

Now knowing that all the enemies of the common school would rally to the support of the democratic ticket in November, 1890 , I conceived it to be my duty to give my support to these schools and to the republican party, providing the objectionable features which I have here described could be eliminated from the Bennett law.

Largely in response to these representations of mine, a committee of leading republicans waited on Governor Hoard at his office to induce him to consent to the elmination of the objectionable provisions in the law; but they found the governor unyielding. He would not listen to any amendment. He was defiant; he declared to the committee that if he was not nominated on the Bennett law as it stood he would run for governor as an independent candidate.

The reader knows the result. Hoard was nominated and the party met its Waterloo the following November. I took the platform for Peck. I made speeches in various parts of the state. At a large meeting in Milwaukee I was one of the principal speakers and there I insisted that the English language in this country was no such invalid that it needed the nursing or protection of law. I insisted that the English language was a giant marching through this country in sevenleague boots and that all the foreign languages combined could not impede its progress. My speech was fully reported in the 
Milwaukee dailies and some of its sentences became slogans in the campaign. In the democratic state convention I was tendered the nomination for superintendent of public instruction, but I declined. I was at Omaha, Nebraska, at the time, but I sent a telegram to the chairman of the convention that I would not run if nominated, nor serve if elected.

The slogan of the republicans in that campaign from every stump in the state was: "Stand by the little red school house!" The speakers pleaded fervently for the English language. They claimed that thousands of children of foreigners in this state were unable to speak English although they were born and had reached the age of maturity in this country. I replied that the great problem with which the foreign-born citizens had to wrestle was not how their children were to learn English, but how to get them to learn their mother tongue. I pointed out the advantage of knowing more than one language and showed what a herculean effort was necessary for our foreign-born citizens to get their children to learn the speech of their fathers. I offered to place $\$ 1,000$ in a bank, the money to be given to the campaign fund of the republicans if they could produce one person of sound mind born in Wisconsin and having lived here 21 years who could not speak English as well as he spoke his mother tongue. The republicans claimed there were a large number of such persons in the state, but they did not accept my challenge.

Peck and his associates on the ticket were overwhelmingly elected. A legislature pledged to repeal the Bennett law was also chosen, and the first act of the legislature the following winter was to repeal this obnoxious law. In 1892 Governor Peck was reelected over John C. Spooner, who was forced to be a candidate for governor on the republican ticket. I voted for Spooner. The Bennett law was a dead issue. I may here add that the corresponding law in Illinois was also re- 
pealed; but there it was done by the republicans. Illinois had no Hoard to interfere with the dotting of "i's" or the crossing of " $t$ 's." The republicans saw their mistake in that state and yielded with alacrity. 


\section{CHAPTER CXLIII.}

\section{MORE POLITICS.}

I have been called a "turncoat" in politics. As I have repeatedly stated I was reared an ardent republican. My father was a whig, but he died before the republican party was born. The story of John Brown read from the New York Tribune made every fibre in me republican. The war of the rebellion happened while I was in my most impressionable years. My enthusiasm for Lincoln and the cause of the north knew no bounds; but I grew tired of the constant waving of the bloody garment in every campaign. In the state university I became imbued with free trade vagaries and so while I was a republican in Wisconsin I voted for Tilden in 1876, for Hancock in 1880 , for Cleveland in 1884 and for reasons of personal loyalty for him again in 1892. From that time to this I have been a staunch conservative republican, in state and national politics. I voted for McKinley in 1896 and in 1900; in 1904 for Roosevelt and in 1908 and 1912 for Taft.

During the whole compaign of 1896 I was on the stump for McKinley, speaking for the most part in English, but in several places in Norwegian and in two places in German. The last night before election I spoke in Superior and reached Madison the next day just in time to vote on my way from the railroad station to my home. I was, I think, the last voter before the polls in the first ward closed. 
The democratic administration of Wisconsin under Peck committed a fatal mistake when it undertook the publication of the Wisconsin soldiers' roster. It seemed clear to me that if such a work was to be published at all the printing should be done by the lowest bidder, that is to say, by the state printer; but the administration gave it to friends at an exorbitant price. I considered this deal as corrupt through and through and I did not think its promoters worthy of the confidence of their fellow citizens. The only answer that Governor Peck made was:

"We politicians have to do such things."

I wrote a long letter to W. F. Vilas, who was then our senator at Washington, urging him to repudiate the roster job and its promoters; but all I got was a reply saying he had received my letter and noted its contents.

So far as Wisconsin was concerned, I severed every connection with the party in disgust; but I still had, so to speak, one foot in the national democratic party. I had great love and admiration for Grover Cleveland. But in 1896 the democratic party was captured, bag and baggage, by America's greatest demagogue, William Jennings Bryan, the wide-mouthed orator of the Platte-itude. I may say in parentheses that I know him because I once spent half a day fishing with him, Col. A. R. Bushnell and ex-Mayor W. H. Rogers on Lake Mendota, at Madison. The national convention which he captured declared itself in favor of the abolishment of our courts, of free riots, and the unlimited coinage of silver at the ratio of 16 to 1 , without regard to what other nations might do. Bryan did not seem to comprehend that the ratio depended on the supply, that is to say, on the commercial value of the two metals. I agreed with the Irishman when he said:

"It is 16 to 1 now, but after election it will be nothing to ate." 


\section{More Politics.}

I repudiated Bryan, with his crown of thorns and cross of gold and the democratic party; made speeches for McKinley and have been a republican stand-patter ever since. I see nothing inconsistent in my course and do not feel that I have anything to regret or for which to apologize. I have in these matters followed my convictions without considering any personal advantage. 


\section{CHAPTER CXLIV.}

\section{PROMINENT WISCONSIN PEOPLE.}

I was born not in the state, but in the territory, of Wisconsin, and having lived practically all my life either at or near the capital it goes without saying that I have at least seen, if not actually met personally, nearly all the men who have been prominent in the political life of the state. I became fairly well acquainted with Wisconsin's first governor, Nelson Dewey. I had his son and his daughter in my classes in the university and I always met the ex-governor when he came to Madison to visit his children. He was a man of large intelligence, but very modest and retiring. He was rather small of stature, quite ordinary in appearance and not apt to attract attention in a crowd. How he came to be elected as our first governor I do not know.

I saw Gov. Alexander Randall deliver a farewell address to the first Wisconsin regiment when it left Milwaukee under Colonel Starkweather. I never met Governor Randall to speak to him, nor did I ever meet Colonel Starkweather to speak to him though I saw him on a number of occasions in command of his regiment.

Governors Farwell, Barstow, McArthur and Bashford I never saw. All the governors from Harvey down to McGovern I have had a speaking acquaintance with and several of them I have known intimately. Those with whom I have been on the most familiar terms were Governors Lewis, Fairchild, 
Washburn, Smith, Rusk, Hoard, Upham, Scofield, La Follette and Davidson.

Of the United States senators I have known Timothy O. Howe, James R. Doolittle, Matt Carpenter, Angus Cameron, Philetus Sawyer, John C. Spooner, William F. Vilas, Isaac Stephenson and R. M. La Follette. If you want my opinion I may say I regard C. C. Washburn as the ablest of our governors and among our senators I should divide the honors evenly between Carpenter and Spooner. It is difficult to determine which one of the two was the more profound jurist and statesman, but I should judge that Spooner was the readier debater, while Carpenter was the more eloquent of the two. If I were to compare the two with their predecessors in the United States senate I would class Carpenter with Daniel Webster and Spooner with Henry Clay. Of course I have known the most of the other state officers that have served since I became a resident of Madison, and the judges of the supreme court.

A very commanding figure in politics in Wisconsin was E. W. Keyes, known also as Postmaster Keyes and as "Boss" Keyes. I made his acquaintance in the ' 60 s, while I was teaching at Albion, and enjoyed his personal friendship the rest of his life. I was for years one of his regular Sunday morning visitors at his private office in the rear end of the postoffice. Among the regular visitors there who came to canvass the political events of the week I may mention Maj. F. W. Oakley, Phil Spooner, Col. Hugh Lewis, Col. Henry Casson, and Col. A. H. Hollister. When Senator John C. Spooner was in town he usually was found in this Sunday morning conclave, other. wise known as "the Senate." If prominent stalwart republicans from other parts of the state spent Sunday in Madison they, too, would come and take in our deliberations. We were all patriots and discussed questions singly with an eye to the welfare of our common country. 


\section{CHAPTER CXLV.}

\section{BECOME POSTMASTER.}

To this I want to add this little sequel. E. W. Keyes died at the venerable old age of 84 . Of course I attended his funeral. The day after his death I received a telephone message asking me to come quickly to Phil Spooner's office on Carroll street. What was wanted of me was not stated, but the order was peremptory. I hastened to Mr. Spooner's office. As soon as I came in he laid before me a paper to sign. On reading it I found it was an application for the office of postmaster in Madison to succeed Keyes. I said:

"I am not a candidate."

Mr. Spooner answered: You have already been appointed; all you need to do is to affix your name to this paper and then go and take the oath of office and enter upon your duties."

Mr. Keyes' bondsmen had the appointment of his successor pending the selection of a new postmaster by the president in Washington and these bondsmen had chosen me without even consulting my wishes. This was so sudden that it took my breath and I signed my name in the wrong way, but this error was easily mended.

I entered the postoffice at once and served for exactly forty days. During these forty days in the wilderness I had nothing to do, but to draw my breath and my salary. The assistant postmaster W. A. Devine did the work, while I looked on and got the pay. I must add, however, that I was a very faithful 
looker-on. Both Mr. Devine and I became candidates for the position at Washington, but this caused no feeling of ill-will between us. I felt that he was more entitled to the position than I was and I may add here that the city of Madison has in Mr. Devine an ideal postmaster. He began at the bottom in the service and had worked his way up gradually to the important position of assistant postmaster. There is no part of the work with which he is not thoroughly familiar. It would have taken me years to acquire this knowledge, nor do I think that I ever would have been able to reach Mr. Devine's efficiency. I now have the honor of being Madison's only living ex-postmaster, a position which I hope to occupy the balance of my days. 


\section{CHAPTER CXLVI.}

\section{R. M. LA FOLLETTE.}

One of the most distinguished sons of Wisconsin is R. M. La Follette. I am not going to make his biography the most conspicuous part of my own autobiography, but he, too, is a native of Dane county. He was a pupil of mine in the state university and like myself he has for fully forty years been a citizen of Madison. I was born in the southeastern part of Dane county ten years before he opened his eyes in Primrose in the southwestern part of the county. He is a striking example of what indefatigable industry, inexhaustible energy and boundless ambition can accomplish. While I have always admired these qualities in him, I have found from my first acquaintance with him certain traits of character that are repulsive to me and as a former mugwump and later a stalwart republican, I have not been at all in sympathy with the political principles and measures that he has advocated.

On account of the great eminence he has attained, not only in Wisconsin, but also as a national figure, I take it for granted that my readers will not object to taking a look at La Follette through my spectacles. The most painful part in doing this is that it has to be written down by my dear friend, Albert $O$. Barton, himself a Primrose boy, who has not only served as one of his private secretaries, but also assisted Senator La Follette in the preparation of his autobiography. Naturally Barton and I see this public character from different angles or view- 
points. I may further add with emphasis that not a word of what I shall have to say is put down in malice. It is my purpose to reveal La Follette and with it La Folletteism as I see it. I mean to hew close to the line, letting the chips fall where they may, my only concern being to tell the truth in regard to this remarkable phenomenon in our political life.

As a student La Follette was industrious, but he became so much interested in one part of his work that he utterly neglected several of his studies. In the latter part of his course he became the editor of the University Press, a college paper founded, as I now remember, by George Raymer, afterwards one of the publishers of the "Madison Democrat." La Follette gave so much time to this paper that his university studies suffered. Then he was exceedingly ambitious to distinguish himself as a public speaker. He took a leading part in the oratorical exercises in the university and during the last part of his university course the first intercollegiate oratorical contests took place. La Follette was chosen to represent the University of Wisconsin at such a contest and returned the winner of the first prize. On his return he was met at the railroad station by the university students and many of its professors, together with several of Madison's prominent citizens, including President Bascom and Postmaster E. W. Keyes, all headed by a band of music. Such honors might easily turn the head of any young man.

The day for graduating came. In those days the faculty met and acted on members of the senior class one at a time. The secretary of the faculty would read a name from his list, beginning at the top of the alphabet. Some professor would make a motion that the person whose name had just been read be given the degree for which he was a candidate. This motion would then be seconded by one or more other professors. The president would then put the motion to a vote and as a rule it was carried without any remarks pro or contra. 
On the occasion to which I here refer we had gotten down to the letter "L" and R. M. La Follette's name was read by the secretary. It was moved and seconded that the candidate be given his degree. But before President Bascom put the motion several professors objected. A professor would state:

"La Follette has not passed in my studies."

Another professor said:

"He is conditioned in my studies."

For this kind of reasons several professors objected to graduate La Follette that year and urged that he ought to attend the university another year and make up the studies in which he had failed. On the other hand it was urged that La Follette was a poor boy; that his mother was a widow and was making great sacrifices for the education of her children; that if $\mathrm{La}$ Follette failed to graduate it would be a most bitter disappointment to her. Then special attention was called to all the outside work that La Follette had done as editor of the University Press and particularly to the great honor that the young man had conferred on his alma mater by winning the first prize at an intercollegiate oratorical contest. Both sides argued the case from the standpoint of what would be best for La Follette. It finally came to a vote. The vote was a tie. President Bascom gave his vote as president in favor of La Follette and in this way he was graduated and got his degree. I have always felt that La Follette was under some obligation to me, because I was one of those who voted for him.

La Follette had great ambition to become an actor. He fancied that he could make his mark in Shakespearian tragedy. His oration, by which he won the first prize, was on "Iago." Iago in Shakespeare's "Othello," is justly regarded as one of the most heartless, hateful and despicable characters ever depicted in literature. To present him properly on the stage requires an artist of great talent and much practice. La Follette seems to have set his heart on playing the part of "Iago." His 
interesting oration on "Iago" would indicate that he had made a profound study of this interesting Shakespearean character. But this matter is wrapped in some mystery and doubt. I have heard it claimed by several that La Follette was assisted in the preparation of this oration by one of Madison's most learned Shakespearean students, Dr. James D. Butler. How much assistance La Follette received from Dr. Butler or from Shakespearean students living in Madison at the time nobody but himself knows; but it is fair to him to assume that he could not, at that time of his life, have made any extensive explorations of Shakespearean lore. For my part I do not believe he had gotten far enough at that time in his literary pursuits to have mastered such Shakespearean critics as S. T. Coleridge, Mrs. Jameson, A. W. Schlegel or W. Hazlitt. If the oration on Iago was wholly his own he might easily have made a career as one of our greatest literary critics and writers.

I said his ambition was to become an actor. With this in view he sought an interview with McCullough and Lawrence Barrett, two distinguished Shakespearean actors of that day. I knew Barrett a little. I had met him on at least two occasions and had had some correspondence with him concerning the question of presenting Henrik Ibsen's "The Pillars of Society" on the American stage. La Follette knowing this came to me for a letter to Barrett and this I gave to him. I was told that both $\mathrm{McC}$ ullough and Barrett advised La Follette not to choose the acting of tragedy as his profession. They told him that his small stature was an insurmountable obstacle. It seems that he had the good sense to accept their advice and so abandoned the idea of playing "Iago" on the stage of a theater. He then decided to make politics his profession and there, as I see him, he has faithfully acted the part of "Iago." What I mean when I apply this severe epithet is that it describes the cruel, heartless manner in which he has treated many of those 
who seemed to him to stand in the way of his own political advancement. He seems to have been willing to use even his own benefactor as a step in the ladder leading to fame and glory. I do not intend to enter upon an extended discussion of the many political vagaries advocated by La Follette, such as primary elections, the formation of all sorts of costly commissions, the physical valuation of railroads, etc. The discussion of these things would make too long a digression in an autobiography. I shall confine myself to pointing out how he has acted in his personal dealings with men during his brilliant political career.

What I call the Iago spirit he began to exhibit when he served as member of congress and of this spirit I now propose to give proof in a few episodes selected helter skelter from La Follette's interesting and strenuous political career.

Although Postmaster E. W. Keyes had been one of the foremost in honoring the student La Follette when he returned to Madison as the prize winner from the intercollegiate oratorical contest and although Mr. Keyes had been one of his principal backers in getting him elected district attorney for Dane county, La Follette as member of congress selected him as one of the men to be removed from leadership in Wisconsin politics.

La Follette looked upon John C. Spooner as a chief obstacle in the way of his own ambition and took every opportunity of showing him disrespect. Mr. Spooner after serving one term in the United States senate moved from Hudson, Wisconsin, back to his former home, Madison, where he opened a law office on South Carroll street. La Follette had had his trouble with Spooner in Washington. They had not always agreed in their recommendations of Wisconsin men for federal offices. La Follette too was out of office, having been defeated the last time he ran for congress and had opened a law office on Main street. One day Mr. Spooner put on his hat and went out to make calls on his colleagues in his profession. He had for- 
gotten the petty conflicts between himself and La Follette in Washington and on his round to the different law offices he also called on La Follette. When La Follette saw Spooner enter his door he immediately addressed him: "I have no time to talk with you, Mr. Spooner," and nothing remained for Spooner to do than to walk out again.

General Fairchild, who had lost an arm on the battlefield of Gettysburg, who had served a term as secretary of state, who had three times been elected governor of Wisconsin, who had served as consul to Liverpool, as consul-general to Paris and as minister to Spain, who had been commander-in-chief of the Grand Army and had been the chief officer of the Loyal Legion and who had been a prominent candidate for the presidency, went to Washington in 1889 to attend the inauguration of President Harrison. While in Washington he called on Corporal Tanner, who had been appointed commissioner of pensions. Not intending to ask any favors of the new commissioner, he went merely to pay his respects. In the course of the conversation Commissioner Tanner asked General Fairchild if there was anything he could do for him. General Fairchild said no, but on reflection he remembered that his old comrade Dr. Ward in Madison, had lost his position as pension examiner during the Cleveland administration. General Fairchild was especially distinguished for his loyalty to his comrades in the civil war. He told Tanner that he would be pleased to see his old friend, Dr. Ward, put back in his old position.

Corporal Tanner had lost both feet in the war and stood on two wooden legs. He used to say that he was a republican as far down as his legs went. Let me add that it was a proud day in my life when I had the opportunity in Madison to shake the hand of this hero of our civil war. Mr. Tanner promised at once to appoint Dr. Ward and entered his name for pension examiner in Madison, Wisconsin. 
It appears that La Follette, who was a member of congress, regarded this appointment as one of his political plums and that he had promised it to another physician in Madison. The next day La Follette called at the pension office to have his candidate appointed and there he learned from Mr. Tanner that the latter on the recommendation of General Fairchild had promised the place to Dr. Ward.

La Follette then immediately wrote this letter to General Fairchild:

"Lucius Fairchild, Madison, Wis. Sir: What right have you, sir, to interfere with my appointments? R. M. La Follette."

This gruff letter gave great pain to General Fairchild. He had intended no harm and had never borne any ill will to La Follette. He carried this letter in his pocket and when he met his friends in the streets of Madison or elsewhere he would take it out of his pocket and show it to them. He showed it to me and that is how I am able to quote it. Had the writer not been filled with the Iago spirit, he would have written a polite letter and explained why it was impossible for him to approve of Dr. Ward's appointment.

La Follette, while in Washington, also had his little differences with Senator Philetus Sawyer and when La Follette later was busy constructing his own political machine in Wisconsin he made Sawyer one of the chief objects of his attacks. He found the senator to be one of the obstacles in the way of his ambition and one that had to be removed, cost what it might.

Philetus Sawyer was wealthy and one of La Follette's chief means of advancing his own interests was to create prejudices against the rich. In fact this is the shortest road to success for any ambitious politician who is himself impecunious.

Now the facts are that the Peck administration brought suit against the republican ex-state treasurers for interest that they 
had gotten on state funds and converted to their own use. This was a matter of long practice. Not a penny of the principal had been lost to the state, but suit was brought against the extreasurers to recover the interest they had received. This interest had been to a very great extent spent to pay the republican campaign expenses, and hence the ex-treasurers did not have the money with which to reimburse the state treasury. The state therefore had to fall back on the bondsmen. The chief bondsman and a man who was abundantly able to pay was Senator Philetus Sawyer.

The suit was pending in the circuit court in Madison. Naturally Sawyer wanted his side well represented in court. $\mathrm{He}$ retained the best legal talent he could get. He offered a retainer to La Folletie. He had two objects in view. One was to get La Follette who lived in Madison to help look up the law bearing on the case and the other to show La Follette that he did not bear him any grudge. Sawyer was anxious to bring the republican party back into power in the state and to this end he wanted to secure perfect reconciliation and harmony between the warring factions and end a dissention which had in his judgment caused the party's defeat. He sent for La Follette to meet him at the Plankinton House in Milwaukee. La Follette went there. In the course of their interview Sawyer explained why he had sent for him and offered him what he thought might be a fair retainer for his services in looking up legal points bearing on the case in court against the ex-treasurers and their bondsmen. I have this story from Mr. Sawyer's own lips. Mr. Sawyer said that La Follette at once began dancing around in the room and shouting: "You can't bribe me, Mr. Sawyer. You can't bribe me." Then he went out in the street and proclaimed that Senator Sawyer had tried to bribe him.

It so happened that R. G. Siebecker was the judge sitting in the circuit court at Madison and Siebecker's wife is a sister 
of La Follette. Mr. Sawyer told me that he was not aware of that fact, but this circumstance gave La Follette's version of the story the appearance of plausibility and the rank and file were ready to believe that Sawyer had tried to buy the influence of the judge's brother-in-law. If the rank and file had been able to look deeper into this matter they would have realized that a case of this magnitude would necessarily go for its ultimate decision to the supreme court of Wisconsin, where La Follette would not have any brother-in-law to influence. In the supreme court the case would be decided entirely on its merits. I leave it to my readers to judge whether this was not an exhibition of the Iago spirit.

La Follette succeeded in getting a strong hold on the Norwegian group of citizens in Wisconsin. In every Norwegian community in the state there was the greatest enthusiasm for "Bob" La Follette. How this happened has been to many a great puzzle, but to me it is no mystery and I think I am able to offer a satisfactory explanation. To say that La Follette courted the favor of the nationality and offered its representatives all sorts of positions is not a sufficient solution of the problem. The offering of political positions is a string that anybody can play upon. La Follette had no monopoly or prerogative in this method of getting popular support.

Making due allowance for La Follette's personal magnetism, the chief source of his popularity and strength among the Norwegians must be looked for elsewhere. To some of my readers it may seem like an egotism verging on megalomania when I here distinctly assert that La Follette was chiefly indebted to me for securing his large following among the Norwegians in Wisconsin. I do not care to go into the details here; but I will state in a general way and leave my readers to search the records for themselves, that way back in the ' 80 s there had arisen a misunderstanding between John Anderson, the publisher of "Skandinaven," and myself. This trouble grew from bad to 
worse until my appointment as minister to Denmark when in connection with the banquet given me at the Palmer House in Chicago we became entirely reconciled. But on my return from Denmark in 1889 the old sores were opened again and our relations became far more strained than they had been before. My side of the matter was fully presented in a pamphlet published in the first part of the '90s; the "Skandinaven's" side was put before its readers in more than a hundred columns of that paper and there never was a second reconciliation between the two Andersons.

As I stated I leave it to the readers to look up the details of this bitter controversy if they are interested, but what I wish to make clear here is that "Skandinaven" would not have espoused the cause of La Follette had it not been for its unfriendly relations to me.

The publisher of "Skandinaven" knew well that John C. Spooner and I were personal friends. Mr. Spooner was an almost daily visitor on my porch, and the friendship existing between us was too deep and genuine to be disturbed by any political considerations.

"Skandinaven" was found in well nigh every Norwegian home in Wisconsin. Its influence in moulding public sentiment among its thousands of readers was simply tremendous and John Anderson would not support any candidate for office who recognized me as his friend. And so it happened that this paper gave all its influence and support to Mr. La Follette. All Norwegians in Wisconsin who had any political ambition realized that their only hope of success lay in giving their allegiance to "Skandinaven" and to La Follette. This explains how it became easy for La Follette to attach to himself all Norwegians in Wisconsin who had any political ambition and their friends.

One of the first men that La Follette selected and recommended for promotion was Mr. N. P. Haugen. In 1894 he brought out Haugen as candidate for the nomination for gover- 
nor. Haugen severed his connection with his old friend Spooner and allied himself with La Follette and "Skandinaven."

The leading Norwegians and the rank and file in the different so-called Norwegian counties filled the caucuses and elected Haugen delegates to the state convention. I may here add that pending the caucuses and assembly and senatorial conventions, I wrote a series of burlesque articles over the signature "Ole Olson." These "Ole Olson" articles were extensively copied not only in Wisconsin, but in the states west of the Mississippi.

"Ole Olson" was an enthusiastic Norwegian writing from Pleasan Spring, Dan Kounti, Viskonsin, who had gone daft on "Hogen" and "Bob Falleson" and wanted Wisconsin and other states administered by his nationality. In his letters to the "Madison Democrat" he wrote:

"Me and Hogen run for guvner. Visconsin vant Norvegen for guvner. Minsota got Norvegen for guvner. Knut Nilson be best guvner dis kuntri ever hav and Knut Nilsen sit in parler vit Yim Hill and drink fine shampan and smok fin cigar vit Yim Hill. An Yim Hill he run big ralerod Sante Pol, Krukston an Davel's Lak. An evry Norvegen in stat Minsota get gud yob on kapitol an fine yerse bull to begin kep hous vit. Visconsin for the Norvegan, dat's my prinsip; dat's vat Ole Olson work for nite an day."

"Skandinaven" sent a special reporter to Madison to find out who "Ole Olson" was. Through a printer in the "Madison Democrat" office my identity was revealed and "Skandinaven" devoted exactly 52 columns of its pages to attacks on the author of the "Ole Olson" burlesque. It succeeded in making me very unpopular and aided in great measure the cause of La Follette. While I was painted as an enemy of my fellow Norwegians, La Follette was lauded as their friend. 
This I consider as a true explanation of how La Follette acquired his great influence and popularity with the Norwegians in Wisconsin.

N. P. Haugen was defeated at the state convention. Maj. W. H. Upham was nominated and elected. In $1896 \mathrm{Mr}$. La Follette himself was a candidate before the state convention, but was defeated by Maj. Edward Scofield, who was nominated and elected. John C. Spooner was elected United States senator. In 1898 La Follette was again a candidate for governor, but was again defeated and Major Scofield was renominated and reelected. It was in this campaign that I became the owner and editor of "Amerika" and I devoted all my energy to promoting the success of the Scofield ticket. La Follette sulked in his tent; in fact La Follette has rarely been known to support anybody but himself in a political campaign.

La Follette had now been defeated in three successive campaigns and it was generally supposed that he had seen his Waterloo. His financial resources had been exhausted; political candidates did not care to cast their lot with a thrice-defeated candidate and he was in fact looked upon as a dead cock in the pit.

How did he rise again and become the chief leader in the politics of Wisconsin? This question is interesting, but I think I am able to answer it.

Senator Sawyer's term was about to expire and he was not a candidate for re-election. The legislature of 1899 was to elect his successor. The candidates before the legislature were J. W. Babcock of Necedah, S. A. Cook of Neenah, Isaac Stephenson of Marinette, all three very wealthy, Stephenson a multi-millionaire, and Joseph V. Quarles of Milwaukee. Quarles had an abundance of brains, but little money. After a prolonged, exciting campaign Quarles was elected. Babcock and Cook took their defeat gracefully, but Stephenson was terribly disappointed and indignant. $\mathrm{He}$ was old. $\mathrm{He}$ 
had served several years as a member of the house of representatives. He had contributed most liberally to the campaign funds of the republican party; he had always been a loyal republican and he desired to round out his career with a term in the United States senate. On account of his services to the party he considered himself entitled to this recognition. He had favored Spooner and he now thought it was Spooner's term to favor him. Spooner, on the other hand, refused to take any part in the election of Sawyer's successor. He did not leave Washington and remained absolutely neutral. This irritated Isaac Stephenson and he swore by all the eternals that he would revenge himself on Spooner. How could this be accomplished? He had millions of money and he knew that La Follette was a brilliant campaigner. Hence he decided to combine his own money with La Follette's brains. He called on La Follette; he put him on his lap, so to speak, and said to him:

"You have had a hard time of it, La Follette. You have been defeated three times in succession and you have gotten to the end of your rope. Hitherto I have opposed you, but I am now going to help you. In Spooner we have a common enemy and by working together we will both get even with him. You are a splendid campaigner and organizer, and I am willing to spend my money - a million dollars if necessary. I want you, La Follette, to begin at once to organize the state, not only by counties and legislative districts; but I want you to create an organization to promote our interest in every school district and I will foot the bills. In this way I will make you governor of Wisconsin and I want Spooner's seat in the United States senate and you shall succeed Quarles when his term expires."

I was not present at this interview. It was, of course, a twahanded chat, but I have no doubt that I have given the gist of it. Soon after this meeting Mr. La Follette accepted an invitation from $\mathrm{Mr}$. Stephenson to take a trip with him in the latter's yacht 
and on this yacht voyage the next state campaign was no doubt carefully mapped out.

La Follette started the campaign of 1900 early. He had a large army of workers in the field visiting and organizing every community in the state. Stephenson footed the bill. Such a campaign was irresistible. La Follette easily controlled the convention and was nominated. The following November he was elected. I cannot help injecting here that one of the issues on which he carried on his campaign was the extravagance of the Scofield administration. He also called attention to this in his first message to the legislature and called for more economy in the state budget. As a state we were then spending less than four million dollars a year, while under La Follette and his successors the budget has increased to eighteen and a half million annually!

La Follette was elected three times, but in his third term he was chosen United States senator to succeed J. V. Quarles.

During La Follette's first term in preparation for the campaign of 1902, Isaac Stephenson founded at great expense the Milwaukee "Free Press." This was made the StephensonLa Follette organ and it was scattered broadcast over the state. In the mean time La Follette had an army of game wardens and oil inspectors in the field and with the "Free Press," the game wardens and oil inspectors and Isaac Stephenson's barrel for incidentals the campaign put up in 1902 was as irresistible as the one in 1900. The irony of it all, an irony which it seems to me should appeal to every thinking man, is that La Follette, who had been going up and down the country like his friend, W. J. Bryan of Nebraska, appealing to the masses, the laboring men, to small farmers and small business men against the great corporations and capitalists, should identify himself with and be helped into office by the wealthiest man in the whole state of Wisconsin. Nay, such is the irony of fate. It is well known that La Follette and Stephenson later on parted com- 
pany and became mortal enemies, and it was after they had become foes that Stephenson is reported to have remarked to his colleague, Chauncey Depew, sitting near him on the senate floor: "In the last campaigns in Wisconsin I have spent $\$ 650,000$ and that thing there is what I got for it," pointing to La Follette who was making one of his record-breaking speeches.

When Scofield in 1898 was renominated for governor J. O. Davidson, a Norwegian-American, was nominated for state treasurer. This was a distinct concession at the time to $\mathrm{La}$ Follette. Davidson was known to be one of his supporters. When La Follette in 1900 received the nomination for governor Davidson was renominated for state treasurer. Davidson served four years as state treasurer and was then in 1902 elected lieutenant governor. After La Follette had been nominated for governor the first time his friends gathered around his Madison home to congratulate him. La Follette made a speech from his porch and seeing Davidson in the crowd he called him up on the porch and presented him as one of those to whom he was chiefly indebted for his success at the state convention. I mention this to add emphasis to the cruel treatment of Davidson by La Follette in the campaign of 1906.

La Follette was chosen senator by the legislature in January, 1905, but he waited until the following January before he turned the governor's office over to his bosom friend J. O. Davidson. In 1906 Davidson announced himself as candidate for governor before the primaries, but La Follette thought he had then squeezed all the juice out of that lemon and proposed to support Mr. Lenroot of Superior for that office. In defense of this treatment of Davidson he uttered these stinging words worthy of Iago: "All men are not equally endowed," meaning that Davidson was not so well qualified for the position as Lenroot. 
A meeting was held in Chicago and it was agreed that "Skandinaven" should support Lenroot and the latter came out as an active candidate; a great blunder was however committed for which La Follette might be to a considerable extent excusable. But it is strange that "Skandinaven" should be so short-sighted.

J. O. Davidson was a Norwegian, while Irvine L. Lenroot was of Swedish extraction. There has always been more or less jealousy and friction between Norway and Sweden and between Norwegians and Swedes, a jealousy which has now and then cropped out also among Swedes and Norwegians in America. But at this particular time the relations between Swedes and Norwegians were particularly strained. The union between Sweden and Norway which had existed since 1814 had just been dissolved. There had been no bloodshed, but Sweden and Norway had been at the point of war. There could be no more unfavorable time to ask Norwegians in Wisconsin to support a Swede for governor and thereby hangs a little tale which I cannot help telling in this connection.

"Skandinaven" had an agent in Wisconsin, yclept Gryttenholm. Gryttenholm was a "Swede-eater." His contempt for everything Swedish bordered on fanaticism. He had made up his mind to prevent the nomination of Lenroot at the primaries and this is the way he set to work to accomplish his object. He visited the various Norwegian settlements in Wisconsin to collect subscriptions due and get new subscribers and at every home that he visited he discussed the gubernatorial campaign. "You cannot support the Swede Lenroot against the splendid Norwegian Davidson."

And the Norwegian agreed with Gryttenholm.

"To make your wishes respected," he said, "you must write a letter to 'Skandinaven' and make it known that you will not support Lenroot, but that you want Davidson for governor. You must write today." 
This message was brought by Gryttenholm to every Norwegian he met and the result was that every mail brought scores if not hundreds of letters from the various Norwegian settlements in Wisconsin visited by Gryttenholm and the burden these letters all bore was "we do not want the Swede Lenroot for governor; but we want the Norwegian Davidson." "Skandinaven" got frightened; it was compelled to abandon Lenroot and give its cordial support to Davidson. In my paper, "Amerika," I had a splendid cartoon showing the publisher of "Skandinaven" seated at a table eating "crow soup" with a wry face out of a big bowl.

Davidson was nominated and elected and La Follette suffered his first defeat since his accession to power. He supported Davidson for election, but the breach between them has never been healed.

The stalwarts having been completely routed in Wisconsin, and the primaries having been adopted, there was little chance for Spooner's success in the primaries to be held in 1908 . His defeat, at least in my judgment, was a foregone conclusion. He therefore decided not to be a candidate for re-election; more than that he decided to resign. He sent his resignation to Governor Davidson in March, 1907, and La Follette, loyal to his benefactor, requested the state legislature to give Spooner's unexpired term to Isaac Stephenson. He had doubtless been hoping that Stephenson would be too old and feeble to succeed Spooner for a six year term and this opportunity to liquidate a debt no doubt was a great satisfaction to him.

But Stephenson was in spite of his nigh eighty years still hale and hearty and as full of political ambition as ever. La Follette had given him a small cut of the senatorial pie. It tasted good and gave him an appetite for more. In addition to this small cut he now wanted a whole pie. Creatly to the annoyance 
of La Follette Stephenson announced himself as a candidate to succeed himself before the primaries in 1908. There were three other candidates, S. A. Cook of Neenah, W. H. Hatton of New London and Francis E. McGovern of Milwaukee. La Follette's choice was Mr. Hatton.

Stephenson opened his big barrel, employed agents in all parts of the state and was nominated. On his own sworn statement he spent $\$ 107,000$ in this campaign, a sad commentary on the influence of money in American politics.

When Stephenson poured out his cash like water to promote the interests of La Follette and "reform," La Follette considered it all right, but when he spent his money in his own behalf and against La Follette it was, of course, all wrong. Stephenson was nominated and elected, but La Follette attempted to have him unseated by a sensational senatorial investigation. This investigation was asked for by the "Milwaukee Journal" and endorsed by the Wisconsin legislature, but everybody knows that La Follette was at the bottom of it. He met a complete Waterloo. This was La Follette's second defeat.

He met with a third defeat the same year as Stephenson was nominated for senator at the primaries. A young man by the name of A. T. Twesme had the audacity to be a candidate for assemblyman against Herman L. Ekern in Trempealeau county. Herman Ekern was an avowed supporter of La Follette and had served as speaker of the assembly. He naturally expected to be nominated, but to the great surprise of everybody he was defeated by the stalwart Twesme. In spite of the primary election law advocated by La Follette and his friends and which was to serve as a panacea to cure all political ills, Ekern disregarded the verdict of the primaries and decided to run as an independent candidate against $T$ wesme.

The district was thoroughly canvassed by La Follette for Ekern and by Governor Davidson in behalf of Twesme. 
Twesme was elected as already stated, La Follette suffering a third humiliating defeat. He was whipped by a man whom he had publicly declared as not sufficiently intellectually equipped to be governor of Wisconsin.

What I admire in La Follette is his pluck, his ambition and his great ability as an organizer. I have no faith in his so-called "reforms," and I deprecate his lack of loyalty to those who have given him their aid and support. Loyalty is to my mind a cardinal virtue and this virtue is sadly lacking in the makeup of Robert (Iago) La Follette. In this respect he is not unlike his more distinguished competitor for the presidential nomination in 1912, Theodore Roosevelt. I regard these two men as chiefly responsible for the election of a democratic president at the polls that year. Had it not been for their insurgency Taft would doubtless have been reelected; times would have been better and better counsels would have prevailed at Washington. Roosevelt and La Follette, though personal enemies, together wrecked the national republican party and La Follette is responsible for the chaotic condition of governmental affairs now existing in the state of Wisconsin. La Follette's lago character has been found out and his quack "reform" remedies have been tried and found wanting. He has seen his best days, both in state and national politics. 


\section{CHAPTER CXLVII.}

\section{DET NORSKE SELSKAB.}

\section{(The Norwegian Society)}

If we look at the Norwegian newspapers in the ' 80 s and '90s we will find them filled with a large number of the most unclean and vicious advertisements conceivable. A large part of the American press was guilty of carrying indecent and fraudulent quack advertising. But these quacks and exploiters of humbug chose the press published in foreign languages as their chief dumping ground. Among its readers they found their largest number of victims. The publishers were willing to sell them space and even to recommend them in editorial "readers," and their subscribers naturally had faith in newspapers published in their own language.

In this matter of advertising the Norwegian press was a disgrace to journalism. Before I became a publisher and editor myself I had publicly warned against this kind of fraud; but my warning had not been heeded. When I got a paper of my own I first decided that its advertising columns were to be clean and then I soon declared war on all the papers that carried this vicious advertising and demanded that they purge their columns of all this fraud and indecency.

My paper, "Amerika," was nothing but a financial wreck, while the papers that I antagonized were rich and powerful. "Amerika" would not be a breakfast for one of them. It was, 
to use a comparison, as if Denmark should declare war against all Europe. Of course I received the cordial and united enmity of them all.

In my calculations I committed a serious blunder. I fully expected that the more than 1,000 Norwegian Lutheran ministers and the Norwegian Lutheran church organs in this country would heartily endorse my program and give me their support. But I had made my reckoning without a host. The Norwegian clergy were sorely lacking in backbone. They did not have the courage to antagonize the widely-read, well-financed and influential Norwegian press. Here and there one would give me some encouragement, but the great majority thought it more prudent to keep strictly neutral and some even had the audacity to give their open support to the enemy of decency.

Among the few ministers who gave me encouragement and assistance I want to mention Rev. Jacob G. Rugland, now of Carpio, N. D., but at the time under discussion serving some congregations around Saude, Iowa.

Inasmuch as Mr. Rugland had the courage of his convictions and was loyal to the cause during these years of storm and stress, I take the liberty of giving a brief sketch of his life. It may at the same time serve as a typical sketch of thousands of members of the Norwegian group of American citizens.

Rev. Jacob G. Rugland was born in Worth county, Iowa, October 16, 1867. His father Gulbrand and mother Sigrid, who were married in Eggedal in Norway in 1850 by the distinguished Jörgen Moe, came to America in 1853. "Rug" is the Norwegian word for "rye" and land in this connection means field. This serves to explain one of the numerous Norwegian farm-names.

The farm Rugland is situated in the upper part of Eggedal. It is well suited for the cultivation of rye, hence its name. Sig- 
rid's father, a Norwegian school teacher, came to America with his daughter and son-in-law and a son, Halvor.

During the civil war Gulbrand was drafted, but Sigrid's brother, Halvor, volunteered to go in his stead as Gulbrand had his family to provide for. Halvor lost his life as a defender of the Union.

The first two years Gulbrand and Sigrid spent in Rock county, Wis., in the service of Rev. Dietrichson. In 1855 they moved to Silver Lake, Worth county, Iowa. Their nearest market was McGregor, 120 miles away. Their farm products were taken to market by Buck and Bright. Gulbrand and Sigrid remained faithful members of Rev. T. A. Torgerson's church. Gulbrand died in 1894 and Sigrid in 1911. Their oldest daughter, Helga, was the first teacher of English and Norwegian schools in Worth county, Iowa. The son, Jacob, graduated at Luther college and then studied for the ministry at the Norwegian Synod's theological seminary.

Rev. Rugland's wife Johanna, is the only daughter of the pioneer pastor, Tollef Rosholdt, in Ottertail county, Minn., and she is the granddaughter of one of the early settlers of Winneshiek county, Iowa, original incorporator and member of the first board of trustees of Luther college, Tore Pederson Skotland. Johanna has six brothers, all graduates of Luther college.

I have given this brief sketch of Mr. Rugland partly as a recognition of his loyalty and of his courage to stand up for the right amid trying circumstances, and partly to give a typical glimpse of the character of the Norwegian-American popula. tion.

I then made the proclamation that I did not demand of every teacher of Christianity and morality that he should buy a gun and a uniform and enlist in my little army; I admitted that all are not born soldiers and fighters; but if I found any of them 
fighting in the ranks of the enemy I would surely use my guns against them. I did aim my guns at some of these and wounded them. They may still be found either as one-armed or onelegged invalids.

In my paper I also protested as vigorously as I was able against the partly sceptical and infidel and partly indecent literature emanating from the most prominent Scandinavian writers, including such authors as Ibsen, Björnson, Brandes, Garborg and others. I made no personal attacks on these writers; but published solemn warnings against the kind of literature that they were producing. The other Norwegian papers in this country looked upon it as a patriotic duty to laud this literature because of the eminence of its authors and the Norwegian ministers, professors and church organs did not have sand and grit enough to join me in this crusade and I was left to carry on this war like that against the indecent and fraudulent advertisements, well nigh single-handed.

While I was defending decency, morality, and Christianity my enemies made me the object of persecution, and the most of those who ought to be my friends left me in the lurch. I have made this statement here in order that my readers may better understand what I am now going to tell about "Det Norske Selskab," which better than anything else illustrates the peculiar position in which I have been placed during the last decade and a half.

Before I got into this conflict concerning the vicious advertising, the sceptic and impure literature, I was regularly invited to visit the various Norwegian communities to give public addresses, and all the churches, academies, colleges and seminaries were open to me. Since this war began the doors of practically every church and school have been closed against me, and I have been called by all sorts of bad names. A prominent teacher in one of the leading colleges has declared me to be the 
clown of the Norwegian-Americans and an insidious foe of all church and educational work among them. He has been able to do this with impunity. It is a long lane that has no turn, and in this connection it is my duty to add that during the most recent years there has been a letting up of hostilities and a disposition to recognize my services to my countrymen at their value. I have received many evidences of a kindlier spirit toward myself.

But now "Det Norske Selskab" and its incipiency.

There lived in Perry, Dane county, Wis., a very talented and ambitious Norwegian Lutheran minister by name Henrik Voldal. In 1900, if my memory serves me, the Norwegian Lutheran churches in the western half of Dane county celebrated their semi-centennial at Mt. Horeb. At the festival leading men in the United church were present as speakers. Prof. F. A. Schmidt, Prof. M. Böckman, Pres. T. H. Dahl, and others. Rev. Henrik Voldal was also one of the speakers and in his address he made a rather violent attack on everything American. Things Norwegian were all right but American ideas and customs were all wrong. The drift of his address was a recommendation to segregate the Norwegians into a group by themselves. The address caused much dissatisfaction. He was severely censured by the Mt. Horeb press and the criticisms in the Mt. Horeb papers found their way into other newspapers. Voldal was advised to pack up and go back to Norway. A man with his views of American life was not wanted in this country. One of the prominent men present afterwards stated to me in a private letter that Voldal had made a great mistake and that he himself was "utterly disgusted" with his address. All this made Voldal very unpopular for the time being and he was in some danger of being removed from his position as pastor of his churches in Perry and Primrose. It appeared that the address he had written for the occasion was 
not as severe and outspoken as the one he actually delivered without his manuscript.

In the midst of his troubles he came to see me. He knew of my enthusiasm for Norwegian culture, so he invited me to come to speak in his three churches and deliver an address which I had given on a number of occasions on the subject of "Our Norwegian Inheritance." He hoped, in this manner, to pour oil on the troubled waters and allay some of the feeling that had been worked up against him. I accepted his invitation and agreed to do all in my power for him in this matter.

Mr. Voldal introduced me to good-sized audiences in his three churches one Sunday in Primrose, in the morning, taking dinner with Christ Engeland at the old La Follette homestead; in the afternoon in the York church, and in the evening in the Perry church. I spent the night as Voldal's guest at the parsonage, but we did not retire until long after midnight. $\mathrm{Mr}$. Voldal expressed himself as greatly pleased with the addresses I had delivered and in which I had praised Norwegian culture to the stars, and said he thought they would have the desired effect. We talked over many things that night and became fast friends. We found that we were of the same view in regard to most questions concerning the welfare of the Norwegians in America. We held the same views in regard to modern Scandinavian literature; we agreed that the writings of many of the leading authors were decidedly hostile to the teachings of Christianity and that much of the latest literature was not only immoral, but even indecent, unfit to be read aloud before a mixed audience. He read to me the address which had caused so much commotion and hostile criticism. Although I knew it was not in every respect identical with the one he had delivered offhand at the semi-centennial festival in Mt. Horeb, still it was the same fundamentally and at his request I printed it in my paper as his Mt. Horeb address. 
During the night "Det Norske Selskab," which afterwards became the subject of so much bitter and excited discussion in the Norwegian press, was born. Voldal and I were its parents. I cannot say now who was its father and who was its mother, but between us two this child, which was to give the Norwegian-Americans so much trouble, was conceived and born. Its christening and presentation to society was to occur later, at Minneapolis.

Mr. Voldal and I agreed that "Det Norske Selskab" was to be, in all respects, a Christian child. The society was not to be controlled by the irreligious element in our NorwegianAmerican population. Though this element was not to be absolutely excluded from membership still the enemies of the Lutheran church were not to be admitted in sufficient numbers to control the society.

The main purpose of the society to be organized was to promote an interest in Norwegian history, literature, art, music, traditions,-in a word, in Norwegian culture. But such elements in this culture as were directly or indirectly unfriendly to the gospel of the Galilean would not be admitted. The devotees and admirers of the later works of Ibsen and Björnson would either have to be kept out of "Det Norske Selskab" or at least take a back seat. On this phase of it Voldal and I were fully agreed, and as the main body of Norwegian Christians in this country were Lutherans the society, "Det Norske Selskab," would be, to all intents and purposes, a Lutheran society. The Norwegian Lutherans were in church matters divided into several organizations, more or less at war with each other. In their church affairs they could not work together, but Voldal and I conceived that in a society of this kind members from the various church bodies could meet on common ground. All church disputes would be relegated to the rear in this society and at the same time no unchristian influences 
would be tolerated. People from the various churches would meet together and discuss Norwegian history, literature, art, etc. They would get better acquainted, would even become fond of each other, and in this manner the road would be paved for that great goal, the aim and ambition of every true and upright Lutheran: A united Norwegian Lutheran church in America. As promoters of this idea we agreed to take as partners Rev. Bendik Bondahl and Rev. O. L. Kirkeberg, two well known ministers in the United church, both enthusiastic workers in the domain of Scandinavian culture in this country. Voldal, Bondahl, and Kirkeberg, being all members of the United church, were to secure friends for this project within the church to which they belonged. I, being at the time affliated with the Norwegian Synod, was to do the same within the Synod body. Mr. Voldal was to exploit the matter at the annual meeting of the United church at Minneapolis and a committee of the most prominent men in the United church and in the Synod was to be gotten together to publish a call for a general meeting to be held in Minneapolis the following winter to organize the society, adopt a constitution and by-laws and elect officers.

During the year 1902 I devoted a separate page of my paper, "Amerika," to create an interest in the proposed organization of the society. I gave the page the heading "Det Norske Selskab," and for this page I received special contributions on a variety of Norwegian subjects from Rev. O. L. Kirkeberg, Rev. Bendik Bondahl, Thomas Lajord, and others. By their very contents these articles were to illustrate the kind of subjects to be discussed and promoted by "Det Norske Selskab."

Henrik Voldal was a great advocate of union and cooperation between the various Norwegian Lutheran church bodies, and he has a very fertile mind. 
In the spring after he and I had had this night session at his parsonage and laid the plans for "Det Norske Selskab" he visited me at Madison with a brand new idea which he had conceived. He had decided that there should be held at Madison, preferably at Lakeside, a great Norwegian Lutheran picnic by all the Lutherans in Dane and adjoining counties. The United church, the Synod, the Hauge, and the Free Church people were all to be invited; but the program was to be in the hands of the United church and Synod people. It was to be a great musical festival and then there were to be four addresses, one in Norwegian and one in English by the two best orators in these languages in the United church and one in Norwegian and one in English by the two best orators in these languages in the Synod.

Mr. Voldal had gotten his plan approved at a district meeting in the United church. As a committee he and Rev. J. A. Bergh of Rock county had been appointed to represent the United church. John Ollis and I were appointed to represent the Synod. The committee met at my office in Madison. We agreed on the time and place and announced to the public that such a grand Lutheran picnic was to be held in Madison. Voldal and Bergh were to find the two eminent speakers to represent the United church. It was left to me to secure the two from the Synod. I chose Prof. Laur Larsen of Luther college to deliver the Norwegian address and obtained his consent. I then invited Rev. A. Bredesen of Stoughton to deliver the English address and he was willing. Mr. Voldal had decided to secure speakers for the United church when he attended the annual meeting of his church at Minneapolis and then report to me. I did not hear from him. On his way home he called on me and informed me that he was very sorry that the Madison picnic or festival would have to be abandoned. $\mathrm{He}$ had been unable to secure speakers. President Hoyme, 
on whom he had depended for the Norwegian address, had refused for the reason that the meeting had been announced as a Lutheran affair. This took my breath. I was utterly dumbfounded. I told Mr. Voldal that I had had some misgivings in this respect in regard to Rev. Bredesen and Professor Larsen, especially the latter, but I was surprised to find that such views were held in the United church.

In the German Missouri Synod and in the Norwegian Synod there has always been great opposition to every form and to every suspicion of syncretism, that is, to any mixing of religions. Missourians and Synod people will not worship together with those who differ with them in doctrine; but as I told Voldal, I was surprised to find that leading men in his church would object to speak from the same platform with Larsen and Bredesen.

Voldal said that he deeply regretted that such was the case. The festival was abandoned and the idea was never revived.

"Very well," I said to Mr. Voldal: "this has taught us a lesson. We have here found a snag that we must avoid when the time comes to call a meeting to organize 'Det Norske Selskab.' We want the society to be Lutheran in all its purposes, in its work and influence, in its membership; but we must avoid using the word Lutheran; if we do use it there will be a protest against syncretism. People will refuse to join it on the plea that it is a mixing of religious views, while the fact is the religious work is not to be a part of the program of 'Det Norske Selskab.' All we want is to keep the society free from all irreligious influences."

To this Voldal agreed. The character of the society, so far as religion is concerned, would appear in the position of the members of the committee who signed the call.

In 1902 such a committee was gotten together. It consisted of prominent professors, ministers and other representa- 
tive men in the Synod and in the United church. All were recognized laborers in the cause of Lutheranism in this country. Of course, Voldal, Bondahl, Kirkeberg and I were among those who signed the call, my name being the last, for a meeting to be held in Oulie's hotel in Minneapolis.

Voldal, P. O. Strömme and I had been appointed as a committee to draft a constitution and by-laws to be discussed at the meeting. I gave Voldal several printed constitutions and bylaws of various societies as samples and requested him to make a prelminary draft of such a document which he might submit to Strömme and me for our consideration. This he did.

In January, 1903, a couple of weeks before the meeting was to be held in Minneapolis, he called on me at my office with his draft of constitution and by-laws in his pocket. He had been appointed to visit the various academies, colleges and seminaries of the United church and he wanted to discharge this duty before attending the Minneapolis meeting. He was going to start on this mission that night and take the 11 o'clock train for St. Paul. Mr. Strömme was not in town.

At my office Voldal produced his draft of a constitution and by-laws and read it to me paragraph by paragraph. I approved the paragraph giving the society the name "Det Norske Selskab in Amerika." I also approved the paragraph stating the purposes of this society in promoting an interest in Norwegian culture and the dissemination of pure and good Norwegian literature. Then he read a paragraph as to who might be eligible to membership. The paragraph read:

"Every man or woman of Norwegian descent may become a member of this society by paying $\$ 1$ a year or $\$ 10$ for a life membership."

I said with astonishment:

"What do you mean, Voldal? I thought this was to be, at least substantially, a Lutheran society, and here you open 
the doors wide for everybody! I am aware that we cannot use the word Lutheran in our constitution, that would lay us open to the charge of syncretism, but I should think there ought to be some restriction as to the eligibility to membership. It seems to me that it should be left to the society to consider every application for membership and then to admit the desirable ones and to refuse admittance to the undesirables. As a Lutheran organization in fact we would be able to keep discordant elements out; besides there are people whose standing in the community is such that we would not desire them as members; but with this paragraph in the constitution every person, notwithstanding how bad his character might be, has to be admitted if he can produce the dollar."

Mr. Voldal said that he thought the society ought to be made as popular as possible; that he wanted a large society to embrace the whole Norwegian population in this country. He said he had discussed the matter with Bondahl and Kirkeberg and others and they had agreed with him that "Det Norske Selskab" should be a society for all the Norwegians in America. I told Voldal that that seemed strange. It was in violation of our agreement when I spent the night at his parsonage, and I referred him to an article in "Amerika" of March 28, 1902, signed by Rev. Bendik Bondahl in which he stated that if others than Lutheran were to be admitted into this society he would have nothing to do with it. I then told Mr. Voldal that I preferred to be counted out. I told him that I would not attend the meeting at Minneapolis. $\mathrm{He}$ answered that he hoped I would be there and he added that I might offer an amendment to the paragraph to which I objected, and it was possible that my view would prevail. I replied that the chances for an amendment after he and his friends had agreed were too small to induce me to make the long journey to Minneapolis and take part in the organization of a society of which I knew in advance I could not be a member. 
"I am not going to Minneapolis," I said.

It was nearly 6 o'clock and I asked Mr. Voldal to go home with me to dinner. He accepted my invitation. After dinner I ordered a cab to call at my house for my guest and take him to the 11 o'clock train for St. Paul and this gave us more time for a visit. By telephone I invited Rev. Thore Eggen and N. O. Starks of this city to come to our house and meet our distinguished guest. Eggen came and spent an hour very pleasantly.

After Rev. Eggen had gone Voldal remained waiting for the cab and we had another opportunity for a twa-handed chat. In the course of our conversation anent "Det Norske Selskab" Mr. Voldal took from his pocket and handed me a list of just 100 names of persons whom he and Bondahl and Kirkeberg had written to and urged to be present at the meeting to be held in Oulie's hall in Minneapolis to organize "Det Norske Selskab."

These hundred names were all of persons well known among the Norwegians in this country as being outside of the pale of the Lutheran church. I do not care to put them in the pillory here as such but many of them were prominent as infidels, sceptics and scoffers at religion. There was not one Lutheran in the whole bunch. I exclaimed:

"Voldal, what do you mean?"

He explained that letters to these hundred persons had been sent pursuant to an agreement between himself, Bondahl, Kirkeberg and some others. I exclaimed again:

"Voldal; this is treason! You are a traitor, sir. I did not expect this of you. At my office I told you that I would not attend the meeting in Minneapolis. Having seen this list of names, I have changed my mind. I am going to attend that meeting and you will find me there. I want to say to you again, sir, that you are a traitor!" 
After that our conversation was anything but cordial. The cab came and I escorted my distinguished guest into it, bid him good-night and said:

"We will meet again in Minneapolis."

The day set for the meeting was January 27, 1903.

To show my enthusiasm in regard to this project and my attitude toward it concerning religious aspects I will here quote from an editorial which I published in "Amerika" on January 9, 1903, only two weeks before the meeting in Minneapolis:

"We hope that as many as possible will attend the meeting and help make a splendid launching of the ship.

"Such a society can be of great benefit to Norwegians on both sides of the Atlantic and we bespeak for it great accession of members and much progress. 'Det Norske Selskab' may depend on 'Amerika's' sympathy and support. Our only condition is, that the elements that are inimical to Christianity be left out. While the society is to be national, it must consist of persons who make a profession of Christianity. Let the infidels get together in their own organizations."

The meeting in Minneapolis was well attended, but the majority of those present were people living in Minneapolis. I may state here parenthetically that the majority of the unchurchly Norwegians are found in the cities. Out of more than 70,000 Norwegians residing in Minneapolis less than 7,000 are church members. The other 63,000 are outside of the pale of all churches. The same proportion as in Minneapolis obtains in most other cities where Norwegians are found in large numbers. Thus it will be seen that it was easy for this unchurchly element in Minneapolis to come to the meeting in sufficient numbers to control it. And this they did.

The hall in which we met was divided into a large room and a smaller one by a wide arched door. This arched doorway separated the sheep from the goats. The ministers and pro- 
fessors and others representing the various Lutheran churches were assembled in the small room. The crowd of nondescripts, from a religious point of view, filled the large room; the latter had the votes.

The meeting had been called for 2 o'clock in the afternoon. As my name was first of those who had signed the call published in the Norwegian newspapers I took the liberty of calling the meeting to order. I stated that the first thing to do was to elect a temporary chairman and I suggested the name of Henrik Voldal. The suggestion received a number of seconds. I put his nomination to a vote. He was unanimously elected and I gave him a seat at a table placed in the arched doorway. I then nominated Prof. Gisle Bothne of Luther College, belonging to the Synod, for temporary secretary; he was also unanimously elected and took his seat at the same table. Then I found a chair in the rear part of the small room. In this small room were Rev. Kirkeberg, Prof. Christian Johnson, of the theological seminary of the United church, Rev. Gustav Oftedal, Senator L. O. Thorpe and quite a sprinkling of more or less prominent professors and ministers in our Lutheran churches.

Rev. Voldal called the meeting to order, made a few remarks on the purpose of the meeting and then it was decided to proceed with the adoption of a constitution and by-laws. The paragraph on the name of the society was quickly adopted with unanimity. Then came the paragraph describing the purposes of the society. One of these purposes was, as the reader will remember, to work for the dissemination of good Norwegian literature among the Norwegians in America. Here those in the large room began to stick pins into me. A person would ask for the floor and inquire whether it was the R. B. Anderson view of good literature that was to obtain in the rules of this society. Another one would get the floor and say that 
if such great writers as Ibsen and $B$ jörnson were to be tabooed they might count him out. One stated that R. B. Anderson had disgraced the Norwegians by his attacks on Norway's greatest sons and did not think him worthy of membership in the society here to be organized. Explanations were made by $\mathrm{Mr}$. Voldal; protests came, especially from the small room, against the making of personal attacks on anybody; but the discussion of what the expression "good literature" meant continued and became more and more vehement. It looked as if it would take hours before this paragraph could be voted on.

Before going to Minneapolis I had considered with the greatest care the position I would probably be forced to take at the meeting. I am not narrow in my views, and I did not like to appear so before the public. I am able to associate with people of all religious and political opinions.

I had no intention of excluding even pronounced infidels from membership in "Det Norske Selskab." All I desired was that the balance of power should always be in the hands of the friends of Christianity, of pure morals and of clean literature and art. I had within my own circle of friends many not interested in church work whom I would be pleased to welcome as members of the society. But I foresaw that as a result of Voldal's treason the meeting would be controlled by the element outside of the church, and I had to find some way of taking a stand in behalf of the Christian religion and Christian ethics. My views would have to be presented in the form of an amendment to the paragraph on membership and I found only one amendment that would answer my purpose.

It was getting near $6 o^{\prime}$ clock in the afternoon. I wanted to take an evening train back to Madison. The meeting was wrangling over the meaning of "good literature," and now and then sticking a pin into me. I therefore asked for the floor and Mr. Voldal recognized me. I said: 
"It will soon be 6 o'clock and time to adjourn for supper. There is slight hope of coming to any agreement in regard to the meaning of 'good literature' in the paragraph now under discussion. I therefore make a motion, Mr. President, that we postpone the discussion of this paragraph until after supper and in the meantime take up for discussion the paragraph which relates to eligibility to membership in order that we may know who shall be entitled to vote at this meeting. Those not entitled to vote will not need to attend the adjourned meeting or take part in its deliberations."

My motion was adopted without much discussion and with but little opposition.

The paragraph, as I have already quoted it in connection with Voldal's visit at my office in Madison, was then read and its adoption was moved and seconded. I then got the floor again. I explained how absurd it was for a committee of prominent Lutherans to call a meeting for the organization of a society to promote Norwegian culture in this land and then open its door for membership to people of every description without any regard to their fitness for the important work which the society was to do. As the paragraph stood the only requisite for membership was the dollar, but the fact that a man can produce a dollar is not sufficient evidence that he is fit to guide the youth of our people in the choice of literature, art and the means of sound culture. I therefore offered as an amendment or substitute for the paragraph under consideration the following:

"Every man and woman of Norwegian descent in good standing and who is a member of a Lutheran congregation may become a member of this society by paying $\$ 1$ a year or $\$ 10$ for a life membership."

As indicated, I was confronted here not by a theory, but by a condition and I saw no other way of testifying to the faith that was in me. The people in the large room howled like a pack 
of wild animals. Shouts were heard: "Put him out! put him out!" There was no opportunity for discussion. There were calls for "question!" "question!"

Mr. Voldal rose to put my amendment to a vote. I heard one man in the small room utter a feeble "Yes," and when the other vote was taken there came a howl like from a thousand wolves screaming "No!" The motion was overwhelmingly defeated. I called for the floor again and after some protests I got it. I said that this vote ended my connection with the organizing of this society. I said I was about to take the train for home and wished to bid them goodbye, but before leaving I desired to speak a few words of admonition and warning, particularly to those in the small room; to those in this assembly who were ministers of Lutheran congregations and professors in Lutheran schools. I reminded the ministers of the solemn oaths they had taken when ordained, of their promise to serve as watchmen on the walls of Zion, and as defenders of the faith.

Then addressing myself to the whole assembly I told them that the society which they were about to organize would be cordially supported by the whole Norwegian press in America with one exception; that exception was my little paper in Madison. From it they would get the criticism they deserved, but I added that I knew this did not worry them.

I do not now remember all that I said, but I do believe I spoke the truth and that I did make some of the servants of the church quake. I donned my coat and cap and left the room. In the hall I was followed by Rev. O. L. Kirkeberg. He threw his arms about me and begged me not to go. He said:

"You have done more than anyone else to promote Norwegian culture in this country and we can't have a society of this kind without you. It would be an anomaly."

I pushed him away. I told him, as I had told Voldal, that he was a traitor and that I could have nothing further to do with 
him. I made haste to get out on the street and the next morning I was back in my office in Madison.

My walking out from the meeting in Minneapolis was the cause of a vast amount of newspaper controversy. Much bitterness was engendered, the after-pains of which are still lingering. I had told the society that it would receive the enthusiastic support of all the Norwegian-American papers, except "Amerika." I kept my promise and began at once to pour. hot shot into the work done at Minneapolis. I had to fight single-handed.

After several months, August 19, 1903, I got Professor Larsen to come out in an editorial in "Kirketidende," but his article was lame and did not do much good. Professor Larsen made a left-handed defense of the amendment I had offered, saying:

"Any other amendment we have not found ourselves able to offer."

Of course, Professor Larsen's purpose seemed to be to support "Amerika," but he appeared very much afraid that he might offend the enemy.

In the early '90s I had been elected an honorary member of the Norwegian-Danish American Press Association. When I got my own paper I became a voting member. When "Decorah-Posten," about the year 1900, celebrated its twenty-fifth anniversary $I$, in accordance with an expressed desire of the publisher, delivered the principal address, that is, made the speech for the guest of honor, Mr. B. Anundsen, the publisher of "Decorah-Posten." At this banquet one of the speakers attacked me personally, sticking pins into me, on account of my published views of some of the leading Scandinavian writers. $\mathrm{He}$ received considerable applause from many of the Norwegian editors who were present. They did not seem to appreciate the utter tactlessness of attacking me at a banquet. 
The day after the banquet the press association held its annual meeting in Decorah. I came late to the meeting and before I got there the speaker who had insulted me at the banquet the evening before had been elected an honorary member. The editor, Mr. Lars Stavnheim, who made the motion, afterwards told me that he had done so for the very purpose of emphasizing the disapproval on the part of the press association of my attacks on the leading writers of Scandinavia. The insult was to be rubbed in, as it were. On account of this action by the press association I immediately sent in my resignation, both as regular and honorary member.

The next year this press association held its annual meeting at Madison, Wis. Two of its leading members, Mr. Anundsen of "Decorah-Posten" and Mr. Sörensen of "Minneapolis Tidende," were guests at our house, but I did not attend any of their meetings or banquets. I mention this here to show how at this time my relations with my colleagues were completely severed, and how utterly isolated I was in my journalistic work.

The publisher of "Decorah-Posten" was the president of the press association. His paper vigorously advocated "Det Norske Selskab" and went out of its way to be rude to me. Rev. O. L. Kirkeberg had been elected president of "Det Norske Selskab" and several non-Lutherans were made officers and directors. The society made but little progress in getting members, in spite of all agitation in the press. It never had more than a few hundred members and while it still exists you have to use a microscope to find it. I do not know who its present officers are, nor do I know of anybody that does know.

I had my hands full in fighting the indecent advertising and the sceptic and immoral literature. Now I had "Det Norske Selskab" also on my hands, and as misfortunes never come singly, this country this year, 1903, received a distinguished visitor from Norway, Thoralv Klaveness, who seemed to have 
come here for the special purpose of recommending modern Scandinavian literature to his countrymen on this side of the Atlantic. It became my duty to aim "Amerika's" guns at him too. I am not overdrawing the picture when I say that I was completely surrounded by enemies, and most of the few friends I had lacked the courage to come to my defense.

The press association and "Det Norske Selskab" entered into a conspiracy to annihilate me. It was arranged that both these organizations were to hold their annual meetings in St. Paul in the early part of September.

A few days before these meetings I happened to spend half a day in St. Paul on my way home. I, in accordance with an old custom, called on the Swedish-Norwegian consul, E. H. Hobe, at his office. He invited me to go with him to a nearby restaurant for refreshments. On our way there we passed the "Nordvesten" publishing house and Mr. Hobe suggested that we should call on the editor, Mr. Chr. Brandt. I consented. On reaching the "Nordvesten" office, on the top floor, we did not find the editor in his office and every room into which we looked was deserted. As we were about to take the elevator down again we heard some talking behind a closed door. Consul Hobe opened the door and there we discovered sitting around a table in deep consultation the editor Brandt, the teacher of music, John Dahle, Mr. Jörgen Lommen and Peer O. Stromme. Their perplexity on seeing me enter the room with Hobe is indescribable. They were utterly confused. They were evidently engaged in hatching out some great conspiracy.

My time was limited as I was to take an early train that evening, but Mr. Hobe invited this quartet to go with us to the restaurant where we were all to take a lunch. They accepted his invitation. At the restaurant there was but little conversation. The four that had come with us were too confused and 
embarrassed to talk about anything. I could see that they were nervous and felt uneasy. It soon became time for me to leave for the railroad station and we all left the restaurant together. Out on the sidewalk I heard the four speak in a low voice to each other saying:

We will meet again tonight at 8 o'clock.

What they were plotting was not at the time clear to me, but I knew there was something in the wind.

I knew that both the press association and "Det Norske Selskab" were to convene there the next week. Consul Hobe urged me to be present at these meetings and to be his guest. I told him this would be impossible. In the meantime I engaged through correspondence a trusted friend to be on hand and take note of what was done and report to me. This he did. I received a full and reliable report. According to previous agreement my name was not to be mentioned at either one of these two meetings; but my correspondent informed me that in all the recesses between the sessions R. B. Anderson was the chief, if not the sole, topic of conversation. They had made up their minds to do me to a finish. And this is how it was to be done.

Peer O. Stromme was to write a series of articles against me. These were to be published in the form of editorials in "Nordvesten." Anundsen and other men of means were to furnish the sinews of war.

"Det Norske Selskab" had secured only about 150 members and of these only 28 attended this meeting at St. Paul. It was therefore agreed to engage Peer O. Stromme as traveling and lecturing agent, to visit all Norwegian communities and get new members. As has before been stated the membership fee was $\$ 1$ per annum or $\$ 10$ for a life membership, and the society agreed to pay Stromme 50 per cent commission. Of course, I do not have these facts from the records of the society which I have never seen, but I make the statement on the authority of 
others, and particularly on the information received from my correspondent whom I had engaged to be present at the above meetings.

Immediately after these meetings the Stromme articles began to appear on the editorial page of "Nordvesten." They were published in eight instalments and amounted to more than 40 columns. In these articles Stromme charged me with being a literary thief, decorating myself with stolen feathers; that I was unpardonably incapable as an editor; that $\mathrm{I}$, as a politician, was shamefully dishonest; that as a man I was vain and extremely malicious, and that my Christianity was the most disgusting hypocrisy. It was these charges that he was to establish in his long series of ponderous articles.

I presume I ought to have brought suit for libel against "Nordvesten," but the paper was located in another state and was known to be in a shaky condition financially. It died from want of support a short time afterwards and it was a common report that the Stromme ebullitions had proven an overdose for its stomach.

During the autumn of 1903 and the following year it seemed to me as if all my countrymen of Norwegian descent were against me. Whichever way I turned I met a brace of bayonets. I had lost the good will of the Scandinavian press because I demanded that it should purge its columns of indecency. I was hated by the so-called liberal, cultured element because I attacked their idols, Ibsen, Björnson, Garborg, Brandes, for their war on the Christian religion and for their unclean writings. I was opposed by all the Norwegian churches because I took the liberty of criticising some of their representative men and leaders. Politically I was friendless among the Norwegians because I was a stalwart republican while they were nearly all enthusiastic admirers and supporters of La Follette. Being myself opposed to all kinds of secret societies and never having 
identified myself with any of them, all the secret organizations among the Norwegian-Americans joined the ranks of my enemies.

As before stated, the churches and schools that had for years been open to me for lectures and addresses of all kinds closed their doors against me. Ministers and professors who might like to invite me to speak did not dare to do so for fear of being black-listed. My enemies made house-to-house canvasses to persuade people to discontinue my paper "Amerika." But I defied them all. I did not hoist any flag of truce or send out any dove of peace.

In speaking of all the opposition that confronted me on every side I deem it my duty to insert here the names of a few persons who showed unflinching loyalty to me and the principles and cause for which I contended. I can not let these memoirs pass out of my hands without expressing in some way my appreciation of their loyal friendship. They verified the old adage that friends in need are friends indeed. The most of them are men in the humbler walks of life but I want the names of some of them recorded here and thus handed down to all who may peruse these pages. Of course I can not mention all, but I make the following selection:

Nels A. Lee, Deerfield, Wis.; P. B. Grinde, Deerfield, Wis.; Hon. Nels Holman, Deerfield, Wis.; Hon. William Nelson, Deerfield, Wis.; Architect Andrew Anderson, Madison, Wis.; A. H. Vick, Madison, Wis.; T. K. Reindahl, Burke, Wis.; Nels Johnson, Westport, Wis.; John Clausen, Westport, Wis.; H. L. Skavlen, Janesville, Wis.; H. G. Haugen, Chicago, Ill.; Ole Gunnuldson, Cambridge, Wis.; T. H. Lea, Madison, Wis.; O. N. Falk, Stoughton, Wis.; Iver Kleven, Klevenville, Wis.; John Vilberg, Mt. Horeb, Wis.; E. P. Kalstad, Amherst, Wis.; A. Holseth, Sioux City, Iowa; O. Jonassen, Sheboygan, Wis.; T. C. Sætra, Stanwood, 
Wash.; Hon. B. Holland, Hollandale, Wis.; Odd Larson, Mauston, Wis.; Jermon Tveit, Mauston, Wis.; Henry Nelson, Whitewater, Wis.; Gilbert Anderson, Whitewater, Wis.; V. Gulbrandson, Albert Lea, Minn.; Hans Gulbrandson, Albert Lea, Minn.; Capt. T. A. Rossing, Decorah, Iowa; R. K. Ulen, Decorah, Iowa; A. L. Kloster, Huxley, Iowa; T. L. Quarve, Fessenden, N. D.; O. H. Jaastad, Fessenden, N. D.; J. H. Kopperdahl, Bellingham, Wash.; T. R. Tobiasson, Hatton, N. D.; I. J. Hauge, Maddock, N. D.; O. C. Froke, Summit, S. D.; Andrew Opheim, Fertile, Minn.; Knud Opheim, Fertile, Minn.

The list might be considerably extended but this is sufficient to show that I had steadfast friends among the rank and file. I owe these and several others not here mentioned a debt of gratitude that I can never pay.

After the conspiracy in St. Paul and the publication of Stromme's malicious articles in "Nordvesten" I secured the services of the very able Norwegian artist Lars Haukaness and got him to make for me a series of cartoons in which "Det Norske Selskab" and the Norwegian press were made the object of the severest sarcasm. Of these cartoons I published more than a hundred in "Amerika." They form a distinct chapter in the history of the Norwegian-American press. Many of them are genuine works of art, and they attracted wide attention. It is the only instance in which a NorwegianAmerican paper has employed a cartoonist on its staff. I have preserved all the cuts and some day I hope to publish these hundred or more cartoons in a separate volume. They will shed valuable light on conditions exisiting among us during the first decade of the present century. 


\section{CHAPTER CXLVIII.}

\section{RUPTURE WITH OUR SAVIOUR'S CONGREGA- TION.}

The jeers and sneers, the malice and contempt directed against me from all sides did not worry me. I had the satisfaction of being conscious that $I$ was in the right and that my enemies were in the wrong, and I felt certain that although I was isolated, still truth would conquer in the end. But one thing occurred in Madison which has been a source of genuine pain and regret to me. My enemies succeeded in driving me and my wife out of Our Saviour's congregation, of which we had for several years been members.

In the summer of 1903 I had been the representative of this congregation at the semi-centennial meeting of the Norwegian Synod at Decorah, Iowa, and my wife and I had hoped to have our spiritual home in this little Madison church till our dying days.

The pastor of this church, Rev. M. C. Waller, had for a couple of years served as my assistant editor. The relations between him and me were most cordial. The congregation had grown and needed all his time and so I got the eldest daughter of Prof. Laur. Larsen to take his place and at the time of which I am now speaking she was my assistant editor.

When Stromme's first article had appeared in "Nordvesten" and had been reprinted in "Amerika" Mr. Waller became very indignant. He immediately called on me at my office and pro- 
posed to call a special meeting at once of the voting members of Our Saviour's congregation to adopt a protest against the attack on my character and send it to "Nordvesten" for publication, and gave me a copy for publication in my paper. P. O. Stromme lived in Madison and was also a member of Our Saviour's congregation; but, as has already been shown, the articles in question did not bear his name, but appeared as editorials in "Nordvesten" of which Mr. Brandt was the publisher and editor. I of course knew that the articles were written by Stromme and did not hesitate to say so; but the resolution to be adopted by Our Saviour's congregation were not to take cognizance of the articles otherwise than as "Nordvesten" editorials.

I told Mr. Waller that it had not occurred to me to ask the congregation to take any notice of these articles, but that I keenly appreciated his good intentions. He insisted that it was the duty of the congregation to defend me against such malicious attacks. I thanked him for his good will and gave my consent, suggesting that all that needed to be done was to pass a resolution that I was a member of the congregation in good standing.

While we were talking Mr. M. W. Odland came in. He had been referred to in the first "Nordvesten," article as my "lickspittle." At my instigation Odland had recently become a member of Our Saviour's congregation. Mr. Waller suggested that Odland also ought to receive a vindication from the congregation.

I have given this in detail to show that the idea of a resolution on the subject by the congregation was wholly the pastor's, Mr. Waller's, initiative. He had come to my office for the very purpose of proposing that a special meeting of the congregation be called. Both Mr. Odland and I simply gave our consent. 
The constitution permitted the pastor to call a special meeting by giving five days' notice in writing and stating the purpose of the meeting. Mr. Waller that same day, which was, I believe, Wednesday, sent to every voting member of the congregation a letter calling a meeting for the following Monday evening.

The following Saturday evening I had an engagement to lecture in DeForest, Wis. There being no train to Madison from DeForest on Sunday I was obliged to remain in that village until Monday morning. Consequently I could not attend service at Our Saviour's church on Sunday, but Mrs. Anderson was there. And P. O. Stromme was there, too, although he was at the time employed out of the city. After the service Mr. Waller, in the presence of all the people present, read the letter which he had sent out the previous Wednesday, made a full explanation of the purpose of the meeting and urged all the voting members not to fail to be present at this very important special meeting. As the people left the church, I was told, Stromme was very busy in talking to the different members, telling them that it would not do to get the congregation mixed up in Anderson's newspaper controversies.

In the afternoon the same day Stromme got several members to meet at a private house where the matter was discussed and there a resolution was adopted declaring that they would have nothing to do with Mr. Waller's proposed meeting and would not attend it. They so notified the pastor.

Monday morning I was back in my office. There I received a call from Mr. Waller and Mr. John Ollis. Mr. Waller had become frightened and had gotten cold feet. He wanted to cancel the call for the special meeting and both he and $\mathrm{Mr}$. Ollis wanted me to give my consent. I stubbornly refused to do so. The meeting had been called not only by letter, but had been announced to the general public in the church after the service. 
Not to hold a meeting would not only leave me in the lurch, but be a violation of the constitution of the congregation. I insisted that the meeting must be held and I now wanted to know whether I was a member in good standing or not.

No meeting was held. Mr. Odland immediately sent a notice to the pastor informing him that he did not care to continue as a member of the congregation, saying that he did not see how it could be of any benefit to him. I was blamed for Odland's resignation, although the fact is I urged him not to present it at that time.

The resolution that I was a member of the congregation in good standing has not yet been adopted. I do not think it ever will be adopted. The incident became very embarrassing to Rev. Waller and he soon left Madison and accepted a call in Minnesota. He is now at Wittenberg, Wis.

Since the autumn of 1903 neither my wife nor I have been inside of Our Saviour's church. The refusal to hold a meeting and vindicate me by giving me a certificate of good standing has, as I anticipated, been used everywhere in the Norwegian communities against me. My enemies say that R. B. Anderson asked the congregation to which he belonged for a certificate of good character, but the congregation knew him too well and would not give it to him. It is made to appear that the initiative was taken not by Mr. Waller, but by me. I have no doubt that I would be well received if I should return to the congregation; in fact, I have been told so, but I cannot do this without sacrificing my self-respect and this I will not do under any consideration. This matter has been a source of untold grief and pain to me, but I see no way out of it unless the congregation will condescend to hold that special meeting and declare that I, at the time, was a member in good standing. You cannot expect others to respect you unless you respect yourself. Self-respect is something totally different from pride or vanity. 


\section{CHAPTER CXLIX.}

\section{MY PORTRAIT IN SNORRE.}

It never rains but it pours. In the midst of the many attacks on me from every side, with the evident purpose of causing my complete undoing, the "Decorah-Posten" published a communication charging me with inserting in the edition of Snorre that I was distributing, my own portrait, representing this as a most disgraceful act on my part and claiming that my portrait had no right to appear in the work. The purpose was to show me up as a man of inordinate vanity and to make me supremely ridiculous with the public. This assault was to serve as the last straw to break the camel's back.

I confess that I ought to have brought suit against the publisher of "Decorah-Posten" for libel. There could be no doubt of the outcome if I had done so; but I shrank from litigation. I have never been in court, and I liked to end my earthly career without suing anybody or being sued, and it now looks as if this ambition of mine is going to be gratified.

This episode occupied so much space in "Decorah-Posten," in "Amerika" and in other papers and took so much of my time and attention that it seems proper to give a brief review of the whole case in these pages.

As the reader will remember there was published in Copenhagen by the Gyldendal publishing house a Danish translation of my little book, "America Not Discovered by Columbus." 
In this book I take the position, which I still maintain, that Columbus had knowledge of the western continent before he entered upon his voyage of re-discovery. I point to his visit to Iceland and claim that he had pretty complete information concerning the Norse voyages to Vinland. I gave a number of reasons why Columbus must have had knowledge of Vinland.

The publication of my book produced considerable interest in the Norse voyages throughout Scandinavia. I also gave a public lecture before the Royal Geographical society in Copenhagen to an immense audience, in which most of the members of the royal family were present.

The Royal Society of Northern Antiquaries then invited Dr. Gustav Storm of the University of Christiania, Norway, to come to Copenhagen to deliver an address on the Vinland voyages. Dr. Storm was regarded as one of the greatest living authorities on the old Norse saga literature; but that did not necessarily involve any thorough investigation of the literature pertaining to Columbus or of American geographical problems.

Both Dr. Storm and I were members of the Royal Society of Northern Antiquaries. I was present at his lecture, in which he tried to locate Vinland in Nova Scotia, and in which he emphatically denied that Columbus had the slightest knowledge of the Norse voyages. I took no issue with him at the meeting where the king and crown prince were present, but after the lecture a number of the members, including Dr. Storm and myself, were invited to a collation at the house of the scholar and poet, Sophus Schandorph, and here the differences between Dr. Storm and me were pretty thoroughly thrashed out—of course in a perfectly friendly manner as behooves scholars and gentlemen.

I may here state without any exaggeration that at this collation Dr. Storm stood alone in his contentions, Dr. Schan- 
dorph, Dr. Wimmer, Dr. Steenstrup, Dr. Stephens and the other scholars present all taking my side. Dr. Storm's lecture was afterwards published materially expanded.

After my return to America a Minneapolis paper, "Budstikken," edited at that time by R. N. S. Sartz, now of Washington, D. C., took occasion to cast slurs on the Norse discovery of America and referred to learned authorities as sustaining its position. I challenged "Budstikken" to produce its authorities.

Through a dissipated brother of Dr. Gustav Storm living in Minneapolis the editor of "Budstikken" succeeded in getting a long article from the learned Dr. Gustav Storm. In this article Dr. Storm presented the same views as he had advocated before the Royal Society of Northern Antiquaries and incidentally cast aspersions on me and on the views I maintain. I accepted the challenge and changed the forum of debate from Minneapolis, Minn., to Christiania, Norway.

A series of articles by me with replies from Dr. Storm was published as a so-called "följeton" in the leading daily called "Dagbladet." On account of serious prevarications on the part of Dr. Storm and also on account of sneering references to me, no doubt provoked by the fact that he was continually losing ground, this controversy grew exceedingly bitter. Dr. Storm even threatened to bring suit against "Dagbladet" for libel. I replied to this by demanding that if he wished to have his character protected he must bring me, not "Dagbladet," into court. Finally the poet Björnstjerne Björnson published an article over his name in "Dagbladet," taking my side, and stating that he had secured the opinions of the leading authorities in Scandinavia and that they all sided with me. He found no scholars supporting Dr. Storm's contention.

The Norwegian storthing in 1900 appropriated a considerable sum of money to aid in the publication of that monumental historical treasure from the thirteenth century, the so-called 
"Heimskringla," written by Snorre Sturlason, so that this work might be made accessible to everybody. As the reader may remember, I as a Luther college student purchased a copy of Snorre in Madison, Wis., and paid $\$ 11.00$ for it. The government of Norway proposed that this subsidized edition should be sold for one crown and 90 öre (about 50 cents); in pasteboard binding with cloth back for two crowns, 50 öre (about 70 cents); and in cloth binding and leather back for three crowns (about 85 cents). The work was to be illustrated by six of Norway's most eminent artists. The supervision of the publication was left with the department of church and education. The printing was put in the hands of J. M. Steenersen \& Co. The original is in Old Norse, but Dr. Gustav Storm, as the greatest living authority on saga literature, was chosen to furnish a translation into modern Norwegian ("rigsmaal") and to write notes and commentaries and furnish a suitable introduction. Storm's work was then to be turned into "landsmaal" by Prof. Schjött. All this was done and the book has had an immense sale. The first edition in rigsmaal was 70,000 copies and subsequent editions were called for.

Dr. Storm prepared a somewhat elaborate introduction. In this he gave a short biography of the author Snorre and a brief history of his time, and then he gave an account of every edition of Snorre in the original and in translations into different languages, omitting in this catalogue my edition of the "Heimskringla," published in London and New York in 1889, and yet mine was the most sumptuous edition of the work ever printed in any language. My edition, as heretofore stated, was in four large octavo volumes with an elaborate introduction, hundreds of foot notes, complete indexes and furnished with two maps, one of the Scandinavian world and the other of the whole world as known to the old Norsemen.

For some reason or other Dr. Storm did not see fit to mention this edition along with all the others. I take it that the 
feud I had engaged in with him about Vinland was still rankling in his blood and he took this way of revenging himself.

I made a deal with the publishers in Norway to distribute this work among the Norwegians in America and immediately received a shipment of 5,000 copies. I at once discovered the omission of my edition of Snorre and wrote a letter to the minister of church and education in Christiania and also to the publishers Steenersen \& Co., calling attention of this fact. In the next edition of 85,000 copies Dr. Storm was ordered to make the necessary correction. As this could not well be made in the plates a note written by him was printed at the end of the volume on the blank page preceding the table of contents. With this correction I was entirely satisfied. I even felt that it gave my edition of Snorre a special conspicuousness.

Shortly thereafter Dr. Storm died. Then I received a letter from the publisher, J. M. Steenersen, requesting me to send him a photograph of myself and materials for a biography, stating that they wished to use them in their edition of Snorre. I sent the photograph and referred him to Salomonsen's encyclopedia for biographical materials. Soon afterwards I received a shipment of 5,000 copies of Snorre and in it inserted in the introduction was a leaf containing on one side a portrait and on the opposite side a sketch of me written by the well known Norwegian Rosencrantz Johnsen. In connection with this sketch he gives a full account of my connection with the Heimskringla.

The above is a truthful statement of this whole affair which became the cause of so much scandal, mainly in "DecorahPosten." It was of no avail that I published in "Amerika," in facsimile, a letter signed by J. M. Steenersen stating that I had had no hand in the inserting of this leaf in Snorre and that the whole thing had been conceived and executed in Norway. It was of no avail that he and others insisted that my name and face had a right to appear in this introduction to the national edition of Snorre. It is a source of regret to me that the pub- 
lisher of "Decorah-Posten," B. Anundsen, a worthy man in many respects, and at one time my close friend, should go to his grave without making the amende honorable. The libel still stands uncorrected by the paper that published it. The charge was made out of whole cloth, but was a dainty morsel in the mouth of my enemies and doubtless did me much harm among people who did not read my paper and so were not familiar with the facts as I have here presented them. "Decorah-Posten" particularly still owes me an apology. 


\section{CHAPTER CL。}

\section{TIME TO CLOSE.}

We are now coming so close to 1914 that it ceases to be history. What has happened during the last ten years seems to belong rather to the living present than to the past. If I am to discuss the most recent events of my life and of my environment at all this will have to be done at some future day, if my life is spared. I may say in a general way that the last ten years of my life have not been particularly eventful. I have gradually withdrawn into my shell and my life has become more and more that of a hermit. I take little or no part in society, and my interests are largely centered in my paper "Amerika." I spend the day at my office and the rest of the time chiefly at my home.

While I have put my best efforts into my journalistic work and have edited well nigh single-handed more than thirty semiannual volumes of "Amerika" since October, 1898, I have not been wholly idle in other literary work.

A few years before I bought "Amerika" I made as thorough an investigation of Norwegian immigration and settlements down to the year 1840 as possible and published my book, "First Chapter of Norwegian Immigration" (1821-1840). In getting the material for this work I visited most of the earliest settlements, including the Fox River settlement in La Salle and adjoining counties in Illinois. I visited as many of the pioneers 
of immigration as possible and carried on an extensive correspondence. The result was the book I have mentioned which describes the first half dozen Norwegian settlements in this country and contains about 60 portraits of immigrants who came to America before 1840 . This book received very complimentary reviews in the Milwaukee Sentinel, the Chicago Tribune, the New York Evening Post and other publications. About the same time with "First Chapter of Norwegian Immigration" I edited for "Normanden" in Grand Forks, N. D., a sumptuously illustrated volume on Norway called "Norge i Billeder." The plates of this book were subsequently sold to the John Anderson Publishing Co. in Chicago, who are now its publishers, and the book has had a large sale. In connection with "Amerika" I edited some years ago a book entitled "Bygdejevning." This book gives an account of the Norwegians in this country dealing with them by the district in Norway from which they came. The introductions are by me, but the story in each case is by a member of the clan described. The articles are all in a more or less light and even humorous vein. Each writer is to show what his clan has achieved on American soil. Hence the name "Bygdejevning," which means the comparing of one clan with another, each striving to make the best showing. I think the best showing was made by the people from Valders, that clan to which my friend A. O. Barton belongs.

The Valders clan shines by its great number of pastors, professors, scholars and literateurs. The Voss district points with pride to its Senator Knute Nelson; the Telemarkings to their late Senator M. N. Johnson; the Hallings have produced Senator Gronna; Sogn claims Gov. J. O. Davidson; Hardanger Governor Herreid, and the Stril Gov. Andrew Lee of South Dakota.

My parents came from Stavanger. The specialty of the Stavanger clan is that of pathfinders. Erik the Red, who discovered and settled Greenland, and his son Leif, who found 
Vinland, were from Stavanger. The sloop Restaurationen with its precious cargo that landed in New York in 1825, came from Stavanger. The father of modern Norwegian immigration, Kleng Peerson, was a Stavangering. The pioneer and financier Halle Steensland came from Stavanger and the writer claims to have been something of a pathfinder himself, at least he has been the first Norwegian-American in various lines of endeavor.

While editing "Amerika" I have found time for considerable writing for English publications and did all the work relating to Scandinavia on a large encyclopedia recently published in this country.

In 1905 I became editor in chief of Norroena Library, a subscription work in 16 volumes, the largest and most sumptuous edition of Scandinavian literature ever published outside of Scandinavia. This work contains the cream of the Scandinavian literature produced during the middle ages. It contains one volume of the Danish Saxo Grammaticus, both the Eddas, Snorre's "Heimskringla," The "Saga of Burnt Njal," the "Volsunga Saga," all the sagas pertaining to the Norse discovery of America, Viktor Rydberg's "Teutonic Mythology" and several other works. Eight of the volumes are my own translations, the remaining eight by other translators, with their consent. The work contains a large number of hand-colored illustrations and is bound in ten different famous historical bindings. The price of the work is from $\$ 50$ to $\$ 2,500$ per set, according to print, paper, illustrations, and binding. My son Hjalmar in Seattle sold about $\$ 40,000$ worth of these works on the Pacific coast. J. P. Morgan bought a set for $\$ 750$.

I received a letter from President Roosevelt complimenting me on Norroena library and stating that he had placed his set in that part of his library which he valued most. I look upon 
Norroena Library as the crowning part of my efforts in the service of Scandinavian literature. The reader will pardon the remark if I call attention to the long, steep and rugged hill to be climbed from my little pamphlet published in 1873 on the historical, literary and linguistic value of the Scandinavian languages to the magnificently printed and bound Norroena Library in 16 volumes in 1905, the sixteenth volume giving with translations into Danish and English in facsimile every scrap of saga manuscript relating to the Norse discovery of America and also in facsimile all the documents found in the Vatican library pertaining to the early church in Greenland.

During the last ten years there has been awakened among the Norwegians in this country a remarkable interest in the old fatherland in the way of "bygdelag" associations, the people of each bygd (district or clan) getting together and organizing themselves into a separate society. Several of them have their own monthly publications. They meet once a year, renew old acquaintanceship, sing Norwegian songs and make speeches in praise of the particular district from which they sprang and of the prominent people belonging to the clan. This movement was greatly aided and promoted by my book called "Bygdejevning". The most of these societies have collected sums of money, which they have sent to their home district in Norway in honor of Norway's centennial. Those "bygdelag" gifts have been very much more popular than the so-called national gift which did not prove a success. As an illustration I may mention that T. K. Reindahl of Burke, Wis., has collected about $\$ 2,500$ as a poor people's fund for his native district Mo, in Telemarken. The fund collected by the Norwegian-Americans from Hallingdal for the native districts amounts to over $\$ 25,000$, while the sums collected for the national gift has not yet (May 21) reached $\$ 50,000$. The bygdelag societies have to a great extent taken the place of the Norwegian-Ameri- 
can Pioneer association organized in the middle of the 90's. I was the speaker at several of the meetings of the Pioneer association and have spoken once at the annual meeting of the Stavangerlag held at Forest City, Iowa. During the past ten years I have lectured at the University of Iowa once and once at the University of Illinois. A few years ago I visited the Pacific coast giving lectures at Seattle, Tacoma, Portland, Oregon, and at various other smaller cities. On this tour I also lectured at the University of Idaho and at the University of Washington. During my three weeks' visit to the coast I lectured every day, sometimes twice a day, and one day three times. I kept my voice unimpaired to the last lecture, but the next day my voice was gone and I did not recover it for two or three months.

I have made a few flying trips to Washington, Philadelphia and New York. In Washington I became well acquainted with the Mexican ambassador de la Barra, who succeeded Porfirio Diaz as president of Mexico.

Now and then I have met distinguished people who have visited Madison. I have gone fishing on Lake Mendota with John Fiske, with Jacob A. Riis and with William Jennings Bryan, have met and shaken hands with Gen. Daniel E. Sickles, "Corporal" Tanner, Russell A. Alger, Theodore Roosevelt and W. H. Taft, Roald Amundson and Henry Lane Wilson. Of Norwegians who have visited this country I have received visits from Col. Angell, Dr. Halfdan, Koht, C. J. Hambro, Einar Hilsen, the Norwegian minister H. H. Bryn and several others; but upon the whole my life has been spent quietly at my home. In addition to the other work that I have mentioned I have gathered materials for two more volumes on Norwegian immigration, but hitherto I have not found the necessary time to arrange these for publication. My first volume on Norwegian immigration ends with the year 1840; 
the second volume is to cover the period from 1840 to 1860 and the third from 1860 to the end of the century.

Many years ago I received from Grand Rapids, Mich., a letter from Mrs. Cornelia Stecketee Hulst, a lady who had become interested in my "Norse Mythology." Our correspondence soon ripened into friendship, a friendship that has continued unbroken to this day. Her husband, Dr. Henry Hulst, is one of the highest living authorities in regard to the application of the Roentgen rays and radium. In his field of research he holds the highest rank in this country and is well known in Europe. The regents of the University of Michigan recently offered to create a special chair for him in the University of Michigan, but this he declined. Mrs. Hulst is an author of note and has written among other things "St. George of Cappadocia, in Legend and History" and "Indian Sketches." She is a teacher in the Grand Rapids, Mich., school and holds a high position in the National Educational Association and in various state associations in Michigan. The Hulsts and we in Madison have been exchanging visits, and the time that they have spent with us in Madison or we with them in Grand Rapids have been truly red-letter days. Of late years they have been coming to Madison in their automobile. The last time they were here they kidnapped me and took me home with them. They made Mrs. Anderson and me believe that I needed an X-ray examination. We made Chicago via Milwaukee the first day, Chicago to Michigan City the next afternoon and Michigan City to Grand Rapids the third day, evidence enough, I should think, that I was in no great need of either X-ray or any other medical treatment. If more evidence were needed I may add that the same evening that we reached Grand Rapids the Hulsts took me with them to call on the Shelbys, where we remained until after midnight. Mr. Shelby is vice-president of the Grand Rapids \& Indiana railroad and 
owns one of the most beautiful and costly homes in the city of Grand Rapids. I am going into this somewhat in detail because I want to tell what may sometimes fall to the lot of an author. While the Shelby family and the Hulsts and I were seated around a table loaded with good things to eat and drink and smoke Mr. Shelby suddenly asked, "Are you Rasmus B. Anderson?" I pleaded guilty. Then he asked me to go with him into his library where he showed me an elegant set of Norroena Library. He said: "Are you the editor of these sixteen volumes?" I told him I was. Then he took me back to the rest of the company and from that moment on I was the lion. Such are nice instances that now and then come in the way of those who have done something in a public way. When Mrs. Anderson and I visited the Hulsts the next summer we were most magnificently entertained by the Shelbys, and through the Hulsts we have met many of the most charming and interesting residents of Grand Rapids.

The Hulsts, and particularly Mrs. Hulst, are largely to blame for my inflicting on the public this story of my life. They have been nagging me in season and out of season by word of mouth and by letter to write my autobiography, and have also requested my wife to give me no peace until I had undertaken the work. During the past year they have instructed Miss Sarah Conlon of the music department of the University of Wisconsin, whose parents live in Grand Rapids, not to neglect nagging me on the same subject. Miss Conlon came highly recommended to us and has become, as it were, a member of our little household. Herself, her parents and her sisters have become a charming addition to our little circle of intimate friends. With the result of all this nagging, the reader is now familiar. It has kept Mr. Barton and me busy for nearly seven months. I think the Hulsts owe us their humble apology. 
The Edda mythology is most profound in thought, most sublime in sentiment. It is unequalled in tempestuous strength, in primitive vigor and in growth of muscle. The ancient Norsemen seemed to have a greater grasp on the immensity of time and eternity than any other race known to history, and this wonderful grasp they expressed in their religion and in their epic literature. Greek mythology is beautiful, but it is scattered and lost in the profusion of charming myths. It has no great central idea to work out. At best the Greeks conceived a chaos and after that a cosmos. The Norsemen penetrated into the primeval beginning and created a pre-chaotic condition of the universe. Out of this they produced chaos. Out of chaos they formed their cosmos; then come their wonderful life and exploits of the gods, with their all-embracing Ygdrasil. After that comes the great internecine feuds between all the beneficent and all the evil forces in Ragnarok, the twilight of the gods; but after Ragnarok the Norsemen saw still further into the future and discovered a regenerated world, a Gimle for the good and a Nastrand for the evil.

Better than anyone else that I know of in this broad land of ours Cornelia Stecketee Hulst has comprehended all the strength, power and beauty; all the profound philosophy contained in the Eddic myths. The goddess Saga must have taken her by the hand and led her into the holiest of holies of Teutondom and brought her face to face with All-Father Odin, the powerful Thor, the gentle and beautiful Balder, the great singer Brage, with Freyja and Idun, the possessor of the youthpreserving and youth-restoring apples. Mrs. Hulst has indeed taken deep draughts from the fountains of Urd and Mimer, and now considering that by unceasing nagging of me during the past few years she has aided my beloved wife in compelling me to undertake the writing of this story of my life, I take great pleasure in revenging myself by bestowing on her this wellmerited commendation. 
I am still the president of the Wisconsin Life Insurance company and of the Wisconsin Rubber company and I still get out a weekly issue of "Amerika." Last year, 1913, I was invited to speak at the great 17th of May festival in Chicago and look upon this invitation as a turn for the better in the public Norwegian feeling toward me. There are, I am happy to say, various evidences that the bitter animosity of which I have been the victim the past dozen years has materially abated.

While I have been in several conflicts and controversies of which I, for considerations of the living, have given no account in this story of my life and while it may seem to some of my readers as if it were impossible for me to live in peace with anybody, I desire to state here that there has never been a ripple of disturbance of the peace and the good will between me and the neighborhood in which I have lived these past thirty-three years. Not once has an unfriendly word been spoken by neighbors to me or by me to them. Our relations have been so cordial that I cannot refrain from mentioning at least those nearest me now living. As a resident I am the patriarch in our block on North Carroll street. My neighbors on my side of the street are Dr. J. K. Chorlog, A. C. Blackburn, H. E. Martin and John Grinde and their families. On the other side of the street are Dr. J. A. Jackson, E. B. Steensland, August Frish and Dr. T. W. Tormey, and their families. Better neighbors no man could desire. We visit on each other's porches and walk in without rapping or ringing the doorbell, and we discuss together all questions between heaven and earth. All the good things that come our way we share with each other and our troubles are smothered in sympathy. I still visit Major Oakley and Philip Spooner every Sunday morning.

And now just a word about our immediate family. Our first child, a daughter, Hannah Burena, died on her birthday one year old. Our second child, Carletta Catherine, married 
a Dane, Peter Vedel, who is harbor engineer in Aarhus, Denmark. They have two children, a girl and a boy. Our third child, George Krogh, married Elizabeth Keeley. They reside in Madison and have four boys and two girls. Our fourth child, Hjalmar Odin, married Cathrine Barry. They live in Seattle and have two boys and a girl. Our fifth child, Rolf Bull, married Mayme Lavin. They have one daughter. Rolf has spent nine years on our rubber plantation in Chiapas, Mexico, and is now its superintendent, but is at present in Madison, having come home by order of President Wilson on account of the disturbed conditions in Mexico.

Looking over my life with all its pleasures and troubles, taking into account the work that my brains and hands have found to do, considering the bitter enmities I have encountered and the warm friends I have won, taking a general survey of my whole career, as a product of American frontier life, with all its inspiring and its discouraging phases, I want to sum it all up in the old phrase which I learned from my Swedish friend Thure Ludwig Kumlien, "Jag är fornögd med lotten minn,"-I am content with my lot. 



\section{ANDERSON BIBLIOGRAPHY,}

Reprinted from "Bibliography of Wisconsin Authors," published by Wisconsin State Historical Society.

Anderson, Rasmus Björn. Natur-Videnskabernes Forhold til Religionen. En Forelasning af P. A. Chadbourne, LL. D., tidligere Professor i Naturhistorie ved Williams College og Professor i Naturhistorie og Chemi ved Bowdoin College, nu Prasident for Universitetet i Wisconsin. Oversat af R. B. Anderson. Madison, Wis.: Trykt i B. W. Suckow's Bog-og Akcidents-Trykkeri, 1869. 16p. O.

The Skandinavian languages; their historical, linguistic, literary, and scientific value. Elucidated by quotations from eminent American, English, German, and French scholars. Notices of these languages by H. W. Longfellow, George P. Marsh, Samuel Laing, Robert Buchanan, Schlegel, Mallet, and others. Madison, Wis.: Democrat Company Printing Office, 1873. 16p. O.

- Den Norske Maalsag. Han Per og ho Bergit. Chicago: Skandinavens Forlag, 1874. 99p. S.

Tro og Fornuft. Tale af Dr. John Bascom, holdt i Assembly Chamber i Madison, Wis., til de examinerede Kandidater af Wisconsin Universitet Söndag Eftermiddag den 13de Juni, 1875. Oversat af R. B. Anderson. Chicago, 1875. 15p. O.

_ Tale ved Femti-Aarsfesten for den Norske Udvandring til Amerika Holdt i Chicago den 5te Juli, 1875. Chicago: Trykt i Skandinavens Bog-og Akcidents-Trykkeri, 1875. 27p. O.

- Norse mytholozy, or the religion of our forefathers, containing all the myths of the Eddas, systematized and interpreted, with an introduction, vocabulary, and index. 2d edition. Chicago: S. C. Griggs \& Company; London: Trubner \& Co., 1876. 473p. O.

4th edition, 1884.

5 th edition, $1890 \%$ 
ANDERSON, RASmus Björn. Hand-book for charcoal burners, by G. Svedelius. Translated from the Swedish by R. B. Anderson, A. M., Professor of Scandinavian languages in the University of Wisconsin. Edited with notes by W. J. L. Nicodemus, Professor of civil engineering in the University of Wisconsin. With twenty-three wood engravings. New York: John Wiley \& Son, 1875. $x v+217 p$. D.

Viking tales of the north. The sagas of Thorstein, Viking's son and Fridthjof the Bold, translated from the Icelandic by R. B. Anderson. Also Tegner's Fridthjof's saga, translated into English by George Stephens. Chicago: S. C. Griggs \& Co., 1877. xviii +370 p. D.

2d edition, 1882.

3d edition, 1889.*

America not discovered by Columbus. An historical sketch of the discovery of America by the Norsemen in the tenth century, with an appendix on the historical, linguistic, literary and scientific value of the Scandinavian languages. Also a bibliography of the pre-Columbian discoveries of America, by Paul Barron Watson. Chicago: S. C. Griggs \& Co.; London: Trubner \& Co., 1877. 120p. D.

3d edition, 1883.

4th edition, 1891.*

In memoriam. Prof. Stephen Haskins Carpenter, LL. D. Address before the State historical society, December 17, 1878. Wisconsin Historical Collections, v. 8, pp. 86-95.

Amerika ikke opdaget af Columbus. En historisk Skildring at Normaendenes Opdagelse af Amerika i det 10de Aarhundrede. Med et Anhang om de nordiske Sprogs historiske, sproglige, literaere og videnskabelige Vaerd. Oversat fra Engelsk efter den anden forbedrede og forogede Udgave af C. Chrest. Portrait. Chicago: "Skandinavens" Bogtrykkeri, 1878. 125p. D.

The influence of reading upon health.

Third Annual Report of the State Board of Health, 1878, pp. 71-78.

Finland and the Kalevala.

Wisconsin Journal of Education, v. 8, 1878, pp. 285-290. 
Anderson, Rasmus Björn. Teutonic mythology.

The American Antiquarian, v. 2, 1879-80, pp. 271-275.

- The Younger Edda: also called Snorre's Edda, or the Prose Edda. An English version of the Foreword; the Fooling of Gylfe, the Afterword; Brage's Talk, the Afterword to Brage's Talk, and the important passages in the Poetical Diction (Skaldskaparmal), with an introduction, notes, vocabulary, and index. Chicago: S. C. Griggs \& Co.; London: Trubner \& Co., 1880. 302p. O.

The Norway music album: a selection for home use from Norway's folk songs, dances, etc., national airs, and recent compositions arranged for pianoforte and solo singing, with a few fourpart songs. Edited and furnished with English text by Auber Forestier and Rasmus B. Anderson. Boston: Oliver Ditson \& Co., 1881. 260p. Q.

Biographical sketch of Lyman C. Draper, LL. D., secretary of the State historical society of Wisconsin. Portrait. Cincinnati: Peter G. Thomson, 1881. 31p. Q.

Synnove Solbakken. By Björnstjerne Björnson. Translated from the Norse by Rasmus B. Anderson. Portrait. Boston: Houghton Mifflin \& Co., 1882. 197p. D.

Magnhild by Björnstjerne Björnson. Translated from the Norse by Rasmus B. Anderson. Boston: Houghton, Mifflin \& Co., 1883. 223p. D.

The fisher maiden. By Björnstjerne Björnson. Translated from the Norse by Rasmus B. Anderson. Boston: Houghton, Miffin \& Co., 1883. 274p. D.

Captain Mansana, and other stories. By Björnstjerne Björnson. Translated from the Norse by Rasmus B. Anderson. Boston: Houghton, Miffin \& Co., 1883. 256p. D.

The bridal march, and other stories. By Bjornstjerne Björnson. Translated from the Norse by Rasmus B. Anderson. Il- 
Anderson, Rasmus Björn. Arne. By Bjönsterne Björnson. Translated from the Norse by Rasmus B. Anderson. Boston: Houghton, Mifflin \& Co., 1883. 200p. D.

- A happy boy. By Björnstjerne Björnson. Translated from the Norse by Rasmus B. Anderson. Boston: Houghton, Mifflin \& Co., 1884. 165p. D.

- Julegave. Et udvalg af Eventyr og Fortaellinger. Chicago: John Anderson \& Co., 1884. 242p. D.

7 th edition, 1890.

History of the literature of the Scandinavian North, from the most ancient times to the present. Translated from the Danish of Frederik Winkel Horn, Ph. D., with a bibliography of the important books in the English language relating to the Scandinavian countries, prepared for the translator by Thorvald Solberg. Chicago: S. C. Griggs \& Co., 1884. ix+507p. O.

The spell-bound fiddler: a Norse romance by Kristofer Janson. Translated from the original by Auber Forestier. With an introduction by Rasmus B. Anderson. 2d ed. Chicago: S. C. Griggs \& Co., 1884. 163p. D.

Mythologie Scandinave. Legendes des Eddas. Traduction de M. Jules Leclercq. Paris: Ernest Leroux, 1886. $\mathrm{x}+$ 293p. D.

- Eminent authors of the nineteenth century. Literary portraits by Dr. Georg Brandes, translated from the original by R. B. Anderson. Portraits. New York: Thomas Y. Crowell \& Co., 1886. vii +460p. O.

Amerikas forste Opdagese. Af forfatteren gjennemset og autoriseret oversættelse ved Fr. Winkel Horn. Portrait. Kjobenhavn: Gyldendalske Boghandels Forlag (F. Hegel \& Son) Graebes Bogtrykkeri, 1866. 80p. O.* 
Anderson, Rasmus Björn. Nordisk mythologi af R. B. Anderson. De Forenede Staters Ministerresident i Kjobenhavn. Oversettelse efter originalens 4de oplag ved Dr. Fr. Winkel Horn. Kristiania: Albert Cammermeyer, 1887. xvi+480p. O.*

With steel portrait and biographical sketch of the author.

The religion of the ancient Scandinavians.

From Homiletic Magazine, v. 16, 1887, pp. 1-6, 69-76.

Non-Biblical systems of religion. A symposium, by the Ven. Archdeacon Farrar, D. D.; Rev. Canon Rawlinson, M. A.; Rev. W. Wright, D. D.; Rabbi G. J. Emanuel, B. A.; Sir William Muir; Rev. Edwin Johnson, M. A.; T. W. Rhys Davids, LL. D., Ph. D.; The Hon. Rasmus B. Anderson; and Rev. Wm. Nicolson, M. A. London: James Nisbet \& Co., 1887. 243p. O.*

Monumentet til Ole Bull. Madison, 1887. 4p. O.

The Lofoden cod fisheries.

United States Consular Reports, v. 25, 1888, pp. 70-82.

- Market for American wares in Denmark and Scandinavia. Ibid., v. 25, 1888, pp. 82-85.

Die erste Entdeckung von America. Eine historische skizze der Entdeckung Amerikas durch die Skandinavier. Autorisirte Uebersetzung von Mathilde Mann. Hamburg: Verlag von J. F. Richter, 1888. 62p. O.*

Teutonic mythology. Translated from the Swedish of Viktor Rydberg, Ph. D., member of the Swedish academy, author of "The Last Athenian," "Roman Days," and other works. London: Swan Sonnenschein \& Co., 1889. xii+706p. O.

Among cannibals: an account of four years' travels in Australia and of camp life with the aborigines of Queensland. By Carl Lumholtz. Translated by Rasmus B. Anderson. With portraits, maps, 4 chromo-lithographs and woodcuts. New York: Charles Scribner's Sons, 1889. xx+395p. O. 
Anderson, RAsmus Björn. The Heimskringla or the sagas of the Norse kings, from the Icelandic of Snorre Sturlason, by Samuel Laing, Esq. 2nd edition, revised with notes by Rasmus B. Anderson. Plates. Maps. London: John C. Nimmo; New York: Scribner \& Welford, 1889. 4v. O.

Scandinavian mythology, the religion of our forefathers. Minneapolis, 1890 . 15p. O.

Same. Madison, 1892.

Where was Vineland? A reply to Prof. Gustav Storm, refuting his arguments in favor of locating Vineland in Nova Scotia, and maintaining that Columbus was acquainted with the Norsemen's discovery of America. Minneapolis, 1891. 12p. O.

Professor Anderson has also contributed to the American supplement of Encyclopedia Britannica; to McClintock \& Strong's Cyclopedia; to Johnson's Cyclopedia; to Killde \& Schem's Cyclopedia; to the last edition of Chambers's Cyclopedia, and to Gilmore's Cyclopedia. He has been a frequent contributor, also, to The Dial (Chicago), to The Nation (N. Y.), and to various other periodicals.

Since the above was issued in 1892, Mr. Anderson has published First Chapter of Norwegian Immigration, 1821-1840. xiv +476 p., with more than 60 portraits of pioneers, 1895 .

Norrona Library. 16 vols. 1905-1906.

Norge i Billeder. Med Indledning og korte Beskrivelser. 196 quarto pages, with 153 full page illustrations. Chicago, John Anderson Publishing Company.

Bygdejævning. Artiker af Repræsentanter fra de forskjellige Bygder i Norge om, hvad deres Sambygdinger har udrettet i Vesterheimen. vi+415 p. Madison, Wis., Amerika Publishing Company, 1903.

He has edited Amerilka since Oct. 1898. 




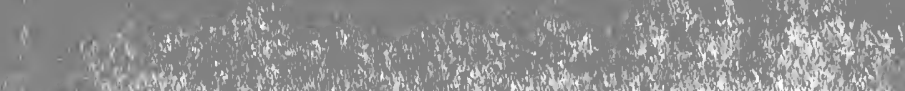

3 (1)

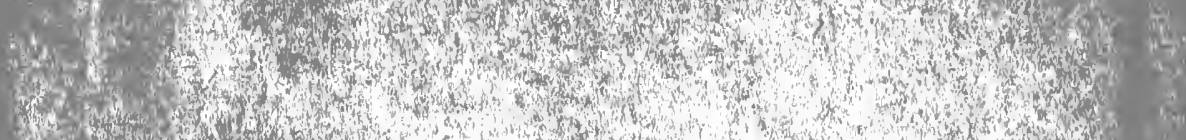

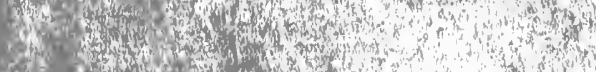
(6)

W.

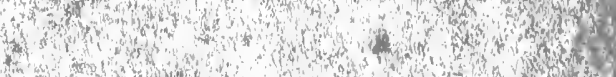

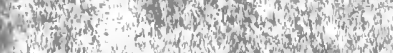

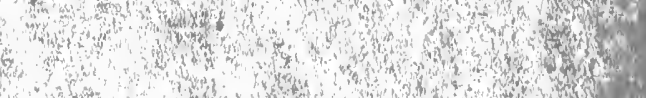

N-

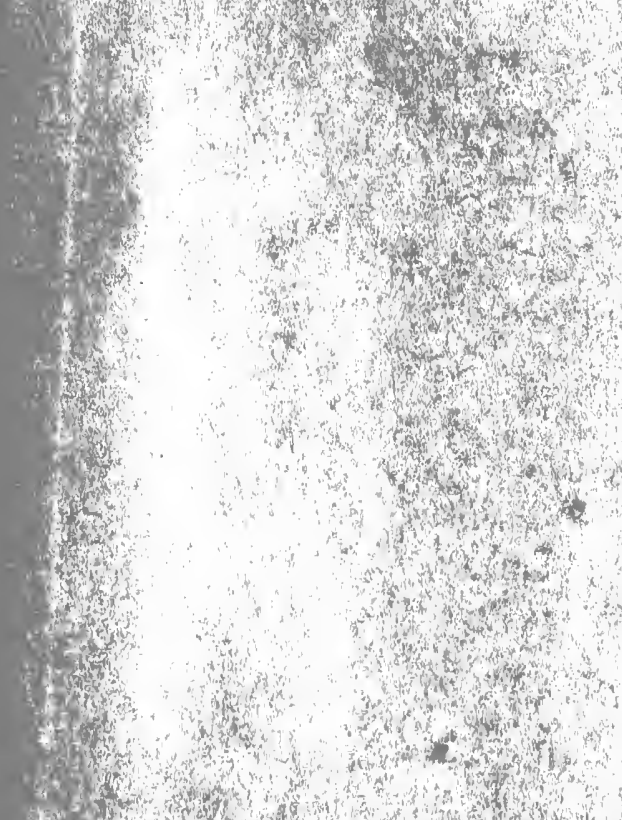

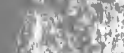

sinterts

(5)

ofint

a

in

$\frac{3}{4}$

(1)

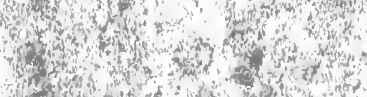

(1)

now

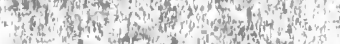

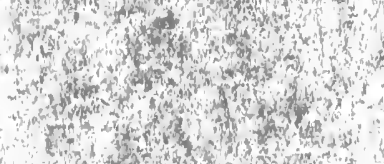

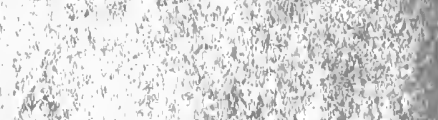

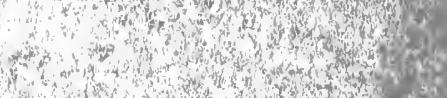

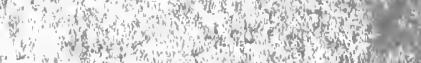
and on

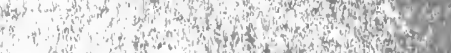

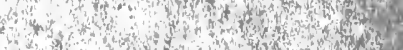

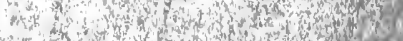

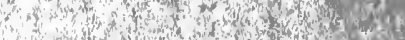

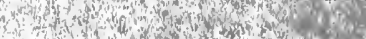

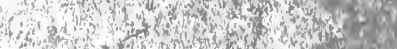

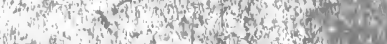

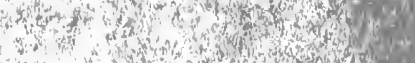
is

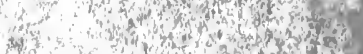
ond

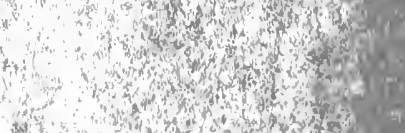

and

iptond

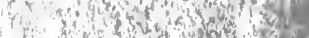

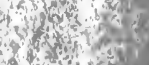
to

$$
\text { nom on }
$$

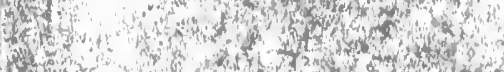
(it)

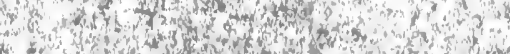

r.

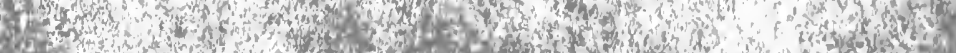

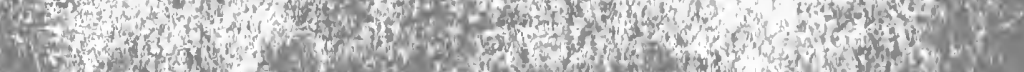

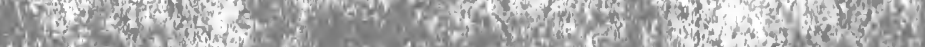

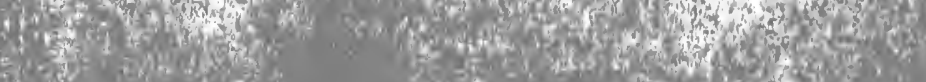
wat $x_{1}$ soves 
